LATVIJAS UNIVERSITĀTES

63. ZINĀTNISKĀ KONFERENCE

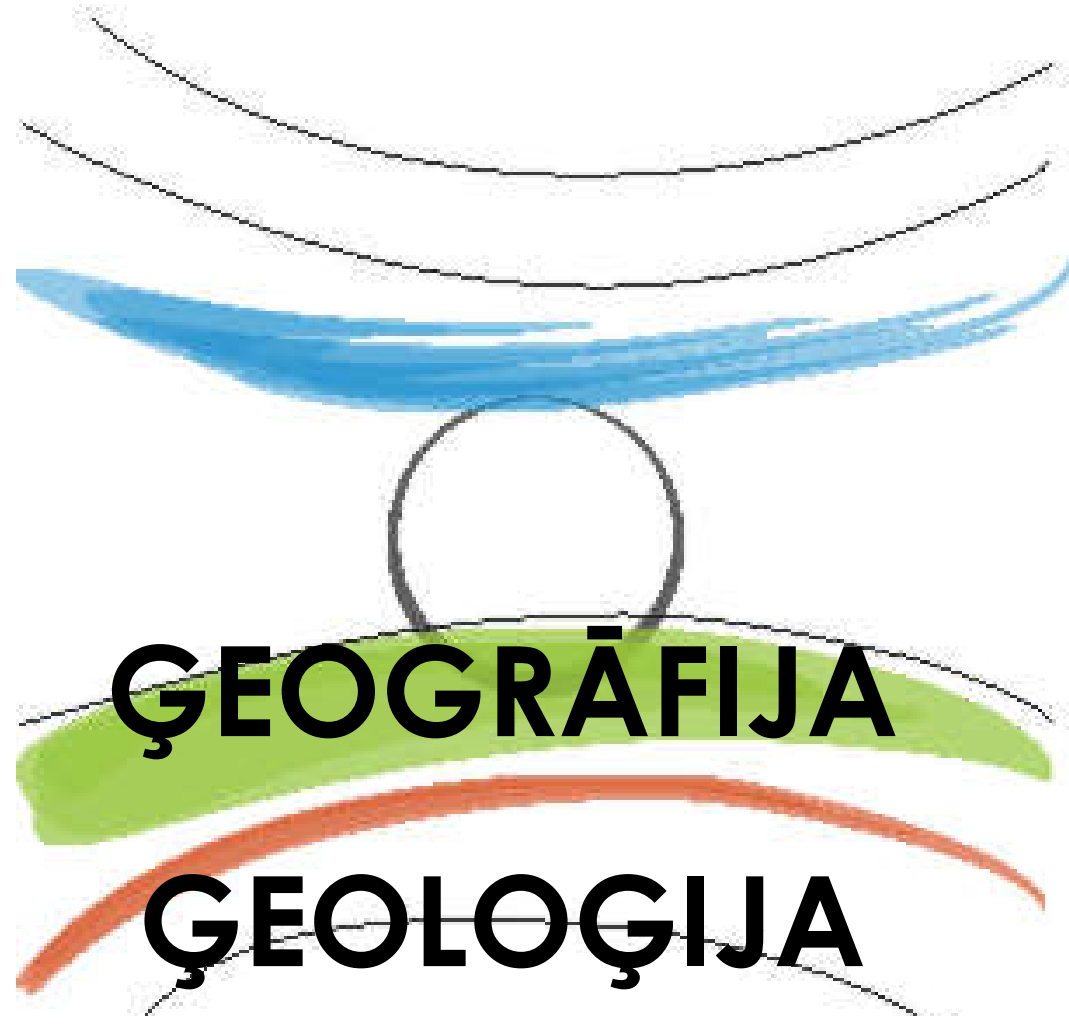

VIDES ZINĀTNE 


\section{LATVIJAS UNIVERSITĀTES}

63. ZINĀTNISKĀ KONFERENCE

\section{ĢEOGRĀFIJA \\ ĢEOLOĢIJA \\ VIDES ZINĀTNE \\ Referātu tēzes}

LU Akadēmiskais apgāds 
UDK $91+5(063)$

Ge540

Ģeogrāfija. Ģeoloǵija. Vides zinātne: Referātu tēzes. Rīga: Latvijas Universitāte, 2005, 221 lpp.

Maketu veidojusi Ineta Grīne

(C) Latvijas Universitāte, 2005

ISBN 9984-770-78-8

Korektore Vija Kaņepe 


\section{Ģeogrāfijas sekcija}

Sekcijas vadītājs Pēteris Šķkingkis

\begin{tabular}{|c|c|}
\hline $\begin{array}{l}\text { Ainavekoloǵija } \\
\text { Koordinators Māris Laiviņš }\end{array}$ & 24.janvāris \\
\hline $\begin{array}{l}\text { Bioǵeogrāfija } \\
\quad \text { Koordinatore Solvita Rūsinga }\end{array}$ & 25.janvāris \\
\hline $\begin{array}{l}\text { Klimatoloǵija un hidroloǵija } \\
\text { Koordinatore Agrita Briede }\end{array}$ & 26.janvāris \\
\hline $\begin{array}{l}\text { Attīstība un plānošana } \\
\text { Koordinators Pēteris Škinkis }\end{array}$ & 28.janvāris \\
\hline $\begin{array}{l}\text { Ģeomātika } \\
\quad \text { Koordinators Aivars Markots }\end{array}$ & 28.janvāris \\
\hline $\begin{array}{c}\text { Ģeogrāfijas un ǵeoloǵijas izglītīibas attīstība } \\
\text { Koordinatore Ligga Zelča }\end{array}$ & 28.janvāris \\
\hline $\begin{array}{l}\text { Cilvēka ǵeogrāfija } \\
\text { Koordinatore Zaiga Krišjāne }\end{array}$ & 31.janvāris \\
\hline
\end{tabular}

\section{Ģeoloǵijas sekcija}

Sekcijas vadîtājs Ervīns Lukševičs

\begin{tabular}{ll}
\hline $\begin{array}{l}\text { Kvartārǵeoloǵija un ǵeomorfoloǵija } \\
\text { Koordinators Vitälijs Zelčs }\end{array}$ & 26.janvāris \\
\hline $\begin{array}{c}\text { Pamatiežu ǵeoloğija } \\
\text { Koordinatori Ervīns Lukševičs, Ģirts Stinkulis }\end{array}$ & 27.janvāris \\
\hline $\begin{array}{c}\text { Lietišķāa ǵeoloǵija } \\
\text { Koordinators Valdis Segliňš }\end{array}$ & 27.janvāris \\
\hline
\end{tabular}

\section{Vides zinātnes sekcija}

Sekcijas vadītājs Olğgerts Nikodemus

Rīgas vides pētījumi 24.janvāris

Koordinators Olǵerts Nikodemus

Vides zinātnes aktuālās problēmas 28 .janvāris

Koordinators Māris Klaviņš 


\section{SATURS}

\section{ĢEOGRĀFIJAS SEKCIJA}

Elga Apsīte, Ilga Kokorīte, Ansis Zīverts, Māris Kḷaviņš. Pierīgas mazo upju

raksturojums

Austra Āboling. Atsevišşu sūnu sugu izplatības īpatnības Latvijā ...

Ilgvars Ābols. Padomju kultūras mantojuma saglabāšana un izmantošana

tūrismā Latvijā

Baiba Bambe. Augi un biotopi dabas liegumā "Vesetas palienes purvs" .........

Andris Bauls, Zaiga Krišjāne. Starptautiskās migrācijas reğionālās atšķirības

Latvijā

Agrita Briede, Gunta Springge, Agnija Skuja. Upes vides stāvoḳ̣a novērtējums

un tā ietekme uz upju kvalitāti

Jānis Brinkzis. Latvijas apdzīvoto vietu teritoriālo plānojumu arhitektoniski telpiskās nostādnes

Pèteris Evarts-Bunders. Pomerānijas vītola (Salix pomeranica Willd) izplatība

Latvijā

Zane Cekula. Vietvārdi pirmajos latgaliešu kalendāros un avīzēs

Armands Celms, Jānis Kaminskis. Nivelējumu paaugstinājumu izmaiņu

analīze līnijās Demene-Jēkabpils un Ainaži-Rīga

Zane Deķere. Makrofîtu vegetācijas izmaiņas un to ietekmējošie faktori

Rīgas līì

Anita Draveniece. Kontinentālo un transformētu okeānisko gaisa masu

biežums Latvijā: g̀eogrāfiskās atšksirības

Pārsla Eglīte. Pretišḳ̄ības migrācijas plūsmu prognozēšanā Latvijā

Tālis Gaitnieks, Imants Liepa. Kūdras substrātu biologiskās aktivitātes

novērtēšanas metodes

Gunta Grišule, Zane Māliņa. Fenoloğiskie trendi Latvijā 20.gadsimtā ................

Dāvis Gruberts. Ģeogrāfiskie priekšstati Augšzemes folklorā

Andris Gērmanis. Koku un krūmu lapu plaukšanas fenoloğiskā parādība

Latvijā

Andris Ģērmanis, Ineta Krastiņa. Kontinentu un valstu asociatīvā fiksācija ...... Aigars Indriksons. Ūdens kvalitāte Latvijas meža ekosistēmās ....................... Gundega Jurāne. Priežu meži Preiḷu novada pilskalnos

Teiksma Kalninga. Ģeogrāfijas mācību procesa vēsturiskā attīstība Latvijā,

Eiropā un pasaulē

Marija Kasparovica. Centrālo vietu dinamiskums un kontinuitāte .................. 51

Aldis Kārklinņ̌s. Latvijas augšṇu klasifikācijas pielīdzināšana PAK - iespējas

un problēmas

Renāte Klimko. Ģeogrāfiskās informācijas sistēmas izmantošana Latvenergo sistēmā

Anita Krampe. Latvijas elektorālie procesi politiskajā ġeogrāfijā .....................

$\bar{A}$ dolfs Krauklis. Galveno komponentu metode ainavekolog̣ijā

Vija Kreile. Mezotrofās augu sabiedrības ar meža silpureni Austrumlatvijā ...

Ženija Krūzmētra. Nekustamā īpašuma tirgus ietekme uz iedzīvotāju

migrācijas procesu Latvijas laukos 
Laila Kūle. Pilsētu un lauku mijiedarbības zonās veiktie telpisko atšķirību pētîjumi Latvijā

Māris Laiviņš. Mežaudze kā ainavas augstumjoslojuma indikators

Dainis Lazdāns, Jūlija Munča, Juris Soms, Aija Ševcova. GIS lietišḳais

pielietojums augšzemes ezeru vides pētījumos ......................... 68

Gunta Lukstinga. Rīgas attīstības plāna atbilstība telpiskās attīstības politikām $\quad 70$

Dace Mangale. Platlapju mežu reğionālās îpatnības ........................... 73

Ivars Matisovs. Latgales pilsētu iedz̄votāju dzīvesvides un mājokḷu apstākḷi .. 74

Zanda Penēze, Ineta Grīne, Inga Rasa. Zemes izmantošanas struktūras

izmaiñas Latvijā vietējā līmenī 20.gadsimtā

Vaira Podskočija. Domāšanas operāciju attīstīšana ğeogrāfijas mācī̌anas

procesā

Anete Pošiva. ĢIS izmantošana pašvaldību teritorijas plānošanā - vīzija un

realitāte

Armands Pužulis. Kurzemes reǵiona telpiskā attīstība un plānošanas pieejas .. Ains Raitvīrs, Edgars Vimba. Latvijas operkulātās diskomicētes

Solvita Rūsiņa. Dabisko zālāju izpēte Latvijā

Liene Salminga. Limnogēno purvu veǵetācija Latvijā

Valdis Segliňš. Ģeogrāfijas zināšanu standarti un programmas dažādos

izglītības līmeņos skolās

Andrejs Svilāns. Invazīvie citzemju koku un krūmu taksoni Nacionālajā

Botāniskajā dārzā Salaspilī

Inese Stūre. Sēlijas reğionālās kultūridentitātes pašreference

94

Pēteris Šķiņkis. Vietējo apstākḷu ietekme uz Latvijas reǵionu attīstības

atškirīīām: formalizētā vērtēšana un attīstības izcelsme

Māra Urtāne. Piekrastes un mitraiṇu biotopi kā aeheoloǵisko pieminekḷu ainava

96

Juris Urtāns. Latvijas pilskalni I un II Pasaules kara frontes līnijās .

97

Armands Vilciņš. Iedzīvotāju skaita izmaiņas kā Rīgas aglomerācijas robežu

noteikšanas indikators

Jānis Vìtiņš. Ogres rajona pilsētu attīstība vēsturiskā un mūsdienu skatījumā

Anita Zariņa. Ainavas koncepcijas sākotne Latvijā

101

Pēteris Zālītis. Mērkstiecīgi izveidoto kokaudžu augšanas gaita un

strukturēšanās Ziemeḷkurzemes un Rietumvidzemes mežsaimniecībās ....

Iveta Žvagiņa, Lelde Enğgele, Laimdota Kalniņa, Sandijs Mešķis. Peldošais

ezerrieksts Trapa natans - atlantiskā laika relikts Pokratas ezerā

Egita Zviedre. Pavedienu mieturītes Chara filiformis Hertzsch ekolog̣ija un

izplatība Latvijā

\section{ĢEOLOĢIJAS SEKCIJA}

Ojārs Āboltiňš, Ivars Strautnieks, Aivars Markots, Vitālijs Zelčs, Martins

Denisovs, Linda Mangale, Anita Plūce, Lāsma Sietinsone, Aiga Statkus,

Agate Teivāne. Glaciotektoniskās deformācijas Lētīžas labajā krastā pie

Lèǵerniekiem

Aija Ceriņa, Laimdota Kalniņa. Kvartāra nogulumu paleobotāniskie pētījumi

Lubāna līdzenumā Zvidzienas apkārtnē 
Aija Dēliņa. Latvijas kvartārsegas ūden̦u reǵionālās atšş̧irības ....................... 114

Aija Dēliņa. Pazemes ūdeṇu pētījumu vēsture Latvijā ................................... 116

Guntis Eberhards. Senais Burtnieks un tā līmeņa izmaiṇu paleohidroloğiskā rekonstrukcija

Guntis Eberhards, Baiba Saltupe. Daugavas krastu stāvoklis un erozijas riska vietas Rīgas HES lejasbjefā

Vija Hodireva. Smago minerālu graudu virsmas morfolog̣ija kāa indikatorpazīme klastisko iežu sedimentoǵenēzē

Vija Hodireva, Indra Zviedre. Vidzemes klastisko iežu cirkonu un granātu tipomorfās pazīmes

Laimdota Kalniņa, Agris Lācis, Georgs Sičovs, Anete Diņָ̧̄ite, Līga Bērtulsone, Stella Aļukēviča. Cenas tīrel̦a attīstības dinamika un to ietekmējošie faktori

Jānis Lapinskis, Mārtiņš Grava. Pludmales sanešu mehāniskā sastāva izmaiṇas Latvijas jūras krasta posmā no Ventspils līdz Miķeḷtornim .......

Ervīns Lukševičs. Bruṇuzivis Andomas kalna devona nogulumos

Ervīns Lukševičs, Girts Stinkulis, Kristīne Tovmasjana, Ivars Zupiņš. Andomas kalna (Krievija, Oṇegas ezera DA krasts) ǵgeoloğiskā uzbūve

Ingrīda Maļika. Hidroǵeoloǵisko apstākḷu izmaiṇas Ķemeru apkaimē un to modelēšana

Aivars Markots, Ojārs Āboltiņš, Ivars Strautnieks, Vitālijs Zelčs, Martins

Denisovs, Linda Mangale, Anita Plūce, Lāsma Sietinsone, Aiga Statkus.

Ledāja reljefa topogrāfija, uzbūve un glaciotektoniskās struktūras pārejas joslā no Austrumkursas augstienes uz Pieventas līdzenumu

Dainis Ozols. Zemledāja ūdensteces Ziemel̦vidzemē

Dainis Ozols. Subglaciālā substrāta evolūcija Ziemel̦vidzemēe ....

Tomas Saks, Andis Kalvāns. Diapīru izvietojuma likumsakarības

Rietumlatvijas piekrastes teritorijā

Valdis Segliňš. Litorīnas jūras stadijas veidojumi Kurzemes piekrastē ........... 143

Valdis Segliņš. Zemes dzīḷu vērtība, cena un nodokḷi

Inga Sevastjanova. Juras nogulumi Dzeldas un Šķervel̦a satekas apkārtnē .......

Juris Soms. Gravu nepastāvīgo ūdensteču nozīme nogulumu erozijas,

transporta un akumulācijas procesu ķēdē hidrogrāfiskā tīkla augšējos posmos

Juris Soms. Mākoṇkalna un tā apkārtnes reljefa formu ǵeomorfoloğiskās

izpētes un kartēšanas rezultāti

Vilnis Stelle. Pelēko mālu veidošanās apstākḷi agrajā pieledāja baseinu attīstības laikā Viduslatvijas un Austrumlatvijas zemienēs

Girts Stinkulis, Kristīne Tovmasjana, Ervīns Lukševičs, Angelīna Zabele.

Devona nogulumu sedimentācijas apstākḷi Andomas kalna apkārtnē (Krievija, Oņegas ezera DA)

Ivars Strautnieks, Aivars Markots, Jānis Dzelzītis, Vitālijs Zelčs, Sintija Antone, Martins Denisovs, Linda Mangale, Lāsma Sietinsone, Agate Teivāne. Cēres radiālās grēdas morfologijias un uzbūves īpatnības 
Māris Zunde. Koksne kā bioindikators ... un ǵeoloǵija: dabiski apraktās senās koksnes izpētes iespējas un problēmas Latvijā

Vitālijs Zelčs, Ivars Strautnieks, Aivars Markots, Jānis Dzelzītis, Inese Celma, Indra Ošuroka, Diāna Paikūne, Anita Plūce, Aiga Statkus, Ilze Veinberga. Ledāja reljefa formu morfoloğija, uzbūve un veidošanās Ziemeḷkursas augstienes Aklāciema masīvā

\section{VIDES ZINĀTNES SEKCIJA}

Jeļena Aleksejeva, Aija Jasāne, Antra Lerha, Guna Šumilo, Inga Vonoga, Santa

Rutkovska. Antropogēnās ietekmes novērtējums ezeru piekrastes rekreācijas zonās: atsevišksu Austrumlatvijas ezeru piemērs

Elga Apsīte, Ilga Kokorīte, Māris Kļaviņš, Ansis Zīverts. Mārupītes ūdens kvalitāte

Maija Balode, Ingrīda Puriņa, Māra Pfeifere, Solvita Strāķe, Ieva Bārda, Jānis Ağis, Miks Veinbergs. Rīgas un Pierīgas ezeru ekoloǵiskais stāvoklis un tā saistība ar toksisko aḷgu masveida attīstību

Gunta Čekstere, Olğgerts Nikodemus. Rīgas vēsturiskā centra apstādījumu struktūras attīstība

Marita Cekule, Irina Gailiša, Mareks Mūrmanis. Vides indikatora "Sabiedrībai pieejamo atklāto teritoriju un pakalpojumu vietējā līmenī " analīze Rīgas pilsētā

Iveta Dubakova, Marina Frolova. Sēra savienojumu pārrobežu pārneses novērtējums Latvijā

Linda Eglīte. Dažādu Latvijas humusvielu salīdzinājums, izmantojot pirolīzes gāzu hromatogrāfiju / masspektrometriju

Dāvis Gruberts, Jana Paidere, Jānis Priedītis, Artūrs Škute. Daugavas palieṇu ezeru ūdens sastāva īpatnības vasarā

Edīte Juceviča, Viesturs Melecis. Augsnes kolembolu cenozes reakcija uz klimata pasiltināšanos desmit gadu periodā

Raimonds Kasparinskis. Ekoloǵisko procesu telpiskās izpausmes Rīgas pilsētas dabas teritorijās

Dace Kaupuža. Muižas Rīgas pilsētā kā kultūrvēsturiskās vides elements ......

Māris Klaviņš. Humusvielu funkcionālie atvasinājumi un to izmantošanas iespējas

179

Ilga Kokorìte. Sateces baseina īpašību ietekme uz virszemes ūdeņu ķīmisko sastāvu

Jorens Kviesis, Pēteris Mekšs, Ruslans Seļezņovs. Virsmas aktīvo vielu augstefektīvā šksidrumu hromatogrāfija

Viesturs Melecis, Edìte Juceviča, Ineta Salmane, Jānis Ventiņš, Voldemārs Spungisis. Meža augsnes mezofaunas izmaiņas sausuma palielināšanās apstāklısos

Olgerts Nikodemus, Dace Granta, Mikus Ranka. Rīgas "Dabas pamatne" izmantošanas problēmas un attīstības iespējas ........................................ 
Valērijs N̦ikuļins. Kaḷiņingradas zemestrīces 2004.gada 21.septembrī seismiskās sekas Latvijā

Valdis Segliņš, Georgijs Sičovs. Trīsdimensijas geofizikālie pētījumi Rīgas

Doma baznīcā

Gunta Sprinğge. Bioloğiskie kvalitātes elementi ūdens vides novērtēšanai

Iveta Šteinberga. Gaisa piesārṇojuma zonējums Rīgas pilsētas siltumapgādes attīstībai

Jānis Šìre. Humusvielu izdalīšana no kūdras, izmantojot dažādas ekstrakcijas metodes

Evija Tērauda, Ol̦gerts Nikodemus, Māris Laiviņš, Guntis Tabors. Ķīmisko elementu ienese ar nobirām uz augsnes priežu mežu ekosistēmās Latvijā

Valters Toropovs, Magnuss Vircavs. Noturīgo organisko piesārṇotāju pārvaldības problēmas un to iespējamie risinājumi Latvijā

\section{LATVIJAS ŪDEŅU VIDES PĒTĪJUMU UN AIZSARDZĪBAS SEKCIJA}

G.Aišpure. Kopepoda Limnocalanus macrurus barošanās intensitātes saistība ar vertikālām migrācijām Botnija līcī

Maija Balode, Māra Pfeifere, Solvita Strāķe, Ingrīda Puriņa, Ieva Bārda, Katrīne Povidiša. Biotestēšanas izmantošanas iespējas vides kvalitātes kontrolē ....

Dāvis Gruberts, Ivars Druvietis. Skuķu (Grīvas) ezera fitoplanktona sezonālās izmaiņas

Mārtiņš Kalniņš. Tekošo saldūdeṇu biotopi Gaujas Nacionālajā parkā

Bārbele Millere-Karulis, Solvita Strāķe, Didzis Ustups, Atis Minde, Georgs Korņilovs. Oglekḷa un biogēno vielu aprite Rīgas līča atklātajā daḷā

Atis Minde, Viesturs Bērziņš. Ũdens temperatūras dinamika Rīgas jūras līča piekrastē un ar to saistītās ihtiofaunas izmaiṇas 2004.gadā

Arkādijs Poppels, Dāvis Gruberts, Ivars Druvietis. Daugavas palienes ezeru hidrobiologisiskā izpēte

Mudìte Rudzīte. Ziemel̦u upespērlenes Margaritifera margaritifera L. populāciju izdzīvotība atkarībā no upes baseina teritorijas apsaimniekošanas veidiem

Zinta Seisuma, Irīna Kuļikova. Metālu uzvedība Daugavas hidrofrontes ūden̄̄ un sedimentā

Agnija Skuja. Maksten̦u Trichoptera sugu sabiedrības dominējošajos Latvijas mazo upju mikrobiotopos

Gunta Springèe, Agrita Briede, Agnija Skuja. Vides faktoru ietekme uz upju biocenožu struktūru

S.Strāķe, A.Ikauniece, G.Aǐ̌pure. Invazīvās sugas Cercopagis pengoi sadalījuma īpatnības Rīgas līcī 


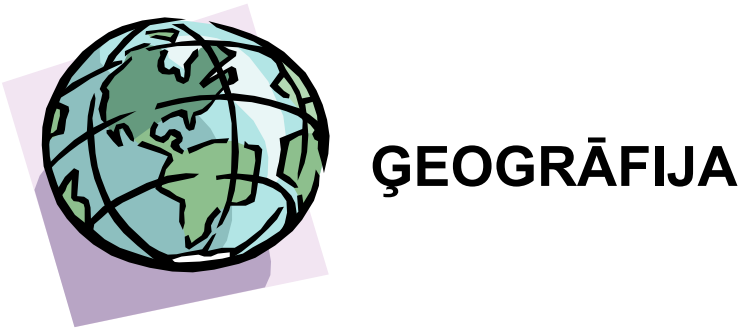

\title{
PIERĪGAS MAZO UPJU RAKSTUROJUMS
}

\author{
Elga APSīTE*, Ilga KOKORĪTE*, Ansis ZĪVERTS**, Māris KĻAVIN̦Š* \\ * - Latvijas Universitāte, Ģeogrāfijas un Zemes zinātņu fakultāte, \\ e-pasts: elga.apsite@lu.Iv \\ ** - Latvijas Lauksaimniecības universitāte, \\ Lauku inženieru fakultāte, e-pasts: aziverts@apollo.Iv
}

Pētījuma mērkis ir apkopot pieejamos hidroloǵiskos un hidroķīmiskos datus par trīs Pierīgas mazajām upēm - Mārupīti, Neriņu un Ķekaviņu, un veikt šo upju hidroloǵisko un hidroḳimisko raksturojumu. Neriņa, Mārupīte un Ķekaviņa atrodas Rīgavas un Tīrel̦u līdzenumā, kur smiltāji mijas ar purviem. Gada nokrišņu daudzums ir $600-650 \mathrm{~mm}$. Neriña ir $18 \mathrm{~km}$ gara, ietek Babītes ezerā, sateces baseina laukums $-74 \mathrm{~km}^{2}$. Mārupīte un Kekaviņa ir Daugavas kreisā krasta pietekas. Mārupītes baseina laukums ir $32 \mathrm{~km}^{2}$ liels, bet Ķekaviṇai - $186 \mathrm{~km}^{2}$. Upju relatīvais kritums ir neliels līdz $1 \mathrm{~m} / \mathrm{km}$. 70. un 80.gados baseinos izveidotas mākslīgās drenāžas sistēmas.

Upju hidroloǵiskā režīma raksturošanai izmantots Latvijā izstrādātais un pielietotais hidrologiskais modelis METQ98 [1; 2; 3; 5]. Matemātiskajam modelim kā ieejas dati izmantoti atmosfēras nokrišņu, gaisa temperatūru un gaisa mitruma deficīta novērojumi (diennakts summas un vidējie) Rīga-Universitāte meteorologiskajā stacijā. Abiem upju sateces baseiniem izdalīi trīs galvenie teritoriju veidi: smiltāju zemes; mežu teritorijas un purvi. Kā modeļa izejas dati iegūti simulētie ikdienas caurplūdumi Mārupītei, Neriņai un Ķekaviņai no 1924. gada līdz 2004. gadam. Matemātiskais modelis kalibrēts, balstoties uz NeriņaPiņki hidrologisko posteni par 17 gadu periodu (1981.-1997.).

No 2002.gada maija līdz 2003.gada aprīlim un 2005.gadā ņemti ikmēneša ūdens paraugi Neriņas upē pie Piņ̧u tilta un Mārupītē trijās vietās: augšpus un lejpus Māras dīķa un augšpus tās ietekas Daugavā, un Ķekaviņai augšpus un lejpus Ķekavas (tikai 2005.gadā). Latvijas Universitātes Ģeogrāfijas un Zemes zinātñu fakultātes Vides kvalitātes monitoringa laboratorijā veiktas ūdens paraugu analīzes šādiem parametriem: $\mathrm{N}-\mathrm{NO}_{3}{ }^{-}, \mathrm{N}-\mathrm{NO}_{2}{ }^{-}, \mathrm{N}-\mathrm{NH}_{4}{ }^{+}, \mathrm{N}_{\mathrm{kop}}, \mathrm{P}-\mathrm{PO}_{4}{ }^{3-}, \mathrm{P}_{\text {kop }}$, 
$\mathrm{Si}_{\text {kop }}, \mathrm{Cl}^{-}, \mathrm{Ca}^{2+}, \mathrm{Mg}^{2+}, \mathrm{K}^{+}, \mathrm{Na}^{+}, \mathrm{HCO}_{3}{ }^{-}, \mathrm{SO}_{4}{ }^{2-}$, kopējā cietība, EVS, ĶSP, BSP ${ }_{5}, \mathrm{O}_{2}$ un ūdens krāsainība. Pētījumā analizēts Mārupītes, Neriņas un Ķekaviņas ūdens ķīmiskais sastāvs un kvalitāte.

Upju izneses (slodzes) aprēksinātas, izmantojot modeli FLOWNORM 1.0 [4].

LandCorine 2000 datu bāze izmantota, lai analizētu zemes apauguma raksturu pētāmajos upju baseinos.

\title{
Literatūra
}

1. Zīverts, A., Jauja, I. (1999) Mathematical Model of Hydrological Processes METQ98 and Its Applications, Nordic Hydrology, Vol. 30 (2), pp. 109-128.

2. Zìverts, A., Apsìte, E. (2001) Watershed Modelling of the Lake Burtnieks in the Present Conditions and Considering the Effect of Climate Change. $9^{\text {th }}$ International Conference on the Conservation and Management of Lakes. Conference Proceeding Sessions 5.5 B-P-31 Biwako, Japan, 292-295.

3. Zīverts, A., Apsīte, E. (2001) Noteces matemātiskā modelēšana Burtnieka un Lubāna ezeru sateces baseiniem. Geogrāfiski raksti (Folia Geographica) IX. Krauklis, A. (red.), Latvijas ġeogrāfijas biedrība (Societas Geographica Latviensis), Rīga, 11.-19.lpp.

4. Grimvall, A. (2002) FLOWNORM 1.0 - a Visual Basic Program for Computing Riverine Loads of Substances and Extracting Antropogenic Signals from Time Series of Load Data. User's Manual. Linkoping University, Department of Mathematics, $15 \mathrm{pp}$.

5. Apsīte, E., Kokorīte, I., Zīverts, A., Kḷaviņš, M. (2004) Izmantojamie noteces aprēķini Latvijas nemonitorētajām mazajām upēm (Neriņas un Mārupītes piemēri). LU 62. Zinātniskā konference, Vides zinātnes sekcijas tēzes, Rīga, 189.-190. lpp

\section{ATSEVIŠĶU SŪNU SUGU IZPLATĪBAS ĪPATNĪBAS LATVIJĀ}

\author{
Austra ĀBOLIN̦A \\ Latvijas Valsts Mežzinātnes institūts "Silava", \\ e-pasts: austra@silava.Iv
}

Pirmās ziņas par atsevišķu sūnu sugu izplatības īpatnībām Latvijā, to piederību dažādiem ǵeogrāfiskajiem elementiem sastopamas jau 20.gs. sākumā prof. K.Kupfera un prof. N.Maltas darbos. Vēlāk, sākot ar pagājušā gadsimta 50.gadiem, sūnu vākumi turpinājušies un paplašinājušies. Tajos piedalījušies sūnu floras pētnieki, ǵeobotāniķi, mežkopji, studenti un dažādi interesenti. Kartējot atradnes Latvijā vairākām sugām ar rietumu un austrumu izplatību (š̄is sugas sevišksi atkarīgas no gaisa mitruma daudzuma), gūta iespēja pārskatīt, papildināt un aktualizēt dažas līdzšinējās atzin̦as. Šajā darbā ar pateicību izmantojām arī B.Bambes, B.Laimes, L.Liepiņas, I.Rērihas, U.Suško, I.Vaivades, E.Vimbas un vairāku citu personu nepublicēto vākumu datus.

Latvijas sūnu florā par sugām ar rietumu izplatību atzīstamas nokarenā stardzīslene Antitrichia curtipendula, sīklapu krokvācelīte Aulacomnium androgynum, trejdaivu bacānija Bazzania trilobata, tamariska frulānija Frullania tamarisci, zilganā baltsamtīte Leucobryum glaucum, tīrā zal̦kāte Scleropodium purum, viengada skrajlapīte Mnium hornum, blīvais sfagns Sphagnum compactum. Vērojams, ka vairākām no minētajām sugām atradnes atrodas ne vien 
valsts rietumu daḷā, bet arī lielo upju (Daugavas un Gaujas) baseinos, līdzīgi kā daudzām vaskulāro augu sugām ar rietumu izplatību. Turpināmi pētījumi par sūnu purvu sugas smalkā sfagna Sphagnum tenellum izplatību Latvijā, kuru N.Malta un J.Strautmanis(1926) arī min pie rietumu sugām, bet kura izplatība vēl pagaidām apzināta nepietiekoši. Krievu briologi M.Ignatovs un O.Afoṇina (1992) šai sugai min plašu sastopamību uz austrumiem no Latvijas: Baltkrievijā, Krievijas Eiropas dal̦ā un ziemel̦austrumos (Arhangel̦skas apgabalā un Komi republikā), taču tā noslēdzas pie Urāliem un turpinās tikai Tālajos Austrumos. Joprojām Latvijā tikai atsevišķkas atradnes ir tādām retajām rietumu sugām, kā zaļajai buksbaumijai Buxbaumia viridis, Baumgartnera un košzaļajai pārzobei Zygodon baumgartneri, Z viridissimus, mīkstajam un jumstinu sfagnam Sphagnum molle, Sphagnum imbricatum, lapsastu krūmītei Thamnobryum alopecurum, starainajai pumpurzarītei Cephaloziella stellulifera (pēdējo sugu 2003.gadā kāpās pie Užavas grīvas atradusi B.Laime). 1998.gadā pirmoreiz Latvijā konstatēta viļnainā şķ̄ibvācelīte Plagiothecium undulatum, kuras līdzšinējās atradnes ir vienīgi Kurzemē (I.Vaivades, L.Liepiṇas un I.Rērihas vākumi). Bez tam, kā jau esam minējuši (Āboliņa, Rēriha, 2004), 2002.gadā Latvijā atrasta agresīvā adventīvā tropu suga parastā līklape Campylopus introflexus (Dicranaceae), kura izplatās no rietumu valstīm. Tās atradnes pagaidām arī ir vien̄igi Kurzemē (I.Rērihas vākumi). Otra agresīvā dienvidu puslodes sūnu suga Orthodontium lineare (Bryaceae), kura Eiropā izplatās līdzīgi parastajai līklapei un jau pienākusi tuvu Latvijas rietumu robežai, pie mums vēl nav reǵistrēta.

Austrumu izplatība pagaidām apstiprinājusies vienīgi Haldana dažādlapei Callicladium haldanianum un bālganajam hipnam Hypnum pallescens.

Jāatzīst, ka arī mūsdienās nav atrisināts jautājums par sūnu rietumu un dienvidu izplatības sugu atšķiršanu. Tas veicams plašākā un dziḷākā skatījumā. Šādas grūtības minējuši jau N.Malta un J.Strautmanis savā 1926.gada darbā.

\section{Atsauces}

Āboliṇa, A., Rēriha, I. 2004. Papildinājumi Slīteres nacionālā parka sūnaugu florai. LU 62.zinātniskā konference. Geogrāfija. Geologija. Vides zinātne. Rīga: 14-16.

Ignatov, M.S., Afonina O.M. 1992. Check-list of mosses of the former USSR. Arctoa, vol.1. (1-2), KMK Scientific Press Ltd, Moskow: 1-85.

Malta, N., Strautmanis, J. 1926. Übersicht der Moosflora des Ostbaltischen Gebietes I. (Allgemeine Bemerkungen und Lebermoose). Acta Horti Bot.Univ.Latv., I, Nr.2. Rīga: 115-142. 


\title{
PADOMJU KULTŪRAS MANTOJUMA SAGLABĀŠANA UN IZMANTOŠANA TŪRISMĀ LATVIJĀ
}

\author{
llgvars ĀBOLS \\ Vidzemes augstskola, e-pasts: ilgvars.abols@va.Iv
}

Pēc PTO prognozēm, nākotnē pieaugs pieprasījums pēc kultūras tūrisma produktiem. Galvenie šo produktu grupas pircēji ir trešās paaudzes pārstāvji, kuru skaits Eiropā strauji pieaug. Pēc Latvijas iestāšanās Eiropas Savienībā arvien palielināsies tūristu skaits no šīm valstīm, tāpēc būtiski valstiskā līmen̄i ir domāt, kādus atšķirīgus kultūras tūrisma produktus Latvija var piedāvāt. No ES valstīm padomju perioda iezīmes salīdzinoši maz sastopamas Polijāa Čehijā un citās Austrumeiropas valstīs. Nesalīdzināmi bagātāks šis mantojums ir Baltijas valstīs. Rietumeiropas tūristiem par šo periodu Latvijā ir lielāka interese nekā par citiem vēsturiskiem periodiem. Padomju periodu nevar izslēgt no Latvijas kultūrvēsturiskā mantojuma, kas daudzviet vēl saglabājies kultūrainavā, bet lēnām un neatgriezeniski sāk aiziet nebūtībā. Vēl daudzviet var atrast, bet arī to skaits samazinās, sadzīves priekšmetus, mēbeles un citas lietas, kas raksturīgas piecdesmitajiem, sešdesmitajiem, septiņdesmitajiem un astoņdesmitajiem gadiem. Tas ir periods, ko nevar izgriezt kā nebijušu, un tā vispusīgai atspoguḷıšanai nepietiek ar Okupācijas muzeju.

Norobežojoties no politiskiem lozungiem, Latvijā ir jāsāk valstiska programma padomju perioda kultūras mantojuma (nevis ideoloğijas) saglabāšanai. To varētu balstīt uz divām darbībām:

$\checkmark$ Pirmkārt, visā Latvijas teritorijā jāapzina š̄ perioda interesantākie un raksturīgākie arhitektūras veidojumi un jāpiešķir tiem valsts aizsargājamo kultūras pieminekḷa statuss, kas aizsargātu tos no pārbūves un rekonstrukcijas;

$\checkmark$ Otrkārt, jāveido Latvijas Etnogrāfiskā brīvdabas muzeja padomju perioda filiāle. Filiāles izveides ideja saskan gan ar arhitekta Kundziņa 1932. gadā definēto muzeja misiju: "Brīvdabas muzejs grib sakopot mūsu tautas kultūras darinājumus tādā sakarībā, kādā tie radušies un lietoti pagājušajos laikos - kopainās uzglabāt sendienu dzīves redzamo saturu, kas ietverts celtnēs, vinu apkārtnē un sakārtojumā, telpu iekšèjā izveidojumā, iedzīves un darba piederumos." (Latvijas Etnogrāfiskais brīvdabas muzejs 2004., ER), gan ar to, kā šāda veida muzeji attīstās citur pasaulē, piemēram, „Norsk Folkmuseum” Oslo vai Maihaugena brīvdabas muzejs Lillehammerā, kur izveidotas divdesmitā gadsimta ekspozīcijas.

Filiāli labāk būtu veidot ārpus Rīgas, vietās, kuras radušās padomju periodā. Vidzemē piemērotas vietas ir Sedas pilsēta vai Zilākalna pagasta centrs Zilaiskalns, bet tā var atrasties arī cituviet Latvijā. 


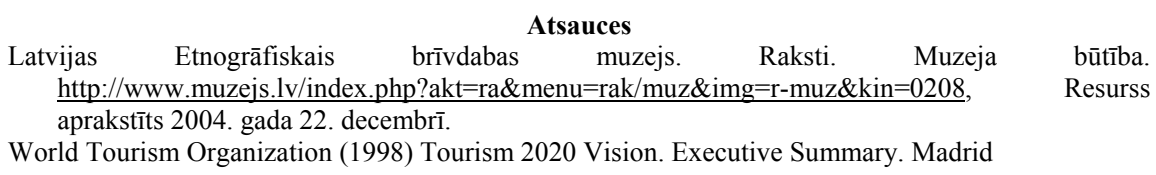

\section{AUGI UN BIOTOPI DABAS LIEGUMĀ “VESETAS PALIENES PURVS”}

\section{Baiba BAMBE \\ LVMI "Silava", e-pasts: baiba@silava.Iv}

Dabas liegums "Vesetas palienes purvs" atrodas Austrumlatvijas zemienes Aronas paugurlīdzenuma Vesetas-Aronas pazeminājuma ZR daḷā, kas stiepjas gar Vidzemes augstienes D nogāzi. Liegums izveidots 1999.gadā ap 130 ha platībā Aizkraukles rajona Aiviekstes un Vietalvas un Madonas rajona Kalsnavas pagastu teritorijā. Palienes purva veǵetācija šeit novērota kopš 20.gs. 70.gadiem, veicot botāniskus pētījumus Vesetnieku meža ekoloǵijas stacionārā (A.Āboliņa). Purvam blakus esošajos mežos 1999.gadā veikta dabisko meža biotopu inventarizācija, un, pamatojoties uz tās rezultātiem, ierosinātas lieguma robežu izmaiņas, lai pievienotu aizsargājamai teritorijai līdzās esošos slapjos un nosusinātos mežus, kuri atbilst dabisko mežu biotopu kritērijiem vai veido vienotu purvu un slapjo mežu kompleksu. Lai pilnīgāk aptvertu palieni pa dabiskajām robežām, 2003.gadā liegums paplašināts DR virzienā, iekḷaujot Eziššlas mežu un aizaugošās slapjās pḷavas ap to.

Lieguma izveidošanas mērķis ir retu augu sugu un biotopu aizsardzība. Lielākās platības aizṇem pārejas un zāḷu purvi, palieņu pḷavas, slapjie meži. Sugu un biotopu daudzveidību palielina ūdeñi un krastmalas - Veseta un tās vecupes, mežu avoksnāji, kā arī atsevišķi nosusināto mežu nogabali. Sausieņu meži sastopami tikai nelielās platībās uz minerālzemes salām purvos un slapjos mežos.

Zāḷu purvu un palieņu pļavu veǵetāciju veido parastās niedres un augsto grīšlı sabiedrības no klases Phragmiti-Magnocaricetea. Valdošās sugas ir Phragmites australis, Carex acuta, C. appropinquata, C. cespitosa. Atzīmēta arī loti reta suga, kas Latvijā sasniedz areāla R robežu - Carex atherodes.

Pārejas purvi tuvāki klases Scheuchzerio-Caricetea veǵetācijai, kur bieži sastop Menyanthes trifoliata, Peucedanum palustre, Carex chordorrhiza, C. diandra, Sphagnum warnstorfii, Calliergonella cuspidata, bet cinos raksturīgas arī sugas no klases Oxycocco-Sphagnetea - Oxycoccus palustris, Drosera rotundifolia, Aulacomnium palustre. Ar niedrēm aizaugošā pārejas purvā konstatēta viena no lielākajām Eiropas nozīmes sugas dzeltenās akmeņlauzītes Saxifraga hirculus populācijām Latvijā, atzīmētas vairākas aizsargājamās orhidejas - Liparis loeselii, Corallorhiza trifida, Dactylorhiza russowii, Gymnadenia conopsea, Hammarbya paludosa. Retās un aizsargājamās sūnas pārejas purvu zemsedzē ir Hamatocaulis vernicosus, Paludella squarrosa, Lophozia rutheana. 
Slapju, oligotrofu priežu mežu veǵetācija no klases Vaccinetea uliginosi ir tuva sūnu purviem, zemsedzē dominē Eriophorum vaginatum, Vaccinium uliginosum, Ledum palustre, Sphagnum angustifolium, S. magellanicum. Periodiski pārplūstošiem melnalksnājiem no klases Alnetea glutinosae raksturīgs ciņains mikroreljefs, zemsedze līdzịga zāḷu purvu augsto grīšlı sabiedrībām un upju krastmalām - Carex appropinquata, C. cespitosa, Calamagrostis canescens, Thelypteris palustris, Phalaroides arundinacea. Liegumam raksturīgi floristiski bagāti jauktu koku niedrāji, kur koku stāvā dominē priede un egle, bet sastop arī melnalksni un purva bērzu. Zemsedze daudzveidīga, bet bez izteiktiem dominantiem - sastop gan klases Vaccinio-Piceetea sugas Vaccinium myrtillus, $V$. vitis-idaea, Moneses uniflora, Pleurozium schreberi, Hylocomium splendens, gan Alnetea glutinosae klasei raksturīgo Calamagrostis canescens, kā arī Crepis paludosa, Cirsium oleraceum, Geum rivale no mezofìto un higrofìto zālāju klases Molinio-Arrhenatheretea. Jauktu koku niedrājā atzīmēta reta grīšlı suga, kas Latvijā aug tuvu areāla D robežai - Carex paupercula. Vietām sastopami arī mežu avoksnāji ar retām aknu sūnu sugām Trichocolea tomentella un Geocalyx graveolens.

Minerālzemes salās sastopami jaukti skujkoku sausieņu meži no klases Vaccinio-Piceetea, kuros veidojas dabiskas lauces. Zemsedzē dominē Pteridium aquilinum, Convallaria majalis, Melampyrum polonicum. Nosusinātos mežos kūdreṇos, kas robežojas ar palienes purvu, veǵetācija līdzīga kā sausieṇu mežos. Uz trupošas koksnes šeit sastop aizsargājamu aknu sūnu sugu Anastrophyllum hellerianum.

Lieguma flora nav pilnībā izpētīta, bet, veicot veǵetācijas pētījumus, atzīmētas ap 250 vaskulāro augu un vairāk nekā 90 sūnu sugas. Konstatētas vismaz 13 aizsargājamās vaskulāro augu un 7 aizsargājamās sūnu sugas. Teritorijā sastopami augstvērtīgi Eiropas nozīmes biotopi 6450 "Upju palieņu plavas", 6430 "Eitrofas augsto lakstaugu audzes", 7140 "Pārejas purvi un slīkšņas", 7160 "Minerālvielām bagāti avoti un avotu purvi”, 91D0 "Purvaini meži”. Fragmentāri atzīmēti biotopi 9080* "Melnalkšņu staignāji” un 9010* "Boreālie meži".

\title{
STARPTAUTISKĀS MIGRĀCIJAS REĢIONĀLĀS ATŠĶIRĪBAS LATVIJĀ
}

\author{
Andris BAULS, Zaiga KRIŠJĀNE \\ Latvijas Universitāte, Cilvēka ǵeogrāfijas katedra, \\ e-pasts: bauls@lanet.Iv, zkrisjan@lanet.Iv
}

Pēc migrācijas plūsmu un apjomu svārstībām 90.gados, kuras ietekmēja gan politiskie, gan sociāli ekonomiskie procesi, 1998.-2002.gadā starptautiskās migrācijas procesi ir nostabilizējušies un galvenokārt balstās uz endogēno 
migrācijas potenciālu, jo būtiski mazinājusies saikne ar NVS valstīm, lai gan ar šo valstu grupu joprojām ir saistīts lielākais ārējās migrācijas apgrozījums. Šajā periodā iezīmējās arī tendence, ka arvien vairāk pieaug migrācijas plūsmas uz Eiropas Savienības valstīm. Pievienošanās ES tiek vērtēts kā būtisks migrāciju ietekmējošs faktors. Iespējamās lielās iecel̦otāju plūsmas no jaunajām dalībvalstīm izraisa ne vien satraukumu ekonomiski labāk attīstīto valstu iedzīvotājos, bet arī atspoguḷojas valstu iecel̦ošanas nosacījumos kā noteiktajos ierobežojumos darba tirgū. Atšķirīgi tiek vērtēts ārzemēs dzīvojošo Latvijas iedzīvotāju skaits. Šis rādītājs svārstās no 20 līdz pat 50 tūkstošiem iedzīvotāju. Daudzi no Latvijas iedzīvotājiem strādā ārzemēs, tomēr precīzs to skaits nav zināms, jo daudzi iedz̄ivotāji nereǵistrējas kā ārzemēs strādājoši. Oficiālā statistika norāda, ka vidēji 1998.-2002.gadā izcel̦oja apmēram 4600 iedzīvotāju, bet iecelıjo no ārvalstīm gandrīz 1900 cilvēku.

Migrācijas intensitāte Latvijas reǵionos 1998.-2002.gadā

1.tabula

uz 1000 iedz̄ivotājiem ( LR CSP Demogrāfijas gada grāmatas 1999-2003)

\begin{tabular}{|l|c|c|c|c|c|c|}
\hline & \multicolumn{3}{|c|}{ Iekšējā migrācija } & \multicolumn{3}{c|}{ Starptautiskā migrācija } \\
\hline $\begin{array}{c}\text { Migrācijas } \\
\text { reğions }\end{array}$ & iebrauc & izbrauc & $\begin{array}{c}\text { Kopējais } \\
\text { apjoms }\end{array}$ & iebrauc & izbrauc & $\begin{array}{c}\text { Kopējais } \\
\text { apjoms }\end{array}$ \\
\hline $\begin{array}{l}\text { Rīgas } \\
\text { aglomerācija }\end{array}$ & 11 & 11 & 22 & 1,2 & 3,2 & 4,4 \\
\hline Lielrīga & 19 & 17 & 36 & 0,6 & 1,2 & 1,7 \\
\hline Viduslatvija & 18 & 20 & 38 & 0,5 & 0,8 & 1,3 \\
\hline Kurzeme & 15 & 15 & 30 & 0,4 & 1,3 & 1,6 \\
\hline Latgale & 17 & 18 & 35 & 0,6 & 1,3 & 1,9 \\
\hline Latvija & 15 & 15 & 29 & 0,8 & 2,0 & 2,8 \\
\hline
\end{tabular}

Aplūkojot reǵionālās atšķirības, redzam, ka lielākas gan iekšējās, gan starptautiskās migrācijas plūsmas ir Rīgas aglomerācijas centrālajai daļai (Rīga, Jūrmala Rīgas rajons). Savukārt, salīdzinot migrācijas intensitāti uz 1000 iedzīvotājiem, augsti rādītāji raksturīgi arī Latgalei.

Pastāvot krasi atšķirīgiem ienākumu līmeņiem un ekonomiskajai aktivitātei starp valsts galvaspilsētu, tās aglomerāciju un periferiālajiem reǵioniem, neizbēgami notiek pastiprināta iedzīvotāju pārcelšanās no lauku rajoniem uz pilsētām vai uz to piepilsētas zonu. Lauku rajonu salīdzinošā nabadzība un mūsdienu dzīves ritmam neatbilstošais sociālo kontaktu intensitātes līmenis ir spēcīgs atgrūšanas faktors lauku rajonos un pievilkšanas faktors pilsētām, it īpaši darbspējīga vecuma iedzīvotājiem. Kā nākamie migrācijas līmeṇi varētu būt darba meklējumi ārzemēs saimniecības nozarēs ar atšķirīgām kvalifikācijas prasībām. Diemžēl šīs plūsmas ne vienmēr tiek pilnībā aptvertas, tāpēc jāpieņem, ka patiesie migrācijas apjomi ir daudz lielāki, nekā to uzrāda oficiālie avoti. 


\title{
UPES VIDES STĀVOKĻA NOVĒRTËJUMS UN TĀ IETEKME UZ UPJU KVALITĀTI
}

\author{
Agrita BRIEDE ${ }^{1}$, Gunta SPRIN̦ĢE ${ }^{1}$, Agnija SKUJA ${ }^{2}$ \\ ${ }^{1}$ LU Ģeogrāfijas un Zemes zinātņu fakultāte, \\ e-pasts: Agrita.Briede@lu.Iv \\ ${ }^{2}$ LU Bioloǵijas institūts
}

Eiropas Parlamenta un Padomes Ūdens struktūrdirektīva 2000/60/EC nosaka rīcību ūdeñu aizsardzības politikas jomā, paredzot, ka ūdens ekoloǵiskās kvalitātes novērtēšanā izmantojamas ne tikai dažādas organismu grupas (zivis, augstākie augi, fitobentoss un bentiskie bemugurkaulnieki), bet arī analizējami ūdens hidromorfologiskie, fizikālie un k̦īmiskie rādītāji, kuri raksturo abiotisko vidi un ietekmē biotopu daudzveidību. Šajā sakarā, lai novērtētu vides ekologisko kvalitāti, svarīgi ir noteikt, kāda ir biocenožu dabiskā mainība un to mainība antropogēni ietekmētos apstākḷos. LU Biologijas institūta Hidrobiologijijas laboratorijai, piedaloties 5.satvara programmas projektā "Upju klasifikācijas standartizācija: struktūras metode dažādu biologisko apskatu rezultātu kalibrēšanai atbilstoši ekoloǵiskās kvalitātes klasifikācijai, izstrādātai Ūdens Struktūrdirektīvas vajadzībām", tika veikti pētījumi 15.Baltijas ekoreǵionā un analizēti iepriekš minētie faktori. Šajā pētījumā tiks atspoguḷoti rezultāti par upēm ar dažādu ekologisko kvalitāti un skatīta to saistība ar vides hidromorfologíiskajām iezīmēm.

Upju vides pētijumu metode (River Habitat Survey), kas tika lietota morfologiisko apstākḷu novērtěšanai, ir izstrādāta Lielbritānijā un kopumā ir atbilstoša izmantošanai Latvijas apstākḷlos. Ķīmiskie rādītāji tika izvēlēti pēc vietas protokolā noteiktajiem (site protocol) prasībām, un pēc tiem netieši var spriest par upes ǵeoķīmisko fonu un antropogēno ietekmi.

Pētījumam tika izvēlētas 24 upes, kas pēc vispārpieņemtās klasifikācijas atbilst vidēja mēroga zemieņu upēm, kurām sateces baseina platība $\geq 100 \mathrm{~km}^{2}$. Vairums upes pēc Štrēlera sistēmas atbilst 2.pakāpei (1:50 000) un tikai četras 3.pakāpei. Pēc hidrologiskajām iezīmēm (izņemot 2 upju posmus) tās ir pieskaitāmas ritrāla upju tipam ar straumes ātrumu $>2 \mathrm{~m} / \mathrm{sek}$. Izmērītais caurplūdums laika periodā no vēla pavasara līdz agrai vasarai variēja no $0,2 \mathrm{l} \overline{\mathrm{d}} \mathrm{dz}$ $3,3 \mathrm{~m}^{3} / \mathrm{sek}$. Kopumā 15 pētitajos upju posmos antropogēnā ietekme ir zema (galvenokārt difūzais organiskais piesārņojums), 9 upes atbilda augstai kvalitātei un ir uzskatāmas kā references vietas. Dominējošais substrāta tips - smilts, oḷi un grants gan neskartajos, gan antropogēni ietekmētajās upēs. Kā parāda RHS metodes rezultāti, raksturīgs ir vienkāršs (2-3 veǵetācijas tipi) krasta nogāzes veǵetācijas veids. Pēc RHS veidlapas datiem tika aprēķināti 2 indeksi - vides kvalitātes novērtēšanas indekss - HQA (Habitat Quality Assessment) un Vides modifikācijas indekss HMS (Habitat Modification Index). HAQ indeksa vērtības variē no 24 līdz $69(\mathrm{p}<0,01,95 \%)$ un vidējā vērtība - 53,2 tiek pārsniegta 58\% gadījumu. 
References vietām šì vērtība mainās no 43 līdz 64 (vidēji 55,9), bet antropogēni ietekmētām vietām no 24 līdz 69 ar vidējo vērtību 51,9. HMS indekss mainās robežās no 1 līdz 4. Visām 24 vietām vidējā vērtība ir 3,3 (p<0,01, 95\%), references jeb augtas kvalitātes vietām vidējā vērtība ir 1.8, bet antropogēni ietekmētiem upju posmiem - 4,2, kas pēc klasifikācijas atbilst dabiskām (neskartām) vai dal̦ēji dabiskām upēm. Saprobitātes indekss, kas tika noteikts pēc makrozoobentosa biocenozēm, starp pētītajiem upju posmiem variēja no 1,64 līdz 2,15 un pēc pieņemtās klasifikācijas 12 upes posmi atbilda augstai vai labai kvalitātei (saprobitātes indekss $\leq 1,8$ ) un 12 - vidējai kvalitātes klasei.

Kopumā zemāks saprobitātes indekss tika novērots upēm ar augstāku HQA indeksu $(\mathrm{r}=-0,49 ; \mathrm{p}=0,04)$. Veiktie pētījumi arī apstiprināja, ka šīm izvēlētajām antropogēni ietekmētajām un neskartajām upju vietām nav būtiskas atšķirības pētīto parametru vidē.

\title{
LATVIJAS APDZĪVOTO VIETU TERITORIĀLO PLĀNOJUMU ARHITEKTONISKI TELPISKĀS NOSTĀDNES
}

\author{
Jānis BRIŅĶı \\ Rīgas Tehniskā universitāte, Arhitektūras un pilsētplānošanas fakultāte, \\ e-pasts: brinkis@bf.rtu.Iv
}

Teritoriāli telpiskā plānošana Latvijā ir mainījusies un evolucionējusi līdz ar pārējiem sabiedrības sociāliem un ekonomiskiem attīstības procesiem. Republikas atjaunotnes 13 gados vairākkārt ir mainīti un papildināti Ministru kabineta noteikumi šai jomā. Taču teritoriālās vides plānošanā vienmēr būs galvenās komponentes, kuras veido plānošanas pamatu, tā nostādnes. Tās paliks nemain̄̄gas neatkarīgi no valsts politikas, sociāli ekonomiskās situācijas un no institucionālā aparāta darbības.

Pie šādām nostādnēm pieskaitāmas:

$$
\begin{array}{ll}
\checkmark & \text { Teritorija - vide; } \\
\checkmark & \text { Apdzīvojuma struktūra - apbūve; } \\
\checkmark & \text { Transporta sistēma - cel̦i. }
\end{array}
$$

Šo nostādṇu nesaraujamā trīsvienība ir līdzsvarojošais pamats ilgspējīga teritoriāli funkcionāla un telpiska plānojuma pakārtotām komponentēm, arī mērķtiecīgai arhitektoniski telpiskai sakārtotībai.

Eiropas Savienības valstu satvarā republikas teritorija ir salīdzinoši neliela $(64,6$ tūkst.km²) un sociālekonomiski tiek uztverta kā viens regions, kurā ir sava regionāli vienota teritoriāla apdzīvojuma funkcionāli telpiska struktūra.

Latvijas dabīgā ainava kā pilsētu un lauku apdzīvojuma galvenā komponente teritoriālā plānošanā jāaplūko ne tikai no dabas aizsardzības, bet arī no teritorijas iedzīvotāju, apmeklētāju, tūristu plūsmu savstarpējās mijiedarbības aspekta. Pievilcīgai un līdzsvarotai dabas, dzīves, darba un atpūtas vides 
veidošanai teritoriālajos attīstības plānojumos ierādāma nozīmīga vieta. Vides reljefa, ūdens objektu, veǵetācijas īpatnību ievērošana un izmantošana ir viena no pamatnostādnēm ainavu projektēšanas un dabas aizsardzības jomā.

Latvijas Republikas administratīvi teritoriālais iedalījums XX gs.

\begin{tabular}{|l|c|c|c|c|c|c|}
\hline & 1935 & 1959 & 1970 & 1979 & 1989 & 2000 \\
\hline Rajoni (apriņki) & 19 & 45 & 26 & 26 & 26 & 26 \\
\hline Pilsētas & 60 & 56 & 56 & 56 & 56 & 77 \\
\hline To skaitā & & & & & & \\
\hline $\begin{array}{l}\text { Republikas } \\
\text { pilsētas }\end{array}$ & 1 & 6 & 7 & 7 & 7 & 7 \\
\hline Rajonu centri & 19 & 40 & 26 & 26 & 26 & 26 \\
\hline Pilsētciemati & - & 34 & 35 & 36 & 37 & - \\
\hline Pagasti & 517 & 649 & 539 & 481 & 465 & 481 \\
\hline
\end{tabular}

Avots: Latvijas 2000. gada Tautas skaitīšanas rezultāti.

Latvijas Republikas Centrālā statistikas pārvalde, 2004

Republikas apdzīvojuma struktūrā eksistē hierarhiski izteikts pilsētu un lauku apdzīvojuma kopums. Iedzīvotāju teritoriālā organizācija jau vēsturiski ir veidojusies uz:

1) attīstîtām monocentriskām, sazarotām policentriskām, lineārām vai šo sistēmu kombinētām struktūrām, kurās izveidojušies dažādas ietekmes apkalpes centri - pilsētas, ciemati un miesti ar atbilstošu, savam laikam optimālu visizdevīgāko sasniedzamību;

2) dažāda mēroga un specifisku lauku saimniecību teritoriju disperso apbūvi ar viensētām, viensētu grupām;

3) dažāda rakstura ražotņu teritoriāli lokālu izvietojumu;

4) galvenā un pakārtotā transporta tīklu kā teritoriālā apdzīvojuma režǵa sasaistes satvaru;

5) apdzīvoto vietu vairāk vai mazāk sakārtotām iekšējām un ārējām inženiertehniskām infrastruktūrām;

6) saglabātu vienojošu dabīgo vidi ar plašām apmežotām un atklātām lauksaimnieciskām teritorijām, ainaviski izteiksmīgu vidi sabiedrības atpūtai un tūrismam.

Mūsdienu teritoriālās plānošanas pamatnostādne tiek saistìta ar līdzsvarotu un ilgspējīgu pilsētu un lauku vienotu kompleksu apdzìvojuma tīkla harmonisku veidošanu. Apdzīvotības kompleksā jāpastāv ciešām funkcionālām, sociāli ekonomiskām saitēm visa veida apbūves, ražošanas, apkalpes, transporta, inženiertehniskās infrastruktūras, rekreatīvās telpas optimāli sakārtotā līdzsvarotā zonējumā.

Šodien strukturāli augstāko pakāpi grupveida apdzīvotības sistēmā veido galvaspilsēta Rīga ar savu administratīvā rajona telpisko struktūru. Minētajā struktūrā dzīvo 892,5 tūkst. jeb $38 \%$ no visas republikas iedzīvotājiem. Te 
izveidojies republikas telpiskā satvara transporta mezgls un visu līmeņu apkalpes iestāžu komplekss. Mūsdienu zemāko pakāpi kompleksā - grupveida apdzīvotības sistēmā veido lauku pagasti ar primāro administratīvo teritoriālo pašvaldību, kuru teritorijām tiek izstrādāti primārie teritoriālie attīstības projekti un detāliplānojumi.

Teritoriālās reformas gaitā tuvākā perspektīvā Nacionālā plānojuma ietvaros sāks veidoties un nākotnē iegūs administratīvu statusu vēl viena augstākās pakāpes kompleksā apdzīvotības sistēma - Rīgas aglomerācija, kura savā tieces laukā jau iekḷauj tuvākos rajonus un to centrus - Tukumu, Jelgavu un Ogri. Šādā šissdienas sociāli ekonomiskā un iedzīvotāju migrējošā apritē dzīvo un strādā 1113,5 tūkst. iedzīvotāji jeb 47\% republikas iedzīvotāju.

Teritoriālā plānojuma sociālo un ekonomisko, kā arī arhitektoniski būvniecisko, inženiertehnisko, ainavisko, sanitārtehnisko pasākumu kompleksa realizācija vienotā pilsētbūvnieciskā vidē tiek uzsākta ar teritoriju zonējumiem. Pie zonējumu galvenajiem plānošanas elementiem jāpieskaita dzīvojamās, ražošanas, transporta, centru, zal̦o stādījumu, rekreāciju, dabas liegumu un inženiertehnisko komunikāciju teritorijas. Šo teritoriju savstarpējā mijiedarbība veido zonētās teritorijas pilsētbūvniecisko struktūru, tās telpisko kompozīciju. Līdz ar to teritoriālos plānojumos pagastā, rajonā un aglomerācijā visu pilsētbūvniecisko elementu kompozīcija, tās pilnveidošana ir viena no teritoriālās plānošanas rezultējošām sastāvdaḷām. Projektējamā nacionālā līmeņa vienotās arhitektoniski telpiskās sistēmas visaugstākā pakāpe iekḷauj sevī visas telpiski kompleksās grupveida struktūras.

Latvijas apdzīvotības sistēmas pārmantotie 26 administratīvie rajoni pēc sava teritoriālā lieluma ir sabalansēti. Rajonu centri šodien veido apdzīvojuma sistēmas galvenos satvara režğa mezglus. Apdzivotības sistēmā dominē 7 republikas pakḷautības un 20 rajona centru pilsētas. Kopā ar pārējām 50 pilsētām tās veido funkcionāli telpisku republikas apdzīvotības sistēmas balsta režği ar vidējo teritoriālo areālu $839 \mathrm{~km}^{2} \quad(28 \times 28 \mathrm{~km})$. Republikas 483 administratīvie pagasti, tāpat kā rajoni, ir teritoriāli līdzsvaroti, un to vidējais lielums nepārsniedz $250 \mathrm{~km}^{2} \quad(16 \times 16 \mathrm{~km})$. Pagastu teritoriālā vienība šo pamatbalsta režği papildina ar starppagastu 111 pilsētbūvnieciski strukturāli attīstîtiem lielciemiem, kuros iedzìvotāju skaits ir visai dažāds - 5000 līidz 10000 iedzīvotāju (Ķekava, Ādaži, Carnikava, Iecava u.c.). Lielciemi šodien veido lauku teritoriju zonālos centrus. Kopā ar mazpilsētām lielciemi lauku apdzīvojuma sistēmas satvarā ir galvenie mezgli, un savā apritē tie iekḷauj $343 \mathrm{~km}^{2}$ $(18,5 \times 18,5 \mathrm{~km})$ republikas teritorijas.

Apdzīvotības sistēmas lauku teritoriju 6268 ciemi un ciemati, kā arī 77 pilsētas, ir tas funkcionāli un arhitektoniski telpiskais loks, kurā organiski iekḷaujas plaša lauku saimniecību viensētu apbūve kā republikas ainaviskās telpas organiska sastāvdaḷa. Šodien republikas pagastos aug un attīstās tautsaimnieciski ražotspējīgas lauku saimniecību viensētas vidēji 100-150 pagastā. 
Republikas teritorijas 26 rajoni ar dominējošiem reǵionāliem centriem un pakārtotiem apakšcentriem nodrošina republikas apdzìvojuma hierarhijas sistēmā pilsētu un lauku iedzīvotājiem optimālu kā sociālās, tā arī ekonomiskās un arhitektoniski telpiskās vides vienotību, kā arī nepieciešamo vajadzību apmierināšanu visos apkalpes līmeņos - ikdienas, periodiskajā un epizodiskajā. Apdzīvoto vietu apbūves kompleksu arhitektoniski vēsturiskais mantojums ir bāze, kura organiski jāiesaista vides reǵionālās arhitektūras attīstībā. Lai izveidotu un nostiprinātu sociālekonomiski un arhitektoniski-telpiski ilgspējīgu harmonisku pilsētu un lauku dzīves vidi, neatkarīgi no tās lieluma visā republikas teritorijā jāizveido jaunas teritoriālās struktūras, kuru formēšana jāsaista ar attīstības cikliem, kas atspogulı strukturāli vienojošo kompleksu mūsdienu attīstības procesus.

Plānojot teritoriju attīstības perspektīvas, ir jārēķinās gan ar tuvāko, gan ar tālākiem periodiem, izvirzot katram no tiem atbilstošus darbības mērḳus un prioritātes. Attīstības mērķi jāsaista ar apdzīvotības sistēmas log̣isku integrēšanos vēsturiski veidotās tradicionālās struktūrās ar dominējošiem republikas novadu un rajonu regionāliem centriem.

Plānojot un realizējot perspektīvās teritoriālreformas, kas saistās ar atsevišķu pagastu un pilsētu apvienošanos, jārēķinās ar ekonomiskiem un arhitektoniski telpiskiem sakariem, kas vēsturiski izveidojušies, kā arī ar kritērijiem jaunas telpiskās kvalitātes realizācijas noteikumiem arī Eiropas Savienības valstīs.

\title{
POMERĀNIJAS VĪTOLA (SALIX POMERANICA WILLD) IZPLATIIBA LATVIJĀ
}

\author{
Pēteris EVARTS - BUNDERS \\ Daugavpils Universitāte, e-pasts: dendroflora@nbd.apollo.Iv
}

Vītolu ǵints Daphnella sekcija ir neliela, labi norobežota, tās pārstāvji sastopami Eirāzijas boreālajā daḷā. No sekcijas sugām Latvijā sastopamas trīs $(S$. acutifolia, $S$. daphnoides un $S$. pomeranica), kā arī vairāki iekšsugas taksoni, hibrīdi un dekoratīvās šķirnes. Sekcijas taksonu noteikšana izsenis radījusi grūtības izplūdušo sugu morfologisko robežu dēḷ. Literatūrā visas minētās sugas vai nu apvieno vienā $S$. daphnoides s.l., vai izdala divas $-S$. acutifolia un $S$. daphnoides. Analizējot Latvijā un kaiminvvalstīs ievākto herbārija materiālu, Nacionālajā Botāniskajā dārzā augošos eksemplārus, kā arī veicot pētījumus dabā, nonācām pie slēdziena, ka pamatota ir $S$. pomeranica izdalīšana patstāvīgas sugas rangā.

Pomerānijas vītols atšķiras no līdzīgā smilšu vìtola ( $S$. daphnoides) ar īsākām, šaurākām, galā strauji nosmailotām lapām. Jaunie dzinumi ap $2 \mathrm{~mm}$ resni ar balti zīdainiem matiniem, pie tam jaunais dzinums un lapas matainas $5-10 \mathrm{~cm}$ garumā. Spurdzes plaukst agrāk par lapām, uz dzinumiem novietojas l̦oti blīvi. 
Jāpiezīmē, ka Pomerānijas vītols ir autohtona Latvijas floras suga atšķirībā no $S$. daphnoides, kas ir ievesta no Centrāleiropas, un jau no 19.gadsimta sākuma izmantota apstādījumiem - galvenokārt kāpu nostiprināšanai, un no turienes plaši pārgājusi savval̦ā.

Suga izplatīta Baltijas jūras dienvidaustrumu un austrumu krastā. Igaunijā sastopama lokāli, galvenokārt dienvidaustrumu dạ̦ā Gaujas baseinā, Lietuvā tikai rietumu dạ̧ā, reti. Izplatības galējā dienvidu robeža sniedzas līdz Kaḷiņingradas apgabalam un, iespējams, ziemel̦ietumu Polijai.

Sugas izplatîbas likumsakarības Latvijā ir diezgan sarežğìtas. Latvijā sastopama gar Daugavu līdz Aizkrauklei, bet it īpaši gar Gauju, kā arī citu, mazāku upju lejtecēs, kuras ietek Rīgas jūras līcī (Jūrmala, Roja, Melnsils). Līča piekrastē konstatētas arī vairākas morfologiski atškirīgas S. daphnoides un S. pomeranica pārejas formas, pie tam, pēc herbāriju materiāliem un personiskajiem novērojumiem spriežot, pēdējos gados arvien vairāk. Acīmredzot šeit noris plaša hibridizācija, kā rezultātā šãdiem eksemplāriem izzūd abas vecāku sugas atškiirošās pazīmes. Sevišksi daudz šādu hibridogēnu paraugu ir no vietām ar pastiprinātu antropogēnu ietekmi. Acīmredzot ir traucēta Pomerānijas vītola normāla svešappute, jo līdzīgos biotopos augošais ekspansīvais $S$. daphnoides plaši hibridizējas. Pomerānijas vītolam būtu nepieciešami īpaši aizsardzības pasākumi, iekḷaujot to arī īpaši aizsargājamo augu sarakstā.

Austrumlatvijā suga nav konstatēta, Vidzemē, Zemgalē un Kurzemē vietām sastopams arī kultūrā.

Latvijā $S$. pomeranica plaši hibridizējas ar $S$. daphnoides, $S$. acutifolia, lıti reti ar $S$. caprea. Relatīvi nelielais hibrīdu skaits, iespējams, izskaidrojams ar to, ka tuvu radniecīgo $S$. daphnoides un $S$. pomeranica hibrīdi ir ārkārtīgi līdzīgi. Par šo abu sugu hibrīdu atšķirīgajām pazīmēm spriest pāragri, dabā to visvieglāk izdarīt, konstatējot, kuras no vecāku sugām atrodamas tuvākajā apkārtnē.

\section{VIETVĀRDI PIRMAJOS LATGALIEŠU KALENDĀROS UN AVĪZĒS}

\section{Zane CEKULA}

LU ĢZZF Reǵionālās ǵeogrāfijas un toponīmikas zinātniskā laboratorija, e-pasts: zane.cekula@vzd.gov.Iv

Līdz šim, pētot Latgales vietvārdus, skatīiti tie rakstu avoti, kuros vietvārdi atrodami svešās valodās - krievu un poḷu. Tāpēc radās doma papētīt, kā tad vietvārdi rakstīti pirmajos latgaliešu valodā izdotajos izdevumos: kalendāros un avīzēs. Manā rīcībā bija 1863.gadā Viḷnā izdotais kalendārs, kā arī divdesmit divi 1905.-1906.gadā iznākušie avīzes "Gaisma" numuri, divi 1906.gadā izdotie avīzes „Sākla” un trīsdesmit deviņi 1906.-1907.gadā iznākušie avīzes "Auseklis” numuri.

19.gs.beigās - 20.gs.sākumā latgaliešiem bijuši daudz ciešāki sakari ar Pēterburgu nekā ar Rīgu. Pēterburgā, meklējot darbu un iztiku, nonākuši daudzi 
tūkstoši latgaliešu, ieguvuši izglītîbu un darbojušies pirmie latgaliešu baznīckungi un citi inteliǵences pārstāvji. Latgalē zemnieku brīvlaišana notika 1861.gada 19.februārī, no 1865. līdz 1904.gadam pastāvēja drukas aizliegums rakstībai ar latīṇu burtiem. Pēc drukas aizlieguma atcelšanas Pēterburgā iznākušas arī pirmās latgaliešu avīzes. „Gaismas” pirmais numurs izdots Pēterburgā 1905.gada 27.novembrī, redaktors - izdevējs Francis Kemps. 1906.gada 15.februārī iznācis latviešu katoḷu avīzes „Sākla” pirmais numurs, redaktors - izdevējs baznīckungs Nikodems Rancāns.

Visvecākais no manā rīcībā nonākušajiem izdevumiem latgaliešu valodā ir 1863.gadā Viḷnā izdotais kalendārs. Tajā vietu nosaukumi rakstīi latgaliski, izmantojot poḷu burtus. Lai uzskatāmi rādītu, kā vietvārdi mainījušies laika gaitā, daļa no tiem apkopota tabulā. Kā pirmais rakstīts kalendārā esošais vietas nosaukums, tad seko atbilstošie vietvārdi no avīzes "Gaisma". Nosaukumi rakstîti tieši tā, kā attiecīgajā izdevumā, saglabājot arī vietvārda locījumu, piemēram, Rybiniszkôs. Trešajā ailē kā pirmais rakstīts pagasta padomē apstiprinātais ciema nosaukums, bet iekavās dažkārt ir vecāko vietējo iedzīvotāju lietotais nosaukums. Tad seko norādes par attiecīgā ǵeogrāfiskā objekta atrašanās vietu - rajons un pagasts (skat. 1.tabulu).

Avīzē "Gaisma" ziņas ir sadalītas: atsevišķi ir izdalīti notikumi dzimtenē, Baltijas Latvijā, pa visu Krieviju, ārzemēs. Upju nosaukumi parādās tekstos maz: Aiviekstes upe, Daugawa, Daugawas upe, Dubnas upe, Maltas upe, pa Neret upi (Daugavas labā krasta pieteka starp Lìvāniem un Krustpili). Maz arī ezeru nosaukumu: Lubòna azars, Ludzas azars, Ràznas azars, Vyšku azars.

Pilsētu nosaukumi rakstīti bez sugas vārda jeb ǵeogrāfiskā termina pilsēta, piemēram, Ludza, Rejga. Nosaukumos parādās géogrāfiskie termini mīsts un mīsteņš: Beržgalia mīstenš, Dagdas mīstenš, Jakobmīsts, Kolupa mīsteņš, Kraslowas un Kràslawas mīstenš, Prejliu mīsts, Pasinias mīstenš, Sommerset mistenš, Waraklaniu mīstenš. Daudzos gadījumos ir minētas muižas, piemēram, Kirupa muiža, Sylauniku muiža, Vabales muiža.

Atsevišķi būtu izdalāmi klosteru, baznīcu, draudžu nosaukumi. Katoḷticīgajā Latgalē baznīcas bija vien̄igās vietas (ja neskaita mājas), kur varēja lūgt Dievu un latviski lasīt lūgšanas grāmatās, no kurām mātes iemācīja bērnus lasīt. Ja baznīckungi bija labvēlīgi noskaņoti un pietiekoši gudri, tad viṇi vienīgie atbalstīja zemniekus ar padomu arī saimnieciskajā dz̄̄vē.

Interesanti, ka visos skatîtajos „Gaismas” numuros, rakstot par Latgales apdzīvotajām vietām, netiek minēts ǵeogrāfiskais termins sādža, bet vienīgi cīms un sola, piemēram, Borsku-kolna cìms, Litowniku cìms, Augšgališu sola, Skryuzmaniu sola. 
Vietvārdi latgaliešu pirmajos izdevumos

\begin{tabular}{|c|c|c|c|c|}
\hline $\begin{array}{l}\text { 1863.gada } \\
\text { kalendārā }\end{array}$ & $\begin{array}{l}\text { Avīzē „Gaisma” } \\
\text { 1905.-1906.gadā }\end{array}$ & $\begin{array}{c}\text { Vietvārdi } \\
\text { 2004.gadāa }\end{array}$ & Rajons & Pagasts \\
\hline Agłouniâ & $\begin{array}{l}\text { Aglyune } \\
\text { Aglyunnes baznīca } \\
\text { Aglyunnes kloštors }\end{array}$ & Aglona & Preil̦u & Aglonas \\
\hline Andrepnâ & Ondrupinis pogosts & $\begin{array}{l}\text { Andrupene } \\
\text { (Ondrupine) }\end{array}$ & Krāslavas & Andrupenes \\
\hline Baltynovâ & $\begin{array}{l}\text { Nu Baltynowas } \\
\text { Baltinowas pogostā }\end{array}$ & Baltinava & Balvu & Baltinavas \\
\hline Bierzgalî & $\begin{array}{l}\text { Beržgalia baznica } \\
\text { Bèržgalia pogosts }\end{array}$ & $\begin{array}{l}\text { Bērzgale } \\
\text { (Bieržgal̦s) } \\
\end{array}$ & Rēzeknes & Bērzgales \\
\hline Bierźûs & $\mathrm{Nu}$ Bèržu & Bierži & Balvu & Bērzpils \\
\hline Bołowûs & $\begin{array}{l}\text { Bolwôs } 1 \mathrm{x} \\
\text { Bolwùs } 3 \mathrm{x} \\
\text { Bolwu 4x } \\
\end{array}$ & Balvi & Balvu & - \\
\hline Brodajszûs & Bradaižûs & Brodaiža & Ludzas & Pildas \\
\hline Bukmujźâ & Pi Bukmuižas & $\begin{array}{l}\text { Ezernieki } \\
\text { (Bukmuiža) }\end{array}$ & Krāslavas & Ezernieku \\
\hline Dagdâ & $\begin{array}{l}\text { Dagda } \\
\text { Dagdas pogosts }\end{array}$ & Dagda & Krāslavas & - \\
\hline Drycanûs & Dricànu pogostā & Dricāni & Rēzeknes & Dricānu \\
\hline Dynaborkâ & $\begin{array}{l}\text { Dinaburga 8x } \\
\text { Dwinska 31x } \\
\text { Dwinskā (Daugpilī) } \\
\text { Nu Daugpiles } \\
\text { Daugpiles apr. } \\
\end{array}$ & Daugavpils & Daugavpils & - \\
\hline Eversmujźâ & Ewersmuižas pogosts & Eversmuiža & Ludzas & Ciblas \\
\hline Galanûs & $\begin{array}{l}\text { Galiani } \\
\text { Galiànu pogosts } 3 \mathrm{x} \\
\text { Galiannu pogosts } \\
\text { Galianu (Wyds- } \\
\text { Muižas) pogosts } \\
\text { Galianu walsts }\end{array}$ & Galēni & Preiļu & Galēnu \\
\hline Josmujźâ & $\begin{array}{l}\text { Jòsmuižas pogosts } 3 \mathrm{x} \\
\text { Josmuižas pogosts } 1 \mathrm{x}\end{array}$ & $\begin{array}{l}\text { Aizkalne } \\
\text { (Josmuiža) }\end{array}$ & Preil̦u & Aizkalnes \\
\hline Jozefowâ & $\mathrm{Nu}$ Jùzupowas & Juzefova & Daugavpils & Naujenes \\
\hline Kołupiê & Kolups & Kalupe & Daugavpils & Kalupes \\
\hline Krosłowâ & $\begin{array}{l}\text { Kraslawa } 2 \mathrm{x} \\
\text { Kraslowa } 2 \mathrm{x} \\
\text { Kràslawa } 2 \mathrm{x} \\
\text { Kràslawas pogosts }\end{array}$ & Krāslava & Krāslavas & - \\
\hline Leyksnâ & $\begin{array}{l}\text { Lejksna } \\
\text { Lejksnas pogosts }\end{array}$ & Līksna (Leiksna) & Daugavpils & Līksnas \\
\hline Liwenmujzâ & $\begin{array}{l}\text { Lejwoni } \\
\text { Lejwònu baznica } \\
\text { Lejwònu pogosts }\end{array}$ & Līvāni (Leivons) & Preiḷu & - \\
\hline $\begin{array}{l}\text { Łudzys } \\
\text { Bazniejcâ }\end{array}$ & Ludza & Ludza & Ludzas & - \\
\hline Łudzys Kaplejcâ & Ludza & Ludza & Ludzas & - \\
\hline
\end{tabular}


LU 63. zinātniskā konference. ĢEOGRĀFIJA

\begin{tabular}{|c|c|c|c|c|}
\hline $\begin{array}{l}\text { Małnowys } \\
\text { Bazniejcâ }\end{array}$ & Malnowà & $\begin{array}{l}\text { Malnava } \\
\text { (Malnova) }\end{array}$ & Ludzas & Malnava \\
\hline Maryenauzâ & Viliakā (Marnauzā) & Vilaka & Balvu & \\
\hline Nidrumujźâ & $\begin{array}{l}\text { Nīdrumuižas draudze } \\
\text { Nīdru-Muižas baznica }\end{array}$ & Nīdermuiža & Preil̦u & Pelēču \\
\hline Osuniê & $\begin{array}{l}\text { Nu Osyunes 1x } \\
\text { Uz Osyuni 1x } \\
\text { Osyunâ 3x }\end{array}$ & Asūne & Krāslavas & Asūnes \\
\hline Passinî & $\mathrm{Nu}$ Pasinia & Pasiene & Ludzas & Pasienes \\
\hline Poszmucowâ & Nu Pušmuciowas & Pušmucova & Ludzas & Pušmucovas \\
\hline Prejlûs & $\begin{array}{l}\text { Prejli } \\
\text { Prejliu pogosts } \\
\text { Prejliu walsts }\end{array}$ & Preiļi & Preil̦u & - \\
\hline Pyłdâ & Nu Pyldas & Pilda & Ludzas & Pildas \\
\hline Rejziekniê & $\begin{array}{l}\text { Rezekne } \\
\text { Rèzekne }\end{array}$ & Rēzekne & Rēzeknes & - \\
\hline Rozentowâ & $\begin{array}{l}\text { Rozentowa } \\
\text { Rozentowas draudze }\end{array}$ & Rozentova & Rēzeknes & Maltas \\
\hline Rundanûs & Rundàni & Rundēni (Rundāni) & Ludzas & Rundēnu \\
\hline Rybiniszkôs & Ribeniûs & Riebiņi & Preil̦u & Riebinu \\
\hline Sarkoniôs & $\begin{array}{l}\text { nu Sarkaniu } \\
\text { Sarkaniu draudze }\end{array}$ & Sarkaņi & $\begin{array}{l}\text { Madonas } \\
\text { Rēzeknes }\end{array}$ & $\begin{array}{l}\text { Sarkaņu } \\
\text { Lendžu }\end{array}$ \\
\hline Sternianôs & $\begin{array}{l}\text { Stèrnine } \\
\text { Stèrnine pogosts }\end{array}$ & Stirniene & Madonas & Varakḷānu \\
\hline Struźanûs & Strùžanùs & Strūžāni & Rēzeknes & Gaigalavas \\
\hline Styglowâ & nu Styglowas & Stiglova & Balvu & Šksilbēnu \\
\hline Uzołmujźâ & Uzulmuižas pogosts & $\begin{array}{l}\text { Ozolmuiža } \\
\text { (Ūzulmuiža) }\end{array}$ & Rēzeknes & Ozolmuižas \\
\hline Uźvałdâ & - & Izvalta (Izvolts) & Krāslavas & Izvaltas \\
\hline Warklonûs & $\begin{array}{l}\text { Warakloni 2x } \\
\text { Waraklòni 3x } \\
\text { Waraklioni 2x }\end{array}$ & Varakḷāni & Madonas & \\
\hline Warkowâ & $\begin{array}{l}\text { Wòrkowa } \\
\text { Wòrkowas pogosts }\end{array}$ & Vārkava (Vorkova) & Preil̦u & Upmalas \\
\hline Wilanûs & $\begin{array}{l}\text { Wilianus } \\
\text { Wiliànim } \\
\text { Wiljanu } \\
\text { Wiliannu pogosts }\end{array}$ & $\begin{array}{l}\text { Viḷāni } \\
\text { Viḷānu muiža }\end{array}$ & Rēzeknes & Viḷānu \\
\hline Wyszkos & $\begin{array}{l}\text { Wyšku 2x } \\
\text { Wišku }\end{array}$ & Višķi & Daugavpils & Višķu \\
\hline
\end{tabular}

Latgaliešu pirmajos izdevumos nav vienotas rakstības, laika gaitā tā nedaudz mainījusies. Pirmajās avīzēs nav mīkstinājuma zīmju, bez tām ir gluži labi iztikts, lietojot burtu i pēc līdzskaņa, piemēram, nosaukums Vị̦āni avīzē „Gaisma” rakstîts Wiliàni, arī Wilianus, Wiliànim, Wiljanu, Wiliannu pogosts. Avīzēs rakstība nedaudz atšķiras, piemēram “Auseklī”” $\quad$-w- vietā jau rakstîts -v-, kā arī lietotas mīkstinājuma zīmes, piemēram, Sylajòni, Vylku cìms.

Jāṇem vērā arī tas, ka rakstību ietekmēja izmantotie materiāli latviešu, poḷu, krievu un citās valodās, kā arī rakstītāju izglītības līmenis. Nereti vienā un 
tajā pašā tekstā vietas nosaukums parādās dažādos variantos. Tomēr latgaliešu pirmajos izdevumos ir nozīmīgs vietvārdu materiāls, kurš līdz šim nav apzināts.

\title{
NIVELĒJUMU PAAUGSTINĀJUMU IZMAIN̦U ANALĪZE LİNIJĀS DEMENE-JËKABPILS UN AINAŽI-RĪGA
}

\author{
Armands CELMS, Jānis KAMINSKIS \\ Valsts zemes dienests, \\ e-pasts: armands.celms@vzd.gov.Iv , janis.kaminskis@vzd.gov.Iv
}

Kopš 2000.gada Latvijas Republikā uzsākti mērījumi Valsts nivelēšanas pamattīkla atjaunošanā. Līdz šim pilnībā pabeigti nivelēšanas darbi desmitajā un astotajā poligonā. Jūras līmeņa novērojumu staciju atkārtotai piesaistei nivelēšanas tīklam iesākti nivelējumi gar Latvijas "zilo" robežu (1.attēls). Pašlaik Latvijā tiek izmantota Baltijas 1977.gada normālo augstuma sistēma. Atjaunojamā nivelēšanas pamattīkla galvenie uzdevumi:

$\checkmark$ definēt augstumu sistēmas izejas līmeni;

$\checkmark$ pēc izveidošanas iekḷaut kopējā sistēmā ap Baltijas jūru saistībā ar Ziemel̦valstīm, tikt iesaistītam vienotajā Eiropas Nivelēšanas Apvienības tīklā (EULN);

$\checkmark$ kopējā sistēmā ar stacionārajiem (permanentajiem) globālās pozicionēšanas punktiem dot zemes vertikālās kustības ātruma vērtību;

$\checkmark$ saistībā ar globālās pozicionēšanas un gravimetriskajiem mērījumiem jādod iespēja precizēt ǵeoīda modeli.

Nivelēšanas pamattīkla atjaunošanā darbi Latvijā pamatā tiek balstīti uz 1929.-1939.gados izveidotā un 1967.-1974.gados pārnivelētā nivelēšanas tīkla. Tikai divās līnijās tiks izpildīti nivelējumi, kur iepriekš netika veikta I un II klases nivelēšana.

Nivelējumi Demene-Jēkabpils līdz Daugavpilij tika izpildīti gar dzelzcel̦a līniju un tālāk pa automaǵistrāli. Darbi tika veikti no maija līdz augusta vidum. Nivelēts tika ar ZEISS digitālo nivelieri DiNi 12T. Nivelētās līnijas kopgarums $130 \mathrm{~km}$. Nivelējumi Ainaži-Rīga tika veikti pa automağistrāli, līnijas kopgarums $125 \mathrm{~km}$. Darbi ritēja augusta un septembra mēnešos. Nivelēts tika ar ZEISS optisko nivelieri Ni002. Darbi tika veikti 2001.gadā.

Nivelējumu paaugstinājumu salīdzināšanai tika izmantotas vērtības starp zīmēm, kuras ierīkotas pirms 1940.gada un laika posmā no 1947. līdz 1974.gadam, kā arī šīs zīmes nivelētas ar pirmās klases nivelēšanas precizitāti. Paaugstinājumu vērtības tika sakārtotas trīs epohās - nivelējumi 1929-1939, 1967-1974 un 2001.gada mērījumi. Šeit gan jāmin, ka no 1929.-1939.gadu nivelējumiem saglabājušās zīmes ir l̦oti mazā skaitā, Tomēr arī tas ir pietiekami, lai dotu ieskatu par paaugstinājumu starpībām tajā laika posmā. 


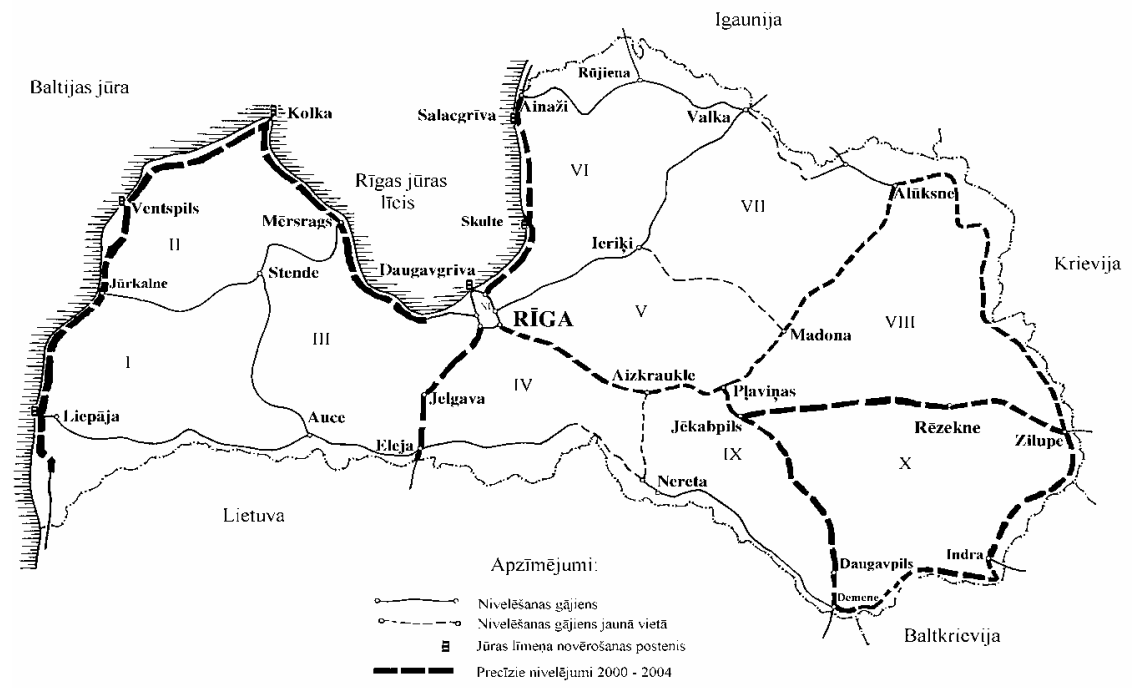

1.attēls. Pirmās klases nivelēšanas pamattīkla shēma.

Analizējot paaugstinājumu vērtību atšķirības starp dažādām epohām, secinām, ka atšķkirības pastāv. Izteiktāk tas novērojam līnijā Ainaži-Rīga. Šajā līnijā atsevišķos posmos atšķirība ir līdz $15 \mathrm{~mm} 20 \mathrm{~km}$ posmā. Linnijā DemeneJēkabpils kopējā paaugstinājuma vērtība salīdzinājumā ar iepriekšējiem mērījumiem palielinās. Kopumā var secināt, ka paaugstinājuma vērtību izmaiñas ietekmē gan Zemes garozas kustîba (O.Jakubovskis, G.Želņins u.c.), kā arī lokālas izmaiņas.

\section{MAKROFĪTU VEĢETĀCIJAS IZMAIN̦AS UN TO IETEKMĒJOŠIE FAKTORI RĪGÁS LĪCī}

\section{Zane DEKSERE}

LU Bioloǵijas institūts, e-pasts: zdekere@email.lubi.edu.Iv

Makrofīti ir ūdenī augošas makroskopiskas aļǵes un vaskulārie augi.

Makrofìtu audzēm jūras piekrastē ir būtiska loma barības vielu apritē un vides struktūras veidošanā kā dzīves, barošanās un nārsta vieta daudziem ūdens organismiem. Darbā izmantoti pēdējo piecu gadu laikā savāktā informācija par makrofītiem, apsekojot gan jūras piekrastes smilšu un akmeṇu sēkḷus, gan lagūnas Rīgas līcī. Šajā laikā konstatētas 8 mieturalğu, 6 zal̦alğgu, 6 brūnalğgu, 8 sārtalğgu un 3 vaskulāro augu sugas. 
Nepārtraukti mainīgie vides apstākḷi - lokālā un Baltijas jūras mērogā, cilvēka pārveidotā vide, eitrofikācija un globālās klimata pārmaiñas ietekmē vielu apriti un līdz ar to arī makrofìtus un citas organismu grupas. Tāpēc ir nepieciešams atjaunot un salīdzināt zinātnisko informāciju par makrofìtu stāvokli un izmaiñām Rīgas līcì.

Organismi, kas apdzìvo Rīgas līci, to skaitā arī makrofìti, atrodas nepārtrauktā stresā abiotisko faktoru, īpaši zemā sāļuma dēḷ. Līdz ar sāļuma gradienta samazināšanos Baltijas jūrā dienvidu-ziemel̦u virzienā Rīgas līcī ir mazākā makrofìtu sugu daudzveidība, salīdzinot ar citām Baltijas jūras daļām. Rīgas līcī ir tikai $12 \%$ no visā Baltijas jūrā sastopamajām makrofītu sugām. Tomēr makrofìtu biomasa Rịgas līcī ir salīdzinoši tikpat liela kā citās Baltijas jūras dal̦ās.

Rīgas līcī 20\% teritorijas ir seklāka par 10 metriem. Teorētiski makrofìti šo teritoriju varētu apdzīvot, tomēr piemērota substrāta esamība vai trūkums lielā mērā nosaka sugu klātbūtni, kvalitatīvo sastāvu un izplatību. Viḷnu darbības dēl lielā daļā piekrastes teritorijas irdenais substrāts tiek transportēts gar krastu, kas padara to neapdzīvojamu. Uz smilšainas grunts ievērojamais algologs H.Skuja pagājušā gadsimta sākumā konstatēja mieturaḷgu audzes līdz pat 5 metru dziļumam, turpretī 21.gadsimtā tās sastopamas tikai līdz 1 metra dziḷumam. Uz cietā substrāta līdz 2 metru dziḷumam dominē zaļaļge Cladophora glomerata, un tā ir sastopama pat līdz 5 metru dziļumam. Daudzgadīgā brūnaļǵge Fucus vesiculosus sastopama 2 līdz 5 metru diḷumā uz akmeņaina substrāta. Dziḷāk par 5 metriem dominē sārtalğes Ceramium tenuicorne un Sphacelaria artica, tomēr makrofiti neveido izteiktu dziļuma gradientu.

Sugu sastāvu un izplatību būtiski ietekmē upju grīvu tuvums. Upju ienestais saldūdens nel̦auj attīstīties sārtalı̆êèm un brūnaļgèem, kuras galvenokārt ir ierihalīnas jūras sugas. Arī ar upju ūdeni ienestās ūden̄̄ izšḳ̄idušās organiskās un humusvielas samazina ūdens dzidrību un līdz ar to arī makrofítu dziļuma izplatības robežu. Pagājušā gadsimta sākumā makrofîtu dziḷākā sastopamības robeža bija 15 metri, bet šobrīd tã ir 9,5 metri.

Būtiskas atšķirīibas novērotas starp lī̌ca austrumu un rietumu krastu: rietumu krastā makrofìtu dziļākā sastopamības robeža ir 9,5 metri, bet austrumu krastā - tikai 5,5 metri. 


\title{
KONTINENTĀLO UN TRANSFORMĒTU OKEĀNISKO GAISA MASU BIEŽUMS LATVIJĀ: ĢEOGRĀFISKĀS ATŠĶIRĪBAS
}

\author{
Anita DRAVENIECE \\ Latvijas Universitāte, Ģeogrāfijas un Zemes zinātņu fakultāte, \\ e-pasts: adis@|za.Iv
}

Latvijas teritorijas ǵeogrāfiskā novietojuma un gareniskās konfigurācijas ietekmē tās klimata okeāniskās iezīmes samazinās austrumu virzienā, turklāt uz vispārējā kontinentalitātes pieauguma fona vēl izpaužas arī Baltijas jūras ietekme, kura sniedzas vidēji 30-80 km attālumā no piekrastes. Latvijas klimata veidošanā liela nozīme ir gaisa masām, kuru vidējā atkārtojamība noteikta 11 gadu periodam (1990-2000), izmantojot sinoptiskās kartes un ikdienas aerologisko novērojumu datus Rīgā un Liepājā (līdz 1992.g.). Gaisa masas objektīvi noteiktas pēc temperatūras $\left(\mathrm{T}_{850}\right)$ un rasas punkta $850 \mathrm{hPa}$ jeb $1,5 \mathrm{~km}$ augstumā, to skaitā aprēķinot pseidopotenciālās temperatūras. Šie rādītāji labi raksturo troposfēras apakšējās dal̦as termisko - mitruma režīmu. Pētījuma rezultāti attiecināmi uz visu Latvijas teritoriju un piln̄̄gi neapšaubāmi uz rietumu un vidusdaļu, jo 30 gadu laikā (sākot no 1962.g.) Rīgā un Liepājā veikto $T_{850}$ novērojumu rindu korelācijas analīze parāda loti ciešu lineāro sakarību $(>0,9)$.

Kontinentālās gaisa masas Latvijā ieplūst vidēji 58 dienas/gadā, turklāt to atkārtojamība ievērojami mainās gada gaitā, un atkarībā no gadalaika Latvijā ieplūst dažādas izcelsmes kontinentālais gaiss. No septembra otrās puses līdz martam lielāks ir kontinentālā subpolārā gaisa (cP) īpatsvars, bet aprīlī septembrī Latvijā biežāk ieplūst sasilis subpolārs $\left(\mathrm{cP}_{\mathrm{s}}\right)$ un vidusplatumu $(\mathrm{cS})$ kontinentālais gaiss. Transformēts okeānisks gaiss pēc savas izcelsmes ir piederīgs okeāniskam gaisam, taču tas ir sausāks, jo, pārvietojoties virs sauszemes, pakāpeniski zaudē mitrumu un tā termiskās îpašības mainās pozitīvā vai negatīvā virzienā atkarībā no gadalaika, un tālākas transformācijas rezultātā tas pakāpeniski pārvēršas par kontinentālu gaisu ar tādām pašām īpašībām kā tāds gaiss, kurš būtu veidojies šādā cilmvietā. Tā kā gaisa masu transformācija notiek vienmēr, gaisa masai pārvietojoties pāri Latvijai tā arī mainās, taču izmaiņas jau notiek lēni, jo visraksturīgākās trajektorijas, pa kādām okeānisks gaiss no Atlantijas okeāna nonāk Latvijā, ir no rietumiem, dienvidrietumiem vai arī ziemel̦rietumiem - no Norvēǵu jūras, un lielākās izmaiņas notiek pirmajās 12 dienās, kad gaisa masa nonāk virs atšķirīgas pagulvirsas un citā geogrāfiskā rajonā, bet turpmākajās dienās izmaiņas arvien samazinās.

Pētījuma pamatā bija mēǵinājums noskaidrot, vai, kādos apstākḷos un cik bieži ir iespējams, ka virs Latvijas atrodas atšķirīgas gaisa masas, izn̦emot tādas dienas, kad dažādu gaisa masu ieplūšana saistīta ar atmosfēras frontu pārvietošanos. Ar šādu mērķi tika izvērtētas diennakts gaisa temperatūru (2 m) atšķirības Latvijas teritorijā visiem mēnešiem (1990-2000), un teritoriāli lielāko 
diennakts temperatūras kontrastu dienās tika analizēts $850 \mathrm{hPa}$ temperatūru un rasas punkta lauks Baltijas reǵionā un plašāk.

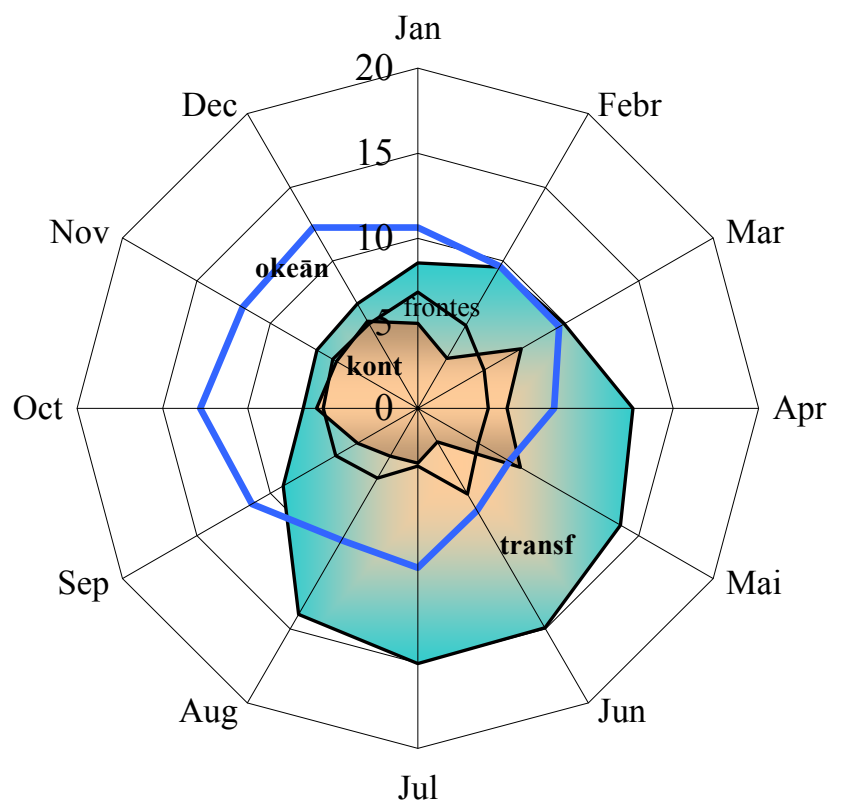

1.attēls. Okeānisku, transformētu okeānisku un kontinentālu gaisa masu vidējā atkārtojamība (dienu skaits) Latvijā, 1990-2000.

No vienas puses, piezemes $(2 \mathrm{~m})$ gaisa temperatūru nevar izmantot par kritēriju gaisa masu identificēšanai tās diennakts svārstību dēl un sakarā ar tās atkarību no pagulvirsas rakstura, kā arī tāpēc, ka īpaši siltajā gadalaikā iespējami gadījumi, kad gaisa masa pēc savas izcelsmes nav auksta, taču sakarā ar intensīviem nokrišņiem pie zemes novēro zemu temperatūru, bet ziemā savukārt iespējama pretēja aina: pie vienas un tās pašas $\mathrm{T}_{850}$ pie zemes temperatūra var būt augstāka intensīvas snigšanas apstākḷos, jo tās ietekmē stipri atdzisušais piezemes gaisa slānis "izzūd". No otras puses, ievērojamas teritoriālas diennakts vidējo temperatūru atšķ̧irības var norādīt uz atšksirīgām gaisa masām.

Latvijas atrašanās vidusplatumos nosaka to, ka ziemas mēnešos pie negatīvas radiācijas bilances katrā ǵeogrāfiskā punktā bieži novēro lielas diennakts temperatūras svārstības $\left(\Delta \mathrm{T}_{\mathrm{d}}\right)$, jo šajā laikā gaisa temperatūru galvenokārt ietekmē virs teritorijas esošā gaisa masa, bet piezemes diennakts temperatūru analīze Latvijā 11 gados parāda, ka arī teritoriāli vērojamas lielas diennakts temperatūru atšķirības $\Delta \mathrm{T}_{\mathrm{d} \text {-ter. }}$ Ziemā ir arī lielākas mēnešu vidējo 
temperatūru atšķirības Latvijas teritorijā. Dienās, kad Latvijas teritoriju šķērso atmosfēras frontes, to abās pusēs ir dažādas gaisa masas, un atkarībā no tā, cik izteikti ir atmosfēras procesi, ziemā visbiežāk $\Delta \mathrm{T}_{\mathrm{d} \text {-ter }}$ ir $5^{\circ}-10^{\circ} \mathrm{C}$, bet var sasniegt pat $18^{\circ} \mathrm{C}$ (2000.g. janvārī), retāk laikapstākḷu atšķirības ir nelielas. Ziemas mēnešos pie viendabīga $850 \mathrm{hPa}$ temperatūras un rasas punkta lauka virs Baltijas un tai piegulošajiem regioniem jeb pie viena gaisa masas tipa Latvijas teritorijā rietumu-austrumu virzienā $\Delta \mathrm{T}_{\text {d-ter }}$ var būt līdz $5^{\circ} \mathrm{C}$ un dažkārt pat $6^{\circ}-6,5^{\circ} \mathrm{C}$, taču novembrī-februārī šādu dienu skaits $<10$, bet martā jau vidēji ap 15 . Šādas atšķirības Latvijā acīmredzot nosaka galvenokārt Baltijas jūras tuvums, reljefa lielformas un citi fizioǵeogrāfiskie faktori.

Novembrī-martā ik mēnesi ir 1-4 dienas, kad $850 \mathrm{hPa}$ temperatūru un rasas punkta laukā atmosfēras frontu nav, bet ir redzamas $T_{850}$ atšksirības, kas var norādīt uz atšķirīgām gaisa masām, turklāt $\Delta \mathrm{T}_{\text {d-ter }}$ Latvijāa, visbiežāk rietumu-austrumu virzienā ir lielākas par $6^{\circ}$, sasniedzot pat $14^{\circ} \mathrm{C}$. No marta līdz oktobrim $\Delta \mathrm{T}_{\mathrm{d}}$ un līdz ar to $\Delta \mathrm{T}_{\mathrm{d} \text {-ter }}$ ir ievērojami mazākas, jo, Saules augstumam pieaugot, pieplūstošās enerǵijas daudzums palielinās un izlīdzinās atškirīības ne vien starp diennakts temperatūras vērtībām, bet arī teritoriālās atšķirības, turklāt daḹeji arī mainās Latvijā ieplūstošo gaisa masu trajektorijas, pieaugot citas izcelsmes, t.i., vidusplatumu un subtropisko gaisa masu īpatsvaram. Pavasarī, vasarā un rudens sākumā arī atmosfēras frontu radītie diennakts temperatūru kontrasti ir mazāki.

Lielas $\Delta \mathrm{T}_{\mathrm{d} \text {-ter }}$ pārsvarā novēro ziemas mēnešos, sākot ar novembri, kad laikapstākḷus nosaka Atlantijas ciklonu sērijas aizmugurē izveidojies augsta spiediena atzars vai augsta spiediena apgabals virs Austrumeiropas ziemel̦u daļas un ar ziemel̦u vējiem Latvijā no Skandināvijas ieplūst transformēts okeānisks arktisks (xA) gaiss vai no ziemel̦austrumiem pāri Karas jūras ledum un aizsalstošajai Barenca jūras dạ̧ai - kontinentāls arktisks (cA) gaiss. Ja augsta spiediena apgabals atrodas virs Austrumeiropas, no Krievijas centrālajiem rajoniem pa anticiklona rietumu perifēriju ieplūst kontinentāls subpolārs (cP) gaiss, bet ziemas mēnešos tas dažkārt veidojas, kad virs Skandināvijas aukstā arktiskā gaisā izveidojas augsta spiediena apgabals un arktiskais gaiss pakāpeniski transformējas par cP gaisu. Meridionālas atmosfēras cirkulācijas apstākļוos, kad ziemel̦u, ziemel̦austrumu vēji atnes Latvijā aukstas gaisa masas un zemas piezemes gaisa temperatūras, valsts rietumu dạ̦ā nereti ir siltāks: temperatūras un rasas punkta lauku analīze $850 \mathrm{hPa}$ līmen̄i parāda, ka Latvijas rietumu daļu ietekmē pakāpi siltākas $(\mathrm{xA} \rightarrow \mathrm{cA}$ vai $\mathrm{mA} \rightarrow \mathrm{xA})$ arktiskās gaisa masas, kas, pārvietojoties virs Baltijas jūras, vēl sasilst un piesātinās ar mitrumu, piemēram, kad Latvijas austrumu dą̧u ietekmē cA gaiss, rietumu un vidusdą̧ā xA gaiss vai sakarā ar ciklona tuvošanos jau ieplūst siltāks (xP vai mA) gaiss.

Sākot ar martu, mēnešu vidējo gaisa temperatūru atšķirības samazinās (piemēram, aprīlī $1,3-2,3^{\circ} \mathrm{C}$ ), un diennakts vidējo temperatūru gaita Latvijā kḷūst 
vienmērīgāka, pie kam $\Delta \mathrm{T}_{\mathrm{d} \text {-ter }}$ ir mazākas nekā ziemas mēnešos (visbiežāk līdz $5,5^{\circ} \mathrm{C}$ ). Vismazākās atšķirības veidojas jūlijā - augustā. Pie tam Latvijā pieaug vidusplatumu (okeānisko transformēto $\mathrm{xS}_{\mathrm{p}}$ un kontinentālo $\mathrm{cS}_{\mathrm{p}}$ ) un subtropisko ( $\mathrm{xS}$ vai $\mathrm{cS}$ ) gaisa masu īpatsvars, kuras ieplūst ar dienvidu, dienvidrietumu vējiem vai dienvidausturmu vējiem no Balkānu-Melnās jūras reǵiona, Viduseiropas, Austrumeiropas. Piemēram, 1994.gada jūlijā gandrīz visu mēnesi valdīja anticiklonāla cirkulācija, kas izraisīja neparasti ilgstošu sausumu un karstumu, 17 dienas Latvijā tika identificēts $\mathrm{xS}_{\mathrm{p}}, \mathrm{cS}_{\mathrm{p}}$ un cS gaiss, un visu mēnesi, izñemot 1 dienu, $\Delta \mathrm{T}_{\mathrm{d} \text {-ter }}<4^{\circ} \mathrm{C}$ (2.attēls).
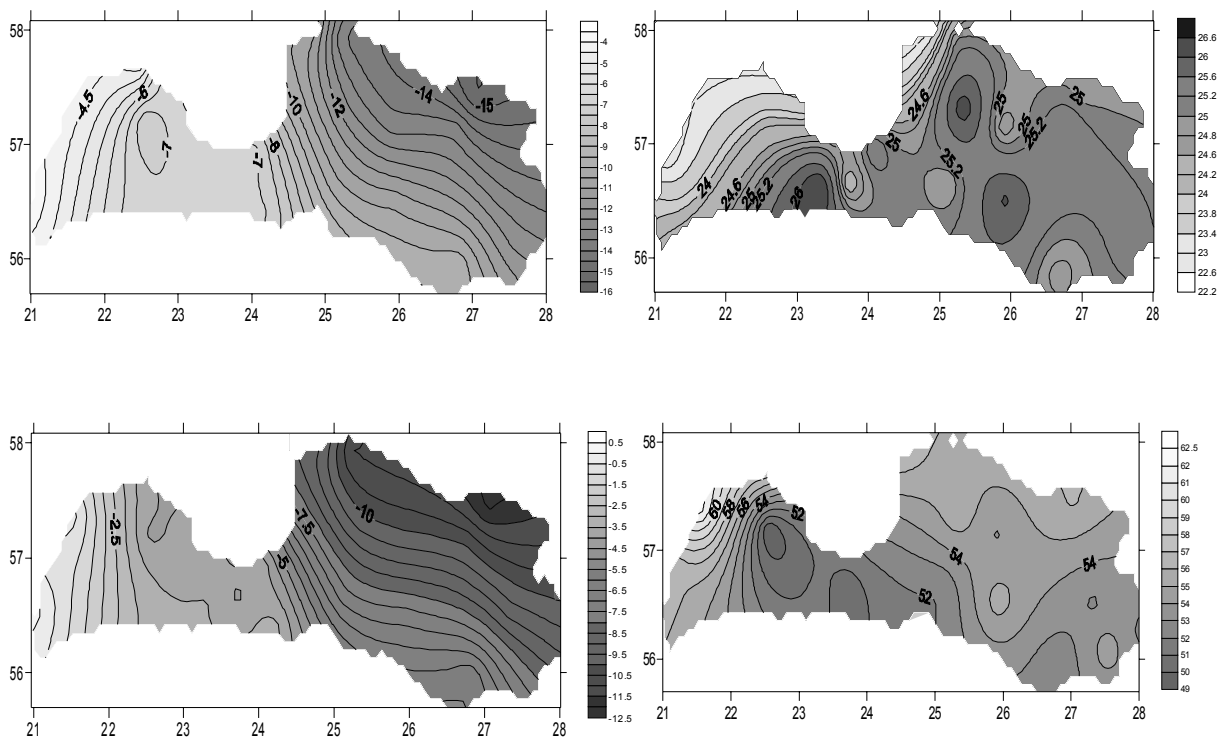

2.attēls. Gaisa temperatūras (augšā) un pseidopotenciālās temperatūras $\left({ }^{\circ} \mathrm{C}\right)$ geogrāfiskais sadalījums piezemes gaisa slānī Latvijā:

A. (pa kreisi) arktiskas (xA-cA) gaisa masas 16_02_1997; B. (pa labi) kontinentāla subtropiska (cS) gaisa masa 30_07_1994.

Izņemot dienas ar atmosfēras frontu pārvietošanos, arī citkārt virs Latvijas teritorijas var atrasties atšķirīgas gaisa masas, kas biežāk var notikt ziemas mēnešos un vairumā gadīijumu saistīts ar augsta spiediena apgabala veidošanos virs Skandināvijas vai Austrumeiropas. Kad Latvijas teritorijā ieplūst dažāasas gaisa masas, valsts austrumu daļā, salīdzinot ar rietumu un vidusdaļu, visbiežāk identificē par pakāpi kontinentālākas gaisa masas, piemēram, kontinentāls gaiss - transformēts okeānisks gaiss vai okeānisks-transformēts - okeānisks gaiss. Novembrī-martā 
kontinentālo un stipri transformētu okeānisko gaisa masu atkārtojamība Latvijas austrumu dạ̧ā salīdzinājumā ar pārējo teritoriju ir palielināta.

Nedaudz lielāka kontinentālo un transformēto okeānisko gaisa masu atkārtojamība Latvijas austrumu daḷā un Baltijas jūras ietekme uz Latvijas klimatu lokālā mērogā, kā arī pastarpināti, veicinot gaisa masu transformāciju, ir nozīmīgi faktori, kuri izpaužas uz vispārējā kontinentalitātes pieauguma fona Eiropas vidusplatumos, pārvietojoties austrumu virzienā, mijiedarbojoties ar citiem klimatu veidojošiem faktoriem un veicinot ievērojamu klimatisko kontrastu veidošanos Latvijā.

\title{
Atsauces
}

Krauklis, Ā., Draveniece, A. (2004). Landscape seasons and air mass dynamics in Latvia. Geogrāfiski raksti / Folia Geographica, 12, 16 - 47.

Draveniece A. (2004). Gaisa temperatūras ǵeogrāfiskais sadalījums Latvijā pie atšķirīgiem gaisa masu tipiem. Latvijas geogrāfija Eiropas dimensijās, 24-26.

\section{PRETIŠĶĪBAS MIGRĀCIJAS PLŪSMU PROGNOZĒŠANĀ LATVIJĀ}

\author{
Pārsla EGLĪTE \\ Latvijas Zinātñu akadēmijas Ekonomikas institūts, \\ e-pasts: spiceina@lza.Iv
}

Migrācijai kā teritorijas iedzīvotāju skaita un sastāva veidošanās komponentei piemīt zināmas īpatnības salīdzinājumā ar dabisko kustību:

$\checkmark$ tā maina ne visjaunāko un visvecāko iedzīvotāju, bet darbaspējīgo jaunākās grupas skaitu un īpatsvaru; līdz ar to izcelıošanas vietās mazinās, bet iecelıošanas - potenciāli palielinās paredzamais dzimstības lìmenis;

$\checkmark$ līdz darbaspējas vecumam izaudzināto un izglītoto jauniešu migrācija rada ekonomiskus zaudējumus donorvalstij vai reǵionam un àtri piesaistāmu bezmaksas attīstības resursu iecelıš̌anas vietās;

$\checkmark$ imigrācija vairumā gadījumu palielina cittautiešu īpatsvaru, kas rada etnisku sarežğîjumu varbūtību;

$\checkmark$ migrācijas intensitāte un pat virziens var kardināli mainīties bez kāda sagatavošanās perioda politisku notikumu vai likumu ietekmē, kā tas piedzīvots, piemēram, abu pasaules karu vai PSRS sabrukuma dēl̨.

Minēto migrācijas īpatnību un tās izraisīto seku dēl valsts mērogā būtu bezatbildīgi atstāt šo procesu pašplūsmā, neregulējot to valsts attīstībai vēlamajā virzienā. Savukārt pirms noteiktu migrācijas plūsmu veicinošu vai kavējošu lēmumu pieņemšanas ir jāizvērtē demogrāfiskās attīstības un darba tirgus prognozes ar dažādiem migrācijas virzienu un intensitātes scenārijiem.

Vairāku valstu un specialitāšu eksperti jau ir piedāvājuši vairākus krasi atšķirīgus starpvalstu migrācijas prognozes variantus Latvijai XXI gadsimta 
pirmajiem gadu desmitiem. To vidū Holandes demogrāfu prognozē līdz 2020.gadam - emigrācijas turpināšanās, tai pakāpeniski mazinoties gan labklājības līmeņu izlīdzināšanās ietekmē ES valstu vidū, gan sarūkot mobilākā vecuma iedzīvotāju skaitam Latvijā 90.gadu zemās dzimstības dēl [1]. Savukārt EUROSTAT un vairāki Latvijas pētnieki paredz imigrācijas atsākšanos, daži jau pēc 5-10, daži pēc 2020.gada [2, 3, 4, 5].

Visā cilvēces vēsturē brīvprātīgā imigrācija ir notikusi virzienā uz reǵioniem, kur gūstami kādi labumi salīdzinājumā ar atstājamo teritoriju:

$\checkmark$ iespēja bez maksas iegūt zemi vai citus resursus,

$\checkmark$ augsts valstī ražotās produkcijas/pakalpojumu noiets, kas uztur pieprasījumu pēc darbaspēka,

$\checkmark$ salīdzinoši augsta darba samaksa pārceḷotāju kvalifikācijai atbilstošos darbos,

$\checkmark$ vietējā darbaspēka sociālā aizsargātība, kas dod iespēju jaunās mītnes zemes pamatiedzīvotājiem izvēlēties nodarbošanos un noteiktu atalgojuma līmeni,

$\checkmark$ uzñēmēju ieinteresētîba minimizēt savas izmaksas un tostarp izmantot iespējami lētāku un mazprasīgu darbaspēku,

$\checkmark$ visiem vai dažām iebraucēju kategorijām labvēlīgi imigrācijas vai pagaidu uzturēšanās noteikumi.

Emigrāciju izraisošie izstūmējapstākḷi, protams, ir diametrāli pretēji:

$\checkmark$ salīdzinoši augsts bezdarbs,

$\checkmark$ bezdarba dēl iespējama zema darba samaksa un ar to saistītā nabadzības izplatība.

Dažās valstīs darbojas arī specifiski faktori:

$\checkmark$ iedzivvotāju izglītotība un valodu prasme, kas palielina varbūtību labi iekārtoties jaunajā mītnes zemē,

$\checkmark$ noteiktu etnisko grupu diskriminācija,

$\checkmark$ militāri konflikti vai to varbūtība politiskas krīzes dēḷ.

Kā vienā, tā otrā faktoru grupā atsevišķie apstākḷi laika gaitā un valsts politikas ietekmē var mainīties, kas padara gandrīz neiespējamu migrācijas prognozēšanu atbilstoši minēto faktoru nākotnē paredzamam iedarbīgumam.

\section{Avoti}

1. Cruijsen H., Eding H., Gjaltema T. Demographic consequences of enlargement of the European Union with the 12 Candidate Countries; Statistics Netherlands, Jan. 2002: 58

2. Zvidriņš P.Latvijas iedzīvotāju attīstība šodien un rīt / Latvija Eiropā: nākotnes vīzijas. LZA Baltijas stratēǵisko pētījumu centrs, Rīga, 2004: 226-241

3. http://www.apollo.lv/portal/articles/35104/print

4. Indāns I. Imigrācija: kad labklājīiba saduras ar identitāti. „Diena” 2004. 3. dec.

5. Zvidriņš P. Depopulācija. Nacionālās intereses: formulējuma meklējumos. Zinātniski pētnieciskie raksti, 1/2004. Rīga: Zinātne, 2004, 74.-104. lpp. 


\title{
KŪDRAS SUBSTRĀTU BIOLOĢISKĀS AKTIVITĀTES NOVËRTËŠANAS METODES
}

\author{
Tālis GAITNIEKS \\ LVMI "Silava”, e-pasts: talis@silava.Iv \\ Imants LIEPA \\ Latvijas Lauksaimniecības universitātes Meža fakultāte, \\ e-pasts: liepa@cs.Ilu.Iv
}

Pēdējos gados strauji palielinās ietvarsējeņu (praktiķi lieto terminu „konteinerstādi”) īpatsvars meža atjaunošanā. Konteinerstādi ir īpaši piemēroti nemeža zemju apmežošanai (piem., bijušās lauksaimniecības zemes). Tādās platībās ir svarīgi stādīt labi mikorizētus stādus. Mikoriza nodrošina kokaugu apgādi ar minerālajām barības vielām, palielina sakņu uzsūcošo virsmu, kā arī veicina sakṇu aizsardzību pret patogēnajām sēnēm. Tādēl konteinerstādu mikorizācija ir viens no nozīmīgākajiem stādu kvalitātes rādītājiem.

Konteinerstādu audzēšanai kā substrāts tiek izmantota kūdra, taču rūpnieciski sagatavota kūdra nenodrošina labvēlīgu vidi mikorizas sēņu attīstībai. Tāpēc, lai izvēlētos piemērotāko substrātu konteinerstādu audzēšanai, svarīgi ir noskaidrot, kā šis substrāts ietekmē mikorizas sēṇu micēlija attīstību. Nepieciešams novērtēt arī substrāta biolog̣isko aktivitāti - respektīvi, substrāta mikrofloras kvantitatīvo un kvalitatīvo sastāvu, jo mikroorganismi sekmē rizosfēras veidošanos.

Darbā tika analizēta mikorizas sēñu Paxillus involutus, Laccaria laccata, Hebeloma crustuliniforme, Piceirhiza bicolorata, Amanita pantherina, Amanita muscaria un Cenococcum sp. micēlija attīstība A/S "Sedas kūdra" un SIA "Laflora" sagatavotajos kūdras substrātos. Mikorizas sēñu micēlija attīstības novērtējums veikts, izmantojot LVMI "Silava" izstrādātu metodiku: ar stikla caurulīti transformējot micēlija-agara gabalinus no kolonijas aktīvās zonas Petri platē ar sterilizētu analizējamo kūdras substrātu. Celulozi noārdošās mikrofloras daudzums analizētajos substrātos novērtēts, izmantojot augsnes suspensijas uzsējumu metodi un augsnes picinu apauguma metodi.

Analizējot substrātu agroķīmiskos rādītājus, secināts, ka "Sedas" substrātam raksturīga zemāka $\mathrm{pH}$ vērtība: 3,3, turpretī "Lafloras" substrāts: 4,9.

Konstatēts, ka no analizētajiem mikorizas sēņu celmiem Cenococcum sp. micēlija attīstība bija kavēta kā "Lafloras", tā "Sedas" substrātos. Analizējot L. laccata micēlija attīstību, konstatēts, ka micēlijs labi attīstās "Sedas" kūdras substrātā, bet tā attīstība kavēta "Lafloras" substrātā. Savukārt mikorizas sēņu Piceirhiza bicolorata micēlijs loti labi attīstās "Lafloras" kūdras substrātā, bet micēlija attīstība nav konstatēta "Sedas" kūdras substrātā. A. muscaria un A. pantherina vienlīdz labi attīstās abos salīdzinātajos substrātos. Secināts, ka minētie substrāti neveicina $H$. crustuliniforme un $P$. involutus micēlija attīstību. 
Pārbaudot dažādu pH vērtību ietekmi uz mikorizas sēṇu micēlija attīstību, konstatēts, ka "Sedas" substrātā ar $\mathrm{pH}=5,8$, l̦oti labi attīstās $P$. involutus micēlijs, savukārt rūpnieciski izstrādātā "Sedas" kūdras substrātā bez barības vielām $(\mathrm{pH}=2,2)$ micēlija attīstîba ir kavēta (1.att.).

Novērtējot celulozi noārdošās mikrofloras daudzumu ar uzsējumu metodi, secināts, ka baktēriju skaits "Lafloras" kūdrā $9 \times$ pārsniedz baktēriju skaitu "Sedas" kūdrā, bet mikroskopisko sēṇu skaits ir 14 reižu lielāks: 122,5 $\pm 8.5 \quad 10^{4}$

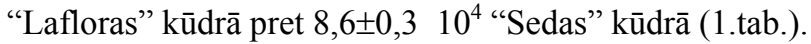

"Lafloras" kūdrā konstatēts lielāks daudzums Trichoderma sp. mikroskopisko sēņu.

Izmantojot augsnes piciṇu apauguma metodi, secināts, ka "Lafloras" substrātā 77,5\% piciņu ir apaugušas ar mikroskopisko sēṇu kolonijām, bet "Sedas" substrātā tikai 20\%.

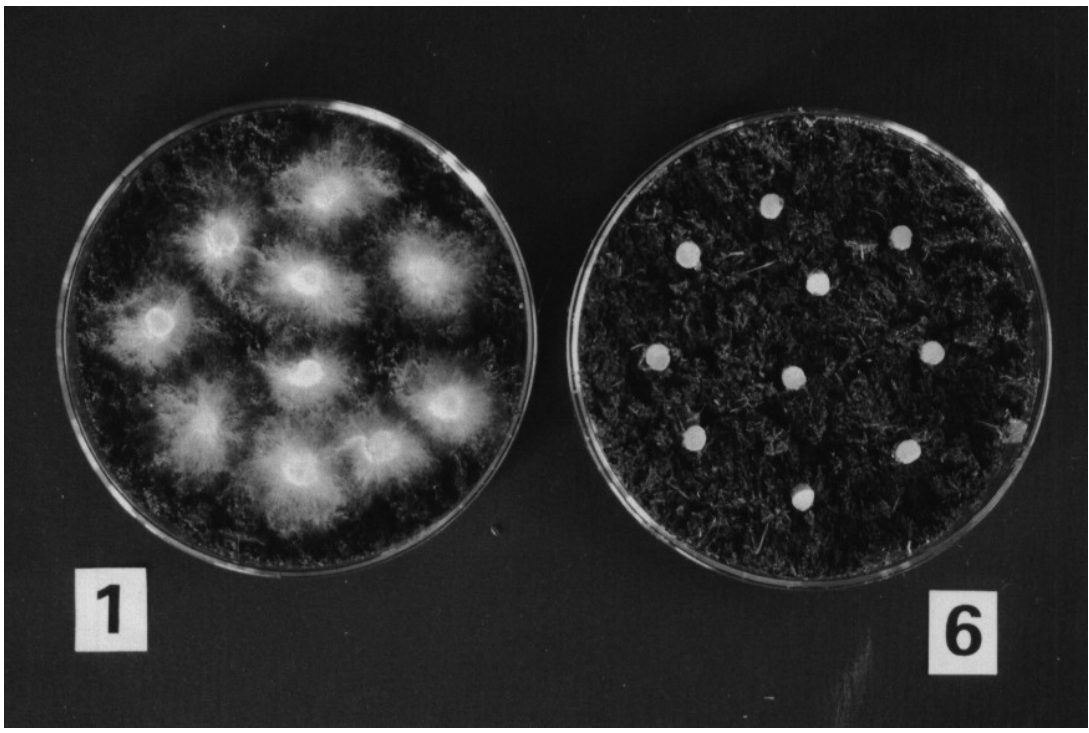

1.attēls. $P$. involutus micēlija attīstība.

1. Konteinerstādu audzēšanai izmantotais kūdras substrāts $(\mathrm{pH}=5,8)$. 6. Sfagnu kūdra $(\mathrm{pH}=2,2)$.

1. tabula

\section{Celulozi noārdošā mikroflora}

\begin{tabular}{|c|c|c|}
\hline Substrāts & Baktērijas & Mikroskopiskās sēnes \\
\hline "Seda" & $3,7 \pm 1,510^{6}$ & $8,6 \pm 0,3 \quad 10^{4}$ \\
\hline "Laflora" & $34,4 \pm 0,810^{6}$ & $122,5 \pm 8,5 \quad 10^{4}$ \\
\hline
\end{tabular}


Novērtējot skujkoku sējeņu mikorizāciju, secināts, ka "Lafloras" substrātā konteinerstādiem raksturīga augstāka mikorizācijas pakāpe un mikorizu vitalitāte, salīdzinot ar "Sedas" substrātu. Tātad substrāta biologískās aktivitātes (celulozi noārdošās mikrofloras daudzums) novērtējums ļauj izvērtēt substrāta mikorizās infekcijas potenciālu.

Turpmākajā darbā nepieciešams pārbaudīt dažādu mikorizas tipu ietekmi uz konteinerstādu morfolog̣iskajiem rādītājiem, lai, izmainot substrāta agroķīmiskos parametrus, veicinātu attiecīgo mikorizas sẹņu attīstību konteinerstādu audzēšanai paredzētajā kūdras substrātā.

\title{
FENOLOĢISKIE TRENDI LATVIJĀ 20.GADSIMTĀ
}

\author{
Gunta GRIŠULE, Zane MĀLIN̦A \\ LU Ģeogrāfijas un Zemes zinātñu fakultāte, \\ e-pasts: ggunta@one.lv, sg01051@lanet.Iv
}

Fenologiskie novērojumi raksturo dabas parādību periodiskumu, savstarpējo sakarību un atkarību no apkārtējās vides apstākḷiem, to ikgadējās izmain̦as var būt globālo izmaiṇu indikators, piemēram, britu fenologi ir pierādījuši, ka pḷavas auzene Festuca pratensis Lielbritānijā zied 13 dienas agrāk nekā pirms desmit gadiem. Fenologiskajos dārzos veikto pētījumu analīze /1965.-2003.gads/ pierāda, ka augšanas periods Eiropā ir kluvis par 9 dienām garāks: augšanas sezona sākas 7 dienas agrāk un beidzas 2 dienas vēlāk.

Latvijā fenologiskie novērojumi uzsākti 19.gadsimta 30.gados (Puzē 1822.gadā, Lestenē un Lubānā - 1824.gadā). Sistemātiskus fenolog̣iskos novērojumus Latvijā veic kopš 1926.gada, kad sāka darboties Latvijas Universitātes asistenta E.Jansona organizētais brīvprātīgo korespondentu fenologu tīkls.

Balstoties uz datu kvantitāti, raksturotas 4 sugu fenologisko fāzu: parastās ievas Padus racemosa un āra bērza Betula pendula lapu plaukšanas sākuma, parastā pīlādža Sorbus aucuparia ziedēšanas, parastās (ziemas) liepas Tilia cordata lapu dzeltēšanas ilggadīgās mainības aspekti un svārstības Latvijā laika periodā no 1927. līdz 1935.gadam un no 1959. līdz 2002.gadam.

Datu kopu analīzē lietoti šādi statistikas pamatlielumi:

$\checkmark$ datu vidējie rādītāji: vidējais aritmētiskais, mediāna un moda ilggadīgajam periodam un pa desmitgadēm visai Latvijas teritorijai ;

$\checkmark$ datu izkliede: minimālās un maksimālās vērtības un amplitūda ilggadīgajam periodam un pa desmitgadēm.

Darba ietvaros tika lietota viena faktora lineārā regresija un neparametriskais Mann-Kendela tests, kas piemērots datu kopu analīzē, kuras neatbilst normālajam sadalījumam, datu kopās ar iztrūkstošām vērtībām un anomālām variantēm, kas raksturīgs fenologisko novērojumu datu rindām. 
Pētījumi saskan ar globālās pasiltināšanās hipotēzi, jo, sākot ar 1983.gadu, visām apskatītajām fenologiiskajām fāzēm vērojamas negatīvās anomālijas - fāze iestājusies agrāk nekā vidēji. Piemēram, bērzu lapu plaukšana pēdējā desmitgadē vērojama vidēji 6 dienas agrāk nekā 20.gs. 60.gados, savukārt liepu lapu dzeltēšana - trīs dienas agrāk. Izmaiņas vērojamas gan reg̣ionālajā, gan lokālajā mērogā. Analoga situācija vērojama visā Eiropā.

Pavasara un vasaras fenologiskajām fāzēm var izdalīt 1 maksimumu un 2 minimumus. Maksimums vērojams no 1959.-1979.gadam, kad fāzes vidēji iestājušās vēlāk. Minimumi savukārt ir 20.gs. 30.gados un pēdējā divdesmitgadē, kad fāzes vidēji iestājušās agrāk, savukārt rudens fenologisko fāzu trendi laika periodā no 1959. līdz 1979.gadam ir lejupejoši /fāzes iestājušās vidēji agrāk/, 1980. līdz 2002.gadam fenologiskās fāzes iestājušās vēlāk.

Trendu izmaiņas izskaidrojamas ar gaisa temperatūras svārstībām 20.gadsimtā.

Augšanas periods Eiropā pēdējo 35 gadu laikā sācies vidēji par 7 dienām agrāk un beidzies par 2 dienām vēlāk, kopējais augšanas periods pagarinājies par 9 dienām. Salīdzinot ar ilggadīgi vidējiem datiem, arī Latvijā augšanas periods ir pagarinājies par 9 dienām.

Fenologiisko fāzu iestāšanās laiks mainās arī telpas griezumā, Latvijā reǵionālās izmainas ir ievērojamas: pavasara fāzēm 8-13 dienas, vasaras fāzēm 9-12 dienas. Rudens fāzes savukārt visā Latvijā iestājas 20-25 dienu laikā.

Fenoloǵisko fāzu iestāšanās laikus ietekmē gan eksogēnie, gan endogēnie faktori, kuri tiks analizēti turpmākajos pētījumos.

\title{
ĢEOGRĀFISKIE PRIEKŠSTATI AUGŠZEMES FOLKLORĀ
}

\author{
Dāvis GRUBERTS \\ Daugavpils Universitāte, e-pasts: davis@dau.Iv
}

Ģeogrāfiskie jēdzieni un priekšstati, ko izmanto ikdienas vajadzībām, bieži vien atšķiras no tiem, kurus esam apguvuši skolas solā. Tajos trūkst zinātniskās terminolog̣ijas, tajā pašā laikā tie ir visai seni un sakņojas mūsu senču arhaiskajos priekšstatos par dabu un pasauli. Atšķirīibā no mūsdienu geogrāfiskajiem priekšstatiem, kas galvenokārt ir aizgūti no t.s. "rietumu kultūras", tie pamatā ir vietējas izcelsmes, veidojušies latviešu zemnieku ikdienas dzīvē no paaudzes paaudzēe, ciešā saskarē ar savas zemes dabu, l̦audīm un kaimiņu tautām. Lai gan daudzos gadījumos tie nesaskan ar mūsdienu priekšstatiem, to izpēte var pavērt jaunas iespējas Latvijas ǵeogrāfijas mācīšanā. Senie priekšstati nav pilnībā zaudējuši savu sākotnējo nozīmi, tāpēc tos arī šodien var izmantot par pamatu t.s. humanitārās geogrāfijas virziena attīstīšanai pamatskolu izglîtīibas programmās. Tie var noderēt arī nākamo Latvijas ǵeogrāfijas mācību grāmatu autoriem, lai 
sekmīgāk kā līdz šim saskaņotu novadu ǵeogrāfijas jautājumus ar Latvijas kultūrvēstures pamatiem.

Augšzeme ir viens no sešiem Latvijas etnogrāfiskajiem novadiem, kurš geogrāfijas mācišanā šodien ir nepelnīti aizmirsts. Savulaik šim nosaukumam bija gan ǵeogrāfiska, gan kultūrvēsturiska nozīme. No 16. līdz 19.gadsimtam Augšzeme ietilpa Kurzemes hercogistē (guberņā) un bija tās nomaļākais, kalnainākais un ezeriem bagātākais novads. Tās pamatiedzīvotāji - augšzemnieki - bija dzimtcilvēki bez tiesībām iegūt labu izglîtību, brīvi cel̦ot un bez muižnieka aţ̦aujas mainīt savu dzīvesvietu. Tikai 18.gadsimta beigās, kad klajā nāca Vecā Stendera "Augstas Gudrības Grāmata no Pasaules un Dabas", arī "nemācītie" latviešu zemnieki populārā veidā tika iepaz̄istināti ar dabaszinātṇu pamatiem. Šis ceḷš tiek iets arī mūsdienu Latvijas ǵeogrāfijas mācīšanā. Līdz ar to mūsdienu ǵeogrāfiskie priekšstati var ievērojami atšķirties no tiem, kas atrodami latviešu folklorā.

Kā liecina Augšzemes teikas un tautasdziesmas, augšzemnieki Daugavas kreiso krastu nekad nav piedēvējuši Latgalei, kā to mēdz darīt mūsdienu politiķi, ierēdņi un žurnālisti, kā arī tūrisma ceḷvežu un ǵeogrāfijas mācību grāmatu autori. Tomēr Augšzemes folklorā trūkst pierādījumu tam, ka tās apzīmēšanai senāk būtu izmantots tāds mūsdienās populārs nosaukums kā 'Sēlija'. Tā vietā visbiežāk lietots Kurzemes vārds. Augšzemes folklorā nav arī drošu apliecinājumu tam, ka tās senie iedzīvotāji paši sevi būtu saukuši par 'sēḷiem'. Šis fakts vedina domāt, ka etnonīms 'sēļi' nav vietējas cilmes, uz ko jau agrāk ir norādījuši vairāki vēsturnieki un valodnieki. Tāpat kā citi Kurzemes hercogistes (guberņas) latvieši, arī augšzemnieki sevi ir dēvējuši par 'kurzemniekiem', tomēr ikdienā tie cits citu saukuši pēc dzīvesvietas, piemēram, 'aizupieši', 'mazsaucieši', 'subatieši' u.t.t. Šī tradīcija ir dz̄iva arī mūsdienās.

Saskaņā ar augšzemnieku priekšstatiem 'Leišu zeme' atrodas blakus kaimiņos, Vidzeme - aiz Daugavas, 'Krievu zeme' - austrumos, Rīga - rietumos, 'Poḷu zeme' - dzil̦i iekšzemē, bet 'Vāczeme' - aiz jūras. Daugavu augšzemnieki acīmredzot ir uzskatījuši par svarīgāko savas zemes robežu, jo tā bija grūti pārvarama upe, kura ne vien prasīja biežus cilvēka upurus, bet arī spēja pasargāt vietējos iedzīvotājus no svešzemju sirotājiem. Augšzemnieku priekšstatos Daugava vairāk līdzinās jūrai vai ezeram nevis citām upēm. Tā ir uzskatīta arī par galveno upi, kurā satek visas citas upes. Iespējams, ka Augšzemes folklorā Daugavas (upes) hidrogrāfiskā tīkla simbols ir "ozols", par ko liecina ne vien tautasdziesmas, bet arī mīklas.

Mūsu senču uztverē Daugava, kalni, purvi, ezeri un citi kultūrainavas objekti nav radušies nejauši (dabiski), bet gan ir Dieva vai Velna radīti vairākos secīgos pasaules radīšanas aktos. Atšķirīibā no mūsdienu ǵeogrāfiem augšzemnieki nav dalījuši savu zemi atsevišķos dabas rajonos (apvidos), jo acīmredzot nav uzskatījuši reljefa īpatnības par pietiekamu pamatu šādam iedalījumam. Tā vietā paliekošu vietu Augšzemes folklorā ir ieguvuši lielie meži un purvi, kuri acīmredzot vairāk nekā reljefs ir saistījuši to uzmanību. Tās bija 
dabiskas robežas, kas nošḳīra apdzīvotos apvidus (ciemus) citu no cita un sadalīja Augšzemi salām līdzīgos novados. Savā starpā tos saistīja lielcel̦i, kuru garums parasti tika mērīts dienās, nevis kādās lineārās mērvienībās.

Augšzemes folklora liecina par to, ka "nemācītie" latviešu zemnieki prata savas ǵeogrāfiskās zināšanas pasniegt vienkāršā un skaidrā valodā, izpratnes padzilịnāšanai izmantojot tēlainus salīdzinājumus. Tomēr tajā būtu veltīgi meklēt šì novada vispārīgu ǵeogrāfisku raksturojumu mūsdienu mācību grāmatu un tūrisma celvežu izpratnē, jo tādam viņu dzīvē nebūtu īpašas nozīmes: viniem acīmredzot nebija tik svarīgi kultūrainavas veidojumu ǵeogrāfiskie (statistiskie) raksturlielumi, cik to sakrālā un saimnieciskā nozīme. Tas vistiešākajā veidā sasaucas ar Antuāna de Sent-Ekziperī "Cilvēku zemi" un mūsu ikdienas dzīvi, kurā precīzas ǵeogrāfiskās norādes joprojām ir svarīgākas par vispārīgiem aprakstiem.

\title{
KOKU UN KRŪMU LAPU PLAUKŠANAS FENOLOĢISKĀ PARĀDĪBA LATVIJĀ
}

\author{
Andris ĢËRMANIS \\ LU Ģeogrāfijas un Zemes zinātņu fakultāte, \\ e-pasts: andrisger@hotmail.com
}

Koku un krūmu lapu plaukšanas fenologiskā parādība Latvijā pētìta, izmantojot pēdējo 80 gadu laikā uzkrātos Latvijas fenoloǵiskos novērojumus un pēdējo 11 gadu fenoloǵiskos novērojumus Ukros. Tādējādi iegūti dati par koku un krūmu lapu plaukšanas secību vienā novērojumu punktā, par lapu plaukšanas gaitu (ğeogrāfiju) Latvijā un meteorologiskajiem apstākḷiem, kuri ietekmē lapu plaukšanu kokiem un krūmiem.

Ar lapu plaukšanas fenoloǵisko parādību fenologi saprot pašu pirmo mazo lapinu parādīšanos, taču pirms tam fenologi fiksē pumpuru piebriešanas fāzi, kura, piemēram, ogulājiem var iestāties jau ziemā, ja vien iestājas salīdzinoši silts un saulains laiks. Nereti ērkšķogām pumpuri piebriest jau marta sākumā, bet ceriņu pumpuru piebriešana nereti novērojama jau rudens beigās un ziemas sākumā, kas nodrošina sliktākus pārziemošanas apstākḷus un agrāku lapu plaukšanu pavasarī.

Pirms lapu plaukšanas ir sākusies sulu cirkulācija. Piemēram, perioda ilgums starp sulu cirkulācijas sākumu un lapu plaukšanas sākumu āra bērzam parasti sasniedz 4-5 nedēļas.

Pētīta arī lapu plaukšanas un ziedēšanas sākuma attiecība dažādām koku un krūmu sugām. Tā, piemēram, vītoli (kārkli) jau 2 nedēḷas pirms lapu plaukšanas ir sākuši ziedēt, baltalkšņi un lazdas pat 5-6 nedēļas iepriekšs, bet pīlādzim no lapu plaukšanas līdz ziedēšanai paiet precīzi viens mēnesis. Savukārt ķiršiem lapas sāk plaukt nedēḷu pirms to ziedēšanas sākuma. 
Ja apskatām lapu plaukšanas saistību ar meteorologiskajiem apstākḷiem, tad te, autoraprāt, jāuzsver tieši gaisa temperatūras lielā ietekme. To pamato fakts, ka sugām, kuras plaukst relatīivi agrāk, ir lielāka fāzes iestāšanās amplitūda. [Ģērmanis 2001]

Apkopojot pēdējo 80 gadu fenologiskos novērojumus, konstatēts, ka šajā laika posmā bērzu lapu plaukšanas sākums svārstījies no 6.marta līdz 1.jūnijam (vidēji parādība iestājusies 4.maijā), bet ievām agrākais lapu plaukšanas datums novērots 2.martā, vēlākais - 20.maijā, bet vidējais - 30.aprīlī. Vērojamas sakarības, ka pagājušā gadsimta 70. un 90.gados lapu plaukšana iestājās salīdzinoši agri, bet 80 .gados - vēlāk.

Pēc 1994.-2002.gada fenologiskajiem novērojumiem Ukros aprēķināta koku un krūmu lapu plaukšanas secība (Iekavās norādīts vidējais lapu plaukšanas sākuma datums. Gadījumā, ja divām sugām pēc vidējiem rādītājiem lapu plaukšana notiek vienā datumā, priekšroka tika dota sugai, kurai ir agrākais fāzes iestāšanās datums kādā no gadiem. Ja arī visagrākie datumi sakrīt, priekšroka tika dota sugai, kurai agrāks ir visvēlākais novērotais fāzes iestāšanās datums.): nokarenā ērkšķoga (6.aprīlī), upene (9.aprīīi), parastā ieva (11.aprīlīi), ceriņi (16.aprīlī), sarkanā jāṇoga (19.aprî̀ī), parastais pīlādzis (20.aprīlì), parastā lazda (21.aprīlī), kārkli (vītoli) (23.aprīlī), āra bērzs (23.aprīlī), baltalksnis (23.aprīlī), parastā zirgkastaņa (25.aprīīî), ķirši (29.aprīīî), mājas ābele (29.aprīlīi), parastā kḷava (29.aprīlī), parastā liepa (2.maijā), parastais ozols (3.maijā), parastā apse (6.maijā), parastais osis (11.maijā).

Pēc šiem datiem iespējams izdalīt trīs lapu plaukšanas vilņus.

I vilnis novērojams aprīḷa pirmajā pusē, kaut arī atsevišķos gados (1999., 2000.) lapu plaukšana ērkšķogām novērota jau marta mēneša trešajā dekādē.

II vilnis sakrīt ar diennakts vidējās gaisa temperatūras paaugstināšanos virs $+5^{\circ} \mathrm{C}$, par ko signalizē cerinu lapu plaukšanas sākums. Turpmāk (aprīḷa trešajā dekādē) notiek masveidīga lapu plaukšana daudzām koku un krūmu sugām. Meteoroloǵiskie novērojumi rāda, ka tas ir laiks, kad gandrīz katru gadu maksimālā gaisa temperatūra pacel̦as līdz $+21,+26^{\circ} \mathrm{C}$.

III vilnis iestājas maija sākumā, kad lapu plaukšanas fenologiskā parādība iestājas Latvijas mežu nemorālajiem kokaugu pārstāvjiem: parastajai (ziemas) liepai un parastajam ozolam. Un arī tad atsevišķos gados (piemēram, 2000.) var novērot lapu apsalšanu ozoliem un arī liepām. Vēl vēlāk lapas sāk plaukt parastajai apsei (6.maijā). Visvēlāk lapu plaukšanas sākums novērojams parastajam osim (11.maijā, kad diennakts vidējā gaisa temperatūra jau pakāpusies virs $+10^{\circ} \mathrm{C}$, sācies bioklimatiskā pavasara trešais (pēdējais) periods). Osis ir īpaši jūtīgs pret pavasara salnām. Autora novērojumi rāda, ka gandrīz katru gadu maija vidū vērojamas salnas uz augsnes (atseviškşos gados (1994., 1996., 1998., 2000., 2004.) pēdējās pavasara salnas uz augsnes novērotas vēl pat jūnija 2.-3.dekādē). Tādēl arī gandrīz katru gadu novērojama ošu, īpaši jauno, apsalšana. Turklāt 
jāṇem vērā, ka mežā, izcirtumā, purvainā vietā mikroklimatiskie apstākḷi ievērojami atšksiras, īpaši jau salnu režīms.

Savukārt koku un krūmu lapu plaukšanas gaitu analizējis A.Zirnītis (1956), izmantojot 1926.-1940. gada fenologiskos novērojumus par 12 koku un krūmu sugām 58 Latvijas punktos. Sastādot lapu plaukšanas sākuma kartoshēmas dažām koku un krūmu sugām, konstatēts, ka visagrākais lapu plaukšanas sākums novērojams Zemgales līdzenumā, bet pēc dažām dienām lapu plaukšana novērojama pārējos valsts dienvidu rajonos. Savukārt visvēlāk lapu plaukšanas sākums novērojams Kurzemes pussalas ziemeļos un Vidzemes augstienē. Vairākām koku un krūmu sugām lapu plaukšanas sākumu būtiski ietekmē arī Alūksnes un Austrumkursas augstiene.

\title{
Literatūra
}

Ģērmanis A. (2001). Pavasaris dzīvajā dabā un meteorologiskie apstākḷi: Ukri, 1990.-2000. Ģeogräfiski Raksti, IX, 74.-90.

Zirnītis A. (1956). Daži pētījumi par Latvijas PSR bioklimatu. LVU Zinātniskie Raksti, 71.-92.

\section{KONTINENTU UN VALSTU ASOCIATİVĀ FIKSĀCIJA}

\author{
Andris ĢËRMANIS \\ LU Ģeogrāfijas un Zemes zinātņu fakultāte, \\ e-pasts: andrisger@hotmail.com \\ Ineta KRASTIN̦A
}

Rīgas Pedagoǵijas un izglītības vadības augstskola, Pedagoǵijas fakultāte, e-pasts: krastina@latnet.Iv

Mācību procesā skolā skolēni dažkārt mēgina automātiski iegaumēt vajadzīgos faktus un sakarības. Tādējādi iegūtās zināšanas ǵeogrāfijā ir nenoturīgas, skolēniem šḳietami nevajadzīgas, bet pats process dažkārt liekas nogurdinošs. Lai bagātinātu un pilnveidotu mācību saturu, var izmantot asociāciju veidošanu un to fiksēšanu.

Asociācijas ir sakarības, kas veidojas starp priekšstatiem uz saskarsmes, līdzības vai pretstata pamata. Asociāciju fiksēšana nozīmē tās saglabāt, atzīmēt kādā noteiktā stāvoklī. Asociācijas izpaužas pārdomās, tās var uzrakstīt esejas veidā, bet var izpausties arī ar mākslas elementu palīdzību.

7.klasēs skolēni ğeogrāfijā apgūst kontinentu (reǵionālo) geogrāfiju. Tādēl autori veikuši pētījumu tieši šajā klašu grupā, nodrošinot arī starppriekšmetu saikni ǵeogrāfijai ar vizuālo mākslu un mājturību.

Vizuālajā mākslā paralēli ǵeogrāfijā apgūstamajai Āfrikas ǵeogrāfijai runā par vizuālās mākslas programmā paredzētajiem siluetiem. Silueti ļoti labi attēloti alu zīmējumos, kas sasaistās ar bagātīgo dzīvnieku valsti, fiksējot to ārējo izskatu un veidolu, kā arī procesus, kas ar tiem saistīti.

Mājturībā, kā liecina pêtījumi, veidojot dažādas kompozīcijas, l̦oti labi noder atšksirīgu ainavu stilizācijas, tādējādi skolēni daudz rūpīgāk iepazīst dabas 
apstākḷus, jo gribas ieraudzìt, saskatīt un izjust skaisto. Fiksējot precīzu attēlu, mēs galvenokārt izvēlamies fotogrāfiju, bet ar dažādiem mākslinieciskās izpausmes pan̄ēmieniem iespējams to pārveidot, pilnveidot un bagātināt, kā arī saskatīt galvenās vērtības. Stilizējot un to fiksējot ar dažādiem materiāliem, iegūti interesanti rezultāti.

Pētot pasaules tautu etnogrāfiju, atklājas loti daudzas līdzības rakstu, krāsu, rotāšanas paṇēmienu izmantošanā, kā arī var labi saskatīt dažādas ietekmes, krāsās daudz kas pārṇemts no Eiropas. L,oti daudz vēsturiski veidojušās dažādas dzīvnieku un cilvēku stilizācijas. Skolēniem l̦oti patīk šie uzdevumi, it īpaši, ja tie balstās uz etnogrāfisko materiālu, jo tas palīdz rosināt arī viṇu fantāziju, tajā pašā laikā akcentē, piemēram, dažādu dzīvnieku tuvāku iepazīšanu un izpēti, lai veiktu konkrētos uzdevumus. Darba procesā skolēni iepazīst ne tikai konkrēto dz̄ivnieku, bet, lai izvēlētos, aplūko arī pārējos, tā rezultātā bagātinot savas zināšanas.

Asociatīvās fiksācijas palīdz ar sasniegtajiem darba rezultātiem iepaz̄īstināt arī pārējos interesentus. Paveiktie darbi skolā regulāri tiek izlikti izstādē, un tas ir stimuls klasesbiedriem un gandarījums darbu autoriem.

Rezultātā tika konstatēts, ka, mācību procesā izmantojot asociatīvo fiksāciju, skolēni daudz vispusīgāk apgūst mācību saturu un viņiem rodas bagātīgāks priekšstats par kontinentiem un atsevišksām valstīm.

\title{
ŪDENS KVALITĀTE LATVIJAS MEŽA EKOSISTĒMĀS
}

\author{
Aigars INDRIKSONS \\ LVMI "Silava", e-pasts: indrikso@silava.Iv
}

Meža ekosistēmās apritē esošais ūdens analizējams vairākos līmeņos: nokrišņi klajumā un zem kokaudzes vainagu klāja, augsnes gruntsūdens un spiediena pazemes ūdens, virszemes notece grāvjos, strautos un upēs.

Mežu pētī̌sanas stacijas "Kalsnava" teritorijā 1960.gadā izveidots Vesetnieku ekoloǵiskais stacionārs, lai raksturotu mežsaimniecisko pasākumu (galvenokārt - hidrotehniskās meliorācijas un kopšanas ciršu) ietekmi uz mežaudžu struktūru un meža hidrologiisko režīmu. Četrdesmit gadu laikā piecos stacionāra nosusināto mežu ūdens sateces baseinos veikti noteces, gruntsūdens režīma un nokrišņu daudzuma mērījumi, kas l̦auj izstrādāt objektīvus modeḷus pārmitro mežu hidrolog̣iskā režīma raksturošanai. Ūdens aprites kvantitatīvie rādītāji kopš 1997.gada papildināti ar biogēno elementu analīzēm.

Iegūtie rezultāti salīdzināti ar laika posmā no 1996.gada jūlija līdz 1997.gada jūnijam nnemto ūdens paraugu analī̌̌u datiem Lielupes ūdens sateces baseina upēs - Viesītē un Sunītē un tajās ieplūstošajos strautos, kas drenē sausieņu mežus.

Biogēnie elementi meliorētās meža ekosistēmās uz dziļas kūdras galvenokārt ienāk ar ūdens pieplūdi ekosistēmai, t.i., atmosfēras nokrišņu sastāvā, 
kam pievienojas lietus laikā noskalotie putekḷi, kas adsorbēti kokaudzēe kā arī līdz ar ūdens pieplūdi no piegulošajām sausienēm vai spiediena pazemes ūdens izplūdi. Meža ar hidromorfām minerālaugsnēm fitocenoze var dal̦ēji izmantot arī augsnes minerālajās struktūrās iekḷautos elementus.

Kā augsnes auglības, tā arī ūdens kvalitātes izmaiņas aptuveni var raksturot ar biogēno elementu ieneses un izneses attiecībām; vispirms - ienese ar atmosfēras nokrišniem un iznese ar ūdens noteci pa grāvjiem.

Lai raksturotu biogēno elementu apriti, tika sastādīta analizēto elementu bilance katram ūdens sateces baseinam. Vesetnieku ekologisiskā stacionāra ūdens sateces baseinu vidējās elementu ieneses un izneses vērtības parādītas 1.tabulā.

1.tabula

Biogēno elementu ienese un iznese no ekosistēmas

Vesetnieku ekologiskā stacionāra nosusinātajos mežos, $\mathrm{kg} \mathrm{ha}^{-1} \mathrm{a}^{-1}$.

\begin{tabular}{|c|c|c|c|c|c|}
\hline Elements & $\begin{array}{l}\text { Ienese ar } \\
\text { nokrišņiem } \\
\text { klajumā }\end{array}$ & $\begin{array}{c}\text { Ienese ar } \\
\text { nokrišņiem } \\
\text { zem vainagu } \\
\text { klāja }\end{array}$ & $\begin{array}{c}\text { Iznese ar } \\
\text { grāvju noteci }\end{array}$ & $\begin{array}{c}\text { Starpība } \\
\text { starp ienesi } \\
\text { klajumā un } \\
\text { iznesi }\end{array}$ & $\begin{array}{c}\text { Starpība } \\
\text { starp ienesi } \\
\text { zem vainagu } \\
\text { klāja un } \\
\text { iznesi } \\
\end{array}$ \\
\hline $\mathrm{N}-\mathrm{NH}_{4}{ }^{+}$ & 14,8 & 13,9 & 7,1 & 7,7 & 6,8 \\
\hline $\mathrm{N}-\mathrm{NO}_{3}{ }^{-}$ & 0,9 & 0,4 & 0,7 & 0,2 & $-0,3$ \\
\hline $\mathrm{P}^{-\mathrm{PO}_{4}{ }^{3-}}$ & 1,4 & 0,8 & 0,2 & 1,2 & 0,6 \\
\hline $\mathrm{K}^{+}$ & 11,9 & 16,2 & 4,2 & 7,7 & 12,0 \\
\hline $\mathrm{Ca}^{2+}$ & 37,8 & 39,6 & 197,2 & $-159,4$ & $-157,6$ \\
\hline $\mathrm{Mg}^{2+}$ & 15,4 & 16,2 & 64,2 & $-48,8$ & $-48,0$ \\
\hline
\end{tabular}

Viena gada laikā slāpekḷa, kālija un fosfora vielu ienese pārsniedz iznesi, turpretī kalcija un magnija iznese pa grāvjiem ir vairākkārt lielāka nekā to ienese meža ekosistēmā ar atmosfēras nokrišniem kā mežos uz dziḷas kūdras, tā arī mežos ar hidromorfām minerālaugsnēm. Pastiprināta $\mathrm{Ca}^{2+}$ un $\mathrm{Mg}^{2+}$ iznese ar grāvju noteci apliecina Latvijas pārmitrajiem mežiem kopumā būtisku īpatnību - ūdens bilances pieplūdes daļā un pārpurvošanās procesā liela loma ir spiediena pazemes ūdens izplūdei no augšdevona dolomīta slāņa. $\mathrm{Ar} \mathrm{Ca}^{2+}$ un $\mathrm{Mg}^{2+}$ piesātinātie ūdeņi daļēji papildina augsnes gruntsūdeņus, daḷēji izķīlējas tieši nosusināšanas tīklā, ar ko, visticamāk, izskaidrojama grāvju noteces ūdens bāziskā reakcija $(\mathrm{pH}>7,0)$.

Ūdenim izplūstot caur vainagu klāju, tajā nadaudz samazinās $\mathrm{N}_{-} \mathrm{NH}_{4}{ }^{+}$un $\mathrm{P}-\mathrm{PO}_{4}{ }^{3-}$ daudzums, bet palielinās $\mathrm{K}^{+}$un $\mathrm{N}-\mathrm{NO}_{3}{ }^{-}$daudzums; $\mathrm{Ca}^{2+}$ un $\mathrm{Mg}^{2+}$ daudzums, kā arī pH rādītāji signifikanti neatšksiras: klajumā vidēji $\mathrm{pH}=6,51$, mežaudzē $\mathrm{pH}=6,31$. Salīdzinājumam - pa grāvjiem aizplūstošajā ūden̄̄ no mežiem ar kūdras augsnēm $\mathrm{pH}=7,32$, no mežiem ar hidromorfajām minerālaugsnēm - $\mathrm{pH}=7,44$ un stacionāra teritorijas dziḷākos grunts slāṇus drenējošā upē Vesetā $-\mathrm{pH}=8,03$. 
Biogēno elementu daudzums mg/l nosusināto un sausieṇu mežu ūdenstecēs

\begin{tabular}{|l|l|l|l|l|}
\hline \multirow{2}{*}{ Elements } & \multicolumn{2}{|c|}{ Objekts nosusinātajos mežos } & \multicolumn{2}{c|}{ Objekts sausieņu mežos } \\
\cline { 2 - 5 } & $\begin{array}{c}\text { Upē ieplūstošie } \\
\text { nosusināšanas } \\
\text { grāvji }\end{array}$ & Upe & $\begin{array}{c}\text { Upē ieplūstošie } \\
\text { strauti }\end{array}$ & Upe \\
\hline${\mathrm{N}-\mathrm{NH}_{4}{ }^{+}}$ & $1,5 \pm 0,2$ & $0,7 \pm 0,2$ & $0,8 \pm 0,2$ & $0,7 \pm 0,04$ \\
\hline${\mathrm{N}-\mathrm{NO}_{3}}^{-}$ & $0,1 \pm 0,04$ & $0,05 \pm 0,03$ & $0,3 \pm 0,1$ & $0,2 \pm 0,01$ \\
\hline $\mathrm{P}^{\mathrm{PO}_{4}}{ }^{3-}$ & $0,04 \pm 0,01$ & $0,03 \pm 0,02$ & $0,2 \pm 0,09$ & $0,08 \pm 0,01$ \\
\hline $\mathrm{Ca}^{2+}$ & $1,0 \pm 0,1$ & $1,7 \pm 0,1$ & $1,6 \pm 0,5$ & $2,3 \pm 0,06$ \\
\hline $\mathrm{Mg}^{2+}$ & $43,4 \pm 1,1$ & $40,5 \pm 2,5$ & $28,4 \pm 2,8$ & $49,6 \pm 0,9$ \\
\hline $\mathrm{pH}$ & $14,7 \pm 0,4$ & $17,0 \pm 1,9$ & $9,1 \pm 1,4$ & $24,9 \pm 0,8$ \\
\hline
\end{tabular}

Izvērtējot pētījumu objektos ievākto ūdens paraugu ķīmisko analīžu rezultātus, izrādījās, ka lielāks biogēno elementu ${ }_{-} \mathrm{N}^{-} \mathrm{NO}_{3}{ }^{-}, \mathrm{P}_{-} \mathrm{PO}_{4}{ }^{3-}$ un $\mathrm{K}^{+}$ daudzums ūdenstecēs ir objektā sausieņu mežos (2.tabula). Savukārt lielāks N$\mathrm{NH}_{4}^{+}, \mathrm{Ca}^{2+}$ un $\mathrm{Mg}^{2+}$ daudzums ir no nosusinātajiem mežiem notekošajā ūden̄i.

$\mathrm{N}_{-} \mathrm{NH}_{4}{ }^{+}$iznese no nosusinātajiem mežiem, kas sastāda $7,1 \mathrm{~kg} \mathrm{ha}^{-1} \mathrm{a}^{1}$ ir liela salīdzinājumā ar amonija noteci upē sausieņu mežu objektā, kur tā sastādīja tikai $0,6 \mathrm{~kg} \mathrm{ha}^{-1} \mathrm{a}^{-1}$. Palielināta biogēno elementu notece no nosusinātajām platīiām veidojas, pateicoties vasarā neizsīkstošajai ūdens plūsmai pa grāvjiem platībās ar dziḷām kūdras augsnēm, turpretī sausieņu mežos strauti ir izsīkuši.

\title{
PRIEŽU MEŽI PREIĻU NOVADA PILSKALNOS
}

\author{
Gundega JURĀNE, \\ Preiļu virsmežniecība, "Kaijas", \\ e-pasts: gundega.jurane@preili.vmd.gov.Iv
}

Priežu meži aprakstīti četros Preiļu novada pilskalnos: Gedušu pilskalnā (Ziemel̦austrumu ǵeobotāniskais rajons), Kategrades, Krupenišku un Borovkas pilskalnos (Dienvidaustrumu ǵeobotāniskais rajons).

Preiļu novada priežu mežos koku stāvā valdošā ir priede kopā ar egli, priede kopā ar platlapjiem vai bērzu, dažreiz bērzs. Visos pilskalnos krūmu stāvā dominē lazda. Koku, krūmu un lakstaugu stāvā sastopamas 64 sugas, no kurām izplatītākās ir platlapju mežu sabiedrību klases Querco-Fagetea Br.-Bl. Et Vlieger 1937 rakstursugas - $\underline{\text { Hepatica nobilis, Aegopodium podagraria, }} \underline{\text { Corylus }}$ avellana, Lonicera xylosteum, Melica nutans, Anemone nemorosa, Carex digitata 


\section{Sugu sastāvs Preiḷu novada pilskalnu priežu mežos}

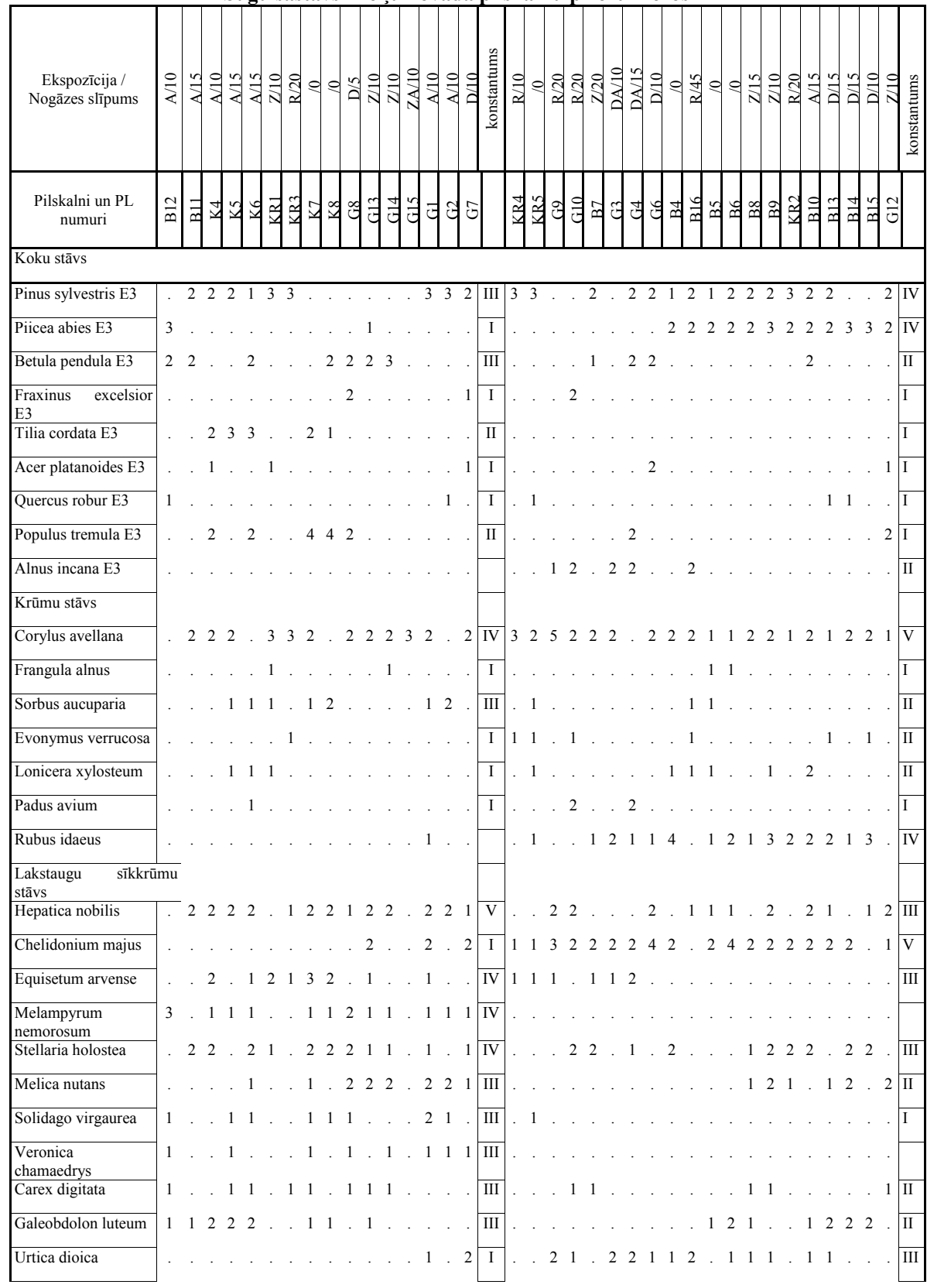




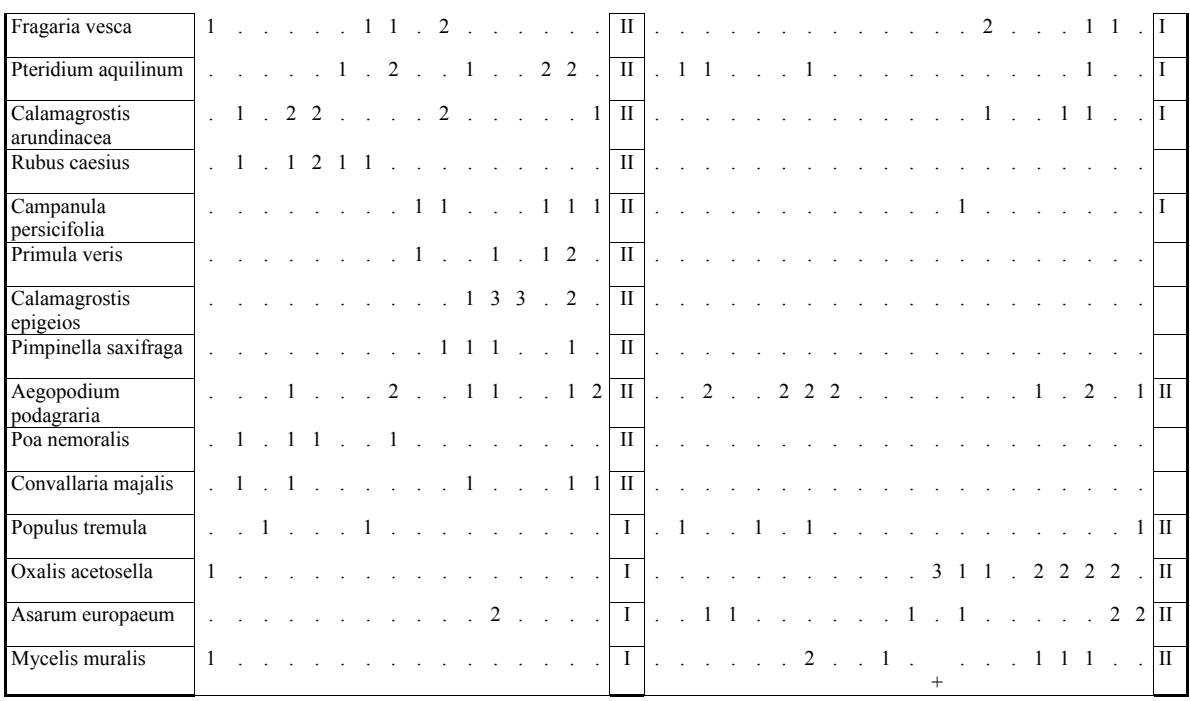

Reti sastopamās sugas (konstantums $=\mathrm{I}$ ):

Abās grupās : Equisetum pratense, Geranium palustre, Veronica officinalis, Galium mollugo, Viola spp.

1.grupā: Vaccinium myrtillus, Trifolium medium, Fragaria viridis, Centaurea scabiosa, Knautia arvensis, Festuca pratensis, Lathyrus pratensis, Lathyrus sylvatica, Luzula pilosa, Agrostis tenuis, Stellaria nemorosa, Lamium purpureum, Actaea spicata, Campanula trachelium.

2.grupā: Humulus lupulus, Anemone nemorosa, Scrophularia nodosa.

Ar TWINSPAN klasifikācijas programmu apraksti sadalīti divās grupās: 1.grupa (16 apraksti - 56 sugas) priede un bērzs - koku stāvā, lazda un pīlādzis krūmu stāvā, lakstaugu stāvā zilā vizbulīte, tīruma kosa, birztalu nārbulis, cietā virza un pumpursmilga; 2.grupa (20 apraksti - 37 sugas) koku stāvā priede un platlapji vai priede un egle, krūmu stāvā lazda kopā ar aveni, segliṇu un sausserdi, lakstaugu stāvā strutene, zilā vizbulīte, tîruma kosa un cietā virza.

\section{ĢEOGRĀFIJAS MĀCĪBU PROCESA VĒSTURISKĀ ATTİSTİBA LATVIJĀ, EIROPĀ UN PASAULĒ}

\section{Teiksma KALNIN̦A}

Pedagogíiskais process ir vienots, organizēts skolas mācību un audzināšanas process ar mērķi veicināt skolēna daudzpusīgu attīstību atbilstoši viņa aktuālajam inviduālās attīstības līmenim un iespējām. Pedagoǵiskais process aptver gan mācību stundas un citas organizatoriskās formas, gan ārpusstundu nodarbes, gan skolēnu pētniecisko darbību (Žogla I.,2001.). 
Pedagoǵiskais process skolā ir mērkstiecīgi organizēts process, lai paātrinātu skolēna pieredzes bagātināšanos un, balstoties uz viṇa individuālajām īpašībām, sekmētu personības attīstību kopumā. Šim mērksim ir pakḷauta mācību un cita veida darbība. 20.gadsimtā tendences pedagoǵiskajā procesā sāka mainīties. Līdz gadsimta vidum dominēja jautājumi "Kā labāk mācīt?", "Kādas metodes izraudzìties?". Gadsimta pēdējā trešdal̦ā akcents pārvietojās uz jautājumu "Kas skolotājam un skolēnam darāms un ko viņi dara klasēe?". Pēdējos divdesmit piecos gados uzmanība pārvietojas uz skolēnu domāšanas veidu, zināšanu un prasmju pašvērtējumu, pedagoǵiski pamatotu izvēli, uz skolotāja prasmi rosināt skolēnu mācīties un daudzpusīgi sevi attīstìt (Žogla I., 2001.).

1.tēze. Pirmās ğeogrāfijas priekšmeta iezīmes vērojamas klosteru skolās, kur tiek veidota prāta, jūtu, gribas nedalāmība. Klosteru skolās zem vārda "ǵeometrija" vairāk māca ǵeogrāfiju. To mācot, visvairāk uzmanību pievērš zemes apdzīvotājiem - cilvēkiem, dzīvniekiem. Pilsētas skolās un garīgajās skolās 3.nodạ̄ā (klasē) mācīja ǵeogrāfiju, vēsturi, dabasmācību. 13.gs. ǵeogrāfijas mācīšanu veicina Hanzas savienības izveidošanās. Ģeogrāfijas pētījumu attīstībā jaunā līmenī liela loma ir universitātes izveidošanai Parīzē, Oksfordā, Romā, Kembridžā 13.gadsimtā.

Ģeogrāfijas izzināšanā liela nozīme bija 15.gs. lielajiem ǵeogrāfiskajiem atklājumiem, kuru ietekmē veidojās zināšanas par Ameriku, Āfriku un Āziju, 17.gadsimtā - arī par Austrāliju un vēlāk - Antarktīdu.

Francijā 17.gadsimtā ierosina ǵeogrāfiju ierindot pirmmācības priekšmetu sarakstā. Apgaismības laikmetā (Dž.Loks, Ž.Ž.Ruso) ǵeogrāfiju pieskaita pie reāliem priekšmetiem un pētnieciskā darbība saistîta ar sajūtu. Ž.Ž.Ruso geogrāfiju uzskata par pirmām derīgām zināšanām: "Jāmācās patstāvīgi, tāpēc, ka ar patstāvīgi iemācīto iegūstam skaidrākus jēdzienus nekā ar citu paskaidroto“ (Ruso Ž.Ž., 1925., 34.lpp.). Šīs atziñas ir pamats skolēnu patstāvīgās darbības attīstîbai ar pētnieciska rakstura uzdevumu risināšanu. Nozīmīga ir atziņa, ka geogrāfijas pētījumi jāsāk ar dzimtās mājas apkārtni, pēc tam jāapraksta pilsēta, jāzīmē un jāiepazīstas ar karti : "Kad rokas daudz strādā, iedoma atpūšas, kad miesa nogurusi, sirds mierīga." (Ruso Ž.Ž., 1939.). Pētījums ir atbildes meklēšana ar citu teoriju palīdzību, jaunu zināšanu radīšana, tāpēc nozīmīgi ir sākt ar tuvāko apkārtni, ņemot vērā iepriekš izteiktās domas. Šìs atziṇas ir nozīmīgas tā laika apmācību sistēmā un savu nozīmi pētnieciskās darbības attīstībā nav zaudējušas vēl šodien.

Liels pavērsiens ǵeogrāfijas mācību metodes attīstībā ir J.Komenska (1592-1670) uzskatu ietekme uz visu mācību procesu: mācìt par to, ka zeme ir apaļa, par jūrām un okeāniem, par zemes dal̦ām, Eiropas valstīm, pilsētām, kalniem, upēm. Pētnieciskā darbā izmanto ožu, redzi, dzirdi, tausti. Lielu nozīmi J. Komenskis pieškirir praktiskajam darbam: "Pār dabu valda tas, kas zina tās likumus, kas iegūti rūpīgu dabas un dz̄ives parādību novērojumu cẹ̦ā" (Komenskis J., 1939., 59.lpp.). 
Ģeogrāfiju mācījās ārpus skolas, pastaigājoties un ceḷojot. Jau toreiz tika ņemti vērā galvenie pamatlikumi:

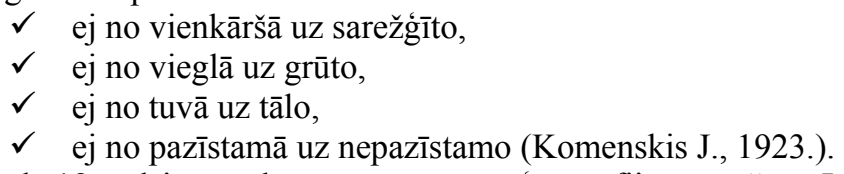

2. Līdz 18.gadsimta sākumam runāt par ǵeogrāfijas mācīšanu Latvijā būtu pāragri, kaut garīgajos rakstos pieminēti nosaukumi Ėǵipte, Sarkanā jūra, Jeruzāleme, Jūdu valsts u.c. Ģeogrāfijas mācīšanu ierobežoja nemitīgā pakḷautība citiem mācību priekšmetiem.18.gadsimtā visa Latvijas teritorija tika apvienota Krievijas impērijas ietvaros. Latviešu skolas palika vācu muižniecības un baznīcas pārzin̄ā. Nebija vienota skolu tīkla, nebija mācību programmu. 1774.gadā tiek izdota G.F.Stendera jeb Vecā Stendera "Augstas gudrības grāmata no pasaules un dabas", kur tiek runāts par pasaules dabu latviešu valodā (Anspaks J. 1998).

19.gs., mācot ǵeogrāfiju kā atsevišķu mācību priekšmetu, lielāka nozīme tiek ierādīta patstāvīgai domai, spriedumam, prasmei apskatìt, apdomāt un izteikties, attīstot pētnieciskās darbības pamatu, spēju spriest par lietām. Šīs atziņas ietekmējušas arī Latvijas skolotājus: J.Cimzi, Jelgavas skolotāju institūta pasniedzējus, skolu muzeju darbiniekus, ǵeogrāfijas metodik̦i P.Sauli-Sleini (Anspaks J. 1998).

3. Atsevišķi skolotāji entuziasti sāka mācìt ǵeogrāfiju. 1859.gadā iznāk sacerētā Baltijas fiziskā geogrāfija "Mūsu tēvzemes aprakstǐšana un daži pielikumi, īsumā saṇemti”. Tiek pavērts ceḷš nopietnai ǵeogrāfijas apguvei. Studējot Tērbatas Universitātē, K.Barons interesējās arī par geogrāfiju, īpaši Baltijas geogrāfiju. K.Baronu droši varam saukt par latviešu nacionālās ğeogrāfijas pamatlicēju. Viña grāmatas beigās ievietotā karte ir pirmais latviešu autora veikums kartogrāfijā, kas balstās uz tā laika atzinumiem Eiropā un pasaulē.

Jau 1867.gadā izdotajā grāmatā "Dzimtenes mācības mācišana skolā" (pēc Kronvalda Ata) pausta doma, ka galvenais ir iepazīt tuvāko apkārtni.

19.gadsimta beigās K.Dēķens vērsās pret vācu mācītāju divkosību un kritizēja mazaktīvos un neapzinīgos latviešu skolotājus (Ūsinšs V., 1975.). 1921.gadā K.Dēḳens sastāda grāmatu "Vadonis dzimtenes mācībā".

4. 20., 30.gados Latvijā likti pamati skolēnu izziņas darbības attīstībai, sekmējot skolēnu zinātkāri ar dažādām patstāvīgā darba formām, kur dažos uzdevumos vērojams pētniecisks raksturs. Liela loma ir tam, ka novērošanā iegūtos datus skolēni salīdzina un apkopo, tādējādi varam runāt par intelektuālo attīstību. Izziņas darbības aktivizēšanai palīdz problēmveida uzdevumi, kā arī cēlonisko sakarību noskaidrošana. Piemēram, "Kāpēc upe nevar tecēt otrādi? ".

Ievērojamu ieguldījumu Latvijas ǵeogrāfijas kā patstāvīga mācību priekšmeta attīstībā devis Ģ.Ramans, Fr.Dravnieks, J.Greste. 
Fr.Adamovičs vēlas, lai dabasmācības un geogrāfijas mācīšana būtu viena skolotāja rokās. Fr.Dravnieka 1928.gadā izdotā "Ģeogrāfijas metodikā" ir nozīmīgs devums mācīšanas paņēmienu attīistībā.

5. Apkopojot ġeogrāfijas mācību procesa attīstības īpatnības, redzam, ka ir vērojami visi metodologiskie pamati jau agrāk. Pakāpeniski vērojami pētnieciskās darbības elementi, kā izziñas intereses attīstǐšana, patstāvīgā darbība un kritiskā domāšana. Vēsturiski vērojamas dažādas pieejas mācību procesa veidošanā, bet pētnieciskās darbības elementi nav sveši. Nozīmīgi ir principi, kam sekoja daudzi pedagogi, kuri apguva ievērojamo pedagogu atziņas un ieviesa to skolu mācību procesā, kas pakāpeniski dažādojās un pilnveidojās. Zinātniski pētnieciskā darbība ir mūsdienu skolēna mācību darbības nepieciešams komponents, kurš sekmē radošas un kritiskās domāšanas, mērḳtiecības, izziņas darbības un patstāvīgas darbības efektivitātes attīstību. Pamatā ir mācību priekšmeta attīstība, skolēnu vecumposms, prasme strādāt patstāvīgi, attīstìt izziņas darbību un kritisko domāšanu, spēt sameklēt un izdalīt no teksta vajadzīgo informāciju, atraisīt kreativitāti. Modelis, kā veikt pētniecisko darbību, ir pētnieciskās pieejas metodoloǵiskais pamats. To veido trīs komponenti - didaktiskais, procesuālais, kriteriālais un sadarbība starp skolēnu un skolotāju. Grūtības, ar kurām saskaras skolēni savā pētnieciskajā darbībā, iespējams pārvarēt, izmantojot dotā pedagogiskā pētījuma izvērtēšanas kritērijus un skolēnu pētnieciskās attīstības darbības modeli, kas palīdz apjēgt, attīstīt un novērtēt pētniecisko darbību skolā, ieviest pedagogiskās inovācijas un atraisīt skolēnu kreativitāti.

\title{
Literatūra
}

1. Dz.Albrehta. Pētīšanas metodes pedagoǵijā.-R.-:Mācību grāmata, 1998,102 lpp.

2. K.Dēķens. Rokas grāmata pedagoǵijā.-R.:Valters un Rapa,1919, 25 lpp.

3. J.Greste. Krist un celties.-R.:Zvaigzne, 1990, 199 lpp.

4. H.Gudjons. Pedagogijas pamatatziņas.-R.:Zvaigzne,1998,394 lpp.

5. I.Žogla. Skolēna izziṇas attieksme un tās veidošanās.-R.:LU,1994,203 lpp.

6. B.Cox. Teaching Skills in Geography.-Melbourne, Australia,1995,p.169-178.

7. J.Fien.Planning and Teaching a Geography curriculum Unit.-Melbourne, Australia.,p. 345.-370.

\section{CENTRĀLO VIETU DINAMISKUMS UN KONTINUITĀTE}

\author{
Marija KASPAROVICA \\ Latvijas Universitāte, Ģeogrāfijas un Zemes zinātņu fakultāte
}

Latvijas apdzīvojums ir veidojies gadu simtiem. Tas atspoguļo apdzīvoto vietu telpisko dispersitāti, funkcionālo diferenciāciju, hierarhiskumu, dinamiskumu laikā un telpā.

Katrai apdz̄̄votai vietai apdz̄̄vojumā ir atšķirīgi vēsturiskās attīstības priekšnoteikumi, dažāds pievilkšanas spēks, pa hierarhijas kāpnēm virzoši impulsi. Sakari starp apdzīvotām vietām ir ne tikai telpiski, bet arī kvalitatīvi un strukturāli. 
Katrā vēstures attīstības periodā viens no apdzīvoto vietu tipiem kḷūst vadošais, apdzīvojuma karkasu veidojošs. Visas valsts apdzīvojuma indikators ir tās centrālās (vadošās) vietas. Centrālās vietas jēdziens bieži tiek lietots kā sinonīms visu citu regiona, rajonu apdzīvoto vietu centram. Centrālo vietu attīstība katrai valstij ir citāda, jo to nosaka geogrāfiskie apstākḷi, vietējās tradīcijas, etnosituācija, piedāvātās tirgus iespējas, ietekmējošais globalizācijas process, ilgtspējīgas attīstības tendences u.c. Centrālās vietas ir:

$\checkmark$ centrtieces centri, kas fokusē materiālu, enerğijas, informācijas, cilvēku plūsmas ar savu pievilkšanas spēku;

$\checkmark$ centrbēdzes (difūzijas) centri, kas, mainoties sociāli ekonomiskajai un politiskajai situācijai valstî, ir spiesti daļu savas funkcijas un cilvēku resursus atdot citām apdzīvotajām vietām.

Centrālo vietu apzināšana un noteikšana ir sociāli ekonomiskās attīstības stratēgiskais mērkịis. Centrālās vietas ļauj salīdzināt reālo ar ideālo izvietojumu, paredzēt to izmaiñas nākotnē. Katra centrālā vieta ir visas apdzīvojuma sistēmas dinamisks elements, kas pakḷauts nepārtrauktām strukturālām un funkcionālām izmaiņām.

Latvijā jau XIX gs. bija izveidojusies vienmērīga kompakti apdzīvoto vietu dislokācija. 1924.gadā izveidoto 19 apriņ̧̧u administratīvo centru funkcijas sāka pildīt pilsētas, kas veidojās par centrālām (vadošām) apdzīvotām vietām. Šāds centrālo (vadošo) apdzīvoto vietu skaits palika nemainīgs visus brīvvalsts gadus. Apriṇkusus nosauca centrālās pilsētas vārdā, izṇemot Ilūkstes apriṇķi, kura administratīvā pārvalde atradās Grīvas pilsētā. Netika mainīti arī apriņķu nosaukumi, izņemot Jaunlatgali, ko 1938.gadā pārdēvēja par Abreni. Iedalot Latviju 19 apriņ̧̧̧os, tika ņemti vērā vēsturiskie un ekonomiskie motīvi, satiksmes ērtības un iedzīvotāju intereses. Analizējot 19 apriņ̧̧u centrālo pilsētu iedzīvotāju skaita dinamiku 45 gadu (1898-1943) garumā, varam secināt, ka (1989, 1914, $1925,1935,1943)$ iedzīvotāju skaits un vieta ir būtiski atšķirīgas. Tās varam iedalìt:

$\checkmark$ pilsētās, kuru ieņemtā vieta visus 45 gadus ir palikusi nemainīga (Rīga 1.v., Rēzekne 6.v., Tukums 9.v.);

$\checkmark$ pilsētas savstarpējā konkurencē ieņēmušas 2.-4.v. (Daugavpils, Liepāja, Jelgava);

$\checkmark$ noticis krass pilsētas augšupejas izrāviens (Valmiera no 15. uz 6.vietu, Ventspils no 10. uz 5.vietu);

$\checkmark$ pilsētas nozīme strauji samazinājusies (Valka no 5. uz 16.v.), jo ar Latvijas valsts robežu nospraušanu pierobežas pilsēta Valka zaudēja dą̧u no savas agrākās nozīmes;

$\checkmark$ reǵiona centrālā pilsēta pēc to iedzīvotāju skaita dinamikas nav pakāpusies augstāk par 11.-13.vietu visu 45 gadu garumā (Bauska, Ludza, Talsi, Jēkabpils) u.c. 
Situācija Latvijas apdzīvojumā mainās 1935.gadā, kad lauku teritorijā izdala 145 kompaktas lauku apdzīvotās vietas - ciemus. Ciemi kḷuva par 225960 disperso lauku apdzīvoto vietu atbalsta centriem, kas jau 1935.gadā uzṇēmās daļu no pilsētu funkcijām. Šie 145 ciemi ilgā vēsturiskā attīstībā bija veidojušies par centrtieces centriem, kḷūstot par lauku apdzīvojuma vadošām kompaktām apdzīvotām vietām. Centrālo vietu - ciemu telpisko proporciju raksturo tas, kā tie izvietojās: Vidzemē 53, Latgalē 53, Zemgalē 22, Kurzemē 17. Pēc iedzīvotāju skaita 145 ciemi dalījās: 20 mazi , 95 vidēji, 22 lieli, 5 l̦oti lieli ciemi. No 1935.gada centrālām lauku apdzīvotām vietām ciemiem 2005.gadā:

- 16 iekḷauti kādā no 77 Latvijas pilsētām,

- 14 ciemi ieguvuši pilsētas statusu,

- 109 ciemi turpina funkcionēt kā nozīmīgas kompaktas lauku apdzīvotās vietas ar apkalpes centra funkcijām,

- 6 ciemi (Abrenes teritorijā) atrodas KFSR sastāvā.

Būtiski centrālās (vadošās) vietas Latvijā mainās okupācijas gados, jo 1949.gadā apriṇķi tika likvidēti un to teritorija sadalīta vēl sīkāk, pārdēvējot tos par rajoniem. Pagastus kā starpposmus starp ciemiem un rajoniem likvidēja. Uz 1950.gada 1.maiju Latviju sadalīja 58 administratīvi teritoriālos rajonos. Rajonu centru funkcijas sāka pildīt 44 pilsētas un 14 kompaktās lauku apdzīvotās vietas ciemi, kuriem piešķīra pilsētciemata statusu. Šo administratīvo rajonu izveidošanas mērḳis bija radīt Latvijas lauku apvidos tādas administratīvi teritoriālās vienības, kas būtu visērtākās okupācijas varas pārvald̄̄šanas uzdevumu veikšanai un kompaktas ekonomiskajā ziņā. Rajonu izveidošana palīdzēja sapludināt un stiprināt partijas un padomju varu Latvijas laukos. Rajonus nodēvēja rajona centrālās pilsētas vai pilsētciemata vārdā, izņemot Gaujienas rajonu, kura administratīvais centrs bija Jaunpiebalgā, un Abrenes rajonu ar centru Viḷakā. Jauno lauku rajonu pat visnomal̦āko apvidus attālums no rajona centra nebija lielāks par 30-45 km. Ar 1950.gadu zināmas iespējas straujāk attīstīties radās tām pilsētām un pilsētciematiem, kas bija kḷuvuši par jaunizveidoto rajonu centriem - visas Latvijas apdzīvojuma centrālām vietām. Jaunizveidoto 58 rajonu centru iedzīvotāju dinamika (1935.-1959.) parāda, ka pilsētas un pilsētciemati strauji savu iedzīvotāju skaitu palielināja, izṇemot Rūjienu.

No 1955. līdz 1962.gadam jau 32 rajonus likvidēja, un to centri zaudēja centrtieces funkcijas, kḷūdami par centrbēdzes centriem, pārejot zemākā rangā. Likvidēto rajonu centri zaudēja centrālās vietas funkcijas. Tie palika par vietējās apkalpes centriem. Notika to funkciju pārprofilěšana. 1970.gada tautskaites materiāli rāda, ka, zaudējot rajona centra funkciju, desmit centros iedzīvotāju skaits strauji samazinājās. Bijušajos rajona centros izvietoja vietējās nozīmes rūpniecības uzṇēmumus, tāpēc tajos palielinājās rūpniecības ražošanas personāls.

1984.gadā parādās jauns veidojums - lauku ciemati. Laukos reǵistrēja 669 ciematus, kuri par centrālām lauku apdzīvotām vietām neizveidojās. 
Centrālās vietas atspoguḷo ne tikai apdzīvojuma dinamiskumu, mobilitāti, bet arī to kontinuitāti, kas izpaužas konkrēto apdzìvoto vietu gadu simtu attīstības nepārtrauktībā, pēctecībā, nepārtrauktā daudzveidībā, kaut arī bija to nopostīšanas un degradācijas periodi. Centrālās (vadošās) apdzīvotās vietas vairāku gadsimtu garumā ir pildījušas kuršu un latgaļu zemju, apgabalu, guberņu, apriņķu, rajonu, novadu u.c. centru funkcijas.

\title{
LATVIJAS AUGŠN̦U KLASIFIKĀCIJAS PIELĪDZINĀŠANA PAK - IESPËJAS UN PROBLËMAS
}

\author{
Aldis KĀRKLIN̦Š \\ Latvijas Lauksaimniecības universitāte, \\ e-pasts: Aldis.Karklins@llu.Iv
}

Augsnes informācijas starptautiskās apmaiņas nepieciešamība, apjomīgu reǵionālo un globālo datu bāzu veidošana, augsnes datu iekḷaušana dažādu pielietojuma programmu sastāvā prasa, lai š̄ informācija būtu standartizēta. Vispirms jau tas attiecas uz augsnes iedalījumu noteiktās jēdzieniskās kategorijās augsnes klasifikācijas taksonos. Šim mērķim ir radīts Pasaules augšņu klasifikators (PAK) - savdabīga sistēma, kas paredzēta nacionālo augšnu klasifikācijas sistēmu taksonu savstarpējai salīdzināšanai. Tādējādi, lai Latvijas augšnnu informāciju padarītu par starptautiski izmantojamu, nacionālo klasifikācijas vienību vietā ir jālieto PAK taksoni. Tā kā Latvijas augšņu klasifikatora un PAK taksoni ir veidoti pēc stipri atšksirīgiem principiem, jāatmet doma par korelatīvas tabulas izveidi, kas ļautu tos vienkārši salīdzināt, tas ir, veikt nosaukumu ,tulkošanu”. Vienīgā iespēja ir augšṇu diagnostikā izmantot atbilstošas metodes un uzkrāt tādu informācijas kopumu, kas l̦auj veikt nepastarpinātu augšnnu klasifikāciju gan atbilstoši nacionālajai sistēmai, gan arī PAK.

PAK nav ideāla sistēma. Tās izvirzìtais mērksis - būt noderīgai visas pasaules augšnu daudzveidības raksturošanai, cenšanās to saglabāt relatīvi vienkāršu, ne pārāk ilgā attīstības vēsture un citi faktori veido situāciju, ka ne vienmēr lietotājs ir apmierināts ar tās ,izšķirtspēju”, kā arī klasifikācijas taksoni vāji korelē ar vietējiem augšnu ǵenēzes apstākḷiem un augsnes veidošanās faktoru kopsakarībām. Tāpēc jāsamierinās ar situāciju, ka dažkārt divas augsnes, kuras ir savstarpēji tuvas Latvijas klasifikācijas sistēmā (iekļaujas viena apakštipa robežās), var tikt iedalītas atšķirīgās PAK augšņu grupās (augstākās klasifikācijas līmenis). Un otrādi, Latvijas sistēmā tālu esošas augsnes var tik apvienotas vienā PAK zemākā taksonā. Tabulā dots automorfo augšņu klasē (atbilstoši Latvijas klasifikācijai) ietilpstošo augšņu tipu salīdzinājums ar PAK augšņu grupām un apakšgrupām.

PAK uzbūves īpatnības praktiski nedod iespēju to izmantot liela mēroga (1:10 000; 1:50 000) augšņu kartēšanā. Kā rāda citu valstu pieredze, ar zināmām 
modifikācijām to var sākt lietot, ja kartēšanas mērogs ir 1:250 000 un mazāks. Taču tā joprojām ir vienīgā metode, ar kuras palīdzību iespējama augsnes datu savstarpējā salīdzināšana situācijā, kad katra valsts lieto savu, uz atšksirīgiem principiem veidotu nacionālo augšņu klasifikācijas sistēmu un atbilstoši šai sistēmai vien pieskaņotu terminoloǵiju.

Latvijas automorfo augšṇu iespējamais salīdzinājums ar PAK taksoniem ${ }^{1}$

\begin{tabular}{|c|c|c|c|}
\hline \multirow{2}{*}{$\begin{array}{l}\text { Augsnes } \\
\text { tips }\end{array}$} & \multicolumn{2}{|c|}{ Galvenās diagnosticējošās pazīmes } & \multirow{2}{*}{$\begin{array}{c}\text { Latvijas klasifikācijas vienību } \\
\text { iespējamā atbilstība PAK } \\
\text { taksoniem }\end{array}$} \\
\hline & $\begin{array}{c}\text { atbilstoši Latvijas } \\
\text { klasifikatoram }\end{array}$ & atbilstoši PAK & \\
\hline $\begin{array}{l}\text { Velēnu } \\
\text { karbonāt- } \\
\text { augsnes }\end{array}$ & $\begin{array}{l}\text { Labi izteikts A } \\
\text { horizonts un } \\
\text { karbonātu sākšanās } \\
\text { dzil̦ums } \leq 60 \mathrm{~cm} \text { no } \\
\text { augsnes virspuses. }\end{array}$ & $\begin{array}{l}\text { Ochric vai mollic } \\
\text { virskārtas horizonts. } \\
\text { Cambic apakškārtas } \\
\text { horizonts, sekundārie } \\
\text { karbonāti, virsējā } \\
\text { glejošanās. }\end{array}$ & $\begin{array}{l}\text { Luvisols (arenic, stagnic, } \\
\text { haplic), Cambisols (stagnic, } \\
\text { mollic, calcaric, skeletic, eutric), } \\
\text { Leptosols (calcaric, eutric), } \\
\text { Phaeozems (stagnic, calcaric). }\end{array}$ \\
\hline $\begin{array}{l}\text { Brūn- } \\
\text { augsnes }\end{array}$ & $\begin{array}{l}\text { Māla iluviāla } \\
\text { akumulācija B } \\
\text { horizontā, karbonāti } \\
\text { dzil̄āk par } 60 \mathrm{~cm} . \\
\text { Iztrūkst E horizonta } \\
\text { un citu } \\
\text { podzolizācijas } \\
\text { pazīmju. }\end{array}$ & $\begin{array}{l}\text { Ochric vai mollic } \\
\text { virskārtas horizonts. } \\
\text { Argic vai cambic } \\
\text { apakškārtas horizonts, } \\
\text { pēkšņa granulometriskā } \\
\text { sastāva maiṇa. }\end{array}$ & $\begin{array}{l}\text { Luvisols (arenic, lamellic, } \\
\text { cutanic, dystric, haplic), } \\
\text { Cambisols (mollic, dystric, } \\
\text { eutric, haplic), Phaeozems } \\
\text { (luvic, abruptic, haplic). }\end{array}$ \\
\hline $\begin{array}{l}\text { Podzol- } \\
\text { augsnes }\end{array}$ & $\begin{array}{l}\text { Augsnes ar } \\
\text { podzolizācijas } \\
\text { pazīmēm (atkrāsots } \\
\text { E horizonts). E un B } \\
\text { horizontos pH KCl } \leq \\
5,5 .\end{array}$ & $\begin{array}{l}\text { Ochric, mollic vai } \\
\text { umbric virskārtas } \\
\text { horizonts. Albic, argic, } \\
\text { cambic apakškārtas } \\
\text { horizonts, albeluvic } \\
\text { mēlviveidīgums, } \\
\text { organiskie augsnes } \\
\text { materiāli. }\end{array}$ & $\begin{array}{l}\text { Albeluvisols (histic, umbric, } \\
\text { arenic, abruptic, haplic), } \\
\text { Cambisols (mollic, dystric, } \\
\text { haplic), Arenosols (hypoluvic, } \\
\text { albic, lamellic, dystric). }\end{array}$ \\
\hline Podzoli & $\begin{array}{l}\text { Augsnes ar } \\
\text { izteiktām } \\
\text { podzolizācijas } \\
\text { pazīmēm (labi } \\
\text { izdalās E un Bs/Bhs } \\
\text { horizonti). }\end{array}$ & $\begin{array}{l}\text { Histic, umbric vai } \\
\text { ochric virskārtas } \\
\text { horizonts. Albic, spodic, } \\
\text { fragic apakškārtas } \\
\text { horizonts. }\end{array}$ & $\begin{array}{l}\text { Podzols (densic, carbic, rustic, } \\
\text { histic, umbric, entic, placic, } \\
\text { fragic, anthric, haplic). }\end{array}$ \\
\hline $\begin{array}{l}\text { Nepiln̄̄gi } \\
\text { izveido- } \\
\text { tās } \\
\text { augsnes }\end{array}$ & $\begin{array}{l}\text { Augsnes ar vāji } \\
\text { izveidotiem } \\
\text { genētiskiem } \\
\text { horizontiem un } \\
\text { seklu augsnes } \\
\text { profilu. }\end{array}$ & $\begin{array}{l}\text { Ochric virskārtas } \\
\text { horizonts. Argic or } \\
\text { cambic apakškārtas } \\
\text { horizonts. }\end{array}$ & $\begin{array}{l}\text { Cambisols (calcaric, eutric, } \\
\text { haplic), Arenosols (calcaric, } \\
\text { protic, eutric, haplic), Regosols } \\
\text { (arenic, aric, calcaric, eutric, } \\
\text { haplic). }\end{array}$ \\
\hline
\end{tabular}

${ }^{1}$ Atbilstoši „World Reference Base for Soil Resources / World Soil Resources Reports No.84. (1998). Rome: FAO. -88 p.”. 


\begin{tabular}{|c|c|c|c|}
\hline $\begin{array}{l}\text { Antropo- } \\
\text { gēnās } \\
\text { augsnes }\end{array}$ & $\begin{array}{l}\text { Augsnes, kuru } \\
\text { veidošanos būtiski } \\
\text { ietekmējusi cilvēka } \\
\text { darbība. } \\
\text { Kultūraugsnes, } \\
\text { rekultivētās un } \\
\text { tehnogēnās augsnes, } \\
\text { apraktās augsnes. }\end{array}$ & $\begin{array}{l}\text { Mollic, chernic, hortic } \\
\text { vai ochric virskārtas } \\
\text { horizonts. Argic, } \\
\text { cambic apakškārtas } \\
\text { horizonts. Organiskie } \\
\text { un } \\
\text { anthropogenomorfologi } \\
\text { skie (aric, garbic, } \\
\text { spolic, urbic) augsnes } \\
\text { materiāli. }\end{array}$ & $\begin{array}{l}\text { Anthrosols (hortic, spodic, } \\
\text { luvic, arenic, regic), Phaeozems } \\
\text { (luvic, pachic, calcaric, vermic), } \\
\text { Regosols (anthropic, garbic, } \\
\text { spolic, urbic, humic). }\end{array}$ \\
\hline
\end{tabular}

\title{
ĢEOGRĀFISKĀS INFORMĀCIJAS SISTËMAS IZMANTOŠANA LATVENERGO SISTËMĀ
}

\author{
Renāte KLIMKO \\ LU Ģeogrāfijas un Zemes zinātņu fakultāte
}

Ar katru gadu ǵeogrāfiskās informācijas sistēmas tiek izmantotas arvien vairāk, līdz ar to arī to nozīme katra cilvēka dzīvē pieaug. Par vienu no tautsaimniecības uzṇēmumiem, kurā tiek izmantotas geogrāfiskās informācijas sistēmas un par kuru es gatavoju ziņojumu, ir VAS LATVENERGO. Ar katru dienu geogrāfiskās informācijas sistēmas nozīme palielinās daudzos uzñēmumos, jo, izmantojot ǵeogrāfiskās informācijas sistēmas darbs, tiek paveikts pilnvērtīgāk.

Latvenergo ir viens no daudzajiem uzñēmumiem, kurā tiek izmantotas ǵeogrāfiskās informācijas sistēmas. Šobrīd geogrāfiskās informācijas sistēmas ieviešana ir kā pilotprojekts Rīgas elektrotīklos. Ja šis projekts izdosies, tad turpināsies darbi ar ǵeogrāfiskās informācijas sistēmas ieviešanu pārējos rajonos. Par pamatinformāciju tiek izmantoti zemo un vidējo spriegumu tīkli, kā arī gaisa tīkli. Ģeogrāfiskās informācijas sistēmas tiek pielietotas šādos virzienos - elektrisko tîklu dokumentācijai, elektrisko tīklu attīstībai (rekonstrukcija, izbūves), ekspluatācijas datu vākšanai, uzkrāšanai par tīklu stāvokli, operatīvajai vadībai. Arī Latvenergo neiztiek bez geogrāfiskās informācijas sistēmas pamatelementiem datortehnikas, datorprogrammas, ǵeogrāfiskajiem datiem, darba metodēm, kā arī bez speciāli apmācīta personāla. Kā jau jebkura projekta izpildē, arī ǵeogrāfiskās informācijas sistēmas ieviešanā ir dažādas problēmas. Tās var iedalīt divās lielās grupās, tās ir iekšêjās un ārējās problēmas. Pie iekšejjām problēmām var pieskaitīt visas tās, kuras rodas neprofesionālu darbinieku dēl vai arī datortehnikas, datorprogrammas un daudzām citām problēmām, kuras var risināt paši Latvenergo darbinieki. Savukārt pie ārējām problēmām tiek pieskaitītas visas tās, kuras paši Latvenergo darbinieki nevar risināt, pie tām pieskaitāmas nepiln̄ības likumdošanā, kartogrāfiskās problēmas, kā arī visas citas, kas rodas projekta īstenošanā.

Sakarā ar informācijas tehnolog̣ijas attīstîbu attīstās arī geoogrāfiskās informācijas sistēmas. Ģeogrāfiskās informācijas sistēmas ieviešana konkrētajā 
uzñēmumā VAS Latvenergo nodrošinās kvalitatīvu darbu, ātrāk palīdzēs noteikt tīklu bojājumus un uzlabos Latvenergo darbību.

\title{
LATVIJAS ELEKTORĀLIE PROCESI POLITISKAJĀ ĢEOGRĀFIJĀ
}

\author{
Anita KRAMPE \\ Latvijas Universitāte, Ģeogrāfijas un Zemes zinātņu fakultāte, \\ e-pasts: Anita.Krampe@lu.Iv
}

Viens no nozīmīgākajiem instrumentiem elektorāta un valdības jeb politisko struktūru raksturošanā ir vēlēšanas. Elektorālā ǵeogrāfija raksturo elektorāta kā balsstiesīgu indivīdu lomu varas veidošanas procesā un nodrošina sistemātisku vēlēšanu telpisko analīzi, kas pēta vēlēšanu rezultātu un vēlēšanu sistēmas organizēšanas un funkcionēšanas telpiskos aspektus.

Elektorālo procesu ǵeogrāfiskie pētījumi atspoguḷo konkrētās teritorijas elektorālo struktūru, kuru veido elektorālās ǵeogrāfijas trīs elementu - vēlēšanas - vēlēšanu iecirknis - elektorāts mijiedarbība.

Vairāk nekā desmit gadu laikā Latvijas elektorālā struktūra main̄ijusies ḷoti dinamiski līdz ar politisko pozīciju maiṇu valstī, un to iespējams izvērtēt, analizējot valsts likumdevējvaras (Saeimas) vēlēšanas, pašvaldību (pilsētas domes, novada domes un pagasta padomes) vēlēšanas, nepieciešamības gadījumā Saeimas izsludinātu Tautas nobalsošanu par kādu aktuālu jautājumu, kā arī 2004.gada 12.jūnijā notikušās pirmās Eiropas Parlamenta vēlēšanas.

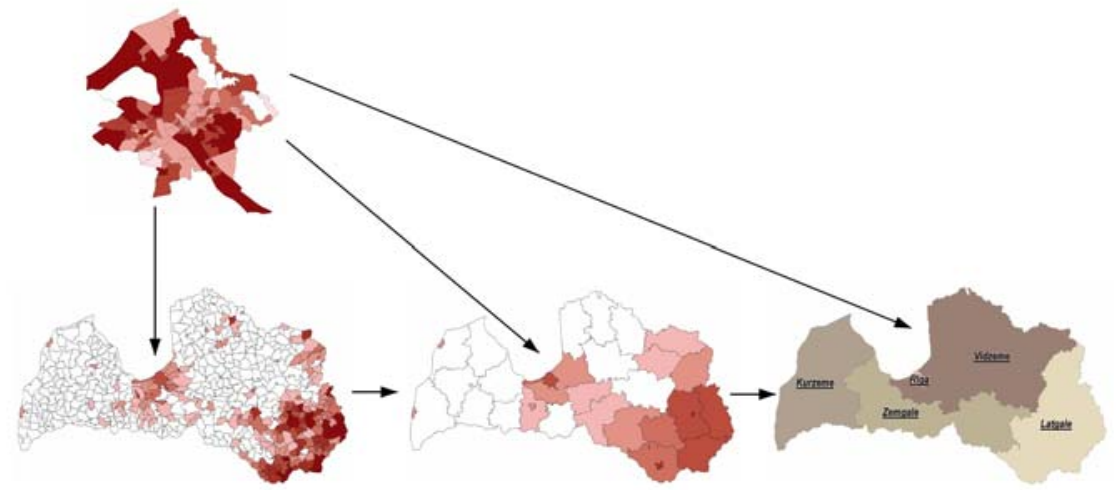

1.attēls. Latvijas elektorālo pētījumu trīs teritoriālo struktūru līmeṇi: lokālais, reǵionālais un nacionālais.

Elektorālās struktūras teritoriālā diferenciācija izvērtējama, veicot vēlēšanu rezultātu telpisko analīzi trīs līmeņos: lokālajā (pilsētas, pagasti), reǵionālajā (rajoni) un nacionālajā (vēlēšanu apgabali) (1.attēls). Tādējādi 
attēlojamas elektorāta balsis trīs teritoriālo struktūru līmeņos, katrā no tiem atspogulıjojot elektorālās struktūras likumsakarības, kas ir saistītas ar teritorijas sociālekonomisko vidi, vēlētāju sastāvu un partiju pārstāvniecību.

Mainoties vēlētāju reǵistrācijas kārtībai Latvijā, 2004.gada janvārī stājās spēkā Vēlētāju registra likums, līdz ar to katrs balsstiesīgais pilsonis valstī ir piesaistīts konkrētam vēlēšanu iecirknim, kas paver jaunas elektorālo pētījumu iespējas Latvijā atšķirībā no iepriekš veiktajiem pētījumiem, fiksējot vēlētāju viedokḷu maiņu laikā un telpā, izdalot atšşirīgas politiskās kultūras, reǵionus ar atšķirīgu politisko pārliecību.

\title{
GALVENO KOMPONENTU METODE AINAVEKOLOĢIJĀ
}

\author{
Ādolfs KRAUKLIS \\ LU Ģeogrāfijas un Zemes zinātņu fakultāte, \\ e-pasts: krauklis@lanet.lv
}

Galveno komponentu metode (GKM) ir viens no daudzdimensiju statistiskās analīzes veidiem. Tā balstās uz kovariācijas vai korelācijas matricu analīzi, pien̦emot, ka analīzē iekḷauto skaitlisko lielumu variācijas pamatā ir neliels skaits integrējošu faktoru jeb galveno komponentu. Būtībā līdzīga ievirze ir arī lielai daļai ainavekologisko pētījumu, tomēr GKM lietojuma pieredze šajā jomā vēl ir nepietiekama, bet matemātiskā formā iegūto rezultātu ainavekoloǵisks skaidrojums bieži vien ir apgrūtināts. Referātā aplūkota pieredze, kas savulaik gūta, izmantojot GKM Vidussibīrijas dienvidtaigas ainavām raksturīgas katēnas izpētē. Publicēto datu izvērtējums un papildu apstrāde deva iespēju arī padziḷināt rezultātu sākotnējo interpretāciju² .

Statistiskai analīzei nepieciešamie dati iegūti 39 bioǵeocenožu parauglaukumos, aprakstot katru no tiem ar 20 skaitliskiem lielumiem (pazīmēm): summārā radiācija virs lakstaugu-sīkkrūmu stāva (1); diennakts minimālā (2) un maksimālā (3) gaisa temperatūra; diennakts minimālais (4) un maksimālais (5) gaisa relatîvais mitrums; augsnes temperatūra $20 \mathrm{~cm}$ dziļumā (6); augsnes mitrums (mm) 0-20 cm slānī (7); pH nedzìvajā zemsegā (8), 0-20 cm (9) un 30$40 \mathrm{~cm}$ (10) slānī; humusa saturs (\%) $0-20 \mathrm{~cm}$ (11) un $30-40 \mathrm{~cm}$ (12) slānī; nedzīvās zemsegas masa (cnt/ha) uz augsnes (13); sūnu (14), lakstaugu un sīkkrūmu (15) dzīvā biomasa (cnt/ha); Linnaea borealis ǵeneratīvo organu (16) un Majanthemum bifolium veǵetatīvo dạıu (17) fenoloğiskais stāvoklis jūlija sākumā; koku skaits (tūkst/ha) mežaudzē (18); baltegles (Abies sibirica) daudzums (stumbru šķērsgriezumu laukums 1,3 m augstumā - $\mathrm{m}^{2} /$ ha) (19); zemes virsas augstums (m) (20). Lai šīs dažādās mērvienībās izteiktās skaitliskās vērtības $\left(a_{i}\right)$ varētu salīdzināt, tās pārveidotas nosacītās vienībās $a_{i}$, atṇemot no

* Природные режимы и топогеосистемы Приангарской тайги. Новосибирск: Наука 1975. 
katra $\left(a_{i}\right)$ šì skaitliskā lieluma mazāko vērtību $\left(a_{\min }\right)$ un dalot starpību $\left(a_{i}-a_{\min }\right)$ ar $a_{i}$ variācijas amplitūdu $\left(a_{\max }-a_{\min }\right)$, t.i.:

$$
a_{i}{ }^{\prime}=\left(a_{i}-a_{\min }\right) /\left(a_{\max }-a_{\text {min }}\right)
$$

Pētījumā salīdzinātas gan bioǵeocenožu pazìmes pēc to variācijas uz $4,3 \mathrm{~km}$ gara profila (transektes), kas šķērso šauras ielejas gultni (370 m vjl) starp divām gandrīz līdzenām ūdensšķirtnēm (430 un 410-420 m vjl) ar plašām labi drenētām nogāzēm, gan pašas biogeocenozes (39 parauglaukumi), ņemot vērā visas 20 pazīmes un to savstarpējo saikni. Šāds ǵeogrāfiskais salīdzinājums ievērojami atvieglo un bagātina ar GKM palīdzību iegūto rezultātu izpratni un lietojumu.

Izmantotā GKM varianta pamatā ir bioǵeocenožu pazīmju kovariācijas matricas, tās īpašvēertību un īpašvektoru aprēḳināšana. Katrs īpašvektors raksturo kādu statistisko sakarību starp pazīmēm, bet katras pazīmes koeficienti (k) parāda, kāds šajā vektorā ir tās "svars". Tādējādi kovariācijas matricas īpašvektorus var uzlūkot arī kā galvenās komponentes. Savukārt īpašvērtības norāda, kādu kopējās dispersijas daļu iekḷauj katra īpašvektora jeb galvenā komponentā atspoguḷotā statistiskā sakarība starp bioǵeocenožu pazīmēm (tabula).

\begin{tabular}{|c|c|c|c|c|c|c|c|c|c|}
\hline \multicolumn{2}{|c|}{ I (76,5\%) } & \multicolumn{2}{c|}{ II (14,5\%) } & \multicolumn{2}{c|}{ III (4,5\%) } & \multicolumn{2}{c|}{ IV (3,1\%) } & \multicolumn{2}{c|}{ V (1,4\%) } \\
\hline $\begin{array}{c}\text { Pazīm } \\
\text { e }\end{array}$ & $k$ & $\begin{array}{c}\text { Pazīm } \\
\text { e }\end{array}$ & $k$ & $\begin{array}{c}\text { Pazīm } \\
\text { e }\end{array}$ & $k$ & $\begin{array}{c}\text { Pazīm } \\
\text { e }\end{array}$ & $k$ & $\begin{array}{c}\text { Pazīm } \\
\text { e }\end{array}$ & $k$ \\
\hline 2 & 0,33 & 5 & 0,40 & 19 & 0,47 & 9 & 0,41 & 10 & 0,41 \\
\hline 8 & 0,31 & 17 & 0,32 & 4 & 0,38 & 11 & 0,41 & 4 & 0,41 \\
\hline 6 & 0,29 & 14 & 0,29 & 12 & 0,23 & 12 & 0,37 & 14 & 0,26 \\
\hline 20 & 0,28 & 3 & 0,26 & 17 & 0,21 & 7 & 0,28 & 9 & 0,25 \\
\hline 19 & 0,27 & 1 & 0,23 & 11 & 0,18 & 15 & 0,20 & 19 & 0,18 \\
\hline 16 & 0,27 & 13 & 0,21 & 13 & 0,16 & 10 & 0,18 & 18 & 0,16 \\
\hline 5 & 0,26 & 18 & 0,20 & 8 & 0,08 & 8 & 0,08 & 7 & 0,13 \\
\hline 4 & 0,25 & 15 & 0,16 & 5 & 0,05 & 16 & 0,07 & 2 & 0,09 \\
\hline 10 & 0,20 & 7 & 0,12 & 7 & 0,01 & 5 & 0,02 & 12 & 0,05 \\
\hline 11 & 0,19 & 10 & 0,08 & 2 & $-0,03$ & 1 & $-0,01$ & 11 & 0,03 \\
\hline 3 & 0,19 & 9 & 0,04 & 15 & $-0,04$ & 3 & $-0,02$ & 13 & $-0,01$ \\
\hline 17 & 0,18 & 19 & 0,02 & 20 & $-0,08$ & 6 & $-0,06$ & 3 & $-0,05$ \\
\hline 12 & 0,18 & 12 & 0,02 & 9 & $-0,11$ & 4 & $-0,07$ & 20 & $-0,05$ \\
\hline 15 & 0,18 & 4 & $-0,09$ & 14 & $-0,13$ & 17 & $-0,07$ & 6 & $-0,15$ \\
\hline 18 & 0,17 & 8 & $-0,22$ & 1 & $-0,17$ & 13 & $-0,08$ & 15 & $-0,17$ \\
\hline 9 & 0,17 & 11 & $-0,23$ & 6 & $-0,22$ & 2 & $-0,18$ & 5 & $-0,17$ \\
\hline 13 & 0,16 & 16 & $-0,24$ & 16 & $-0,22$ & 20 & $-0,21$ & 1 & $-0,18$ \\
\hline 14 & 0,16 & 20 & $-0,25$ & 3 & $-0,24$ & 18 & $-0,27$ & 8 & $-0,26$ \\
\hline 1 & 0,16 & 2 & $-0,33$ & 18 & $-0,28$ & 19 & $-0,27$ & 16 & $-0,27$ \\
\hline 7 & 0,10 & 6 & $-0,34$ & 10 & $-0,42$ & 14 & $-0,34$ & 17 & $-0,43$ \\
\hline
\end{tabular}

Pirmā galvenā komponente, kas izsmel̦ 76,5\% no kopējās dispersijas, asociējas ar katēnas modeli jeb hipsometriskā faktora ietekmi. Tajā noteicošā loma ir tām bioǵeocenožu pazīmēm, kuras saista cieša lineāra korelācija ar aukstā gaisa noplūdi no apvidus augstākajām vietām uz zemākajām. Otrā galvenā komponente $(14,5 \%)$ parāda katēnas polaritāti: pazīmēm ar augstākajām pozitīvo 
un negatīvo koeficientu skaitliskajām vērtībām ir pretēji arī variācijas trendi. Ar hipsometriskā faktora ietekmēm maz saistītām pazīmēm koeficientu vērtības otrajā komponentē tuvas nullei. Taču ar augstākajām koeficientu skaitliskajām vērtībām šīs pazīmes pārstāvētas trīs pārējās galvenajās komponentēs, kuras gan veido tikai l̦oti nelielu kopējās dispersijas dalı, tāpēc statistiskā ziṇā nav pārliecinošas. Tomēr ainavekoloǵiskā skatîjumā arī šīs komponentes norāda uz visnotal būtiskām kopsakarībām.

Trešā komponente $(4,5 \%)$ akcentē bioǵeocenožu variācijas saikni ar baltegli, kura šajā taigas ainavā ir visizplatîtākā suga. Tā ir arī sukcesiju noslēguma stadiju suga, lai gan ļoti jūtīga pret uguni, kā arī dažiem citiem traucējumiem. Ceturtā $(3,1 \%)$ komponente atspoguḷo sakarības, kuras izraisa hidrogrāfiskā tīkla sākumposmi ("frontālās" noteces pārvēršanās lineārās ūdenstecēs) uz nogāzēm dažādā augstumā, bet bieži vien arī pie ūdensšķirintnēm. Šìs fluviāli subhidromorfās komponentes raksturīga izpausme ir paaugstināts tekoša ūdens daudzums augsnē (pa laikam arī uz augsnes), kas asociējas ar mazāku augsnes skābumu, lielāku humusa daudzumu un ievērojamu lakstaugu biomasu. Piektajai komponentei paliek galēji maza $(1,4 \%)$ kopējās dispersijas daļa, un tajā atspogulotās kopsakarības ir neskaidras.

Salīdzinot aplūkotās kovariācijas matricas īpašvērtības, jāṇem vērā, ka analīzē iekḷautie bioǵeocenožu parauglaukumi raksturo ainavu nevis kā platību, bet gan ainavas šķērsgriezumu pa vienu līniju. Dal̦eji tāpēc tik liels ir katēnas kopsakarību (I un II īpašvektors) pārsvars pār pārējām trim galvenajām komponentēm. Domājams, šis kontrasts būtu krietni mazāks, pie tam droši vien mainītos arī paši galvenie komponenti, ja parauglaukumi l̦autu vienlīdz pilnīgi aprakstīt ainavu gan profilā, gan plānā.

\title{
MEZOTROFĀS AUGU SABIEDRĪBAS AR MEŽA SILPURENI AUSTRUMLATVIJĀ
}

\author{
Vija KREILE \\ Teiču dabas rezervāta administrācija, \\ e-pasts: vija.kreile@teici.gov.lv
}

Latvijas Ziemel̦austrumu un Dienvidaustrumu ǵeobotāniskajos rajonos oligotrofos mežos ar neizteiktu krūmu un paaugas stāvu meža silpurene Pulsatilla patens sastopama kopā ar pḷavas silpureni Pulsatilla pratensis un Cladina ğints ķērpjiem.

Mezotrofos priežu mežos meža silpurene parasti veido augu sabiedrības ar citām lakstaugu sugām. Koku stāvā valdošā ir priede, dažreiz kopā ar bērzu vai egli. Krūmu un paaugas stāvu veido egle, pīlādzis, āra bērzs, kadiķis, trauslais krūklis, parastais ozols. Sastopamas gan asociācijas Vaccinio vitis-idaeo-Pinetum 
rakstursugas (brūklene, dzeltenā zeltgalvīte, aitu auzene, viršāju grīslis), gan asociācijas Vaccinio myrtilli-Pinetum rakstursugas (mellene, spīdīgā stāvaine).

Ar TWINSPAN klasifikācijas programmu apraksti sadalīiti divās grupās: Calamagrostis arundinacea-Pinus sylvestris sabiedrībai (37 apraksti) lakstaugu stāvā raksturīga niedru ciesa, dziedniecības mugurene, bet Calamagrostis epigeios-Pinus sylvestris sabiedrībai (29 apraksti) - slotinu ciesa, mazais mārsils, meža zemene, klinšu kaulene. Pirmā sabiedrība ar mazāku vidējo sugu skaitu biežāk sastopama vecākos mežos, bet otrajā sabiedrībā ir jaunāki meži ar bagātāku lakstaugu stāvu.

Sugu konstantums mezotrofajās augu sabiedrībās ar meža silpureni

1 - Calamagrostis arundinacea-Pinus sylvestris sab.

2 - Calamagrostis epigeios-Pinus sylvestris sab.

\section{Augu sabiedrība $\quad 1 \quad 2$}

Koku stāvs E3

Pinus sylvestris

$\begin{array}{ll}\mathrm{V} & \mathrm{V}\end{array}$

Betula pendula

II

V

Krūmu stāvs E2

Picea abies

Sorbus aucuparia

$\begin{array}{ll}\mathrm{V} & \mathrm{V}\end{array}$

Betula pendula

IV IV

Juniperus communis

IV III

Frangula alnus

III III

Quercus robur

III III

Populus tremula

II III

Pinus sylvestris

II II

Lakstaugu-sīkkrūmu stāvs E1

Pulsatilla patens

Calluna vulgaris

Vaccinium vitis-idaea

Convallaria majalis

I II

Vaccinium myrtillus

Calamagrostis arundinacea

Melampyrum pratense

Solidago virgaurea

V V

V $\quad$ V

Polygonatum odoratum

V IV

$\mathrm{V} \quad$ IV

V IV

Festuca ovina

$\mathrm{V} \quad$ III

Hieracium umbellatum

IV $\quad \mathrm{V}$

Luzula pilosa

IV IV

Scorzonera humilis

IV III

III V

III III

Thymus serpyllum

Calamagrostis epigeios

III III

Fragaria vesca

III II

Rubus saxatilis

II IV

I $\mathrm{V}$

II III

Agrostis tenuis

II III

II III 


$\begin{array}{lcr}\text { Knautia arvensis } & \text { I } & \text { III } \\ \text { Sorbus aucuparia } & \text { II } & \text { II } \\ \text { Chimaphila umbellata } & \text { II } & \text { II } \\ \text { Trientalis europaea } & \text { II } & \text { II } \\ \text { Carex ericetorum } & \text { II } & \text { II } \\ \text { Arctostaphylos } \text { uva-ursi } & \text { II } & \text { II } \\ \text { Trommsdorfia maculata } & \text { II } & \text { II } \\ \text { Geranium sanguineum } & \text { II } & \text { II } \\ \text { Picea abies } & \text { II } & \text { I } \\ \text { Koeleria grandis } & \text { I } & \text { II } \\ \text { Viola canina } & \text { I } & \text { II } \\ \text { Antennaria dioica } & \text { I } & \text { II } \\ \text { Sieglingia decumbens } & \text { I } & \text { II } \\ \text { Viola rupestris } & \text { I } & \text { II } \\ \text { Pimpinella saxifraga } & \text { I } & \text { II } \\ \text { Quercus robur } & \text { I } & \text { II } \\ \text { Melampyrum polonicum } & \text { I } & \text { II } \\ \text { Veronica spicata } & \text { I } & \text { II } \\ \text { Galium album } & \text { - } & \text { II } \\ \text { Pleurozium schreberi } & & \\ \text { Hylocomium stendens } & \text { V } & \text { V } \\ \text { Dicranum polysetum } & \text { V } & \text { V } \\ \text { Ptilium crista-castrensis } & \text { IV } & \text { IV } \\ & \text { III } & \text { III }\end{array}$

Reti sastopamas sugas (konstantums $=\mathrm{I}$ ):

Abās sabiedrībās: E3: Picea abies, E2: Acer platanoides, Amelanchier spicata, Corylus avellana, Rubus idaeus, Salix caprea, E1: Achillea millefolium, Betula pendula, Campanula rotundifolia, Chamerion angustifolium, Corylus avellana, Deschampsia flexuosa, Dianthus arenarius, Diphasium complanatum, Dryopteris carthusiana, Epipactis atrorubens, Frangula alnus, Galium boreale, Goodyera repens, Juniperus communis, Lathyrus sylvestris, Melica nutans, Monotropa hypopitys, Orthilia secunda, Pilosella officinarum, Pinus sylvestris, Poa pratensis, Populus tremula, Pteridium aquilinum, Rubus idaeus, Succisa pratensis, Veronica officinalis, E0: Aulacomnium palustre, Cladina arbuscula, Cladina rangiferina, Polytrichum juniperinum, Rhytidiadelphus triquetrus

Tikai Calamagrostis arundinacea-Pinus sylvestris sab.: E1: Anthoxanthum odoratum, Astragalus glycyphyllos, Carex digitata, Equisetum hyemale, Festuca rubra, Lathyrus vernus, Lotus corniculatus, Rosa sp., Rumex acetosella, Silene nutans, E0: Dicranum scoparium

Tikai Calamagrostis epigeios-Pinus sylvestris sab.: E2: Salix pentandra, E1: Acer platanoides, Agrostis gigantea, Astragalus arenarius, Carex digitata, Dactylis glomerata, Dracocephalum ruyschiana, Gypsophila fastigiata, Hypericum perforatum, Lathyrus pratensis, Lycopodium clavatum, Maianthemum bifolium, Molinia caerulea, Mycelis muralis, Potentilla erecta, Pyrola chlorantha, Rumex acetosa, Taraxacum officinale, Trifolium medium, Vaccinium uliginosum, Viburnum opulus, Vicia cassubica, E0: Brachythecium campestre, Brachythecium starkei, Peltigera canina. 


\title{
NEKUSTAMĀ İPAŠUMA TIRGUS IETEKME UZ IEDZİVOTĀJU MIGRĀCIJAS PROCESU LATVIJAS LAUKOS
}

\author{
Ženija KRŪZMĒTRA \\ Latvijas Lauksaimniecības universitāte, \\ e-pasts: zenija.kruzmetra@llu.Iv
}

Nekustamā īpašuma tirgus ir viens no nosacījumiem, kas dod iespēju cilvēkiem mainīt esošo dzīves telpu pret vēlamāku. Cilvēku attieksme pret dzīves vietu formējas atkarībā no tā, cik lielā mērā tā dod iespēju darboties un apmierināt daudzveidīgās vajadzības, cik lielā mērā nodrošina iedzīvotājiem labvēlīgu ekonomisko un sociālo vidi. Pie tam, pieaugot iedzīvotāju ienākumiem, pilsētu iedzīvotājiem ar ienākumiem virs vidējā līmeṇa ir iespējas meklēt viṇu vērtību sistēmai atbilstošāku dzīves vidi - ğimenes mājoklim izvēloties individuālo māju, nevis dzīvokli. Pēdējos gados arvien vēlamākas individuālo māju celtniecībai kḷūst teritorijas ar izdevīgu novietojumu - galvaspilsētas un jūras vai Rīgas jūras līča tuvumā, vai galvaspilsētas tuvumu savienojot ar pievilcīgu ainavu. Tā rezultātā virknē pašvaldību iedzīvotāju skaits pieaug.

Salīdzinot nekustamā īpašuma darījumu skaitu ar zemi un zemi ar ēkām lauku pašvaldību griezumā, var teikt, ka aina ir l̦oti neviendabīga. Aktivitātes ziņā izdalās Rīgas rajons, kur visvairāk darījumu notiek pašvaldībās, kas tieši robežojas ar Rīgas pilsētu. Aktīvāks nekustamā īpašuma tirgus veidojas arī ap citām lielajām pilsētām, tāpat pašvaldībās, kas atrodas pie jūras, un arī pašvaldībās, kur ir augsts rekreatīvais potenciāls, attīstīta infrastruktūra. Visaktīvākais nekustamā īpašuma tirgus vērojams Rīgas rajona Mārupes, Babītes, Stopiṇu, Ķekavas, Garkalnes,

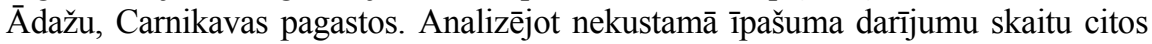
rajonos ar augstāku nekustamā īpašuma tirgus aktivitāti, izdalās, piemēram, Limbažu rajona Skultes un Liepupes pagasts, Tukuma rajona Lapmežciema un Engures pagasts, Jelgavas rajona Ozolnieku novads, Cēsu rajona Priekuḷu pagasts, Talsu rajona Kolkas pagasts u.c.

Teritorijās ar augstu nekustamā īpašuma tirgus intensitāti vērojamas būtiskas izmainas gan dabas vidē, gan sociālekonomiskajā vidē. Daudzas lauku teritorijas kḷūst ekskluzīvas, jo uz tām vairāk pārceḷas labi situēti cilvēki. Šajās teritorijās raksturīga krasa sabiedrības sociālā pārstrukturēšanās, jo diezgan intensīvi ienāk pilnīgi cits iedzīvotāju sociālais slānis, kuru dzīves līmenis, dzīves stils, intereses un vērtību sistēma būtiski atšķiras no pamatiedzīvotāju dzīves. Līdz ar to nekustamā īpašuma tirgus, no vienas puses, veicina lauku sabiedrības sašķeltību, atsvešināšanos starp dažādām sociālajām grupām un indivīdiem, bet, no otras puses, jaunu, materiāli situētu cilvēku ienākšana šajās lauku pašvaldībās veicina gan uzṇēmējdarbību, gan mājvietu un vides sakopšanu. Šajās vietās vērojama teritoriju statusa maiņa.

Vērojama arī otra iedzīvotāju pārvietošanās plūsma, kura ir valsts institūciju organizēts process, t.i., mazturīgo virzīšana uz pašvaldībām, kur ir 
salīdzinoši zemas nekustamā īpašuma vērtības un pēc tiem nav pieprasījuma. Kā piemēru šeit var minēt Kalnciema pilsētas lauku teritoriju un Elejas pilsētas lauku teritoriju Jelgavas rajonā. Līdz ar to šo teritoriju statuss pazeminās.

Šīs jaunās sabiedrību pārstrukturējošās tendences ir pietiekami nozīmīgas, lai padziļināti izvērstu to pētī̌sanu.

\title{
PILSĒTU UN LAUKU MIJIEDARBĪBAS ZONĀS VEIKTIE TELPISKO ATŠĶIRĪBU PĒTĪJUMI LATVIJĀ
}

\author{
Laila KŪLE \\ Latvijas Universitāte, Ģeogrāfijas un Zemes zinātņu fakultāte
}

Pētījums veikts uz Latvijas zinātniskās literatūras avotu analīzes un izvērtējuma pamata. Autore iepazinās ar zinātniskajiem rakstu krājumiem, izdotiem pēc Latvijas neatkarības (Ģeogrāfiskie Raksti (1999-2004), LZA Vēstis (1991-2004), LLU Vēstis 2000-2004), konferenču krājumiem, kā arī ar atsevišşki publicētiem pētījumu rezultātiem. Autore ir veikusi arī nelielu ieskatu padomju periodā Latvijā veiktajos pētījumus par pilsētu un lauku sadures zonām.

Padomju tradīcija bija censties nodalīt pilsētas un laukus administratīvi, kas noteica, ka šis sadalījums bieži turpinājās arī pētniecībā. Tomēr jāatzīst, ka padomju periodā nozīmīga loma tika ierādīta rajonu (regionālajai) plānošanai, kas, lai arī tika veikta centralizēti un nedemokrātiski, tika balstîta uz pētījumu rezultātiem. Padomju periodā tika veikti pētījumi, balstoties uz 1962.gada PSRS Komunistiskās partijas kongresā apstiprināto tēzi par lauku dzīves apstākḷu tuvināšanu pilsētām, kā rezultātā tika izstrādāts pamatojums veidot ciematus jeb agropilsētas (V.Timofejevs) [1]. Šajā periodā pilsētu un lauku sadures teritorijas tika pētītas, galvenokārt no šādiem aspektiem - svārstmigrācijas process un lielo pilsētu, galvenokārt Rīgas, aglomerācijas robežas noteikšana un darbaļaužu atpūtas iespējas lielo pilsētu pierobežā (A.Bauls, arī galvenokārt Rīgas apkārtnē (V.Apsītis, O.Buka, L.Kartunova, J.Trušinsš). Tāpat pētījumi tika veikti par pilsētu formu (G.Melbergs, M.Lūse, E.Pučinš̌, J.Piešinšs, V.Šteins) un ar to saistītajiem transporta attīstības aspektiem, tomēr dziḷāki pêtījumi par pilsētu formu un to saistību ar reālo un administratīvo robežu netika veikti [2. 3. 4]. Vairāki autori savu pētījumu rezultātā nonāk pie līdzīgiem secinājumiem, tāpat kā pētnieki rietumvalstīs, kam ir iespēja pētìt pilsētu un lauku telpisko struktūru attīstību un mijiedarbību tirgus ekonomikas apstākḷıs. Piemēram, ,pilsētas struktūras sastāvdaļas jāsasaista ar piepilsētas zonas plānošanas elementiem” un „tikai kompleksi analizējot pilsētu izaugsmi, varēs mērkstiecīgi veidot jaunas telpiskas struktūras atbilstoši progresīvām pilsētu attīstības tendencēm” (O.Buka, 1969.). Piepilsētas zona ir kḷuvusi par Rīgas nepieciešamību, pilsēta arvien vairāk ietekmē tās tuvumā esošās teritorijas dzeramā ūdens avoti, transporta maǵistrāles, cita infrastruktūra, izvietoti rūpniecības uzñēmumi, atpūtas teritorijas, nav saskaņotas lauksaimniecības 
uzṇēmumu intereses - tā rezultātā 1966.gadā tika izstrādāts LPSR Valsts pilsētu celtniecības projektēšanas institūtā Rīgas piepilsētas zonas projekts (V.Apsītis, 1969.) [2].

Pēc neatkarības atjaunošanas daudzi institūti savu darbību izbeidza un tajos strādājošie pētnieki pievērsās praktisko jautājumu risināšanai. Pētniecības darbus turpināja Latvijas universitāšu mācību spēki. Lai gūtu priekšstatu, kādi pētījumi veikti pilsētu un lauku mijiedarbības zonās, autore saskārās ar virkni problēmām. Šie ir pētījumi, kas aptver gan dabas, gan sociālos jautājumus, gan pilsētu, gan lauku teritorijas - tāpēc parasti tiek aplūkoti vides zinātnes, ǵeogrāfijas vai teritorijas plānošanas un pilsētbūvniecības ietvaros. Diemžēl Latvijas apstāklı pētnieki cenšas izmantot visas iespējas savus darbus publicēt arī citu zinātṇu nozaru izdotajos krājumos, kā rezultātā, lai tiešām gūtu pilnīgu priekšstatu par Latvijā veiktajiem pētījumiem, literatūras izpēte ir jāturpina.

Kopumā secinājumi par to, kādi pētījumi ir veikti pilsētu un lauku mijiedarbības zonās Latvijā pēc 1991.gada, ir šādi. Veiksmīgi tiek turpināti pētījumi par lielo pilsētu, īpaši Rīgas, aglomerācijas robežas noteikšanu un svārstmigrācijas procesiem, kā arī par lielo pilsētu pavadoņpilsētām (Z.Krišjāne, A.Bauls, J.Jankevics, Z.Melnbārde, P.Šk̦iņķis, M.Kasparovica). Tiek pētīti ilgtspējīgas pilsētu attīstības jautājumi - indikatori un iespējamās stratēǵijas, zalı zonu nozīme (O.Nikodemus, K.Āboltiņa, A.Z̄̄lāns, A.Melluma), pilsētvides īpatnības lokālā līmen̄̄ Rīgas pilsētā (A.Bauls, Z.Krišjāne, G.Mežciema). Saistībā ar administratīvo teritoriālo reformu vairāki pētnieki ir pievērsušies formālo robežu izpētei (P.Šķiņksis, I.Vilka, E.Vanags). Transporta jautājumi izpēte ir nepietiekama, trūkst transporta problēmas visaptverošu pētījumu, arī tādu, kas analizētu tās cēloṇus, nevis tikai piedāvātu problēmas risinājumus piepilsētas teritorijām (I.Vircavs, N.Sprancmanis). Ir pētījumi, kas pievēršas lauku identitātei (D.Saktiņa), trūkst pilsētu un lauku identitātes salīdzinošo pētījumu. Teorētiskiem pilsētu attīstības, iedz̄̄votāju koncentrācijas un polarizācijas jautājumiem tirgus ekonomikas apstākḷos veltīti pētījumi veikti pēdējos gados (I.Francis [6], A.Vilciņš [5]). V.Apsītis atzīmē atšksirības Latvijas lauku un pilsētu arhitektūrā, apbūves attīstībā un apkārtējās vides organizācijā, kā arī attīstības īpatnības kādreizējās pilsētu nomalēs [7]. Ģimenes māju būvniecībai un cilvēku ilgtermiņa migrācijas sakarībām, arī š̄ procesa pastiprinātai attīstībai Rīgas ietekmē, pievēršas LLU pētnieki (V.Strīksis, K.Špoǵis) [8].

Kopumā autore secina, ka Latvijā tikpat kā nav pētījumu par pilsētu izplešanās procesiem (formāliem un neformāliem, haotiskas un plānotas), pilsētas un lauku sadures zonas teritoriālo apveidu un tās visaptverošu ietekmi uz vidi, sociālajiem un ekonomiskajiem procesiem. Latvijā pētījumu trūkst par pilsētas malas augšanas procesu un tā rezultātā notiekošo zemes lietojumveida mainu, iedzīvotāju dzīves veida un vērtību maiņu, urbāno vērtību saduri ar tradicionālajām lauku vērtībām, par iemesliem, kas rada un sekmē šos telpiskos procesus pēc industrializācijas procesa lielākās pilsētu transformācijas dēḷ, ko 
rada tādi procesi kā ekonomiskās sistēmas maiṇa, jauno komunikāciju veidu ietekme, mobilitātes pieaugums, globalizācija.

Kopumā pētījums l̦auj izdarīt secinājumus, ka Latvijā ir veikti pētījumi par lauku un pilsētu teritoriju mijiedarbību, lai gan bieži tas nav bijis šo pētījumu sākotnējais pamatmērksis. Nepieciešami pētījumi, kas vairāk var sniegt risinājumus pilsētu un lauku sadures zonās pieaugošām attīstības problēmām vietējo problēmu virzīti pētījumi ar pielietošanas iespējām, kā arī jāveicina starpdisciplīnu pētījumi, tādi, kas integrē dažādas nozares - vides, dabas un cilvēkǵeogrāfijas, teritorijas plānošanas, pilsētbūvniecības, transporta un lauksaimniecības nozares.

\title{
Atsauces
}

1. A.Boruks (1995) Zemnieks, zeme un zemkopība Latvijā: no senākiem laikiem līdz mūsdienām, Rīga

2.Arhitektūra un pilsētbūvniecība Latvijas PSR: Rakstu krājums (1969), Rīga

3. Rayonnaya planirovka i gradostroitelstvo v Latviiskoy SSR (1989), Riga

4. E.Pučinšš, J.Piešiņš, M. Lūse (1977) Žiloy kompleks malovo goroda, Riga

5. Ģeogrāfiskie raksti (1999-2003), Latvijas Ģeogrāfijas biedrība, Rīga

6. I.Francis (2001) Rīgas teritoriālās struktūras transformācijas. 115.-12-.lpp/ Starptautiskās konferences "Ekonomisko un sociālo procesu attiecību transformācijas procesi, tendences, rezultāti”, Rīga: Biznesa augstskola Turība.

7. V.Apsīis (2000) Latvijas Arhitektūra astoṇdesmit gados (1920-2000), LZA Vēstis A.-2000., 54.sēj, nr.1./2. (606./607.), 82.-89.lpp., Rīga

8. V.Strīkis, K.Špoǵis (2002) Privātās investīcijas Latvijas laukos. 13.-18.lpp. / LLU Raksti 7 (302), Jelgava.

\section{MEŽAUDZE KĀ AINAVAS AUGSTUMJOSLOJUMA INDIKATORS}

\author{
Māris LAIVIN̦Š \\ Latvijas Universitāte, Ģeogrāfijas un Zemes zinātņu fakultāte, \\ e-pasts: laivins@silava.Iv
}

Mežaudze ir konservatīvs ainavas elements, un tās sugu sastāvs atspoguḷo Latvijā būtiskāko vides faktoru - irdeno nogulu, kā arī klimatisko apstākḷu reǵionālās atšķirības. Šo sakarību kvantitatīvai raksturošanai meklēta saistība starp kokaudzes valdošo sugu un vietas absolūto augstumu, kurš netieši indicē augsnes cilmiezi un klimata stāvokli. Analizēta audzes valdošās sugas īpatsvara atkarība no pagasta maksimālā augstuma (pagasta maksimālais augstums labāk un precīzāk par pagasta vidējo augstumu raksturo teritorijas augstuma atšķirīibas).

Statistiski ticamas $(\mathrm{p}>0,95)$ vidēji ciešas sakarības starp kokaudzes valdošo sugu un pagasta lielāko augstumu $(\mathrm{n}=481)$ ir 4 sugām: baltalksnim $(\mathrm{r}=0,49)$, priedei $(\mathrm{r}=-0,45)$, eglei $(\mathrm{r}=0,37)$ un apsei $(\mathrm{r}=0,35)$. Statistiski ticamas $(\mathrm{p}>0,95)$, bet vājas korelācijas sakarības starp minētajiem parametriem ir bērzam $(\mathrm{r}=0,16)$, ozolam $(\mathrm{r}=$ $0,15)$ un osim $(r=-0,13)$. Turpmāk analizēsim datus par 4 sugu (priede, egle, baltalksnis, apse) audžu izplatību, kurām ir lielāka vides indikatorvērtība. 
Sašķel̦ot Latvijas teritoriju 6 augstuma līmeņos ar 50 m intervālu, priedes audžu īpatsvars katrā nākamajā līmenī samazinās par 7\%, bet eglei pieaug par $4 \%$, baltalksnim par $2,5 \%$ un apsei par $0,9 \%$ (1.tab.).

1.tabula

Priedes, egles, baltalkšņa un apses audžu īpatsvars dažādos augstuma līmeṇos (aprēkiniem izmantots taisnlīnijas korelācijas-regresijas vienādojums)

\begin{tabular}{|l|c|c|c|c|}
\hline \multirow{2}{*}{$\begin{array}{c}\text { Augstuma } \\
\text { intervāls, } \\
\text { m v.j.l. }\end{array}$} & Priedes & Egles & Baltalkšņa & Apses \\
\cline { 2 - 5 } & 44,0 & 14,0 & 4,2 & 2,3 \\
\hline $0-50$ & 37,0 & 18,0 & 7,0 & $3,2$. \\
\hline $51-100$ & 29,0 & 22,0 & 9,2 & 4,0 \\
\hline $101-150$ & 22,0 & 26,0 & 12,0 & 4,9 \\
\hline $151-200$ & 15,0 & 30,0 & 14,2 & 5,7 \\
\hline $201-250$ & 8,0 & 34,0 & 16,7 & 6,6 \\
\hline $251-300$ & \multicolumn{3}{|c}{} \\
\hline
\end{tabular}

Areāls katrai no šīm sugām aptver vismaz trīs bioǵgeogrāfiskās zonas boreālo, temperālo, submeridionālo un zīmīgi, ka submeridionālajos regionos tās ir raksturīgas montānajai augstumjoslai. Priede ir kontinentāla suga, egle un apse ir subkontinentālas sugas (neviena no šīm sugām nav sastopama okeāniskajā sektorā), bet baltalksnim optimāli augšanas apstākḷi ir subokeāniskajā sektorā. Atšķiras šo sugu prasības pēc barības vielām augtenē. Priede augu sabiedrības veido galvenokārt oligotrofos, turpretim pārējās trīs sugas - egle, apse un baltalksnis mezoeitrofos un eitrofos augšanas apstākl̦os. Tātad šo sugu audžu izplatība arī Latvijā ir saistāma ar noteiktiem vides apstākḷiem, tā atspoguḷo augtenes un klimata ipatnības.

Egles, baltalkšņa un apses audžu lielāks apjoms augstienēs ir indikators tam, ka augstienēs ir kontinentālāks klimats, kā arī auglīgāks substrāts (augstienēm raksturīgi glacigēnie mālsmilts un smilšmāla barības vielām bagāti nogulumi). Turpretim priedes audžu lielāka izplatība zemienēs, bet mazāka augstienēs saistīta ar to, ka zemienēs ir nabadzīgs substrāts (marīnie, eolie un organogēnie nogulumi), te vērojams arī mikro- un mezoklimata kontinentalitātes efekts, kas ir labvēlīgs priedes augšanai.

Priedes, egles, baltalkšña un apses audžu izplatības augstuma gradients, tāpat arī pēc platības nelielo ozola un oša audžu saistība ar noteiktām virsas formām, l̦auj Latvijas teritorijā nodalīt trīs geogrāfiskās ainavas augstuma līmeņus, kuriem raksturīgs noteikts augšanas apstākḷu edafiskais un klimatiskais fons (ekologiskais potenciāls), kā arī noteikts augāja pamattips (teritorijai raksturīga ar vidi līdzsvarota noslēdzošā sukcesijas stadija).

Pirmais - zemākais līmenis (priedes mežaudžu josla), līdz $30 \mathrm{~m}$ v.j.l., ietver Piejūras zemieni un lielāko upju lejasteču apgabalus ar maz saposmotu virsu, galvenokārt nabadzīgu augteni (bet ar ļoti dažādiem mitruma apstākḷiem) un vāji kontinentālu (relatīvi Latvijai) klimatu. Meža pamatsabiedrības ir 
oligotrofo boreoatlantisko un subkontinentālo priežu mežu sabiedrības (Betulion pubescentis, Ledo-Pinion, Dicrano-Pinion, Cytiso-Pinion).

Otrais - vidējais līmenis (ozola un oša mežaudžu josla), līdz 100 m v.j.l., ietver upju zemes, augstieņu zemākās daļas un augstieņu nogāzes (nolaidenumus), pārsvarā ar saposmotu virsu, mezoeitrofiem augšanas apstākḷiem, kā arī vāji un vidēji kontinentālu klimatu. Mežu pamatsabiedrības ir palieņu baltalkšṇu meži, ozolu un skābaržu meži, submontānie liepu un kḷavu meži (Alnion incanae, Carpinion betuli, Tilio platyphylli-Acerion pseudoplatani)

Trešais - augstākais līmenis (egles mežaudžu josla), augstāk par 100 m v.j.l., ietver augstienes un līdzenumus pārsvarā ar mezoeitrofiem augšanas apstākḷiem, kā arī vidēju un stipru klimata kontinentalitāti. Mežu pamatsabiedrības ir melnalkšņu, submontānie liepu un kḷavu, egḷu un subkontinentālie priežu meži (Alnion glutinosae, Tilio platyphylli-Acerion pseudoplatani, Piceion abietis, Cytiso-Pinion).

Tātad redzams, ka meža augšanas apstākḷi dažādos ainavas augstuma līmeņos ir krasi atšķirīgi un atspoguḷo vides apstākḷu reǵionālās īpatnības (2.tab.).

2. tabula

Augšanas apstākḷi un kokaudzes valdošo sugu īpatsvars ainavas augstuma līmeṇos

\begin{tabular}{|c|c|c|c|c|c|c|c|c|c|c|}
\hline \multirow{2}{*}{$\begin{array}{l}\text { Augstuma } \\
\text { līmenis } \\
\text { m v.j.1. }\end{array}$} & \multicolumn{3}{|c|}{$\begin{array}{l}\text { Mežaudžu trofisko grupu } \\
\text { ipatsvars, \% }\end{array}$} & \multicolumn{7}{|c|}{ Dažādu kokaudžu īpatsvars, \% } \\
\hline & $\begin{array}{c}\text { Oligo- } \\
\text { trofā }\end{array}$ & $\begin{array}{l}\text { Me- } \\
\text { zo } \\
\text { trofā }\end{array}$ & Eitrofā & $\begin{array}{c}\text { Prie- } \\
\text { des }\end{array}$ & Egles & $\begin{array}{c}\text { Balt- } \\
\text { alkšņa }\end{array}$ & $\begin{array}{l}\text { Ap- } \\
\text { ses }\end{array}$ & $\begin{array}{c}\text { Ozo- } \\
\text { la }\end{array}$ & Oša & $\begin{array}{l}\text { Citu } \\
\text { sugu }\end{array}$ \\
\hline $\begin{array}{l}\text { Zemākais, } \\
0 \text { - } 40\end{array}$ & 24,1 & 63,3 & 12,6 & 62,5 & 7,3 & 1,7 & 0,7 & 0,3 & 0,5 & 27,0 \\
\hline $\begin{array}{l}\text { Vidējais, } \\
41-100\end{array}$ & 8,8 & 57,6 & 33,6 & 39,3 & 18,0 & 6,6 & 2,5 & 0,9 & 1,2 & 31,8 \\
\hline $\begin{array}{l}\text { Augstākais, } \\
>100\end{array}$ & 4,5 & 53,3 & 42,2 & 26,7 & 22,0 & 9,5 & 4,4 & 0,3 & 0,6 & 36,5 \\
\hline
\end{tabular}

Augstuma līmeņi jeb augstumjoslojums ir Latvijas ainavu fundamentāla iezīme, kas atspoguḷo ainavas vecumu, homogenitāti un citas īpatnības un kas ir svarīga augāja ğeogrāfisko struktūru definēšanā un veǵetācijas kartēšanā.

\section{ĢIS LIETIŠĶAIS PIELIETOJUMS AUGŠZEMES EZERU VIDES PËTİJUMOS}

\section{Dainis LAZDĀNS, Jūlija MUNČA, Juris SOMS, Aija ŠEVCOVA}

Daugavpils Universitāte, e-pasts: juris@dau.Iv

Līdz ar informācijas tehnologiju straujo attīstību pieaug arī nepieciešamība pēc jaunām geogrāfiski saistīto vides datu fiksēšanas, analīzes un vizualizācijas formām. Ģeogrāfiskās informācijas sistēmas (ĢIS), kas jau vairāk nekā desmit 
gadus tiek uzskatītas par atsevišķu IT un tehniskās ǵeogrāfijas nozari, ir tieši tas instruments, kas paver daudz plašākas ǵeotelpisko datu analīzes iespējas visdažādākajās zinātņu un saimniecības sfērās. Pilnā mērā tas attiecas arī uz dabas aizsardzību un vides stāvokḷa novērtējumu. Tieši pēdējais no nosauktā ir visizplatîtākais ĢIS izmantošanas veids vides zinātnē (www.gis.lv; www.esri.com), jo tas neprasa speciālu pieeju ǵeogrāfiskās informācijas sistēmām, un šim nolūkam var izmantot jau tirgū esošos ĢIS produktus.

Augšzemes augstienē atrodas vairākas nozīmīgas īpaši aizsargājamās dabas teritorijas (İADT), toskait Augšzemes aizsargājamo ainavu apvidus, dabas parks "Svente", dabas parks "Medumu ezeraine", Sasalı ezera dabas liegums. Taču nevienai no šīm teritorijām nav izstrādāts dabas aizsardzības plāns (DAP). DAP izstrāde un ieviešana, kā arī tajos ieteikto apsaimniekošanas pasākumu ietveršana pašvaldību teritoriālās attīstības plānos nav iedomājama bez ĢIS lietišksā pielietojuma. Tas vienlīdz attiecas gan uz pētījumu organizēšanu, gan uz iegūto datu telpisko piesaisti, analīzi un vizualizāciju, gan uz lēmumu pieņemšanas atbalsta datu bāzes izveidošanu.

N̦emot vērā iepriekš teikto, Daugavpils Universitātes studiju programmas "Vides zinātne" studējošie uzsākuši ilgtermiṇa minēto İADT kompleksu izpēti, savos pētījumos izmantojot ǵeomātikas sniegtās iespējas. Pētījumu nepieciešamību pastiprina arī fakts, ka Medumu un Sventes ezeri saskaņā ar Eiropas Savienības Biotopu direktīvu (1992) ir aizsargājami ezeru biotopi (mezotrofas ūdenstilpes ar bentisku mieturaļğu augāju).

Sventes ezera, Medumu ezera, Sasalı ezera un Melnezera izpētē līdz šim tikušas izmantotas tradicionālās vides stāvokḷa novērtēšanas metodes (www.ezeri.lv). Taču, ņemot vērā faktu, ka iegūtie dati ir geogrāfiski saistīti ar Zemes reālo virsu un mērījumu punktu vai paraugošanas vietu koordinātu noteikšana un to kartogrāfiskā piesaiste dabā iepriekšējos gados sagādāja zināmas grūtības, rodas pārliecība, ka pētījumu sērijas raksturo datus laika griezumā nevis vienam konkrētam punktam, bet laukumam, kurā izkliedēti vairāki punkti. Tieši tāpat par salīdzinoši neprecīziem jāuzskata arī agrāk iegūtie laukumveida objektus raksturojošie skaitliskie lielumi, piem., ezeru spoguḷa platîba, sateces baseina un tajā esošo dažādo zemes lietojumu veidu platības, ezeru dziļumu kartes u.c. Lai novērstu minētās nepilnības, ezeru vides pētījumos tika izmantoti tālizpētes dati, informācijas mobilās iegūšanas tehnolog̣ijas (GPS) un ĢIS.

LR Valsts zemes dienesta sagatavotās ortofotokartes tika izmantotas, lai izveidotu LKS-92 koordinātu sistēmai piesaistītu kartogrāfisko pamatni. Tas bija nepieciešams, jo praksē noskaidrojās, ka šī paša dienesta Kartogrāfijas pārvaldes nociparotā satelītkarte M 1:50000 ir loti tālu no piln̄̄bas, un daudzos tematiskajos slāņos, arī virszemes ūdens objektus atainojošajā slān̄̄, nesaiste pārsniedz $25 \mathrm{~m}$.

Iegūtā pamatne tika lejupielādēta GPS iekārtā "Trimble XT", tādā veidā nodrošinot ērtu navigāciju dabā un mērījumu punktu vai paraugošanas vietu LKS- 
92 koordinātu piesaisti on-line režīmā ar precizitāti $\pm 1 \mathrm{~m}$. Veicot nākamās mērījumu sērijas, GPS l̦āva sameklēt iepriekš fiksētos punktus un atkārtot datu ieguvi precīzi tajā pašā vietā. Paralēli ar GPS ir plānots veikt arī kartēšanas uzdevumus, piem., ezeru aizauguma joslas noteikšanu vai, savienojot to ar "Furuno" eholokācijas iekārtu, iegūt ezeru dziḷuma kartes.

ĢIS programmatūra (ArcView 8.3) tika izmantota visplašāk. Ar to tika veiktas parastās operācijas - punktveida objektu, līnijveida objektu un laukumveida objektu (poligonu) *.shp failu izveidošana, tajos atainojamās informācijas ciparošana un rediğěšana, atribūtu tabulu veidošana, GPS iegūto datu importēšana un apstrāde, ǵeogrāfiski saistīto vides datu vizualizācija, laukumveida objektu (piem., sateces baseinu) platības aprēķināšana u.c.

Pieredze rāda, ka, izmantojot ĢIS un analizējot dažādos gados iegūtos aerofotouzn̄ēmumus un liela mēroga topogrāfiskās kartes, var noteikt ūdenstilpju konfigurācijas izmaiņas un līdz ar to aprēķināt ezeru aizaugšanas tempus, kāa arī sateces baseinu zemes lietojuma veidu ipatsvara izmaiņas. Uz minēto faktu pamata var prognozēt vides stāvokḷa attīstības virzību un līdz to arī izstrādāt ieteikumus Sventes ezera, Medumu ezera, Sasaļu ezera un Melnezera ūdens resursu aizsardzībai un saprātīgai izmantošanai.

Pilnībā pabeidzot iesākto pētījumu programmu un izvietojot datus un digitālās ĢIS kartes uz ArcIMS karšu servera, tiks radīta vides pārvaldības informācijas sistēma, kas būs noderīga daudziem cilvēkiem, arī teritoriju attīstības plānotājiem un valsts un pašvaldību institūciju darbiniekiem. Minētā interaktīvā datu bāze l̦aus optimizēt lēmumu pieņemšanas procesu un saglabāt Augšzemes dabas vērtības, paredzot šì reǵiona ilgtspējīgu attīstību.

\title{
RĪGAS ATTĪSTĪBAS PLĀNA ATBILSTĪBA TELPISKĀS ATTİSTİBAS POLITIKĀM
}

\author{
Gunta LUKSTIN̦A \\ LU Ģeogrāfijas un Zemes zinātņu fakultāte, \\ e-pasts gunta.lukstina@lu.lv
}

Latvija, iestājoties Eiropas Savienībā, ir iegājusi citā politiskajā telpā. Šodien ir svarīgi zināt, vai Latvijā un Eiropā ,runā vienā telpiskās attīstības un plānošanas valodā”. Nepieciešams noskaidrot, vai Latvijas pašvald̄̄bas, izstrādājot telpiskās attīstības plānošanas dokumentus, n̦em vērā Eiropā, Baltijas jūras reǵionā un Latvijā pieņemtās attīstības politikas. Atbildes uz šiem jautājumiem tika meklētas, izvērtējot 2004.gada beigās sabiedrības apspriešanai nodoto Rīgas attīstības plānu, kurš sastāv no Ilgtermiṇa attīstības stratēgijas līdz 2025.gadam, Attīstības programmas 2006.-2012.gadam un Teritorijas plānojuma 2006.2018.gadam, ietverot Rīgas vēsturiskā centra saglabāšanas un attīstības plānu. 
Atzīstami, ka, lai gan valsts normatīvie dokumenti to nenosaka, Rīgas pilsēta ir sagatavojusi Rīgas ilgtermiņa attīstības stratēǵiju, iezīmējot Rīgas pilsētas nākotnes redzējumu, misiju, stratēgiskos mērķus, pamatnostādnes un izvēelēto attīstības ceļu mērķu sasniegšanai. Rīgas pilsētas ilgtermiņa attīstības vīzijā Rīga ir ,,iespēju pilsēta ikvienam”. Tā ir vērsta uz kvalitatīvu vidi, iedzīvotāju labklājību un izglītotu sabiedrību, kas darbotos vitālas ekonomikas vidē. Bet tā neietver jēdzienu par dzīves kvalitāti.

Rīgas ilgtermina attīstības stratēgóijā noteiktie trīs prioritārie mērķi (izglītota un prasmīga sabiedrība, dzīve pilsētvidē ar kvalitatīvām apkaimēm un Austrumu-Rietumu saikni izmantojoša ekonomika) tikai daļēji sakrīt ar Lisabonas stratēégijā noteiktajiem Eiropas Savienības attīstības mērķiem ekonomiskā, sociālā un ekologiskā atjaunotne un Latvijas nacionālo pozīciju Lisabonas stratēgijas sakarā - Latvijas ekonomisko attīstību panākt uz zināšanām balstitu ekonomiku.

Vērtējot Rīgas pilsētas attīstības dokumentus kopumā, atzīmējams ir tas, ka trūkst savstarpējas sasaistes starp stratēgijā un teritorijas plānojuma paskaidrojuma rakstā noteikto attīstības politiku un teritorijas plānojuma grafiskajā daļā paredzēto pilsētas struktūras attīstību un teritoriju aţ̦auto (plānoto) izmantošanu. Pretēji attīstības plānā apgalvotajam, ka pilsēta tiek veidota kompakta, plānos redzams, ka jaunā apbūve veidojas atrauti no vēsturiskā centra, izklaidus un notiek pilsētas teritorijas sadrumstalošana. Teritorijas plānojumā nav ievērota stratēgeijas ilgtermiṇa pamatnostādne, ka Rīgai jāizvairās no jaunu, neurbanizētu teritoriju apgūšanas, dodot priekšroku degradēto un citu jau urbanizēto teritoriju revitalizācijai un attīstībai. Netiek ievērots princips veidot tādu apdzīvotās vietas struktūru, kas taupītu enerğiju un samazinātu satiksmi.

Attīstības plānā ir paredzēta ievērojama rīcības brīvība attīstìtājiem jauno centru izveidē Rumbulā, pie Spilves lidlauka, Lucavsalā, starp Mežaparku un Čiekurkalnu, kas sevi neattaisno no sabiedrības interešu viedokḷa. Jaunie centri šobrīd netiek veidoti ar stingriem pašvaldības definētiem nosacījumiem, nosakot dažādās centrā nepieciešamās funkcijas - paredzot teritorijas vispirms sabiedriskai apbūvei, tad darījumiem, dz̄ivošanai. Diskutējams arī jauno centru izvietojums. Piemēram, Lucavsalā paredzētais jaunais pilsētas centrs radīs papildus satiksmi pāri Salu tiltam.

Jaunā apbūve, savrupmāju dzīvojamie rajoni Biķernieku mežā, Buḷıusalā, teritorijā starp Bullı̣upi un Spilves pḷavām, gar Vecdaugavu, Mangaḷsalā, Trīsciemā, Vecāķu mežā, Lucavsalā, Dārziņos u.c. tiek izvietoti mežos un mežaparkos, palieņu plavās vai esošu ǵimenes dārziṇu teritorijās. Pretēji Olborgas saistībās „Olborga+10 - iedvesma nākotnei”, kuras ir parakstījusi Rīgas pilsēta, noteiktajam - izvairīties no esošo dabas teritoriju urbanizācijas plānojumā ir paredzēta pastiprināta dabas teritoriju apbūve. Jaunā apbūve tiecas izmantot jebkuru teritoriju. Tā tiek paredzēta arī celtniecībai nelabvēlīgos apstākḷos, applūstošās vietās un riska teritorijās pretēji dokumentā „Vadlīnijās 
Eiropas kontinenta ilgtspējīgai telpiskajai attīstībai" ierosinājumam pilsētu izplešanos tādās teritorijās, kuras pakḷautas plūdu riskam, ierobežot.

Vides jautājumi nav pietiekoši apskatîti visos attīstības plāna dokumentos. Vāji iezīmētas tēmas par ūdens un gaisa kvalitāti, iztrūkst par energoefektivitāti un mikroklimatu. Netiek veidots dabas teritoriju ekologiskais tīklojums - vienota telpiskā struktūra, kas nodrošinātu dabas teritoriju savstarpēju sasaisti un sasaisti ar Pierīgas teritorijām, un šo dabas teritoriju kompleksu izmantošanu rekreācijai. Plānojums izveido "zaļas salas", samazina un izrobo pilsētas zal̦ās platības.

Pilsētas attīstības politikā nav ievērtēta Rīgas vērtība - trīs lielo upju sateces, ezeru un kanālu savienotā ūdens sistēma. Pamatnostādne ir, ka jānodrošina pieūdens teritoriju attīstība, tajās veidojot augstvērtīgu darījumu un dzīves vidi, kā arī publisko ārtelpu, gar ūdensmalām atstājot $10 \mathrm{~m}$. Noteiktā $10 \mathrm{~m}$ josla ir nepietiekoša, lai veidotu apstādījumu un rekreācijas sistēmu gar ūdenstilpnēm un nodrošinātu pieejamību tām. Pie un ap ūdeniiem tiek paredzētas plašas teritorijas jaunai savrupmāju apbūvei.

Rīgas attīstības plānā iekl̦auta politika samazināt nepieciešamību pēc privātā autotransporta pilsētā. Sabiedriskās transporta sistēmas attīstība tiks balstīta uz moderniem ātrgaitas tramvajiem, bet tas nepārliecina, ka tādējādi tiks atrisinātas visas pilsētas transporta un sabiedriskā satiksmes problēmas. Trūkst transporta plānu sasaistes un vienotas sabiedriskā transporta sistēmas izveide ar Rīgas aglomerāciju. Plāns pretēji Rīgas reǵiona plānošanas dokumentos paustajam norāda, ka starptautiski Rīga ir êrti un ātri sasniedzama. Attīstības plānā trūkst argumentu ostas teritorijas paplašināšanai un tās ievirzīšanai iekšzemē, iekḷaujot Bolderājas apbūves un Mangalsalas dabas teritorijas (Piejūras dabas parks).

Attīstības plānā nav izvērtētas sociālās noslāṇošanās un sociālo grupu izolācijas tendences. Plāns vērsts uz investoru, turīgo Rīgas iedzīvotāju un zemes īpašnieku interesēm, tajā netiek aptverti visi sociālie slāņi un nav noteikti pilsēplānošanas pasākumi sabiedrības grupu sociālās noslāṇošanās novēršanai.

Kopumā izvērtējot Rīgas attīstības plānu, jāatzīst, ka tas ir sasteigts plānošanas dokumentu kopums, kuri nav savstarpēji saskaņoti. Izvirzītie mērķi un politikas nav saskaņā ar reāli teritorijas plānojumā paredzēto perspektīvo pilsētas struktūru un zemes izmantošanu. Iztrūkusi starpsektoriāla integrācija, atbilstoši nav notikusi horizontālā un vertikālā sadarbība, plāna izstrādē nav pietiekami bijuši iesaistīti citi pilsētas departamenti un sabiedrība. Rīgas attīstības plāns nevirzīs pilsētas attīstību ilgtspējīgas attīstības virzienā, tas neatbilst daudzām Eiropā un Baltijas jūras regionā pieņemtajām telpiskās attīstîbas politikām un vadlīnijām. Tā paredzētā pilsētas struktūra nav kompakta. Jaunais attīstības plāns, pretēji apgalvotajam, nav turpinājums iepriekšējam attīstības plānam, trūkst argumentētu pamatojumu pieņemtajiem jaunajiem teritorijas plānojuma risinājumiem. Attīstības plāns izstrādāts Rīgas pilsētas robežās, nemeklējot pietiekošu sasaisti ar Rīgas rajona un Rīgas plānošanas reǵiona plānošanas dokumentos noteiktajiem 
risinājumiem un politiku. Svarīgākais turpmākā plānošanas procesa ieteikums ir izvērtēt Rīgas struktūras un zemes izmantošanas priekšlikumus, ņemot vērā ilgtspējīgas pilsētas attīstības plānošanas principus un uzsākt kopīgu Rīgas un Rīgas aglomerācijas plānošanas procesu.

\title{
PLATLAPJU MEŽU REĢIONĀLĀS İPATNĪBAS
}

\author{
Dace MANGALE \\ Latvijas Universitātes Ģeogrāfijas un Zemes zinātņu fakultāte, \\ e-pasts: dace.mangale@tvnet.Iv
}

Latvijā Eiropas platlapju meži atrodas sava izplatības areāla ziemel̦u dal̦ā, un tie veido lapukoku mežu pabeigtu veǵetāciju. Mūsu valsts platlapju mežos galvenās kokaudzi veidojošās sugas ir ozols (Quercus robur) un osis (Fraxinus excelsior). Retāk izplatītas ir pārējās nemorālās koku sugas: liepa (Tilia cordara), kḷava (Acer platanoides), goba, vīksna (Ulmus glabra, U. laevis), bet Latvijas pašos DR ḷoti niecīgās platībās sastopami arī skabārži (Carpinus betulus). Pārsvarā platlapju koku sugas aug mistraudzēs - tīraudzes veido ļoti reti, bet kḷava, goba un vīksna tās neveido vispār.

Latvijā ir piemērotas augsnes un klimatiskie apstākḷi, kas varētu sekmēt platlapju mežu plašāku izplatību, taču cilvēka saimnieciskās darbības rezultātā tie sastopami reti. Lai gan platlapju meži ir izplatîti visos Latvijas dabas reǵionos jeb ainavzemēs, to teritoriālais sadalījums ir dažāds. To nosaka tas faktors, ka platlapju mežus veidojošās sugas ir ekologiski prasīgas un ka ne visur augtenes apstākḷi ir vienādi. Tā augšanu ietekmē gan augtenes mitruma režīms hidromorfisms, gan tas, cik augtene bagāta ar barības vielām - trofiskums, gan arī dabiskie traucējumi - pašizrobošanās, ko izraisa koku bojāeja vecuma dēl, un ūdens līmeña svārstību radītie traucējumi palienēs.

Analizējot platlapju mežu reǵionālās īpatnības pēc Latvijas Valsts meža reǵistra 2004.gada datiem, var teikt, ka platlapju mežiem Latvijā raksturīgas šādas iezīmes:

1. Latvijā platlapju mežiem bagātākais regions ir Rietumzemgale, kas būtu izskaidrojams ar labvēlīgo klimatu un bagātīgajām augtenēm. Nedaudz mazāk platlapju ir Rietumlatvijas augstienēs (Rietumkursā, Austrumkursā) un pacēlumos, nolaidenumos (Dienvidvidzemē, Ziemel̦idzemē), kuros izplatīti glaciālie mālsmilts un smilšmāla nogulumi. Samērā mazās platībās platlapji sastopami Austrumvidzemē, Austrumlatgalē un Ventas zemē.

2. Visos Latvijas dabas regiionos platlapju audzes galvenokārt sastopamas eitrofajos meža tipos: gāršā un vērī. Pārējos meža augšanas apstākḷu tipos platlapji sastopami retāk, īpaši oligatrofajos meža tipos, kuros ir nabadzīgi augu barošanās apstākḷi un kuros veidojas mazražīgākas, vienkāršākas bioǵeocenozes. Nelielas atšksirības vērojamas starp platlapju koku sugām. Kḷava un ozols samērā 
bieži sastopami mezotrofajā meža tipā - damaksnī. Savukārt osis bieži saistāms arī ar slapjajiem meža tipiem: slapjo gāršu un slapjo vēri.

3. Vecuma struktūra platlapju audzēm ir proporcionāla. Visās vecuma grupās, izṇemot pāraugušās audzes, ir novērojams samērā vienmērīgs sadalījums. Citāds stāvoklis novērojams, skatoties atsevišķi pa koku sugām. Osim un kḷavai lielāks īpatsvars ir jaunaudzēs, gobai - briestaudzēs un vidēji vecās audzēs, bet liepai pusi no audžu platībām veido pāraugušas audzes.

\title{
LATGALES PILSĒTU IEDZĪVOTĀJU DZĪVESVIDES UN MĀJOKL̨U APSTĀKL্ডI
}

\author{
Ivars MATISOVS \\ Rēzeknes Augstskola /Daugavpils Universitāte, \\ e-pasts: ivars@dau.Iv
}

Latvijas kultūrvēsturiskajā novadā atrodas 13 pilsētas, kas ievērojami atšķiras pēc to ǵeogrāfiskā stāvokḷa un dabasvides apstākḷiem, aizṇemtās platības un telpiskās struktūras, etniski konfesionālās piederības, demoğeogrāfiskajiem un sociāli ekonomiskajiem rādītājiem. Par novada lielpilsētām tiek uzskatītas Daugavpils un Rēzekne, pie vidēji lielām pilsētām tiek pieskaitīit rajonu centri Krāslava, Ludza, Balvi un Preil̦i, kā arī Līvāni, savukārt mazpilsētu kategorijā ietilpst Dagda, Kārsava, Varakḷāni, Viḷāni, Viḷaka un Zilupe.

Patlaban Latgales pilsētās dzīvo aptuveni 210 tūkstoši cilvēku jeb 57,5\% no novada iedzīvotāju kopskaita. Mūsdienās visās Latgales pilsētās vērojama depopulācija. Vairākās mazpilsētās (Kārsavā, Viḷakā, Zilupē) šis process aizsācies vēl padomju laikā, tomēr pēdējā desmitgadē visstraujāk iedzīvotāju skaits sarucis rūpnieciskajos centros Daugavpilī, Rēzeknē un Līvānos. Tagad šīs pilsētas ir zaudējušas lielu un strauji augošu rūpniecības pilsētu statusu un kḷuvušas par daudzfunkcionāliem centriem ar vidēju attīstības līmeni. Tās atrodas reǵenerācijas stadijā, kad pēc lielo ražotņu sabrukuma nozīmīga iedzīvotāju dą̧a ir kḷuvusi par bezdarbniekiem un ir spiesta veikt sociāli profesionālu transformāciju vai arī darba meklējumos migrēt - pārsvarā uz Rīgas reǵionu vai uz ārzemēm.

Veiktais pētījums liecina, ka būtiski atšķiras arī Latgales pilsētnieku dzīvesvides un mājokḷu apstākḷi. Latvijas 2000.gada tautas skaitīšanas rezultāti uzrādījuši vairākus interesantus faktus. Piemēram, pēc mājokḷu uzcelšanas perioda skaitliski lielākā iedzīvotāju grupa visos Latgales rajonu centros, arī abās novada lielpilsētās, mīt 1981.-1990.gadā būvētajos namos, pie tam Daugavpilī $58,4 \%$ iedzīvotāju dzīvo vairāk nekā 50 dzīvokḷu lielās mājās, kas ir otrs augstākais rādītājs valstī. Savukārt Līvānos, Varakḷānos un Viḷānos lielākā pilsētnieku grupa apdzīvo 1971.-1980.gados būvētās, pārsvarā daudzdzīvokḷu 
mājas, bet Dagdā, Kārsavā, Viḷakā un Zilupē visvairāk apdzīvotas ir 1946.1960.gadā būvētās ēkas.

3,8\% Latgales pilsētnieku dzīvo līdz 1918.gadam būvētajās èkās, pie tam šis rādītājs atsevišķās pilsētās būtiski atšķiras, svārstoties robežās no 0,5\% Balvos līdz 7,3\% Krāslavā. Toties 1996.-2000.gadā uzceltajos namos mīt tikai 0,5\% Latgales pilsētnieku, kas uzskatāmi parāda ekonomiskās aktivitātes un iedzīvotāju labklājīibas līmeni novadā pēc valstiskās neatkarības atgūšanas. Jāpiebilst, ka tieši pēdējos gados jaunu èku būvniecība vai veco māju renovācija sāk atdzimt. İpaši tas attiecināms uz Daugavpili, kas, piemēram, 1999.-2001.gadā viena pati saņēmusi $62,8 \%$ no Latgalē ieguldītajām valsts investīcijām un pratusi piesaistīt aptuveni $95 \%$ no Latgalē ienākušajām ārvalstu investīcijām, galvenokārt no Krievijas, Lietuvas un ASV.

Visu Latgales pilsētu attīstības indekss 1999.-2001.gadā ir bijis negatīvs. Arī attīstības rangs šajā laika periodā vairumam Latgales pilsētu, izņemot Daugavpili, Preiļus un Līvānus, ir samazinājies. Starp septiņām savā attīstībā visvairāk atpalikušajām Latvijas pilsētām sešas atrodas Latgalē, pie tam Kārsava (75.), Viḷāni (76.) un Viḷaka (77.) šo sarakstu noslēdz.

Atšķirīgs ir Latgales pilsētu iedzīvotāju nodrošinājums ar labierīcībām. Piemēram, 95-99\% pilsētnieku ir nodrošināti ar savu virtuvi, gāzi un elektrību. Izṇēmums ir Varakḷāni, kur oficiālā statistika uzrāda ievērojami zemākus skaitļus. Ūdensvads un tualete mājoklī, kanalizācija, vanna, duša vai pirts, kā arī centrālapkure, - ar to ir nodrošināti $75-80 \%$ Latgales pilsētnieku. Tomēr šīs labierīcības nav pieejamas vairumam pilsētnieku Viļakā, Kārsavā, Zilupē un Varakḷānos. Savukārt karsto ūdeni saņem tikai 61\% Latgales pilsētnieku, pie tam Viḷānos un Zilupē bez šìs elementārās labierīcības spiesti iztikt vairāk nekā 90\% iedzīvotāju.

2003.-2004.gadā Daugavpilī un Rēzeknē, iesaistot vietējo augstskolu studentus, tika veikts pilsētvides ainavas kvalitātes komplekss novērtējums. Jāatzīmē, ka kopumā pilsētvides ainavas kvalitāte abās Latgales novada lielpilsētās novērtēta kā gandrīz identiska - Daugavpils ainavas vidējais novērtējums ir 27,6 punkti, bet Rēzeknes - 27,7 punkti. Konstatēts, ka abu pilsētu ainavai piemīt vidēji augsta estētiskā kvalitāte, kas gan ievērojami atšķiras dažādos pilsētu rajonos.

\section{Literatūra}

Ietekmes uz vidi novērtējums (2002). Rīga, IVN birojs.

Latvijas 2000.gada tautas skaitīšanas rezultāti (2002). Rīga, LR CSP.

Latvijas rajonu pilsētas un pagasti. Statistisko datu krājums (1998). Rīga: LR VSK: Latvijas Statistikas institūts.

Reǵionu attīstība Latvijā (2002). Rīga: VSIA "Reǵionu attīstība".

Turlajs J., Milliņš G. Latvijas apdzīvotās vietas (1998). Rīga: Jāṇa sēta.

Vides rādītāji Latvijā 2003.gadā. Statistikas biḷetens (2004). Rīga: LR CSP. 


\title{
ZEMES IZMANTOŠANAS STRUKTŪRAS IZMAIN̦AS LATVIJĀ VIETËJĀ LİMENĪ 20.GADSIMTĀ
}

\author{
Zanda PENĒZE, Ineta GRĪNE, Inga RASA \\ Latvijas Universitāte, Ģeogrāfijas un Zemes zinātņu fakultāte, \\ e-pasts: zanda.peneze@lu.Iv
}

Zemes izmantošanas struktūras izmaiņām piemīt vil̦nveida raksturs, ko nosaka gan sociāli ekonomisko apstākl̦u maiņa, gan arī citi temporāli fluktuējoši faktori.

Šobrīd Eiropā lauku teritorijās ir vērojami divi pretēji procesi lauksaimniecības un mežu zemju intensifikācija vai arī to pamešana.

Pirmajā gadījumā lauksaimniecības un mežu zemes tiek pēc iespējas intensīvāk apsaimniekotas, meliorētas, tiek audzētas monokultūras. Lai šādām teritorijām vieglāk piekļūtu, tiek izbūvēti jauni cel̦i. Rezultātā notiek lauku kultūrainavas homogenizācija vai fragmentācija, un samazinās tās daudzveidība. Otrajā gadījumā zeme, kuras izmantošana prasa pārāk lielus kapitālieguldījumus un kas neatmaksājas, tiek izslēgta no ekonomiskās aprites. Tādējādi notiek šo zemju apmežošana vai dabiskā pārkrūmošanās. To var noteikt gan dabiskie faktori (mazauglīgas augsnes, nelabvēlīgs reljefs vai klimats), gan sociālie faktori (demogrāfiskā struktūra, iedzīvotāju migrācija), gan ekonomiskie faktori (pieejamība vietējam, regíionālam, starptautiskam patēriņa tirgum), gan arī nepieciešamās tehnikas pieejamība un politiskās nostādnes nacionālā un globālā līmenī. Tāpat būtisks ir teritorijas novietojums attiecībā pret dažādu pakalpojumu centriem. Marginalizācija negatīvi ietekmē ainavu daudzveidību. (Jongman, 2002a, Jongman, 2002b, Canarella, 2002).

Daudzos gadījumos zemes izmantošanas intensifikācija vienā teritorijā veicina marginalizāciju citā. Šie procesi izmaina lauku kultūrainavas veidolu gan vietējā, gan reǵionālā, gan arī Eiropas kontekstā. Baltijas valstīs, toskait Latvijā, marginalizācijas process īpaši iezīmējas, sākot ar 20.gs. vidu, mainoties sociālekonomiskajām un politiskajām situācijām. (Mander, Rainer, 2004).

Zemes izmantošanas struktūra Latvijā 20.gs. laikā kopumā ir ievērojami mainījusies. Pirms Otrā pasaules kara valstī dominēja lauksaimniecībā izmantojamo zemju platības. 1935.gadā to bija 57,3\%, mežu īpatsvars - 26\%. Pēc Otrā pasaules kara iedzīvotāju deportācijas uz Krieviju, kolektivizācijas, apdzìvojuma centralizācijas, viensētu degradācijas un vienlaidus meliorācijas dēl lauksaimniecībā izmantojamo zemju platības samazinājās, bet mežu platības pieauga. Šis process ir turpinājies arī pēc Latvijas neatkarības atgūšanas. 2004.gada sākumā mežu bija 44,7\%, lauksaimniecībā izmantojamās zemes $38,3 \%$, krūmāji - 1,9\% no kopējās valsts teritorijas.

Līdzšinējie pētījumi Taurenes un Gudenieku pagastā ir parādījuši, ka viens no faktoriem, kas ietekmējis zemes izmantošanas struktūru šajos pagastos, ir marginalizācija. To noteikuši kā dabiskie, tā arī sociālpolitiskie apstākḷi. Minētais 
process intensīvi norisinās arī pēc Latvijas neatkarības atgūšanas. (Penēze et al., 2004a, Nikodemus et al., 2005).

Līdzīgas tendences tika konstatētas, analizējot zemes izmantošanas struktūras mainu Priekuḷu, Bārtas, Vecsaules un Nautrēnu pagastos. Pētījumā tika izmantotas 20. gs. 20.-30.gadu topogrāfiskās kartes (1911. 1916., 1927.gadu situācijas atspogulojums) un 90 .gadu beigu aerofotouzñēmumi. Dati telpiski tika apstrādāti, izmantojot ĢIS.

Salīdzinot 20.gs. 20.-30 gadu datus ar 90.gadu beigu datiem, tika secināts, ka kopumā visos četros iepriekš minētajos pagastos ievērojami ir palielinājies mežainums un samazinājušās lauksaimniecībā izmantojamo zemju platības. Agrāko mežu masīvu teritorijas ir paplašinājušās un, aizaugot laucēm un nelielajām kādreiz lauksaimniecībā izmantojamām zemēm, tās kḷuvušas homogēnākas.

Jauni mežu puduri un nelieli masīvi ir parādījušies agrāk esošo lauksaimniecībā izmantojamo zemju vietās. Līdz ar to kultūrainava 20.gadsimtā te ir kļuvusi heterogēnāka un ieguvusi mozaīkveida raksturu. Īpaši tas izteikts Burzavas paugurainē Nautrēnu pagastā un Embūtes paugurainē Priekules pagastā. Tāpat jaunu mežu puduru un masīvu parādīšanās, kā arī veco paplašināšanās, ir vērojama visu pagastu nomalēs un teritorijās, kas atrodas tālāk no apdz̄ivojuma centriem vai ir grūtāk sasniedzamas. Paugurainēs un pagastu nomalēs 20.gs. laikā viskrasāk ir samazinājies viensētu skaits. Datu analīze l̦āva secināt, ka pagastu nomales un paguraines ir arī teritorijas, kur šobrīd visintensīvāk norit teritoriju aizaugšana ar krūmiem, lai gan Gudenieku pagasta Kurmāles pauguraines daḷā šis process nav tik izteikts. Tas tiek skaidrots ar lauksaimniecības kultūrvesturiskajām tradīcijām un ārvalstu lauksaimnieku klātbūtni (Penēze et al., 2004a).

Pētāmajās teritorijās tika veikta arī iedzīvotāju aptauja, lai noskaidrotu vinuu viedokli par šodienas lauku kultūrvidi un kultūrainavās notiekošajiem procesiem (Penēze, 2004b). Datu analīze parādīja, ka respondenti izmaiņas lauku kultūrainavās 20.gs. kopumā vērtē kā būtiskas un turklāt negatīvi. Šodienas ainavas vizuālā kvalitāte vinuu skatījumā ir zema, ko nosaka lauksaimniecībā izmantojamo teritoriju aizaugšana ar krūmiem. Tādēl arī loǵiska bija respondentu pozitīvā attieksme pret to, ka lauku vidi ir nepieciešams uzlabot, sakopjot ainavu. Būtiski atšķirīgs viedoklis iezīmējās starp respondentiem Vecsaules pagastā, no kuriem vairums nepiekrita šim viedoklim. Iespējams, tas izskaidrojams ar to, ka Vecsaules pagasts salīdzinājumā ar pārējiem analizētajiem pagastiem šobrīd visintensīvāk tiek izmantots. Tāpat arī viensētu izvietojums šeit ir vienmērīgāks. Šie aspekti būtiski ietekmē šodienas pagasta ainavas kvalitāti

Kopumā var secināt, ka Latvijā zemes izmantošanas struktūras izmaiņas lokālā līmen̄i, salīdzinot 20.gs. 20.-30.gadus ar 90.gadu beigām, dažādās vietās ir bijušas līdzīgas un arī turpmākās tendences iezīmējas līdzīgi. Iespējams, ka nākotnē Latvijas lauku kultūrainava varētu klūut homogēnāka un līdz ar to zaudēt savu atraktivitāti, jo samazināsies tās atklātums un saskatāmība, kas no iedzīvotāja redzes leņķa palielina ainavas vizuālo kvalitāti. Tātad samazināsies ainavas 
daudzveidība. Tas ir drauds lauku tūrismam un līdz ar to arī lauku vides attīstības iespējām. Tâdēl ir būtiski vietējām pašvald̄̄bām, gan arī attiecīgām valsts institūcijām pārdomāt tos pasākumus, kas vērsti, lai uzlabotu lauku vidi un dažādotu lauku kultūrainavu. Šajā sakarā svarīgi būtu izvērtēt tās priekšrocības, ko Latvijai dos pievienošanās Eiropas ainavu konvencijai jeb Florences konvencijai.

\section{Literatūra}

Canarella, C. 2002. Process of marginalization of agriculture: the role of non-agricultural sectors to support economic and social growth in rural areas. Journal of Central European Agriculture. 3(3): 206-215.

Jongman, R.H.G. 2002a. Homogenisation and fragmentation of the European landscape: ecological consequences and solutions. Landscape and Urban Planning. 58: 211-221.

Jongman, R.H.G. 2002b. Landscape planning for Biological diversity in Europe. Landsacpe Research. 27: 187-195.

Mander, Ü., Rainer, K. 2004. Changing landsacpes in Northeastern Europe based on examples from the Baltic countries. In: The new dimension of the Europeans landsacpe. http://library.wur.nl/frontis/landscape/toc_landscape.html (15.11.2004.)

Nikodemus, O., Bell, S., Grīne, I., Liepiņš, I. 2005. The impact of economic, social and political factors on the landscape structure of Vidzeme Uplands in Latvia. Landscape and Urban Planning. 10: 57-67.

Penēze, Z., Nikodemus, O., Grīne, I., Rasa, I. Bell, S.2004. Local changes in the landscape structure of Kurzeme during the $20^{\text {th }}$ century. Geogräfiski raksti: Folia Geographica, 12: 56-65.

Penēze, Z., Nikodemus, O., Bell, S. 2004b. Latvijas lauku kultūrainavas vērtības. In: Latvijas geogrāfija Eiropas dimensijās. III Latvijas geogrāfijas kongress. Rīga: Latvijas Ģeogrāfijas biedrība. 36-37.

\section{DOMĀŠANAS OPERĀCIJU ATTĪSTİŠANA ĢEOGRĀFIJAS MĀCĪŠANAS PROCESĀ}

\section{Vaira PODSKOČıJA}

Ģeogrāfijas mācīšanas izpratnei skolotājam jāpārzina pedagoǵiskie un psiholoǵiskie procesi, kas pavada mācīšanās gaitu. Vācu pedagogs H.Gudjons [2; 255.] par pedagoǵisko atziņu uzskata, ka mācību process tiek zinātniski plānots un sakārtots didaktiskajos model̦os, kuru izmantošana atkarīga no katra skolotāja meistarības. Lai zināšanas kḷūtu par skolēnu personisko vērtību, ir jāpārzina domāšanas psihologija, kas uztver un analizē priekšstatu un jēdzienu mijsakarības. Izvēlētā temata aktualitāti pamatoju ar pedagoǵes I.Žoglas [8;102.] pêtîto atziņu, ka skolotājs izvēlas metodes, lai palīdzētu skolēniem mācîties un veidot personības pozitīvo attieksmi [9.] pret dabas un sociālo vidi.

Svarīgākā nozīme šajā procesā ir funkcionālai domāšanai. Tādēḷ savā darbā aplūkoju tās mehānismus un analizēju iespēju, kā padarīt racionālāku ǵeogrāfijas mācišanos. Vadoties no 2000.gadā pabeigtā pētījuma par skolēnu vēsturisko domāšanu pilsoniskās un valstiskās apziņas attīstī̌sanā, personiskajā pieredzē aprobētās atziņas izmantoju ǵeogrāfiskās domāšanas veidošanai. 
Cilvēka zinātniskā domāšana attīstās dabiskās augšanas un mācīšanās kopsakarībās. Domāšana neveidojas tikai dabiskā procesā, bet gan dabas un sociālās vides mijsakarībās. Zinātniskā domāšana personībai attīstās vispārizglītojošā skolā, atbilstoši Izglītības likumam, mācību priekšmetu sistēmās. Mācot vēsturi un ǵeogrāfiju, skolēnu domāšanu attīstu ar priekšmetu valsts standartos [6.] noteikto priekšstatu un jēdzienu apguves mijsakarībām. Attīstot personības apzin̄ā saprašanu par pasauli kā vienotu un veselu vēstures un ǵeogrāfijas mijsakarībās, skolēni apguva dabas un sociālās vides priekšstatus mācību priekšmetu jēdzienu sistēmās. Lai sekmīgi veiktu nosprausto uzdevumu, aplūkoju pedagoǵijas un psihologijas zinātnieku pētījumus par vispusīgi attīstītas personības domāšanu. Noderīgās atziņas izmantoju un pārbaudīju praksē.

Igaunu psihologs P.Tulviste [5.], veicot pētījumu par cilvēku domāšanu mazo tautu dzīivē totalitārisma apstākļos, atzinis, ka domāšanas tipus un ātrumu determinē sociālā kultūrvide. Cilvēku domāšana neattīstās vienkārši dabīgā veidā, bet gan atbilstoši tuvākās vides kultūrai un sociālai pieredzei, kuru apzināti pārmanto. Par zinātnisko domāšanu viņš argumentē spriedumu, ka tā attīstās atbilstoši vispārējās izglītības mērķiem, kādi pastāv valstī un tiek risināti mācību priekšmetos. N̦emot vērā šos nosacījumus, sāku pētît, kā var attīstît skolēnu domāšanu ar ǵeogrāfijas mācību satura uzdevumiem.

Izmantojot mācību metodes kā pedagog̣iski psiholoǵiskos ietekmes ārējos faktorus, aktivizēju skolēnu domāšanu geogrāfijas priekšstatu un jēdzienu saprašanas attīstīšanai. Psihologi un pedagogi ir izpētījuši, ka jebkura cilvēka domāšana sākas ar izpratni no iekšienes par notikumiem tuvākajā vidē. Veicot pētījumu par skolēnu vēsturisko domāšanu un vadoties no personiskā pieredzē gūtās pārliecības, tika formulēti psihiskie procesi domāšanā.

Priekšstatît nozīmē atpazīt būtiskās pazīmes, redzot, dzirdot un izprotot uztverto notikumu likumsakarības domāšanas funkcionālajā saprašanā.

Priekšstati ir kodētas sajūtas atmiņā, kad notikumu pazīmes tikušas skaidri un saprotami apzinātas domāšanas operācijās.

Agrākajā mācīšanās gaitā izveidojušies priekšstati skolēna atmiņā saglabājās līdz aktualizācijai, ko asociācijas vispārina sintezē jaunajos priekšstatos jēdzienu formās.

Mācīšanās sākās ar būtisko pazīmju atcerēšanos analog̣ijās. Par analogiju nozīmi mācīšanās procesā p.m.ē. rakstījis Aristotelis[1.], tādēḷ jaunās informācijas apguvi balstīju uz personiskajā pieredzē uzkrātiem priekšstatiem. Jēdzienus veido priekšstatu kopums ar vispārināto jēgu par notikumiem vai parādībām priekšstatu sistēmās par pasauli kā vienotu un veselu. Noderīga ir loǵikas pētnieka I.Vedina [7.] atziña, ka priekšstatu un jēdzienu mijsakarību noskaidrošanai izmantojamas būtiskās un nebūtiskās pazīmes.

Lai attīstītu priekšstatu un jēdzienu saprašanu, geogrāfijas priekšmeta apguvē izvēēējos operāciju aktivizēšanu domāšanā. Vadoties no psihologu Ž.Piažēe [4.], B.Teplova [17.], N.Menčinskas [13.] u.c. pētījumiem par operāciju 
funkcijām, mācību metodes tika izmantotas kā domāšanas ārējie ietekmes līdzekḷi, lai attīstītu priekšstatu un jēdzienu saprašanu. Iepazīstoties ar Maslova [12.] vajadzību teoriju kā psihisko procesu iekšējo rosinātāju, personības motivāciju izmantoju apkārt notiekošā izpratnei.

Skolēnu ǵeogrāfiskā domāšana ir zinātniskās domāšanas sastāvdaḷa, kuru attīsta mācīšanas un mācišanās vienotajā procesā. Operācijas izvirza sīkas un specifiskas darbības, kas neietilpst problēmas vispārinājumā, bet uzskatāmi kombinē risinājuma stratēgiju ar pamatpazīmēm. Krievu pedagogi V.Davidovs [10.] un N.Menčinska [12.] pētījumos ir lietojuši abstrahēšanās operāciju, kur tā veic apskatāmā notikuma izdalīšanu un nodalīšanu no vispārīgajiem priekšstatiem apgūstamās problēmas risināšanā. Pēc krievu psihologa B.Teplova [16.] pētījuma par karavadoņu domāšanas stratēgiju atzinumiem, vispārināšana augstākajā līmeni iespējama, ja argumentācijā apvieno vairākos priekšmetos apgūtos likumus, kuri atspoguḷo būtisko un nebūtisko pazīmju analizēšanu, salīdzināšanu un sintezēšanu. Ģeogrāfijas priekšmeta apguve ir cieši saistīta ar norisēm dabā, kuras izskaidro fizikas, ķīmijas, bioloğijas un astronomijas likumi. Lai vispārizglītojošā skolā [6.] attīstītu priekšstatu saprašanu par pasauli kā vienotu un veselu cilvēku dzīvei nepieciešamu vidi, ar vajadzīgo pazīmju sistematizēšanu, jēdzienus klasificē ǵeogrāfijas, dabas vides, ekonomikas un sociālās dzīves kategorijās. Operācijas domāšanā neparādās tīrā veidā, bet tiek funkcionāli sasaistītas apgūstamās problēmas uzdevumu risināšanā. Tā ǵeogrāfijas valsts standartā ietvertais mācību saturs kḷūst par mācīšanas un mācǐšanās vienotā procesa problēmu.

Mācību saturam kḷūstot par apguves problēmu, tas tiek sadalīts atbilstoši skolēna vecuma posmiem pa klasēm. Ģeogrāfiju skolēni sāk apgūt 6 . klasē. Tas ir 12/13 gadu vecumā, kad, pēc austriešu psihologa Ž.Piažē [4.] un daudzu pedagogu atzinuma, skolēni ir spējīgi operatīvi strādāt domāšanā. Šajā sakarībā ir jāatceras krievu psihologa L.Vigotska [19.] pētījumi par tuvākās un tālākās darbības iespēju zonām atbilstoši vecuma posmiem. N̦emot vērā skolēnu attīstību un sagatavotības pakāpi, izmantojot atbilstošas mācību metodes, tika aktivizētas operācijas skolēnu domāšanā. Ģeogrāfijas likumsakarību apgūšanai izmantoja vingrinājumu refleksiju ar mērķtiecīgiem uzdevumiem. Izmantojot fiziologa I.Pavlova [14.] un biologa V.Detjē pētījumus, tika ņemts vērā, ka ikviena reakcija veidojās atkārtoto vingrinājumu rezultātā. Attīstot funkcionālo saprašanu apziņā, iepazinos ar fiziologa I.Sečenova [16.] pētījumu pieredzi, ka visi psihiskie akti, kas saistīti ar domāšanu, attīstāmi refleksīvi, aktivizējot fizioloǵiskos dotumus. Mācīšanās uzdevumi skolotāja formulējumā kḷuva par apziņas ārējo ierosu operāciju dinamikai skolēna domāšanā.

Atmiṇu priekšstati operācijās uztvēra acs muskuļu un roku kustības, kas runāja, rakstīja, zīmēja un modelēja. Priekšstati sintezējās mijsakarībās uzdevumu aktivizēto asociatīvo saikṇu dēḷ. Asociatīvie priekšstati aktualizējās domāšanā, ja skolēnu atmiṇā ir uzkrāti sākotnējie priekšstati, kuri tiek atpazīti ar atbilstošo 
uzdevumu veiktām ierosām. Asociāciju lomu personības attīstībā ir aplūkojusi psiholoǵe A.Karpova [3.]. Atpazītie priekšstati ar asociācijām viegli piesaista jauno priekšstatu būtiskās pazīmes. Determinētie domāšanas mehānismi uztvere un iztēle operatīvi atlasa un kombinē pazīstamos un jaunos priekšstatus.

To panāk, formulējot uzdevumus, kas skar skolēnu apziņas personisko pieredzi - atcerieties, kā ekskursijā izskatījās jūra un Rīgas līcis pie Kolkas... ?

Ar abstrahēšanas operāciju no vispārīgiem priekšstatiem tiek izdalīta apgūstamā problēma par Baltijas jūras ūden̦iem, kuru detalizēti iztirzā stundas gaitā.

Skolotāja jautājumi rada impulsus analizēšanas, salīdzināšanas, konkretizēšanas dinamikai, kas sintezē informāciju, individuālajā pieredzē klasificējot, sistematizējot, vispārinot, kodējot un pārnesot jaunā situācijā, veidojot jaunos priekšstatus jēdzienu formās. Domāšanā tiek šķelti zināmie priekšstati, kuros ar būtiskām pazīmēm operācijas iestrukturē jaunveidojumus. Skolēnu apzinātajā domāšanā priekšstati un jēdzieni atrodas savstarpēji nosacītā dinamikā. To sekmē zināšanu pilnveidošanās mācīšanās gaitā, kā arī sekmē individuālo vērtību priekšstatus. Pētot individuālo stilu, psiholoǵe A.Karpova [3.] uzsvērusi, ka nozīmīgie priekšstati par tuvāko vidi personībai izveidojās vispārizglìtojošā skolā.

Lai attīstîtu apzināto saprašanas funkciju, domāšanas procesā tiek izmantotas desmit operācijas. Tīrā veidā atsevišķai operācijai nav iespējams izsekot. Taču ar mērḳtiecīgiem uzdevumiem varam konstatēt konkrēto darbību dinamikai. Uzsākot apgūt jaunu tematu, geogrāfijas stundā skolotājs aktivizē abstrahēšanas operāciju, kuras uzdevums ir izdalīt un nodalīt mācīšanās problēmu no vispārējiem priekšstatiem par pasauli. Mācīšanās problēmu veido stundā apgūstamais temats, kuru veido priekšstatu un jēdzienu kopums konkrēto lietu vai parādību apzīmēšanai. Abstrahēšanas nozīmi mācīšanās procesā ir pētījuši daudzi krievu pedagogi un psihologi S.Rubinšteins, N.Menčinska, B.Teplovs.

Analizēšanai tiek doti uzdevumi - nosauc būtiskās un nebūtiskās pazīmes.

Salīdzināšanas operāciju ierosina uzdevumi, kuri liek atpazìt redzēto, dzirdēto, izjusto; atrast kopīgās un atšksirīgās pazīmes, sameklēt pretstatus.

Konkretizēšanu veic ar uzdevumiem: parādi kartē, atrodi tabulā, formulē galveno domu, nosauc būtiskās pazīmes...!

Sintēzes dinamiku ierosina uzdevumi, kas liek savienot raksturīgās pazīmes, priekšstatus, vispārināt notikumus.

Klasificēšanu veic ar būtiskām un nebūtiskām pazīmēm sakārtot tabulā, grafikā....

Vispārināšana notiek, apvienojot vienādas pazīmes, parādības, notikumus konkrētās likumsakarībās, kas tiek atgriezeniski analizētas būtiskās pazīmēs.

Kodēšanas un dekodēšanas operācijās iegūtie priekšstati par kādu parādību vai notikumu tiek aplūkoti ǵeogrāfijai atbilstošos simbolos. Piemēram, novērojumos temperatūras izmaiṇas atspogụ̣o grafiska līkne. Reljefa stāvokḷus 
kartē atspoguļo noteikta visiem labi zināma krāsa. Dekodējot pieņemtos apzīmējumus, tiek iegūti priekšstati par kalnu augstumu, zemienēm, jūru un ezeru dziļumu u.c.

Ģeogrāfijas mācību priekšmeta starpkursu izkārtojumā skolēniem jāapgūst daudz dažādu pieņemto simbolu, bez kuriem nav iespējama sistematizēšana mācišanās gaitā. Simbolos tiek ietverta konkrēta informācija par apgūstamo priekšstatu vai jēdzienu.

Sistematizēšanai parasti tiek pakļauti priekšstati, kas satur liela apjoma informāciju. Tādēḷ, lai vieglāk un pārskatāmāk varētu orientēties, sistematizēšanai izmanto kodētos priekšstatus.

Ģeogrāfijā tie ir temperatūru un nokrišņu novērojumu diagrammas, reljefa apzīmējumi un daudzie simboli kartēs. Kad iepriekš aplūkotās operācijas temata apguvē detalizēto darbu ir padarījušas, kārta priekšstatu pārnesei jaunā situācijā. Tā parasti ir tālāk aplūkojamā valsts vai nākamais reǵions, kas tiek apgūts ar iepriekš analizētām būtiskām un nebūtiskām pazīmēm. Pazīmju pārnešana ir apgūstamo priekšstatu un jēdzienu sasaistošais faktors, jo cilvēks visu jauno uztver un pieņem pēc saprotamā un pazīstamā.

Par to, kā izvērtēt domāšanu mācīšanās procesā, B.Blūms [10.] un amerikāņu pedagogu grupa veikuši pētījumu, kura gaitā izveidota taksonomija dinamikas konstatěšanai. Taksonomija ir sadalīta pa līmeņiem, kuri ietver domāšanā izmantotās operācijas. Līmeṇu gradācija nav adekvāta Ž.Piažē operāciju sistēmai domāšanā. B.Blūma taksonomijas līmeņos operāciju dinamika ir apvienota un savienota atbilstoši uzdevuma formulējumam. Lai nesajauktu abas lietas, jāatceras, ka Ž.Piažē pētīja bērnu domāšanas gaitu un logiiku, bet B.Blūms, jau pazīstot šo pētījumu, - kā konstatēt un izvērtēt domāšanas efektivitāti mācī̌anās sasniegumos.

\title{
ĢIS IZMANTOŠANA PAŠVALDĪBU TERITORIJAS PLĀNOŠANĀ - VĪZIJA UN REALITĀTE
}

\author{
Anete Pošı̃A \\ SIA „ĢIS Projekts”, e-pasts: anete@gisprojekts.Iv
}

Pašvaldību teritorijas un līdz ar to arī teritorijas attīstības plānošanu Latvijā nosaka gan Teritorijas attīstības plānošanas likums (30.10.1998.), gan Teritorijas plānošanas likums (12.06.2002.), kā arī sīkāk reglamentē MK Vietējās pašvaldības teritorijas plānošanas noteikumi (Nr.883., 19.10.2004.). Šais dokumentos dotas teritorijas plānošanas vadlīnijas, taču praktiski nav skartas plānošanā lietojamās kartogrāfiskās metodes, izṇemot norādes uz grafiskā (kartogrāfiskā) materiāla nepieciešamību. Vienīgi MK noteikumos Nr.883. minēts, uz kādas kartogrāfiskās pamatnes veicama plānojuma izstrāde, kā arī 
noteikts, ka plānojuma grafiskā daļa jānodod vektoru datu formātā LKS-92 koordinātu sistēmā.

Tādējādi ǵeogrāfisko informācijas sistēmu (ĢIS) ${ }^{3}$ lietošana pašvaldību teritorijas plānošanā ir tikai pašvaldību un/vai teritorijas plānojumu izstrādātāju iniciatīva. ĢIS izmantošanas nepieciešamība un efektivitāte atkarīga gan no pašvaldības prasībām teritorijas plānojuma izstrādei, gan plānojuma izstrādātāja darba metodēm un tehniskajām iespējām, kā arī nepieciešamo datu pieejamības. Galvenā ĢIS priekšrocība teritoriju plānojumos ir iespēja apvienot datus no dažādiem avotiem un dažādiem tematiskajiem slāņiem vienā ērti lietojamā datu kopā, kas ḷauj veikt plānošanas vajadzībām nepieciešamās analīzes funkcijas arī pēc plānojuma izstrādes pabeigšanas.

Galvenie šķēešsli plašākai ĢIS ieviešanai pašvaldību teritoriju plānošanā saistās, pirmkārt, ar lielajiem izdevumiem, kas nepieciešami piemērotas datortehnikas un programmatūras iegādei, otrkārt, nozares speciālistu trūkumu, sevišķi ārpus lielajām pilsētām, treškārt, ar datu ieguves un savietojamības problēmām, ceturtkārt, ar ĢIS ieviešanas nerentabilitāti nelielās lauku teritorijās. Tāpēc pašlaik savas teritorijas ĢIS ievieš pārsvarā pilsētu un rajonu pašvaldības.

Referātā aplūkotas ar pašvaldību G̦IS izveidi un lietošanu saistītās problēmas dažādu ieinteresēto institūciju skatījumā. Secinājumi par pašreizējo situāciju un ĢIS pielietojuma iespējām tuvākajā nākotnē balstīti galvenokārt uz nozares speciālistu viedokli un vērtējumu. Iezīmēta situācija, kas raksturo līdz šim izstrādāto teritorijas plānojumu atbilstību ĢIS principiem, kā arī pašvaldību nodrošinājumu un iespējas ieviest ĢIS bāzētas analīzes un lēmumu pien̦emšanas metodes nākotnē. Referātā aplūkotas ĢIS izmantošanas īpatnības pilsētu un lauku pašvaldībās, kā arī iespējas datu apmaiņai ar citām valsts institūcijām un komercstruktūrām; optimālais datu apmaiṇas un ĢIS izmantošanas modelis salīdzināts ar pašreizējo situāciju un tuvākajā nākotnē prognozējamajām tendencēm.

\section{KURZEMES REĢIONA TELPISKĀ ATTĪSTĪBA UN PLÄNOŠANAS PIEEJAS}

\section{Armands PUŽULIS}

\section{Kurzemes reǵions.}

Kurzemes plānošanas reǵiona teritorija ir formāli noteikta ar MK noteikumiem. Kā tāds tas ir 5 esošo administratīvo rajonu un 2 lielo pilsētu sakopojums. No vienas puses, šāds dalījums ir nosacīti mākslīgs, jo funkcionālās robežas nesakrīt un vietām pārsniedz esošās robežas. Īpaši tas ir izteikts Tukuma

\footnotetext{
${ }^{3}$ Referāta ietvaros jēdziens ,ǵeogrāfiskās informācijas sistēmas" pamatā tiek lietots sašaurinātā izpratnē, ar to saprotot vektoru kartogrāfisko materiālu, kas savienots ar datu bāzi.
} 
virzienā. Tūrisma nozarē attīstīta sadarbība, kas pārsniedz šīs robežas. Šeit ir nesakritība ar vēsturisko un kultūras reǵiona robežu. Otra problēma - nosacītās robežas ietekmē reǵiona identitāti. Tas šādā kontekstā nav pētīts, tomēr var atstāt būtisku ietekmi (līdzās ekonomiskajiem faktoriem). Pretruna - reg̣ions ir veidots no ,augšas”, identitāte - jāveido no „apakšas”. Kamēr nav skaidra regiona formālā vieta administratīvajā un plānošanas sistēmā, ir grūti izveidot reāli funkcionējošu reǵionu. Rezultātā - formāli ir plānošanas reǵions, ir lēmēj- un izpildinstitūcija, bet nav reǵionālās kopības. Būtiska loma identitātes veidošanā ir izpildinstitūcijām - attīstības aǵentūrām.

\section{Vērtības un resursi, problēmas un tendences.}

Reǵiona teritorijā ir noteikts resursu kopums, kas ir vairāk vai mazāk dabiski nosacīts vai attīstības laikā saimnieciski iegūts. Resursus var izmērīt un raksturot ar noteiktiem kvantitatīvajiem vai kvalitatīvajiem rādītājiem. Vērtības turpretim ir lēmējinstitūciju noteiktas, kas noder par pamatu tālākai attīstības plānošanai. Resursi ir ārēji nosakāmi un raksturojami, vērtības - ir iekšējs teritoriāls lēmums. Reǵionālā līmenī šāda kopēja vienošanās iespējama gadījumā, ja ir izveidota ekonomiski spēcīga reǵionāla līmen̦a pašvaldība vai ir vispārēja vienošanās spēcīgas reǵionālas identitātes gadījumā.

Kurzeme ir kontrastu reǵions. Pašlaik nozīmīgākie ekonomiskie centri Ventspils un Liepāja atstāj ietekmi uz plašāku teritoriju, bet ir vāji, lai noderētu par reǵiona attīstības motoru. Arvien krasāk izpaužas reǵiona marğinālais efekts to ietekmē novietojums valsts nomalē attiecībā pret Rīgu kā nacionālo attīstības motoru, no vienas puses, un reǵiona iekšējām teritorijām, no otras. Vērojama teritoriālā attīstības tendenču polarizācija - apbūve, atpūta, tūrisms un pakalpojumi kopumā attīstās piekrastē un lielajās pilsētās un lauksaimniecība un mežsaimniecība - pārējā teritorijā. Šāds sadalījums veido mazāk un vairāk labvēlīgās teritorijas gan investīciju, gan perspektīvās attīstības jomā ar tam pavadošajiem raksturojumiem - bezdarbu, migrāciju, cilvēkresursu trūkumu noteiktās jomās. Minētā situācija atstāj ietekmi uz reǵiona konkurētspēju kopumā un dzīves kvalitāti atsevišķās teritorijās.

\section{Kurzemes attīstības plānošana un telpiskais plānojums.}

Tiesību aktos noteiktais sadalījums starp teritorijas plānojumu un attīstības programmu ir mehānisks. Būtībā te ir jautājums - nevis, kā ievērot vienā attīstības programmā noteikto teritorijas plānojumā un otrādi, bet gan - kā integrēt dokumentus vienotā sistēmā. Pašreiz esošie reǵionālās politikas dokumenti un tiesību akti nedod atbildi uz šo jautājumu. Iespējamais risinājums - izveidot vienotu reǵiona attīstības dokumentu, kas sastāv no 3 daļām:

$\checkmark$ attīstības stratēǵija nosaka ilgtermiņa attīstības mērķus,

$\checkmark$ teritorijas plānojums nosaka ilgtermiņa telpiskās attīstības virzienus,

$\checkmark$ attīstības programma nosaka vidēja termiņa rīcības. 
Šāds sadalījums l̦autu izvairīties no ilgtermiņa un īstermiņa plānošanas apvienojuma programmā un loǵiski pamatotu telpiskās plānošanas ilgtermiṇa vietu attīstības plānošanas sistēmā.

No tā izriet būtisks jautājums - kas ir teritorijas plānojums reǵionālajā līmenī? Pašlaik reǵiona plānojums nav tiesiski regulēts satura līmenī. Esošās plānošanas tendences nosaka teritorijas struktūrplānu kā dokumenta formu un transportu, apdzīvojumu un lauku vidi kā saturu. Jāpiezīmē, ka šāds traktējums nenosaka plānojamās reǵionālā līmeņa saturiskās robežas. Rezultātā var būt nacionālā un reg̣ionālā plānošanas līmeņa dokumentu kompetences pārklāšanās.

Risinājums. Tiesiski būtu nosakāmas kompetences robežas reǵionālajam līmenim attiecībā pret nacionālo un zemāku līmeni. Ieteicams detalizēt reǵiona līmeņa plānojuma saturu atkarībā no tā, kādas funkcijas piešķir reǵionālajam līmenim vispār.

\section{Reğiona plānojuma nepieciešamība.}

Latvijas plānošanas sistēma ir veidojusies kā centralizēta, un reǵionu līmenim nav izveidojušos plānošanas tradīciju. Šādā situācijā ir nozīmīgi juridiski saistoši dokumenti, kam ir strikti noteikta ietekme. Pašlaik reǵiona līmen̦a plānošanas dokumentiem ir ieteikuma raksturs. Rezultātā - ņemot vērā regiionālas identitātes trūkumu, ierobežotos finansēšanas apjomus un neskaidro reǵionālo kompetenci, izveidojas situācija, ka reǵiona plānošanas dokumenti ir maznozīmīgi pašam reǵionam.

No otras puses, Reǵiona attīstības dokumenti ir būtiski reǵionam, jo tie var noteikt intereses, kas pārsniedz pašvaldības kompetenci un aptver visu reǵionu. To nosaka nepieciešamība pēc teritoriālās kohēzijas, ko atbalsta Eiropas Savienība. Beidzot, tas attiecas uz subsidaritātes ievērošanu reǵionālā līmenī.

\section{Informācija reǵiona plānošanas dokumentu izstrādei.}

Reǵionālajā līmen̄̄ nav izveidojies vienots skatījums uz datiem, uz ko balstāms regiona attīstības dokuments.

Attīstības jautājumi balstāmi uz reǵiona salīdzinošajām priekšrocībām. To noteikšanai ir jābūt galvenajam attīstības stratēgijas dokumenta uzdevumam. Šajā sakarā būtiski veikt ekonomiskās attīstības prognozes pētījumu, kas būtu pamats stratēgiskās izvēles noteikšanai. Dažādos dokumentos kā salīdzinošās priekšrocības Kurzemes regionā minētas:

$\checkmark$ Kurzemes ostu potenciāls (lielās, mazās ostas),

$\checkmark$ lielās pilsētas kā ekonomiskie mezgli,

$\checkmark$ mazpārveidota dabīga jūras piekraste (daba, kultūrvide, ainavas, zvejniecība), lielas dabiskas (dabas) teritorijas tūrisma attīstībai un investīciju piesaistei atbilstošajās nozarēs.

Tomēr būtībā tie ir virzieni, kas daudzviet ir līdzīgi.

Analizējot datus, būtu jānodala reǵionu kopējās problēmas no katra reǵiona specifiskajām problēmām. Tālāk kopējās problēmas būtu risināmas ar 
valsts programmu vai atbalsta palīdzību, bet specifiskajām problēmām būtu atsevišksas valsts programmas, ko administrē ministrija vai arī reǵions.

Otrs sadalījums būtu saistāms ar nozarēm, kas ir stratēǵiskas attīstības veicinātājas no nozarēm, kas ir pakalpojumu sniedzējas. Stratēǵiskā analīze un tālākās stratēgiskās rīcības būtu vēršamas uz stratēg̣iskajām nozarēm, veidojot atbilstošas saites ar pakalpojumu (pakārtotajām) nozarēm.

Nepieciešamie dati būtu pakārtojami minētajiem principiem. Būtībā, lai varētu noteikt zemes izmantošanas tendences, būtu nepieciešami dati iespējami zemākā statistiskajā līmenī - pašvaldību griezumā. No otras puses, lai noteiktu salīdzinošas priekšrocības, ir jābūt starptautiskajam kontekstam - tas ir, ES atbalsta instrumentu politikai, pasaules tirgus un attīstības tendencēm. Vairāk būtu jābalstās uz kvalitatīvajiem rādītājiem, jo kvantitatīvie rādītāji bieži nav pieejami vai arī ir tādā griezumā, kas nav izmantojami atbilstošajā jomā.

Ir divas pieejas telpiskajam plānojumam: teritorijas plānojums un teritorijas struktūrplāns, iepējams - abu apvienojums. Katrā gadījumā plānojuma saturs balstāms uz ilgtermiņa attīstības mērķiem.

Pašlaik kā pieņemamākais variants reǵionā tiek atbalstīts struktūrplāns, ar tālāku mērḳi to detalizēt un izstrādāt teritorijas plānojumu.

Nepieciešamā informācija balstāma uz iespējamo reǵiona atbildību. Kā perspektīvas jomas veidojas profesionālās izglīīibas, cel̦u, medicīnas uc. jautājumu plānošana.

Kurzemes plānotāji vienojās, ka svarīgākās būtu jāattēlo problēmteritorijas, kur ir jāpiesaista nauda vai arī kuras var pelnīt. Jākoncentrējas uz regionāla līmeņa jautājumiem - transports, ostas, cauruḷvadi, lidostas, tūrisms.

Piekrastei būtu nosakāmas vienotas prasības plānošanai. Pašlaik nav iespējams reǵionā līmenī strikti regulēt apbūvi piekrastē.

Svarīgi ir noteikt zemes, kas nav transformējamas. Pašlaik to arī ir iespējams veikt tikai kā vadlīnijas.

\section{Esošā plānošanas situācija un plānošanas problēmas.}

Sadarbībā ar Flandrijas Kopienas valdību Kurzemes plānošanas reǵionā ir izstrādāts plānošanas dokumentu satvars - Kurzemes regiona attīstības stratēǵija /KRAS/ (programmas dokuments) - apstiprināts 2.darba variants un Kurzemes reǵiona telpiskās stratēg̣ijas /KRTS/ satvars (teritorijas struktūrplāns), kas noderēs par pamatu tālākai plānojuma izstrādei.

KRAS balstās uz Latvijas attīstības plānu /LAP/ struktūrfondu finansējuma san̦emšanai, kas saturiski ir vērstas uz LAP prioritāšu reǵionālu izvērsumu. Plānošana ir veikta, balstoties uz zināmām prioritārām jomām, nevis uz plašākām reǵiona reālajām vajadzībām. Rīcības dą̧a ir sagatavota logiskās matricas formā, kas paver iespējas to papildināt ar jauniem projektiem un aktivitātēm. Ir paredzēts papildināt un pārstrādāt šo dokumentu. 
KRTS ir telpiskais struktūrplāns, kas balstīts uz telpiskās struktūras analīzi, koncentrējoties uz infrastruktūru, apdzīvojumu un lauku vidi. Pašlaik šim projektam ir pêtījuma statuss, un to var izmantot par pamatu tālākajam darbam.

Lai sekmīgi varētu veikt attīstības plānošanas dokumentu izstrādi, būtu jāveic šādi pasākumi:

$\checkmark$ valsts līmen̄̄ skaidri jādefinē reǵionālā politika, ietverot reǵionālās pašpārvaldes sistēmas izveidi,

$\checkmark$ jānosaka reǵionālā līmeņa atbildība, funkcijas un finansējums,

$\checkmark$ jādefinē un jānostiprina reǵionālo izpildinstitūciju statuss,

$\checkmark$ jāizveido tiesiskais regulējums vienotam regionālā līmeņa attīstības politikas dokumentam.

Esošajā situācijā reǵiona telpiskie un attīstības plānošanas dokumenti ir jāintegrē vienotā regiona dokumentu sistēmā ar mērķi noteikt un attīstīt reǵiona salīdzinošās priekšrocības telpiskā aspektā un konkrētās rīcībās.

\title{
LATVIJAS OPERKULĀTĀS DISKOMICĒTES
}

\author{
Ains RAITVĪRS \\ Igaunijas Lauksaimniecības universitātes Zooloǵijas un botānikas institūts, \\ e-pasts: ain@zbi.ee \\ Edgars VIMBA \\ Latvijas Universitātes Bioloǵijas fakultāte, \\ e-pasts: evimba@lanet.Iv
}

Diskomicētes ir liela askusēṇu grupa, kurai aski ar sporām veidojas apotēcijos. Savukārt operkulātās diskomicētes ir tās, kuru aski pēc sporu nogatavošanās atveras ar vāciņu.

Operkulātās diskomicētes Latvijas dabā ir ļoti plaši sastopamas. Par tām materiāli ir uzkrāti gan herbārijos, gan arī nedaudzi dati atrodami literatūrā. Sistemātiski, vadoties pēc šo sēnuu klasifikācijas jaunākajā literatūrā, Latvijā atrastās operkulātās diskomicētes pieder 10 dzimtām un 45 gintīm.

Ekolog̣iski operkulātās diskomicētes pieder dažādām sēṇu trofiskajām grupām. Visvairāk tās ir sastopamas kā augsnes saprotrofi, kuru augļ̧̣ermeņi veidojas gan virs zemes, gan arī augsnē jeb subnstrātā (pazemes). Tālāk seko karbotrofi - sēnes, kuras attīstās ugunskuru vietās un meždedzēs, koprotrofās sēnes, ksilotrofās sēnes un parazītiskās sēnes. Šo sēṇu sadalījumu trofiskajās grupās redzam 2. tabulā. 
Latvijas operkulāto diskomicēšu sistemātiskā piederība

\begin{tabular}{|l|c|c|}
\hline \multicolumn{1}{|c|}{ Dzimta } & Ginšu skaits & Sugu skaits \\
\hline Pezizaceae & 3 & 18 \\
\hline Ascobolaceae & 2 & 6 \\
\hline Helvellaceae & 2 & 10 \\
\hline Discinaceae & 3 & 5 \\
\hline Rhizinaceae & 1 & 1 \\
\hline Morchellaceae & 3 & 9 \\
\hline Tuberaceae & 1 & 4 \\
\hline Pyronemataceae & 25 & 58 \\
\hline Sarcoscyphaceae & 2 & 3 \\
\hline Sarcosomataceae & 3 & 3 \\
\hline Kopā & 45 & 117 \\
\hline
\end{tabular}

2.tabula

Operkulāto diskomicēšu sadalījums trofiskajās grupās
\begin{tabular}{|c|c|}
\hline Trofiskā grupa & Sugu skaits \\
\hline Augsnes saprotrofi: & \\
virszemes & 61 \\
pazemes & 9 \\
\hline Karbotrofās sēnes & 19 \\
\hline Koprotrofās sēnes & 11 \\
\hline Ksilotrofās sēnes & 7 \\
\hline Parazītiskās sēnes & 3 \\
\hline Grupa nav noteikta & 7 \\
\hline
\end{tabular}

Jāatzīmē arī, ka vairākas lāčpurnu (Morchellaceae) un rumpuču (Helvellaceae) dzimtas sēnes ir ēdamas.

Latvijas Republikas Ministru kabineta Noteikumos par īpaši aizsargājamo sugu un ierobežoti izmantojamo īpaši aizsargājamo sugu sarakstu ierakstītas 3 operkulāto diskomicēšu sugas:

$\checkmark$ smiltāju kaussēne - Peziza ammophila Durieu \& Mont.

$\checkmark$ èzelı ausene - Otidea onotica (Pers.:Fr.)Fuckel

$\checkmark$ toverīšu sarkosoma - Sarcosoma globosum (Schmidel: Fr.)Casp.

\section{DABISKO ZĀLĀJU IZPĒTE LATVIJĀ}

\section{Solvita RŪSIN̦A}

Latvijas Universitāte, Ģeogrāfijas un Zemes zinātņu fakultāte, e-pasts: solvita.rusina@lu.Iv

Zālāju izpēte nav atraujama no Latvijas augāja izpētes kopējās vēsturiskās gaitas. Veǵetācijas pētījumi Latvijā sākās tikai 20.gs. sākumā, un tas ir veselu gadsimtu vēlāk nekā pirmās publikācijas par floru. Viena no pamattēmām 
Latvijas augāja izpētē tradicionāli bijusi veǵetācijas klasifikācija. Tas ir likumsakarīgi, jo tā ir gan fitosociologijas centrālā problēma līdz pat mūsdienām, gan arī pamatmetode, ar kuras palīdzību mēs iepazīstam un izzinām augu sabiedrības (Александрова 1969; Dierschke 1994; Ewald 2003).

Latvijas dabisko zālāju tipologija dažādos izpētes posmos balstīta uz atšķirīgiem kritērijiem, tai bijuši arī atšķirīgi mērķi. Atkarībā no klasifikācijas pieejas un tās lietojuma var izdalīt trīs posmus:

Saimnieciskā tipoloǵija. Izstrādes laiks un tipoloǵijas aktīva izmantošana aptver laika posmu no 20.gs. sākuma līdz 60.gadiem. Latvijas zālāju tipologiju izstrādāja J.Vārsbergs, vēlāk to papildināja V.Tērauds (1972) un P.Pommers, detalizētu klasifikācijas variantu izstrādājusi arī G.Sabardina (1958).

Nepieciešamību izveidot Latvijas dabisko zālāju klasifikāciju noteica lauksaimniecības straujā attīstība 19.gs. beigās un 20.gs. sākumā un pāreja no graudaugu saimniecības uz lopkopību. Tas radīja vajadzību apzināt dabiskās lopbarības bāzes (pḷavu un ganību) stāvokli, platību un produktivitāti. Līdz ar strauju dabisko zālāju platību samazināšanos (pārvēršanu kultivētās pḷavās un ganībās) šì tipologiija lauksaimnieku rindās zaudēja nozīmi, bet fitosociologi to nekad nav plaši lietojuši.

Zālāju veǵetācijas fizionomiskā klasifikācija pēc dominantu metodes. Klasifikāciju izstrādāja G.Sabardina (Сабардина 1957). Tā vairāk vai mazāk plaši lietota no 20.gs. 50. līdz 80.gadu sākumam. Būtībā tikai ar G.Sabardinas darbību aizsākās mērḳtiecīga dabisko zālāju veǵetācijas izpēte, kas deva pirmās ziņas par sugu sastāvu, augu sabiedrību daudzveidību, to izplatības īpatnībām Latvijā. Laiks no 1952. līdz 1973.g. ir ražīgākais pēc iesaistīto pētnieku un publikāciju skaita.

Floristiskā klasifikācija pēc Brauna-Blankē metodes. Pirmās publikācijas parādījās 1996.gadā, bet intensīva zālāju augu sabiedrību izpēte pēc šīs metodes un rezultātu publicēšana sākās tikai pēc 2000.gada (Jermacāne, Laiviņš 2001). Lai gan pētījumu priekšmets un mērķis - izstrādāt Latvijas dabisko zālāju veǵetācijas klasifikāciju arī šajā pētījumu posmā palika tas pats, tomēr bija vairāki faktori, kas noteica jaunas klasifikācijas sistēmas izveides nepieciešamību un līdz ar to arī metodes nomainu.

Pirmkārt, arvien biežāk parādījās kritika gan no Eiropas, gan pašu Krievijas skolas sekotāju puses, ka dominantu metode nedod gaidītos rezultātus polidominantām augu sabiedrībām, kādas ir vairums zālāju sabiedrību. Otrkārt, iepriekšējā klasifikācija ignorēja daudzas retas augu sabiedrības, kurām šobrīd liela nozīme biologiskajās daudzveidības izpētē. Treškārt, sākot no 20.gs. 90.gadiem strauji paplašinās starptautiskā sadarbība dabas aizsardzības un biologiskās daudzveidības izpētes un apsaimniekošanas jomā. Reǵionāla un globāla mēroga sadarbība rada nepieciešamību pēc vienotas zinātniskas valodas attiecībā uz bioloǵiskās daudzveidības saglabāšanas mērķobjektiem. $\beta$ daudzveidības analīzē (īpaši bioǵeogrāfiskos pētījumos) jābūt vienotai izpratnei 
par augu sabiedrībām (biotopiem) vismaz vienas bioǵeogrāfiskās telpas ietvaros, bet dabas aizsardzībai nepieciešama klasifikācija, kas atpaz̄̄stama arī vienotā politiskajā telpā.

Citi virzieni dabisko zālāju izpētē saistāmi galvenokārt ar laiku no 20.gs. 50. līdz 70.gadiem. Šajā laikā aktīvi notika zālāju augu sugu ekoloǵijas, fitoindikācijas, veǵetācijas vertikālās un horizontālās struktūras pētījumi (galvenokārt G.Sabardinas vadībā). Otrs virziens, kas sāka attīstīties jau 20.gs. 20.gados un nav zaudējis nozīmi arī mūsdienās, bet īpaši populārs bija 1930.1960.gados (V.Tērauda, P.Konrāda, P.Pommera u.c. darbi), ir dabisko un kultivēto zālāju un tajos dominējošo sugu ražība un attīstība dažādu ielabošanas pasākumu (mēslošana, meliorācija, ecēšana) ietekmē.

Dierschke H. (1994) Pflanzensoziologie. Verlag Eugen Ulmer, Stuttgart, 683 S.

Ewald J. (2003) A critique for phytosociology. Journal of Vegetation Science 14: 291-296

Jermacāne S., Laiviņš M. (2001) Latvijā aprakstīto augu sabiedrību sintaksonu saraksts. Latvijas Vegetācija 4: 115-132.

Tērauds V. (1972) Pļavas un ganības. Zvaigzne, Rīga, 342 lpp.

Александрова В.Д. (1969) Классификация растительности. Наука, Ленилград, 275 стр.

Сабардина Г.С. (1957) Луговая растительность Латвийской ССР. Изд. АН ЛССР, Рига, 303 стр.

\section{LIMNOGĒNO PURVU VEĢETĀCIJA LATVIJĀ}

Liene SALMIN̦A

Latvijas Dabas fonds, e-pasts: Isalmina@latnet.Iv

Limnogēno purvu veǵetācija pētìta 61 objektā Kurzemē, Zemgalē, Vidzemē un Latgalē. Pēc veǵetācijas tipa pētîtās augu sabiedrības var iedalīt 5 grupās: zāḷu purvu, pārejas purvu, ezera-purva ekotona, augsto grīšlu un krūmāju sabiedrībās.

Klāsteru analīzes rezultātā (Sørensen, $\beta=-0.25$ ) izdalīta 21 grupa un saskaņā ar Centrāleiropas veǵetācijas klasifikācijas sistēmu tās pielīdzinātas šādām asociācijām: Cladietum marisci, Caricetum elatae, Carici Menyanthetum, Caricetum paniculatae, Caricetum gracilis, Caricetum ripariae, Caricetum distichae, Calletum palustris, Caricetum rostratae, Caricetum limosae, Sphagno - Caricetum rostratae, Rhynchosporetum albae, Caricetum lasiocarpae, Caricetum magellanicae, Caricetum buxbaumii, Eleocharitetum quinqueflorae, Schoenetum ferruginei, Chrysohypno-Trichophoretum alpini, Myricetum gale. Izdalītas arī divas augu sabiedrības - Thelypteris palustris sabiedrība un Eriophorum vaginatum sabiedrība. Saskaņā ar Centrāleiropas veǵetācijas klasifikāciju, izdalītās augu sabiedrības pieder 3 klasēm: Scheuchzerio Caricetea nigrae, Phragmiti - Magnocaricetea un Franguletea alni.

Vairākām asociācijām izdalīti to varianti. Augu sabiedrību raksturošanai izmantota indikatorsugu analīze, un katrai augu sabiedrībai noteiktas tai 
raksturīgās sugas. Tikai limnogēnajos purvos sastopamas Thelypteris palustris sabiedrība un asociācijas Carici - Menyanthetum, Caricetum magellanicae, Calletum palustris, bet lielākoties limnogēnajos purvos sastop Cladietum marisci, Caricetum paniculatae, Caricetum buxbaumii, Caricetum distichae, Eleocharitetum quinqueflorae, Chrysohypno - Trichophoretum alpini.

Pavisam 222 sugas konstatētas pētītajos limnogēnajos purvos (167 vaskulāro augu un 55 sūnu sugas). Limnogēnajos purvos sastopamas gan sugām nabadzīgas, gan bagātas augu sabiedrības. Vidējais sugu skaits parauglaukumā variē no 6,2 sugām asociācijā Calletum palustris līdz 17,8 sugām asociācijā Caricetum magellanici. Limnogēnajos purvos konstatētas 18 īpaši aizsargājamas vaskulāro augu sugas un 8 īpaši aizsargājamas sūnu sugas.

\title{
ĢEOGRĀFIJAS ZINĀŠANU STANDARTI UN PROGRAMMAS DAŽĀDOS IZGLITTĪBAS LİMEŅOS SKOLĀS
}

\author{
Valdis SEGLIN̦Š \\ LU Ģeogrāfijas un Zemes zinātṇu fakultāte, \\ e-pasts: valdis.seglins@lu.Iv
}

Ģeogrāfijas apgūšana plašā kontekstā un visā izglītības procesā skolās Latvijā ir pozitīvs izņēmums visā Eiropā. Tam pamatā ir ne tikai jauniešu zinātkāre un mācīšanas tradīcijas, bet arī valsts īpatnējais ǵeogrāfiskais novietojums un saimnieciskās dzīves atkarība no šo ǵeogrāfisko priekšrocību izmantošanas mainīgā pasaulē.

Kopš valstiskās neatkarības atjaunošanas ǵeogrāfiskā izglītība skolās ir nepārtrauktās pārmaiṇās un adaptācijā, kas būtiski ir mainījušas ne tikai mācību saturu, ilgumu (stundas), proporcijas starp dažādiem priekšmetiem, visumā, par labu izmaksu ziṇā lētākiem sociālās ievirzes priekšmetiem un atvieglotām prasībām zināšanu novērtējumā. Citiem vārdiem, Latvijā daudz īsākā laikā tika realizētas visas iespējamās izglītības sistēmas kḷūdas, kuras attīstītās Rietumeiropas zemes savās nacionālajās sistēmās pakāpeniski paveica pēdējo 20 gadu laikā. Arī mūsu zemē zemākais punkts tūlīt tiks sasniegts ar ticības mācības, ētikas, mājturības un kultūrvēstures un to pavadošu priekšmetu pilnīgu iekḷaušanu jau obligātās vidējās izglītības sistēmā.

Līdzīgi, kā tas ir Eiropas lielākajā dal̦ā, ǵeogrāfijas mācīšanas sistēmu veido mācību iestāžu akreditācija, skolotāju izglītību un kvalifikāciju normējoši profesiju standarti, apliecinoši dokumenti un tālākās izglītības iespējas. Citi sistēmas elementi ir mācību sistēmas vispārīga reglamentācija un noteikumi, kas prasību kopumu nosaka atsevišķu mācību priekšmetu līmen̄̄. Arī ǵeogrāfijā, atbilstoši klašu grupām, ir noteikti izglītības standarti, tas ir sākuma punkts un prasību kopums. To skaidro Mācību programma (paraugprogramma jeb vadlīnijas), un to ir iecerēts vietēji adaptēt konkrētas skolas apstākḷos, akcentējot 
geogrāfisko izvietojumu, skolas lielumu, nodrošinājumu ar mācību līdzekliem, skolotāja kvalifikāciju un tamlīdzīgi.

Saturiski ǵeogrāfijas kurss pēc dominantēm ir iedalāms trīs dalāas, kur sākumskolā tās ir dabas un vides zināšanas, pamatskolā - dabas geogrāfija un vidusskolā - cilvēkǵeogrāfija. Līdz ar Dabaszinību mācību standarta ieviešanu ar paplašinātu pārklājumu līdz 6. klasei, tradicionālā dabas ğeogrāfija mūsdienās aptver vairs tikai trīs kases (7.-9.). Atbilstošie standarti nosaka dabas ǵeogrāfijas komponentes dažādās standartu apskatītajās klašu grupās šādi:

\begin{tabular}{|c|c|c|}
\hline $\begin{array}{c}\text { Dabaszinības } \\
\text { 1.-6. klasei }\end{array}$ & $\begin{array}{c}\text { Geogrāfija } \\
\text { Pamatskola (7.-9.kl.) }\end{array}$ & $\begin{array}{c}\text { Ģeogrāfija } \\
\text { Vidusskola (10.-12.kl.) } \\
\end{array}$ \\
\hline $\begin{array}{l}\text { Zeme un tās vieta Visumā } \\
\text { Planēta Zeme Saules sistēmāa. } \\
\text { Zemes litosfêra. } \\
\text { Zemes hidrosfêra. } \\
\text { Zemes atmosfêra. } \\
\text { Zemes dabas ainavas. }\end{array}$ & $\begin{array}{l}\text { Zināšanas un izpratne par } \\
\text { Zemes dabas sistēmām, } \\
\text { dabas procesiem un } \\
\text { parādībām } \\
\text { Zeme- Saules sistēmas } \\
\text { planēta. Zemes izcelšanās un } \\
\text { veidošanās. } \\
\text { Zemes litosfēra un reljefs. } \\
\text { Zemes hidrosfēra. } \\
\text { Zemes atmosfêra, zemeslodes } \\
\text { klimats. } \\
\text { Dabas geogrāfiskās ainavas } \\
\text { pasaules dal̦ās. }\end{array}$ & $\begin{array}{l}\text { Zemeslodes dabas resursi, to } \\
\text { uzbūve, sastāvs, veidošanās, } \\
\text { attīstība, pārveidošanās un } \\
\text { izvietojuma likumsakarības. }\end{array}$ \\
\hline
\end{tabular}

Tās ir pamatprasības, kas tālāk attīstāmas programmās, kuru paraugi tika IZM ISEC izstrādāti 2004.gadā, balansējot pieejamo stundu skaitu un standartos noteikto zināšanu apjomu apguvei. Visumā tie ir veiksmīgi, lai arī būtu uzlabojami nākotnē, tomēr tikai pēc tā piemērošanas pieredzes izvērtējuma, kad Mācību programmas paraugi tiks adaptēti konkrētos skolu visai atšksirīgos apstākḷos.

Visai atšḳirīga ğeogrāfijas mācīšanas sistēmas veidošanas pieredze ir citās pasaules valstīs, it īpaši ASV. Pieredze ASV ir īpaša ar vispārzināmām izcili vājām ǵeogrāfijas zināšanām apmācāmajiem, sistēmas pārstrukturēšanas pakāpeniskumu gandrīz 25 gadu laikā un atzīstamiem pēdējo gadu sasniegumiem. Izšķiroša loma šajā sistēmā noteikta tieši skolotājiem un to kvalifikācijām, kā arī jaunajam ASV Nacionālajam ǵeogrāfijas standartam (t.s. 18 punktu standarts) skolās. Skolotāju kvalifikācija ir noteikta par izšķirošo. Tieši vidusskolas skolotājs ir atbildīgs par priekšmeta programmas realizāciju visā apmācību procesā. Atškirības ir g̀eogrāfisko zināšanu izvietojumam trīs dažādos zināšanu blokos (sociālās zinātnēs kā atseviškss priekšmets, citos sociālo zināšanu jomu priekšmetos kā nozīmīgs elements un zinātnes priekšmetos kā Zemes un kosmosa zinātņu priekšmets). İpatnēji, ka vidusskolas mācību programmas un plānus geogrāfijā un sociālajās zinātnēs apstiprina Nacionālā Padome tikai kopā ar universitāšu atbilstošo bakalaura programmu. No ǵeogrāfijai atvēlēto stundu skaita ASV kopš 2003.gada to ir vidēji par 20-25\% vairāk nekā pašreiz Latvijā, 
tas pats attiecināms uz citiem dabaszinību priekšmetiem, kas būtiski ierobežo sociālo un humanitāro priekšmetu lomu un nozīmi. ASV Nacionālā zinātnes padome, Skolotāju dažādās asociācijas un Padomes, kā arī sabiedrības vairākums to uzskata par pareizu globālā darba tirgus attīstības nodrošināšanai nākotnē un ASV nacionālo interešu sasniegšanai ārpus tās teritorijas.

\title{
INVAZIVIE CITZEMJU KOKU UN KRŪMU TAKSONI NACIONĀLAJĀ BOTĀNISKAJĀ DĀRZĀ SALASPILĪ
}

\author{
Andrejs SVILĀNS \\ Latvijas Nacionālais botāniskais dārzs, Latvijas Dendrologu biedrība, \\ e-pasts: andrejs.svilans@nbd.apollo.lv
}

Nacionālajā botāniskajā dārzā (NBD) Salaspilī ir uzkrāta viena no lielākajām dzīvo augu kolekcijām Ziemel̦austrumeiropā, toskait aptuveni 5000 dažādu kokaugu taksonu. Daudzu introducētu taksonu vecākie un nereti vienīgie eksemplāri Latvijā aug tieši NBD. Tas nozīmē, ka pastāvīgi šīs kolekcijas novērojumi var palīdzēt laikus novērtēt šo taksonu invāzijas iespējas arī pārējā Latvijas teritorijā. Botāniskais dārzs (un tam pielīdzināmās teritorijas) var būt sava veida agrās brīdināšanas stacijas citzemju taksonu invāzijas novērošanai un arī novēršanai.

Pētîjums tika veikts 2003. un 2004.gada vasarā NBD teritorijā. Tika ievākti ārpus stādīšanas vietām konstatēto citzemju koku un krūmu paraugi. Tā kā vairums no atrastajiem augiem bija jauni (vai arī regulāras pḷaušanas dēl bija pieejamas tikai atvases), to sistemātiskās piederības noteikšana bija ierobežota. Dažreiz sējeņi tika izrakti tālākai audzēšanai kultūrā, lai vēlāk precizētu to taksonomisko piederību.

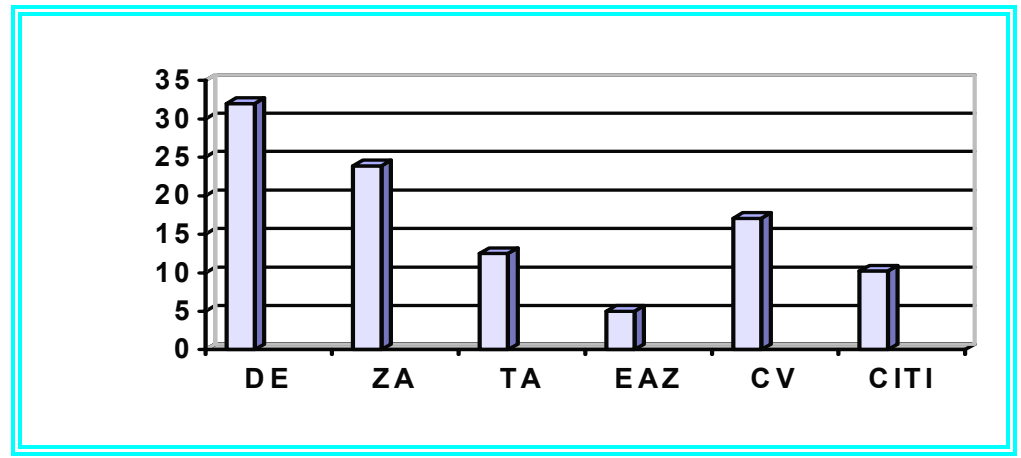

1.attēls. Pašizsējas cel̦ā vairojošos citzemju kokaugu taksoni pa izcelsmes reǵioniem (procentos no konstatēto taksonu kopējā skaita). 
NBD teritorijā invāzijas pazīmes konstatētas 167 kokaugu taksoniem, 92 no tiem novēroti pašizsējas gadījumi. Provizoriskie dati liecina, ka pašizsēja visbiežāk novērota Dienvideiropas (DE), Ziemel̦amerikas (ZA) un Tālo Austrumu (TA), retāk Eirāzijas (EAZ) sugām. Samērā bieži pašizsēja konstatēta neogēniem taksoniem (CV), kas dabā nav sastopami un radušies, krustojoties tuvradniecīgām sugām ex situ apstākḷlos. Atsevišķos gadījumos konstatētie sējeņi ir uz vietas, krustojoties NBD kolekcijās stādītām kokaugu sugām, radušies jauni hibrīdi.

\title{
SĒLIJAS REĢIONĀLĀS KULTŪRIDENTITĀTES PAŠREFERENCE
}

\author{
Inese STŪRE \\ Latvijas Universitāte, Ģeogrāfijas un Zemes zinātņu fakultāte, \\ e-pasts: Inese.Sture@lu.Iv
}

Sēlijas atklāsmi kopš 1980. gadu beigām un 1990. gadu sākuma ir rosinājuši Latvijas lielpilsētu zinātnes un kultūras dzīves pārstāvji, uzsākot plašu un daudzpusīgu pēc satura Sēlijas apzināšanas un popularizēšanas programmu. Lai izzinātu Sēlijas reǵiona pašvaldību un iedzīvotāju uzskatus un pašraksturojumu jeb t.s. pašreferenci reǵionālās identitātes uzturēšanā, 2004.gada vasarā īstenots pētījums, kurā tika veiktas 38 daļēji strukturētas intervijas. Pētījuma mērķauditorija bija pašvaldību vadītāji un darbinieki, jo šīs institūcijas ir lēmumu pieņēmēji teritoriju attīstībā un plānošanas darba ietvaros tām visvairāk vajadzētu iedziḷināties reǵiona identitātes jautājumos, kā arī pārzināt vietējās sabiedrības attieksmi un noskaņojumu. Tādēl intervijas tika veiktas ar pašvaldību vadītājiem (11), pašvaldību plānošanas speciālistiem (17), kultūras dzīves vadītājiem (5) un ilggadējiem vietējiem iedzīvotājiem (5).

Iegūto datu analīze l̦āva izdarīt šādus secinājumus:

1. Sēlija ir Latvijas kultūrvēsturisks reǵions ar visvājāk izteikto reǵionalitāti: Sēlijas robežās nepastāv vienoti administratīvi teritoriāli veidojumi, un tā ir sadalīta starp Latgales un Zemgales plānošanas reǵioniem. Latvijai kopumā šāda situācija nav labvēlīga, jo reǵionālo kultūras atšksirību izzušana draud ar kultūru daudzveidības noplicināšanos un attīstības resursu samazināšanos.

2. Sēlijas novadnieciskuma apziņa Sēlijā dzīvojošajiem iedzīvotājiem kopumā ir visai neskaidra telpas (robežas, centrs), laika (kad Sēlija ir pastāvējusi) un satura (ar ko Sēlija atšķiras no citiem Latvijas novadiem) skatījumā, tomēr tā spilgtāk ir izteikta Sēlijas centrālajā dạ̦ā un tiek uzturēta galvenokārt pašvaldību kultūras norisēs.

3. Bez valsts atbalsta Sēlijas reǵionālās kultūridentitātes saglabāšanās ne tikai zinātnieku pētījumos, bet arī cilvēku izjūtā ir apdraudēta triju iemeslu dēḷ: (1) Sēlija kā reǵions ir pastāvējis ḷoti senā pagātnē, un tā izjūta vietējiem iedzīvotājiem ir zudusi, bet no jauna akcentētā Sēlijas identitāte ir tikai desmit gadus ilga un nav paguvusi pilnībā iesakņoties, (2) daudzās vietās pat Sēlijas kodoldal̦ā (ap Seci, 
Ẽrberği, Mazzalvi un citur) iedzīvotāju lielākā daļa ir iebraucēji, kuriem nav izteikta reǵionāla piederība un kuri nav aktīvi Sēlijas identitātes atbalstītāji un (3) bez ārēja atbalsta kultūras darbinieku entuziasms var izsīkt.

4. Visefektīvākais veids Sēlijas kā kultūrvēsturiska reǵiona attīstībai ir valsts kultūrvēsturisko regiionu attīistības politikas (Pamatnostādņu) izstrāde un īstenošana, kur galvenie rīcības uzdevumi ir atbilstoša likumprojekta un Programmas sagatavošana un pieņemšana Ministru kabinetā.

\title{
VIETĒJO APSTĀKL̨U IETEKME UZ LATVIJAS REĢIONU ATTĪSTİBAS ATŠĶIRĪBAĀM: FORMALIZĒTĀ VĒRTĖŠANA UN ATTİSTİBAS IZCELSME
}

\author{
Pēteris ŠĶIIN̦ĶIS \\ Latvijas Universitāte, Ģeogrāfijas un Zemes zinātņu fakultāte, \\ e-pasts: rsc@apollo.lv
}

Vietējo apstākḷu ietekme uz Latvijas reǵionu attīstības atšķirībām: formalizētā vērtēšana un attīstības izcelsme

Kopš 2003.gada reǵionālās attīstības politikas izstrādes un īstenošanas vajadzībām Latvijā atsākts darbs pie sistemātiskas reǵionālās attīstības procesu identifikācijas un analīzes. 2004.gadā tika apstiprināti jauni noteikumi īpaši atbalstāmo teritoriju noteikšanai. Šīs teritorijas potenciāli var pretendēt uz relatīvi lielāku reǵionālās attīstības programmu atbalstu. Atbalstāmās teritorijas pamatā noteiktas, izmantojot attīstības indeksa aprēķinus. Teritorijas attīstības indekss tiek aprēķināts atbilstoši jau aprobētai metodikai un tiek lietots kā sintētisks, vispārinātais attīstības līmeņa un attīstības tendenču novērtēšanas rādītājs. 2004.gadā apstiprinātās Reǵionālās politikas pamatnostādnes paredz 2005.gadā izveidot reǵionālās politikas ieviešanas uzraudzības un novērtēšanas sistēmu. Viena no veidojamās sistēmas pamatsastāvdalāām ir reǵionālās attīstības uzraudzība. Tās uzdevumi ir identificēt pārmaiņas sociālajā un ekonomiskajā situācijā valstī, atsevišķās tās daḷās un nodrošināt informāciju reǵionālās politikas ietekmes novērtēšanai. Tam nepieciešams apkopot un analizēt informāciju par demogrāfisko, sociālo un ekonomisko situāciju un attīstības tendencēm plānošanas reǵionos. Attīstības raksturošanai un atšķirību noteikšanai tiek izmantoti kvantitatīvie rādītāji, pamatā statistikas dati, kuri izmantojami vienkāršotai reǵionu salīdzināšanai. Tie atspoguḷo reǵionu atšķirības Latvijā kopumā, palīdz identificêt būtiskas atšķirīibas starp reǵioniem pēc atsevišķiem indikatīviem rādītājiem (piemēram, atšķirības demogrāfiskajā struktūrā, nodarbinātī̄ā, ekonomiskajā aktivitātē u.c.).

Par pamatu izmantojot gan aprēķinātos, gan atsevišķos rādītājus, atbalsta programmu īstenošanai un turpmāk arī plašāk izvērstai reǵionālās politikas ieviešanai tiek formalizēta reǵionu attīstības un arī Latvijas Reǵionālās attīstības 
politikas vērtēšana. Tas ir atzin̄̄gi vērtējams darbs, jo, izstrādājot laikā salīdzināmu attīstības rādītāju sistēmu, jau šobrīd var identificēt teritoriju attīstības izmainu tendences pēdējo 5-6 gadu periodā. Tās galvenokārt attiecināmas uz reǵionu, rajonu teritorijām un strukturāli vienotu vietējo teritoriju kopām, un iezīmē sociālo un ekonomisko procesu vispārējo virzību.

Attīstības vispārējās virzības noteikšana l̦auj labāk saskatīt notiekošo, bet tas ir nepietiekami lēmumu pieņemšanai, kuri var būt būtiski attīstības ietekmēšanai labvēlīgāku izmaiņu virzienā. Tam ir nepieciešama informācija un analīze, kas l̦auj izprast to vai citu parādību cēloṇus. Mērogā lielāku procesu pamatā ir vispārēji, ar reǵionu struktūru maz saistīiti ekonomiskie un politiski apstākḷi (globālo struktūru ietekme, valsts vispārējās stratēǵiskās intereses u.c.) vai arī atsevišḳi, noteiktos vietējos apstākḷos radušies un arī vietējā līmenī reprezentēti procesi. Uzņēmēju aktivitāte, inovatīvu resursu piesaiste, tīklveida sadarbības struktūru rašanās, līderu aktivitāte un citi attīstības indikatori vairāk raksturo un attiecas uz attīstības atšķirīibām vietējā mērogā. Šie un vēl arī citi līdzīgie var tikt dēvēti par sociālās vides rādītājiem. Tie nereti veido vai ilustrē teritoriju attīstības raksturu, izmaiņu dinamiku un kopumā sastāda lielākā mērogā saskatāmās pārmaiṇas.

Sociālās vides apstākḷu pamatā ir nosakāmi kritiskie - attīstību ierobežojošie vai veicinošie faktori, kuru esamība vai trūkums ir vietējo teritoriju attīstības atšķirīibu un arī liela mēroga attīstības procesu izcelsmes pamatā. Šie kritiskie faktori, piemēram, iedzīvotāju skaits teritorijā, sociālo grupu spektrs, apdzīvoto vietu lielumu attiecības apdzīvojuma tīklā, piepilsētas, pierobežas vai citas novietojuma situācijas u.c. ir raksturojami gan ar kvantitatīviem, gan arī kvalitatīviem rādītājiem. Reǵionālās attīstības procesu vadības efektivitāte lielā mērā var būt atkarīga no lēmumu un rīcību vērstības kritisko faktoru izmantošanas vai mainīšanas virzienā.

\title{
PIEKRASTES UN MITRAIN̦U BIOTOPI KĀ AEHEOLOĢISKO PIEMINEKĻU AINAVA
}

\author{
Māra URTĀNE \\ Latvijas Lauksaimniecības universitāte, Lauku inženieru fakultāte, \\ e-pasts: mara.urtane@llu.Iv
}

Apzinot un apmeklējot arheoloǵijas pieminekli, parasti tiek aplūkota neliela teritorija, kuru sedz kultūras slānis vai raksturo mākslīgi veidotas zemes formas. Tomēr vietas izvēli bieži ir nodrošinājušas plašas purvainas teritorijas vai gravu un strautu sistēma, kas veidoja ietvērumu kādai nelielai platībai, kuru izmantoja cilvēks. Ūdens un purvainas vietas darbojas kā fizisks šķērslis, kas deva papildu drošību apdzīvotajai vai kulta vietai.

Ūdens bija nepieciešams cilvēka tiešo dzīvības funkciju uzturēšanai. Dzīves vietu tiešā tuvumā atrodas bagātīgi avoti vai strauti. Arī gadījumos, kad 
apmetne vai pilskalns ir upes vai ezera krastā, izvēlēta vieta blakus avotam vai strautam, kas nodrošināja ūdeni visos gadalaikos, arī neaizsalstot ziemā. Mūsdienās tie dažās vietās izsausējuši un kopumā tikai dažos pieminekḷos, ja avoti un strauti minēti folklorā, šie ainavas elementi tiek minēti un aplūkoti kopā ar apmetnes, pilskalna vai kulta vietas ainavu.

Ūdensteces un krātuves nodrošināja labu pārtikas ieguvi. Īpaši tas attiecas uz akmens un bronzas laika arheolog̣ijas pieminekḷiem, kad galvenais pārtikas avots bija zivis, ūdensputni, gliemeži, kas mitinājās piekrastes seklajos ūdeņos. Arī lielāku medījumu iegūšanai tika izmantotas vietas pie ūdeņiem, kur dzīvnieki nāca padzerties, vai arī to takas uz dzeršanas vietām, ekolog̣isko koridoru veidošanās un to prasmīga izmantošana no cilvēka puses.

Ar lopkopības attīstību ganībām labi varēja izmantot palienu neaizaugošās plavas. Tās tika izvēlētas upju, ezeru, strautu malās. Tika veidotas mākslīgas ūdenskrātuves - dzirdināšanas vietas. Mūsdienu ainavā krastu aizaugšana ir neatbilstoša ainava arheologijas pieminekḷa ainavai, īpaši dzīves vietas tuvumā. Tomēr pēdējo piecu gadu laikā gar upēm un ezeriem atkal parādījušās makšķernieku takas, gar kurām veidojas specifiska veǵitācija. Bet noganītas pḷavas praktiski ir zudušas piekrastes ainavās.

Transportam ar laivām un ziemā pajūgos pa ledu vai vasarās gar ūdens krātuvju neapaugušajiem krastiem, veidojot cel̦us, tika izmantoti gan ezeri, gan lielākas un mazākas upītes. N̦emot vērā krasta līniju un upju gultņu izmaiņas laika gaitā, mūsdienās šo saistību ir grūti nolasīt dabā. Arī cilvēka veiktās transformācijas - upju iztaisnošana, ezeru nosusināšana, šo faktora nolasǐšanu mūsdienu ainavā padara neiespējamu. Bet, pastāvot pašreizējai ekolog̣iskajai nostādnei - atjaunot upju gultnes pirmatnējā vietā, ja tās tikušas iztaisnotas, rodas cerība atjaunot arī šos ainavas elementus arheologisko pieminekḷu ainavā.

Piekrastes un mitraiņu biotopi arheoloǵisko pieminekḷu ainavā ir neatñemama sastāvdal̦a, un no ainava ekologijas viedokḷa tās ir teritorijas, kurās pastāvīgi vai periodiski ir notikusi cilvēka iedarbība, līdz ar to radot noteiktas transformācijas to struktūrā, kas ir dabas un kultūrvēsturisko aktivitāšu rezultāts.

\title{
LATVIJAS PILSKALNI I UN II PASAULES KARA FRONTES LĪNIJĀS
}

\author{
Juris URTĀNS \\ Latvijas Kultūras akadēmija, e-pasts: urtans@lka.edu.Iv
}

Latvijas teritorija atradās I un II Pasaules kara aktīvo kaujas darbību zonās, kas noteikti ir ietekmējis zemes virspusi un ainavu.

Latvijas pilskalni (patlaban Latvijā valsts aizsardzībā ir 473 pilskalni) l̦oti bieži senatnē ir tikuši ierīkoti reljefa izcēlumos. Tas noteica arī to, ka pilskalni ir tikuši izmantoti 20.gs. militārajās darbībās. I Pasaules kara laikā daudzmaz noturīga krievu-vācu frontes līnija pastāvēja ap 2,5 gadus; II Pasaules kara laikā 
noturīgāka frontes līnija Kurzemē pastāvēja ap 8 mēnešus. Abu karojošu pušu frontes līnijās un to aizmugurēs abos pasaules karos tika izbūvēts milzīgs, šobrīd praktiski neaptverams daudzums dažāda apjoma militāra rakstura būvju. Ja senie pilskalni atradās frontes līnijās vai to tuvumā, tad gandrīz vienmēr arī tie saistībā ar to izcilo stāvokli tika izmantoti militāro būvju veidošanai. Dažos gadījumos var konstatēt, ka kā aizsegs ir izmantoti pilskalnu senie grāvji un val̦ni, bieži kā aizsegs, iebūvējot bunkurus, ir izmantotas ienaidnieka apšaudei pretējās pilskalnu nogāzes. Pilskalnu plakumi savukārt izmantoti ierakumu līniju un ugunspunktu izbūvei. Visas karojošās puses pilskalnus kā reljefā izceltas vai augstākās vietas izmantoja ienaidnieka novērošanai. Dažos gadījumos novērošanas vajadzību nodrošināšanai tika izbūvētas īpašas būves (Daugmales Sakaiņu pilskalns, Smārdes Milzukalns). Tā ka abu karojošu pušu karavīri pārsvarā iepriekš nebija bijuši saistīti ar Latviju, tad pilskalniem kā senvēstures pieminekļiem netika veltīta nekāda uzmanība, un ticami, ka militārpersonas maz apzinājās, ka militārās būves tiek veidotas senos nocietinājumos.

Pēc I Pasaules kara ierakumus pilskalnu plakumos aizlīdzināja zemes īpašnieki; ierakumi pilskalnu nogāzes lielākoties netika aizlīdzināti. Dažos gadījumos kara laika zemnīcas pilskalnu nogāzēs vēl vairākus gadus pēc I Pasaules kara beigām tika izmantotas dzīvošanai. Kolektivizācija pēc II Pasaules kara neveicināja ierakumu aizlīdzināšanu, tāpēc šì kara ierakumi pilskalnos ir saglabājušies daudz lielākā mērā.

Šobrīd varbūt ir vērts uzdot jautājumu, vai militāro būvju paliekas Latvijas pilskalnos ir uzlūkojamas tikai kā senvēstures pieminekḷa postījums vai varbūt tās varētu uzskatît arī par pilskalnu nesenāka izmantojuma liecībām. Ja tas tā, tad kā tādas arī militārās būves varētu tikt uzlūkotas par Latvijas pilskalnu kultūrvēsturiskās nozīmības jaunāko laiku liecinājumiem.

\title{
IEDZĪVOTĀJU SKAITA IZMAIN̦AS KĀ RĪGAS AGLOMERĀCIJAS ROBEŽU NOTEIKŠANAS INDIKATORS
}

\author{
Armands VILCIN̦Š \\ Latvijas Universitātes Ģeogrāfijas un Zemes zinātņu fakultāte, \\ e-pasts: Armands.Vilcins@lu.Iv
}

Aglomerāciju robežu noteikšana ir salīdzinoši sarežgīits pētījumu virziens, taču tas ir nepieciešams, lai nodrošinātu centrālās pilsētas veiksmīgu funkcionēšanu un prognozētu iespējamās iedz̄ivotāju plūsmas. Tieši iedzìvotāju plūsmas un pārbraucienu biežums ir viens no galvenajiem kritērijiem, kas limitē aglomerācijas ārèjās robežas. Šo pārbraucienu biežumu pētīšanai tiek izmantotas gan tiešās metodes (aptaujas dzivesvietās, darbavietās), gan netiešās metodes (nodokḷu pārskaitījumu apjoms starp pašvaldībām, sabiedriskā transporta kursēšanas biežums un maršrutu skaits). Urbanizācijas procesa sākotnējās fāzes laikā notiek iedzīvotāju 
dzīvesvietas izvēle pēc potenciālās darbavietas atrašanās vietas un dzīvesvietas tuvināšanās darbavietai. Iedzīvotāji pārcel̦as no lauku rajoniem un mazpilsētām uz centrālajām vietām, lielākajām pilsētām, lai atrastu darbavietu potenciāli aktīvākā darba tirgū un dzīvotu tuvāk darbavietai. Notiekot suburbanizācijas procesam, iedzīvotāji dod priekšroku patīkamākiem, labvēlīgākiem dzīves apstākḷiem ārpus lielpilsētām. Suburbanizācijas procesa attīstība ir tiešs iedzīvotāju labklājības līmeña celšanās rezultāts, jo dzīvesvietas izvēle attālu no darbavietas prasa lielākus ikdienas līdzekḷu ieguldījumus nekā dzīve pilsētā, tuvāk darbavietai.

Novērtējot iedzīvotāju skaita izmaiņas piepilsētas teritorijā, ir iespējams konstatēt urbanizācijas procesa norises stadiju aglomerācijā un arī izmantot šīs izmaiñas par vienu no indikatoriem pilsētas aglomerācijas robežu noteikšanai. Aktīvas urbanizācijas apstākḷlos tieši centrālajai aglomerācijas pilsētai pakḷautajā teritorijā iedzīvotāju skaits migrācijas dēl samazinās visvairāk, taču nevis vienmērīgi, bet atkarībā no attāluma. Visvairāk zaudē teritorija, kas atrodas vidējā attālumā no centrālās pilsētas un attālu no sekundārajiem centriem. Centrālajai pilsētai piegulošajās teritorijās salīdzinoši daudz cilvēku izšķiras dzīvesvietu nemainīt, bet ietekmes zonas perifērijā uz centrālo pilsētu pārcelties orientēto iedzīvotāju īpatsvars ir salīdzinoši neliels.

Sākoties urbanizācijas procesa otrajai fāzei - suburbanizācijai iedzīvotāju skaita pieaugums ir pakāpenisks un cieši saistīts ar attālumu no centrālās pilsētas. Vispirms tiek aizpildītas centrālajai pilsētai tuvākās privātmāju apbūvei piemērotās teritorijas, kurām seko nākamās tuvākās utt. Tādējādi praktiski jebkurā aglomerācijas procesa fāzē, sekojot iedzīvotāju skaita izmainu procesiem, ir iespējams noteikt aglomerācijas robežu. Galvenā indikatoru grupa aglomerācijas robežu noteikšanai ir ar iedzīvotāju migrāciju saistītie rādītāji (migrācijas saldo, iebraukušo un izbraukušo skaits, migrācijas rādītāji noteiktās vecuma grupās).

Iespējamie ierobežojumi iedzīvotāju skaita izmaiņu noteikšanas gadījumā ir fakts, ka arī urbanizācijas procesa fāzu noteikšanas pamatā ir tieši iedzīvotāju migrācijas rādītāji, tādēl iedzìvotāju skaita izmaiņas nevar būt vienīgais aglomerācijas robežas noteikšanas indikators. Arī iedzīvotāju dabiskās kustības rādītāji iespaido kopējā iedzīvotāju skaita izmainuu tendences, tādē jāievēro arī dabiskās kustības fons visā teritorijā kopumā. Īpaši būtiski tas attiecas uz Rīgas aglomerāciju, jo Latvijā pastāvošā depopulācija rada situāciju, kad arī negatīvas iedzīvotāju skaita izmaiņas var būt aglomerācijas teritoriju raksturojošs rādītājs, ja vien migrācijas saldo ir pozitīvs. Rīgas aglomerācijā suburbanizācijas procesi pēdējos gados ir tik aktīvi, ka migrācijas apjoms dzēš negatīvo dabisko pieaugumu un iedzīvotāju skaits Rīgai tuvākajās pašvaldībās pārsvarā pieaug. Teritorija ar pozitīvu iedzīvotāju skaita pieaugumu ar katru gadu paplašinās, tomēr nepārtrauktu novērojumu rindu izjauc pēc 2000.gada tautskaites veiktie iedzīvotāju skaita pārrēķini pagastos un pārrēķināto datu nepieejamība par laika periodu līdz 2000.gadam. 


\title{
OGRES RAJONA PILSĒTU ATTĪSTİBA VĒSTURISKĀ UN MŪSDIENU SKATİJUMĀ
}

\author{
Jānis VĪTIN̦Š \\ e-pasts: studentsjan@inbox.Iv
}

Ogres rajonā pirmās pilsētas tipa apdzīvotās vietas veidojušās Dievukalnā un Lielvārdes pilskalnā tagadējās Lielvārdes pilsētas teritorijā, pie Ķentes pilskalna tagadējās Ogres pilsētas teritorijā, Vīnakalnā netālu no tagadējās Ikšķiles pilsētas. 12.gadsimtā Lielvārde un Ikšķile jau bijušas nozīmīgas apdzīvotās vietas, to turpmāku attīstību pārtraukusi vācu feodālu agresija Baltijā. Tās sākumā vislielākās iespējas attīstīties pilsētai bijušas Ikšķilē, jo tā atradusies divu svarīgu tranzītceļu (A-R un Z-D) krustojumā. No Ikšķiles aizsākusies kristietības (katoḷticības) izplatīšana Latvijāa, 16 gadus (1185-1201) tā bijusi pirmā „Rīga” un Ikšksiles bīskapijas centrs. Tomēr drīz vien ienācēji tās novietojumu atzinuši par neizdevīgu, kam iemesls bijušas grūti pārvaramās Daugavas krāces, vērā ņemamais attālums no Rīgas jūras līča, kā arī tas, ka sākotnēji izvirzītais mērķis - iebraukt un nostiprināties pēc iespējas tālāk iekšzemē, lai apkārtējās teritorijās būtu ērti izplatît kristietību un tās pakḷaut sācis realizēties. Tādējādi, sākotnēji domāto galveno atbalsta punktu pārceḷot uz Rīgu, Ikšķiles nozīme mazinājusies, un, tāpat kā Lielvārde, arī turpmākajā laika gaitā tā par pilsētu nav kḷuvusi, kas izskaidrojams ar nepārtrauktajiem karadarbības radītajiem postījumiem Polockas cel̦a tuvumā, kā arī ar muižu izveidošanos pie agrākajām mūra pilīm un muižnieku ieinteresētību saglabāt kontroli pār apkārtējo teritoriju un iedzīvotājiem.

Atkārtotas pilsētu attīstības vēsmas Ogres rajonā parādījušās tikai 19.gs. 2.pusē pēc Rīgas-Daugavpils dzelzcel̦a līnijas atklāšanas. Tomēr līdz pat 1.pasaules karam šīs līnijas esamība veicinājusi attīstību tikai Ogrē un Ikšķilē, jo tur esošās muižas un to zeme kopš 1630.gada piederējušas Rịgas pilsētai, kas piel̦āvusi kūrortu un vasarnīcu apbūves attīstību tās apkārtnē. Turpretim Ķegumā un Lielvārdē, kur zeme piederējusi atsevišķiem muižniekiem, š̄i parādība nav izpaudusies. Izšḳirošā loma kompakta apdzìvojuma tālākā attīstībā pie dzelzceļa līnijas bijusi 1920.gada agrārajai reformai, pēc kuras tagadējās Ogres, Ikšķiles un Lielvārdes teritorijās esošo muižu zemes sadalītas apbūves gabalos un attīstìties sākusi arī Lielvārde (Rembates ciems). Savukārt tagadējā Ķeguma teritorijā esošās muižas zemes tikušas sadalītas jaunsaimniecībās, tādēl kompakts apdzīvojums tolaik tur vēl nav veidojies.

Visstraujāk attīstījusies Ogre, kas jau 1928.gadā ieguvusi pilsētas tiesības un izvirzījusies par otro apmeklētāko kūrortu Latvijā aiz Jūrmalas. Turpretim Ikšķile, būdama vasarnīcu kolonija, līdz pat 1940.gadam apbūves blīvuma un attīstības ziṇā atpalikusi no Lielvārdes, kurai jau 1924.gadā piešķirts ciema statuss (tas bijis viens no visstraujāk augošajiem ciemiem Rīgas apriņ̧̧̄i). Pavisam atšķirīgs faktors veicinājis Ķeguma attīstību - hidroelektrostacijas celtniecība. Tomēr tolaik 
uzskatīts, ka kompaktas apdzīvotās vietas veidošanās Ķegumā nebūtu vēlama (20.30.gados Latvijā ierobežota lielu rūpniecības objektu rašanās laukos un biezi apdzīvotu vietu veidošanās ap tiem); pēc tā, kā arī pēc 20.-30.gados izstrādātiem Ogres un Lielvārdes izbūves projektiem netieši var spriest par to, ka pirmās Latvijas brīvvalsts laikā rūpes par zināma līdzsvara saglabāšanu starp cilvēku un dabu Daugavas ielejā bijušas daudz lielākas nekā mūsdienās.

Apdzīvoto vietu attīstības gaitu un veidolu ievērojami deformējusi padomju periodam raksturīgā industrializācija, kolektivizācija un daudzstāvu ēku būvniecība, kā rezultātā Ogre no kūrorta tikusi pārvērsta par rūpnieciski attīstītu rajona centru, Lielvārde, Ikšksile un Ķegums - par pilsētciematiem - kolhozu centriem.

Kopš 1992.gada arī Lielvārde, Ikšķile un Ķegums ir pilsētas, taču to infrastruktūra un labiekārtojuma līmenis pagaidām vēl stipri atpaliek no pilsētvidei atbilstošā, visvairāk tas attiecināms uz Ķegumu, kur pilsētas centrs dabā praktiski nav identificējams. Mūsdienās visu četru pilsētu, it sevišķi Ogres, attīstībā vērojamas iezīmes, kas liecina par zināmu izpratnes trūkumu pilsētplānošanā gausi tiek apgūtas padomju periodā neefektīvi izmantotās vai novārtā pamestās teritorijas, savukārt pašvaldības ir loti naskas uz vēl neskarto, padomju laikā apbūvei neparedzēto mežaino platību un ūdeņu krastu apgūšanu, nerēķinoties ar sabiedrības interesēm un neapzinoties savas darbības sekas tālākā nākotnē.

Tā kā pilsêtas atrodas uz vienas no Rīgas aglomerācijas asīm, saistībā ar darba svārstmigrāciju un automobilizācijas līmeņa pieaugumu tām aktuālas kḷūst transporta radītās problēmas - pieaugošā satiksmes intensitāte veicina trokšnu līmeņa un gaisa piesārņojuma palielināšanos, pilsētas šķērsojošāa automaǵistrāle rada pastiprinātus draudus gājēju drošībai. Ikšķilē gājēju pārvietošanās starp abās pusēs automağistrālei esošajām pilsētas dạ̧ām tiek organizēta pa vairākiem tuneļiem un caurbrauktuvi, bet Ogres pilsētas robežās $6 \mathrm{~km}$ garumā ir tikai 2 neapgaismoti tunel̦i, un Lielvārdē un Ķegumā tādu nav vispār. Lai gan tiek plānota apvedcel̦a izbūve uz $\mathrm{Z}$ no pilsētām, kas esošo automaǵistrāli dal̦ēji atslogos, vieglā transporta dēl satiksmes intensitāte tāpat turpinās pieaugt, tāpēc vien̄̄gais risinājums ir jaunu tuneļu izbūve.

\title{
AINAVAS KONCEPCIJAS SĀKOTNE LATVIJĀ
}

\author{
Anita ZARIN̦A \\ LU Ģeogrāfijas un Zemes zinātņu fakultāte, \\ e-pasts: anita.zarina@lu.Iv
}

Latvijas geogrāfijas vēsturē ainavpētījumus dabā pirmais ir sācis Kamils Ramans un tādējādi gan izstrādājis un teorētiski pamatojis, gan iedzīvinājis praksē pirmo ainavas zinātniski geogrāfisko koncepciju. Lai tuvāk izprastu šodienas ainavas uztveri Latvijā, ir aktualizējama tās priekšvēsture gan ikdienas valodas, gan zinātniskā kontekstā. 
Vārds ainava latviešu valodā pirmo reizi parādās Frīdriha Mālberǵa stāstā „Platā ēna”, kas sarakstīts 1885.gadā: „Bija jauks pavasara rīts. Rimts un rāms klusums valdīja pār lielo un skaisto Ainavas muižu, kā arī pār viñas jo plašajiem tīrumiem..." [Mālberğis 1925, 253]. Lai gan paskaidrojumā dotie Gemälde, Landschaft tikai iepazīstina lasītāju ar jaunvārda jēgu, ainava šajā tekstā simbolizē muižas ainas: tās l̦audis, darbus, dabu.

Te ainavai ir saskatāma zināma līdzība ar 15.gs. beigās radušos holandiešu landschap ar nozīmi „lauksaimniecības ēku grupējums, iežogoti lauki, kā arī administratīvs apgabals" [Bunkše 2000; 34-35]. Vēlāk gan vārds ieguva māksliniecisku nozīmi, un līdz pat 19.gs. beigām tas tika saistīts ar glezniecības žanru, kur lineāro perspektīvu gleznās pamazām nomainīja cita ainavas koncepcija - telpa [Le Floch 1996].

Atšķirībā no citu valodu vārdiem (piemēram, landscape, Landschaft, paysage, maastik) ainava neietver vārdu zeme, bet gan ir veidojusies no saknes vārda aina, kas Latviešu Konversācijas vārdnīcā (I, 1927) tiek skaidrots kā „priekšmeta vai notikuma jutekliski uztverama parādība; attēls”. Literatūrzinātnieks K. Karulis [2001] raksta, ka, domājams, ainavas pamatā ir Mālberǵa dzimtajā Dundagā vietvārdos sastopamais lībiešu vārds àina ar nozīmi zāle, siens.

N̦emot vērā, ka aina un ainava vēl bija paretam lietoti vārdi [Karulis 2001], ne visās tālaika latviešu vārdn̄īās šie vārdi tika skaidroti. Toties 19.gs. beigās J.Dravnieka izdotajā Konversācijas vārdnīcā [1893, 29] vārdam ainava ir dots izvērsts skaidrojums: „Ainava ir pēdējā laikā pieņemts vārds pretī vācu Landschaft (bilde) ... Ainavas daiḷkrāsošanas priekšmets ir daba ... Bez tam, kā mākslinieks dabu uzlūko, var būt trejādas ainavas: 1) uzskata ainava, daba visā savā patiesībā (būves, pilsētas, drupas); 2) ideāla ainava (arī vēsturīga vai varonīga), kura dabu idealizē, un 3) jūsmu ainava, kura izrāda dabu, kāda tā ir, dzejiskā uzskatā ...". Arī vēl pēc 30 gadiem ainava ir "dabas skats vai tā gleznojums; peizāža”" [Konversācijas vārdnīca 1927, 29]. Šeit jāpiebilst, ka, piemēram, angḷu valodā vārdam landscape ir daudz plašāka nozīme, uz ko norāda arī Edmunds Bunkše [2000, 36]: „anglu valodā tas ietver gan zemi (land), gan ainu (scape); tātad praktiskas (zeme) un subjektīvas, estētiskas (aina) asociācijas."

Tomēr latviešu literārās valodas leksikā 20.gs. sākumā vārds ainava tiek lietots arī ārpus glezniecības konteksta. Kronvaldu Ata „Der Unterricht in der Heimatkunde” [1867] tulkojumā [„,Dzimtenes mācība” 1922] aina un ainava tiek tulkoti no vācu Bild: ,,... Iekšèji bērna dvēsele pamazām radinās tuvākās apkārtnes mazās ainas plastiski veidot. Aplūkojamam laukam pastāvīgi izplešoties, pieaug arī ainavas...". Tālaika dažādos publicētos izdevumos, arī atklātnēs un fotogrāfijās, ainava ir saprotama gan kā dabasskats, gan kā ikdienišķa aina no dzīves. Tā, piemēram, zem virsraksta Ķemeru ainavas redzams gan restorāna tuvplāns, cilvēki pastaigā pa parka ceḷu, gan sieviete sērūdeņraža vannā [Latviešu Konversācijas vārdnīca I, 1927-1928]. 
Līdztekus ainavas ienākšanai latviešu valodas leksikonā, rietumos attīstās arī zinātniskais ainavas termins. Aptuveni pirms 200 gadiem vācu ǵeogrāfs Humbolts ar ainavas jēdzienu izsaka reǵiona kopējās īpašības. 1850.gadā Rozenkrancs (Rosenkranz) ainavas definē kā hierarhiski organizētas visu dabas valstu lokālas sistēmas [Bastian 2001]. Savukārt Vācijā jau 20.gs. sākumā tiek iedibināta ainavu zinātnes skola Landschaftskunde, kuru interesē ,ar zinātniskām metodēm analizējamas dabas veidoto struktūru telpiskās izpausmes" [Rougerie, Beroutchachvili 1991].

Latvijas geogrāfi un dabaspētnieki (R.Putniņš, Ģ.Ramans, K.Kupfers, K.Melderis u.c.) savos darbos 20.gs. sākumā terminu ainava jeb Landschaft vēl lieto paretam. Taču jau 1911.gadā iznākušajā K.Kupfera „Baltische Landeskunde” atlantā „Igaunijas un Kurzemes kalnu un ūdenu pārskata kartē” blakus apzīmējumiem nogāzes, pauguru virsmas, kalna virsotnes parādās Hügellandschaft (paugurainuu ainavas). Vēlāk arī 1925.gadā iznākušajā „Grundzüge der Pflanzengeographie des Ostbaltischen Gebietes" Kupfers floras apakšapgabalus iedala ainavās jeb reǵionos.

Tomēr publicēti pētījumi par ainavām, kādi tie tika veikti kaimiņzemē Igaunijā (J.Granö), Latvijas zinātnē izpaliek. Vien 1935.gadā tiek publicēts Ģederta Ramana vadībā veiktais pētījums par „Latvijas teritorijas ǵeogrāfiskiem reǵioniem", kur reǵionu aprakstā ir saskatāma holistiska izpratne par telpu, kas visnotaḷ cieši sasaucas ar darba ievadā apskatītiem ǵeogrāfijas uzdevumiem: ,,... Jaunākos laikos ǵeogrāfija sākusi darīt kaut ko vairāk par analīzi. Tā iet no analīzes uz sintēzi, no atsevišķ teritorijas elementu izplatības pētījumiem uz pašu teritoriju kā telpu, kur elementi ietilpst, atrodas dažādās savstarpējās attiecībās, reaǵē viens ar otru un pār visu, - noteic teritorijas ārējo izskatu ǵeogrāfiskā ainavā” [Ramans 1935, 178].

Savukārt vien̄̄gā līdz 2.pasaules karam publicētā ainavas definīcija ir atrodama Latviešu Konversācijas vārdnīcā [VI, 1931], un tās autors ir Ģ.Ramans: „Geogrāfiskā ainava ir lielāka vai mazāka zemes virsmas dạ̧a ar visiem tās objektiem, formām un līnijām, kā tie redzami cilvēka acij. Ģeogrāfiskā ainava ir sintētisks jēdziens un satur daudz ǵeogrāfisku elementu: zemes virsmas formas, ūdeņus, veǵetāciju, cilvēku, viṇa mājokļus un darbus ... Tās izpratnei vajadzīga ne vien speciāla geoogrāfiska izglìtība, bet zināmā mērā arī estētiska nojauta. Pēdējā palīdz vērotājam uztvert geoogrāfiskās ainavas vispārējo noskaņojumu, pirmā - ieraudzīt ainavas sastāvdaļas, no kurām šis noskaņojums rodas...”.

\section{Atsauces}

Bastian O. (2001) Landscape ecology - towards a unified discipline? // Landscape Ecology No 16, p. 757-766.

Bunkše E. V. (2000) Sirēnu balsis jeb g̊eogrāfija kā cilvēcīga erudīcija. Rīga, Norden AB

Le Floch S. (1996) Bilan des définitions et méthodes d'évalution du paysage // Ingénieries - EAT No 5, p. 23-32.

Karulis K. (2001) Latvijas etimolog̣ijas vārdnīca. Rīga, Avots

Konversācijas vārdnīca I (1893) Jelgava, J. Dravnieka apgāds 
Kronvald O. (1867) Der Unterricht in der Heimathskunde. Dorpat, Universitäts Buchändler

Kronvaldu A. (1922) Dzimtenes mācība. Rīga, A. Gulbja apgāds

Kupffer K. R. (1911) Baltische Landeskunde. Atlas. Rīga, Verlag von G. Löffler

Kupffer K.R. (1925) Grundzüge der Pflanzengeographie des Ostbaltischen Gebietes. Rīga, Verlag der

Buchhandlung G. Löffler

Latviešu Konversācijas vārdnīca I, VI (1927;1931) Rīga, A. Gulbja apgāds

Mālbergíis F. (1925) Platā ēna // Raksti. Rīga, A. Gulbja apgāds, 253.-264. lpp.

Ramans Ģ. (1935) Latvijas teritorijas geogrāfiskie reǵioni // Ģeogrāfiski Raksti V. Rīga, Latvijas Ģeogrāfijas biedrība, 178.-240.lpp.

Rougerie G., Beroutchachvili N. (1991) Géosystèmes et paysages. Bilan et méthodes. Paris, Armand Colin

\title{
MĒRĶTIECĪGI IZVEIDOTO KOKAUDŽU AUGŠANAS GAITA UN STRUKTURĒŠANĀS ZIEMEĻKURZEMES UN RIETUMVIDZEMES MEŽSAIMNIECĪBĀS
}

\author{
Pēteris ZĀLITTIS \\ LVMI “Silava”, e-pasts zalitis@silava.Iv
}

Kokaudzes diferenciācija, tās strukturēšanās valdaudzē un starpaudzē ir nenovēršams process, kas raksturo koku savstarpējo konkurenci. Audzē līdz ciršanas vecumam saglabājas, kā arī jaunas generācijas veidošanā, t.i., meža dabiskā atjaunošanā piedalās tikai neliela daḷa no pašreizējās valdaudzes kokiem. Valdaudzes koku skaita izmaiñas un tuvākajos gados krājas kopšanas cirtēs izcērtamās starpaudzes parametri joprojām tiek prognozēti saistībā ar audzes vidējo augstumu - valdaudzes koku skaits nepamatoti tiek uzskatīts kā audzes augstuma funkcija. Visās apgrozībā esošajās augšanas gaitas tabulās (1924.gada Pagaidu, Tjurina, Vargasa de Bedemāra), kas pagaidām ir vienīgais audzes parametru prognozes instruments, iestrādāta audzes koku skaita visintensīvākā samazināšanās tieši jaunaudzēs, līdz valdaudzes vidējais augstums sasniedz 1015 metrus. Atbilstoši tam tiek plānotas arī kopšanas cirtes, paredzot izvākt visu pašreizējo starpaudzi un arī dą̧u no valdaudzes tievākajiem kokiem.

Krājas kopšanas ciršu normatīvi savulaik izstrādāti uz plaša empīriskā materiāla bāzes, kas raksturo reāli iespējamo mērķa krāju $\left(\approx 300 \mathrm{~m}^{3} \mathrm{ha}^{-1}\right)$ cērtamā vecuma kokaudzēs, paredzot samērā intensīvu $\left(60-80 \mathrm{~m}^{3} \mathrm{ha}^{-1}\right)$ audzes izretināšanu 30-40 gadu vecumā un nedaudz vājāku $\left(40-60 \mathrm{~m}^{3} \mathrm{ha}^{-1}\right)$ arī pēc 20 gadiem. Tas pamatoti uzskatāms par lietderīgāko apsaimniekošanas režīmu sākotnēji pārbiezinātās jaunaudzēs, kas vēl joprojām dominē mūsu mežos.

Taču mūsu mežos krasi pieaug tādu jaunaudžu īpatsvars, kurās sākotnējais (2-5 m augstās jaunaudzēs) kociņu skaits nepārsniedz 2000 gab.ha $^{-1}$. Atkārtotie novērojumi mūsu ierīkotajos parauglaukumos liecina par šādu audžu savdabīgo augšanas gaitu: 30-40 gadus vecās audzēs starpaudze tikpat kā neveidojas, kokaudze ir augstražìga, un valdaudzes šḳērslaukuma samazināšana atbilstoši 
pašreizējiem normatīviem nav saimnieciski izdevīga - pie lielāka šķērslaukuma reāli iespējama ir kokaudzes krājas palielināšanās, visticamāk, līdz $500 \mathrm{~m}^{3} \mathrm{ha}^{-1}$.

Augšanas gaitas prognozēšanai un starpaudzes kā kopšanas cirtēs izcērtamās dal̦as aprēķināšanai izmērīts samērā liels skaits kokaudžu, kuras, visticamāk, veidojušās no nosacīti retām jaunaudzēm. Audžu izvēle balstās uz empīriskos novērojumos iegūtu atziṇu - koku stumbri ir resnāki tajās audzēs, kas veidojušās no retākām jaunaudzēm.

Pētījumu objektu izvēlei kamerāli izmantota datu krātuvē "Latvijas meža fonds" uzkrātā informācija. Izstrādāta īpaša programma, ar kuras palīdzību ikvienā no divām Valsts mežsaimniecībām (Ziemel̦urzemes un Rietumvidzemes) ikkatrai no trīs galveno sugu (priede, egle, bērzs) tīraudzēm (sastāva koeficients $8 \div 10$ ) izvēlēts viens nogabals pie audzes vidējā augstuma $\boldsymbol{H}(\mathrm{m})=10,11,12 \ldots \boldsymbol{H}_{\max }$. Izvēlētajā nogabalā kokaudzes krāja ir visaugstākā starp pieciem nogabaliem ar visresnākiem kokiem pie dotā augstuma.

Ikvienā no izvēlētajām audzēm īslaicīgā parauglaukumā izdastoti visi koki, tos sagrupējot valdaudzē un starpaudzē; tāpat tiek izmērīti valdaudzes un starpaudzes koku augstumi, lai varētu aprēķināt kokaudzes daḷu parametrus vidējo caurmēru, vidējo augstumu, stumbru šksērslaukumu, koksnes krāju un sortimentu struktūru.

Analīzes gaitā apstiprinājās mūsu pieṇēmumi par jaunībā izretināto audžu augšanas gaitas savdabībām, kas nav raksturojamas ar līdz šim zināmiem model̦iem. Reāli iezīmējas iespējas būtiski palielināt kokaudzes krāju cērtamā vecuma audzēs, taču tad jāatsakās no pašreiz populārā krājas kopšanas ciršu režīma ar valdaudzes dal̦as izciršanu līdz piel̦autajam atstātās daḷas šksērslaukumam. Krājas kopšanas cirtēm jāreducējas līdz faktiskās starpaudzes un kalstošo koku izciršanai, bez atkārtošanās intervāla un tīraudzes vecuma ierobežojumiem.

Datu krātuvē fiksētās priežu valdaudzes krājas kā audzes augstuma funkcijas līknes abās mežsaimniecībās praktiski saplūst, taču priežu jaunaudžu savlaicīgas izretināšanas pozitīvās sekas striktāk izpaudīsies Ziemel̦kurzemes MS; arī Rietumvidzemes MS audzēs krājas pieaugums būs ievērojams.

Izretinot eglu jaunaudzes, valdaudzes krāja krasāk palielināsies Rietumvidzemes MS; neliela, aptuveni $50 \mathrm{~m}^{3} \mathrm{ha}^{-1}$ valdaudzes krājas palielināšanās prognozējama ar̄̄ Ziemel̦urzemes MS.

Nenoliedzami pozitīvas, kaut arī apjoma zin̄ā mazākas nekā skuju koku tīraudzēs, krājas izmaiņas sagaidāmas arī bērzu audzēs. Augstākās kokaudzēs Rietumvidzemes MS krājas vidējās vērtības ir nedaudz lielākas nekā Ziemel̦kurzemes MS, taču starpība nav statistiski signifikanta. 


\title{
PELDOŠAIS EZERRIEKSTS TRAPA NATANS - ATLANTISKĀ LAIKA RELIKTS POKRATAS EZERĀ
}

\author{
Iveta ŽVAGIN̦A \\ Latvijas Universitāte, Ģeogrāfijas un Zemes zinātņu fakultāte, \\ e-pasts: ivetazv@inbox.lv \\ Lelde EN̦ĢELE \\ Latvijas Dabas fonds, e-pasts: lelde@lycos.com \\ Laimdota KALNINA \\ LU Ģeogrāfijas un Zemes zinātņu fakultāte, \\ e-pasts: Laimdota.Kalnina@lu.lv \\ Sandijs MEŠK়IS \\ LU Ģeoloǵijas institūts
}

Latvijā peldošais ezerrieksts Trapa natans ir reta un apdraudēta suga, kas saglabājusies tikai atsevišksās vietās. Ir nepieciešams aktualizēt un precizēt informāciju par ezerriekstu, lai šo sugu saglabātu kā bioloǵiskās daudzveidības un Latvijas kultūrainavas sastāvdal̦u.

Pētījuma mērķis ir apkopot informāciju par ezerrieksta bioloǵiju un ǵeogrāfiju: sistemātisko piederību, vēsturi un izplatību, kā arī augšanas apstākḷiem un augu sabiedrībām.

Holocēna klimatiskā optimuma jeb atlantiskajā laikā plaši izplatījās siltummīlošās platlapju, kā arī atlantiskās sugas. Atlantiskais laiks aptver laika posmu pirms apmēram 7500 līdz 4800 gadiem, kad Baltijas jūras ieplaku aizpildīja Litorīnas jūras siltie un sāļie ūdeņi, bet tās krastā dz̄̄voja mezolīta jeb vidējā akmens laikmeta cilvēki, ko šī perioda pusē pakāpeniski nomainīja neolīta jeb jaunākā akmens laikmeta cilvēki.

Ozols, kḷava un liepa šai laikā auga daudz vairāk uz ziemel̦iem nekā to veǵetācijas robežas ir tagad. Latvijas teritorijas mežu sastāvā to bija ievērojami vairāk nekā mūsdienās. Reliktais ezerrieksts, kura tagadējās veǵetācijas ziemel̦u robeža ir Latvijā - Balvu rajona Pokratas ezers, toreiz auga Ziemel̦u Savo ūdenskrātuvēs Somijā. No tā var secināt, ka klimats toreiz bija vismaz par 2-3 siltāks kā tagad.

Ezerrieksta atliekas vai putekšn,i konstatēti l̦oti daudzos Latvijas ezeru (Klāṇu, Pūricas, Durbes, u.c.) nogulumu slāņos, kuri uzkrājušies atlantiskā laika beigu posmā vai subboreālā laika sākumā. Īpaši daudz ezerriekstu putekšñu un riekstu atliekas, to vidū arī apdegušas, atrastas neolīta laika apmetnēs vai to tuvumā esošajos ezeros, piemēram Lubānā, Burtniekā, kā ar̄̄ bijušajos Litorīnas jūras lagūnu reliktajos ezeros - Sārnatē un Ģipkā. Domājams, ka neolīta cilvēks ezerriektus ne tikai izmantoja uzturā, bet, iespējams, arī mēǵināja tos audzēt.

Bez minētajām vietām ezerriekts fosilā stāvoklī arī Osā, Piestiñā, Vecpiebalgā, Stilvja (Stulvja) ezerā, Dvietē, Ičā, Malnavā, Balvos (Galenieks, et.al. 1957.). Ir ziņas, ka ezerrieksts audzis Viesītes ezerā, Rencēnu dzirnavezerā, kā arī Varakḷānu apkārtnes ezeros. Mūsu gadsimta pirmajā pusē to augli atrasti 
izskalotos kūdras gabalos ezera krastā Saukas pagastā, kā arī Kārsavā. Ezerriekstu pētnieks A.Apinis raksta, ka pēc nepārbaudītām ziņām 20.gs. trīsdesmitajos gados tie redzēti arī Ludzas tirgū (Apinis, 1936).

Ezerriekstu dzimtā ietilpst tikai viena mūsdienās sastopama gints ezerrieksts Trapa, kas izplatīta Eirāzijā un Āfrikā no mērenās klimata joslas līdz pat tropu joslai.

Peldošajam ezerriekstam Trapa natans ir l̦oti plašs ǵeogrāfiskais areāls, taču tas izplatīts atsevišķās salveida kolonijās. Mūsdienu ziemeḷu izplatības robeža ezerrieksta atsevišksāam izolētām audzēm stiepjas aptuveni gar 5457ºiemel̦u platuma (Tahtadžjans 1981). Mūsdienās Latvijā peldošais ezerrieksts sastopams ļoti reti: tikai Klaucānu, Priekulānu un Pokratas (Pakrates) ezeros. Nosaukums Trapa radies no vārda calcitrappa - ragainis. Literatūrā minētas līdz 30 ezerriekstu sugām, daži autori to uzskata par vienu polimorfu sugu, taču V. Vasiljjevs min līdz 200 ezerriekstu sugām. Ši gints ir īpaši tuva ludvigijām Ludwigia (5., 228. lpp.). Ezerrieksts ir viengadīgs ūdensaugs, radniecisks naktssveču (Oenotheraceae) dzimtai. Pēdējā laikā to iedala atsevišksā dzimtā Trapaceae (Hydrocaryaceae). Labvēlīgos apstākḷıos brīvā dabā (Dienvidāzijā) ezerrieksts var būt daudzgadīgs (Apinis, 1936.). Sastopamas šādas Trapa natans formas: $f$. subcoronata Nath. (lielākā dą̧a no Klaucānu ezerā augošiem augiem), f. laevigata Nath. (lielākā dal̦a no Pakrates ezerā augošiem augiem); f. coronata Nath., $f$. subconocarpa Nath., $f$. elongata Nath., $f$. conocarpa Aresch., kā arī pārejas veidi no $f$ coronata Nath. uz $f$. conocarpoides Nath., un no $f$. laevigata Nath. uzf. conocarpa Aresch. (Galenieks, et.al, 1957).

Ezerrieksts aug no stipra vēja un viḷnošanās pasargātos stāvošos vai lēni tekošos ūdeños - nelielos ezeriņos, vecupēs, upju un ezeru līčos līdz 1-2,5 m, retāk līdz 3 m dziḷumā. Augs sastopams ūdeños, kas nabadzīgi ar kalcija sāļiem, bet bagāti ar organiskajām vielām (Gams, 1925). Tas nav sastopams apvidos, kur ūdeni satur nozīmīgu sāls daudzumu. Mūsdienās augšanai mazāk piemērotos apstākḷos (nepietiekama ūdens temperatūra veǵetācijas periodā, vēja un viḷnu ietekme) areāla ziemeļu daļā notiek pastiprināta dabīgā atlase - ezerrieksta formu pilnveidošanās vai arī izmiršana (Vasiljevs,1960).

Pokratas ezerā 2004.gada augustā veikti veǵetācijas apraksti fitocenozēs ar ezerriekstu. Veǵetācija aprakstīta pēc Brauna-Blankē metodes 27 parauglaukumos, kuru izmērs ir $4 \mathrm{~m}^{2}$ (1. tabula).

Aprakstītās fitocenozes izveidojušās uz dūņainas grunts $0,8-1,5 \mathrm{~m}$ dziḷumā, tās ir sugām nabadzīgas (2-5 augu sugas), parasti tajās dominē (nereti veido tīraudzes) peldošais ezerrieksts. Augu sabiedrību kopā ar ezerriekstu veido spožā glīvene Potamogeton lucens, iegrimusī raglape Ceratophyllum demersum, dzeltenā lēpe Nuphar lutea u.c. peldošo ūdensaugu sugas. Ezerrieksta augu sabiedrībā konstatētas 11 augu sugas (1.tabula). 
Augu sabiedrības ar peldošo ezerriekstu Trapa natans sugu sastāvs

\begin{tabular}{|c|c|c|c|c|c|c|c|c|c|c|c|c|c|c|c|c|c|c|c|c|c|c|c|c|c|c|c|c|}
\hline Parauglaukuma nr. & 1 & 2 & 3 & 4 & 5 & 6 & 7 & 8 & 9 & 10 & 11 & 12 & 13 & 14 & 15 & 16 & 17 & 18 & 19 & 20 & 21 & 22 & 23 & 24 & 25 & 26 & \begin{tabular}{|l|}
27 \\
\end{tabular} & \multirow{4}{*}{ 는 } \\
\hline Dzilums (m) & & 1.2 & 1.2 & 1.5 & 1.4 & 1.2 & 0.8 & 0.8 & 1 & 1.3 & 1.4 & 1.4 & 1.2 & 0.8 & 1.1 & 1.1 & 1 & 1.1 & 1.1 & 0.8 & 1.3 & 1.4 & 1.5 & 1.4 & 1.5 & 1.2 & 1.4 & \\
\hline Grunts & $\mathrm{D}$ & $\mathrm{D}$ & $\mathrm{D}$ & $\mathrm{D}$ & $\mathrm{D}$ & $\mathrm{D}$ & $\mathrm{D}$ & $\mathrm{D}$ & $\mathrm{D}$ & $\bar{D}$ & $\mathrm{D}$ & $\mathrm{D}$ & $\mathrm{D}$ & $\mathrm{D}$ & $\bar{D}$ & $\mathrm{D}$ & $\mathrm{D}$ & $\mathrm{D}$ & $\mathrm{D}$ & $\bar{D}$ & $\mathrm{D}$ & $\mathrm{D}$ & $\mathrm{D}$ & $\mathrm{D}$ & $\mathrm{D}$ & $\mathrm{D}$ & $\mathrm{D}$ & \\
\hline Sugu skaits & 2 & 2 & 3 & 2 & 2 & 3 & 4 & 3 & 4 & 2 & 2 & 5 & 2 & 5 & 3 & 4 & 2 & 5 & 2 & 3 & 4 & 2 & 1 & 3 & 2 & 2 & 1 & \\
\hline Trapa natans & 50 & 95 & 90 & 20 & 50 & 50 & 50 & 60 & 40 & 90 & 90 & 80 & 80 & 30 & 40 & 95 & 80 & 40 & 95 & 40 & 30 & 95 & 90 & 80 & 98 & 90 & 98 & $\bar{V}$ \\
\hline Potamogeton lucens & & & & 20 & 20 & 30 & & & & + & 5 & + & 10 & & 10 & & + & & & & 30 & + & & 5 & + & + & & III \\
\hline $\begin{array}{l}\text { Ceratophyllum } \\
\text { demersum }\end{array}$ & & 1 & + & & & & 30 & & + & & & + & & 20 & & + & & 30 & + & 5 & + & & & & & & & III \\
\hline Nuphar lutea & 1 & & + & & & & & 1 & & & & & & + & & & & & & + & 2 & & & 20 & & & & II \\
\hline Potamogeton natans & & & & & & + & & & 2 & & & + & & & + & 1 & & & & & & & & & & & & 1 \\
\hline Sparganium emersum & & & & & & & & 5 & & & & + & & & & 1 & & & & & & & & & & & & $\mathrm{~T}$ \\
\hline Spirodela polyrhiza & & & & & & & + & & & & & & & + & & & & + & & & & & & & & & & I \\
\hline Lemna minor & & & & & & & + & & & & & & & & & & & + & & & & & & & & & & $\mathrm{T}$ \\
\hline Phragmites australis & & & & & & & & & 3 & & & & & & & & & & & & & & & & & & & $\mathrm{I}$ \\
\hline Cicuta virosa & & & & & & & & & & & & & & + & & & & & & & & & & & & & & $\mathrm{I}$ \\
\hline $\begin{array}{l}\text { Hydrocharis morsus- } \\
\text { ranae }\end{array}$ & & & & & & & & & & & & & & & & & & + & & & & & & & & & & $\mathrm{I}$ \\
\hline
\end{tabular}

Atsevišķ ezerrieksta eksemplāri sastopami niedres Phragmites australis un upes kosas Equisetum fluviatile audzēs aptuveni $20 \mathrm{~cm}$ dziḷumā. Arī literatūrā ir ziņas, ka seklūdens joslā ezerriekstu nomāc citi augi (niedres, meldri, u.c.) (Vasiljevs, 1960.). Savukārt fitocenozēs lielākā dziļumā dominējošais ezerrieksts nereti gandrīz 100\% nosedz ūdens spoguli ar savu lapu rozetēm un tādējādi kavē gaismas iekḷuššanu ūdenī un nomāc iegrimušos ūdensaugus.

Pokratas ezera nogulumu palinologiskie pētījumi liecina, ka ezerriekts šai ezerā ir audzis pēdējos 5000 gadu, visu laiku kopš atlantiskā laika beigām. Tā putekšn,u daudzums nogulumos ir mainīgs, bet mūsdienās to daudzums ir līdzịgs tam, kāds tas bija īsi pēc tā ieviešanās ezerā. Būtiska ezerrieksta putekšņu daudzuma samazināšanās vai pat izzušana novērojama vairākkārt, bet pēdējā konstatēta $32 \mathrm{~cm}$ dziļumā, ko, iespējams, var attiecināt uz "mazo ledus laikmetu" viduslaikos.

\section{Literatūra}

Apinis A.1936. Ezerrieksts Klaucānu ezerā. IM Skolu Muzeja izdevums, Rīga, 27 lpp.

Galenieks P., Bumbure M., Jaudzeme V., Līvena Dz., Pētersone A. 1957. Ezerriekstu dzimta Hydrocaryaceae Raimann. 54. dzimta., Latvijas PSR flora. Latvijas valsts izdevniecība, Rīga, 352. - 353. lpp.

Politere I 1998. Senais ezerrieksts. - Lauku Avīze, 12. 09. 1998., 7. lpp.

Tahtadžjans A. L. 1981. Augu dzīve 5(2). Prosvesčenije, Maskava, 230.-232. lpp.

Vasiljevs V. N. 1960. Ezerrieksts un tā kultūras perspektīvas PSRS. PSRS Zinātṇu akadēmija, Maskava, 100 lpp. 


\title{
PAVEDIENU MIETURĪTES CHARA FILIFORMIS HERTZSCH EKOLOĢIJA UN IZPLATİBA LATVIJĀ
}

\author{
Egita ZVIEDRE \\ Latvijas Universitāte, Bioloǵijas fakultāte, Botānikas un ekoloǵijas katedra, \\ e-pasts: egita.zviedre@dabasmuzejs.gov.Iv
}

Pavedienu mieturīte Chara filiformis ir Latvijā reta saldūdens mieturalğgu suga. Suga ir viegli atpazīstama pēc tās reducētajiem īszariem. Visām pārējām Latvijā augošajām mieturītēm îszari ir labi attīstīti.

Pirmās trīs šīs sugas atradnes Latvijā konstatēja Uvis Suško Garajā ezerā (Botāniskais kvadrāts 27;28/53), Černavu ezerā (29/47) un Pelečinas ezerā (27/45) (Suško 1997).

Sugas ekologijas un izplatības pētījums veikts 2002.-2004.gada vasarā visā Latvijas teritorijā, izñemot Alūksnes, Cēsu, Gulbenes, Kuldīgas, Limbažu, Valkas un Ventspils rajonā. Pētījumi veikti vidēji piecos dažādos saldūdens biotopos katrā rajonā.

Konstatētas desmit jaunas sugas atradnes DA Latvijā. Visvairāk jaunu sugas atradņu konstatēts Daugavpils rajonā, kurš salīdzinājumā ar citiem rajoniem arī apsekots labāk. Daugavpils rajonā pavedienu mieturīte konstatēta Baltezerā (25/45), Sitas ezerā (29/48), Sventes ezerā (27/44), Daugavpilī, plānotā HES ūdenskrātuvē (27/46) un Riču ezerā (29/47). Savukārt Krāslavas rajonā tā aug Sīverā (25/52) un Geraņimovas - Ilzas ezerā (24/51), Ludzas rajonā - Bižas ezerā (19/53), Preiḷu un Rēzeknes rajonā - Feiman̦u ezerā (22/49-50), bet Jēkabpils rajonā - Vinnaukas ezerā (23/37), kas pagaidām ir vistālāk uz rietumiem zināmā atradne. Paredzams, ka, turpinot sugas sastopamības un izplatības pētījumus, būtu iespējams konstatēt jaunas atradnes, īpaši Latgalē un Sēlijā.

Suga sastopama galvenokārt tikai ezeros. Vienīgi Daugavpils plānotā HES ūdenskrātuvē tā aug mākslīgi veidotā ūdenstilpnē. Pavedienu mieturīte nav konstatēta tekošos ūdeņos - grāvjos un upēs, kā arī dīḳos. Ūdeṇi, kuros konstatētas pavedienu mieturītes, ir dzidrūdens, ar labu caurredzamību (no 1,9 m Feimaṇu ezerā līdz $6,5 \mathrm{~m}$ Sventes ezerā). To trofiskie stāvokḷi novērtēti kā mezotrofi un eitrofi. Maksimālais dziļums, kādā suga sastopama, atbilst caurredzamībai pēc Seki diska. Pavedienu mieturītes veido tīraudzes vai sabiedrības ar citām mieturaļgèm. Parasti tās sastopamas vietās, kur ir vai nu smilšains, vai ar nelielu dūņu kārtu klāts substrāts. Seklākajās vietās, tuvu krastam, kur ir lielāka viḷnu ietekme, īpatņi ir mazi $(\operatorname{li} \mathrm{dz} 10 \mathrm{~cm})$, savukārt dzil̄ākajās vietās to garums sasniedz 40-50 centimetrus.

\section{Literatūra}

Suško U. 1997. Augšdaugavas dabisko ezeru botāniski-limnologisko pētījumu rezultāti Indricas un Varnaviču ezerainēs - Daba un Muzejs. Rīga, ADverts. 7: 33.-39. Ipp. 


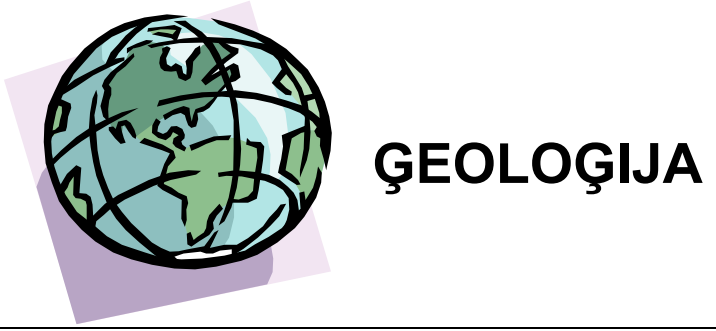

\section{GLACIOTEKTONISKĀS DEFORMĀCIJAS LËTİŽAS LABAJĀ KRASTĀ PIE LËĢERNIEKIEM}

\section{Ojārs ĀBOLTIN̦Š, Ivars STRAUTNIEKS, Aivars MARKOTS, Vitālijs ZELČS, Martins DENISOVS, Linda MANGALE, Anita PLŪCE, Lāsma SIETINSONE, Aiga STATKUS, Agate TEIVĀNE \\ Latvijas Universitāte, Ģeogrāfijas un zemes zinātņu fakultāte, e-pasts: zeme@lanet.Iv}

Pētījumu vieta atrodas Kursas zemienē, Pieventas līdzenuma dienviddaļā, tuvu Pampāļu paugurvalı̧ı ziemel̦u nogāzei. Tā ir līdz $2 \mathrm{~km}$ plata lēzeni vilı̧nota pamatmorēnas līdzenuma daļa, kas atrodas R no Ventas ielejas un stiepjas gar tās kreisā krasta pietekas Lètīžas lejteci.

Teritorija atrodas pārsvarā 55-65 m vjl., kaut gan maksimālais augstums sasniedz 68-72 m vjl. Lēzeni viḷnoto virsmas saposmojumu rada garenstieptu, ZZR-DDA virzienā orientētu, zemu drumlinveida formu un ieplaku mija. Vaḷnveida formu garums sasniedz 200-600 m, platums mainās no 75 līdz 200 m, bet relatīvais augstums ir 3-6 m. Ledāja izcelsmes formu radīto saposmojumu sarežğī Lētīžas un Šķerveļa ielejas, šo upju pietekas un sengravas.

Kvartārnogulumu segas biezums pēc M 1:200000 ǵeologiskās kartēšanas materiāliem (Juškevičs u.c., 1997) pārsvarā ir mazāks par $10 \mathrm{~m}$. To veido galvenokārt pēdējā apledojuma morēnas smilšmāls vai mālsmilts, ko vietām pārsedz glaciolimniski māli un sakrokoti ledājkušanas ūdeņu nogulumi (Straume, 1979).

Pētījumu teritorija, tāpat kā visa Kursas zemiene un tajā ietipstošais Pieventas līdzenums kopumā, atrodas virs Z-D virzienā stiepta subkvartāra virsas lielpazeminājuma, kas stiepjas starp Austrumkursas un Rietumkursas pamatiežu pacēlumiem un pakāpeniski sašaurinās dienvidu virzienā. Pamatiežu virsas augstums ir 40-50 m vjl. Pētījumu vietā subkvartāra virsu veido juras sistēmas ieži, kas pieder Kelovejas stāva iežu slāņkopai ( $\mathrm{J}_{2} \mathrm{pp}$ - Papiles svīta), kas sastāv no tumša vai tumšpelēka māla, baltas smilts un brūnog̣̦u slānnmijas. Māls satur daudz tumšas krāsas organiskā materiāla - brūnogles un pārogḷotas koksnes 
gabalus. Lētīžas upes krastos atsedzas ledāja nogulumos asimilēti Juras iežu atrauteņi (Āboltinš et al., 2004).

Glaciotektoniskās struktūras atsedzas Lētižas upes ielejas labā pamatkrasta kraujā, apmēram $2 \mathrm{~km}$ no ietekas Ventā, 0,5 km DDR no Lēǵernieku mājām. Līdz $15 \mathrm{~m}$ augstās krasta kraujas apakšējā dal̦ā atrodas divi, līdz $5 \mathrm{~m}$ augsti atsegumi, orientēti gandrīz Z-D virzienā. D atsegumā izsekojama lielāka slāṇu litoloǵiska dažādība un glaciodislokāciju daudzveidība. Guļošās krokas apakšējā spārnā 3 apakšêjie slāṇi sagul gandrīz horizontāli, līdzīgi kā ziemeḷu atsegumā slāņu lielākā daļa. Atsegumos redzami ledāja nogulumos asimilēti juras nogulumi. To apakšējā dal̦ā redzams diamikts ar sīkkārtotām baltas krāsas juras smiltīm, kurās ir melnas, pārogḷotas koksnes ieslēgumi. Diamiktam uzgul tumšpelēks, tumšs sīkslāņots smilšmāls un mālsmilts ar irdenām brūnoglēm un melniem vai tumšbrūniem koksnes gabaliem. Slānī sastopami labi noapaļoti oḷi, pirīta vai markazīta konkrēcijas un oranžbrūnas krāsas dzelžotas smilts ievilkumi. Augstāk to nomaina pelēkbrūna morēnas mālsmilts ar oḷiem un grants graudiem. Pelēkbrūnā morēna ir sīkplātņaina, kurā plātnīšu kritums ir gandrīz vertikāls. Uz morēnas slāņu un diamikta kontaktiem redzamās vilkšanas krokas atspoguḷo bīdes deformācijas un norāda uz ledāja radīto spiedienu no ZZA. Virs gandrīZ horizontāli saguḷošiem slāņiem atrodas sakrokoti slāņi, kas atšķiras gan pēc litolog̣iskajām īpatnībām, gan arī pēc noblīvêtības pakāpes un krāsas. Tumšpelēks, vietām gandrīz melns morēnas smilšmāls pārliecoties veido arī gulıošās krokas augšējo spārnu. Raksturīgi, ka morēna ir loti blīva, ar labi noapalıotiem gludiem oḷiem. Morēnas plātņu kritums ir gandrīz vertikāls. Morēnas slānī ir vairākas līdz $3 \mathrm{~cm}$ biezas, izlocītas oranžbrūnas smilts ievilkumu josliņas un gaišākas krāsas, 1-4 mm biezas smilts-grants kārtiņas. Krokas kodolā izsekojami sakrokoti dažādgraudainas un aleirītiskas smilts slāņi ar tumšbrūna vai pelēkbrūna māla un mālaina aleirīta starpkārtināam, kā arī dažus cm biezs brūnas morēnas slānis un gaišbrūna (ķieg̣eḷkāsas) morēnas mālsmilts ar grants graudiem un oḷiem. Atsegumā kopumā ir redzami dažādas krāsas morēnas slāni, bet dominē tumšpelēkā, gandrīz melnās krāsas morēna ar asimilētiem juras sistēmas nogulumiem, to skaitā organiskajām atliekām (gliemežu čaulām, amonītu drumslām u.c.). Tādējādi viens no svarīgākajiem morēnas krāsu noteicošajiem faktoriem ir ledāja gultnes iežu litologiskās īpatnības.

Morēnas slāņos guḷošajā krokā un diamiktā zem tās izmērīto oḷu garenasu maksimumi diagrammās (STEREONET) ir izkliedēti un maksimumi nav lielāki par 6\%, tādējādi norādot uz oḷu rotācijas kustību. Visās diagrammās galvenie oḷu maksimumi izvietoti DR sektorā un atspoguḷo virzienu, kas ir paralēls ledājkustības un materiāla pārvietošanas virzienam - no ZZA un vērsts perpendikulāri valı̧nveida reljefa formu gareniskajām asīm. 


\title{
Literatūra:
}

Āboltiņš, O., Strautnieks I., Zelčs V. \& Markots, 2004. Stop 10: The River Lētiža bluff outcrop at Légernieki. International Field Symposium on Quaternary Geology and Modern Terrestrial Processes, Western Latvia, September 12-17, 2004: Excursion Guide. Rīga, University of Latvia, 2004, pp. 57-59.

Juškevičs, V., Kondratjeva, Mūrnieks, A. un Mūrniece, S., 1997. Latvijas g̊eologisiskā karte. Mērogs 1:200000. 31. lapa - Liepāja. Paskaidrojuma teksts un kartes. Valsts Ģeologijas dienests, Rīga. 49 $1 \mathrm{pp}$.

Straume, J., 1979. Lednikovije obrazovanija. Geologičeskoje strojenije i poleznyje iskopajemyje Latvii. Zinātne, Rīga, s. 302-310.

\section{KVARTĀRA NOGULUMU PALEOBOTĀNISKIE PĒTĪJUMI LUBĀNA LĪDZENUMĀ ZVIDZIENAS APKĀRTNË}

\author{
Aija CERIN̦A \\ LU Ģeoloǵijas institūts, e-pasts: caija@inbox.Iv \\ Laimdota KALNINA \\ LU Ģeogrāfijas un Zemes zinātņu fakultāte \\ e-pasts: Laimdota.kalnina@lu.Iv
}

Lubāna līdzenumā Zvidzienas apkārtnē paleobotāniski pētīti pleistocēna un holocēna nogulumi.

Pleistocēna starpmorēnu nogulumus ar augu atliekām Lubānas zemienē pirmo reizi konstatējis V.Ālers inženierǵeologiisko pētījumu urbumā 1958.gadā, un šai vietā (starp Zvidzes un Eiṇu ezeriem, Zvidzes upītes labajā krastā) 1960.gadā pētîjumi turpināti (Krūkle, Lūsiņa, Stelle, 1962). Autori atzīmē, ka pēc petrogrāfisko analī̌̌u rezultātiem abas Zvidzienas griezuma morēnas varētu uzskatīt par pēdējā apledojuma veidojumiem un nogulumus starp tām par stadiāliem. Arī augu makroatlieku sastāvs, kurā ir gan ūdensaugi, kas liecina, ka nogulumi veidojušies ūdens baseinā, gan no sauszemes ienestie, kas floru raksturo kā "izteikti ziemelniecisku" (Selaginella selaginoides, Betula nana, Arctostaphylos uva-ursi), to apliecina. Tomēr, izvērtējot sporu un putekšņu diagrammas līkņu gaitu, autori secina, ka starpmorēnu nogulumi tomēr atbilst Risa-Virma starpledus laikmetam un raksturo klimata pasliktināšanos un vēsa kontinentāla klimata iestāšanos, kas saistīts ar Virma apledojuma tuvošanos.

I.Danilāns (1973) griezumu nosacīti pieskaitīja Lejasciema slāņiem.

Tālākajos pētîjumos konstatēts, ka starpmorēnu nogulumu augšèjā daļa ieslēgta nogulumus pārklājošajā morēnā atrauteņa veidā, bet pārējās starpmorēnu nogulumu daḷas griezumā jaunajā 63.urbumā novērojama pretēja mālaino un smilts nogulumu saguluma secība salīdzinājumā ar agrāk zināmo (Meirons, Mūrniece, 1982). Augu makroatlieku analīze (A.Cerina) apstiprina agrāko pētījumu rezultātus (1.tab.). Nogulumu sporu un putekšņu spektri (analizējusi L.Kalnina) vienveid̄̄gi. Dominē kokaugu putekšṇi, tomēr vairāk nekā 30\% sastāda zālaugu putekšñi. Raksturīgs Betula putekšņu pārsvars, starp kokiem 
diezgan daudz Corylus putekšņu. Platlapji parādās vienlaikus ar Selaginella selaginoides un Betula nana. Z.Meirons Zvidzienas starpmorēnu nogulumus pieskaita Rogaļu slāņiem (Meirons, 1986).

Leduslaikmeta beigu posma un holocēna nogulumu griezuma veidošanās apstākḷus Zvidzienas apkārtnē vispilnīgāk raksturo Eiṇu ezera palinologiiskā diagramma (Seglins, Kalnina, Lacis, 1999). Pārējās palinologiskās diagrammas raksturo holocēna nogulumu griezumus tikai senajās cilvēku apmetnēs. Zvidzes apmetnē izsekota Lubāna zemienes akmens laikmeta kultūru attīstība no vidējā mezolīta līdz vidējam neolītam ieskaitot (Loze I., 1988). Zvidzes apmetne atrodas senā Lubāna ezera ZR krastā, Smaudžu ciema teritorijā. Zvidzes apmetnē I.Jakubovska analizējusi 3 griezumus (C rakuma t.s. Zvidzienas Krogs, un 2 griezumus B rakumā, no kuriem pēdējam publicēti arī alğgu analīzes dati), bet G.L,evkovska 1 griezumu, ko papildina diatomeju pētījumi, kurus veicis R.Džinoridze. Zvidzes B rakumā nogulumos noteiktas arī augu makroatliekas (Loze, Jakubovskaja, 1984; Ceriņa, 2004). Griezumā izdalītas vairākas lokālās augu makroatlieku asociācijas: I - ūdensaugu, int. 195-105 cm dziḷumā, kurā pārsvarā ūdensaugu atliekas, nedaudz piekrastes, plavu augu atliekas. Ruderālo augu atlieku sugu daudzveidība un neliels atlieku skaita pieaugums iezīmējas dziḷuma int. 155$130 \mathrm{~cm}$, kas pēc arheologiskajiem datiem atbilst vēlajam mezolītam.

Ogḷoti Trapa natans riekstu fragmenti visvairāk sastopami int. 130 $105 \mathrm{~cm}$, šai etapā visvairāk arī neoglotu Trapa riekstu fragmentu, kas varētu liecināt par šì auga optimālajiem augšanas apstākḷiem apmetnes tuvumā. Šai laikā, agrā neolīta pirmā puse, augs visplašāk lietots pārtikā. Etapam atbilst vislielākai skaits atrasto lazdas riekstu fragmentu.

II - ūdensaugu, piekrastes, pḷavu augu asociācija, int. 105-80 cm. Agrā neolīta otrā puse. Ezerā daudz ūdensrožu, Calinia flexilis, C. minor, Salvinia natans, joprojām Trapa natans, bet mazāk. Notikusi ezera līmen̦a pazemināšanās, krasi pieaudzi piekrastes augu un plavu augu atlieku daudzums.

III - piekrastes augu, pḷavu un ūdensaugu asociācija, ruderālo augu izplatības maksimums. Vidējā neolīta kultūra. Ezeram viszemākais līmenis. Int. 35-70 cm. Parādās Rumex acetosella, pieaug balandu skaits; samazinājies ogḷoto ezerrieksta fragmentu un lazdu riekstu atlieku skaits, kas, iespējams, norāda uz savvaļas augu lomas samazināšanos pārtikā. Sastopami dzintara graudiṇi, kas atbilst aheologu dzintara izstrādājumu atradumiem. Intervāla augšdaḷā pieaug seklu ūdeñu ūdensaugu (Batrachium sp.) un piekrastes augu daudzums, kas norāda ezera līmeņa pakāpenisku celšanos.

IV - piekrastes un ūdensaugu asociācija (int. 30-10 cm), atlieku skaits neliels. Domājams, ka nogulumi veidojušies subatlantiskās transgresijas laikā. V - asociācija (int. 5-10 cm) atbilst SA3 laikam un praktiski mūsdienām. Raksturīga Urtica dioica sēklu dominante.

Uz ziemel̦iem no Eiņu ezera esošās apmetnes teritorijā holocēnq griezumu palinoloǵisko izpēti veikušas G.L,evkovska un L.Kalniņa. 
1.tabula

Zvidzienas griezuma starpmorēnu nogulumu augu makroatlieku sastāvs

\begin{tabular}{|c|c|c|c|c|}
\hline \multirow[b]{3}{*}{ Augi } & \multicolumn{3}{|c|}{ 63.urbums } & \multirow{3}{*}{$\begin{array}{c}\text { Krūkle, } \\
\text { Lūsiņa, } \\
\text { Stelle, } 1963\end{array}$} \\
\hline & Slāṇa dziḷums & $8,3-8,5 \mathrm{~m}$ & $10,0-12,7 \mathrm{~m}$ & \\
\hline & Nogulumi & smilts & smilts & \\
\hline Koki, tundras krūmi, puskrūmi & Atliekas & & & \\
\hline Pinus silvestris L. & mizas fragmenti & & & * \\
\hline Salix sp. & lapu fr. & & 11 & \\
\hline & pogalas & & 15 & \\
\hline Betula nana $\mathrm{L}$. & $\begin{array}{l}\text { lapas fr. } \\
\text { riekstini }\end{array}$ & $\begin{array}{c}1 \\
13\end{array}$ & $\begin{array}{c}1 \\
14\end{array}$ & $\begin{array}{ll}* \\
*\end{array}$ \\
\hline & spurdzes spārniņi & 6 & 7 & $*$ \\
\hline Betula sp. & $\begin{array}{l}\text { spurdzes spārniņi } \\
\text { riekstini }\end{array}$ & & 1 & \\
\hline Arctostaphylos uva-ursi (L.) & kauleņi & & & $*$ \\
\hline Spr. & & & & \\
\hline Kseromezofiti & & & & \\
\hline Rumex sp. & riekstiņi & & 1 & \\
\hline $\begin{array}{l}\text { Chenopodium sp. } \\
\text { Caryophyllaceae gen. }\end{array}$ & $\begin{array}{l}\text { seklas } \\
\text { sēklas }\end{array}$ & & & $*$ \\
\hline Taraxacum sp. & sēklas & & & * \\
\hline Mitru pḷavu un purvu augi & & & & \\
\hline Sphagnum sp. & zariņi & & & * \\
\hline Bryales & zariņi ar lapām & l̦oti daudz & l̦oti daudz & * \\
\hline $\begin{array}{c}\text { Selaginella selaginoides (L.) } \\
\text { Lk. }\end{array}$ & megasporas & & 1 & * \\
\hline $\begin{array}{l}\text { Eleocharis palustris (L.) R. et } \\
\text { S. }\end{array}$ & & & & * \\
\hline Carex spp. & riekstiņi & 2 & 3 & * \\
\hline Ranunculus sp. & riekstiņi & & & * \\
\hline $\begin{array}{c}\text { Menyanthes trifoliata L. } \\
\text { Ūdensaugi }\end{array}$ & sēklas & & & * \\
\hline Salvinia natans (L.) All. & megaspora & & & 1 \\
\hline Characeae gen. & oogoniji & 4 & & * \\
\hline Potamogeton filiformis Pers. & kauleņi & 2 & & $*$ \\
\hline Batrachium sp. & riekstiņi & & & * \\
\hline Hippuris vulgaris $L$. & kauleñi & & & * \\
\hline Fungi & sklerociji & 50 & $>100$ & * \\
\hline
\end{tabular}

\title{
LATVIJAS KVARTĀRSEGAS ŪDEŅU REĢIONĀLĀS ATŠĶIRĪBAS
}

\author{
Aija DËLIN̦A \\ LU Ģeogrāfijas un Zemes zinātņu fakultāte, \\ e-pasts: aija.delina@lu.Iv
}

Latvijā ir veikti daudzskaitliski pētijumi, nosakot kritērijus, pēc kuriem Latvijas teritorija ir rajonēta gan pēc ǵeomorfologiskiem, geobotāniskiem, veǵetācijas, augšņu, mežaudžu, biotopu, klimatiskiem, ainavu kritērijiem un pēc kritēriju kompleksiem, izdalot, piemēram, dabas apvidus. Dažādās rajonēšanas 
galvenā atšķirīiba ir izvēlētās pazīmes vai kritēiiji, jo ar dažādam metodēm izdalītie reǵioni teritoriāli ir līdz̄̄gi. Kvartāra nogulumu pazemes ūdeñi kā tiešs kritērijs jeb pazīmju komplekss tiek izmantots retāk, bet bieži tas ir iestrādāts pastarpināti, jo visi minētie piemēri tieši vai netieši satur pazemes ūdeṇus raksturojošus elementus. Līdz ar to vispārīgu priekšstatu par sekli iegulošo pazemes ūdeņu reǵioniem var gūt no izdalītajiem Latvijas dabas apvidiem.

Pazemes ūdeṇu vispārīgam raksturojumam tradicionāli tiek izmantotas divas nozīmīgas kritēriju grupas - ķ̄imiskais sastāvs un pazemes ūdeņu līmeņi. Latvijā pazemes ūdeñi ir pētīti jau sen, ietverot kā sastāva, tā līmeņu mērījumus, tomēr iepriekšējo mērījumu vērtība ir salīdzinoši zema - ir tikušas izmantotas dažādas metodes, nereti trūkst mērījumu punktu precīza piesaiste, ir ievērojama laika starpība starp dažādiem mērījumiem, un laika gaitā mainījušies vides apstākḷi. Lai gan šajos pētijjumos ir uzkrāts ievērojams faktu materiāls, to apkopojumi nesniedz jaunas zināšanas, un šie materiāli ir ierobežoti izmantojami tālākai detalizācijai vai regiionalizācijai. Turpinot faktu materiāla uzkrāšanu vai papildinot vēsturiskos mērījumus ar metodiski jauniem mērījumiem, nav iespējams papildināt jau esošās zināšanas. Tādēḷ Latvijas kvartārsegas nogulumu pazemes ūdeņu rajonēšanai ir jāmeklē jaunas metodiskas pieejas, jauni kritēriji un pazīmes.

Pazemes ūdeņu spiediens, ko vienkāršoti sauc par ūdens līmeni, ir visjūtīgākais parametrs pazemes ūdeņu raksturošanā. To ietekmē daudzi faktori (iežu granulometriskais sastāvs, reljefs, klimatiskie un hidrogrāfiskie rādītāji uc.), kādēḷ tas ir l̦oti mainīgs un to ir nelietderīgi izmantot kā rajonēšanas pazīmi. Tajā pašā laikā pazemes ūdeņu spiediena (līmeņa) mērījumi ir neaizstājami vietēja mēroga pētījumos. Nenoliedzami, ka vietēja mēroga pazemes ūdeņu spiediena kartogrāfiskus attēlus ir iespējams ǵeneralizēt, bet tādējādi ir iespējams piel̦aut lielas kḷūdas, jo, veicot šādu procedūru nevilšus tiek izmantotas priekšzināšanas par teritorijas vispārīgo uzbūvi, ņemti vērā blakusapstākḷi, un iegūtie rezultāti būs ar zemu pievienoto vērtību.

Pašlaik mūsu rīcībā nav pietiekami daudz zināšanu, kā, pārejot no gruntsūdens līmeņu mērīšanas no zemes virsmas uz gruntsūdens spiediena mērījumiem, būtu iegūstami reǵionalizācijai izmantojami kritēriji, un tas būtu pētāms nākotnē.

Līdzīgi arī kvartārsegas nogulumu pazemes ūdeņu ķīmiskais sastāvs tieši nav izmantojams regiionalizācijā vairāku iemeslu dēḷ, jo:

$\checkmark \quad$ tas ir loti jūtīgs pret antropogēnām ietekmēm, un ne vienmēr ir iespējams droši nodalīt ietekmju apjomu,

$\checkmark$ ķ̄imisko sastāvu ietekmē daudzi dabas faktori, tas ir zināms no iepriekšējiem pētījumiem par pazemes ūdeņu aizsargātību,

$\checkmark$ ķīmiskā sastāva veidošanās norit trīs zonās - aerācijas zonā notiek oksidēšanās, ūdeṇi bagātinās ar silīcija savienojumiem, karbonātiem, pašreizējie dati, kas ir mūsu rīcībā, liecina, ka gruntsūdens līmen̄̄ un kapilārās pacelšanās zonā notiek visintensīvākās ķīmiskā sastāva 
izmaiṇas, mainoties oksidēšanās - reducēšanās apstākḷiem, bet dziḷāk, gruntsūdens slāṇos, pārsvarā notiek sajaukšanās un sastāva izlīdzināšanās procesi.

Kopumā Latvijas kvartārsegas nogulumu ūdeņiem nav būtiskas ķīmiskā sastāva atšķirības dažādos reǵionos. Iespējams, ka dažādu procesu norise kapilārajā zonā varētu būt rajonēšanas pazīme, bet mūsu rīcībā vēl nav pietiekami jūtīgu pētījuma metožu, kas lautu noteikt kritērijus procesu pamatotām reǵionālām konstrukcijām.

Pašreizējās zināšanas l̦auj veikt Latvijas kvartārsegas nogulumu ūdeṇu rajonēšanu pēc pazīmēm, kas ir netieši iekḷautas arī citās rajonēšanās, pēc drenētības apstākḷiem, augāja, īpaši koku stāva īpatn̄īām, geomorfoloğiskiem elementiem, klimatiskiem apstākḷiem. Izdalot rajonus pēc minētajām paz̄mēem, iezīmējas teritorijas, kas ir vizuāli līdzīgas dabas apvidu kartēs izdalītajām. Tas netieši apliecina gan sekli iegulošo pazemes ūdeņu lomu dabas apvidu atšksirībās, gan ainavisko pazīmju nozīmīgumu, uzrādot pazemes ūdeņu reǵionālās atšķirīibas.

\title{
PAZEMES ŪDEN̦U PĒTĪJUMU VĒSTURE LATVIJĀ
}

\author{
Aija DÉLIN̦A \\ LU Ģeogrāfijas un Zemes zinātnuu fakultāte, \\ e-pasts: aija.delina@lu.lv
}

Rakstiskas ziņas par Latvijas pazemes ūdeņiem, galvenokārt par minerālūdenuu dabiskajām izplūdes vietām, ir zināmas jau kopš 18.gadsimta beigām. Tie ir dabas pētnieku pieraksti par novērojumiem atsevišķos punktos, kur pazemes ūdeñiem ir zināmas kādas atšķirīgas, specifiskas īpašības, turklāt pētîtas un aprakstītas tiek tikai pazemes ūdeṇu dabiskās izplūdes vietas zemes virspusē. Sistemātiski pazemes ūdeņu, arī kvartāra nogulumu ūdeņu, pētījumi Latvijā aizsākās 19.gs, un par tiem ir pieejami atšķirīgas kvalitātes un detalizācijas pētījumu un novērojumu apraksti. 18.un 19.gs. pazemes ūdeņu izpētes vēsture Latvijā ir līdzịga kā citur Rietumeiropāa, bet 20.gs. sākumā pazemes ūdenuu pētījumi Latvijā, īpaši Baltezera apkārtnē, ir vieni no modernākajiem tā laika Eiropā, un te strādā augsti kvalificēti speciālisti, piemēram, Tīms, Bīmanis, Smrekers u.c. Situācija mainās 20.gs. vidū, mainoties valstiskajai iekārtai Latvijā. Pētījumi ir l̦oti plaši, aptveroši un detāli, tikai dažādu metožu pielietojums nereti atšķ̧iras no citur pasaulē tai laikā pieņemtā.

Pazemes ūdeņu pētījumos Latvijā var izdalīt vairākus etapus, kuros atšķiras pētîjumu objekti un pētījumu metodes.

Plašie pazemes ūdeņu pētījumi Latvijā ir snieguši visaptverošu informāciju par Latvijas hidrog̉eolog̣iskajiem apstākḷiem, pazemes ūdeņu raksturīgām iezīmēm un īpatnībām, bet turpmāk, ņemot vērā pētījumu virzienus citur pasaulē, būtu paplašināmi pazemes ūdeņos noritošo procesu in situ pētījumi. 
Pazemes ūdeṇu pētījumu etapi Latvijā

\begin{tabular}{|c|c|}
\hline Etaps & Īss raksturojums \\
\hline $\begin{array}{l}\text { 18.gs. beigas - } \\
\text { 19.gs. sākums }\end{array}$ & $\begin{array}{l}\text { Punktveida empīriski novērojumi. Tiek pētītas pazemes ūdencu izplūdes } \\
\text { vietas zemes virspusē (avoti), aprakstīta avotu apkārtne, ūdens daudzums, } \\
\text { ùdens organoleptiskās īpašības, temperatūra. }\end{array}$ \\
\hline 19.gs. & $\begin{array}{l}\text { Punktveida empīriski novērojumi un pētījumi. Tiek pētītas pazemes ūdencu } \\
\text { izplūdes vietas zemes virspusē un gruntsūdeņi. Papildus iepriekšêjiem tiek } \\
\text { pētîts arī vispārīgs kị̄miskais sastāvs (makrokomponenti). }\end{array}$ \\
\hline $\begin{array}{l}\text { 19.gs. beigas - } \\
\text { 20.gs. vidus }\end{array}$ & $\begin{array}{l}\text { Areāli pētījumi. Pētījumi tiek veikti vairākos ūdens horizontos, } \\
\text { pārsniedzot } 100 \mathrm{~m} \text { dzil̦umu. Tiek pētīti pazemes ūdeñu resursi, režīms, } \\
\text { sastāvs. Pētījumi galvenokārt tiek veikti ūdensapgādes un meliorācijas } \\
\text { problēmu risināšanai, kā arī vietējo balneologisko resursu izpētei. }\end{array}$ \\
\hline $\begin{array}{l}\text { 20.gs. vidus (pēc } \\
\text { II Pasaules kara) - } \\
\text { 20.gs. beigas }\end{array}$ & 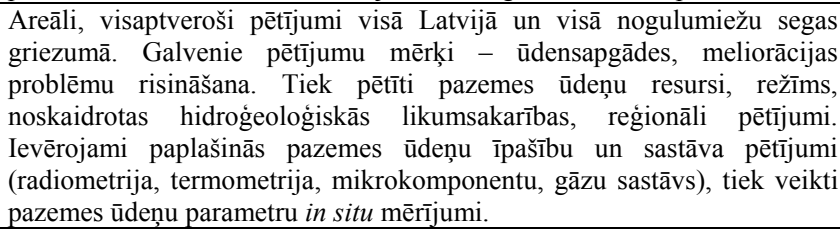 \\
\hline $\begin{array}{l}\text { 20.gs. beigas - } \\
\text { 21.gs. sākums }\end{array}$ & 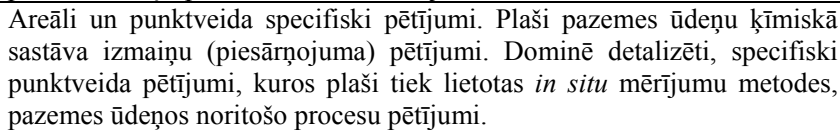 \\
\hline
\end{tabular}

\title{
SENAIS BURTNIEKS UN TĀ LITMEN̦A IZMAIN̦U PALEOHIDROLOĢISKĀ REKONSTRUKCIJA
}

\author{
Guntis EBERHARDS \\ Latvijas Universitāte, Ģeogrāfijas un Zemes zinātņu fakultāte, \\ e-pasts: guntise@navigator.Iv
}

\section{Galvenie etapi}

$\checkmark$ Pēdējā apledojuma segledāja degradācijas sākums Burtnieka ezerdobes rajonā. Aprimušā ledus izkušana uz augsto drumlinu korēm (13.313.1 tūkst.g.a.), vairākus desmitus metru bieza „mirušā”, apraktā ledus saglabāšanās plašajā ieplakā un starpdrumlinu pazeminājumos.

$\checkmark$ Virsledus kušanas ūdeņu baseina izveidošanās, galvenokārt ledus krastos, māla un aleirìta uzkrāšanās.

$\checkmark$ Plašā virsledus baseina samazināšanās un tā līmeņa pazemināšanās, kušanas ūdeņu straumju ieplūšana un smilšaini-aleirītisku nogulumu uzkrāšanās. Gar drumlinu nogāzēm fragmentāri iezīmējas pirmās vāji izveidotās virsledus baseina krasta linijas (53-52,50 m).

$\checkmark$ Pakāpeniska ezerdobē apraktā ledus izkušana, inversijas reljefa formu rašanās, vienota plašā senā Burtnieka izveidošanās (alerodā?) ar seklāko ziemel̦u daļu (Ziemel̦u ezeru) un dziļo dienvidu dalı. Izrobota krasta līnija, daudzas pussalas un salas. Krasta līnija 47-46 m vjl .(7-6 m virs tagadējā līmeña). 
Apraktā ledus masām izkūstot Sedas ielejveida pazeminājumā, uz Burtnieku noplūst Burgas palieku ezera (atradās tagadējā Sedas purva rajonā) ūdeņi, veidojas Sedas ieleja un plašā Sedas delta, kas garo Burtnieku sadala divās atšķirīgās dal̦ās (krasta līnija 44,5-44 m vjl.). Ezera ūdeņiem ieplūstot regresējošā Vidussalacas pieledāja baseinā, veidojas Salacas ieleja lejpus Mazsalacas.

$\checkmark$ Senā, plašā Burtnieku ezera izzušana ( $\mathrm{DR}_{3}$ laikā?), glaciolimnisko smiltāju pārpūšana, iekšzemes kāpu veidošanās gar ezerieplakas DA, A malu, arī bijušā Ziemel̦u ezera dibenā.

$\checkmark$ Ezera atjaunošanās PB-BO laikā (10-8,8 tūkst.g.a.), vairākkārtējas nelielas amplitūdas (1-3 m) ezera līmeṇa svārstības mainīgo klimatisko apstākḷu ietekmē, Salacas iegraušanās.

$\checkmark$ Atkārtota plašā Burtnieka ezera akvatorijas samazināšanās un līmeņa pazemināšanās (līdz 41 m vjl.) BO laikā (8,8-8,1 tūkst. g.a.). Sausa, relatīvi barga klimata apstākḷ̆os sfagnu sūnu, detrīta un kūdras kārtinu uzkrāšanās Sedas deltas gultnēs, gar ezerieplaku (Zvejnieku un Silzemnieku pussalas). Saglabājas lokāli, nelieli ezeriņi.

$\checkmark$ Atlantiskā klimatiskā optimuma apstākļos Burtnieks atjaunojas, daḷēji appludina bijušā Ziemel̦u ezera ieplaku līdz Rūnu pussalai, pārējā tās dạ̦ā vairāki Rūjas caurtekoši ezeri. Krasta līnija 43,5-43 m vjl. Turpinās Sedas deltas pagarināšanās un paplašināšanās, veidojas neskaitāmas attekas ar ezeriniem, salinas un pussalas.

$\checkmark$ Sākot ar atlantisko laiku, Salacai lēnām iegraužoties, vidējais ezera līmenis lēni pazeminās, bet pēdējo 2-2,5 tūkst. gadu laikā pieaug līdz ar nogulumu uzkrāšanos un seklās ezerieplakas pārpurvošanos.

$\checkmark$ Mūsdienu etapā (pagājušajā gadsimtā) radikāla antropogēnā iedarbība: ezera līmen̦a pazemināšana (1929.g.) par $1 \mathrm{~m}$, upju un strautu iztaisnošana, mežu un ieplaku meliorācija, seklā ezera strauja eitrofikācija un aizaugšana, pakāpeniska ezera vidējā līmen̦a celšanās.

\section{DAUGAVAS KRASTU STĀVOKLIS UN EROZIJAS RISKA VIETAS RĪGAS HES LEJASBJEFĀ}

\section{Guntis EBERHARDS, Baiba SALTUPE}

Latvijas Universitāte, Ģeogrāfijas un Zemes zinātņu fakultāte, e-pasts: guntise@navigator.Iv

Daugavas gultnes un krastu erozijas vietu sadalījumu un procesu intensitāti HES darbības rezultātā nosaka gultnes un krastu geolog̣iskā uzbūve un atšķirīgo iežu izskalojamība, arī pirms HES uzcelšanas un vēlākajos gados veiktie apdraudēto krastu nostiprinājumi un to izvietojums. Minimāla loma peldošo ledu 
ārdošajai darbībai palu laikā, dabiskajiem nogāžu un sala procesiem, regulārajām ūdenslīmeņa svārstībām un dabiskajam krastu apaugumam.

Krastu apsekošana un kartēšana parādīja, ka krastu erozijai ir lokāls raksturs. Ap 16 km garajā lejteces posmā līdz Vanšu tiltam Rīgā tiešai straumes iedarbībai un erozijas riskam pakḷauti tikai 5 iecirkṇi $1,8 \mathrm{~km}$ kopgarumā (5\% no abu Cel̦a Daugavas krastu kopgaruma).

Pēc gultnes un krastu ǵeolog̣iskās uzbūves īpatnībām un krastu erozijas Daugava Rīgas HES lejasbjefā sadalās 3 atšķirīgos posmos. Pirmais posms (1$1,5 \mathrm{~km}$ ) tieši lejpus HES aizsprosta: upes gultni un krastus veido cieti, praktiski vāji erodējami pamatieži (Daugavas svītas dolomīti, dolomītmerğel̦i). Otrais posms līdz Ķengaragam-Katlakalnam (ap $6 \mathrm{~km}$ ). Daugavas gultne, arī krasti erodēti pamatiežos (Salaspils un Pḷavinuu svītas), garākos iecirkṇos pamatiežu virsa ieslīgst 1-2 m zem upes līmeña (vietās, kur izplatīti Salaspils svītas māli un merğelii), krastus veido viegli izskalojami smilšaini grantaini un mālaini aluviālie upes terašu nogulumi. Galvenie krastu erozijas iecirkṇi. Trešais posms no Zaķu un Lucavsalas augšgala līdz Vanšu tiltam. Daugavas gultnē un krastos irdeni, main̄̄ga sastāva, viegli izskalojami aluviālie, iekšêjās deltas un lagūnu smilšaini grantainie, dūņainie un mālainie nogulumi. Galvenās Daugavas straumes krastu eroziju novērš dažādos laikos ar dažādām konstrukcijām veiktie krasta nostiprinājumi. Lokālos nenostiprinātos iecirkņos vai vietās, kur krastu stiprinājums ir bojāts, spēcīgu vētru laikā notiek pakāpeniska krasta noārdīšana vilı̧u darbības dēl. Nav datu par Daugavas gultnes dziļumeroziju.

Pēc erozijas riska Daugavas posmu sadalījums šāds: 1.posmā - gultne un krasti relatīvi stabili, nenozīmīgs iespējamais erozijas risks. 2.posmā - lokālos 200-300 m garos iecirkṇos, kur gultni pavada akumulatīvas Daugavas terases, ir paaugstināta erozijas riska vietas ar apbūves un infrastruktūras (ceļu, ielu) apdraudējumu, lauksaimniecības zemju un apbūves platību (Doles sala) noskalošanas risks. Lielākajā dạ̦ā erozijas apdraudēto krastu (Dārziņu rajons Latgales priekšpilsētā) nostiprināti, bet reāli apdraudētos četros iecirkṇos nepieciešami neatliekami krastu nostiprināšanas darbi. 3.posmā potenciāls Daugavas gultnes dziļumerozijas risks un iespējama krasta stiprinājumu (arī Rīgas centra krastmalu) aizsargfunkciju zaudēšana. Nav zināma pagājušāā gadsimtā ar atšksirīgām metodēm un tehnologijām nostiprināto būvju kvalitāte un tagadējā drošība.

Nepieciešami atkārtoti Daugavas gultnes dziļummērījumi, batimetrisko plānu sastādī̌sana, Daugavas gultnes dziļumerozijas un nostiprināto krastu zemūdens daļas grunšu stabilitātes novērtējums. 


\title{
SMAGO MINERĀLU GRAUDU VIRSMAS MORFOLOĢIJA KĀ INDIKATORPAZĪME KLASTISKO IEŽU SEDIMENTOĢENËZĒ
}

\author{
Vija HODIREVA \\ LU Ģeoloǵijas institūts, e-pasts: vhodirev@lanet.Iv
}

Veicot Latvijas klastisko iežu (galvenokārt augšdevona un kvartāra vecuma) mineraloǵiskos pētījumus, par oriǵinālu un aktuālu jāatzīst jauniegūtā informācija par smago minerālu graudu virsmas morfologiju. Šādi detalizēti pētījumi Latvijā sākti tikai nesen. Analizējot vairāku plašāk izplatīto smago minerālu graudu virsmu īpatnības, bija iespējams konstatēt nogulumu materiāla iespējamos transportēšanas veidus, kā arī izsekot izmaināām pēcsedimentācijas procesā.

Ļoti izteiktas indikatorpazīmes novēro uz daudzu granātu grupas minerālu graudu virsmām. Piemēram, piropa un almandīnpiropa veidošanās un izmainas dažādos endogēnos un eksogēnos apstākļıs atspoguḷojas to ārējā izskatā. Var izdalīt primārās piropa graudu formas, kuras minerāls iegūst magmatiskajā minerālveidošanās stadijā vai kimberlīta diatrēmas veidošanās un attīstības laikā, un sekundārās, kas saistītas ar minerāla pārveidošanos dažādos hipergēnos apstākḷos.

Visbiežāk var diagnosticēt četru paveidu piropu graudu primārās virsmas formas, kas atbilst šādām stadijām:

1) augšanas stadija magmatiskajā kausējumā. Šai stadijai atbilst idiomorfi kristāli ar izteiktām skaldnēm; 2) apkušanas stadija magmatiskajā cilmvietā. Šīs stadijas laikā pirops iegūst raksturīgo ovālo formu, bet uz tā virsmas veidojas lēzeni izcilnīši, adatveida izciln̄̄̄si, līkumainas lēzenas kores. Graudu virsma kḷūst vil̦naina; 3) kelefitizācijas stadija, kuras laikā granāts nonāk pazemināta spiediena un gaistošo savienojumu aktīvā ietekmē. Ap granātu veidojas kelefïta apvalks, kura biezums parasti ir mazāks par milimetru; 4) hidrotermālās pārstrādes stadija. Granāts plaisā, notiek graudu lobīšanās, un veidojas šķ̄̌šanas mikroreljefs, grauds iegūst savdabīgu virsmu.

Minētās smago minerālu graudu formas sedimentoǵenēzē saglabājas, ja to pārnese nav bijusi tāla.

Sekundārās graudu virsmas formas var iedalīt ar šḳišsanu saistītās un formās, kas veidojušās mehāniskās apstrādes rezultātā. Granātiem var izdalīt trīs šķı̄šanas morfolog̣iskos tipus - dislokācijas, kuboīdu un piramidālipakāpienveida. Dislokācijas šksišanas rezultātā veidojas negatīvas reljefa formas kapilāru un ķ̣̄lveida kanālu izskatā, kā rezultātā grauds iegūst bālu, emaljai līdzīgu izskatu. Kuboidālais šķ̄̌šanas tips raksturīgs ar pārsvarā pozitīvu reljefa formu veidošanos kuboīdu formā. Piramidālajam-pakāpienveida šķ̄̌šanas tipam raksturīga nošķeltu vai smailu piramīdu reljefa veidošanās uz graudu virsmas, piramīdu virsma līdzīga rombododekaedram. Dažādiem autoriem šksišsanas formu terminolog̣ija un klasifikācija var būt atšksirīga. Pie tam daudzi pētnieki dažas no aprakstītajām virsmas formām nesaista ar šks̄išanu, bet gan ar augšanu, par ko pasaules ǵgeologu diskusija turpinās. 
Terigēnajā sedimentoǵenēzē mehāniskā graudu apstrāde rada uz to virsmas dažādus nošķēlumus, robus, skrambas. Reizēm, ņemot vērā raksturīgās pazīmes, izdodas atšķirt ledāju, alūvija, pludmales, eolos un citus apstrādes veidus. Piemēram, ledājiem raksturīgas sarežğîtas uzbūves virsmas ar lieliem nošķēlumiem, arkveida, paralēliem vai subparalēliem pakāpieniem. Graudiem, kuri pārnesti ūdens un ledāja vidē, raksturīgi sīki robinini, mazas un seklas rievas, skrāpējumi, sīki bḷodveida atšķēelumi. Pludmales tipa apstrādes veidam raksturīgas tās pašas formas, kas upju un ledāju kušanas ūdeñu straumēm, tikai graudu reljefs nav tik izteikts, robiṇu un skrāpējumu izmēri niecīgāki, bet to skaits lielāks, kā rezultātā grauds iegūst sīkgrubuḷainu, matētu virsmu.

Latvijā granātu grupas minerāli, īpaši piropi, ir konstatēti augšdevona Gaujas, Ogres, Mūru, Žagares, Ketleru, Šķervel̦a svītās un kvartāra nogulumos. Detalizēti tie pētīti iespējamajos dimanta pavadonnminerālu starpkolektoros Gaujas, Ogres, Ketleru svītās un kvartāra sistēmā. Dažu raksturīgāko Latvijas piropu graudu SEM mikrofotogrāfijas apkopotas attēlā.
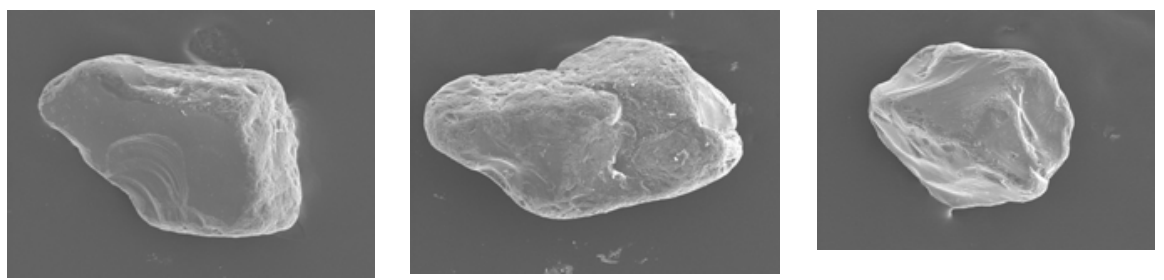

Att. Ogres svītas klastisko iežu piropa graudi: a) maz nodeldēts; b) l’oti izmainīts. Grauda lielākā daļa ķ̄imiski korodēta. Vēl saglabājušās agrīnās plaisāšanas virsmas, kas rada grauda neregulāro formu; c) ar sīkākiem nošķēlumiem, parasti veidojas materiāla pārneses procesā ūdens straumē. Frakcija 0,5-0,25 mm.

\title{
VIDZEMES KLASTISKO IEŽU CIRKONU UN GRANĀTU TIPOMORFĀS PAZĪMES
}

\author{
Vija HODIREVA, Indra ZVIEDRE \\ LU Ģeoloǵijas institūts, \\ e-pasts: vhodirev@lanet.Iv; indra.zviedre@vgd.gov.Iv
}

Pētot klastisko iežu minerālu tipomorfismu, var iegūt informāciju par minerālu genēzi - sastāva izmaiņām, transporta un sedimentācijas vidi. Tipomorfās pazìmes palīdz noskaidrot minerālu vecumu un cilmavotu.

Cirkonu un granātu tipomorfās pazīmes un to izmaiņas pētītas atšķirīga vecuma un genēzes klastiskajos iežos Vidzemē. Dabīgais smago minerālu koncentrāts paraugots atšķirīgas ǵenēzes - aluviālajos (Kaibala), limniskajos (Ķī̌sezers) un marīnajos (Saulkrasti) kvartāra klastiskajos nogulumos. Smagiem minerāliem bagāti slāņi paraugoti devona perioda Gaujas svītas smilšakmens 
atsegumos Bāles smilšu karjerā (Bāle 2, Bāle 10) un Kankarīšu iez̄i (Kankarīši 4, Kankarǐši 5).

Cirkonu un granātu tipomorfās pazīmes noteiktas kvartāra klastisko iežu nemagnētiskajā frakcijā 0,3-0,2 mm un devona (tikai cirkona) klastisko iežu nemagnētiskajā frakcijā $0,16-0,1 \mathrm{~mm}$. No katra parauga atlasīti 200 minerāla graudi, kuri iedalìti pēc noteiktām pazīmēm.

Pazīmes izdalītas, ņemot vērā galvenās īpašības, kas liecina par minerālu ǵenēzi, t.i., graudu noapalıotība, forma, virsmas reljefa īpatnības, krāsa, caurspīdība un iekḷāvumi.

Cirkoni gan kvartāra, gan devona iežos ir līdzīgas noapalıtības pakāpes vidēji šķautņains vai vidēji noapaļots (35-47\% no kopējā graudu skaita) un vairāk nekā puse graudu ir ieapaļas formas (1.att.).

Kvartāra nogulumos cirkons visbiežāk sastopams bezkrāsains, gaiši dzeltens un pelēks, ieapaļas un apaļas formas graudinu veidā (58\%-68\%). Raksturīgas arī iegarenas, garenas (prizmatiski kristāli), ovālas formas (30\%-38\%). Reti sastop plākšn,veida graudus ar izteiktu plaisainību ( $2 \%-5 \%$ no kopējā graudu skaita).

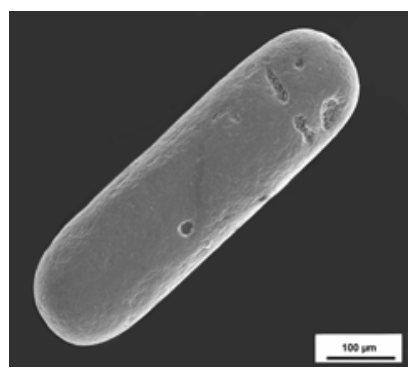

1.att. Labi noapaḷots cirkona grauds no aluviāliem nogulumiem

(paraugs - Kaibala, frakcija 0,2-0,16 mm)

Devona vecuma nogulumu smago minerālu asociācijā cirkona garudi ir dažādas noapalıotības, izṇemot labi noapalıotus. Biežāk sastop ieapaļas formas paveidus - 51\% līdz $68 \%$ no kopèjā graudu skaita. Iegarenie paveidi aizṇem attiecīgi 33\% līdz 48,5\% no cirkona daudzuma paraugā.

Daudzveidīga ir cirkona krāsa augšdevona klastisko iežu smago minerālu asociācijā. Neatkarīgi no grauda apveida, noapalotības pakāpes un caurspīdības, cirkoni mēdz būt bezkrāsaini, gaiši dzelteni, rozā, pelēki. Sastop arī sarkanbrūnus cirkonus, kas vizuāli līdzīgi tumšiem granātiem. Nosakot ķīmisko sastāvu, konstatēts, ka šie cirkona paveidi satur hafniju (Hf). Iespējams, to izcelsme saistīta ar kembrija vecuma nogulumiem.

Kvartāra kliedṇu smago minerālu asociācijā visbiežāk sastop asšḳautnainus granātus. Graudu noapalsotības pakāpei pieaugot, samazinās šādu graudu skaits un tendence ir konstatèta visos paraugos (2.att.). Praktiski nav sastopamas kristālu daudzskaldņu, idiomorfas formas graudi. 


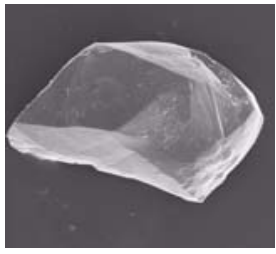

a)

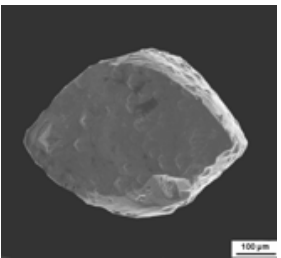

b)

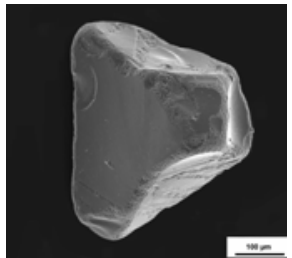

c)

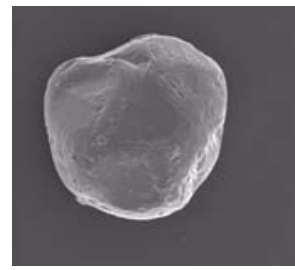

d)

2.att. Granātu graudi: a) asšķautņains granāts ar gludu virsmu, palielinājums 200x (V.Hodirevas foto); b) šķautņains granāts ar skulpturētu virsmu (paraugs - Saulkrasti, frakcija 0,4-0,3 mm); c) vidēji šķautņains granāta grauds (V.Hodirevas foto); d) vidēji noapaḷots granāts, palielinājums 200x (V.Hodirevas foto).

Granātu graudi nemagnētiskajā frakcijā $0,4-0,3 \mathrm{~mm}$ visbiežāk ir asšķautņaini - 53,5\% līdz 73\% no kopējā graudu skaita, no kuriem 10\%-14\% ir ar skulpturētu virsmu. Samērā bieži, neatkarīgi no noapaļotības pakāpes, tajos ir tumšo minerālu iekḷāvumi, apmēram 7\%-17\% no kopējā graudu skaita.

Devona perioda klastiskie ieži tikuši vairākkārt pārskaloti, un atšķirībā no kvartāra kliedņiem to minerālu graudi ir labāk noapaļoti, matētu virsmu, samazinātu caurspīdību un bieži tumšākā krāsā.

Kvartāra klastiskajos iežos sastopamie cirkoni un granāti ir daudzveidīgākas formas un noapalıtōibas pakāpes.

\section{CENAS TITREĻA ATTİSTİBAS DINAMIKA UN TO IETEKMĒJOŠIE FAKTORI}

\section{Laimdota KALNIN̦A}

LU Ģeogrāfijas un Zemes zinātņu fakultāte, e-pasts: Laimdota.Kalnina@lu.Iv.

\section{Agris LĀCIS}

Valsts ǵeoloǵijas dienests, e-pasts: agris.lacis@vgd.gov.Iv

\section{Georgs SIČOVS}

SIA "Baltijas Zemes resursi", e-pasts: geo@geo.Iv

Anete DIN̦ĶITTE

SIA "Balt-Ost-Geo"

\section{Līga BËRTULSONE}

LU Ģeogrāfijas un Zemes zinātņu fakultāte, e-pasts: ligab@L4.Iv

Stella AL̨UKËVIČA

LU Ģeogrāfijas un Zemes zinātņu fakultāte

Cenas tīrelis atrodas Viduslatvijas zemienes Tīrelı līdzenumā. Cenas tīrelis kā dabīgs purvs pēc platības ir bijis Latvijā otrais lielākais aiz Teiču purva. Pēc Kūdras fonda datiem, Cenas tīrel̦a (KF nr.1691) platība pārsniedz 10600 ha. 
Kūdras izstrādes un meliorācijas rezultātā pašlaik no tā neskartā stāvoklī ir palikušas tikai Cenas tīrel̦a (2 133 ha) un Melnā ezera (317 ha) dabas liegumi, kā arī teritorija izpētes teritorijas ziemel̦dạ̦ā uz dienvidiem no Jaunmārupes. Teritorija, kas atrodas dienvidaustrumos no Cenas tīrel̦a dabas lieguma, pagaidām vēl ir neskarta, taču tā iekḷauta ieguvei plānoto un kūdras fabrikas "Olaines kūdra" iznomāto teritoriju sarakstā.

Purva dienvidu un austrumu, bet vēlāk arī ziemeḷietumu daḷā sagatavoti kūdras ieguves lauki, un dažos no tiem kūdras ieguve sākta jau vairāk nekā pirms 40 gadiem. Kūdras ieguve Cenas tīrelī turpinās arī šobrīd, bet tās apjoms samazinās. Kūdras ieguves apjoms 2002.gadā bija 62 tūkstoši tonnu, bet 2001.gadā - tikai 25 tūkstoši tonnu. Purva dienviddaļā atsevišķi lauki jau ir pilnībā izstrādāti un veikta to rekultivācija, ierīkojot ganības vai citādi šo teritoriju izmantojot lauksaimniecībā. Pēdējos gados lauki, kur tiek pārtraukta kūdras ieguve, tiek atstāti purva renovācijai (purva pašatjaunošanās).

Pēc Baltijas ledus ezera regresijas, pirms 11 000-10 500 gadiem, purva vietā palika viļ̣nots līdzenums. Cenas tīrẹ̦a vietā bija izveidojies plašs reljefa pazeminājums, kura virsmas absolūtā augstuma atzīmes svārstījās no 6,8 līdz 7,2 m, bet šīs plašās ieplakas malas pacēlās līdz 9,0-9,5 m. Nevienmērīgās akumulācijas ieplaku un tās krastus pārsvarā veido smalkas un putekḷainas smiltis, bet atsevišķās vietās arī mālsmilts. Šie kvartāra nogulumi, kuru biezums sasniedz 15 m, brīvi l̦āva iefiltrēties atmosfēras nokrišn,iem, gruntsūdens iegūla salīdzinoši dziḷi, un tādē neveidojās pārmitri apstākḷi, kas veicinātu kūdras uzkrāšanos un purva veidošanos.

Par purva izveidošanos laiku mitruma sastrēguma joslā starp tagadējo Baltijas jūras krastu un senajiem krastu veidojumiem liecina zemā tipa kūdras ${ }^{14} \mathrm{C}$ datējumi, kas norāda, ka šis slānis veidojies pirms 4331£66 gadiem. Šai laikā, paaugstinoties gruntsūdens līmenim, pārmitrā pḷavā, augiem un kokiem atmirstot, sāka veidoties koku-zāl̦u kūdra, bet putekšņu diagramma atspoguḷo izmainas purva apkārtnes mežos, kuru sastāvā pakāpeniski samazinājās platlapju daudzums, kas norāda arī uz gada vidējās temperatūras pazemināšanos.

Kopš šī laika purvs “audzis” gan vertikāli, gan arī aizņēmis arvien plašāku teritoriju, līdz 20.gadsimta sākumā tas bija izveidojies par lielu augstā tipa purvu ar labi izteiktu grēdu-liekņu un grēdu-akaču mikroreljefu. Aerofoto uzñēmumos redzams, ka neskartajā Cenas tīreļa dalāâ, kur šobrīd izveidots dabas liegums, labi izdalās trīs kupoli: viens teritorijas ziemeļu dạ̦ā, otrs austrumos, bet trešais izvietots dienvidos un ir jau dalı̄eji norakts. Izvērtējot absolūtā augstuma atzīmes plānā, kupoli izsekojami pa +13 m un dal̦ēji pa +12 m horizontāli. Ieplaka, kas izdalās purva virsmā, nodala ziemeļu un dienvidu kupolus. Robeža reljefā starp abiem Cenas tīrę̧a neskartās dal̦as kupoliem un austrumu dą̧as kupolu nav izteikta. Izstrādāto un ekspluatācijā esošo kūdras lauku vidū pacel̦as Melnā ezera kupols, kura absolūtie augstumi sasniedz 13,6-13,8 m un kurš ir augstāks par Cenas tīrel̦a rietumdal̦as kupoliem. 
Purva rietumdaḷā kūdras uzkrāšanās plašajā reljefa pazeminājumā saistīta ar grunts pārpurvošanos, ko varēja sekmēt gruntsūdens celšanās, kas ieplakā radīja pārmitrus apstākḷlus un veicināja mitrumu mīlošu augu - grīšlı un niedru augšanu. To pierāda augu atliekas zemā tipa koku-grīšlı,u, koku niedru, grī̌šlu sfagnu, kā arī pārejas koku-grīšlı, grīšlı-sfagnu, koku - niedru kūdrā, kas uzgul minerālgruntij. Purva barošanās galvenokārt notika no minerālvielām bagātākajiem gruntsūdeņiem (šajā gadījumā sakarā ar to, ka substrātu veido smiltis, tie bija ievērojami nabadzīgāki kā citviet) vai arī tā barošanās bija jaukta, kur bez gruntsūdeņiem zināmu vietu ien̦ēma nokrišņu ūdeņi. Tas veicināja pārejas un dažviet pat augstā tipa kūdras veidošanos virs minerālgrunts. Kūdras pelnainība (minerāldaļiņu īpatsvars) ir maza un reti pārsniedz 5\%, bet sadalī̌sanās pakāpe mainās no $25 \mathrm{līdz} 60 \%$. Cenas tīrelis tā lielākajā daḷā veidojies, pārpurvojoties minerālgruntij, par ko liecina tas, ka kūdras iegulas pašu apakšējo dạıu veido ļoti labi sadalījusies (vairāk nekā 60\%) kūdra. Izṇēmums ir Cenas tīrę̧a austrumdaļa, ko vietām ir sedzis sekls baseins, jo zem kūdras ieguḷ līdz $0,8 \mathrm{~m}$ biezs sapropel̦a slānis. Seklajam baseinam aizaugot, ir veidojies purvs, kas aizñēmis plašu teritoriju. Domājams, ka Litorīnas jūras transgresija varēja veicināt gruntsūdens celšanos, jo tās krasta veidojumi sastopami 5-6 m virs tagadējā jūras līmeņa, kas maz atšksiras no purva pamatnes absolūtā augstuma atzīmēm (aptuveni $+7 \mathrm{~m}$ ).

Kūdras uzkrāšanās veicināja ūdens līmeņa celšanos purvā, un līdz ar to samazinājās minerālvielām salīdzinoši bagāto gruntsūdeņu ietekme. Tā saglabājās tikai ieplakas malās, kur turpināja uzkrāties zemā tipa kūdra. Lielāka nozīme purva barošanā kḷuva nokrišnu ūdeņiem, kurā minerālvielu ir ļoti maz. Tas noveda pie izmaiņām augu valstī, un sāka izzust grīşsil, niedres un koki. Tos nomainīja oligotrofie augi, starp kuriem dominē dažāda veida sfagni, dažkārt spilves. Kūdras uzkrāšanās apstākḷi nav veicinājuši tās sadalīšanos, jo sfagnu kūdras sadalīšanās pakāpe reti pārsniedz $15 \%$. Kā liecina ${ }^{14} \mathrm{C}$ augstā tipa kūdras datējumi, tā sākusi uzkrāties vismaz pirms $2464 \pm 64$ gadiem. Augstās jeb sūnu kūdras uzkrāšanās temps ir ievērojami lielāks nekā zemā tipa kūdra un sasniedz apmēram 1,3 mm gadā. Pētot vēsturiskos materiālus, var spriest, ka izstrādātajās purva platībās situācija bijusi līdzīga.

Visā purva teritorijā sākotnēji uzkrājās zemā un pārejas tipa kūdra, un to pārsedza augstā tipa kūdra. Atsevišksās vietās labvēlīgi noteces apstākḷi un paaugstinājumi purva pamatnē radījuši apstākḷus, kas kavējuši augstā tipa purviem raksturīgas augu valsts un līdz ar to arī kūdras veidošanos. Šajos apstākḷıs turpinājusi uzkrāties tikai zemā vai pārejas tipa kūdra. Savukārt atšķirīgie hidroloǵiskie apstākḷi dažviet radījuši apstākḷus straujākiem kūdras uzkrāšanās tempiem un atsevišķu kūdras kupolu izcelsmei un attīstībai.

Purvu ezeru veidošanās notikusi laikā, kad koku-grīsșlu fitocenozi nomainīja oligotrofā spilvju-sfagnu fitocenoze. Ezeru pamatnes veido kūdra, un to gultnes nesasniedz minerālgrunti. Purva ezeriņu dziḷums svārstās no 0,5 līdz 2-5 m. 
Veiktie pētījumi l̦auj secināt, ka:

$\checkmark \quad$ purvs Cenas tīrel̦a teritorijā sācis veidoties atlantiskā laika beigās, kad, paaugstinoties gruntsūdens līmenim, pārmitrā plavā, augiem un kokiem atmirstot, sāka veidoties koku-zāḷu kūdra;

$\checkmark \quad$ purva veidošanās sākumā valdīja klimatiskā optimuma apstākḷi, kas bija labvēlīgi platlapju mežu izplatībai purva apkārtnē, kā arī veicināja lielas biomasas veidošanos purva teritorijā un tās sadalīšanās procesus;

$\checkmark$ mainoties klimatam, zemā un pārejas tipa veǵetāciju subboreāla vidus posmā, kad purva apkārtnē dominēja subboreālie eg̣̣u meži, apmēram pirms 4200 gadiem, nomainīja augi, kas barojās galvenokārt ar nokrišņu ūdeñiem;

$\checkmark$ augstā purva galvenais veidotājaugs ir fuskuma sfagns, izņemot atsevišķus nelielus intervālus, kuros palielinās šaurlapu sfagna un spilves īpatsvars, bet kūdras pašā augšējā slānī daudzās vietās purvā dominē magelānsfagns.

\title{
PLUDMALES SANEŠU MEHĀNISKĀ SASTĀVA IZMAIN̦AS LATVIJAS JŪRAS KRASTA POSMĀ NO VENTSPILS LİDZ MIĶEĻTORNIM
}

\author{
Jānis LAPINSKIS, Mārtiņš GRAVA \\ Latvijas Universitāte, Ģeogrāfijas un Zemes zinātņu fakultāte, \\ e-pasts: janisI@lanet.Iv
}

20.gs. otrajā pusē ir veikti vairāki augstvērtīgi pētījumi par jūras krasta zonas specifisko nogulumu, toskait arī pludmales sanešu mehānisko sastāvu, šksirotību, noapalıotību un mineraloǵiski petrogrāfiskajām īpatnībām. Iegūtie dati tika izmantoti litomorfodinamisko procesu un reljefa formu ǵenēzes novērtēšanā, kā arī citu lietišksu jautājumu risināšanā (Ульст, 1964; Knaps, 1966; Knaps, 1982). Lai gan lielākā daḷa vispārīgo jautājumu jau ir atbildēta, trūkst kvalitatīvas un salīdzināmas informācijas par sanešu parametru izmaiṇu tendencēm ilgtermin̄ā, atklātas Baltijas jūras morfodinamisko iecirkṇu robežās.

Pētījuma vieta tika izvēlēta, ņemot vērā uz krasta posmu no Ventspils ostas ziemel̦u mola līdz Mik̦el̦tornim attiecināmo agrāko pētījumu epizodisko raksturu un šim posmam raksturīgo augsto mainību. Lauka darbi saistībā ar pludmales parametru noteikšanu un paraugu ievākšanu tika veikti 2002., 2003. un 2004.gada vasaras beigās.

Pludmalēm Latvijā ir raksturīga l̦oti izteikta sezonālā mainība: atkarībā no dominējošās viļņošanās intensitātes, gaisa temperatūras un vēja virziena notiek sanešu apmaiņa starp dažādām krasta nogāzes dal̦ām, ietekmējot pludmales sanešu sastāvu un daudzumu dažādās tās dal̦ās. Paralēli notiek arī sanešu apmaiṇa krastam paralēlā vērsumā (Komar, 1998; Aubrey, 1979). Tāpēc, analizējot sanešu 
mehāniskā (granulometriskā) sastāva izmaiņas viena ar litodinamiskajām barjerām norobežota krasta iecirkņa ietvaros, var spriest par dominējošo sanešu kustības virzienu, deficīta zonām un galvenajiem sanešu plūsmas papildināšanās avotiem. Ilgtermiņa pētījumi savukārt dod iespēju konstatēt un novērtēt iespējamās izmaiņas apskatāmajā krasta iecirkn̄̄ kā litoǵeomorfā slēgtā sistēmā mainīgu hidrometeorologisko parametru kontekstā.

Pētījumu objekts ir apmēram $38 \mathrm{~km}$ garš krasta posms, kura pirmajos $10 \mathrm{~km}$ un Ovī̌su raga virsotnei tuvākajos divos km dominē sanešu materiāla deficīta apstākḷi, bet pārējā dạ̦ā - mainīgas intensitātes akumulācija. Deficīta posmā novērojama 3 - 18 m augsta krasta krauja, kas veidota dažāda vecuma un sastāva jūras, eolos un glacigēnos nogulumos. Pludmales platums deficīta posmā sezonāli un telpiski mainās no $5(0)$ līdz 30(35) m robežās, bet pārējā iecirkṇa dạ̧ā - no 25(10) līdz 70(100) m. Uz austrumiem no Ovī̌su raga sakarā ar krasta orientācijas izmaiņām DR-ZA virzienā vērstās garkrasta sanešu plūsmas transportspējas mazinās, bet samazinās arī DR vētru loma šīs iecirkṇa daļas attīstībā.
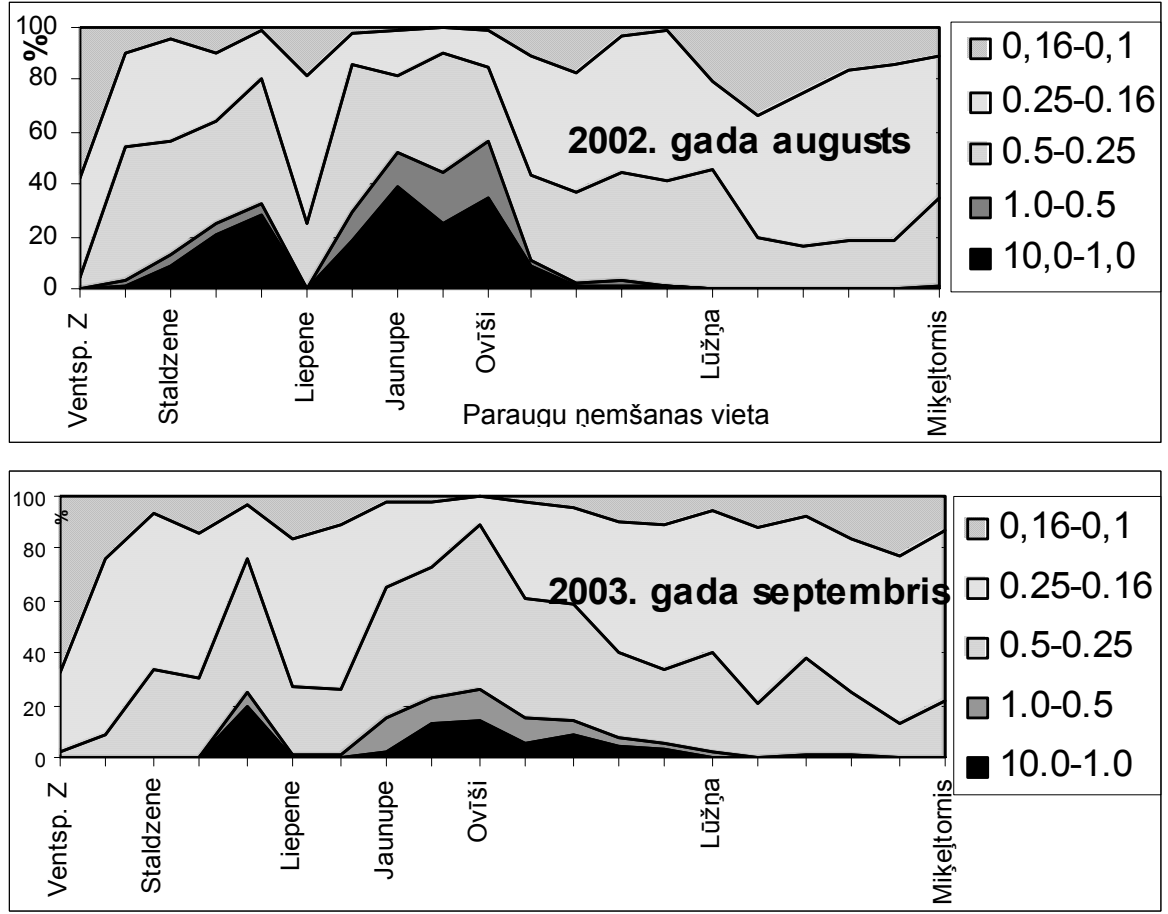


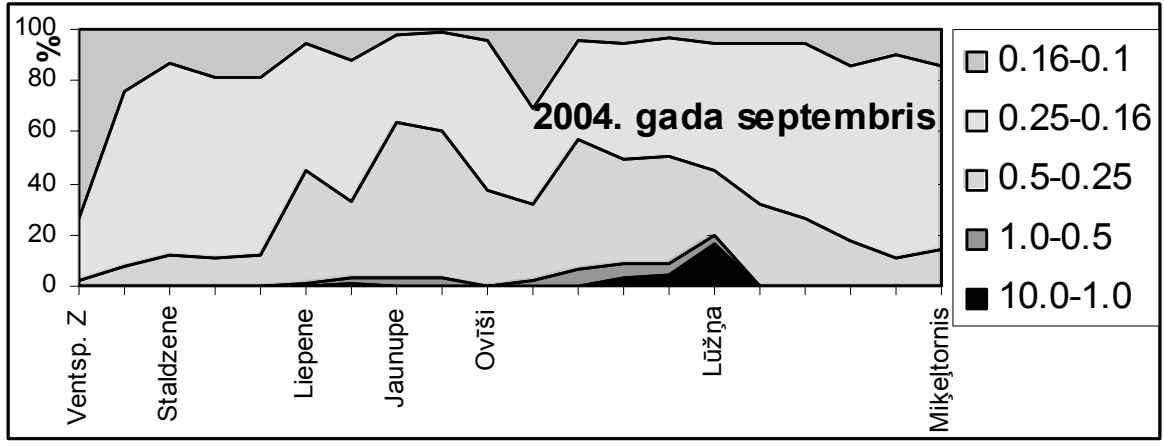

1.attēls. Pludmales sanešu mehāniskais sastāvs jūras krasta posmā Venta-Miḳeḷtornis.

Pludmales sanešu paraugi tika noṇemti 19 vietās ik pēc diviem km, katrā vietā iegūstot ,vidējo paraugu" no visā pludmales platumā izvietotiem rakumiem (Булгакова, 1982). Paraugu ǵeogrāfiskā piesaiste veikta ar GPS, atkārtoto (ikgadējo) paraugošanu veicot tajā pašā vietā ar precizitāti dabā +/-20 m. Paraugi tika sijāti LU ĢZZF Kvartārvides laboratorijāa, izmantojot standarta sietu komplektu.

Iegūtie rezultāti liecina, ka:

$\checkmark \quad$ laika posmā starp 2002.gada vasaru un 2004.gada rudeni, kad netika novērota neviena vētra un krasta nogāzes erozija praktiski nenotika, pludmales sanešu mehāniskais sastāvs ievērojami izmainījās, uzlabojoties arī tā šķirotības pakāpei;

$\checkmark$ ir notikusi smalkāko nozīmīgo sanešu frakciju $(0,50-0,10) \mathrm{mm}$ akumulācija, galvenokārt uz 0,25-0,16 frakcijas rēķina (1.att.);

$\checkmark$ paaugstināta grants un rupjo smilšu klātbūtne 2004.gadā konstatēta uz austrumiem no Ovī̌su raga - Lūžņā, pretēji šim krasta posmam tipiskajam sanešu sadalījumam, kuram raksturīga rupjo frakciju koncentrēšanās uz Ovīšu raga un uz dienvidiem no tā līdz Staldzenei;

$\checkmark \quad$ visticamāk, bezvētru perioda laikā ir notikusi būtiska smalkā sanešu materiāla migrācija pa krasta zemūdens nogāzi uz augšu, pārsedzot rupjāko frakciju materiālu, kas parasti vētru laikā tiek izskalots un nonāk apritē no zemūdens nogāzē un krasta kraujā eksponētajiem glacigēnajiem un vecākiem litorālajiem nogulumiem;

$\checkmark \quad$ tā kā saneši uz austrumiem no Ovīšu raga var nonākt tikai ar garkrasta sanešu plūsmas starpniecību, rupjo frakciju procentu pieaugumu pludmalē var izskaidrot ar:

sanešu plūsmas piesātinājuma pakāpes samazināšanos un līdz ar to mazāku šajā akumulācijas veidotajā krasta posmā nonākušā jaunā materiāla daudzumu (bezvētru perioda sekas); 
smalko frakciju pārvietošanās uz eolās akumulācijas zonām, iepriekš akumulētajiem rupjākajiem sanešiem paliekot pludmalē.

\section{Literatūra}

Aubrey, D.G., 1979. Seasonal patterns of onshore/offshore sediment movement. Journal of Geophysical Research, vol. 84. 6350 p.

Булгакова Е.А. 1982. Некоторые особенности морфологии и динамики современного берега Балтийского моря. Современные эксодинамические процессы и методы их исследования. Рига, Латвия, с. 32-56.

Кнапс Р., 1966. Перемещение наносов у берегов Восточной Балтики. Таллин, Валгус, с. 21 - 39. Кнапс Р., 1982. Влияние неровности береговой линии на вдольбереговой поток наносов. BALTICA, vol.7. Vilnius, c. 195-202.

Komar P. D. 1998. Beach processes and sedimentation. Prentice Hall, New Jersey, 544 p.

Ульст В.Г. 1964. Накопление тяжолых минералов в современных прибрежно-морских отложениях. Теоретические вопросы динамики морских берегов. Москва, Наука.

\section{BRUN̦UZIVIS ANDOMAS KALNA DEVONA NOGULUMOS}

\section{Ervīns LUKŠEVIČs}

Latvijas Universitāte, Ģeogrāfijas un Zemes zinātņu fakultāte, Ģeoloǵijas nodaļa, e-pasts: Ervins.Luksevics@lu.Iv

Daudzveidīgas mugurkaulnieku fosīlijas ievāktas Andomas kalna devona nogulumu griezumā, kas atsedzas Oņegas ezera dienvidaustrumu krastā (Krievija, Vologdas apgabals). Starp bezžokḷeņu un zivju atliekām, kas iegūtas vairākos stratigrāfiskos līmeņos no litologíiski atšķirīgiem slāņiem (Lukševičs u.c., 2005), krasi dominē bruņuzivju, īpaši antiarhu, fosīlijas. Fosīliju preparēšana turpinās, tāpēc šeit tiek sniegta tikai sākotnējā mugurkaulnieku atlieku interpretācija. Bruņuzivju klasi (Placodermi) pārstāv trīs kārtas - PTYCTODONTIDA, EUARTHRODIRA un ANTIARCHA. Ptiktodontīdu atliekas ir retas, tās (Ctenurella sp.) atrastas tikai augšējās slāņkopas apakšdaļā fosīlo mugurkaulnieku bagātākā kompleksa ietvaros. Eiartrodīru, kas galvenokārt pieder gintij Plourdosteus, atliekas sastopamas biežāk, tomēr to vertikālā izplatība arī ir samērā šaura, aptverot vidējās slāṇkopas augšdaļu un augšējās slāṇkopas apakšdaļu. Gan sugu skaita, gan atlieku daudzuma ziṇā dominē antiarhi, kas pieder divām gintīm: Asterolepis un Bothriolepis, ar vairākām sugām. Lielākoties bruņuzivju atliekas ir atsevišķi kauli un bruṇu plātņu fragmenti, tomēr sastopamas arī vairākas savstarpēji savienotas plātnes un pat pilnīgi veseli skeleti ar labi saglabājušos galvas un vidukḷa bruņām, arī acu ābolu sargājošās bruņas. Bruņuzivju taksonomiskais sastāvs ḷauj izdarīt sākotnējo secinājumu par vidējās un augšèjās slāṇkopas iespējamo vecumu kā atbilstošu Franas laikmeta sākumam. 


\title{
Literatūra
}

Lukševičs E., Stinkulis Ģ., Tovmasjana K., Zupiņš I. 2005. Andomas kalna (Krievija, Oņegas ezera DA krasts) ǵeologiskā uzbūve. LU 63.zinātniskā konference. Ģeogrāfija. Ģeologíija, Vides zinātne. Referātu tēzes.

\section{ANDOMAS KALNA (KRIEVIJA, ON̦EGAS EZERA DA KRASTS) ĢEOLOĢISKĀ UZBŪVE}

\author{
Ervīns LUKŠEVIČS ${ }^{1}$, Ģirts STINKULIS ${ }^{1}$, Kristīne TOVMASJANA ${ }^{1}$, Ivars ZUPIN̦Š ${ }^{2}$ \\ ${ }^{1}$ Latvijas Universitāte, Geogrāfijas un Zemes zinātṇu fakultāte, Geoloǵijas nodaḷa, \\ e-pasts: Ervins.Luksevics@lu.Iv, Girts.Stinkulis@lu.Iv, Kristine.Tovmasjana@lu.Iv; \\ ${ }^{2}$ Latvijas Dabas muzejs, \\ e-pasts: Ivars.Zupins@dabasmuzejs.gov.lv
}

Andomas kalns ir līdz $1 \mathrm{~km}$ garš un $1,5 \mathrm{~km}$ plats zemesrags, ievērojams reljefa pacēlums Oñegas ezera dienvidaustrumu krastā dažu simtu metru attālumā uz dienvidiem no Andomas upes ietekas, Vologdas apgabala Vitegras rajonā. Apkārt kalnam plešas neapdzīvots purvains līdzenums, bet kalnā izvietotas piecas sādžas. Andomas kalna ziemel̦u un dienvidrietumu mala veido līdz $55 \mathrm{~m}$ augsto Oñegas ezera stāvkrastu, kurā atsedzas ievērojami dislocēta, bieza devona nogulumu slānnkopa un to plānā kārtā klājošie pleistocēna nogulumi. Devona nogulumi satur daudzveidīgas organismu atliekas un pēdu fosīlijas. Andomas kalna izvietojums Galvenā devona lauka ziemel̦u malas tuvumā, slāņkopas uzbūves un dislokāciju raksturs, kā arī fosīliju daudzveidība, ir bijis pamats, lai to iekḷautu Krievijas republikas nozīmes geoloǵisko dabas pieminekḷu sarakstā.

Andomas kalna ǵeologiskā uzbūve ir samērā maz pētīta, publikācijās tiek sniegtas tikai ļoti vispārīgas ziņas par šo nogulumu vecumu un ġenēzi (Зоричева, 1973). Senākajās publikācijās Andomas kalna devona iežus pieskaitīja kontinentālo veidojumu klāstam, kaut arī tajos ir atrastas fosīlo zivju atliekas, kuras Baltijā atrodamas marīnas ğenēzes iežos. Īpatnēja nogulumu uzbūve, dislokāciju raksturs, neviennozīmīga nogulumu veidošanās apstākḷu interpretācija un bagātīgas organismu atliekas noteica nepieciešamību veikt atkārtotu ǵeoloǵisko izpēti. Detalizēti sedimentologiski paleontologíiski pētījumi, kā arī ǵeologiiskās kartēšanas darbi Andomas kalnā 2002.-2004. gadā veikti pēc Sankt-Pēterburgas Universitātes pārstāvja Aleksandra Ivanova iniciatīvas sadarbībā ar Krievijas pētniekiem. Ir sastādīts devona nogulumu griezums, veikta 10 iežu paraugu pilna granulometriskā (Jānis Lukševičs) un mineraloğiskā analīze (Angelīna Zabele), vairāk nekā 20 punktos ievāktas seno zivju un bezžokḷeņu atliekas, sagatavota Andomas kalna 1:10 000 mēroga ǵeoloǵiskā karte.

Augstākais Andomas kalna punkts atrodas $83,8 \mathrm{~m}$ virs jūras līmeņa; augstākais atseguma punkts (apmēram $76 \mathrm{~m}$ v.j.l., pēc geogrāfiskās pozicionēšanas sistēmas uztvērēja datiem) konstatēts uz ZR no Gņevaševskas sādžas, netālu no Andomas kalna augstākās virsotnes kalna ziemeḷu malas vidū. 
Devona nogulumi veido apmēram 3,5 km garu atsegumu joslu gar ezera krastu un gravās, kas lielākoties izvietotas gar vāji un stipri konsolidēto iežu slāņu kontaktiem un parasti ir izsekojamas tikai dažu desmitu metru attālumā no ezera krasta. Devona ieži veido gandrīz nepārtrauktas atsegumu sienas divos Andomas kalna nogabalos - kalna ziemel̦dạ̦ā no Oḷkovas sādžas austrumos līdz Gñevaševskas sādžai rietumos un tālāk uz rietumiem, un kalna dienvidrietumu dạ̧ā, no Pavḷikovskas sādžas ziemel̦os līdz Kļimovskas sādžai dienvidos (1.att.). Andomas raga zemā ziemel̦rietumu mala ir apaugusi ar mežu, un ezera krastā novērojami oḷu un laukakmeņu krāvumi. Devona slāņkopu šeit veido mālaini nogulumi, kuru atsegumi viegli apaug un aizbirst. Pēc devona nogulumu sastāva un uzbūves ir iespējams izdalīt trīs svītas, no kurām divas virsējās ir samērā labi raksturotas ar apakšējā Franas pastāva mugurkaulnieku kompleksiem (Иванов и др., 2003). Devona nogulumi ir spēcīgi glaciotektoniski krokoti, tie ieguḷ dažādos lenķos, krītot galvenokārt vai nu austrumu-dienvidaustrumu virzienā (azimuts 84$136^{\circ}$ ), vai arī rietumu-ziemel̦rietumu virzienā (azimuts $254-310^{\circ}$ ). Atsevišksi nogulumu bloki ieguḷ vertikāli un ir pat apvērsti. Jāatzīmē, ka kroku vērsums visā Andomas kalna teritorijā ir labi izturēts, un tas ir aptuveni perpendikulārs pleistocēna ledāju kustības virzienam šajā teritorijā (Velichko et al., 2004; Demidov et al., 2004).

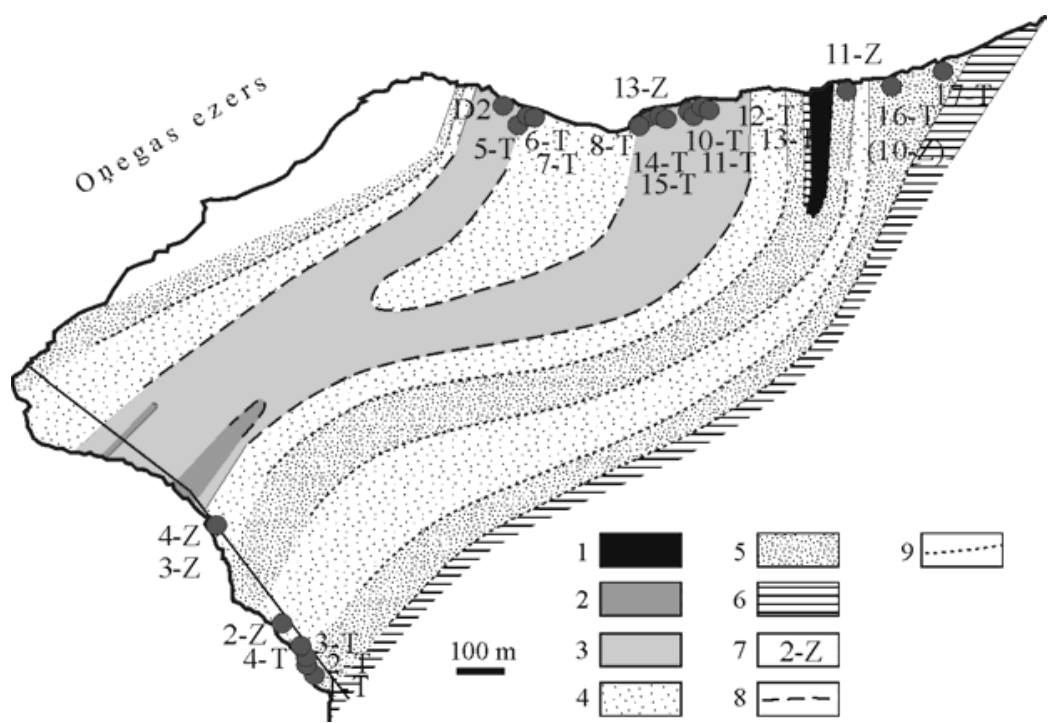

1.attēls. Devona nogulumu izplatība Andomas kalnā Oṇegas ezera krastā, Vologdas apgabals, Krievija. Apzīmējumi: 1 - brekčija (ğeologiskais vecums neskaidrs); 2-6 - devona nogulumu slāņkopas (2 - senākā, 6 - jaunākā); 7 - fosīliju ieguves vietas; 8 - iespējamo svītas ranga litostratigrāfisko vienību robežas; 9 - cita ranga slāṇkopu robežas. 


\title{
Literatūra
}

Demidov I.N., Houmark-Nielsen M., Kjær K.H., Larsen E., Lysa A., Funder S., Lunkka J.-P., Saarnisto M. 2004. Valdaian glacial maxima in the Arkhangelsk district of northwestern Russia. - In: Ehlers J. and P.L. Gibbard (eds) Quaternary Glaciations - Extent and Chronology. Elsevier B.V., pp. 321336.

Velichko A.A., Faustova M.A., Gribchenko Yu.N., Pisareva V.V., Sudakova N.G. 2004. Glaciations of the East European Plain - distribution and chronology. - In: Ehlers J. and P.L. Gibbard (eds) Quaternary Glaciations - Extent and Chronology. Elsevier B.V., pp. 337-354.

Иванов А.О., Лукшевич Э.В., Стинкулис Г.В., Безносов П.А., Зупиньш И.А. 2003. Андомская гора - уникальный геологический памятник. - Палеонтология и природопользование. Тезисы докладов XLIX сессии Палеонтологического общества. Ред. Н. В. Кручинина, Н. Г. Крымгольц. С-Петербург. 98-100 с.

Зоричева А. И. 1973. Северные районы Русской платформы. - В кн.: Девонская система (ред. Наливкин Д. В., Ржонсницкая М. А., Марковский Б. П.). Москва. $106-113$ с.

\section{HIDROĢEOLOĢISKO APSTĀKĻU IZMAIN̦AS ĶEMERU APKAIMĒ UN TO MODELÉŠANA}

\author{
Ingrīda MAL̦IKA \\ Latvijas Universitātes Ģeogrāfijas un Zemes zinātñu fakultāte, \\ e-pasts: forele@inbox.Iv
}

Par pētījuma objektu ir izvēlēti Ķemeru apkaimē esošie sērūdeñi, kuri veidojas Augšdevona Salaspils horizontā. Lai izpētītu to saistîbu ar zemāk un augstāk ieguḷošajiem pazemes un virszemes ūdeņiem, kā markiējošie tiks izmantoti neorganiskie sēra savienojumi: sērūdeṇradis un sulfătjoni. Šādu izvēli nosaka tas, ka vienīgie nozīmīgu sēra savienojumu daudzumu saturoši ieži - ğipši, ar kuriem saistīta sērūdeņraža veidošanās, Latvijas centrālajā daļā plaši izplatîti tikai Salaspils svītas iežos, bet augstāk un zemāk iegulıšajos iežos to nav vispār vai arī to daudzums un izplatība ir loti lokāla. Šo neorganisko sēra savienojumu kvantitatīvo noteikšanu veikuši arī iepriekšējie pētnieki, tāpēc šo parametru izmaiņām varēs izsekot plašā laika periodā.

Hidroǵeoloǵiskā datormodelēšana tiek veikta, izmantojot specializētu modelēšanas programmu paketi - Groundwater Vistas, ar kuru var izveidot pazemes ūdeṇu plūsmu modeli, izsekot ūdens dalinu kustībai slānī vai starp slāņiem, kā arī modelēt ūdens ķ̄ìmiskā sastāva maiņas.

Izveidotajā datormodelī būs redzamas pazemes ūdeņu izmaiņas: griezumā līdz vietējam sprostslānim starp augšdevona Pḷaviņu un Amatas ūdens horizontu, plānā - no Rīgas jūras līča ziemeḷos līdz Lielā Ķemeru tīreḷa dienvidiem dienvidos, no Lielupes austrumos līdz Valguma ezeram rietumos. Šajā teritorijā iepriekšējos gados veikti detāli ǵeologiskie un hidroǵeoloǵiskie pētījumi, kuri sniedz detālu geoloǵisko un hidroǵeologisko informācija par pētāmo teritoriju, kas l̦auj veikt griezuma stratifikāciju un model̦a izveidošanu.

Šajā teritorijā kvartāra un devona ūdeņu horizonti ir hidrauliski saistīti, tāpēc izmaiñas vienā no tiem rada izmaiņas otrā. Iepriekš veiktajos pētījumos aprakstīts, 
ka novērotas ūdeṇu sastāva un līmeṇa maiņas laikā un telpā, bet tās nav analizētas kopumā, apskatot pazemes un virszemes ūden,us kā vienotu sistēmu.

Apstrādājot un izanalizējot dažādos laikos veiktos sērūdeñu pētījumus, Kemeru hidrometeorologiskās stacijas novērojumus Lielajā Kemeru tīrelī (1946.1995.) un Kūrortu pārvaldes novērojumu urbumu datus (1971.-1996.), varēs izveidot datormodeli, kurš l̦aus spriest par pazemes ūdeņu līmeņiem un ķīmisko sastāvu:

$\checkmark$ netraucēta režīma apstākḷıs (pirms intensīvas sērūdeņu ieguves),

$\checkmark$ intensīvas sērūdeņu ekspluatācijas apstākḷlos,

$\checkmark$ sērūdeņu ierobežotas ekspluatācijas apstākḷos beidzamajos 10 gados.

2004.gada ruden̄̄ veiktie lauku pētījumi (sērūdeņraža un sulfātu koncentrāciju analītiska noteikšana, līmeṇu mērījumi) ļaus kalibrēt datormodeli, kas nodrošinās tā adekvātu darbību.

Pētījuma rezultātā varēs prognozēt, cik lielā mērā agrākās un nākotnē paredzamās gruntsūdeņu līmeņu maiņas, kuras izraisījuši dažādi faktori: meliorācija, ezeru līmeņu maiņa, pazemes ūdeņu ieguve, ietekmē Salaspils horizonta pazemes ūdeņu ķīmisko sastāvu - galvenokārt sērūdeņraža saturu ūdeņos.

Izveidojot hidroǵgoologisko modeli, būs iespējams noskaidrot, kas un cik lielā mērā nosaka Augšdevona Salaspils ūdens horizontā esošu ūdeņu ķīmiskā sastāva un līmeņa izmaiņas un izpētīt pazemes ūdeņu līmeṇu un k̦īmiskā sastāva izmaiņu saistību. Izmantojot izveidoto modeli, varēs noteikt, kurās teritorijās gruntsūdens līmeṇa maiṇa visbūtiskāk ietekmēs Salaspils ūdens horizontu un tajā notiekošos sērūdeņraža veidošanās procesus.

\title{
LEDĀJA RELJEFA TOPOGRĀFIJA, UZBŪVE UN GLACIOTEKTONISKĀS STRUKTŪRAS PĀREJAS JOSLĀ NO AUSTRUMKURSAS AUGSTIENES UZ PIEVENTAS LĪDZENUMU
}

\author{
Aivars MARKOTS, Ojārs ĀBOLTIN̦Š, Ivars STRAUTNIEKS, Vitālijs ZELČS, \\ Martins DENISOVS, Linda MANGALE, Anita PLŪCE, Lāsma SIETINSONE, \\ Aiga STATKUS \\ Latvijas Universitāte, Ģeogrāfijas un Zemes zinātñu fakultāte, \\ e-pasts: Aivars.Markots@lu.Iv
}

Ledāja reljefa topogrāfija un uzbūves īpatnības pārejas joslā no Austrumkursas augstienes uz Pieventas līdzenumu tika pētītas Braņ̧̧u karjerā, kas ir viens no lielākajiem šajā teritorijā. Šie pētījumi papildina līdzšinējās zināšanas (Strautnieks, 1998; Zelčs, 1993) par ledāja reljefa topogrāfijas un glaciotektonisko struktūru kopsakarībām Vārmes-Zirṇu Degēra rievoto morēnu laukā. Braņķu karjers atrodas Austrumkursas zemienes rietumos, Vārmes nolaidenuma dieviddal̦ā, Cieceres kreisajā pamatkrastā. Nolaidenuma lēzeni vilụnoto virsmu rada gandrīz meridionālā virzienā stiepti valı̧i, kura relatīvais augstums mainās no 8 līdz 15 m, 
platums ir 500-750 m un garums - 4-6 km. Šo valı̧nu virsu sarežǵī zemu un šauru šķērsenisku grēdu sakopojumi. Ap $15 \mathrm{~km}$ R no Braņķu karjera Ventas ielejas virzienā abas reljefa formu sistēmas pakāpeniski izzūd zem Ventas sprostezera nogulumiem, kuri uzkrājušies vēlāk - leduslaikmeta beigu posmā.

Teritorijā pamatiežu virsa atrodas $60-70 \mathrm{~m}$ v.j.l., un to veido augšdevona Ketleru svītas pelēks ar spilgti sarkaniem ielāsmojumiem un sarkanbrūns dolomīts, aleirolīts un māls, ko uz ziemel̦iem no Cieceres ielejas nomaina Žagares svītas zilganpelēks smilšakmens, aleirolīts un māls. Pirmskvartāra iežus pārsedz pleistocēna nogulumi, kuru biezums caurmērā ir 10 m (Juškevičs u.c., 1997). Taču, kā liecina izstrādāto karjeru dziḷums, pozitīvajās reljefa formās ledāja nogulumu kopējais biezums parasti svārstās no 12 līdz $25 \mathrm{~m}$. Iespējams, ka daudzviet subkvartārā virsa ir fiksēta uz pirmskvartāra iežu atrauteņiem un to veidotajām glaciotektoniskajām struktūrām.

Kopumā Vārmes-Zirņu Degēra rievoto morēnu lauks veido ap $40 \mathrm{~km}$ garu un 5-10 km platu Z-D virzienā stieptu joslu (Strautnieks, 1998). Tā aptver apmēram 1500 rievoto morēnu grēdas, kas grupējas subparalēlās sērijās ar nelieliem pārtraukumiem. Š̄̄s sērijas ir diezgan nevienmērīgi izkliedētas un veido D virzienā nedaudz izliektus lokus, kas ķị̄veidīgi satuvinās uz Vārmes nolaidenuma nogāzes.

Starpgrēdu pazeminājumi ievērojami pārsniedz grēdu platumu. Attālums starp grēdu korēm svārstās no 120-400 m līdz $1000 \mathrm{~m}$. Atsevišksu grēdu garums mainās no $150-300 \mathrm{~m} \mathrm{līdz} 600-1200 \mathrm{~m}$, platums - no dažiem desmitiem metru līdz pat $300 \mathrm{~m}$, bet dominējošais relatīvais augstums ir 2-8 m. Tas liek domāt, ka Ventas ledāja mēles atkāpšanās ātrums nepārsniedza 300 m gadā.

Branķu smilts karjerā atsedzas abu krustojošos sistēmu vaļ̦nu kores daļas uzbūve. Vaļ̧ı kore ir veidota no stipri deformētiem pamatiežu atrauteņiem, dezintegrētas un izlocītas daudzkrāsainas lokālās morēnas un dažādu citu morēnas fāciju un glacioakvālo, galvenokārt glaciofluviālo, nogulumu starpkārtām. Lielākā dạa pamatiežu atrauteṇu un ievilkuma struktūru sastāv no Žagares svītas zalıganpelēka vai zilganpelēka smilšakmens, aleirolīta un māla. To iespējamais pārvietojuma attālums nepārsniedz $0,8-2,6 \mathrm{~km}$. Dominē izteiktas zvīṇveida uzbīdījumu glaciotektoniskās struktūras un nošķēluma tipa pārvietojumi, kā arī dažāda izmēra un morfologiskā paveida krokas. Lineāro injektīvo kroku šarnīii ir aptuveni paralēli meridionālā virzienā stieptā valı̧na garenasij. Uzbīdījuma struktūru veidošanās gaitā stresa virziens $\mathrm{R}$ sienā ir mainījies no RDR uz ZR. Kopumā oḷu garenisko asu orientācija pārsvarā ir paralēla injektīvo kroku šarnīriem un perpendikulāra uzbīdījuma virzienam. Karjera ziemeļu sienā slāņu krituma azimuts svārstās plašā sektorā no RDR līdz AZA, kas atspoguḷo spriegumu lauka izmaiṇas meridionāli stieptā vaḷna proksimālajā dạ̧ā.

Iegūtie rezultāti ļauj izvirzīt šādu nogulumu uzkrāšanās un deformāciju secību: (1) dažādu fāciju ledājkušanas ūdeņu nogulumu nogulsnēšana un diamikta uzkrāšanās ledāja malas zonā un šo nogulumu agrīnā deformācija; (2) morēnas 
izgulsnēšanās zemledāja apstākḷ̆os, tās un agrāk noguldīto un deformēto nogulumu sakrokošana lineārās antiklinālās krokās, kas morfologiiski atspoguḷojas kā meridionālā virzienā stieptas valınveida grēdas; (3) noslēdzošā deformācija, kuras rezultātā radās zvīņveida uzbīdījumi un jaunākie atrauteņi lineāro antiklinālo kroku spārnos un starpvaļnu ieplakās, un notika lineāro kroku saspiešana no starpvalı̧nu pazeminājumiem vērstā spiediena ietekmē; starpvaļnu ieplaku sabīīijuma struktūras pēc ledāja nokušanas radīja šauro un zemo šķērsenisko grēdu sistēmas; (4) pieledāja sprostezeru attīstība hipsometriski zemākos līmeņos.

\title{
Literatūra
}

Zelčs, V., Strautnieks, I., Āboltiņš, O. \& Markots, A., 2004. Stop 4: The Braņķi gravel pit at Zirņi. International Field Symposium on Quaternary Geology and Modern Terrestrial Processes, Western Latvia, September 12-17, 2004: Excursion Guide. University of Latvia, Rīga, 2004, pp. 60-63.

Juškevičs, V., Kondratjeva, S., Mūrnieks, A. un Mūrniece S., 1997. Latvijas ǵeologiiskā karte. Mērogs 1:200 000. 31.lapa - Liepāja. Paskaidrojuma teksts un kartes. Valsts Ģeoloğijas dienests, Rīga, 49 lpp.

Strautnieks, I., 1998. Austrumkursas ausgtienes ledāja reljefa formas un to ǵenēze. Doktora disertācijas kopsavilkums. Latvijas Universitāte, Rīga, 55.

Zelčs, V., 1993. Diverğentā tipa glacidepresiju zemieņu glaciotektoniskās reljefa formas. Doktora disertācijas kopsavilkums. Latvijas Universitāte, Rīga, 1993, 105 lpp.

\section{ZEMLEDĀJA ŪDENSTECES ZIEMEĻVIDZEMĒ}

\author{
Dainis OZOLS \\ Ziemel̦vidzemes Biosfēras rezervāts, \\ e-pasts: ozolsdainis@hotmail.com
}

Visā daudzveidīgo procesu klāstā, kas noteica pleistocēna reljefa formu un nogulumu veidošanos, būtiskākā loma bija subglaciālajiem kušanas ūdeņiem. To kustību noteica ledāja pamatnes termika (auksts/silts) un ledāja plūsmu un mēḷu evolūcija, mijoties to aktivitātes (sērdži) un pasivitātes etapiem.

Liecības par subglaciālajām ūdenstecēm Ziemel̦vidzemes zemienēs (augstienēs formas ir līdzīgas) ir saglabājušās kā dažādā mērā izteiktas ielejveida formas:

Senlejas (dziḷas subglaciālās ielejas) - teritorijas izteiktākās negatīvās reljefa formas - 5-20 m dzil̦as, stāvām nogāzēm, l̦oti daudzveidīgas pēc morfologijas, ar slīpiem un nelīdzeniem terasveida laukumiem, kas nereti klāti ar laukakmeņiem (Vitrupe, Rūja, Salaca), ar osiem un osu terasēm (Rūja, Saruma ez.), ar atzarojumiem un paralēlajām gultnēm (Svētupe).

Ielejveida pazeminājumi - seklākas, vienotā tīklojumā savienotas formas, kas kopā ar tās nodalošajām (piemēram, drumlinveida) formām šķērsgriezumā veido sinusoīdai līdzīgu profilu. 
Seklie ielejveida pazeminājumi - atgādina ielejveida pazeminājumus, bet ir seklāki, plānā neregulārāki, izplūdušāki.

Vēl teritorijā ir izplatîtas šaurākas, dažāda dziļuma, lielākoties seklas ielejveida formas, kas visbiežāk ir šķērsas iepriekšminētajiem veidojumiem - kā atzarojumi no tiem; mēdz atrasties nogāzēs un pozitīvo formu augšdạ̦ā. Lai komunicējot nerastos pārpratumi, tās varētu dēvēt par šksērsajiem ielejveida pazeminājumiem.

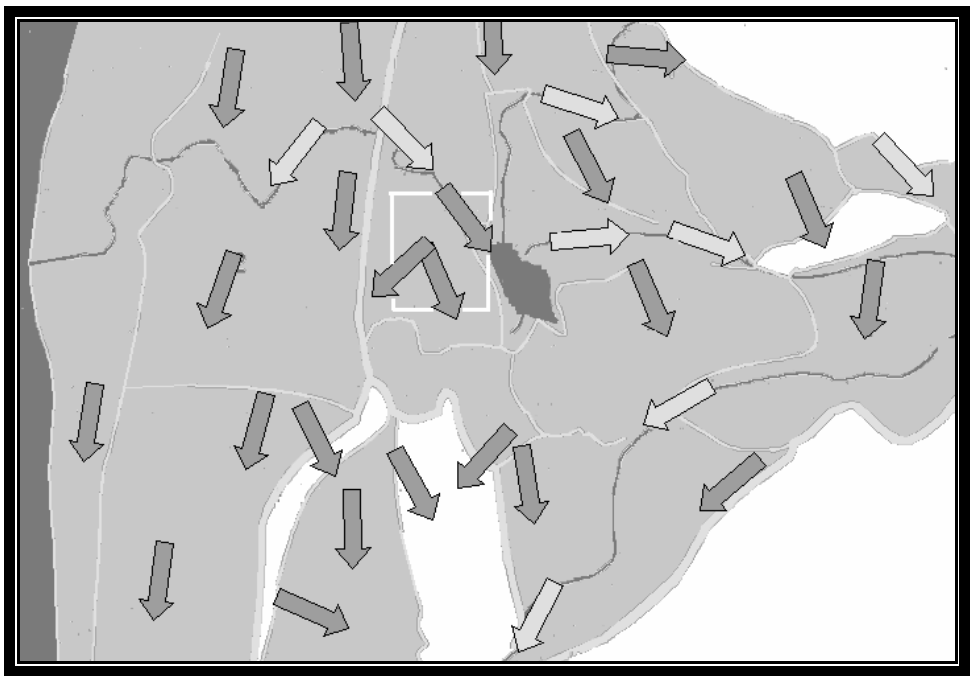

1.att. Zemledāju ūdensteču virzieni Ziemel̦vidzemē; gaišie apgabali - augstienes; gaišākās bultiņas attēlo no sākotnējā atškirīigus noteces virzienus sērdža cikla noslēgumā; rāmītis attēla centrā - 2.attēlā redzamās kartes novietojums.

Par zemledāja ūdeņu plūsmu virzieniem liecina senleju un pazeminājumu virzieni un savstarpējais novietojums, kā arī slīpslāņojuma orientācija glacifluviālo nogulumu atsegumos.

Lielos vilcienos subglaciālā notece Ziemel̦vidzemē notika atbilstoši zemieņu orientācijai, mainoties sērdža cikla gaitā (Ozols, 2004). Detāli analizējot reljefu, atrodam vismaz 2 secīgu generāciju atstātās pēdas (2.att.).

Burtnieka ieplakas R malā novērojamas ZR-DA virziena ūdensteču pēdas (ielejveida pazeminājumi un senlejas), kas pēc virziena sakrīt ar Burtnieka ieplakas orientāciju un DR-ZA (atsevišķi seklie un šķērsie ielejveida pazeminājumi), kas veidojušās pa ledāja plaisojumu, ūdenstecēm meklējot ceḷu uz Rīgas līča ieplaku pāri šai vietā zemajai ledusšķirtnei/ūdensšķirtnei.

Kā Rīgas līča, tā Burtnieka ieplakas ledāja mēlēm novērojama likumsakarība, ka sērdža noslēgumā daḷa noteces notiek A virzienā (attiecīgi pa Saruma ezera un Rūjas un Sedas senlejām - 1.att.). 


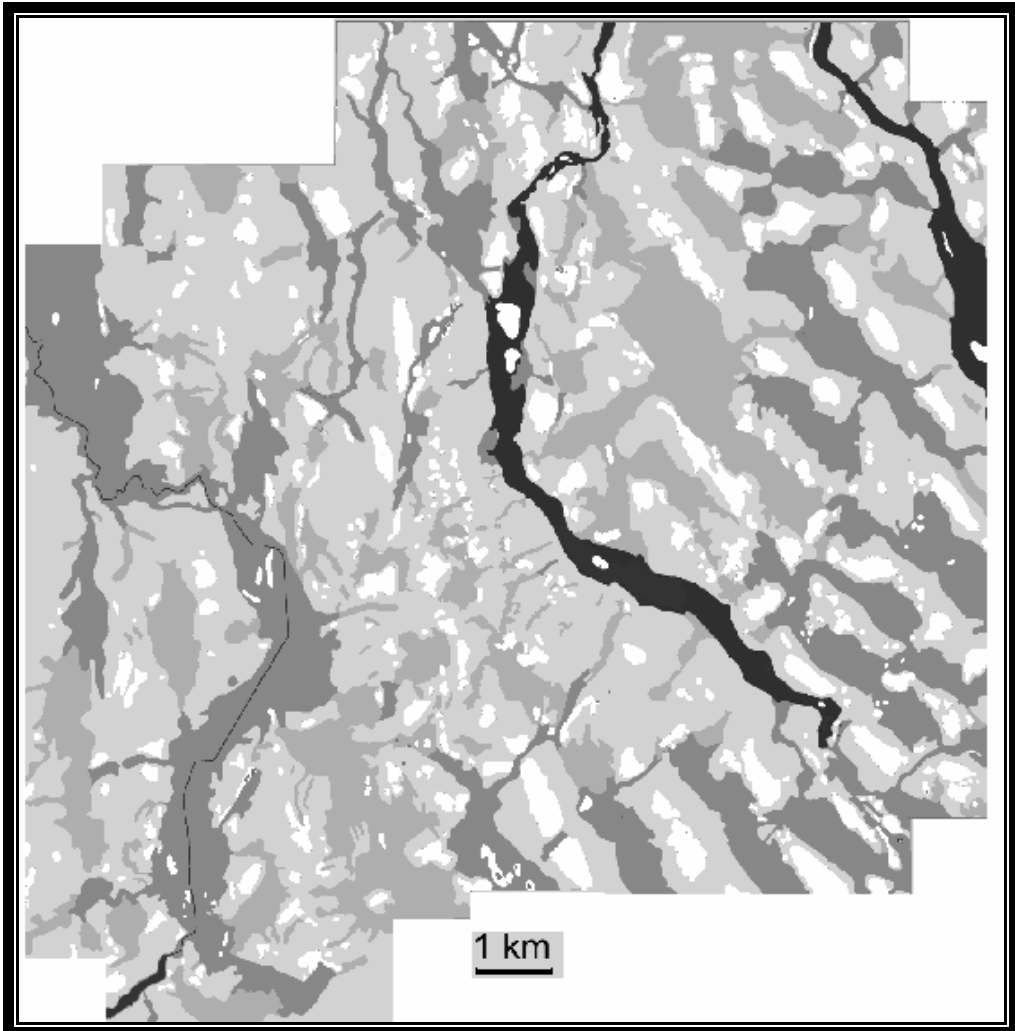

2.att. Reljefa raksturs Burtnieka ieplakas RZR dạ̦ā (kreisajā malā İǵes ieleja, vidū - Ķireles senleja, labajā augšējā stūrī Salacas izteka no Burtnieka). Pazeminājumi atkarībā no to izteiktības tonēti tumšāk vai gaišāk pelēki, pauguri - balti.

\section{SUBGLACIĀLĀ SUBSTRĀTA EVOLŪCIJA ZIEMEĻVIDZEMĒ \\ Dainis OZOLS \\ Ziemelıvidzemes Biosfēras rezervāts, e-pasts: ozolsdainis@hotmail.com}

Nozīmīgākie pleistocēna ledāju subglaciālās erozijas un akumulācijas procesi Ziemelllatvijā ir saistīti ar ledāja mēḷu un plūsmu darbību sērdžu režīmā. 


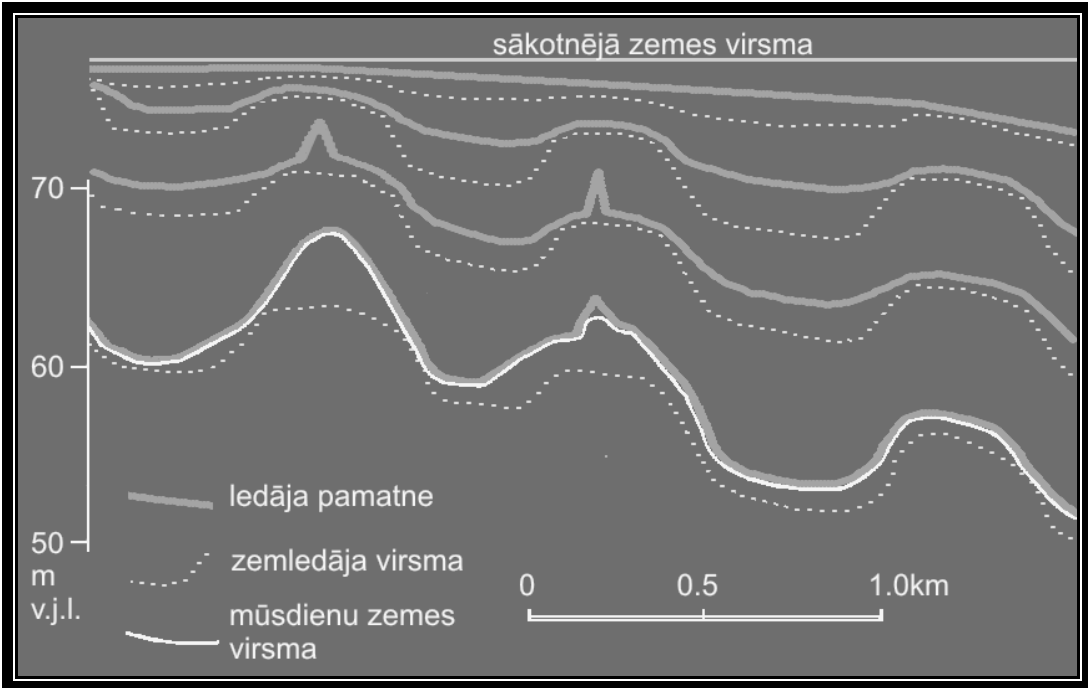

1.att. Reljefa šḳērsgriezums - zemledāja virsmas evolūcija (principiāla shēma).

Zīmējumā attēloti secīgi ledāja pamatnes un zemledāja virsmas stāvokḷi -no sērdža cikla glaciālās erozijas sākuma līdz mūsdienu reljefa izveidošanai.

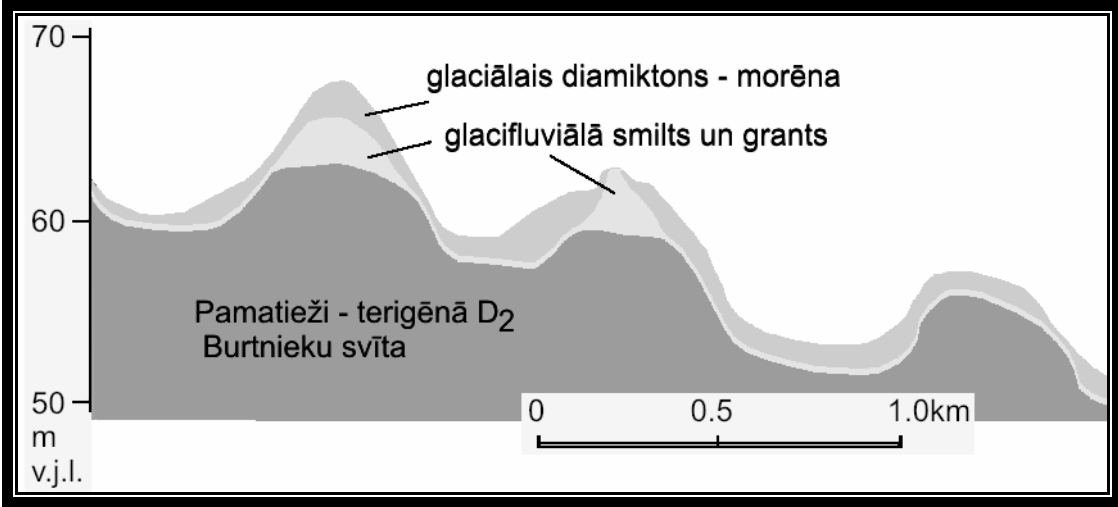

2.att. Vienā sērdža ciklā izveidojušos nogulumu principiāla shēma.

Profils 1. un 2.attēlam ņemts no reāla reljefa griezuma Burtnieka ieplakas R daḷā. 
Dati par sērdža etapiem un atstātajām liecībām.

\begin{tabular}{|l|l|l|}
\hline $\begin{array}{l}\text { Augstiene } \\
\text { (leduš̌ķirtne) }\end{array}$ & Zemiene (ledāja mēle) & Liecības \\
\hline
\end{tabular}

1. Sākums; ledāja mēles pamatnē rodas un nonāk kušanas ūdeņi, kas, nerodot brīvu noteci, izraisa pārsedzošā ledāja nonākšanu peldošā stāvoklī

\begin{tabular}{|l|l|l|}
\hline & $\begin{array}{l}\text { Ledāja pamatnes atraušanās no substrāta } \\
\text { līdz ar piesalušo nogulumu slāni - } \\
\text { Zemes iekšējā siltuma un kušanas ūdeņu } \\
\text { pieplūdes rezultātā }\end{array}$ & $\begin{array}{l}\text { Tiešu liecību nav; ūdens un ledus } \\
\text { blīvumu atšķirības lauj peldēt } \\
\text { ledum ar nogulumu kravu }\end{array}$ \\
\hline
\end{tabular}

2. Aktīvā fāze; uzpeldējusī ledāja dą̧a (t.s., kinemātiskais vilnis) virzās ledāja malas virzienā; kušanas ūdeṇi tek ledāja mēles gala un malu (ledusšşirtṇu) virzienā

Smilts un grants nogulsnēšanās

plaisainā

uz

subglaciālā

pacēluma gulošā

ledus tukšumos, caurkusumos;

caur šīm vietām

kušanas ūden̦i pēc

materiāla

nogulsnēšanas

izplūda virs ledāja

(no lejas uz augšu)
Erozija plānā ūdens starpslānī, kas nodala ledāju no pagulošā substrāta; Veidojas seklu sazarotu gultņu tīkls; Akumulācija - plašākos zemledāja tukšumos, kas, iespējams, veidojušies ledāja plaisu vietās;

Zonas, kurās ledājs daḷēji kontaktēja ar pagulošo substrātu, ledāja kustības laikā bija ar l̦oti mainīgu hidrodinamikas un spiediena režīmu; ūdens straumes - ar izteiktu sanesu piesātinājumu (brižiem turbidītu režīmā);

Nogulumu iesaiste kustībā ledāja/substrāta berzes un augsta porūdens spiediena apstākḷıs
Erozijas mezoformu zīmējums zemienēs;

Nogulumu l̦oti mainīgā litologija drumlinveida formu un starpdrumlinu ieplaku griezumos;

Augsts aleiropelītiskā materiāla saturs smilts un grants nogulumos zemienēs;

Mezo- un mikroformu raksturs ledusšķirtņu zonās, nogulumi kupolveida pauguru sastāvā

3. Beigu fāze; kinemātiskais vilnis pietuvojas ledāja mēles galam; subglaciālie ūdeņi gūst brīvāku noteci, ledājs vēl, turpinot kustību, nonāk ciešākā kontaktā ar pagulošo substrātu

Ledāja berze pret pagulošajiem ar ūdeni piesātinātajiem nogulumiem rada pusšḳidru dubḷu masu, kas, turpinot kristies subglaciālo ūdeñu spiedienam, tiek iespiesti ledāja pamatni un pagulošo substrātu nodalošajos tukšumos; izveidojies diamiktons pārklāj iepriekšējās fāzēs nogulsnēto materiālu un atūdeņojies kḷūst par nogulumiem, ko parasti dēvē par ledāja pamatmorēnu
Morēnas materiāla pārsegs dominējošās daļas reljefa formu sastāvā; nereti pakāpeniskā pāreja morēnas materiālā no granšaini oḷainajiem iepriekšējās fāzes nogulumiem; morēnas slāniskā uzbūve

4. Pēcsērdža fāze - pāreja uz nākošā sērdža sākumu; ledāja kustība stipri lēnāka; subglaciālā notece pārkārtojas uz konverǵējošu ieleju tīklu, kurās hidrostatiskais spiediens tikai epizodiski var pārsniegt pārsedzošā ledus spiedienu 


\begin{tabular}{|l|l|l|}
\hline & $\begin{array}{l}\text { Notece turpinās subglaciālajās ielejās; } \\
\text { tajās, atkarībā no situācijas, notiek } \\
\text { dziļuma erozija vai akumulācija; }\end{array}$ & $\begin{array}{l}\text { Saglabājušos un aprakto } \\
\text { subglaciālo ieleju tīkls; } \\
\text { nogulumi tajās (osos, osu } \\
\text { terasēs), akmeņu klājieni, } \\
\text { viendabīgi smalkais smilts un } \\
\text { aleirīta materiāls, kas pilda } \\
\text { apraktās ielejas }\end{array}$ \\
\hline
\end{tabular}

\title{
CEMENTA RAŽOŠANA UN TĀS IZEJVIELAS BALTIJAS VALSTĪS
}

\author{
Dace RUTKA \\ Valsts ǵeoloǵijas dienests, \\ e-pasts: dace.rutka@vgd.gov.lv
}

Viena no tautsaimniecības nozarēm, kura, pārvarējusi krīzi pagājušā gadsimta deviņdesmito gadu sākumā, tagad sekmīgi attīstās visās trijās Baltijas valstīs, ir cementa ražošana. Šìs nozares pirmsākumi Latvijā un Igaunijā meklējami jau 19.gs. Savukārt, lai arī Lietuvā cementa ražošanai ir salīdzinoši nesenas tradīcijas (rūpnīca darbojas no 1952.gada), tā tomēr pēc saražotās produkcijas daudzuma gandrīz neatpaliek no Igaunijas, kura šajā ziṇā ir līderis Baltijas valstu vidū.

Baltijas valstīs izmanto tā dēvēto "slapjo" ražošanas tehnoloǵiju. Kalıkakmeņiem un māliem jau malšanas procesā tiek pievienots ūdens. No sadrupinātā materiāla iegūst duļ̧̣i, kuras minerālās daļas sastāvā ir 76\%

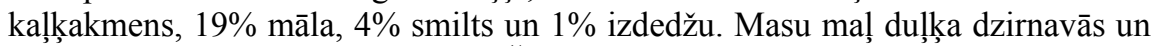
tad novada speciālos baseinos. Šeit tiek ņemtas duḷkses analīzes. Pēc to rezultātiem un attiecīgas korekcijas duḷki pārsūknē vienā lielā baseinā, kur to regulāri maisa. No baseina duļ̧̣i pa caurulēm pārsūknē uz krāsni, kur, augstās temperatūrās apdedzinot, iegūst klinkeru - cementa ražošanas starpproduktu. Pēc klinkera atdzesēšanas to pa konveijeru nogādā uz dzirnavām, kur samaḷ līdz pulverim kopā ar ǵipšakmeni. Ģipšakmens piedeva nepieciešama cementa saistīšanās laika regulēšanai. Malšanas procesā pievienojot vēl citas piedevas, iegūst dažādu marku cementu. Gatavo cementu pa caurulēm ar gaisa palīdzību aizpūš uz uzglabāšanas silosiem. Patērētājiem cementu nogādā pulverveidā ar cementu vedējām automašīnām vai arī fasētu maisos.

Igaunijā pašlaik vienīgā cementa ražotāja ir Kundas cementa rūpnīca. "Kunda Nordic Cement" akciju sabiedrība tika izveidota 1992.gadā un tagad ietilpst Heidelbergas cementa ražotāju grupā. Galvenās cementa ražošanas izejvielas - kalıķakmeni un mālu - iegūst netālu no Kundas. Kalı̧̧̧akmens atradne Louna-Aru, kurā ieguve notiek no 1956.gada, atrodas $8 \mathrm{~km}$ no cementa rūpnīcas. Atradnes derīgo slānnkopu veido vidusordovika Lasnamē un Uhaku svītu kalı̧̧akmeņi, tās biezums vidēji $11 \mathrm{~m}$. Segkārtas biezums 2-2,5 m, to veido kvartāra ieži. Kalı̧̧akmens ieguve notiek vienā kāplē, kura aptver praktiski visu 
derīgo slāņkopu. Ieguves procesā ar spridzināšanu kalıkakmens tiek sadrupināts, pēc tam ar ekskavatoriem iekrauts automašīnās un nogādāts uz drupinātavām. Louna - Aru atradnes krājumi pakāpeniski tiek izmantoti. Pie pašreizējiem ieguves apjomiem rūpnīcai izmantošanai iedalītās zemes robežās kalıkakmens krājumu pietiks aptuveni 25 gadiem. "Kunda Nordic Cement" izmanto KundaMereaadne māla atradni, kas izvietota $2 \mathrm{~km}$ no rūpnīcas. Derīgo slāņkopu atradnē veido kembrija Lontovas svītas māli, un tās vidējais biezums ir $31 \mathrm{~m}$. Segkārtu veido kvartāra ieži, tās biezums nepārsniedz $2 \mathrm{~m}$. Karjerā ieguve notiek vienā $8 \mathrm{~m}$ augstā kāplē ar ekskavatoriem. Kunda-Mereaadne atradnes krājumi nodrošina rūpnīcas vajadzības uz laika posmu līdz 100 gadiem.

Lietuvā vienīgā cementa ražotāja ir a/s "Akmenes Cementas", kas atrodas Naujoji Akmenes pilsētā. Akciju kontrolpakete šajā uzņēmumā pieder privātiem Lietuvas investoriem. No 2001.gada oktobra 34\% uzņēmuma akciju tika pārdoti kompānijai "Rughy Holding B.V." no Lielbritānijas. Kalı̧kakmeni jau no rūpnīcas darbības sākuma iegūst Karpenai atradnē, kas izvietota $2 \mathrm{~km}$ uz ziemeļaustrumiem no cementa rūpnīcas. Segkārtas biezums atradnē mainās no $1,5 \mathrm{~m}$ līdz $10,5 \mathrm{~m}$, derīgā slāņa biezums 5,4 m līdz 27,1 m, vidēji apmēram 16-8 m. Ieguvi veic, ar spridzināšanu sadrupinot derīgo slāni, pēc tam ar ekskavatoriem to iekraujot kravas automašīnās un transportējot uz rūpnīcu. Kalı̧̧ k̦akmens krājumu Karpenai atradnē pie pašreizējiem ražošanas apjomiem pietiks aptuveni uz 70 gadiem. Mālus iegūst Šaltiškiai atradnē, kas izvietota aptuveni $20 \mathrm{~km}$ uz dienvidaustrumiem no Naujoji Akmenes rūpnīcas. Triasa vecuma māli šeit iegul zem $1,5 \mathrm{~m}$ līdz 14,5 m biezas segkārtas. Māla slāņa biezums mainās no 23,6 līdz $41 \mathrm{~m}$, vidēji apmēram $25 \mathrm{~m}$. Pēc segkārtas noṇemšanas mālus ar ekskavatoriem ielādē vagonos un pa dzelzcelıu nogādā uz Naujoji Akmeni. Šaltiškiai māla atradnē derīgo izrakteni iegūst no 1980.gada, un tās krājumi pie pašreizējiem ieguves apjomiem nodrošinās rūpnīcas darbu uz 30 gadiem.

Cementa ražošna Latvijā, Brocēnos, tika sīkāk iztirzāta jau pagājušā gada konferencē prezentētajā ziņojumā.

\section{DIAPĪRU IZVIETOJUMA LIKUMSAKARĪBAS RIETUMLATVIJAS PIEKRASTES TERITORIJĀ}

\section{Tomas SAKS, Andis KALVĀNS}

Latvijas Universitātes, Ģeogrāfijas un Zemes zinātņu fakultāte, e-pasts: tomas@modlab.Iv, e-pasts: andis@spic.lv

Ulmales sērijas starp ledus un ledus laikmeta nogulumu veidošanās laiku un apstākḷiem joprojām ir nepiln̄̄gi izzinātas. Daudzos Baltijas jūras stāvkrasta atsegumos pie Ulmales, Jūrkalnes, Strantes un citur var novērot, ka šie nogulumi bieži ir ledāja deformēti. Viena no raksturīgākajām un labāk izteiktajām deformācijas struktūrām ir aleirīta materiāla diapīra struktūras smalkas smilts 
nogulumos. Novērojumi liecina, ka šīs diapīra struktūras ir izvietotas grupās, kur attālums starp atsevišķām diapīra struktūrām ir no dažiem desmitiem līdz diviem simtiem metru. Savukārt attālums starp atsevišķām diapīru grupām ir vairāki kilometri.

Atsevišķu diapīru struktūrelementu uzmērījumos ir konstatēts, ka diapīi nav izometriski, bet daudzos gadījumos ir iegareni, vērsti vairāk vai mazāk A$\mathrm{R}$ virzienā; vairāku diapīru struktūrām $Z$ malās ir novērotas uzbīdījuma tipa struktūras; mazāko diapīru raksturīga iezīme ir asimetriska uzbūve, to $\mathrm{Z}$ mala parasti ir stāvāka par D malu.

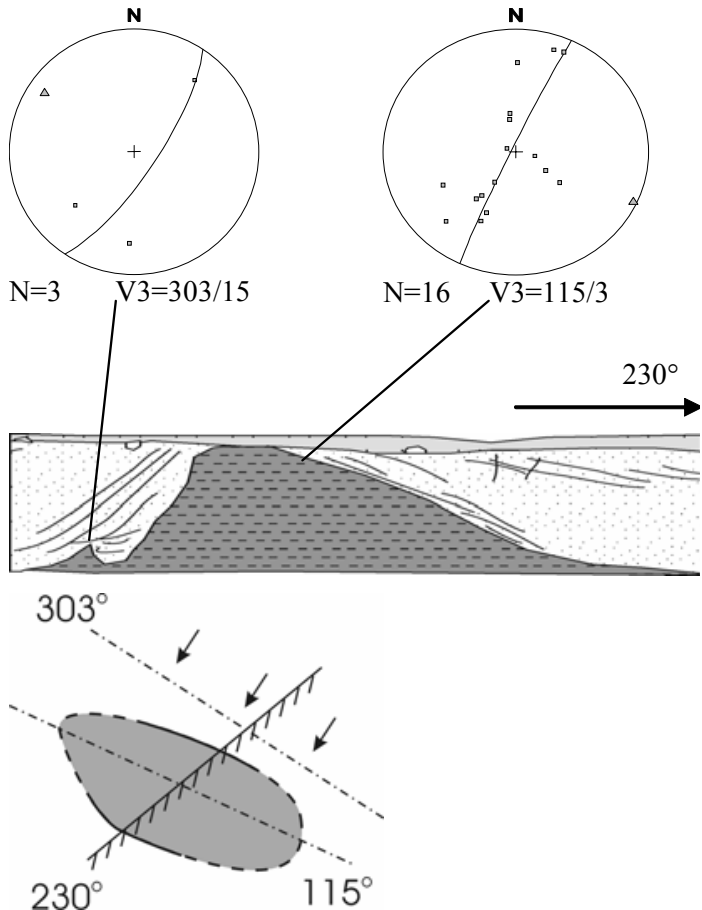

1.att. Saliktas diapīra struktūras uzbūve pie Ulmales (garkrasta profila 28170-28220 metri). Attēlā ar raustītu līniju parādītas iespējamās struktūras asis, ar bultin̄ām - iespējamais spriegumu gradientu virziens un ar ieslīpām līnijām - krasta līnijas orientācija.

Piemēram, diapīra struktūras pie Strantes (28170-28220 metru atzīmes, 1.att.) šķietamās ass orientācija pēc mērījumiem ir ZRZ-DAD virziens, savukārt krasta orientācija ir aptuveni uz $230^{\circ}$. Ja diapīrs būtu izometrisks jeb sfērisks, tad jebkurā griezumā iegūtā škietamā ass būtu orientēta perpendikulāri griezumam. Tātad diapīrs ir iegarens, izstiepts. Lielākā mērogā diapīra struktūras garā ass 
varētu būt paralēla ledāja malai un ledāja radītā poru ūdens un statiskā spiediena/sprieguma izolīnijām.

Diapīra struktūru asimetriskā uzbūve liecina par vairākiem to veidošanās aspektiem: pirmkārt, diap̄̄ra struktūras ir veidojušās ledāja malas zonā, vietā, kur ir bijis vislielākais porūdens, kā arī ledāja statiskās un dinamiskās slodzes gradients; otrkārt, diap̄iru jau izveidotās struktūrformas varēja tikt pārveidotas ledāja dinamiskās slodzes apstākḷos vēlākos ledāja uzvirzī̌̌anās etapos.

Izmantoti profesora Vitālija Zelča, kā arī ĢZZF studentu - Ivetas Blūmentāles, Dinas Jegorovas, Gitas Norenbergas, Jel̦enas Vasiḷovas, Pētera Birzgal̦a, Māra Nagḷa, Edgara Kipges 2004.gada vasaras sezonā veikto lauka pētījumu materiāli.

\title{
LITORĪNAS JŪRAS STADIJAS VEIDOJUMI KURZEMES PIEKRASTĒ
}

\author{
Valdis SEGLIN̦Š \\ LU Ģeogrāfijas un Zemes zinātņu fakultāte, \\ e-pasts: valdis.seglins@lu.Iv
}

Litorīnas jūras nogulumi un veidojumi Latvijas piekrastē zināmi un ir pētîti jau gandrīz gadsimtu, un pirmās tiešās norādes par tiem sniedz M.Galeniece, K.Cukermanis, vēlāk arī S.Buhards, V.Zāns, J.Saule-Sleinis, tomēr pirmo apkopojošo un daudzpusīgo pētījumu izstrādā E.Grīnbergs tikai 1957.gadā, un tas joprojām noder par atskaites punktu šādas ievirzes pētījumiem. Vēlākos gados to papildina G.Kḷeimenovas, I.Veinberga, I.Daņilāna, V.Ulsta un citu pētnieku darbi.

Latvijā tradicionāli tiek izdalītas tikai divas Litorīnas jūras transgresijas, un to veidojumi ir dabā viegli atpazīstami veidoto līdzenumu distālajās dą̧ās kā erozijas kāples vai terases, akumulatīvi krasta valnīši vai rupja materiāla trasēta senā krasta līnija, nereti akcentēta ar akmeṇu rindām attiecībā uz maksimālo Lit ${ }^{\mathrm{a}}$ transgresīvo fāzi. Dominējošām formām raksturīga linearitāte, un tās viegli izsekojamas smilšainajā līdzenumā pat 3-5 km posmos kā 0,3-1,2 m augsti un 5$30 \mathrm{~m}$ plati valıni, bet tie tikai daļeji ir uzskatāmi par tiešu krasta līnijas pazīmi, jo vismaz daḹeji tie ir veidojušies zem senās jūras ūdens līmeṇa. Šādos gadījumos gandrīz vienmēr paralēli valı̧niem dažu simtu metru attālumā ir konstatējamas kāpu grēdas vai formu grupas. Litorīnas jūras maksimālās transgresijas krasta līnija zināma 6,8 m v.j.l. dienvidos līdz 14,7 m ziemeḷos. Vēlā jeb otrā Litorīnas jūras transgresija Lit ${ }^{\mathrm{b}}$ ir mazāk izteikta un tās līmenis ir zemāks, tā ir arī salīdzinoši īslaicīga. Vēlās transgresijas krasta formas ir vāji izteiktas, nereti par grūti atpazīstamas reljefā, neveicot nivelēšanas darbus, un visbiežāk ir vāji izteiktas abrāzijas kāples un akumulatîvi seno krasta līniju marķējoši valnīši. Litorīnas otrās transgresijas krasta līnija tiek atzīmēta no 1,9 m v.j.l. dienvidos un sasniedzot 89,7 m ziemel̦os. Minētās viena vecuma krasta līniju augstuma izmaiṇas ir 
izostatisko kustību rezultāts un nosaka atšķirīgu Litorīnas jūras transgresiju skaitu Baltijas austrumkrastā (Lietuvā - 3, Somijā - 4, bet Zviedrijā - 8).

Litorīnas jūras vairākas transgresijas atpazīstamas arī pēc masīviem piekrastes smilšu jaunveidojumiem un izteiktām piekrastes lagūnu formām. Abu morfologiski visai atšķirīgo formu grupu telpisko sasaisti Kurzemes piekrastē nosaka senās jūras vilı̣u darbība. Tās rezultātā notika masveidīga smilts materiāla pārvietošanas augšup pa Baltijas ledus ezera regresijas rezultātā izveidoto lēzeno zemūdens nogāzi, nošķirojot trīs pamata granulometriskās komponentes: no morēnas izskalotais rupjais materiāls (laukakmen̦i, oḷi, oḷaina un grantaina smilts) palika savā sākotnējā atrašanās vietā vai tika nedaudz pārvietots, sīkdispersās suspendētās dalininas tika pārvietotas uz Gotlandes un Rīgas līča centrālās daļas ieplakām, bet smalko materiālu viḷni pārvietoja krasta virzienā. Maksimālā sedimentācija bija vērojama tieši regresīvās fāzēs, kad no zemūdens nogāzes augšdạ̧ā uzkrātā smilts materiāla veidojās ne tikai akumulatīvie līdzenumi, bet tika iesaistîts uz ziemeliem virzītajā sanešu plūsmā, veidojot lagūnu pāržmaugas un plašas akumulatīvās terases. N̦emot vērā, ka holocēna laikā kopš Litorīnas jūras transgresijas jaunākas nav zināmas, tad mūsdienu Baltijas jūras piekrastes daļas granulometriskais sastāvs var tieši norādīt uz Litorīnas laika paleoǵeogrāfiskajiem apstākḷiem un var l̦aut rekonstruēt tā laika sedimentācijas apstākḷus. Papildu informāciju šādiem mērḳiem sniedz piekrastes lagūnas, kas ir jūtīgs indikators par apstākḷu maiņām laika posmā pēc maksimālās Litorīnas jūras transgresijas (Lit $\left.{ }^{\mathrm{a}}\right)$. Papes, Liepājas, Engures un Kaņiera ezerā veiktie pêtījumi l̦auj raksturot Kurzemes piekrasti kā plašu lagūnu attīstības zonu Litorīnas laikā un pieļaut tādu eksistenci teritorijās, kuras pašreiz ir segtas ar jaunākiem nogulumiem vai ir vēlākā laikā abradētas. Konstatēts, ka piekrastes lagūnu veidošanās un attīstība ir tieši saistīta ar piekrastes sanešu plūsmas intensitāti un hidrologiskā tīkla attīstību pieguļošā sauszemes dậ̄ā. Lagūnu ezeru saglabāšanās nosacījums ir tā caurtece un palu ārkārtas caurplūdes. Minētais l̦auj būtiski detalizēt paleoǵeogrāfiskās rekonstrukcijas konkrētajam Baltijas jūras attīstības posmam.

Litorīnas jūras eksistences laiks Latvijas teritorijā nav pietiekami datēts, bet Lietuvā pēdējos gados ir veikti plaši pētījumi, kas l̦auj maksimālo (Lit' ${ }^{\mathrm{a}}$ ) transgresiju datēt kā notikušu pirms $6200-5900{ }^{14} \mathrm{C}$ gadiem, bet vēlo transgresiju $\left(\mathrm{Lit}^{\mathrm{b}}\right)$ - pirms $3600-3400{ }^{14} \mathrm{C}$ gadiem. Lietuvas teritorijā papildus tiek izdalīta vēl agrīnāka (t.s. pirmā) Litorīnas transgresija pirms $8500-7800{ }^{14} \mathrm{C}$ gadiem, kuras viennozīmīgi interpretējamas liecības Latvijas teritorijā līdzšinēji nav zināmas. Šim posmam Kurzemes piekrastē visdrīzāk atbilst materiāla mobilizācija zemūdens nogāzē.

Tomēr vēl pēc Lit ${ }^{\mathrm{b}}$ regresijas vairākās piekrastes lagūnās vērojamas nogulumu sastāva un biotas izmainnas, kas norāda uz vēl kādu vēlāku vājāki izteiktu transgresīvu ciklu. Tas ir laiks, kad sāk veidoties piejūras zemienes purvi un paaugstinās gruntsūdens līmenis, tomēr pašreiz to patiesāk ir raksturot kā vietējas ingresijas un kā palu ūdens radītu vietēji paaugstinātu līmeņu rezultātu. 


\title{
ZEMES DZĪĻU VĒRTĪBA, CENA UN NODOKL̦I
}

\author{
Valdis SEGLIN̦Š \\ LU Ģeogrāfijas un Zemes zinātṇu fakultāte, \\ e-pasts: valdis.seglins@lu.Iv
}

Zeme, tajā vai citā nozīmē, ir viena no lielākajām nacionālajām bagātībām, un zemes mērkstiecīga izmantošana ir vērsta uz ekonomisko attīstību, kā arī tā ir valsts politikas sastāvdaļa, orientējoties uz sociālo vienlīdzību un politisko stabilitāti. Plašākā nozīmē zemes politika aptver visus zemes izmantošanas aspektus un ar tiem saistitos procesus, kas ļauj no zemes resursiem iegūt praktisku labumu, ievērot valsts drošǐbas intereses un līdzsvarot valsts, sabiedrības un zemes īpašnieku intereses. Šajā kontekstā "zeme" nozīmē zemes virsmas platību ar vai bez tās uzlabojumiem, ar zemes resursiem, zemes dzịḷu noderīgām īpašībām un derīgiem izrakteņiem, kas atrodas virs un zem zemes, un vērtējama kā resurss un arī kā īpašumtiesību objekts.

Zemei ir ne tikai ekonomiska nozīme, un politika šajā sektorā neaprobežojas tikai ar zemi, bet tā savstarpēji saista ekonomiskās, reǵionālās attīstības un vides aizsardzības nozaru politikas un stratēǵijas. Zemes izmantošanas attīstības plānošana ir neațemama zemes politikas sastāvdal̦a, un nākotnē arvien vairāk paplašināsies plānotāju loma zemes izmantošanas lietās.

ANO Eiropas Ekonomiskās komisijas zemes administrēšanas vadlīnijās tiek ieteikts, izstrādājot zemes politikas dokumentus, ņemt vērā katras valsts vitāli svarīgās vajadzības definēt nekustamā īpašuma tiesības, noteikt tā vērtību un racionāli pārvaldīt, jo vismaz $20 \%$ no to iekšzemes kopprodukta var tikt iegūti no zemes, īpašuma un būvniecības.

Zemes politikas pamatmērķis ir nekustamā īpašuma vērtības palielināšana, un Latvijā pašreiz valsts kopējās zemes kadastrālā vērtība sastāda 1,7 miljardu LVL, ēku un būvju kadastrālā vērtība tiek lēsta 5,4 miljardu latu apmērā. Kopā tie ir 384465 zemes īpašumi un 214980 zemes lietojumi un valdījumi, tas ir kopā 616164 zemes nodalījumi. Privāto īpašnieku rokās atrodas 334840 zemes īpašumi kopā 3005 474,9 ha jeb 46,5\% no valsts kopplatības. Atbilstoši Civillikuma 1042.p. Zemes īpašniekam pieder ne vien tās virsa, bet arī gaisa telpa virs tās, kā arī zemes slāni zem tās un visi izrakteni, kas tajos atrodas. Zemes īpašnieks var pēc sava ieskata rīkoties ar savas zemes virsu, gaisa telpu virs tās, kā arī ar zemes slāņiem zem tās, ja vien viņš ar to neskar svešas robežas (1043.p.). İpašuma lietošanas tiesības aprobežojumu noteic vai nu likums, vai tiesas lēmums, vai arī privāta griba ar testamentu vai līgumu, un šis ieprobežojums var attiekties kā uz dažu lietu tiesību piešķiršanu citām personām, tā arī uz to, ka īpašniekam jāatturas no zināmām lietošanas tiesībām, vai arī jāpacieš, ka tās izlieto citi (1082.p.). Šos apgrūtinājumus un aprobežojumus valsts ir noteikusi ar Zemes dz̄̄ḷu likumu (1976) un tā detalizāciju ar Ministru kabineta 1997.gada 8.jūlija noteikumiem Nr.239. 
No valstī apzinātām un izpētītām 2200 dažādu būvmateriālu atradnēm VĢD kadastrā ir pieejami dati par 2093. No tām Valsts nozīmes derīgo izrakteņu atradņu sarakstā ir iekḷautas 28 būvmateriālu izejvielu atradnes (to A kategorijas krājumi). Papildus vēl īpaši aizsargājamās dabas teritorijās (2004) atrodas 128 atradnes, no tām 93 smilts, smilts un grants atradnes. Balstoties uz 2003.gada ieguves apjomiem, izpētīto ğipšakmens krājumu pietiks aptuveni - 50 gadiem, smilts -100 , smilts un grants maisījums -200 , dolomìts -210 , māls -1130 , bet kaļ̧akakmens - 1310 gadiem. Pašreizējais ieguves zemais līmenis precīzi atbilst Hūberta līknes labajam spārnam un norāda uz nepieciešamību principiāli pārvērtēt zināšanas par izrakteni un tā nozīmi patēriņa tirgū.

Zemes dzịḷu likums nosaka, ka zemes dzịlı vērtība netiek ietverta īpašuma kadastrālajā vērtībā, par zemes dzīlēm nav jāmaksā īpašuma nodoklis (6.p.2.d.) un zemes dzīles un zināšanas par tām Latvijā nav vērtējamas kā zemes vērtības palielināšana. Tas nel̦auj zemes dzīles vērtēt pēc tradicionālām īpašumu vērtēšanas metodēm, nosakot to pēc veiktajiem darījumiem, piemērojot aizvietošanas vērtību vai atsevišķi nosakot pamatlīdzekḷu un neiegūtās pel̦nas vērtības, vai piemērojot kādas apdrošināšanā izmantojamās risku noteikšanas metodes. Netieši tas norāda uz vērtībām, kas ir tuvākas zināšanām kā priekšmetiskiem lielumiem, un šādos apstākḷos objektīvu cenu var noteikt tikai tirgus izsoles, bet līdz tam - nodokḷu maksājumu un ekspluatācijas izdevumu novērtējumi.

Tikai dabas resursu nodoklis (DRN) ir interpretējams kā tieši saistîts ar derīgajiem izrakteņiem, jo pārējie ir attiecināmi kā pret jebkuru citu saimniecisko rīcību valstī. DRN lielums ir atkarīgs no derīgā izrakteña veida, un tas svārstās

robežās no $0,01 \mathrm{LVL} / \mathrm{m}^{3}$ smilšmālam un mālsmiltij līdz $1,00 \mathrm{LVL} / \mathrm{m}^{3}$ šūnakmenim, bet vidēji svērti valstī tas 2004 .gadā bija $0,07 \mathrm{LVL} / \mathrm{m}^{3}$. Tā var tikt noteikta kā zemākā tirgus vērtība zemes dz̄̄lēm un zināšanām par tām, kas ir būtiski zemāka pat par sadzīves atkritumiem (nodokḷa minimālā vērtība noteikta kā $0,25 \mathrm{LVL} / \mathrm{m}^{3}$ ). Tas kontrastē ar piedāvājuma cenu, kas svārstās vidēji $0,82-0,95 \mathrm{LVL} / \mathrm{m}^{3}$ un ir izteikti lokāla, kā arī attiecināma tikai uz preci, bet ne uz krājumiem.

\title{
JURAS NOGULUMI DZELDAS UN ŠĶERVEĻA SATEKAS APKĀRTNĒ
}

\author{
Inga SEVASTJANOVA \\ Latvijas Universitātes Ģeoloǵijas institūts, \\ e-pasts: Inga.Sevastjanova@vgd.gov.Iv
}

Dzeldas un Šķervel̦a satekas apkārtne (Kuldīgas raj., Nīkrāces pag.) ir viena no nedaudzajām vietām Latvijā, kur ir iespējams aplūkot juras nogulumus. Te atrodas aizsargājamais ǵeologiskais objekts - Zoslēnu raga atsegumi. Dažu kilometru rādiusā no minēto upīšu satekas vairākās vietās atsedzas balti, l̦oti vāji konsolidēti smilšakmen̦i ar retiem mālu, brūnog̣̣u un pārogḷotas koksnes 
iekḹāvumiem. Lielāko atsegumu relatīvais augstums sasniedz pat $16 \mathrm{~m}$. Nogulumi atbilst vidējās juras Kelovejas stāvam, Papiles svītai. Jau pagājušā gadsimta pirmajā pusē atzîts, ka tiem ir fluviāla genēze, jo smiltīs iekḷauto mālu un og̣̣u lēcu forma plānā atgādina upju gultnes. 2000.gadā Ģ.Stinkulis un Z.Tamanis, salīdzinot slīpslāņojuma krituma orientāciju divos blakusesošajos atsegumos šajā apkārtnēe, izteica pieñēmumu, ka nogulumi ir veidojušies meandrējošā upē (Tamanis, 2000).

2004.gada vasarā kopā ar doktoranti K.Tovmasjanu un Dr.ğeol. Ģ.Stinkuli dokumentēts atsegums, kas atrodas Dzeldas kreisajā krastā $200 \mathrm{~m}$ augšpus Zoslēnu raga. Griezuma apakšdal̦ā slāņi ir neizturēti, bieži izķīẹjas. Slāṇu sagulums un tekstūras norāda uz to, ka tie ir piegultnes sēres veidojumi, tomēr, lai to droši pierādītu, nepieciešami papildu pêtījumi. Griezuma augšdaļā atsedzas $\sim 4 \mathrm{~m}$ bieza upes gultnes nogulumu slāņkopa. Tās pamatnē ieguḷ konglomerāts, kura atlūzas veido samērā blīvi mālu un mālainu og̣̣u oḷi, bet matrice sastāv no nešķirota smilšaini mālaina materiāla. Graudu izmērs slāņkopas ietvaros pakāpeniski samazinās virzienā uz augšu.

Apkopojot slīpslāņojuma krituma orientācijas mērījumus, kas veikti vairākos atsegumos šājā apkārtnē, konstatēts, ka seno straumju dominējošie virzieni samērā krasi atšķiras pat nelielos attālumos. Slīpslāņojuma krituma orientācija mainās plašā diapazonā - uz ziemel̦iem, ziemel̦rietumiem, rietumiem un dienvidrietumiem.

Jautājums par juras nogulumu minerālo sastāvu joprojām ir diskutabls, jo iepriekš publicētie dati ir pretrunīgi: P.Liepiṇš (Liepiņšs, 1961), E.Dreijers (Дрейер, 1958) u.c. uzskata, ka juras smiltis ir monominerālas, savukārt B.Klagiša (Tamanis, 2000) raksta, ka tās ir oligomiktas. Pēc autores datiem, kvarca saturs smiltīs mainās no 90,8 līdz 99,8\%, turklāt apakšējai robežai ir gadījumu raksturs, kas saistīts ar vizlu (īpaši muskovīta) daudzuma palielināšanos - līdz pat $8,9 \%$. Vairumā gadījumu kvarca saturs ir virs $98,5 \%$, bet laukšpatu daudzums nekad nepārsniedz 1\%. Sastopami arī karbonāti (0,2-0,4\%) un ḷoti reti šķiedru gipsis $(0,2 \%)$, kas ir autigēns. Rupjākajās frakcijās sastopami granītu, aleirolītu un smalkraudainu smilšakmen̦u gabaliņi. Tātad jāpiekrīt uzskatam, ka juras smiltis ir monominerālas.

Kvarca graudi pārsvarā ir l̦oti labi noapaļoti, to forma ir tuva sfēriskai. Sastopami arī graudi ar reǵenerācijas apmalītēm. Tiem ir raksturīgas samērā līdzenas skaldnes un labi izteiktas kristalogrāfiskās formas. Dažkārt reǵenerācijas apmalītes ir jau sekundāri noārdītas. Bieži sastopami uz pusēm pārlūzuši graudi. Kvarcs pārsvarā ir ar ieslēgumiem - rūdu minerāliem, rutila adatināam, gāzu vai šķidrumu pūslīšiem u.c. Graudu virsmas ir samērā stipri korodētas, sfēriskiem graudiem mēdz būt arī gludas, pulētas. No smagajiem minerāliem sastopami galvenokārt rūdu minerāli (40-78\%), daudz cirkona, turmalīna, rutila, staurolīta, sfēna, l̦oti maz piroksēnu, amfibolu un granātu. 


\title{
Secinājumi:
}

Jaunie dati apstiprina Ģ.Stinkuļa un Z.Tamaņa izteikto pieņēmumu par to, ka Dzeldas un Šķervel̦a satekas apkārtnē sastopamie juras nogulumi ir veidojušies meandrējošā upē.

Par nogulumu sanesu avotu acīmredzot ir bijuši smilšakmeņi ar reǵenerācijas cementu.

Autore izsaka pateicību M.ǵgeol. K.Tovmasjanai, Dr.ǵgeol. Ģ.Stinkulim un M.ǵeol. A.Zabelei par palīdzību lauku darbos un vērtīgiem padomiem datu interpretācijā.

\section{Literatūra}

Liepiņš P. 1961. Juras sistēma // Latvijas PSR ġeologija.- Rīga, Zinātṇu Akadēmijas izd., 104.-108. lpp.

Tamanis Z. 2000. Dienvidkurzemes juras nogulumi. Bakalaura darbs. - Rīga, 49 lpp.

Дрейер Э. 1958. Отчет о поисковых работах на формовочные пески в районах Рудбаржи, Вадаксте, Балдоне. Рига. VĢF

\section{GRAVU NEPASTĀVĪGO ŪDENSTEČU NOZĪME NOGULUMU EROZIJAS, TRANSPORTA UN AKUMULĀCIJAS PROCESU ĶĒDË HIDROGRĀFISKĀ TĪKLA AUGŠĖJOS POSMOS}

\author{
Juris SOMS
}

Daugavpils Universitāte, e-pasts: juris@dau.Iv

Latvijā mērḳtiecīgi un ilgtermiņa nepastāvīgo ūdensteču gultnēs notiekošo erozijas/akumulācijas procesu apjoma un dinamikas pētījumi nav veikti, tāpēc šobrīd par hidrogrāfiskā tīkla augšējo posmu - nelielu, patstāvīgi funkcionējošo pieteku - strautu un mazo upīšu gultņu aizsērēšanu (silting-up of river bed - angl.) varam spriest tikai uz pastarpinātu faktu un netiešu novērojumu pamata. Klimatisko faktoru vai cilvēka darbības izraisīta lineārās erozijas procesu pastiprināšanās sateces baseinos izjauc jau izveidojušos dabisko erozijas/akumulācijas līdzsvaru visos hidrogrāfiskā tīkla posmos. Līdz ar to paātrināta augšņu noskalošana un gravu attīstība nosaka drupu materiāla lielu apjomu nokḷūšanu upju palienēs un gultnēs. Jau 1897.gadā V.Lohtins atzīmēja (Lohtin, 1897), ka viens no galvenajiem upes transportētās cietās noteces avotiem ir nevis krastu un gultnes izskalošana, bet augšnu erozijas produkti, kuri no ūdensguves baseina virsmas tiek attransportēti ar bezgultnes plūsmu un gravu starpniecību.

Lai novērtētu gravu nepastāvīgo ūdensteču nozīmi nogulumu erozijas, transporta un akumulācijas procesu k̦ēdē hidrogrāfiskā tīkla augšējos posmos, var lietot absolūtos raksturlielumus, t.i., aprēķināt kopējo drupiežu apjomu, kas izskalots, veidojoties un attīstoties gravai, vai relatīvos raksturlielumus, t.i., pētījumu gaitā noteikt cietās noteces apjomu nepastāvīgās ūdensteces 
funkcionēšanas laikā un iegūtos skaițus attiecināt uz ilgāku laika periodu, parasti 1 gadu.

Pirmo no nosauktajiem raksturlielumiem var izskaițıt, balstoties uz dabā nomērītiem gravu morfometriskajiem parametriem, matemātiskajām likumsakarībām un atbilstošo programmatūru. Izmantojot negatīvo reljefa formu vispārināti aprakstošus 3D modelıus, var aprēķināt lineārās erozijas procesu gaitā no gravas gultnes izskalotā materiāla, respektīvi - upes gultnē nonākušā materiāla daudzumu. Dienvidaustrumlatvijas upju ieleju nogāzēs visbiežāk ir izveidojušās īsas, nesazarotas, $100 \mathrm{lī} \mathrm{dz} 300 \mathrm{~m}$ garas un 3 līdz $12 \mathrm{~m}$ dziḷas gravas, to erodētā materiāla daudzums attiecīgi svārstās no $500 \mathrm{~m}^{3} \mathrm{lī} \mathrm{dz} 8000 \mathrm{~m}^{3}$. No tā izriet, ka hidrogrāfiskā tīkla augšējos posmos DA Latvijā ir nonācis no $800 \mathrm{t} \mathrm{līdz} 15000 \mathrm{t}$ drupu materiāla no katras gravas.

Tā kā cieto noteci veido izšķīdušās vielas, suspendētais un pa gultni pārvietotais materiāls, bet cietā notece ir funkcija no caurplūduma $P_{s}=f(Q)$ (Metodi izučenija ..., 1982; Knighton, 1998; u.c.), tad šo raksturlielumu var aprēķināt, dabā nosakot caurplūdumu, izšķ̄īdušo vielu koncentrāciju un sanešu apjomu. N̦emot vērā to, ka gravu nepastāvīgās ūdensteces kā erozijas/transporta/akumulācijas hidrogrāfiskās sistēmas sastāvdaļas funkcionē sniega kušanas vai intensīvu lietusgāžu gadījumos, cieto noteci raksturojošās maksimālās vērtības jānosaka pavasara palos un, izmantojot iegūtos rezultātus, var matemātiski izskaitļot cieto noteci citiem laika posmiem.

Caurplūduma aprēķināšanai gravu strautos tika izmantota tradicionālā analītiskā metode, nepieciešamos straumes ātruma mērījumus gultnes šķērsprofila laukumos veicot ar digitālo šķidrumu plūsmas ātruma mērītāju SWOFFER ${ }^{\mathbb{R}} 3000$ (mērījumu precizitāte $\pm 1 \%$ ). Kopējais izšķīdušo vielu daudzums tika noteikts dabā, izmantojot "Hydrolab" firmas Surveyor 4a datu apstrādes aparatūru un MiniSonde zondi, kura ir aprīkota ar atbilstošo sensoru. Suspendētā un pa gultni pārvietotā materiāla apjomi tika noteikti ar fluviālajā ǵeomorfologijāā pieņemtajām metodēm (Tools in fluvial ..., 2003), ievācot noteikta tilpuma paraugus un pēc tam iegūstot gaissausā sanešu materiāla masu.

Veiktie mērījumi un aprēķini parāda, ka cietās noteces caurplūdums gravu strautos vidēji ir robežās no $73 \mathrm{~g} / \mathrm{m}^{3} \mathrm{~s}$ līdz $170 \mathrm{~g} / \mathrm{m}^{3} \mathrm{~s}$, attiecīgi cietās noteces apjoms diennaktī, ņemot vērā aprēķinātās caurplūduma vērtības - līdz 6,3 t/d (salīdzinājumam ūdens noteces apjoms gravu strautos ir 1380 līdz $4200 \mathrm{t} / \mathrm{d}$ ). Pārrēḳinot uz gravu ūdensguves baseinu, iegūstam vērtību līdz $102 \mathrm{~kg} / \mathrm{d}$ *ha.

Atkarībā no uztverošās upes hidrometriskajiem parametriem (gultnes slīpums, straumes ātrums, min. un max. caurtece u.c.) noteikta daļa drupu materiāla tiek akumulēta gultnē, kā rezultātā samazinās gultnes garenkritums, straumes ātrums, upes dziļums un šķērsgriezuma laukums. Tas savukārt veicina augu atlieku un dūņu uzkrāšanos upes gultnē, eitrofikāciju un pastiprinātas gultnes aizaugšanu kopumā. Eitrofikācijas procesu paātrina arī no aramzemes plakniskās erozijas gaitā upītēs ieskalotais dulı̧kainais un koloidālais augsnes 
materiāls, kas satur $\mathrm{NH}_{4}^{+}, \mathrm{NO}_{3}^{-}, \mathrm{PO}_{4}{ }^{3-}$ un $\mathrm{K}^{+}$jonus un līdz ar to nodrošina paaugstinātu barības vielu saturu ūden̄̄.

Apkopojot iegūtos rezultātus, var secināt, ka gravu nepastāvīgajām ūdenstecēm ir nozīmīga loma nogulumu erozijas, transporta un akumulācijas procesu ksēēe hidrogrāfiskā tīkla augšējos posmos, turklāt erozijas procesu intensifikācija upju sateces baseinos neizbēgami veicina šo upju aizsērēšanu un tekošo ūdeņu ekosistēmu degradāciju.

\title{
Literatūra
}

Knighton D., 1998. Fluvial Forms and Processes. - London, Arnold. pp.120.

Lohtin V.M., 1897. O mehanizme rečnogo rusla. -S-Peterburg. - 348 lpp. (krievu val.)

Metodi izučenija gidrologičeskogo režima vodnih objektov. Red. Vuglinskij V.S. i dr. -Leningrad, Gidrometeoizdat, 1982. - 202. - 203.lpp. (krievu val.)

Tools in Fluvial Geomorphology. Edit. G.Mathias Kondolf, Herve Piegay. -Chichester, John Wiley \& Sons, - pp. $425-453$.

\section{MĀKOŅKALNA UN TĀ APKĀRTNES RELJEFA FORMU ĢEOMORFOLOĢISKĀS IZPĒTES UN KARTĒŠANAS REZULTĀTI}

\author{
Juris SOMS \\ Daugavpils Universitāte, Dabaszinātņu un matemātikas fakultāte, \\ e-pasts: juris@dau.Iv
}

2004.gada aprīī Latvijā tika izveidota jauna īpaši aizsargājama dabas teritorija (http://www.vidm.gov.lv/vad/Latviski/Likumd/MK/264.htm) - dabas parks "Rāzna". Tā ir otra lielākā İADT, kuras platība ir $532 \mathrm{~km}^{2}$. Lai sekmīgi realizētu šìs teritorijas ilgtspējīgu attīstību, nepieciešams izstrādāt tās dabas aizsardzības plānu. Minētā plāna izstrāde un ieviešana, kā arī tajā ieteikto apsaimniekošanas pasākumu ietveršana pašvaldību teritoriālās attīstības plānos nav iedomājama bez detālas informācijas par reljefu un atbilstošā kartogrāfiskā materiāla. Reljefa izpēte un liela mēroga ǵeomorfologisko karšu izveidošana, it sevišķi digitālā formātā, kalpo par pamatu sekmīgai İADT dabas vērtību, šajā gadījumā - ǵeomorfoloǵisko dabas pieminekḷu apzināšanai, šo objektu aizsardzības pasākumu plāna izstrādei un teritorijas sekmīgai, vidi un biotopus saudzējošai apsaimniekošanai un pārvaldībai, piem., - nosakot potenciālos erozijas apdraudētos areālus, izdalot apmežojamos apgabalus un tamlīdzīgi.

Latgales augstienes reljefa pētîjumi aizsākas un tiem veltītās publikācijas paradās jau XX gs. 30.gados (Ramans, 1935; Slaucītājs, 1935; Sleinis, 1936). Laika gaitā dati par Latgales augstienes kopumā un tās atsevišķu reljefa vidējformu veidošanās apstākḷiem, ǵeolog̣iskās uzbūves un morfologíjas īpatn̄̄bām tiek papildināti ar daudzu ievērojamu kvartārǵeologu veiktajos pētījumos iegūto informāciju (Āboltiņš, 1989, 1995; Meirons, 1975; Straume 1979(a) un 1979 (b); Markots, 1995; u.c.). Pēdējos gados Latvijas teritorijas geolog̣iskās un ǵeomorfoloǵiskās izpētes darbi snieguši plašu informāciju gan par 
reljefa vidējformu ǵenēzi, gan tipolog̣iju reǵionālā un globālā kontekstā (Zelčs V., Dzelzītis J., 2003; Zelčs, Markots, Dzelzītis, 2003), tomēr vairumā gadījumu uz pētījumu pamata izveidotais kartogrāfiskais materiāls ir pārāk generalizēts un veidots mazā mērogā (Dreimanis, Zelčs, 1996), tādējādi apgrūtinot tā izmantošanu iepriekšminēto uzdevumu veikšanai.

Pagājušā, 2004.gadā, lauku ekspedīciju gaitā tika iegūti jauni dati par Latgales augstienes Dagdas pauguraines D dalas reljefu Mākoņkalna apkārtnē, starp Rāznas ezera glaciodepresiju un Maltas pazeminājumu. Vasaras-rudens sezonas laikā veiktie ǵeoloğiskie pētijumi (>120 urbumi ar rokas ǵeologisko urbi, $>80$ zondējumi un atsegumu izpēte šurfos) liecina par minētās teritorijas vidējformu kompleksa izvietojuma mozaīkveida raksturu un sarežğītiem formveidojošiem procesiem. Diemžēl pētījumu teritorijas ietvaros nav smilts-grants karjeru, kuros varētu gūt vispilnīgāko informāciju par formveidojošo iežu raksturu un slāņu sagulumu, tādējādi apgrūtinot reljefa vienību genētisko identifikāciju. Dabisku un mākslīgi veidotu atsegumu trūkums tika daḷēji kompensēts, nozīmīgākajām reljefa formām veicot urbumu sērijas "virsotne - pakāje" un uz iegūto datu pamata konstruējot ğeoloǵiski-ǵgeomorfoloǵiskos profilus.

Pêtījumu teritorijas virsmas saposmojumu noteicošais reljefs veidojies augšpleistocēnā, kad visu Latvijas un arī Rāznavas pauguraines D daļu klāja pēdējā - Vislas apledojuma segledāja periferiālā sega. Vidējreljefa formu rašanās saistīta ar ledāja ǵeologisko darbību, galvenokārt nevienmērīgu ledāja nogulumu uzkrāšanos un glaciotektoniskajiem procesiem Rāznas glaciodepresijas un Maltas pazeminājuma ledus mikromēḷu konverǵences zonā, kā arī ledāja kušanas ūdenuu erodējošo un akumulējošo darbību periferiālās segas degradācijas gaitā. Pēcleduslaikmetā (holocēnā) glaciālo procesu veidotā reljefa tālāku pārveidi noteica galvenokārt fluviālie procesi - gravu veidošanās un plakniskā noskalošanās, kā arī nogāžu procesi un cilvēka saimnieciskā darbība, bet pazeminājumus - pārpurvošanās.

Pêtījumu teritorijas dominante gan ainaviskā, gan morfologiskā izpratnē ir Mākoņkalns (skat. 1.att.), kurš tiek saukts arī par Volkenbergu, Padebešu kalnu, Muokūn,kolnu.

Mākoņkalns ir lielpaugurs, kura absolūtais augstums sasniedz 248,4 m v.j.l., relatīvais augstums ir 54,1 m, tā pamatnes garums R-A virzienā pārsniedz $500 \mathrm{~m}$, bet platums Z-D virzienā - $350 \mathrm{~m}$. Tas ir iegarens, trapecveidīgas konfigurācijas, l̦oti augsts lielpaugurs ar saposmotām nogāzēm. Pēc morfoloǵiskām pazīmēm tas ir paugurmasīvs. Tā virsmas saposmojuma galvenās īpatnības nosaka vairāki, hipsometriski zemākā līmenī (218226 m v.j.l.) esoši sīkpauguri, kuri novietojušies uz paugurmasīva A un $\mathrm{Z}$ nogāzēm (skat. 2.att.). Atsevišķās vietās Mākoņkalna nogāzes saposmo sengravas. No $Z$ un D to ieskauj daudzi mērenas sīkpauguri un kēmi. 


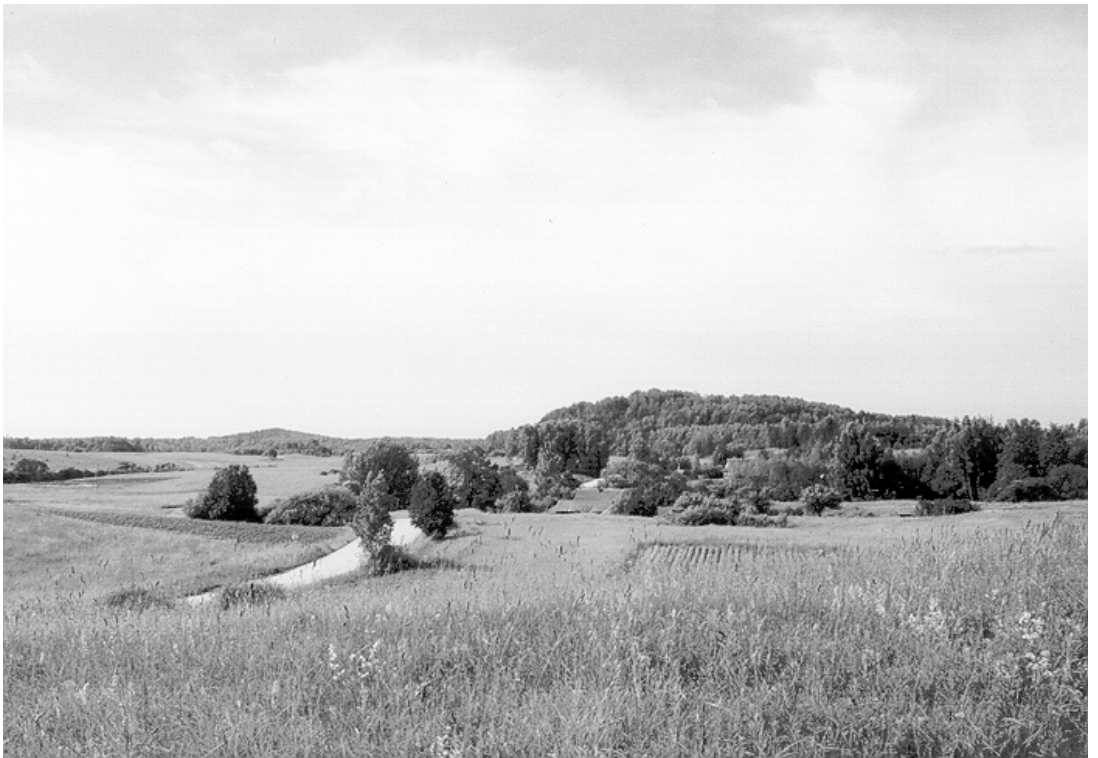

1.att. Rāznavas pauguraine uz D no Rāznas ezera. Attēla labajā pusē redzams Mākoṇkalns, kreisajā - Augstumkalns. Foto J.Soms, 2004.g. jūl.

Virsotnes daḷā Mākoņkalna formveidojošo nogulumu virsējo daļu veido smalkgraudaina, putekḷaina smilts ar grants piejaukumu un smilšmāla vai mālsmilts lēcām, kuru 2,5-3 m dziļumā nomaina rupjgraudaini nogulumi ar oḷakmeniem. Ol̦akmeņi un laukakmen̦i lielā daudzumā atsedzas arī Mākoṇkalna nogāžu virspusē.

N̦emot vērā šīs reljefa formas morfologijas īpatnības (plašs lielpaugurs ar saposmotu virsmu, virsmas saposmojumu veidojošie sīkpauguri atrodas uz kopējā pacēluma), Mākoņkalna reg̣ionālo izvietojumu (no Rāznas glaciodepresijas un Maltas pazeminājuma plūstošo ledus mikromēḷu konverǵences zona Latgales augstienes iekšējā apvidū), hipsometrisko novietojumu, kā arī formveidojošo nogulumu raksturu, Mākoṇkalns varētu tikt ierindots reljefa glacigēnās grupas glaciotektoniskajā apakšgrupā un tikt uzskatīts par pirmmasīvpauguru.

Mākoņkalns veido pētījumu teritorijas hipsometriski augstāko līmeni. Otro, zemāk novietoto līmeni (218-228 m v.j.1.), pārstāv uz DA no Ubogovas ezera morēnas izvietotais dauguḷu un kēmu vidējpauguru, kā arī valınveida pauguru reljefs. Šajā grupā kā savdabis izcel̦as koniskas formas kēmu vidējpaugurs - Augstumkalns (228,3 m v.j.l.), kura relatĩvais augstums ir 32,1 m. Trešajā, vēl zemāk novietotajā līmen̄̄ (190-205 m v.j.l.), atrodas uz ZR un R, un uz A no Mākoņkalna esošie plakanvirsas lielpauguri un vidējpauguri, kā arī daudzie morēnas un kēmu sīkpauguri, kas izkaisīti visā pêtījumu teritorijāa 
Urbumu dati liecina, ka plakanvirsas pauguri ǵenētiski identificējami kā zvonci ar glaciostrukturālu pamatni, tādējādi tos var uzskatīt par glaciotektoniskiem pauguriem ar glaciolimnisko nogulumu segu. Visbeidzot, ceturto, viszemāk hipsometriski novietoto līmeni (175-190 m v.j.l.), veido starppauguru ieplakas, purvi (piem., Valna pūrs) un pārpurvotas ieplakas, kā arī ezeru katlienes.

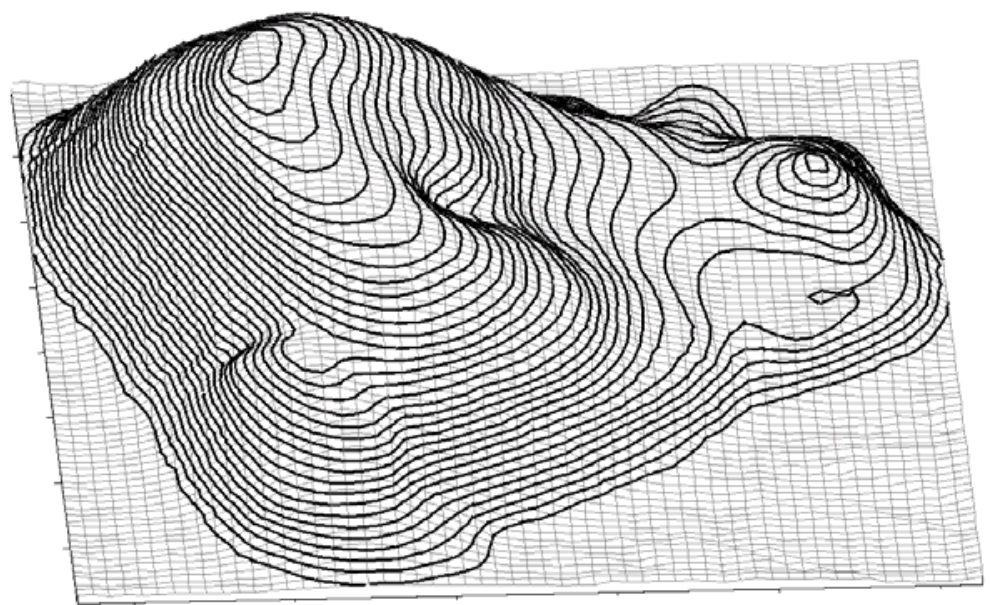

2.att. Mākoṇkalna reljefa digitālais modelis - skats no $\mathbf{Z}$ (šķēluma augstums 1,5 m)

Diemžēl nogulumu struktūrelementu pētījumu trūkums nel̦auj rekonstruēt mikromēḷu lokālo kustību dotajā apvidū, taču daudzu, izstieptas formas, pauguru un paugurgrēdu garenasu orientācija l̦auj netieši spriest par to veidošanos laterāla spiediena apstākḷos.

\section{Literatūra}

Āboltiņš O., 1989. Gḷaciostrukturi i ḷednikovij morfoǵenez. -Rīga, Zinātne, 284 s.

Āboltiňš O., 1995. Latgales augstiene. Enciklopēdija "Latvija un latvieši”: Latvijas daba, 3.sēj. -Rīga, Latvijas Enciklopēdija, 87-89.lpp.

Dreimanis A., Zelčs V., 1996. Ģeomorfoloǵiskā karte. Pasaules ǵeogrāfijas atlants. -Rīga Jāṇa sēta, 10.1pp.

Markots A., 1995. Lielais Liepukalns. Enciklopēdija "Latvija un latvieši”: Latvijas daba, 3.sēj. -Rīga, Latvijas Enciklopēdija, 123.lpp.

Meirons Z., 1975. Reljjef Latgal̦skoj vozvihšennosti i sopredeḷnikh rajonov Vostočno-Latvijskoj ņizmennosti // Danilans I. (red.), Voprosi četvertičnoj ǵeoloǵii, t. 8. -Rīga, Zinātne, 48.-82.lpp.

Ramans Ģ., 1935. Latvijas teritorijas g̊eogrāfiskie reǵioni. Ģeogrāfiskie raksti, 5.sēj. Rīga, 178241.1pp.

Slaucītājs L., 1935. Par Latvijas un atsevišķo augstumu apgabalu morfometriju. Ģeogrāfiskie raksti, 5.sēj. Rìga, 15-28.lpp.

Sleinis I., 1936. Latvijas reljefs: Latgales augstiene. Latvijas zeme, daba un tauta, 1.sēj. Rīga, 135137.lpp.

Straume J., 1979(a). Sovremennij rel̦jef Latvii: l̦edņikovije obrazovanija. Ģeologiččeskoje strojenije i poleznyje iskopajemyje Latvii. -Rīga, Zinātne, 303.lpp. 
Straume J., 1979(a). Latgaļskaja vozvišennostj. Ģeoloǵičeskoje strojenije i poleznyje iskopajemyje Latvii. -Rīga, Zinātne, s. 367.

Zelčs V., Dzelzītis J., 2003. Glaciotectonic Map of Latvia. Paper No. 24-12. Sesion No. 24. T10. Glaciogeological and geomorphological evidence of ancient ice streams and outlet glaciers. In: Shaping the Earth: A Quaternary Perspective. The XVI INQUA Congress Programs with Abstracts. Reno, Nevada, July 23 - 30, 2003.

Zelčs V., Markots A., Dzelzītis J., 2003. Map of Late Weichselian directional ice-flow features of Latvia. Paper No. 24-12. Sesion No. 24. T10. Glaciogeological and geomorphological evidence of ancient ice streams and outlet glaciers. In: Shaping the Earth: A Quaternary Perspective. The XVI INQUA Congress Programs with Abstracts. Reno, Nevada, July 23 - 30, 2003.

http://www.vidm.gov.lv/vad/Latviski/Likumd/MK/264.htm - skatīts 16.12.2004

\section{PELĒKO MĀLU VEIDOŠANĀS APSTĀKḶI AGRAJĀ PIELEDĀJA BASEINU ATTĪSTİBAS LAIKĀ VIDUSLATVIJAS UN AUSTRUMLATVIJAS ZEMIENĒS}

\section{Vilnis STELLE}

LU Ģeoloǵijas institūts

Glaciolimnisko nogulumu kompleksa zemienēs virs morēnas kopā ar mālainajiem nogulumiem divas apakšèjās māla lentes - lielākā vai mazākā daudzumā - satur rupjgraudainu iežu materiālu - cieto iežu olīšus, morēnas gabalus, granti, kā arī ūdenī maz apstrādātas pelēku mālu atliekas 0,5-3,0, retāk $5,0 \mathrm{~cm}$ apmērā. Viduslatvijas zemienē mālu atliekas atrastas Ozolnieku un Spartaka karjeros Iecavas krastā, Progresa un Sarkanā māla karjeros Lielupes labajā krastā, pie Bemberiem u.c. Analogi māli līdzīgos saguluma apstākḷos atrasti Zilānu karjerā pie Krustpils un pie Praulienas Madonas rajonā. Divos tuvu veiktos urbumos pie Zilāniem glaicolimniskajos nogulumos 8,2 un $9,0 \mathrm{~m}$ dziļumā, iespējams, atrasta pelēko mālu primāra iegula $0,55 \mathrm{~m}$ biezumā. Pilnīgāks priekšstats par pelēkajiem māliem tika iegūts meliorācijas grāvja atsegumā pie Līvbērzes. Iegulai ir kupolveida forma, kuras augstums sasniedz apmēram 1,20 m, garumā pārsniedzot 5,0 m. Pelēko mālu kupolu apliec un pārsedz slokšņu māli, virs kuriem gul smalkgraudainas Baltijas ledus ezera smiltis.

Jāuzsver, ka pelēkie māli nekur nav atrasti morēnā, tātad tos nav iznīcinājis ledājs, bet gan spēcīga ledāja kušanas ūdeņu transgresija, kuru izraisījis krass vidējās temperatūras kāpums, iezīmējot pāreju uz leduslaikmeta beigu posma siltāko daḷu. Šajā laikā sākās plašu pieledāja baseinu veidošanās zemienēs, kur sedimentējās sarkanbrūnie slokšņu māli, kas nomainīja pelēkos mālus. Tomēr neskaidrs paliek jautājums par pelēko mālu izcelsmi un paleoǵeogrāfiskajiem apstākḷiem šajā laikā. Māli uzkrājās slēgtās ezera tipa ūdenskrātuvēs mierīgos apstākḷıos, bet tiem nav raksturīgo pieledāja baseinu iezīmju. Nogulumu krāsa pamatā ir iezilgani pelēka (Jelgavas tuvumā) vai vāji iebrūni pelēka (Zilānos). Materiāls atbilst mālainiem aleirīiem vai aleirītiskiem māliem ar neskaidru kārtojumu vai bez tā. Māla un aleirīta daḷiņu pienesums 
baseinos, domājams, bijis neliels, visticamāk, siltākajos vasaras mēnešos - jūlijā un augustā. Līdz šim nav atrasts pilnībā neskarts mālu slānis. Var pieņemt, ka mālu maksimālais biezums nepārsniedza $2 \mathrm{~m}$. Regresijas rezultātā māli vairāk vai mazāk varēja nokḷūt atmosfēras ietekmē, uz ko norāda dal̦ēja krāsu maiṇa no zilganpelēkas uz iezaļganpelēku krāsu, kā arī lielāka vai mazāka slāṇa augšdaḷas sacementēšanās, ar ko varētu izskaidrot māla gabalu saglabāšanos sākotnējos pieledāja ezeru dinamiskajos veidošanās apstākḷos.

\title{
DEVONA NOGULUMU SEDIMENTĀCIJAS APSTĀKḶI ANDOMAS KALNA APKĀRTNĒ (KRIEVIJA, OŅEGAS EZERA DA)
}

\author{
Ģirts STINKULIS ${ }^{1}$, Kristīne TOVMASJANA ${ }^{1}$, Ervīns LUKŠEVIČS ${ }^{1}$, Angelīna ZABELE ${ }^{2}$ \\ ${ }^{1}$ LU Ģeogrāfijas un Zemes zinātñu fakultāte, \\ e-pasts: Girts.Stinkulis@lu.Iv, Kristine.Tovmasjana@lu.Iv, Ervins.Luksevics@lu.Iv \\ ${ }^{2}$ LU Ģeoloǵijas muzejs, e-pasts: Angelina.Zabele@lu.Iv
}

Andomas kalna krokotajā devona slāņkopā sastop galvenokārt klastiskos nogulumus: smilšakmen,us, aleirolītus un mālus. Augstās, plašās un nepārtrauktās atsegumu sienas Oṇegas ezera krastā deva labas iespējas šo nogulumu detalizētiem sedimentologiskajiem pētījumiem 2002.-2004.gadā. Pētījumi vēl nav pabeigti, taču pašreiz ir iespējams gūt zināmu priekšstatu par Andomas kalna devona slāņkopas sedimentācijas apstākḷiem. Šiem pētījumiem ir liela nozīme, jo tie sniedz datus par līdz šim maz pazīstamu iecirkni Austrumeiropas platformas devona baseinos, kurš, domājams, atradies netālu no noneses apgabala.

Andomas kalna devona slāņkopas apakšdaļai raksturīgi tumši sarkani, brūngani un dzelteni aleirītiski smilšakmeņi un mālaini aleirolīti. Nogulumiem ir vāja šķirojuma pakāpe un augsts vizlas saturs. Ir novērojami vairāki cikli, kur graudu izmēri samazinās uz augšu. Tekstūras ir grūti izšķiramas, tomēr dominē horizontāls slāņojums un slīpslān,ojums. Vietām sastop izskalojuma virsmas un gultnes. Devona griezuma vidusdą̣ā nogulumu sastāvs un krāsa strauji mainās. Pārsvarā mijas aleirītiski māli, aleirolīti, smalk- un vidējgraudaini smilšakmeņi, bet vietām ir arī konglomerāti, ko veido māla saveltņi un mugurkaulnieku detrīts. Dažviet mijas mālainu aleirolītu un smalkgraudainu smilšakmen̦u kārtiņas ar biezumu tikai līdz dažiem centimetriem. Smilšakmeņiem ir raksturīgs muldveida slīpslāņojums, straumju un viḷnu ripsnojums, retāk izsekojamas samērā biezas regulāras slīpslāņotās sērijas, kas, domājams, ir veidojušās zemūdens sērēs. Māliem un aleirolītiem visbiežāk ir horizontāls slāņojums. Nogulumos, it sevišķi aleirolītos, ir daudz organismu eju. Devona slāņkopas augšdaļā dominē smilšakmen̦i ar konglomerātu starpslāņiem, kuros sastop zivju atliekas. Smilšainās nogulas pārsvarā ir uzkrājušās zemūdens grēdās, retāk sēkḷlos. Slīpslāņotajās sērijās sastop reaktivācijas virsmas, un uz slīpajiem slānīšiem bieži ir vizlas un māla sakopojumi. 
Nogulumu sastāvs, struktūra, tekstūra un fosīlijas liecina par to veidošanos ūdens vidē, pārsvarā straumju ietekmē. Mugurkaulnieku asociācijas, daudzās organismu ejas, kā arī laterālā virzienā vairāku kilometru attālumā izturētais nogulumu sastāvs norāda uz jūras apstākḷiem. Vismierīgākajos apstākḷıs (plūdmaiņu līdzenumā?) ir veidojusies devona slāņkopas vidusdaļa, bet ātru straumju režīmā (plūdmaiṇu straumēs vai deltu attekās?) ir uzkrājušās griezuma augšdaļas smilšainās nogulas. Domājams, ka straumju režīmā ir veidojušās arī griezuma apakšdaļas nogulas. To vājā šķirotības pakāpe un īpatnējā tumšsarkanā un brūnā krāsa, iespējams, norāda uz cita noneses apgabala eksistenci Andomas kalna devona slāṇkopas veidošanās sākotnējos laikposmos, salīdzinājumā ar vēlākajiem laikposmiem. Iespējams arī, ka noneses apgabals nav mainījies, bet laika gaitā tā denudācijas rezultātā pārnesei ir kḷuvuši pieejami atšķirīgi, labāk sadēdējuši cilmieži.

Turpmākajos pētījumos 2005.gadā ir plānots pabeigt Andomas kalna devona griezumu detalizētos sedimentologiskos pētījumus. Pamatojoties uz iežu sastāva, tekstūras un struktūras īpatnībām, tiek izskatīta iespēja devona slāṇkopu iedalīt trīs litostratigrāfiskajās vien̄ibās, kuras atbilst tās augšminētajai apakš-, vidus- un augšdaļai.

\title{
CĒRES RADIĀLĀS GRĒDAS MORFOLOĢIJAS UN UZBŪVES İPATNĪBAS
}

\author{
Ivars STRAUTNIEKS, Aivars MARKOTS, Jānis DZELZĪTIS, Vitālijs ZELČS, \\ Sintija ANTONE, Martins DENISOVS, Linda MANGALE, Lāsma SIETINSONE, \\ Agate TEIVĀNE \\ Latvijas Universitāte, Ģeogrāfijas un Zemes zinātņu fakultāte, \\ e-pasts: Ivars.Strautnieks@lu.Iv
}

Cēres radiālā grēda atrodas Ziemeļkursas augstienē, Vanemas pauguraines vidusdaļā. Tā izvietojusies aptuveni $7,5 \mathrm{~km}$ platā glaciodepresijā starp Aklāciema masīvu rietumos un Zvāres, Raudas-Laminuu un Plieņu paugurgrēdām austrumos.

Cēres grēda ir iegarena un orientēta DDR-ZZA virzienā, paralēli glaciodepresijai, bet perpendikulāri Vanemas pauguraines garenasij. Grēdas garums ir $6 \mathrm{~km}$, platums ap $3 \mathrm{~km}$, bet relatīvais augstums sasniedz 40-55 m. Tās augstākā virsotne Sudmalkalns pacel̦as $107 \mathrm{~m}$ v.j.l. Cēres grēda šķērsgriezumā ir asimetriska - rietumu un ziemel̦u nogāzes ir stāvākas un augstākas. Ziemel̦u nogāze salīdzinājumā ar pārējām ir augstāka, un tajā labi redzamas 2 kāples, kuras saposmo virsmas noteces erozijas reljefa formas. Cēres grēdas virsai raksturīgs neliels slīpums dienvidu-dienvidaustrumu virzienā un arī lēzenas nogāzes.

Grēdas virsma ir viegli viḷnota. Tās augstākās dal̦as virsmas viḷnojumu veido daudzu savstarpēji perpendikulāru grēdu 2 sistēmas (1.att). Grēdu garums ir vairāki simti metru, platums ap $100 \mathrm{~m}$, bet relatīvais augstums daži metri, tām ir 
lēzenas nogāzes. Morfoloǵiski izteiksmīgākās ir Cēres radiālajai grēdai paralēli orientētās reljefa formas.

Cēres radiālā grēda atrodas uz pirmskvartāra virsas pacēluma, kuru saposmo nelieli lokāli augšdevona terigēno iežu virsas paaugstinājumi un pazeminājumi (Juškevičs, 1999), kas morfologiiski atgādina erozijas drumlinus. Kvartāra nogulumu vidējais biezums ir ap $40 \mathrm{~m}$, bet grēdas augstākajā daļā sasniedz 50-60 m. Detāli veiktie iekšèjās uzbūves pētîjumi (Strautnieks, 2000; Strautnieks et al., 2004) liecina, ka pārsedzošais slānis ir $0-5 \mathrm{~m}$ biezs augšpleistocēna morēnas smilšmāls un mālsmilts. Zem pārsedzošās morēnas 12$15 \mathrm{~m}$ dziḷajos karjeros Cēres grēdas ziemeļdą̧ā dominē ledāja deformēti glacioakvālie nogulumi ar tajos ietvertiem nelieliem devona smilšakmens atrauteniem, vietām arī līdz $1 \mathrm{~m}$ biezi diamikta un morēnas slāņi. Savstarpēji paralēli sagul̦ošajos, krokotajos glaciofluviālo nogulumu slāņos ir redzams slīpslāņojums. Formveidojošajos nogulumos redzamas dažāda izmēra un morfolog̣isko paveidu krokas. Lielākās ir gareniskā izliekuma krokas, kuru šarnīri ir aptuveni paralēli Cēres grēdas garenasij. To amplitūda ir ap 6 m. Antiklinālās gareniskās krokas ir Cēres grēdas virsmu saposmojošo mazo drumlinveida formu veidojošās struktūras. Galveno kroku spārnos aleirīta un smalkgraudainas smilts starpslāņos ir novērojamas tecējuma krokas un atūdeņošanās struktūras. Raksturīga īpatnība ir arī dažādu ǵenerāciju un izmēru diapīrkrokas. Detālpētījumu laikā formveidojošajos nogulumos tika veikti plaknisko un vairāk nekā 1500 lineāro struktūrelementu mērījumi. Cēres grēdas ziemeļrietumu malā (rietumu karjerā) dominējošais oḷu linearitātes virziens ir ZR, bet krituma azimuts $20^{\circ}-30^{\circ}$. Kroku rietumu spārnos oḷu garenasis krīt ZR vai DR virzienā. Tuvāk Cēres grēdas austrumu malai (austrumu karjerā) oḷu garenasis krīt Z-ZA virzienā. Minētie krituma virzieni liecina par ledāja spiediena virziena mainu grēdas ziemel̦galā. Reǵionālais ledājkustības virziens ir no Z, bet reljefa formas veidošanā nozīmīgs ir laterālais spiediens no ieplakām. Šāds spiedienu sadalījums raksturīgs radiālo starpmēlu paugurgrēdu un drumlinu veidošanā.

Pēc morfolog̣ijas un iekšējās uzbūves īpatnībām Cēres grēda ir analoǵiska Valdelvitsas-Johanistāles pauguriem, kurus J.Piotrovskis (1997) klasificējis kā megadrumlinus. J.Straume (1979) Cēres grēdu raksturojis kā stūra masīvu.

Svarīgi atzīmēt, ka glaciodepresijā līdzās Cēres grēdai izvietotas vairākas citas, paralēlas, morfologiski un pēc uzbūves līdzīgas reljefa formas - Oksles grēda un citas, tādējādi, iespējams, ka tās kopā veido megadrumlinu lauku. 


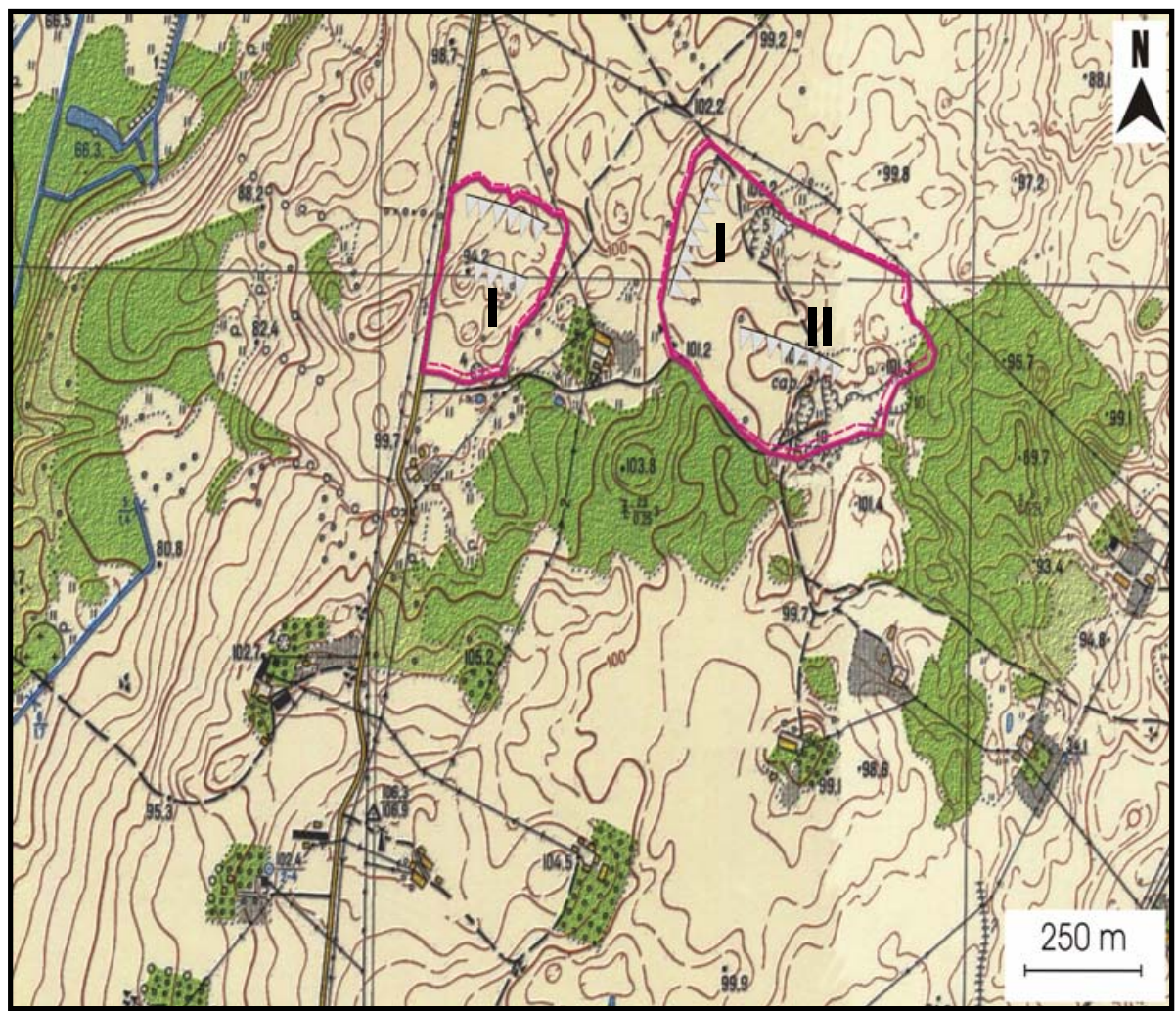

1.att. Cēres grēdas augstākās dạ̦as virsmas saposmojuma īpatnības un referātā iztirzāto griezumu (I un II) novietojums. Vertikālais griezums $2 \mathrm{~m}$.

\section{Literatūra}

Juškevičs, V., 1999. Kvartāra nogulumi // Latvijas ǵeoloǵiskā karte. Mērogs 1:200000. 42.lapa Jūrmala. Paskaidrojuma teksts un kartes. Rīga, Valsts Ģeologijas dienests. 8.-24. lpp.

Piotrowski, J. A., 1997. Introduction to Stops 7 and 8. Stop 8. Gravel pit in the mega-drumlin at Wandelwitz. In: Piotrowski, J. A. (ed.), Field Symposium on Glacial Geology at the Baltic Sea Coast in Northern Germany. Excursion Guide. University of Kiel, pp. 23-24 and 26-28.

Straume, J. (1979). Ģeomorfologija. In: Misāns, J., Brangulis, A., Danilāns, I. and Kuršs, V. (red.), Ģeologičeskoje strojenie i poleznye iskopajemye Latvii, Zinātne, Rīga, s. 297-439.

Strautnieks, I., 2000. Cēres pacēlums. Latvijas Universitātes 58. zinātniskā konference. Zemes un vides zinātņu sekcijas. Referātu tēzes. Rīga, 01.-04.02.2000., 155-156.lpp.

Strautnieks, I., Zelčs, V., Markots, A. \& Dzelzītis, J., 2004. Stop 4: The gravel pits at Cêre. International Field Symposium on Quaternary Geology and Modern Terrestrial Processes, Western Latvia, September 12-17, 2004: Excursion Guide. Rīga, University of Latvia, 2004, pp. 21-24. 


\title{
DEVONA PALEOEKOSISTËMAS TROFISKĀ STRUKTŪRA DELTU ZONĀ
}

\author{
leva UPENIECE \\ LU Ģeoloǵijas institūts, e-pasts: upeniece@lanet.Iv
}

Ekosistēmas trofisko struktūru veido biocenozes locekḷu barošanās jeb trofiskās attiecības. Ikviens biocenozes loceklis ir kādas barības ķēdes posms.

Paleoekosistēmas trofisko struktūru ir iespējams rekonstruēt, ja ir konstatējami trofiskie līmeņi un tiem atbilstoši organismi. Tādi gadījumi ir retums, bet pie ideāliem sedimentācijas un organismu atlieku saglabāšanās apstākḷiem var daḷēji rekonstruēt paleobiocenozi un tās trofisko struktūru (Maisey, 1994; Upeniece, 2001a). Pagaidām vien̄̄gā paleontolog̣ijas zinātnei zināmā devona deltu zonas paleoekosistēmas trofiskā struktūra ir konstatēta Latvijā, Lodes (Liepas) atradnē.

Lodes devona mālu atradne atrodas deltu zemūdens zonas paleonogāzē, kur straujā sanešu materiāla sedimentācijas dēḷ organismu atliekas tika strauji apsegtas ar māla dulı̧i, nodrošinot labus fosilizācijas apstākḷus (Kuršs u.c., 1998, 1999). Lodes paleoekosistēmas organismu komplekss (Upeniece, 2001b) ietver visus trofiskās struktūras veidojošos līmeņus:

1) producentus (aḷges un augstākie augi);

2) primāros konsumentus (aug- un detrītēdājdzīvnieki). Tie ir: a) bezmugurkaulnieki - bentosa organismi (gliemen̦vēži, lapkāji, vēžskorpionu juvenīlie īpatņi, bezskeleta organismi, dažādi dūṇēdājorganismi) un zooplanktons; b) mugurkaulnieki - detrītēdāji un bentofāgi (bruņuzivju mazul̦i, bezžoklenii).

3) sekundāros konsumentus (bezmugurkaulnieki - vēžskorpioni; mugurkaulnieki - bentofăgi, planktonēdāji, lielo plēsējzivju mazuḷi);

4) trešās pakāpes konsumentus (mugurkaulnieki - liela un vidēja izmēra plēsīgās zivis).

Lodes paleobiocenozē konstatētas arī destruktoru darbības pēdas (ihnofosīlijas) un parazītisku organismu atliekas zivju ķermeņos (Upeniece, 1999a,b). Jāpiebilst, ka pašreiz šīs ir senākās zināmās zivju parazītu atliekas paleontologíiskajā hronikā.

Lodes atradnes mālos ir atrastas gandrīz visas galvenās devona mugurkaulnieku grupas: bezžokleņi, bruņuzivis, akantodes, daivspuru un starspuru zivis. Iztrūkst tikai skrimšlızivis, kuras ir atklātu jūru iemītnieces. Tā kā deltu rajonos to daudzveidīgās barības bāzes dēl mita vai nārstoja dažādu grupu zivis, tad šajos nogulumos konstatētās bagātīgi pārstāvētās mugurkaulnieku un bezmugurkaulnieku, kā arī augu atlieku fosīlijas ir veiksmīgi izmantojamas devona paleoekosistēmas trofiskās struktūras rekonstrukcijā.

Lodes zināmais fosīlo organismu komplekss ietver 15 zivju sugas (t.sk. piecas jaunatklātas zivju sugas pēdējos gados), bagātu bezmugurkaulnieku un augu atlieku klāstu. Lielākā daḷa no šiem organismiem ir raksturīgi tikai Lodes 
svītai. Vairākas zivju un bezmugurkaulnieku grupas ir pārstāvētas gan ar juvenīliem, gan ar pieaugušiem īpatņiem. Augstais juven̄ilo īpatñu kopskaits liecina par piemērotām barošanās un vairošanās vietām deltu zonā.

Daudzveidīgajā ihtiofaunas kompleksā ir pārstāvētas zivis no dažādiem trofiskiem līmeņiem: pirmās, otrās un trešās pakāpes konsumenti. Iedalījums līmeņos pamatojas uz šo zivju morfologiskajām īpatnībām: mutes un žokḷu uzbūvi, ķermen̦a formu un izmēriem. Pēc barošanās veida zivis var iedalīt kādā no ekoloǵiskajām grupām: bentofāgi, zooplanktofāgi, detrītēdāji, augēdāji un plēsējzivis. Plēsējzivju vien ir 9 sugas. Daži fito- un zooplanktona patērētāji pārstāv primāro un sekundāro konsumentu līmeni (kā tas ir arī mūsdienās), jo ir spējīgi baroties dažādos veidos.

\title{
Literatūra:
}

Kuršs V., Lukševičs E., Upeniece I., Zupiņš I. 1998. Augšdevona klastiskie nogulumi un zivju atliekas Lodes mālu karjerā Latvijā (I dạ̦a). Rīga, Latvijas Geologijas Vēstis, Nr.5, 7.-19.lpp.

Kuršs V., Lukševičs E., Upeniece I., Zupiņš I. 1999. Augšdevona klastiskie nogulumi un zivju atliekas Lodes mālu karjerā Latvijā (II dal̦a). Rīga, Latvijas Geologijas Vēstis,Nr.6,10.-17.lpp.

Maisey J.G., 1994. Predator-prey relationships and trophic level reconstruction in a fossil fish community. Environmental Biology of Fishes 40, p.1-22.

Upeniece I. 1999a. Fossil record of parasitic helminths in fishes. $5^{\text {th }}$ International Symposium on Fish Parasites. Abstracts, p.154. Česke Budejovice.

Upeniece I. 1999b. Pirmie parazītisko plakantārpu atradumi fosīlā veidā. Rīga, Latvijas Geoloǵijas Vèstis, Nr.7, 36.lpp.

Upeniece, I. 2001a. The unique fossil assemblage from the Lode Quarry (Upper Devonian, Latvia). Mitteilungen aus dem Museum fur Naturkunde in Berlin - Geowissenschaftliche Reihe, 4, p.101119.

Upeniece I. 2001b. Trophical relations of Lode organism assamblage, Lower Frasnian, Latvia. Obruchev Symposium: Evolutionary palaeoichthyology. Abstracts, p.45.Moscow.

\section{KOKSNE KĀ BIOINDIKATORS ... UN ĢEOLOĢIJA: DABISKI APRAKTĀS SENĀS KOKSNES IZPËTES IESPËJAS UN PROBLËMAS LATVIJĀ}

\author{
Māris ZUNDE \\ LU Latvijas vēstures institūts, \\ e-pasts: zunde@lanet.Iv
}

Mūsdienās, līdzīgi kā iepriekšējos gadsimtos, arī Latvijas teritorijā vietām atklāti parasti ar smiltīm vai granti segti vai nesen dalēeji atsegušies labi saglabājušies seni ozolu stumbri (Galenieks 1930; Eberhards 1991; u.c.). Savukārt kūdras slāņos nereti atrasti samērā labas kvalitātes seni priežu celmi - paliekas no kādreizējiem mežiem (piemēram, Grewingk 1881). Šie stumbri un celmi attiecināmi uz kokiem, kuri auguši pirms aptuveni 500-4000 gadiem, bet senākie pat pirms 6000-7000 gadiem (koksnes aptuvenais datējums noteikts ar radioaktīvā oglekḷa $\left({ }^{14} \mathrm{C}\right)$ metodi vai pēc nogulumu slāṇa, kurā koku paliekas atklātas pēc senāk 
noskaidrotā absolūtā vecuma). Šo koku labi saglabājusies koksne liecina, ka tā nokļuvusi anaerobos apstākḷ̆os relatīvi īsā laikā, visticamāk, lielos plūdos vai gruntsūdens līmeņa straujas celšanās laikā. Tātad apraktās koksnes aptuvenais absolūtais datējums norāda uz šādas katastrofāla rakstura dabas parādības norises laiku, bet, atklājot vienlaikus apraktus koku stumbrus vai celmus lielākā teritorijā, ir iespējams novērtēt šīs dabas parādības norises mērogu.

Salīdzinot ar iepriekš minēto, ievērojami precīzāku un plašāku informāciju par vides stāvokḷa maiņām pagātnē, t.i., koku augšanas laikā, var sniegt tipiskie bioindikācijas rādītāji - šo koku gadskārtu platuma vai blīvuma dati. Mūsdienās, piemēram, Vācijā, no ozolu gadskārtu platuma datiem sastādītās absolūtās dendrohronologiskās skalas l̦auj vērtêt ar viena gada precizitāti vides stāvokḷa pārmaiņas, kas notikušas vairāk nekā 10000 gadus ilgā laikposmā. Pēc seno koku gadskārtām un to absolūtajām dendrohronologiskajām skalām zinātnieki vērtē klimata, ūdens, vēja, zemes virskārtas līmeņa maiņas, uguns un vēl citu ekologisko faktoru izpausmi un pārmaiņas pagātnē. Tādējādi labas kvalitātes senā koksne vērtējama kā nozīmīgs informācijas avots par vides pārmaiņām tūkstošiem gadu ilgā laikposmā. Šis informācijas apjoms un tās nozīme vēl vairāk pieaug starpdisciplināru pētījumu rezultātā.

Diemžēel Latvijā līdz šim minēto seno koku koksne nav pētīta, līdz ar to dạ̧a no tajā uzkrātās informācijas jau gājusi zudumā. Par senas ozola un priedes koksnes absolūtā vecuma noteikšanu ieinteresēti ir arheologi, jo iegūtās absolūtās dendrohronologiskās skalas izmanto kultūrvēsturisko objektu datēšanai. Taču dabiski apraktas, ar kultūrvēsturiekiem objektiem nesaistītas simtiem un pat tūkstošiem gadu senas koksnes datējumi arheologiem Latvijā pagaidām ir maz saistoši, tāpēc organizācijas, kas pēta Latvijas seno laiku vēsturi, uzṇemties organizēt un pilnībā finansēt gan tās datēšanu, gan arī rezultātu analīzi nevar. Paliek atklāts jautājums: kā seno koku koksnē un tās gadskārtās fiksēto informāciju pie mums Latvijā saglabāt (vismaz zinātnieku nākamām paaudzēm) un kuras zinātnes pārstāvji būtu ieinteresēti šo darbu veikt? Iespējams, ka seno koku gadskārtu dendrohronoloǵiskās skalas zināmu jautājumu skaidrošanā varētu izmantot arī kvartārǵgeologijas speciālisti? Kamēr atbildes uz šiem jautājumiem nav rastas, atklāto seno stumbru koksne paliek nepētìta. Tā parasti iet bojā vai tiek savlaicīgi apstrādāta un izmantota, un vismaz lielākā daļa no tajā ietvertās informācijas, kā tas ir noticis līdz šim, tiek neatgriezeniski zaudēta.

\section{Literatūra}

Galenieks, P., 1930. Apraksta ozolmeža atliekas pie Daugavpils. Latvijas Universitātes Botāniskā dārza raksti Iacta Horti Botanici Universitatis Latviensis). Rīga, Nr.1/3, 69-74.lpp.

Grewingk, C., 1881. Zur Pfahlbautenfrage Liv-, Est- und Kurlands. Sb. GEG, Dorpat, S.49-50.

Eberhards, G., 1991. Mums tikai viena Gauja. Rīga, 72-74.lpp. 


\title{
LEDĀJA RELJEFA FORMU MORFOLOĢIJA, UZBŪVE UN VEIDOŠANĀS ZIEMEĻKURSAS AUGSTIENES AKLĀCIEMA MASĪVĀ
}

\author{
Vitālijs ZELČS, Ivars STRAUTNIEKS, Aivars MARKOTS, Jānis DZELZĪTIS, Inese \\ CELMA, Indra OšUROKA, Diāna PAIKŪNE, Anita PLŪCE, Aiga STATKUS, Ilze \\ VEINBERGA \\ Latvijas Universitāte, Ģeogrāfijas un zemes zinātnu fakultāte, \\ e-pasts: Vitalijs.Zelchs@lu.Iv
}

Aklāciema paugurmasīvs veido Ziemeḷkursas augstienes Vanemas pauguraines hipsometriski augstāko daļu. Paugurmasīva garums ZZRDDA virzienā ir $16 \mathrm{~km}$, bet tā platums mainās no $4 \mathrm{~km}$ ZZR galā līdz $8 \mathrm{~km}$ DDA. Tas atrodas 120-174 m vjl. Paugurmasīva nogāžu relatīvais augstums sasniedz 30$60 \mathrm{~m}$, bet augstākās virsotnes pacel̦as $70-120 \mathrm{~m}$ virs pieguḷıšajiem pazeminājumiem un zemieņu līdzenumu apvidiem. Augstākajā dạ̦ā paugurmasīva virsa galvenokārt ir vilı̧nota, ko rada iegarenu, ZR-DA virzienā orientēti pauguru un lineāru ieplaku mija. Vietām sastopami pauguri ar kupolveida virsotnēm un ieapaļas, līdz $15 \mathrm{~m}$ dziļas ieplakas. Atsevišķu pauguru relatīvais augstums sasniedz 35-40 m. Dziḷākās ieplakas aizṇem ezeri. Paugurmasīva ziemeḷdaḷā atrodas arī vairāki iegareni subglaciālo iegultṇu ezeri, kuru izvietojums sakrīt ar ielejveida formu izplatîbu subkvartāra (pamatiežu) virsā.

N̦emot vērā ledāja reljefa formu sistēmu sakārtojumu trijstūra veidā, Aklāciema paugurmasīvs tiek klasificēts kā stūra masīvs, kas atdalījis Ventas (Usmas) ledāja lobu no Viduslatvijas (Zemgales) loba (Veinbergs, 1968; Meirons, 1972; Straume, 1979; Āboltinsš, 1989). Tradicionāli tiek uzskatīts, ka tas veidojies, aktīvā ledāja malas zonā uzkrājoties morēnas, tekošo un stāvošo ledāja kušanas ūdeņu nogulumiem, kas bieži deformēti ledāja spiediena ietekmē.

Paugurmasīvs atrodas uz pamatiežu virsas lokāla pacēluma, kura augstums mainās no 50 līdz 88 m v.j.l. Pacēlumam ir samērā stāva ZZA nogāze (Juškevičs u.c., 1999). Pamatiežu lokālo pacēlumu saposmo virkne ielejveida formu. Dziḷākā no tām sasniedz $76 \mathrm{~m}$ z.j.l. Litoloğisko robežu pamatiežu virsmā starp paugurmasīva Z daḷā (Kamparkalna un Lejaslabiṇu apkārtnē) izplatītajiem augšdevona terigēnajiem un D un DA dal̦ā raksturīgajiem karbonātiežiem un sulfātiežiem iezīmē denudācijas kāple. Pamatiežus klāj 60-80 m biezi pleistocēna nogulumi, kuru biezums ledāja reljefa augstākajās vietās var sasniegt pat 100$110 \mathrm{~m}$. Visbiezākā pleistocēna nogulumu sega ir konstatēta Z no pamatiežu lokālā pacēluma augstākās daļas. Pēc Z.Meirona (1972) datiem paugurmasīvs sastāv galvenokārt no glaciofluviāliem starpmorēnu nogulumiem, kuru vecums ir 56055 TSL gadu (Meirons un Juškevičs, 1984). Atkārtoti smilts materiāla datējumi no diviem 18 un $20 \mathrm{~m}$ dziļumā iegulıšiem postsedimentāri deformētiem slāņiem Lejaslabiņu karjerā ir diskutabli, jo uzrāda, ka smilts graudi tikuši apbērti pirms $42 \pm 3$ un $85 \pm 5$ tūkst. OSL gadiem (pers. korespondence ar J.Piotrowski). Kopumā pleistocēna griezumā dominē glaciofluviālie nogulumi, kas veido līdz 
$80 \mathrm{~m}$ biezu slāņkopu. Slāņkopas apakšejāa daḷā ir raksturīgs aleirītiskais un smilšainais materiāls, bet tās $50 \mathrm{~m}$ biezo augšêjo daļu veido oḷi, grants, kā arī smilts-grants nogulumi. Teritorijā ir izsekojamas divi pēdējā apledojuma morēnas slāņi (Meirons, 1972). Apakšejais no tiem atrodas zem glaciofluviālajiem nogulumiem un, visticamāk, ir nogulsnēts Vislas apledojuma agrajā vai vidējā posmā. Iespējams, ka šì apakšêjā morēna veido asimetriskas diapīrkrokas, kas atsedzas Lejaslabiņu karjerā A sienā $20 \mathrm{~m}$ dziļumā. Augšējā morēna ir uzkrājusies Vislas apledojuma vēlajā posmā. Tā ir dažāda biezuma un izsekojama ar pārtraukumiem. Pie tam augšējai morēnai raksturīga komplicēta struktūra, ko nosaka gan tās faciālā dažādība, gan arī tās līdzdalība zvīṇveida uzbīdījumu un dažāda tipa kroku uzbūvē. Subkvartāra virsas pazeminājumos un ielejveida iegrauzumos konstatēti arī vecāki pleistocēna nogulumi.

Aizvadītā gada pavasarī un vasarā pirmoreiz tika veikti Aklāciema masīva ledāja reljefa mezoformu detāli iekšējās uzbūves pētījumi Lejaslabiṇu grants karjerā, kas atrodas $5 \mathrm{~km}$ DA no Talsiem, $2 \mathrm{~km}$ A no Kamparkalna un ir viens no lielākajiem Latvijā. Karjers paver iespēju veikt gandrīz $40 \mathrm{~m}$ biezas ledāja kušanas ūden̦u nogulumu slāṇkopas augšêjās dal̦as un morēnas saguluma apstākḷu un struktūrelementu izpēti. Tika izdarīti ap 200 plaknisko struktūrelementu un 1300 morēnas un glaciofluviālo nogulumu makrolinearitātes mērījumi.

Visa karjerā atsegtā pleistocēna nogulumu slāņkopas daļa ir glaciotektoniski deformēta. Glaciofluviālie nogulumi aptver šādas litofācijas: (1) oḷi; (2) oḷi ar smilts un/vai grants matrici; (3) grants; (4) smilts; (5) diamiktons, kas radies oḷiem postsedimentāri iegrimstot vai arī tos iespiežot aleirīiskajā materiālā sekojošo glaciotektonisko deformāciju gaitā. Sākotnēji glaciofluviālie nogulumi ir uzkrājušies proglaciāli kā sandru nogulumi. Ledāja malai tuvojoties, sandru nogulumu uzkrāšanos un pieledāja megabloku (skibas) deformāciju struktūru veidošanos pakāpeniski nomainīja izkusuma, gravitācijas plūsmas, sablīvējuma un deformācijas morēnas nogulsnēšana. Tomēr, kā rāda deformācijas struktūru analīze, Aklāciema paugurmasīvam raksturīgā ledāja reljefa vidējformu topogrāfija ir radusies zemledāja glaciotektonisko deformāciju rezultātā, kuru laikā agrāk noguldītā zemledāja gultnes materiāla bloku pārvietošana notikusi ZZR-DDA virzienā. Šajā procesā ledāja gultnē radās ZA un DR virzienā vērsti lokālspriegumi, kas noteica lineāru antiklinālu diapīrkroku un tām atbilstošo zemledāja radiālā tipa reljefa formu attīstību. Vietās, kur ledāja gultnes slīpuma izmainu dēl veidojās vienpusējās orientētās spiedes apstākḷi, notika zemledāja gultnes radiālās reljefa formu transformācija marğināla tipa veidojumos. Jāuzsver, ka aprakstīto glaciotektonisko deformāciju struktūru un zemledāja reljefa formu veidošanās procesu pavadīja ledāja nogulumu sākotnējā biezuma izmaiņas. 


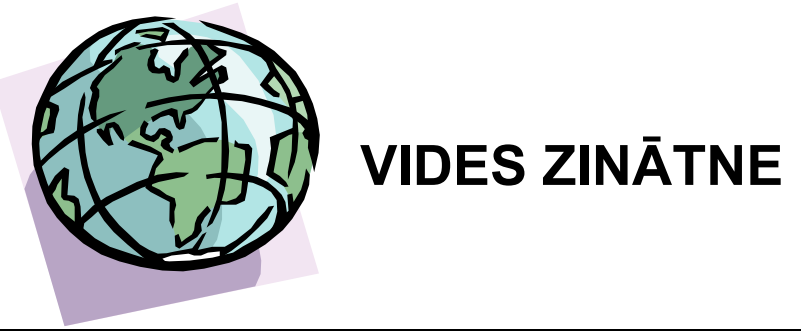

\title{
ANTROPOGËNĀS IETEKMES NOVËRTËJUMS EZERU PIEKRASTES REKREĀCIJAS ZONĀS: ATSEVIŠK়U AUSTRUMLATVIJAS EZERU PIEMËRS
}

\author{
Jeļena ALEKSEJEVA, Aija JASĀNE, Antra LERHA, Guna ŠUMILO, Inga VONOGA, \\ Santa RUTKOVSKA \\ Daugavpils Universitāte, Dabaszinātņu un matemātikas fakultāte, \\ e-pasts: jaleksejeva@one.Iv, smileinga@inbox.Iv, sumilo@one.Iv, santal@dau.Iv
}

Darba gaitā tika pētītas 5 Austrumlatvijas ūdenstilpju piekrastes rekreācijas zonas: Radžu ūdenskrātuve (Jēkabpils pilsētas teritorijā), Zuju ezers (Jēkabpils rajona Asares pagastā), Alūksnes ezers (Alūksnes pilsētas teritorijāa), Zirgezers (Krāslavas pilsētas teritorijāa), Stropu ezers (Daugavpils pilsētas teritorijā). Pētījums tika veikts 2004.gada jūnija-augusta mēnešos. Darba rezultātā tika noteikts tūristu un rekreantu atsevišķu ietekmes faktoru novērtējums uz ūdenstilpju piekrastes rekreācijas zonām.

Pētijuma īstenošanai tika izmantotas Newsome D., Moore S.A., Dowling R.K. (2002.) antropogēnās ietekmes uz vidi novērtěšanas metodes.

Visās piekrastes rekreācijas zonās aktīvākās tūrisma sezonas laikā (jūnijs augusts) samazinās augu sugu daudzums un īpatņu blīvums. Katrā no teritorijām ir vairāk nekā divas cilvēku izveidotas takas. Tās maina biotopu veidojošos faktorus un negatīvi ietekmē apkārt esošās teritorijas. Gar takām tika novērota izteikta augu segas nomīì̌šanas pakāpe (skat. 1.tabulu).

Kā redzams 1.tabulā, vismazākā augu sugu daudzveidība ir uzreiz pie takām. Pieaugot attālumam no takām, pieaug augu sugu daudzveidība. Tas uzskatāmi pierāda negatīvo antropogēno iedarbību. Atšksirīgi rezultāti tika iegūti, apsekojot piekrastes rekreācijas zonas pilsētu un lauku teritorijās. Lai gan Alūksnes ezers atrodas pilsētas teritorijāa, tas izvietots pie pilsētas parka un pie tā nav iespējams piekḷūt ar automašīnām (apmēram $1 \mathrm{~km}$ atpūtniekiem ir jāiet kājām). Šie faktori tiešā veidā veicina augu sugu daudzveidības saglabāšanos. Zuju ezera piekrastes rekreācijas zonā konstatēts otrs lielākais augu sugu daudzveidības skaits. Zuju ezers atrodas Asares pagastā, līdz ar to atpūtnieku 
intensitāte (aktīvās tūrisma sezonas laikā ezeru vienā dienā apmeklēja vidēji 40 cilvēki) nav tik liela kā pilsētās un nomīdīšanas pakāpe ir zemāka. Vismazākais augu sugu daudzveidības skaits ir Radžu ūdenskrātuves un Zirgezera tuvumā. Tā kā minētās ūdenstilpes atrodas Jēkabpils (vidējais apmeklētāju skaits dienā - 250) un Krāslavas (vidējais apmeklētāju skaits dienā 80) pilsētu teritorijās, arī atpūtnieku skaits un antropogēnais noslogojums ir lielāks nekā laukos.

1.tabula

Augu sugu skaits pētāmo ūdenstilpju piekrastes rekreācijas zonās

\begin{tabular}{|l|c|c|c|}
\hline & Pie takas & 3 m attālumā & 6 m attālumā \\
\hline Zuju ezers & 9 & 10 & 13 \\
\hline Zirgezers & 7 & 10 & 10 \\
\hline Radžu ūdenskr. & 7 & 8 & 8 \\
\hline Alūksnes ezers & 5 & 10 & 18 \\
\hline kopā & $\mathbf{2 8}$ & $\mathbf{3 8}$ & $\mathbf{4 9}$ \\
\hline
\end{tabular}

Visās pilsētu teritorijās esošajās ūdenstilpju piekrastes rekreācijas zonās tika konstatēti koki ar dažādiem bojājumiem (skrāpējumi, grebumi, lauzti zari, iecirtumi u.tt.), bet vienīgajā lauku teritorijā - Zuju ezera piekrastē bojātu koku nav. Tas liecina par lauku teritoriju iedzīvotāju saudzīgāku attieksmi pret dabu.

Alūksnes ezera un Radžu ūdenskrātuves peldvietu teritorijās (katrā) ir 2 koki ar atsegtām koku saknēm, jo tie atrodas ūdenstilpes tuvumā un ir pakḷauti ūdens erozijai. Savukārt Zuju, Stropu ezera un Zirgezera piekrastes rekreācijas zonu teritorijās 4-5 koki ar atsegtām saknēm, piemēram, pie Stropu ezera ir smilšaina augsne, kas pakḷauta spēcīgai vēja erozijai, turpretim Zuju un Zirgezera teritorijās koku saknes tiek pakḷautas pastāvīgai apmeklētāju ietekmei (koku saknes bieži vien tiek izmantotas kā sēdvietas), kā arī atrodas tiešā ūdens tuvumā.

Visās pilsētu teritorijās ir liels labiekārtojuma elementu skaits (speciāli iekārtotas ugunskura vietas, sēdvietas, galdi, tualetes, atkritumu urnas, geērbtuves u.c.), turpretim lauku teritorijā vispār netika konstatēti šādi elementi. Pieredze liecina - jo lielāks labiekārtojuma elementu skaits, jo mazāk tiek negatīvi ietekmēta pati rekreācijas zona un tai piegulıošās teritorijas (mazāks nomīdījums, aplauzto zaru, atkritumu skaits, u.tml.).

Visās peldvietu teritorijās nav liels cilvēku radīto atkritumu skaits, jo pilsētu peldvietu teritorijas tiek uzkoptas, bet laukos tūristu un rekreantu plūsma nav tik izteikta un līdz ar to radīto atkritumu apjoms ir mazāks.

\section{Secinājumi un ieteikumi:}

1. vislielākā tūristu un rekreantu plūsmas negatīvā ietekme uz piekrastes rekreācijas zonām ir Alūksnes, Daugavpils, Jēkabpils un Krāslavas pilsētu teritorijās;

2. pilsētu teritorijās ir nepieciešama regulārāka uzkopšana, kā arī peldvietas izmantošanas noteikumu izstrāde, kas veicinātu sabiedrības atbildīgāku attieksmi; 
3. nepieciešams uzstādīit informatīvas zīmes ar norādi uz peldvietas atrašanās vietu, lai mazinātu jaunu un stihisku peldvietu veidošanos.

\title{
MĀRUPĪTES ŪDENS KVALITĀTE
}

\author{
Elga APSīTE*, Ilga KOKORĪTE*, Māris KĻAVIN̦Š*, Ansis ZīVERTS** \\ * - Latvijas Universitāte, Ģeogrāfijas un Zemes zinātņu fakultāte, \\ e-pasts: elga.apsite@lu.Iv \\ ** - Latvijas Lauksaimniecības universitāte, Lauku inženieru fakultāte, \\ e-pasts: aziverts@apollo.Iv
}

Pētījuma mērķis - raksturot Mārupītes ūdens kvalitāti pēdējo triju gadu laikā. No 2002.gada maija līdz 2003.gada aprīlim un 2005.gadā ņemti ikmēneša ūdens paraugi Mārupītē trijās vietās: augšpus un lejpus Māras dīķa un augšpus tās ietekas Daugavā. Latvijas Universitātes Ģeogrāfijas un Zemes zinātñu fakultātes Vides kvalitātes monitoringa laboratorijā veiktas ūdens paraugu analīzes šādiem parametriem: $\mathrm{N}_{-\mathrm{NO}_{3}}^{-}, \mathrm{N}_{-} \mathrm{NO}_{2}^{-}, \mathrm{N}_{-} \mathrm{NH}_{4}^{+}, \mathrm{N}_{\text {kop }}, \mathrm{P}-\mathrm{PO}_{4}{ }^{3-}, \mathrm{P}_{\text {kop }}, \mathrm{Si}_{\text {kop }}, \mathrm{Cl}^{-}, \mathrm{Ca}^{2+}, \mathrm{Mg}^{2+}$, $\mathrm{K}^{+}, \mathrm{Na}^{+}, \mathrm{HCO}_{3}^{-}, \mathrm{SO}_{4}{ }^{2-}$, kopējā cietība, EVS, KSSP, $\mathrm{BSP}_{5}, \mathrm{O}_{2}$ un ūdens krāsainība.

Pētìjumā analizēta ne tikai Mārupītes ūdens kvalitāte, bet arī tās ķīmiskais sastāvs, hidroloğiskais režīms un upes slodzes dažādiem hidroḳīmiskajiem parametriem. Ikdienas caurplūdumi simulēti, izmantojot matemātisko modeli METQ98. Upes slodžu aprēķināšanai izmantots FLOWNORM modelis. LandCorine 2000 datu bāze izmantota, lai analizētu zemes apauguma raksturu Mārupītes baseinam.

\section{RĪGAS UN PIERĪGAS EZERU EKOLOĢISKAIS STĀVOKLIS UN TĀ SAISTİBA AR TOKSISKO AĻĢU MASVEIDA ATTĪSTİBU}

\author{
Maija BALODE, Ingrīda PURIN̦A, Māra PFEIFERE, Solvita STRĀĶE, \\ leva BĀRDA, Jānis AĢIS, Miks VEINBERGS
}

Toksiskās aļges ir ne vien nopietna globāla mēroga problēma, bet tieši skar arī Latvijas ūdenstilpes, sevišķu aktualitāti iegūstot rajonos, kam raksturīga liela antropogenā slodze un augsts viegli noārdāms organisko vielu saturs vidē. Pēdējos gadu desmitos virknē Latvijas ūdenstilpju konstatētas būtiskas toksisko alğgu īpatsvara pieauguma tendences, vasarās izraisot intensīvu "ūdens ziedēšanu", kas savukārt izraisa ūdens dzidrības samazināšanos, skābekḷa deficītu un pūšanas procesu sākšanos vidē. Bez jau minētajām parādībām bīstamo alığu masveida savairošanās parasti saistās ar aḷgu toksīnu (hepatotoksīnu un neirotoksīnu) producēšanu un to izdalī̌sanos apkārtējā vidē, kas savukārt negatīvi ietekmē pārējo ūdens organismu attīstību, radot to reproduktīvo spēju zudumu un mirstību, kā arī būtisku sugu daudzveidības samazināšanos. 
Darba mērḳis - noteikt toksisko alğgu problēmas aktualitāti Rīgas un Pierīgas ūdenstilpēs, analizēt ar bīstamo aļǵgu attīstību saistītās ekoloǵiskās problēmas un veikt potenciālā riska novērtējumu. Tā īstenošanai tika veikti ekologiska un toksikologiska rakstura pētījumi 13 saimnieciski nozīmīgos ezeros (Gaiḷezerā, Linezerā, Velnezerā, Bābelītī, Ķ̄ǐšezerā, Juglas ezerā, Langstinuu ezerā, Lielajā Baltezerā, Mazajā Baltezerā, Sidrabezerā, Sekšu ezerā, Venču ezerā, Lilastes ezerā, Pulksteņezerā), galveno uzmanību pievēršot rekreācijas nozīmes ūdenstilpēm un dzeramā ūdens avotiem. Pētījumu laikā (1997.-2004.g.) tika apzinātas ūdenstilpes, kurās iespējama toksisko aļgu masveida attīstība. Tika noteikta bīstamo aḷğ "ziedēšanas" intensitāte un dinamika, analizēti tās cēloṇi un sekas. Toksisko cianobaktēriju (zilą̧ğu) attīstība izvērtēta saistībā ar vides faktoriem, ūdenstilpju antropogeno slodzi un to eitrofikācijas līmeni. Tika noteiktas aļgu toksīnu (hepatotoksīnu - mikrocistīnu) koncentrācijas, to producēšanas intensitāte, toksiskuma pakāpe un bīstamība. Darbā aplūkotas vides faktoru izmantošanas iespējas toksisko alı̆gu attīstības un toksiskuma prognozēšanā. Noteikta toksisko alı̆gu problēmas aktualitāte Rīgas un Pierīgas ūdenstilpēs, apzināti "karstākie punkti", novērtēta situācijas nopietnība saistībā ar pārējo ūdensorganismu attīstību, kā arī ar mājdzīvnieku un cilvēku veselību. Lai noskaidrotu bīstamo aḷgu ietekmi uz hidrobiontu attīstību, lauku pētījumi tika papildināti ar eko-toksikoloǵiskiem eksperimentiem, kā testobjektus izmantojot dažāda trofiskā līmeņa ūdens organismus (zooplanktonu un zivju mazuļus), tos eksponējot toksisko cianobaktēriju streinu klātbūtnē.

Pētījumu rezultāti liecina par toksisko alğgu problēmas aktualitāti daudzos Rīgas un Pierīgas ezeros (jo sevišķi Lielais un Mazais Baltezers, Langstinuu ezers, Bābelītis u.c.), norādot uz nepieciešamību toksisko alğgu testēšanu nekavējoties iekḷaut nacionālā monitoringa programmā, sevišķu uzmanību pievēršot peldūdeṇu un dzeramā ūdens kvalitātei. Apsekojot minētās ūdenstilpes, atklājās, ka aļǵu toksīni atrodas ne tikai alğgu šūnās, bet spēj pārvietoties pa barības ķēdi un bioakumulācijas cel̦ā uzkrāties citos ūdensorganismos, būtiski ietekmējot to attīstîbu: samazinot zooplanktona olu produkciju, kavējot to šķilšanos un atsevišķos gadījumos izraisot organismu mirstību (piemēram, 2002. un 2003.gada vasarā Lielajā Baltezerā, kur tika novērota gliemju un zivju bojāeja). Antopogēnai slodzei pakḷautās ūdenstilpes uzrādīja intensīvu toksisko aļgu (Microcystis spp., Anabaena spp., Oscillatoria spp. u.c.) attīstību un alsgu toksīnu klātbūtni koncentrācijās, kas tuvas dzeramajā ūden̄̄ maksimāli pieļaujamajām koncentrācijām (MPK), bet atsevišksos gadījumos pat to ievērojami pārsniedza. Augstākās mikrocistīna koncentrācijas tika uzrādītas toksisko cianobaktēriju "ziedēšanas" kulminācijas periodā.

Rezultāti liecina par nepieciešamību turpināt zinātniskus pētījumus par toksisko aḷgu ietekmi uz ūdens organismu attīstību, sevišķu uzmanību pievēršot to reprodukcijas spējām, kas varētu ievērojami ietekmēt hidroekosistēmu sugu daudzveidību. Pētījumi parādīja nepieciešamību sagatavot ar potenciāli toksisko 
aļğu problēmu saistītu informatīvo materiālu (ietverot iespējamos risinājumus "ziedēšanas" intensitātes samazināšanai riska ūdenskrātuvēs), kas varētu tikt izmantots vidi un sabiedrības veselību sargājošo institūciju, masu saziņas līdzekḷu un sabiedrības informēšanai.

\title{
RĪGAS VĒSTURISKĀ CENTRA APSTĀDĪJUMU STRUKTÜRAS ATTİSTİBA
}

\author{
Gunta ČEKSTERE, Olǵgerts NIKODEMUS \\ LU Ģeogrāfijas un Zemes zinātņu fakultāte, \\ e-pasts: guntac@inbox.lv; nikodemu@lanet.lv
}

Saskaṇā ar Rīgas pilsētas vēsturiskā centra (RVC) saglabāšanas un attīstības plānu viena no š̄is teritorijas neatṇemamām vides sastāvdaḷām ir apstādījumi. Viens no "dabas pamatnes" elementiem - apstādījumi - ietekmē pilsētas mikroklimatu, samazina ķīmisko piesārņojumu un troksni, vibrācijas, producē skābekli un vienlaikus pilda iedzīvotāju rekreācijas, veselības saglabāšanas, izglītošanas, ekosistēmas, pilsētas reprezentācijas u.c. funkcijas.

Faktors, kas var ietekmēt apstādījumu funkcionalitāti un nozīmi pilsētvidē, ir apstādījumu struktūra. To nosaka struktūras elementu (ķ̄ịli, zal̦ās līnijas un kabatiņas, apzaļumoti laukumi) savstarpējais izvietojums, kas izveidojas līdz ar urbānās teritorijas attīstību.

RVC apstādījumu struktūras vēsturiskās attīstības analīzē izmantotas Latvijas Nacionālās bibliotēkas Kartogrāfisko iespieddarbu, Reto grāmatu un rokrakstu nodaļas un Latvijas Valsts vēstures arhīva kartes un Latvijas Fotogrāfijas muzeja un Rīgas Vēstures un kuğniecības muzeja fotogrāfijas, kā arī literatūras pētijumi. Kā pamatmateriāls mūsdienu situācijas raksturojumam ir izmantots apstādījumu inventarizācija, kas veikta 2002.gadā (Nikodemus u.c., 2003).

Pamatojoties uz veikto pētījumu, RVC apstādījumu struktūras attīstībā var izdalīt vairākus posmus. Galvenās konstatētās apstādījumu struktūras attīstības likumsakarības pilsētas veidošanās laikā ir:

1. Laika periodā no 13. līdz 17.gs. - pastāv atsevišķas privātas iniciatīvas, kuru rezultātā iezīmējas izolēta salveida apstādījumu (dārzi) struktūra ar atsevišķi augošiem kokiem Vecrīgā un ārpus pilsētas mūriem, kā arī sakṇu dārzu pusloks ārpus valņiem.

2. Laika periodā no 18.gs. līdz 19.gs. sākumam - privātas iniciatīvas un pilsētas rātes iesaistīšanās pastaigu aleju veidošanā iezīmē lineārās apstādījumu struktūras (radiālais princips) pazīmes.

3. Laika periodā no 1812. līdz 1879.g. - Daugavas plūdi un priekšpilsētu nodedzināšana ir galvenie iemesli apstādījumu veidošanai saskaņā ar jaunajiem pilsētbūvnieciskās struktūras plāniem un projektiem ārpus Vecrīgas. Šis princips 
tiek izmantots arī brīvo teritoriju apsaimniekošanā. Tiek veidoti publiskie apstādījumi ar reprezentatīvu un rekreācijas nozīmi

4. Laika periodā no 1879. līdz 1914.g. - notiek fortifikācijas sistēmas likvidēšana, kas ir iemesls publisko apstādījumu veidošanai ar rekreācijas nozīmi, īpaši domājot par mazturīgākajiem pilsētniekiem un pilsētas ventilāciju.

Pirmo reizi parādās neliela tendence apstādījumu platību samazināšanai daudzstāvu apbūves, transporta sistēmas attīstības un pazemes komunikāciju izbūves vajadzībām.

5. Laika periodā no 1914. līdz 1940.g. - brīvo teritoriju apzaļumošana, esošo laukumu pārveidošana, struktūras tālāka attīstība.

6. Laika periodā no 1945. līidz 1991.g. - Otrā pasaules karā sagrauto ēku teritoriju apzaļumošana, kā arī parku apbūve.

7. Laika periodā no 1991. līdz 2002.g. - apstādījumu struktūras sadrumstalošanās autostāvvietu, biroja ēku, tirdzniecības un izklaides centru būvniecības dēl zaļajās teritorijās. Raksturīga pēcpadomijas laika apstādījumu struktūras iezīme.

Tādējādi pašreizējai RVC apstādījumu struktūrai raksturīgs ir horizontālais princips. Apstādījumu struktūru veido parki, skvēri, dārzi, zaļie laukumi, ielu, pagalmu, publisko ēku apstādījumi un priekšdārzi. Apstādījumu telpiskais izvietojums ir cieši saistīts ar pilsētbūvniecisko plānojumu. Vecrīgas teritorijā ar neregulāras apbūves struktūru apstādījumi sastopami kā atsevišksi koki, laukumi, skvēri. Ķīḷveida princips ir Bulvāra zaļajam lokam, ko veido Viesturdārzs, Vērmanes dārzs, Kanālmalas apstādījumi, Esplanāde un Anatomikuma apzalıumotās teritorijas, kā arī priekšdārzi un ielu apstādījumi. Vecrīgu no otras puses aptver Daugavmalas apstādījumi. Ārpus Bulvāru zal̦ā loka regulāras taisnstūra apbūves teritorijās ir izveidojies režǵveida apstādījumu struktūras princips. Kā pārejas elements starp ielu, pagalmu un parku, dārzu apstādījumiem ir priekšdārzi. Virzienā uz perifēriju aiz Ārrīgas loka palielinās pagalmu apstādījumu īpatsvars un nozīme, kas kopā ar Ziedoṇdārzu, atsevišķiem skvēriem un ielu apstādījumiem iezīmē jaunu zaļo pusloku.

Mūsdienās perimetriālās apbūves atjaunošanas rezultātā izzūd skvēri, kas izveidoti pēc Otrā pasaules kara, savukārt pagalmu apbūves dēḷ samazinās plašie apstādījumiem bagātie pagalmi, kas ir nozīmīgi iedzīvotāju atpūtai un vides kvalitātes nodrošināšanai pilsētas vēsturiskajā centrā. Perspektīvā var prognozēt, ka, palielinoties antropogēnai slodzei uz ielu apstādījumiem, sagaidāma ielu apstādījumu nozīmes samazināšanās (Čekstere u.c., 2004).

Līdz ar to vienīgā iespēja palielināt apstādījumu nozìmi RVC pilsētas vides kvalitātes paaugstināšanā ir veidot ekoloǵiski kvalitatīvus stādījumus plašajos pagalmos. 
Atsauces

Nikodemus, O., Zvirgzds, A., Cekule, M., Čekstere, G., Granta, D., Šveisberga, I. (2003). Apstādījumi Rīgas vēsturiskajā centrā un to nozīme pilsētvides kvalitātes paaugstināšanā. Rīgas vides un ilgtspējības profils. Rīga: Rīgas dome, Rīgas vides centrs „Agenda 21”, 23-29.

Čekstere, G., Osvalde, A., Karlsons, A., Nollendorfs, F., Paegle, G. (2004). The Effect of Urban Environment on the Mineral nutrition status of street trees in Riga, the problems and possible solution. Rīga: LU Zinātniskie raksti, Zemes un vides zinātnes (iesniegts publicēšanai).

\title{
VIDES INDIKATORA “SABIEDRĪBAI PIEEJAMO ATKLĀTO TERITORIJU UN PAKALPOJUMU VIETËJĀ LĪMENĪ““ ANALİZE RĪGAS PILSĒTĀ
}

\author{
Marita CEKULE, Irina GAILIŠA \\ LU Ģeodēzijas un Ģeoinformātikas institūts, \\ e-pasts:cekule@one.Iv , igailisha@btv.Iv \\ Mareks MŪRMANIS \\ SIA Datorkarte
}

Viens no mūsu svarīgākajiem uzdevumiem ir atstāt nākamajām paaudzēm dinamisku un ilgtspējīgu pasauli, kurā atrisinātas būtiskākās vides problēmas (Lindahl, 2003).

20.gs. 90.gados ilgtspējības koncepciju, kurā ietverta vides kvalitātes novērtēšana, par savas politikas mērki pienēema liels skaits organizāciju dažādos administratīvajos līmeņos, no ANO Ģenerālās asamblejas un Eiropas Savienības līdz nacionālajām, reǵionālajām un vietējām institūcijām (Silfverberg, 2003).

Cilvēka izveidotā specifiskā pilsētvide nosaka apkārtējās vides kvalitāti, kas ietekmē vispārējo dabas procesu attīstību kopumā.

Pilsētvides kvalitāti veido dažādi komponenti - sociāli, ekonomiski, ekolog̣iski, medicīniski, komunikāciju, mākslinieciski estētiski, informācijas utt.

Vides jeb "zalie" indikatori ir zinātniski mērījumi, kas atspoguḷo vides apstākḷu izmaiņas laika gaitā.

Pieeja sabiedriskajām atklātajām teritorijām un pakalpojumiem ir nozīmīga dzīves kvalitātes un vietējās ilgtspējības nodrošināšanai.

Rīgas attīstības plānā (1995) ir uzsvērts, ka katras pilsētas ekonomikā svarīga loma ir iedzīvotāju apkalpei, kas ietver daudzveidīgus pakalpojumus, kas nepieciešami pilsētas iedzīvotāju ikdienas dzīvē. Iedzīvotāju apkalpes sektora apjoms ir atkarīgs no pilsētas iedzīvotāju skaita, un tam ir proporcionāli jāmainās līdz ar iedzīvotāju skaita izmaināàm. Savā attīstības gaitā apkalpes struktūras pielāgojas pilsētas iedzīvotāju izvietojumam, no kā katrs šīs sfēras dalībnieks ir atkarīgs. Iedzīvotāju labklājīiba lielā mērā ir atkarīga no pilsētas sabiedriskās apkalpes tīkla attīstības līmeña. Sabiedriskā apkalpe dod iespēju iedzīvotājiem apmierināt kultūras un izglîtības, mācību, veselības, sociālās aprūpes, atpūtas un brīvā laika pavadīšanas iespējas. 
Balstoties uz ANO atbalstīto CEROI programmu - pilsētu ziņojumi par vides stāvokli internetā un tās izstrādātajiem Eiropas vienotajiem indikatoriem, tika veikta indikatora - sabiedrībai pieejamās atklātās teritorijas un pakalpojumi vietējā līmenī izpēte un datu kompleksā analīze Rīgas pilsētā.

Kā atklātās teritorijas pilsētā tika definēti: parki, dārzi, skvēri, atklātie laukumi daudzstāvu namu kvartālos, kapsētas ar atpūtas un kultūrvēsturisko nozīmi, mežaparki, pḷavas, meži, atklātās sporta zonas - skolu sporta laukumi. Pakalpojumi tika definēti kā: primārie veselības aprūpes pakalpojumi, sabiedriskā transporta līnijas, publiskās skolas, pārtikas veikali, bankas, otrreizējās pārstrādes uzṇēmumi vai sadzīves atkritumu apsaimniekošanas pakalpojumi.

Indikatora datu apstrādē izmantotā mērvienība - iedzīvotāju skaits, kas dzīvo līdz $300 \mathrm{~m}$ attālumā no sabiedriskajām atklātajām teritorijām vai pakalpojumiem / kopējais iedzīvotāju skaits $=\%$ no kopējā iedzīvotāju skaita (Metodolog̣ijas tabulas, 2001).

Indikatora analīze un novērtējums tika veikts pilsētas administratīvajās robežās, atsevišķi izdalot pieeju iedzīvotājiem (\%) atklātajām teritorijām un pakalpojumiem katrā no 6 administratīvajiem rajoniem.

Rīgas iedzīvotājiem ir ḷoti laba piekḷūšana pārtikas veikaliem - 92,40\%, kā arī sabiedriskā transporta pieturām (autobuss, tramvajs, trolejbuss), kas dal̨ēji nodrošina arī ikdienas darījumu veikšanu, ar minimālo kursēšanas biežumu reizi pusstundā $(88,27 \%)$.

Vairāk nekā pusei iedzīvotāju ir laba piekḷūšana obligātajām mācību iestādēm $(55,83 \%)$ un primārajiem veselības aprūpes pakalpojumiem $(54,33 \%)$. $43,81 \%$ pilsētas iedzìvotāju ir laba piekḷūšana bankām.

Atklātās un rekreatīvās teritorijas pilsētas iedzīvotājiem ir viegli sasniedzamas (82,94\%). Šeit gan jāizdala 2 izṇēmumi:

$\checkmark$ zaļās rekreatīvās teritorijas pilsētas centrā un perifērijā, kuras nav tik viegli sasniedzamas pilsētas iedzīvotājiem - tikai 30,48\%,

$\checkmark$ atklātie laukumi pilsētas centrā un daudzstāvu namu apbūves rajonos $(52,42 \%)$.

Labs nodrošinājums pilsētā ir ar atkritumu konteineriem otrreizējai pārstrādei un otrreizējās pārstrādes uzṇēmumiem (64,19\%).

Viskritiskākā situācija ir ar atklātajām sporta zonām un ēkām, pieeja kurām sabierībai ir bezmaksas - tikai 30,67\% (Atskaite, 2003). 


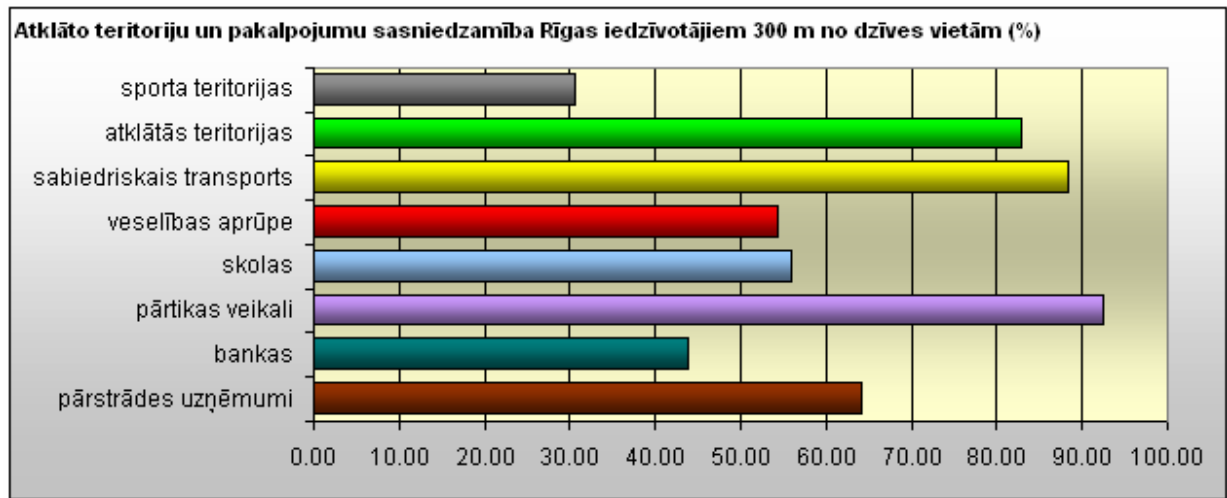

Atsauces

Lindalh E. 2003. Vides indikatori Norčēpingā. Rīgas vides un ilgtspējības profils. Rakstu krājums /2003. Rīgas dome. Rīgas vides centrs “Agenda 21”. 65.-66. lpp.

Silfverberg K. 2003. Ilgtspējības pamatindikatoru izstrādāšanas process Helsinkos. Rīgas vides un ilgtspējības profills. Rakstu krājums /2003. Rīgas dome. Rīgas vides centrs “Agenda 21”. 70.-74.lpp.

Ceḷā uz vietējās ilgtspējīibas profilu - Eiropas vienotie indikatori. 2001. Metodologijas tabula:

Indikators Nr. A.4.

Rīgas attīstības plāns 1995.g. - 2005.g. 1995. Rīgas pilsētas Dome.

Pētnieciskā darba "Sabiedrībai pieejamās atklātās teritorijas un pakalpojumi vietējā līmenī Rīgas pilsētā" atskaite. 2004. Rīga.

\title{
SĒRA SAVIENOJUMU PĀRROBEŽU PĀRNESES NOVĒRTĒJUMS LATVIJĀ
}

\author{
Iveta DUBAKOVA, Marina FROLOVA \\ Latvijas Hidrometeoroloǵijas aǵentūra, \\ e-pasts: iveta.dubakova@meteo.Iv, epoc@meteo.Iv
}

Šì raksta uzdevums ir novērtēt sēra savienojumu piesārṇojuma pārrobežu pārnesi Latvijas teritorijā laika posmam no 1986.gada līdz 2000.gadam. Lai veiktu kvalitatīvu novērtējumu, tika veikta gaisa kvalitātes datu statistiskā apstrāde (gadam, kā arī siltajam un aukstajam gada periodam), gaisa masu pārvietošanās trajektoriju analīze un tendences analīze pēc Mann-Kendall testa vielu gada vidējām un trajektoriju koncentrācijām.

1994.gada 7.jūnijā Latvijas Ministru kabinets ratificēja Ženēvas 1979.gada konvenciju „Par gaisa piesārņojuma pārrobežu pārnesi lielos attālumos”, un 1997.gada 17.jūnijā Latvija pievienojās Ženēvas protokolam „Par kopējās programmas gaisa piesārņojuma izplatības lielos attālumos novērošanai un novērtēšanai Eiropā ilgtermiņa finansēšanu (EMEP)" (1984.g.). Šis protokols paredz Latvijas iesaistǐšanos starpvalstu piesārņojuma novērojumu un gaisa piesārņojuma izplatības lielos attālumos novērtējuma programmā. 
Uz šo starptautisko saistību pamata Latvijā tika izveidotas 2 EMEP (Kopējā programma gaisa piesārņojuma izplatības lielos attālumos novērošanai un novērtēšanai Eiropā) stacijas, kurās tiek veikti regulāri gaisa un nokrišņu kvalitātes novērojumi un kas izvietotas dažādos fizikāli-ǵeogrāfiskos reǵionos ar atšķirīgiem klimatiskiem apstākḷliem: Vidzemes augstienē (Zosēnu stacija) un Piejūras zemienē (Rucavas stacija).

Atmosfēras gaisa un nokrišṇu kvalitātes novērojumi Rucavas stacijā sākti 1985.gadā, bet Zosēnos - 1994.gadā.

Rucavas stacija atrodas republikas dienvidrietumu daḷā, $10 \mathrm{~km} \mathrm{uz}$ austrumiem no Baltijas jūras un $50 \mathrm{~km}$ uz dienvidiem no Liepājas. Stacijas augstums ir $18 \mathrm{~m}$ virs Baltijas jūras līmeña. Rucavas stacija atrodas tiešā no Eiropas industriāli attīstītajām valstīm nākošā atmosfēras gaisa piesārņojošo vielu pārrobežu pārneses ietekmē. Stacijas starptautiskais kods - LV10.

Lai novērtētu atmosfēras gaisa kvalitāti, kas formējas pārrobežu pārneses ietekmē citos fizikāli ǵeogrāfiskos apstākḷlos, kā arī lai nodrošinātu šādu staciju nepieciešamo daudzumu visā teritorijāa, izvēlēta Zosēnu stacija. Stacija atrodas Latvijas ziemeļaustrumu dạ̦ā, $30 \mathrm{~km}$ uz dienvidaustrumiem no Cēsīm. Stacijas augstums ir 193 m virs Baltijas jūras līmeņa. Stacijas starptautiskais kods - LV16.

Laika periodā no 1985.gada līdz 2000.gadam augstākās sēra koncentrācijas tika novērotas gada aukstajā laika periodā (oktobris-marts). Šajā periodā ir vislabāk izteikta (statistiski pamatota) koncentrāciju lejup ejoša tendence $(\mathrm{p}<0.05)$.

Gaisa masu kustību trajektoriju analīze Latvijas teritorijā laika periodam no 1986. līdz 2000.gadam parādīja, ka lielākā daļa gaisa masas tiek ienesta no R un ZR (līdz 40\% no kopējā gada apjoma) - no Dānijas, Baltijas jūras un Skandināvijas. Lai gan dominējošie ir R un ZR virzieni, 2 reizes augstākas sēra saturošo vielu koncentrācijas Rucavas un Zosēnu stacijas uzrāda pie gaisa masu pārvietošanās virzieniem no centrālās un austrumu Eiropas (DR un D sektori). Zosēnos paaugstinātas sēra savienojumu koncentrācijas fiksētas arī pie DA, A un ZA trajektoriju sektoriem. Pie šīm trajektorijām atmosfēras gaisa piesārņojums uz Latviju nāk no Krievijas, Baltkrievijas un Ukrainas.

$\mathrm{SO}_{2}$-S sektorālās tendences analīzes rezultāti parādīja statistiski būtisku lejupejošu trendu DR un D, kā arī ZA, A un DA trajektoriju sektoros, izṇemot silto sezonu Rucavā, kur ir augšupejošs trends pie R un ZR trajektoriju sektoriem.

Sēra savienojumu koncentrāciju lejupejošas tendences abās Latvijas EMEP stacijās apstiprina Ženēvas konvencijas "Par robežšķērsojošo gaisa piesārṇošanu lielos attālumos" dalībvalstu izstrādāto protokolu "Par sēra izmešu vai to pārrobežu plūsmu samazināšanu par 30\%" (08.07.1985.) un "Par tālāko sēra izmešu samazināšanu" (14.06.1994.) izpildi. 


\title{
DAŽĀDU LATVIJAS HUMUSVIELU SALĪDZINĀJUMS, IZMANTOJOT PIROLİZES GĀZU HROMATOGRĀFIJU/ MASSPEKTROMETRIJU
}

\author{
Linda EGLITTE \\ LU Ģeogrāfijas un Zemes zinātņu fakultāte, \\ e-pasts: leglite@hotmail.com
}

Humusvielas (HV) ir bioloǵiski noturīgi, ķīmiski heterogēni augstmolekulāri savienojumi, kuru sastāvu veido ar dažādām skābekli saturošām funkcionālajām grupām aizvietotas aromātiskas struktūras, kas savstarpēji saistītas ar alifātiskām ķēēem. Humusvielas veido lielāko daļu no kūdrā, augsnē, lignītā, dabas ūdeṇos un to sedimentos esošajām organiskajām vielām. N,emot vērā to lielo molekulmasu un komplicēto uzbūvi, ar tradicionālām analīzes metodēm humīnskābes ir grūti salīdzināt, tādēl parasti humusvielu izpētei tiek izmantota kompleksa pieeja, tas ir, HV tiek analizētas ar vairākām metodēm. Šajā pētījumā kā pamats tiek ñemti pirolīzes gāzu hromatagrāfijas/masspektrometrijas (pirolīzes-GH/MS) rezultāti, papildus salīdzinot arī humusvielu infrasarkanos spektrus. Pirolīzes procesā humusvielu molekulas tiek sagrautas līdz pat 200-300 dažādu mazmolekulāru savienojumu, kas tālāk tiek identificēti un analizēti ar gāzes hromatogrāfu un masspektrometrijas detektoru. Tādējādi šì metode l̦auj savstarpēji salīdzināt dažādas humusvielas pēc to struktūru veidojošiem elementiem.

Darbā tika analizētas un salīdzinātas dažādu izcelsmju humusvielas, kuras izdalītas gan no virszemes ūdeņiem (Salacas, Daugavas, Inčupes upēm un Islienas ezera), kā arī no dažādām kūdrām izdalītās humusvielas.

1.tabula

Humusvielu pirolīzes degradācijas produktu relatīvās proporcijas, \%

\begin{tabular}{|c|c|c|c|c|c|c|c|c|}
\hline \multirow[b]{2}{*}{ Produkti } & \multicolumn{4}{|c|}{ Virszemes ūdenu humusvielas } & \multicolumn{3}{|c|}{ Kūdras humusvielas } & $\frac{\text { Komerciā }}{\text { la }}$ \\
\hline & Inăpes & Salacas & Isienss & Deugavas & Kačouk & Olainesk. & Bimanak & Tehum \\
\hline & G1 & D1 & B1 & A1 & P1 & R2 & $\mathrm{O} 2$ & S2 \\
\hline Alkylbenzenes & 0,8 & 2,5 & 2,3 & 1,6 & 2,2 & 1,3 & 6,9 & 4,7 \\
\hline Phenols & 5,8 & 6,0 & 9,0 & 8,3 & 6,9 & 4,7 & 6,9 & 1,7 \\
\hline Alkylphenols & 5,6 & 12,4 & 10,5 & 10,0 & 12,5 & 13,4 & 10,7 & 4,6 \\
\hline $\begin{array}{l}\text { Aromatic aldehydes } \\
\text { and ketons }\end{array}$ & n.f. & 1,2 & 1,4 & 0,8 & 1,5 & 0,9 & n.f. & n.f. \\
\hline $\begin{array}{l}\text { Phenolic aldehyde } \\
\text { and ketons }\end{array}$ & 5,0 & 1,7 & 3,5 & 5,9 & 8,5 & 4,7 & n.f. & 0,2 \\
\hline $\begin{array}{l}\text { Benzenecarboxylic } \\
\text { acids }\end{array}$ & 5,0 & 4,2 & 4,0 & 2,9 & 1,4 & 0,3 & 9,8 & 10,6 \\
\hline $\begin{array}{l}\text { Alkylbenzenecarbox } \\
\text { ylic acids }\end{array}$ & 0,7 & 2,0 & 1,0 & 0,7 & 1,0 & 0,3 & 2,4 & 2,1 \\
\hline Phenolic acids & 27,7 & 18,9 & 24,8 & 22,0 & 22,0 & 13,6 & 6,0 & 9,4 \\
\hline Alkylphenolic acids & 6,7 & 1,7 & 2,5 & 1,9 & 1,1 & n.f. & 4,7 & 5,9 \\
\hline Other phenolic acids & 3,5 & 1,7 & 3,0 & 4,2 & 14,1 & 11,2 & n.f. & 0,2 \\
\hline
\end{tabular}




\begin{tabular}{|l|c|c|c|c|c|c|c|c|}
\hline Polyaromatics der. & n.f. & 1,1 & 0,3 & n.f. & 1,0 & 0,1 & 2,9 & 5,6 \\
\hline Unclassified arom. & 5,8 & 3,4 & 3,7 & 3,2 & 4,6 & 4,6 & 8,5 & 9,6 \\
\hline Arom (biphenyl) & 1,2 & 0,8 & 1,1 & 0,6 & 1,5 & 0,6 & n.f. & 0,6 \\
\hline Alkane & n.f. & n.f. & n.f. & n.f. & n.f. & 0,2 & 2,9 & 5,0 \\
\hline Alkene & n.f. & n.f. & n.f. & n.f. & n.f. & n.f. & 2,0 & 0,5 \\
\hline Alcohols & n.f. & n.f. & n.f. & 0,2 & 0,1 & 4,5 & 1,3 & 3,8 \\
\hline $\begin{array}{l}\text { Aliph. aldehyde and } \\
\text { ketons }\end{array}$ & 0,3 & 0,3 & 0,3 & 0,1 & 0,1 & 0,7 & n.f. & 0,5 \\
\hline $\begin{array}{l}\text { Aliph. } \\
\text { monocarboxylic } \\
\text { acids }\end{array}$ & 4,5 & 5,9 & 4,0 & 6,8 & 7,1 & 20,9 & 23,1 & 21,5 \\
\hline $\begin{array}{l}\text { Aliph. dicarboxylic } \\
\text { acid }\end{array}$ & 10,8 & 14,1 & 10,1 & 7,4 & 3,4 & 6,2 & 2,4 & 3,2 \\
\hline $\begin{array}{l}\text { Aliph. tricarboxylic } \\
\text { acid }\end{array}$ & 2,7 & 3,0 & 2,7 & 1,8 & n.f. & n.f. & n.f. & n.f. \\
\hline Unclassified aliph. & 0,4 & 0,4 & n.f. & 0,4 & 0,7 & 1,8 & 1,6 & 1,9 \\
\hline & & & & & & & & \\
\hline Furans cyclic & 0,2 & 0,4 & 0,4 & 0,4 & 0,3 & 0,1 & 0,9 & 1,3 \\
\hline $\begin{array}{l}\text { Aliphatic } \\
\text { comp. }\end{array}$ & n.f. & 0,0 & n.f. & 6,1 & 0,0 & 1,4 & n.f. & 0,3 \\
\hline Carbohydrate der & & & & & & & & \\
\hline & 2,8 & 2,1 & 2,1 & 4,6 & 3,3 & 1,5 & 2,4 & n.f. \\
\hline N comp & n.f. & 0,1 & 0,1 & 0,1 & 0,4 & 0,0 & n.f. & n.f. \\
\hline Aromatic N comp & 0,9 & 0,1 & 0,7 & n.f. & n.f. & n.f. & n.f. \\
\hline P comp & 0,1 & 0,3 & 0,3 & 0,0 & 0,1 & 0,4 & 0,7 \\
\hline S comp & 0,9 & 0,5 & 1,2 & 0,6 & 0,6 & 0,4 & 0,4 \\
\hline Pyrrole deriv. & $1,8 . f$. & n.f. & n.f. & 0,2 & n.f. & n.f. & n.f. \\
\hline Pyridine deriv. & 3,5 & 3,8 & 1,9 & 1,7 & 1,9 & 1,5 & 2,8 \\
\hline & 8,6 & 6,2 & 3,9 & 4,5 & 2,2 & 2,9 \\
\hline $\begin{array}{l}\text { Unidentified } \\
\text { compounds }\end{array}$ & & & & & & & \\
\hline
\end{tabular}

Galvenie pirolīzes produkti (1.tabula) ir metoksibenzoskābes, metoksibenzoli, alkilbenzoli, aizvietoti fenoli, furāni, alkāni, alkēni, taukskābes, kā arī slāpekli, sēru un fosforu saturoši savienojumi. Iegūtie rezultāti lauj salīdzināt dažādas izcelsmes humusvielas, kā arī spriest par to strukturālo uzbūvi un iespējamajiem HV veidošanās avotiem (lignīns, proteīni u.c.).

Izmantojot pirolīzes - GH/MS un papildus vēl citas kjīmiskās analīzes metodes (IR, NMR, UV), iespējams iegūt visai labu HV raksturojošu informāciju. 


\title{
DAUGAVAS PALIEŅU EZERU ŪDENS SASTĀVA İPATNĪBAS VASARĀ
}

\author{
Dāvis GRUBERTS, Jana PAIDERE, Jānis PRIEDĪTIS, Artūrs ŠKUTE \\ Daugavpils Universitāte, \\ e-pasts: davis@dau.Iv
}

Daugavpils Universitātes, Latvijas Universitātes un SIA "Limnologijas institūts" kopīgā pētnieciskā projekta ietvaros 2004.gada 18.-28.jūlijā veikti ūdens sastāva un īpašību pētījumi 24 ezeros, kuri atrodas Daugavas palienē Daugavpils un Jēkabpils rajonu teritorijā. Ezeru ūdens masu hidroḳīmiskās un hidrofizikālās īpašības pētītas to centrālajā dal̦ā ar Hydrolab Surveyor 4 zondi, veicot mērījumus virsējā ūdens slān̄i, kā arī ik pēc metra dziḷākajos slāņos. Vienlaikus ezeru centrālajā daļā ar Seki disku noteikta ūdens caurredzamība un no $0,5 \mathrm{~m}$ dziļuma ar batometru ievākti paraugi ķīmiskajām analīzēm. Tās veiktas 19.-29.jūlijā Daugavpils Reǵionālās vides pārvaldes ekologiskajā laboratorijā un Daugavpils Universitātes Vides k̦īmijas laboratorijā saskaṇā ar standartmetodēm. Pētījuma rezultātā iegūti dati par Daugavas palieņu ezeru ūdens temperatūras, $\mathrm{pH}$, elektrovadītspējas, mineralizācijas, izšḳīdušā skābekļa, duḷkainības un reducēšanās-oksidēšanās potenciāla vertikālo sadalījumu un noskaidrotas atsevišķu biogēno elementu koncentrācijas ezeru virsējos slāņos vasaras periodā.

Iegūto datu sākotnējā analīze parāda izteiktu ūdens masu termisko stratifikāciju sešos dziļākajos ezeros (skat. attēlu) un liecina par vietējo vides faktoru nozīmi biogēno elementu sadalījumā, kā arī norāda uz iespējamo korelāciju starp atsevišşkiem hidrolog̣iskajiem un hidroķīmiskajiem radītājiem.

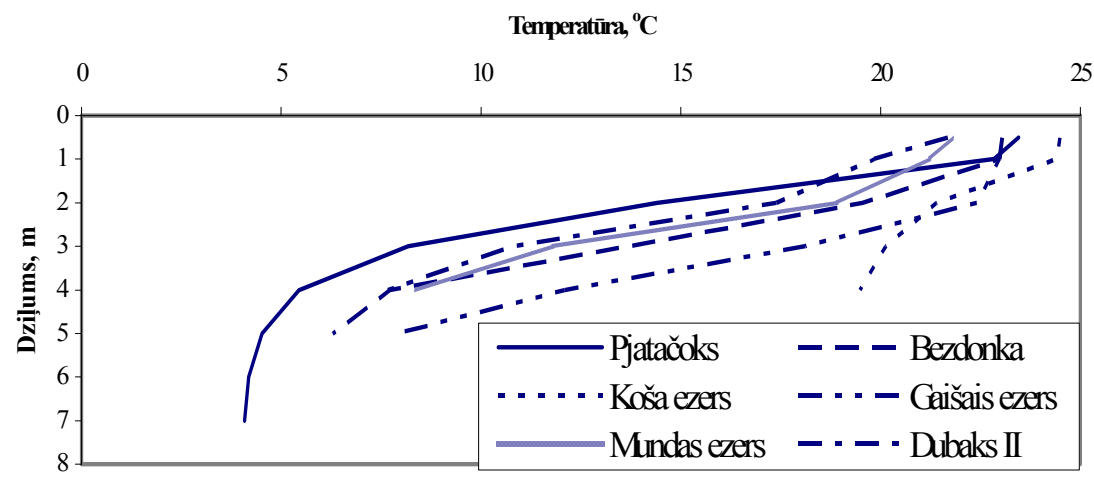

Dziḷāko Daugavas palienes ezeru termiskā stratifikācija 2004. gada 18.-27. jülijā 


\title{
AUGSNES KOLEMBOLU CENOZES REAKCIJA UZ KLIMATA PASILTINĀŠANOS DESMIT GADU PERIODĀ
}

\author{
Edīte JUCEVIČA, Viesturs MELECIS \\ LU Bioloǵijas institūts, \\ e-pasts ejucevica@email.lubi.edu.lv
}

No 1992. līidz 2002.gadam veikti ilgtermiņa pētỉjumi par klimata izmainuu ietekmi uz priežu lāna augsnes kolembolām Ziemel̦vidzemes biosfēras rezervātā. Pētījumi veikti trīs dažāda vecuma priežu audzēs: jaunā audzē (30-40 gadu), vidēja vecuma audzē (50-70 gadu) un vecā audzē (150-200 gadu). Augsnes paraugi (skaits - $\mathrm{n}=100$, lielums $-5 \mathrm{~cm}^{2} \times 10 \mathrm{~cm}$ ) - kolembolu uzskaitēm ievākti vienreiz gada augusta beigās vai septembra sākumā pēc īpašas shēmas ar augsnes urbi augsnes pētījumiem paredzētajā parauglaukumā. Kolembolas no augsnes paraugiem izdalītas ar modificētu temperatūras un mitruma gradientu nodrošinošu ekstraktoru. Kopumā paraugos konstatētas 66 kolembolu sugas. Sugu bagātība parauglaukumos svārstās robežās no 47-55 sugām, bet to blīvums - no 7300-8300 ind./m². Laikā no 1992.-2002.g. pēc vietējās meteostacijas (Rūjiena) datiem konstatēts statistiski būtisks pozitīvo $\left(>4^{\circ} \mathrm{C}\right)$ gaisa temperatūru summas pieauguma trends. Tajā pašā laikā nokrišņu daudzums un augsnes mitrums svārstījās pa gadiem. Datu analīzes rezultātā, izmantojot nemetrisko multidimensionālo skalēšanu (NMS), tika iegūtas divas asis, kas izskaidro attiecīgi $48,6 \%$ un $38,6 \%$ no kopējās datu variācijas. Pirmā ass sakrita ar pozitīvo temperatūru summu izmaiṇu trendu $(r=0,66, p=0,05)$ un tādēl tika interpretēta kā klimata pasiltināšanās negatīvā ietekme uz kolembolām, it īpaši euedafiskajām sugām, kas apdzīvo augsnes O horizonta apakšējos slāṇus. Otrā ass tika interpretēta kā augsnes mitruma fluktuāciju ietekme uz hemiedafiskajām kolembolām, kas apdzīvo nedzīvo zemsedzi; tās korelācija ar augsmes mitrumu $\mathrm{r}=-0,62, \mathrm{p}=0,05)$. Kolembolu sugu bagātība visos pētītajos parauglaukumos pêtījumu periodā pakāpeniski samazinājās no 29-36 sugām līdz 13-26 sugām. Korelācija starp NMS asīm $(\mathrm{r}=0,455, \mathrm{p}=0,05)$ norāda uz mijiedarbības efektu, kas pastāv starp pozitīvajām temperatūrām un augsnes mitrumu. Mežaudzes vecumam nebija nekādas ietekmes uz kolembolu sugu kompleksa struktūru, tādēl novērotās izmaiņas nav saistāmas ar ekoloǵiskajām sukcesijām. Kolembolu sugu kompleksu reakcijas deva iespēju secināt, ka konstatētajām izmaiṇām sugu sabiedrībās nav lokāls, bet gan reǵionāls raksturs. Izskaițojot vidējo parauglaukumu (sugu sabiedrību) temporālo trajektoriju NMS asīs visiem trim parauglaukumiem, tika konstatēts, ka 1 NMS ass sakrīt ar temporālo gradientu un pozitīvo temperatūru pieauguma trendu. Tajā pašā laikā, sugu sabiedrību temporālo vektoru lielā mērā nosaka otrs ekologiski svarīgs faktors - nokrišņi un augsnes mitrums. Šo faktoru mijiedarbība izpaužas kā savdabīgas vektora "cilpas" sugu sabiedrību vektoru temporālajā trajektorijā. 


\title{
EKOLOGISKO PROCESU TELPISKĀS IZPAUSMES RĪGAS PILSĒTAS DABAS TERITORIJĀS
}

\author{
Raimonds KASPARINSKIS \\ Latvijas Universitāte, Ģeogrāfijas un Zemes zinātņu fakultāte, \\ e-pasts: raimo@tvnet.lv
}

Cilvēka saimnieciskās darbības ietekmē pilsētās pieaug antropogēnā slodze uz dabas ekosistēmām, kas noved pie ekosistēmu augtenes apstākḷu izmaiņām. Mežu un plavu ekosistēmu reakcija uz antropogēno ietekmi galvenokārt ir augsnes erozija, pārpurvošanās un pārkrūmošanās. Tā rezultātā iepriekšminētās ekosistēmas kḷūst nestabilas, jo sugu invāzija pilsētvidē ir vairāk izplatīta kā dabiskajā vidē.

Ekoloǵisko procesu telpiskās izpausmes pētijums tika veikts 2004.gadā Rīgas pilsētas dabas pamatnes inventarizācijas projekta ietvaros, apsekojot un novērtējot pašreizējo mežu un plavu ekosistēmu attīstības stāvokli. Iegūtie rezultāti tika atlikti kartēs, mērogā 1:10 000. Paralēli dati fiksēti inventarizācijas veidlapās.

Pārkrūmošanās process tika iedalīts: atsevišķu krūmu, puduru veidošanās un vienlaidus pārkrūmošanās stadijā. Pārkrūmošanās process ir ekosistēmu dabiska attīstība sukcesionālā cel̦ā. Dabiskās sukcesijas, no atsevišķ̧u krūmu līdz puduru veidošanās, dinamika ir raksturīga galvenokārt Rīgas pilsētas nekoptu pḷavu ekosistēmās (piemēram, Rumbulas lidlauka un Spilves pḷavās), kā arī krastmalās, savukārt š̄is dabiskās sukcesijas stadijas ir vērtējamas ar augstu dinamiku un intensitāti gandrīz visos Rīgas pilsētas mežos. Pārkrūmošanās process sāk kḷūt dinamiskāks antropogēnās ietekmes dēl un saistāms ar augtenes trofiskuma izmaiņām, galvenokārt - biogēno elementu, piemēram, slāpekḷa un oglekḷa savienojumu pieplūdes dēḷ, kā sekas ir pastiprināta graudzāḷu invāzija, kā arī dabas teritorijās vērojama meža paaugas pastiprināta attīstība. Gandrīz lielākajā dạ̧ā no apsekotajām ekosistēmām ir vērojama atsevišķu krūmu un puduru veidošanās stadija, savukārt otra lielākā nozīme ir raksturīga vienlaidus pārkrūmošanās procesam, tā rezultātā mainās koku un krūmu sugu konkurences apstākḷi, oriğinālajos skujkoku-priežu mežos „iespiežas” agresīvās, pret mainīgiem vides apstākḷiem tolerantākās lapukoku pameža pioniersugas, piemēram, bērzi, pīlādži, kārkli, lazdas, korintes, ievas, kadiķi, klintenes, segliņi u.tml. Vienlaidus pārkrūmošanās lielākā intensitāte vērojama Mežaparkā, kā arī Juglas meža masīvā, dạ̦ā no Biķernieku meža un Šmerḷa meža, kā arī Rīgas pilsētas periferiālajā dą̧ā, kas nav kopta.

Pārpurvošanās process ir raksturīgs teritorijās ar pārlieku mitruma daudzumu, piemēram, reljefa ieplakās kur notiek ūdens akumulācija, veidojas stāvošs üdens, jo gruntsūdens līmenis ir pārāk augsts un gruntsūdens slāṇa kapacitāte ir pārāk zema attiecībā pret pieplūstošo nokrišnnu daudzumu. Pārpurvošanās procesu vēsturiskā skatījumā Rīgas pilsētas dabas teritoriju ekosistēmu dinamikā ir ienesusi cilvēka saimnieciskā darbība, aizberot daudzās 
nelielās upītes, kā arī veidojot ceļu un apbūves uzbērumus. Otra pārpurvošanās stadija ir sezonāli pārmitrās vietas, kam raksturīgs bioindikators ir sezonāli pārmitras augtenes veidošanās, piemēram, niedres u.tml. augi. Šì stadija ir uzskatāma par pārpurvošanās procesa sākuma stadiju. Dabisko stāvošo ūdens teritoriju klājums lielākā intensitātē ir gar ūdenstilpju krastmalām, tātad saistāms vairāk ar pḷavu ekosistēmām. Cilvēku saimnieciskā darbība ir veicinājusi pārpurvošanos arī Mārupes upes ielejā. Mārupītes lejtecē pēc tiltu izbūves, tā ir kḷuvusi sezonāli pārmitra un pamazām pārpurvojas.

Augsnes erozijas intensitāte Rīgas pilsētā, galvenokārt mežu ekosistēmās, ir atkarīga no diviem faktoriem: augsnes veğetācijas tolerances, ko nosaka organisko vielu daudzums augsnē, tātad, cik ilgā laika posmā veǵetācija spēj atjaunoties. Pētījumā noskaidrots, ka mazāk tolerantas pret augsnes eroziju ir smilts granulometriskā sastāva augsnes. Sevišķi nenoturīgas augsnes ir galvenokārt Rīgas pilsētas ziemeļu daḷā. Šajos meža masīvos vēsturiski ir bijušas celıjošās kāpas, kā rezultātā augsnes sega pilnībā vēl nav izveidojusies, tāpēc ir viegli degradējama. Otrs noz̄īmīgākais faktors ir cilvēku noslodzes uz rekreācijā izmantojamiem mežu masīviem. Šādā skatījumā apdraudētākie ir Šmerḷa un Biḳernieku meža masīvi.

Gala rezultātā salīdzinot pārkrūmošanās procesu starp mežu un plavu ekosistēmām, intensīvāks tas ir mežu ekosistēmās, kur agresīvās meža paaugas pioniersugas vieglāk migrē, jo mežu ekosistēmas Rīgas pilsētas dabas pamatnē nav tik defragmentētas kā plavu ekosistēmas, kur agresīvās augu sugas nevar attīstīt invāzijas dinamiku.

Savukārt pārpurvošanās process vairāk raksturīgs pḷavu ekosistēmām, bet pārkrūmošanās procesi pḷavās nav tik izteikti, jo meža paaugas sugas nelabprāt attīstās mitrās teritorijās, tādēḷ arī pḷavu ekosistēmām raksturīga vairāk sezonāli pārmitru augu sugu attīstība nekā mežu ekosistēmām.

\title{
MUIŽAS RĪGAS PILSĒTĀ KĀ KULTŪRVĒSTURISKĀS VIDES ELEMENTS
}

\author{
Dace KAUPUŽA \\ LU Ģeogrāfijas un Zemes zinātņu fakultāte, \\ e-pasts: puza@latnet.Iv
}

Kultūrvēsturiskā vide ir cilvēces attīstības gaitā apzinātas darbības rezultātā radīta vieta, ja tai vai atsevišķiem tās elementiem ir vēsturiska, zinātniska, mākslinieciska, ainaviska vai citāda saglabājama kultūras vērtība. Teritorijas attīstības rezultātā līdzvērtīgi notiek kultūrvēsturiskās vides izmaiṇas un jaunas vides veidošanās. Kultūrvēsturiskā vide liecina par sabiedrības dzīvesveidu, tradīcijām, tā atspoguḷo mijiedarbību starp cilvēka radīto un dabas vidi, kultūras ainavu un to elementu rašanos/izveidošanos, kuri ir konkrētās 
sabiedrības vēsturiskās attīstības spogulis, kā arī sabiedrības identitātes apliecinājums kādai vietai, pilsētai un valstij kopumā. Kā Rīgas pilsētas vēsturiskās vides attīstības, kultūrvēsturiskās ainavas elements, pilsētbūvniecības un arhitektonikas spogulis būtu izcel̦amas Rīgas muižiņas.

Ziņas par muižināam ir sastopamas jau no 14.gs. Līdz 18.gs. ārpilsētas muižu pamatmērķis bija to īpašnieku nodrošināšana ar pārtiku un dažādiem papildienākumiem. Lielākā daļa muižinuu izveidojās 18.gs., to noteica vairāki apsvērumi - š̄ gadsimta otrās puses apgaismības idejas, kas aicināja atgriezties pie dabas, kā arī viduslaiku cietokšṇpilsētas pārapdzìvotība. Tādēḷ Rīgas apkārtnē (Pārdaugavā, gar Ķī̌sezeru, Juglas ezeru u.c.) apgaismības ideju ietekmē radās izpriecu muižiņas, kuru ziedu laiki ilga līdz 19.gs. vidum, kad kapitālisma attīstība mainīja sabiedrības intereses, kā prioritāti nostatot nevis izpriecas, bet gan saimniecisko darbību. Līdz ar to palielinājās iedzīvotāju skaits un muižiņu teritorijas sadalīja gruntsgabalos, veidoja ielu tīklu un apbūvēja.

Literatūras avotos minēts, ka 1591.gadā namnieku lietošanā bija 37 muižiņas, rātskungiem - 14. Namnieku muižiņu skaits strauji pieaug 17.gs., gadsimta beigās lauku novadā bija 93 muižiņas. 18.gs. to skaits vēl palielinās, jo pilsētā jūtams ekonomiskais uzplaukums. Bijušo muižinu kompleksu paliekas ir saglabājušās arī šodienas Rīgas vidē. Pētera Blūma un Krišjāņa Veitnera sastādītajā muižu sarakstā ir apzinātas vairāk nekā 80 muižinas vai arhitektoniski tipologiski muižināām atbilstošas èkas un ēku kompleksi. Visas muižiņas ir iedalītas 4 kategorijās: A - saglabājusies muižas apbūve; B - lokalizējama muižas centra atrašanās vieta (saglabājušās palīgēkas, parka paliekas); C - muižas nosaukums saglabājies toponīmikā; D - par muižu saglabājušās tikai vēsturiskas liecības.

No nepilnām 90 apzinātājām muižināām, vairāk nekā 50 atbilst A un B kategorijai. 25 objekti no apzinātajām, pašlaik vēl eksistējošām muižināām vai arhitektoniski tipologiski muižiņām atbilstošajām ēkām ir iekḷautas Valsts kultūras pieminekḷu aizsardzības inspekcijas kultūras pieminekḷu sarakstā.

Zinātniskās izpētes gaitā tika apsekotas A un B kategorijas muižinas, novērtēts to stāvoklis, vides sakoptība un ainava kopumā. Balstoties uz iegūtajiem rezultātiem, sastādītas muižu novietojuma un pašreizējā stāvokḷa kartes.

\title{
HUMUSVIELU FUNKCIONĀLIE ATVASINĀJUMI UN TO IZMANTOŠANAS IESPËJAS
}

\author{
Māris KL̨AVIN̦Š \\ Latvijas Universitāte, Vides zinātnes nodaļa
}

Latvijas dabas vidi raksturo augsts organisko vielu saturs, kas lielā mērā nosaka ūdeņu un augsnes īpašǐbas un šajās vidēs noritošo biologisko procesu raksturu, bet vienlaikus ietekmē vides piesārṇojuma likteni un tā degradācijas raksturu. Jāatzīmē arī tas, ka augsnes un kūdras organiskās vielas uzskatāmas par 
nacionālas nozīmes resursu, ņemot vērā to, ka augsnes organiskās vietas nosaka tās auglību vai arī var kalpot kā vērtīga izejviela (kūdra). Vidē esošās organiskās vielas veidojas sadaloties dzivvajiem organismiem, to metabolitiem un veidojoties no zemmolekulāriem savienojumiem, bet līdz ar to koncentrācija, sastāvs un uzbūve rezultējoši atspogul̦o vidē noritošos gan dabiskas, gan arī antropogēnas izcelsmes procesus. Organiskā viela vidē dominējoši sastāv no humusvielām: augstmolekulāriem katjonītiem, kuru šks̄īība ir atkarīga no pH un kuri ir bioloǵiski noturīgi. Humusvielas veidojas, sadaloties dzīvajiem organismiem, to metabolītiem. Vienlaikus jāatzīmē, ka humusvielas spēj saistīt stabilos kompleksos dažādas vidi piesārņojošās vielas, tādējādi ietekmējot to pieejamību dzīvajiem organismiem.

Pētījuma mērksis ir izpētīt iespējas iegūt humusvielu funkcionālos atvasinājumus un izvērtēt to izmantošanas iespējas, rodot jaunas humusvielu pielietojuma jomas, gan arī pētot humusvielu uzbūvi. Ar šo mērksi iegūti humusvielu alkil-, nitro-, sulfo-, sulfopropil-, tio-, nitro-, aminoatvasinājumi, kā arī humusvielu atvasinājumi, kurus raksturo paaugstināta virsmas aktivitāte.

\title{
SATECES BASEINA İPAŠĪBU IETEKME UZ VIRSZEMES ŪDEŅU ĶİMISKO SASTĀVU
}

\author{
Ilga KOKORĪTE \\ LU Ģeogrāfijas un Zemes zinātņu fakultāte, \\ e-pasts: ikokorite@hotmail.com
}

Virszemes ūdeņu kvalitāti un to ķīmisko sastāvu lielā mērā nosaka dominējošie procesi sateces baseinā, kā arī sateces baseina īpašības, piemēram, ǵeoloǵiskā uzbūve, augšņu struktūra, zemes lietojuma veidu sadalījums, sateces baseina platība un citas. Līdz ar to zināšanas par dažādām ietekmēm sateces baseinā ir nepieciešamas, lai nodrošinātu ūden̦u apsaimniekošanu un aizsardzību. Š̀̃ pētījuma mērḳis ir analizēt sakarības starp izšksīdušo vielu notecēm un sateces baseina raksturlielumiem.

Pētījumā tika izmantoti Latvijas Hidrometeoroloǵijas aǵentūras dati par izšksīdušo vielu koncentrācijām un caurplūdumu mērījumiem (1990.-2001.g.). Informācija par baseinu platībām un zemes lietojuma veidu sadalījumu iegūta no Latvijas Vides aǵentūras (digitālā karte Corine Land Cover Latvija). Biogēno elementu slodžu aprēķināšanai no sateces baseina un biogēno elementu aizturēšanas aprēķināšanai (nutrient retention) izmantots statistiskais Mesaw modelis (Grimvall \& Stålnacke 1996).

Pētījuma rezultāti liecina, ka gan biogēno elementu, gan arī izšks̄īdušo neorganisko vielu notece ir atkarīga no sateces baseina platības, kā arī no zemes lietojuma veidu platībām sateces baseinā. Pozitīva korelācija pastāv starp izšk̦īdušo vielu notecēm un sateces baseina platību $(\mathrm{r}=0.35-0.68)$. Vāja korelācija pastāv starp vielu notecēm un zemes lietojuma veidu īpatsvaru (\%) sateces baseinos. 
Modelēšanas rezultāti rāda, ka lielākās slāpekḷa un fosfora slodzes rada lauksaimniecības teritorijas, īpaši Lielupes baseinā. Slāpekḷa aizturēšana pētītajos apakšbaseinos sastāda no 8-88\% no kopējās slāpekḷa slodzes apakšbaseinā, savukārt fosfora aizturēšana apakšbaseinos ir mazāka (0.6-48\%).

Grimvall, A. and Stålnacke, P. (1996). Statistical methods for source apportionment of riverine loads of pollutants. Journal of Environmetrics. 7: 201-213

\title{
VIRSMAS AKTİVO VIELU AUGSTEFEKTĪVĀ ŠĶIDRUMU HROMATOGRĀFIJA
}

\author{
Jorens KVIESIS, Pēteris MEKŠS, Ruslans SEĻEZŅOVS \\ LU Ķīmijas fakultāte, e-pasts: cations@inbox.Iv
}

Uzrādot labu virsmas aktivitāti un paaugstinātu noturību pret apkārtējās vides iedarbību, katjoniskās virsmas aktīvās vielas (VAV) ievērojami paplašina VAV izejvielu klāstu, radot principiāli jaunas iedarbības kompozītmateriālus lateksu suspensijām. Savā pielietojamībā tās būtiski uzlabo suspensiju stabilitāti, pateicoties polimerizēties spējīgai $\mathrm{C}=\mathrm{C}$ dubultsaitei, ar tās spēju kovalenti saistīties ar disperso fāzi $[1,2]$. N̦emot vērā veidoto materiālu ekspluatācijas noturību, kas, iespējams, pārsniedz to funkcionālās darbības nepieciešamību, veikta šo jaunsintezēto savienojumu analī̌̌u apstākḷu izstrāde, ar perspektīvu to noteikšanai vides paraugos. Pētījumā piedāvājam eksperimentālu novērtējumu VAV pārstāvju analīzes iespējām apgrieztās fāzes augstefektīvās šķidrumu hromatogrāfijas (AF AEŠH) apstākḷos [3-6].

Augstas virsmas aktivitātes un adsorbcijas īpašības uzrāda katjoniskās VAV, kas spējīgas veidot efektīvus polimerizācijas centrus bez iniciatoru klātbūtnes:

$1 \mathrm{H}_{25} \mathrm{C}_{12} \mathrm{HNCOCH}=\mathrm{CHCOO}\left(\mathrm{CH}_{2}\right)_{2} \mathrm{~N}^{+}\left(\mathrm{CH}_{3}\right)_{3}{ }^{-} \mathrm{O}_{3} \mathrm{SC}_{6} \mathrm{H}_{4} \mathrm{CH}_{3}$

$2 \mathrm{H}_{25} \mathrm{C}_{12} \mathrm{OOCCH}=\mathrm{CHCONH}\left(\mathrm{CH}_{2}\right)_{2} \mathrm{~N}^{+}\left(\mathrm{CH}_{3}\right)_{3}{ }^{-} \mathrm{O}_{3} \mathrm{SOCH}_{3}$

$3 \mathrm{H}_{25} \mathrm{C}_{12} \mathrm{HNCOCH}=\mathrm{CHCONH}\left(\mathrm{CH}_{2}\right)_{2} \mathrm{~N}^{+}\left(\mathrm{CH}_{3}\right)_{3} \quad{ }^{-} \mathrm{O}_{3} \mathrm{SC}_{6} \mathrm{H}_{4} \mathrm{CH}_{3}$

Savienojumu 1-3 struktūras apstiprinātas masspektrometriski (MS) (1.att.), iegūstot līnijas ar m/z - 369, 369 un 368, kas atbilst katjonu molekulārajai masai.

Kvalitatīvai savienojumu izdalīšanai izmantota AF AEŠH, par nekustīgo fāzi lietojot oktadecilsilikagelu, bet par kustīgo - 0,01M citrāta šķīdumu metanolā (buferēšanas diapazons pH 1,1-6,4), kas izvēlēts dēl tā lielās šķīīibas organiskajā fāzē.

Pirmā izsekojamā tendence šo savienojumu hromatogrāfijā ir augstā joslu simetrija pie zemām $\mathrm{pH}$ vērtībām (pH 2,1-3) ar optimālu sadalījuma konstanšu $\mathrm{k}^{\prime}$ vērtību $\left(1<\mathrm{k}^{\prime}<10\right)$ iegūššnu. Vides $\mathrm{pH}$ palielināšana līdz 6 ievērojami palielina k' vērtības, joslām izdaloties vēlāk, vienlaikus kḷūstot asimetriskām. 


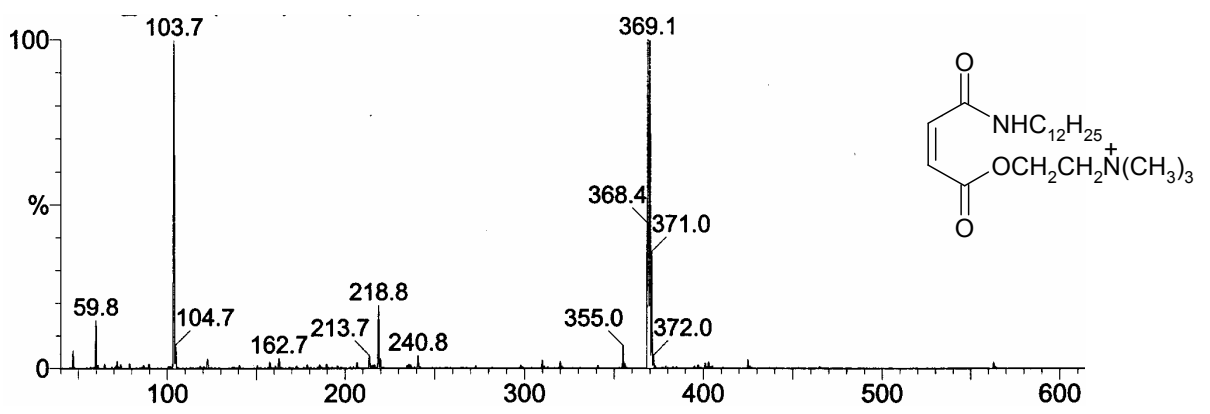

1.att. Maleīnskābes atvasinājuma 2 masspektrs iegūts LC-MS ar tiešo ievadi; plūsmas ātrums $0,2 \mathrm{ml} / \mathrm{min}$; pozitīvā ḳīmiskā jonizācija, kapilāra un konusa spriegumi $2,80 \mathrm{kV}, 30 \mathrm{~V}$.

Sekojot kustīgās fāzes satura izmaiņai pie nemainīga pH (2.att.), optimāla katjonisko VAV izdalīšana novērojama pie 70-75\% metanola šş̄îduma. Samazinot metanola saturu kustīgajā fāzē līdz 40-50\%, k'vērtības ievērojami pieaug, apgrūtinot katjonisko VAV izdalīšanos. Tas izskaidrojams ar salīdzinoši lielo molekulas lipofīlo alkilgrupu $-\mathrm{C}_{12} \mathrm{H}_{25}$. Savukārt palielinot metanola koncentrāciju kustīgajā fāzē virs $95 \%$ novērojama savienojumu tūlītēja izdalīšanās, samazinot adsorbcijas/desorbcijas raksturlieluma vērtību līdz nullei.

Metanola tilpumdaļa kustīgajā fāzē maina ne tikai izdalīšanas laikus, bet ietekmē arī selektivitāti - to spilgti iezīmē tuvā k' vērtības savienojumu pārim - 1, 3. Šo savienojumu selektīvai izdalīšanai piemēroti analīzes apstākḷi ar zemāku ( $<75 \%)$ organiskās piedevas koncentrāciju (skat. 2.att.).

Sadarbes spējas starp kustīgo un nekustīgo fāzi mainās atbilstoši polāro un hidrofobo grupu attiecībai katjoniskajās VAV. Kustīgās fāzes polaritāte $P$ iezīmē savienojumu struktūrālās atšķirības uz izdalīšanās laiku un k'vērībām. Savienojuma 3 slāpekḷa atoma nomaina pie dodecilgrupas $\left(-\mathrm{C}(\mathrm{O}) \mathrm{NHC}_{12} \mathrm{H}_{25}\right)$ pret skābekli $\left(-\mathrm{C}(\mathrm{O}) \mathrm{OC}_{12} \mathrm{H}_{25}\right)$ saskaņā ar Rekera fragmentu hidrofobitātes konstantēm [7] samazina savienojuma 2 kopējo hidrofilitāti. Palielinoties kustīgās fāzes polaritātei atšķirības novērojamas hidrofobākā savienojuma 2 augstajās sadalījuma konstantes vērtībās (skat. 2.att.). No tā izriet arī savienojuma 1 izdalīšanās, kur sadalījuma konstanšu k' vērtības palielinās apgabalā ar samazinātu metanola koncentrāciju.

Attiecībā pret pētītajām katjoniskās dabas VAV, oktadecilsilikagēlu saturošās kolonnas (ZORBAX SB-C18 $(4,6 \times 150 \mathrm{~mm}))$ efektivitāte $N$, ko raksturo ar teorētisko šksīvju skaitu (TŠS) (1.tab.), ir ievērojami mazāka (3000-700 TŠ), salīdzinot ar atbilstošiem lielumiem, kas iegūti ar testējošo maisījumu (toluols, benzanilīds), kas ir ap 10000 TŠ. Turklāt īpaši mazas $N$ vērtības kḷūst, palielinoties kustīgās fāzes $\mathrm{pH}$. 


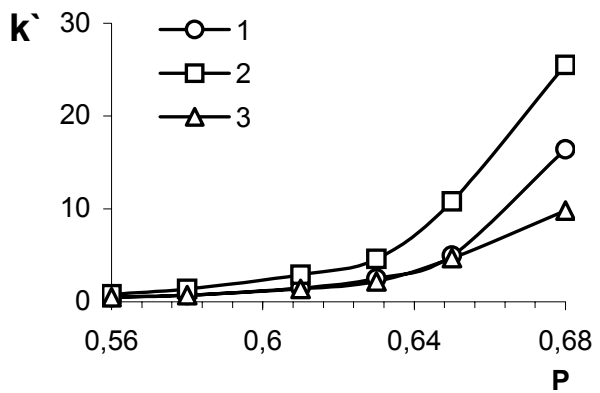

2.att. Maleīnskābes atvasinājumu kapacitātes faktora $k^{\prime}$ atkarība no kustīgās fāzes polaritātes. ZORBAX SB-C18 $(4,6 \times 150 \mathrm{~mm})$ kolonna, pildīta ar oktadecilsilikagela (dąinu izmērs $5 \mu \mathrm{m}), \lambda=$ $254 \mathrm{~nm}$, plūsmas ātrums $0,8 \mathrm{ml} / \mathrm{min}$; kustīgā fāze: $\mathrm{CH}_{3} \mathrm{OH} / \mathrm{KH}_{2} \mathrm{PO}_{4} \mathrm{M} 0,01$ buferšķīdums pie pH 3,0

Teorētisko šḳīju skaita atkarība no metanola satura kustīgajā fāzē (pH 3)

\begin{tabular}{|c|c|c|c|c|c|c|}
\hline \multirow{2}{*}{$\begin{array}{c}\text { Savie- } \\
\text { nojums }\end{array}$} & \multicolumn{6}{|c|}{ Metanola procentuālais saturs kustīgajā fāzē $\varphi_{\mathrm{MeOH}}$} \\
\cline { 2 - 7 } & 95 & 90 & 85 & 80 & 75 & 70 \\
\hline $\mathbf{1}$ & 1870 & 1700 & 1200 & 1580 & 1700 & 1070 \\
\hline $\mathbf{2}$ & 3100 & 2300 & 2600 & 1900 & 2300 & 2000 \\
\hline $\mathbf{3}$ & 2700 & 2600 & 2400 & 2200 & 1600 & 720 \\
\hline
\end{tabular}

Salīdzinot pētījumā vērojamās tendences AF augstefektīvā šķidrumu hromatogrāfija ir piemērota metode šāda tipa VAV izpētē.

\section{Literatūra}

Klimenkovs I., Zhukovska I., Uzulina A., Zicmanis A., Guyot A. C. r. chim., 2003, 6, 11/12, 1295.

Grigorjeva A., Kaspars G. Latvijas K̦īmijas Žurnāls, 2004, 2, 160.

Vogt C., Heinig K. Fresenius J. Anal. Chem., 1999, 363, 612.

Llenado R.A., Jamieson R.A. Anal. Chem., 1981, 53, 174R.

Parris N. J. Liq. Chromatogr., 1980, 3, 1743.

Nishikawa M., Katagi M., Miki A., Tsuchihashi H. J.Health Science, 2003, 49(2), 138.

Rekker. R.F. Eur. J. Med. Chem., 1970, 14, 479.

\section{EKOLOĢISKO PROCESU VĒRTĖJUMS MEŽAPARKĀ}

\section{Evija ĻESN̦EVSKA}

Latvijas Universitāte, Ģeogrāfijas un Zemes zinātņu fakultāte, e-pasts: evijalesn@inbox.Iv

Mežaparks ir viena no sabiedriski nozīmīgākajām zaļajām platībām Latvijas galvaspilsētā. Apsekojot šo teritoriju 2004.gadā projekta "Rīgas dabas pamatnes precizēšana" ietvaros, tika noskaidrots, ka nepieciešama detalizētāka 
Mežaparka izpēte, lai apzinātu tajā notiekošos ekoloǵiskos procesus un tendences, uz kā balstoties varētu spriest par Mežaparka attīstības perspektīvām un nepieciešamajiem apsaimniekošanas pasākumiem.

Lai noskaidrotu pašreizējo situāciju, apsekojot un vizuāli novērtējot tika veikta meža masīva kartēšana pēc divām pazīmēm - pārkrūmošanās procesu intensitātes un nomīdīšanas pakāpes. Katrai pazīmei tika izdalītas četras klases. Pārkrūmošanās: 0 - nenotiek; 1 - atsevišķi krūmi; 2 - pudurveida; 3 - vienlaidus. Nomīdīšana: 0 - nav novērojama; 1 - rets taku tîkls; 2 - blīvs taku tīkls; 3 teritorija vienmērīgi stipri nomīdīta, veǵetācija saglabājusies puduros.

Sīkākai izpētei un meža ekologiskos procesus ietekmējošo faktoru noteikšanai tika izvēlēti 17 parauglaukumi, no kuriem tika paņemti augsnes (O un A horizontu), priežu mizas un sūnu (Pleurozium schreberi) paraugi, lai ar ķīmisko analīžu palīdzību noteiktu biogēno elementu un smago metālu saturu dažādās vides komponentēs.

Lai spriestu par ekologisko situāciju un tās izmaiñām laika gaitā, iegūtie rezultāti tiks salīdzināti ar līdzīgu pētniecisko darbu, kas tika veikts 1988.gadā (Andersone L., 1988. Mežaparka ǵeoekoloǵiskais vērtējums), veicot telpisko un ķīmisko parametru analīzi.

Pētījumu rezultāti rāda, ka intensīvāka nomīdīšana vērojama Ķīšezera krastā, kas ir iecienīta vieta pastaigām, dz̄ivojamo masīvu apkārtnē (pie Aplokciema, Viestura un Ostas prospekta stūra), kā arī Viestura un Meža prospekta stūrī, kur cilvēki šķērso mežu, lai saīsinātu ceḷu, dodoties uz mājām vai sabiedriskā transporta pieturām. Kopumā pēdējo piecpadsmit gadu laikā nomīdī̌anas procesiem bijusi tendence samazināties, tas, iespējams, saistīts ar teritorijas pārkrūmošanos.

Pārkrūmošanās Mežaparkā notiek nevienmērīgi. Kā liecina iegūtie kartēšanas rezultāti, šo procesu nosaka vairāki faktori. Viens no tiem ir reljefs: pārkrūmotās teritorijas biežāk atrodas reljefa pazeminājumos, kur ir vairāk barības vielas un lielāks augsnes mitrums. Otrs ietekmējošais faktors ir antropogēnais piesārṇojums, jo vairākās vietās tieši joslās ap ielām un gājēju celiņiem tika konstatēta intensīvāka pārkrūmošanās.

\section{MEŽA AUGSNES MEZOFAUNAS IZMAIN̦AS SAUSUMA PALIELINĀŠANĀS APSTĀKĻOS}

\section{Viesturs MELECIS, Edīte JUCEVIČA, Ineta SALMANE, Jānis VENTIN̦Š, Voldemārs SPUN̦ĢIS}

LU Bioloǵijas institūts, e-pasts: vmelecis@email.lubi.edu.Iv

Globālā klimata izmaiņas daudzos pasaules reǵionos izpaužas kā šiem reǵioniem netipiski sausuma periodi. Ilgstošam ekstremālam sausumam kā ekologiskam faktoram ir negatīva ietekme uz mērenās joslas ekosistēmām. 
Turpretī īslaicīgām, periodiskām sausuma epizodēm var būt selektīva ietekme uz dažādām sugām, kas kopumā var radīt izmaiņas ekosistēmas funkcionēšanā. Datu par biocenožu struktūras izmaiṇām periodiska, īslaicīga sausuma ietekmē līdz šim nav, tādēl šo procesu izpētei pēdējos gados veltīta īpaša uzmanība, gan pētot sausuma ietekmi model̦eksperimentos, gan analizējot ilgtermiņa ekoloğisko pētījumu datus.

Pētīta pakāpeniski pieaugoša sausuma, kas izpaudās kā augusta mēneša vidējās gaisa temperatūras palielināšanās un nokrišņu daudzuma samazināšanās trends piecu gadu periodā (no 1993.-1997.g), ietekme uz priežu lāna augsnes mezofaunas sugu bagātību un blīvumu. Pētījumi veikti ilgtermiņa ekologisko pētìjumu programmas (LTER) ietvaros, Latvijas nacionālā LTER tīkla parauglaukumos Ziemel̦vidzemes biosfēras rezervātā. Pētīti augsnes sīkposmkāji - kolembolas un ērces, sīksliekas, divspārņu un vaboḷu kāpuri. Paraugi augsnes faunas analīzēm ievākti vienreiz gadā - augusta beigās trijās dažāda vecuma mežaudzēs - 30-40 gadu, 50-70 gadu un 150-200 gadu vecās audzēs. Augsnes mezofaunas uzskates veiktas, izmantojot augsnes urbjus - sīkposmkājiem ievākti 100 paraugi $\left(5 \mathrm{~cm}^{2}\right.$ x $\left.10 \mathrm{~cm}\right)$, sīksliekām 30 paraugi $\left(23 \mathrm{~cm}^{2}\right.$ x $\left.10 \mathrm{~cm}\right)$ un kukaiņu kāpuriem 30 paraugi $\left(69 \mathrm{~cm}^{2}\right.$ x $\left.30 \mathrm{~cm}\right)$. Sīkposmkāju izdalīšana no paraugiem veikta ar fototermoeklektoriem, sīksliekas izdalītas ar mitro piltuvju metodi, bet kāpuri uzskaitīti ar paraugu drupināšanas metodi. Augsnes mitrums noteikts gravimetriski. Izmantoti Rūjienas meteostacijas dati par gaisa temperatūras un nokrišņu izmaiṇām dotajā laika periodā. No 1993. līdz 1997.gadam konstatēta gada vidējās gaisa temperatūras pieauguma un nokrišņu daudzuma samazināšanās, taču statistiski ticami šo izmainuu trendi bija novērojami tieši augustā, t.i., vienu mēnesi pirms augsnes faunas uzskaitēm.

Lai noskaidrotu klimatisko faktoru ietekmi uz augsnes faunas struktūru un sugu daudzveidību, izmantota galveno komponentu metode (PCA). Datu analīze veikta vairākos etapos:

1. Meteoroloǵisko parametru analīze. Augsnes faunas struktūra (indivīdu blīvums, sugu daudzveidība) konkrētajā uzskaites brīdī patiesībā ir dažādu vides faktoru, toskait klimatisko faktoru, vairāk vai mazāk ilgstošas iepriekšējas darbības rezultāts. Dažādām organismu grupām atkarībā no to attīstības īpatn̄īām nozīmīgas var būt dažāda ilguma iepriekšējo periodu temperatūras vai nokrišñu daudzuma ietekmes. Tādēl meteoroloǵisko datu matricas struktūra tika veidota, iekḷaujot divu pēc iedarbības ilguma atšķirīgu main̄̄go grupas: īstermiña augusta mēneša un ilgtermiņa - janvāra-augusta periodu raksturojošie rādītāji: gaisa vidējā temperatūra, pozitīvo temperatūru summas $\left(>+4^{\circ} \mathrm{C}\right)$, nokrišņu summa un ariditātes indekss ( $\mathrm{I}=\mathrm{P} / \mathrm{T}+10, \mathrm{P}$ - apskatāmā laika perioda nokrišnu summa, $\mathrm{T}$ - vidējā gaisa temperatūra). Augsnes mitrums izdalīts kā atsevišķs parauglaukumiem specifisks faktors. Ar PCA izdalītā pirmā galvenā komponente raksturo klimata īstermiņa izmaiņas. bet otrā galvenā komponente - ilgtermiņa izmaiņas periodā no janvāra līdz augustam. 
2. Augsnes faunas izmaiñas raksturojošo parametru analīze. Augsnes faunas matricas struktūru veido šādas main̄̄gās: kolembolu, oribatīdērču, gamazīnērču, sīkslieku vidējais blīvums un sugu bagātība, divspārņu kāpuru blīvums un dzimtu skaits, slieku un vaboḷu kāpuru blīvums.

3. Korelāciju analīze starp galvenajām komponentēm, kas izdalītas no meteorologisko parametru un augsnes faunas izmaiņas raksturojošo rādītāju matricām, un augsnes faunas struktūru raksturojošo galveno komponentu ekolog̣iskā interpretācija.

4. Augsnes faunas izmaiņas raksturojošo mainīgo kopējās dispersijas struktūras analīze. Lai noskaidrotu katra meteorologisko faktoru kompleksa isstermiña vai ilgtermiņa faktoru - ietekmes īpatsvaru uz konkrēto augsnes faunas rādīiāju, veikta to dispersijas struktūras analīze, izdalot piecas dispersijas komponentes: tiešā meteoroloǵisko faktoru īstermiņa ietekme, tiešā meteoroloǵisko faktoru ilgtermina ietekme, dispersija, ko nosaka augsnes faunas struktūru raksturojošo main̄̄go savstarpējās korelācijas gan īstermiņa, gan ilgtermiņa ietekmes gadījumos un neizskaidrotā dispersija. Dispersijas komponentiem atbilstošo ietekmes īpatsvaru statistiskais būtiskums novērtēts pēc F-testa.

Analīze parādīja, ka īstermiņa meteorologiskajiem faktoriem, kas raksturo sausuma palielināšanos augustā, ir statistiski būtiska negatīva ietekme uz kolembolu sugu bagātību, bet pozitīva ietekme uz oribatīdērču sugu bagātību, kā arī uz divspārņu kāpuru blīvumu un dzimtu skaitu augsnē. Ilgtermiña meteorolog̣iskajām ietekmēm, kas izpaužas galvenokārt kā janvāra-augusta vidējo gaisa temperatūru un pozitīvo temperatūru svārstības pa gadiem, savukārt konstatēta pozitīva ietekme uz sīkslieku, gamazīnērču un oribatīēēču blīvumu. Augsnes mitrumam kā ekologiskajam faktoram mezofaunas struktūras izmain̄ās izrādījās mazāka nozīme nekā temperatūrai.

\title{
RĪGAS “DABAS PAMATNE” - IZMANTOŠANAS PROBLĒMAS UN ATTĪSTİBAS IESPËJAS
}

\author{
Olǵgerts NIKODEMUS, Dace GRANTA, Mikus RANKA \\ Latvijas Universitāte, Ģeogrāfijas un Zemes zinātņu fakultāte, \\ e-pasts: olgerts.nikodemus@lu.Iv
}

Dabas un apstādījumu vienoto telpisko struktūru (turpmāk - dabas pamatni) veido šādas funkcionāli atšķirīgas pilsētas telpiskās struktūras vienības: apstādījumi (parki, skvēri, priekšdārzi, pagalmu apstādījumi, ielu un dzelzcẹ̦a apstādījumi, krastmalu joslas apstādījumi), mežaparki, meži un īpaši aizsargājamās dabas teritorijas, kapsētas, mazdārziņi, ūdensteces un ūdenstilpes.

Zinot, ka parasti "dabas pamatnes" platību apsaimniekošana prasa lielus finanšu līdzekḷus, bet tās nedod viegli aprēķināmu pel̦nu, Latvijā un arī citās valstīs aktuāls ir jautājums, cik lielas platības pilsētā nepieciešams atvēlēt "dabas 
pamatnei”. Eiropas pilsētās šajā ziṇā ir atšķirīga pieredze. Vācijas pilsētās, piemēram, Berlīnē, "zaļie areāli" aizṇem 35\% no pilsētas teritorijas, Hamburgā $50 \%$ (tanī skaitā 28\% aizñem lauksaimniecībā izmantojamās zemes), Drēzdenē $62 \%$ (lauksaimniecībā izmantojamās zemes 36\%), Diseldorfā - 18\% un Brēmenē - $\quad 37 \%$ (www.trend.partisan.net/, www.fhhl.hamburg.de/ Behoerden/ Umveltbohoerde/, www.dresden.de/, www.stadtgruen-bremen.de/, www. duesseldorf.de/). Rīgā "dabas pamatne" aizṇem 54,2\% (www.ceroi.net/ reports/riga). Vienlaikus nepieciešams atzīmēt, ka minētos skaitlıus nav iespējams savstarpēji salīdzināt, jo teritorijas, kuras pieskaita pie dabas pamatnes, pēc to izmantošanas starp pilsētām atšķiras. Veicot Rīgas "dabas pamatnes" inventarizāciju, redzams, ka daudzviet Rīgas pilsētas attīstības plānā (1995.2005.g.) (1995) paredzēts izveidot apstādījumu teritorijas, kur pašreiz atrodas rūpniecības un dzīvojamā apbūve. Tomēr plašo Spilves pḷavu teritoriju dēl dabas pamatnei pēc izmantošanas veida pieskaitāmās teritorijas Rịgā patiešām aizṇem aptuveni 56\% platības. Izstrādājot jauno Rīgas attīstības plānu 2006.-2018.gadam, redzams, ka perspektīvā "dabas pamatne" Rīgas pilsētā varētu aizṇemt tikai $18,9 \%$ no sauszemes teritoriju platības un, pieskaitot ūdensteces un ūdenstilpes, $31,7 \%$ no pilsētas kopējās platīibas.

Ļoti nozīmīgs pilsētas ilgtspējīgas attīstības indikators ir "zalı areālu" aizņemtā platība attiecībā pret kopējo iedzīvotāju skaitu. Helsinkos uz katru "zaļā areāla" hektāru dzīvo 29,5 iedzīvotāji (The Core..., 2002), Berlīnē 108,6, bet Rīgā aptuveni 47,4 iedzīvotāji. N̦emot par pamatu jauno Rīgas attīstības plānu, perspektīvā publiski pieejamā dabas pamatne Rīgā uz vienu iedzīvotāju var samazināties divas reizes.

Iepriekš minētie skaiţ̦i raksturo tikai "dabas pamatnes" kvantitatīvo aspektu, bet nesniedz ieskatu to kvalitātē, jo daudzos gadījumos relatīvi nelielas kvalitatīvas dabas teritorijas sniedz lielāku ekologiisko, ekonomisko un estētisko efektu nekā plašas degradētas teritorijas. Dabas pamatnes kvalitāti nosaka tās spēja pildīt tai noteiktās funkcijas. Parasti dabas pamatnes struktūrām tiek noteiktas šādas funkcijas:

$\checkmark$ attīrot atmosfēras gaisu un ūdeņus no piesārṇojums, slāpējot trokšņus no automagistrālēm un rūpniecības rajoniem, pilsētas vides kvalitātes uzlabošana;

$\checkmark$ pilsētas klimata veidošana, nodrošinot iedzivotājiem komfortablu dzīves apstākḷu;

$\checkmark$ gaisa apmaiñas veicināšana;

$\checkmark$ biolog̣iskās un ainaviskās daudzveidības saglabāšana un attīstīšana;

$\checkmark$ pilsētas iedzīvotāju un viesu nodrošināšana ar atpūtas vietām;

$\checkmark$ pilsētas tēla veidošana.

Referātā detālāk tiek analizētas Rīgas "dabas pamatnes" spējas pildīt minētās funkcijas. 


\title{
BALTIJAS REGIONA SEISMISKO PROCESU İPATNĪBAS TELPĀ UN LAIKĀ
}

\author{
Valērijs N̦IKUĻıINS \\ Valsts ǵeoloǵijas dienests, e-pasts: nikulin@vgd.gov.lv.
}

Kaļiņingradas apgabalā (Krievija) 2004.gada 21.septembrī notika 3 jūtamas zemestrīces. Magnitūda stiprākai no tām sasniedza lielumu 5,0 pēc Rihtera skalas. Intensitāte zemestrīces epicentrā sasniedza VI balles pēc $M S K-64$ skalas. Šis notikums no jauna apstiprināja stipras, jūtamas zemestrīces iestāšanās iespēju Baltijas valstīs, jo pirms 28 gadiem notika Osmusāres zemestrīce - Igaunijā (magnitūda 4,7 pēc Rihtera skalas).

Projektējamos un jau esošos rūpnieciskos objektos (īpaši inženiertehniskas nozīmes - aizprosti un pazemes gāzes krātuves), kā arī lielajās pilsētās, jāṇem vērā seismisko notikumu bīstamība. Pirmkārt, ir vajadzīga sapratne par seismisko procesu attīstîbas tendencēm, to saistību ar tektonisko uzbūvi un zemes garozas kustībām.

Analīze par Baltijas regiona $\left(\varphi=54^{\circ} \mathrm{N}-60^{\circ} \mathrm{N}\right.$ un $\left.\lambda=18^{\circ} \mathrm{E}-30^{\circ} \mathrm{E}\right)$ stipru zemestrīču izplatību telpā un laikā parādīja, ka lielākā daļa vēsturisko un mūsdienu zemestrīču izvietotas gar Baltijas jūras piekrasti un depresijas zonās (Gdaņskas depresija un Gotlandes grābens).

Seismiski aktīvi slāṇi atrodas līdz $20 \mathrm{~km}$ dziļumā, tos veido metamorfogēnie granitoīdi.

Ir jāatzīmē divi seismisko notikumu "klusuma" periodi: no 1616 . līdz 1821.gadam un no 1912. līdz 1976.gadam. Šajā laikā galvenokārt notika seismiskās enerǵijas uzkrāšanās. Turpretim šie procesi aktivizējušies laikā no 1821. līdz 1912.gadam, kā arī no 1976. gada līdz šodienai.

Maksimālais laika intervāls starp enerǵijas "izlādēšanos" ir apmēram 390 gadi. Baltijas reǵionā iespējamās zemestrīces novērtētais maksimālais magnitūdas lielums 5,2 pēc Rihtera skalas.

\section{KAĻIŅINGRADAS ZEMESTRĪCES 2004.GADA 21.SEPTEMBRĪ SEISMISKĀS SEKAS LATVIJĀ}

\author{
Valērijs N̦IKUĻINS \\ Valsts ǵeoloǵijas dienests, e-pasts: nikulin@vgd.gov.lv.
}

Šī gada 21.septembra zemestrīce Kaļiningradā bija jūtama plašā Baltijas reǵiona teritorijā un Skandināvijā. Galveno, divu pirmo grūdienu (pavisam 3 zemestrīces) magnitūda attiecīgi bija 4,8 un 5,0 pēc Rihtera skalas. Zemestrīces cilmvieta atradās $10 \mathrm{~km}$ dziḷumā. Stiprākās zemestrīces epicentrā satricinājuma intensitāte sasniedza VI balles pēc $M S K-64$ skalas. 
Pirmo divu grūdienu satricinājums tikai bija jūtams Latvijā, ar 2,5 stundu intervālu, pēc vietējā laika aptuveni 14:06 un 16:34.

Lai novērtētu satricinājuma līmeni, dažādos valsts rajonos veica iedzīvotāju aptauju (anketēšanu). Savāktas un apkopotas vairāk nekā 120 anketas no 14 apdzīvotām vietām. Satricinājumu intensitāti novērtēja pēc Starptautiskās 12 ballu $M S K-64$ skalas.

Šo datu analīze parādīja, ka satricinājumu intensitāte IV-V balles bija sajūtama galvenokārt Liepājā, Rīgā un Jūrmalā, t.i., piekrastes joslā. Dažviet intensitāte varēja sasniegt pat VI balles.

Zemestrīču galvenie bojājumi ir saistīiti ar plaisu rašanos sienās un griestos īpaši vecās mājās, kā arī èku augšējos stāvos.

Pētījumos noteica satricinājumu intensitātes atkarību no lokāliem inženierǵeologiskiem un hidroǵeoloǵiskiem apstākḷiem. Nelabvēlīgi inženierğeologiiskie apstākḷi (irdenas un apūdeņotas gruntis) paaugstina šo intensitāti. Šādi apstākḷi raksturīgi Latvijas teritorijas lielā dạ̦ā.

\title{
TRĪSDIMENSIJAS ĢEOFIZIKĀLIE PĒTĪJUMI RĪGAS DOMA BAZNĪCĀ
}

\author{
Valdis SEGLIN̦Š \\ LU Ģeogrāfijas un Zemes zinātñu fakultāte, \\ e-pasts: valdis.seglins@lu.lv \\ Georgijs SIČovs \\ SIA Baltijas Zemes resursi, \\ e-pasts: geo@geo.Iv
}

Rīgas Doms ir vairākkārtīgi ticis pārbūvēts un papildināts, un pašreiz vairākas būves konstrukcijas ir bojātas un savas funkcijas nepilda, ir konstatētas arī vairākas pamata konstruktīvo elementu deformācijas.

Radiolokācijas pētījumi Doma baznīcā tika iecerēti kā metodes iespēju apzināšana konkrētajos kultūrvēstures un darbojošās relig̣iska kulta ēkas apstākḷos, neiejaucoties esošā lietu kārtībā, un pētījums tika realizēts kā trīs atšķirīigas komponentes ar individuāli izstrādātu metodiku un atbilstošu tehnisko bāzi.

Pētījumi tikai veikti vairākos posmos 2004.gada aprīlī un maijā, sākot ar pārskata pētījumiem apzinot slēptās komunikācijas, grīdas segumu uzbūvi un materiālu īpašības, slēptās konstrukcijas kultūrslānī, kā arī geoloǵisko uzbūvi līdz 7 m dziḷumam un gruntsūdens līmeni. Dzilākāa slāņa izpētei tika noteikta antenu sistēma ar frekvenci zemāku par $300 \mathrm{MHz}$, bet augšējai griezuma dạ̦ā - ar frekvenci augstāku par $1 \mathrm{GHz}$. Pētījumā tika izmantots Radar Systems Inc. ražots GEORADAR ZOND 12C. Izstarojošās antenas frekvence 1,5 GHz, kas paredzēta inženierǵeologiiskiem un būvkonstrukciju pētījumiem. Iegūto signālu digitāla regíistrācija ḷāva sākotnēji pierakstīt nepārtrauktu signālu rindu (ar $115 \mathrm{KHz}$, 14 pieraksti sekundē), bet datu turpmākā apstrāde tiek veikta ar specializētu datorprogrammu Prizm 6.01. 


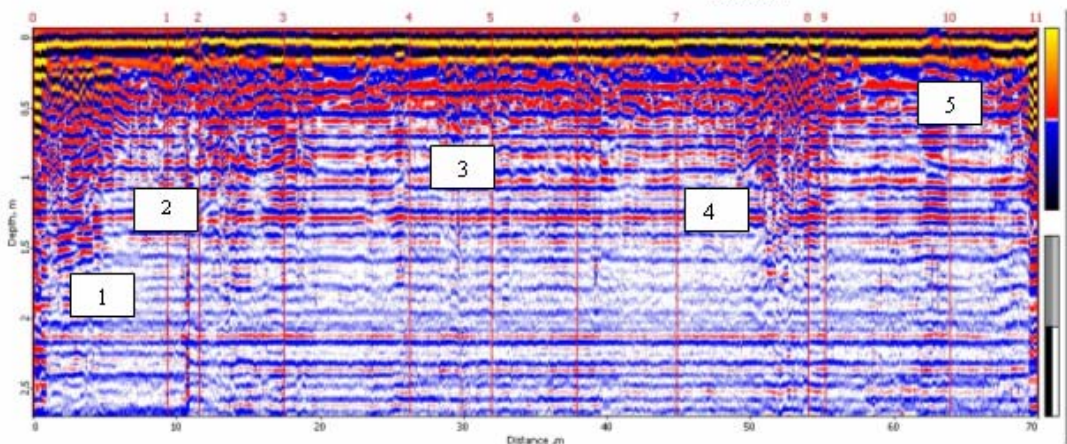

1.attēls. Centrālās ass profila radarogrammas apstrādāts pieraksts un interpretācijas piemēri. Apzīmējumi: 1 = baznīcas pamatu fragments, 2 = aprakts konstrukcijas elements (sena mūra daļa), $3=$ raksturīgs pārrakts slānis, $4=$ atseviškss objekts pazemē, iespējams, neatsegta kapene; $5=$ altāra telpa ar armēta betona grīidu.

Detalizācijas pētījumi tika veikti baznīcā pirms altāra, kur tika konstatēta grunts neviendabīga struktūra. Šeit tika izveidots vietējais ǵeodēziskais atbalsta un piesaistes tīkls un radiolokācijas pētījumi tika veikti ar $1,5 \mathrm{GHz}$ antenu sistēmu, datu apstrāde ar Prizm 6.01, bet pēc atseviškso profilu datu harmonizācijas, ar Prizm Layers 3D.

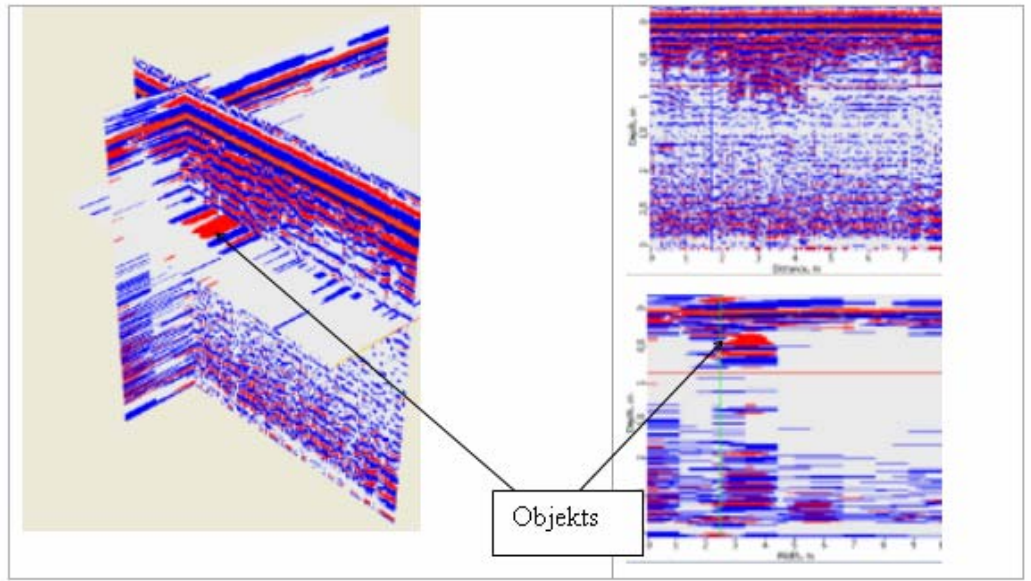

2.attēls. Detalizācijas iecirkṇa apstrādātie dati norāda uz kapenes lokalizāciju telpā un tās izmēriem. Tās eksistence tika pārbaudīta un apstiprināta. 
Tomēr visnozīmīgākie rezultāti tika iegūti veicot trīs dimensiju analīzi baznīcas kolonnas (pīlāra) viendabīguma pētījumos. Kolonna ir deformēta, un tai ir vairākas vizuāli atpaz̄̄stamas plaisas, tā tika pētīta tik tālu, cik tas bija iespējams, neveicot grīdas seguma atsegšanu, šajā posmā kolonna tika pētīta līdz 2,3 $\mathrm{m}$ augstumam.

Pêtījumi tika realizēti, to vairākkārtīgi skanējot visapkārt divos līmeņos un pa vertikāli (visas četras skaldnes). Tādējādi pirmo reizi tika iegūts kolonnas trīsdimensiju attēls, kuram sekojošās signālu filtrācijas procedūras l̦āva iegūt pamatotu, interpretējamu un vizuāli augstvērtīgu attēlu. Iegūtie rezultāti bija pietiekami, lai Rīgas Domā tiktu uzsākti ārkārtas nostiprināšanas un restaurācijas darbi.

\title{
BIOLOĢISKIE KVALITĀTES ELEMENTI ÜDENS VIDES NOVÉRTÉŠANAI
}

\author{
Gunta SPRIŅĢE \\ LU Ģeogrāfijas un Zemes zinātņu fakultāte, \\ e-pasts: gspringe@email.lubi.edu.Iv
}

Līdz ar Latvijas iestāšanos Eiropas Savienībā ES normatīvo aktu ieviešana Latvijā ir aktuāls vides aizsardzības uzdevums. Eiropas Parlamenta un Padomes 2000.gada 23.oktobra direktīva 2000/60/EC, kas nosaka struktūru Eiropas Kopienas rīcībai ūdeñu aizsardzības politikas jomā jeb Ūdens struktūrdirektīva (Water framework directive), ir ES galvenais likums ūdens aizsardzības jomā un nosaka pamatprincipus ilgtspējīgai ūdens politikai Eiropas Savienībā.

Saistībā ar šo Direktīvu Latvijā pieņemti vairāki normatīvie akti, kas nosaka mērķus un paredz darbības ūdens aizsardzības jomā, no kuriem galvenais ir Ūdens apsaimniekošanas likums ar grozījumiem, kas izsludināti līdz 2004.gada 1.maijam. Tajā minēts, ka virszemes ūdeņu stāvoklis ir virszemes ūdensobjekta vispārīgā kvalitāte, kura jānovērtē pēc ūdens objekta sliktākajiem ekologiskās un ķīmiskās kvalitātes rādītājiem. Ministru kabineta 2004.gada 19.oktobra noteikumi Nr.858 "Noteikumi par virszemes ūdensobjektu tipu raksturojumu, klasifikāciju, kvalitātes kritērijiem un antropogēno slodžu noteikšanas kārtību", kas izdoti saskaņā ar Ūdens apsaimniekošanas likumu, paredz ekologiskās kvalitātes vērtējumu veikt pēc fitoplanktona sastāva, sastopamības un biomasas, makrofîtu, zoobentosa, zivju sugu sastāva un sastopamības, kā arī zivju populācijas vecuma struktūras. Upēs un ezeros vides vērtējumā jāizmanto arī fitobentosa rādītāji, bet pārejas un piekrastes ūdeņos - makroskopiskās aļǵes un segsēkḷi.

Latvijā līdz šim ekologiskās kvalitātes noteikšana upēs visbiežāk pamatojusies un bentisko bezmugurkaulnieku izmantošanu, savukārt ezeru vērtējums balstīts uz fitoplanktona sugu sastāvu un biomasu. Atbilstoši Ūdens struktūrdirektīvai Latvijā līdz šim 5. satvara programmā realizēts projekts "Upju 
klasifikācijas standartizācija: struktūras metode dažādu biologisko apskatu rezultātu kalibrēšanai atbilstoši ekoloǵiskās kvalitātes klasifikācijai, izstrādātai Ūdens Struktūrdirektīvas vajadzībām” (STAR), kurā Baltijas ekoreǵiona valstis pārstāv Latvija (LU Bioloğijas institūts). Projekta rezultāti, kas iegūti, veicot references vietu izpēti, liecina, ka dažādi biologiskās kvalitātes elementi raksturo vides ekologísko stāvokli dažādā telpiskā mērogā: zivis un makrofìti izmantojami upju raksturošanai upju baseina līmen̄i, bet bentiskie bezmugurkaulnieki un fitobentoss - biotopa līmenī. Projekta izstrāde liecina, ka Latvijā šobrīd trūkst speciālistu, kas atbilstoši ES prasībām var veikt ūdens vides novērtēšanu, izmantojot visus minētos biolog̣iskās kvalitātes elemntus.

\title{
GAISA PIESĀRŅOJUMA ZONĒJUMS RĪGAS PILSĒTAS SILTUMAPGĀDES ATTĪSTĪBAI
}

\author{
Iveta ŠTEINBERGA \\ Latvijas Hidrometeoroloǵijas aǵentūra, \\ e-pasts: Iveta.Steinberga@meteo.Iv
}

Darba izstrādes mērķis - slāpekḷa dioksīda $\left(\mathrm{NO}_{2}\right)$ zonu tehniskās dokumentācijas izstrāde Rīgas pilsētas siltumapgādes attīstībai. 2004.gada sākumā tika izstrādāta Rīcības programma gaisa kvalitātes uzlabošanai Rīgā laika periodam līdz 2009.gadam, kas apstiprināta ar Rīgas domes 06.07.2004. lēmumu Nr.3247 "Par rīcības programmas gaisa kvalitātes uzlabošanai Rīgā apstiprināšanu". Minētajā programmā kā viens no pasākumiem gaisa kvalitātes uzlabošanai ir Rīgas domes saistošo noteikumu izstrāde (tiks veikta saskaņā ar likuma "Par piesārņojumu" 14.panta otro dalıu), kuros jāparedz piel̦aujamo siltumapgādes veidu diferencēšana atkarībā no faktiskā un prognozējamā gaisa piesārņojuma līmeņa ar slāpekḷa dioksīdu $\left(\mathrm{NO}_{2}\right)$. Tā kā slāpekḷa dioksīda piesārṇojuma zonējuma kartes izstrādātas 2001.gadā, radās nepieciešamība atkārtoti izstrādāt zonējumu, pamatojoties uz jaunākajiem datiem par piesārņojuma emisiju apjomiem un transporta plūsmām.

Slāpekḷa oksīdu galvenais emisijas avots ir dažāda veida degšanas procesi, neatkarīgi no kurināmā veida, kā arī degvielas sadegšana dzinējos. Sākotnēji degšanas procesā rodas slāpekḷa monooksīds (NO), kas, nonākot atmosfērā, reaǵe ar atmosfērā esošo skābekli, veidojot slāpekḷa dioksīdu $\left(\mathrm{NO}_{2}\right)$. Piel̦aujamo slāpekḷa dioksīda piesārņojuma līmeni reglamentē Ministru kabineta noteikumi Nr. 588-21.10.2003 "Noteikumi par gaisa kvalitāti”, kuros atbilstoši Eiropas Savienības direktīvai 1999/30/EC iekḷautas tādas pašas prasības gaisa kvalitātei kā citās Eiropas Savienības dalībvalstīs. Lai nodrošinātu cilvēka veselības un vides aizsardzību, slāpekḷa dioksīdam noteikti vairāki robežlielumi cilvēka veselības aizsardzībai un ekosistēmu aizsardzībai. Lai veicinātu pakāpenisku gaisa kvalitātes uzlabošanu, ieviesta t.s. pielaides robeža. Tas ir lielums, par kādu 
īslaicīgi (attiecīgajā gadā) tiek palielināts robežlielums. Pielaides robeža ir noteikta procentos no attiecīgā robežlieluma, un tās lielums definēts minētajos MK noteikumos. Jāpiezīmē, ka pielaides robeža ir spēkā tikai robežlielumiem cilvēka veselības aizsardzībai. Gada robežlielums ekosistēmu aizsardzībai ir stingri noteikts un nemain̄̄gs $-30 \mathrm{mkg} / \mathrm{m}^{3}$.

Apkopojot pēdējo 6 gadu gaisa kvalitātes monitoringa rezultātus, redzams, kopš 2000.gada Rīgas centrā tiek novēroti slāpekḷa dioksīda gada normatīva cilvēka veselības aizsardzībai pārsniegumi. Lai detalizēti analizētu slāpekḷa dioksīda piesānnojuma izplatību Rīgas pilsētā, veikta modelēšana. Novērtēti stacionārie (atskaites 2-Gaiss par piesārņojuma apjomiem 2003.gadā) un mobilie piesārņojuma avoti Rīgā. Kopējais stacionāro slāpekḷa dioksīda $\left(\mathrm{NO}_{2}\right)$ emitētāju īpatsvars ir 845 dažādas darbības iekārtas, summārais emisiju apjoms 1192 tonnas, kas salīdzinājumā ar 2002.gadu ir palielinājies par aptuveni 150 tonnām.

Esošās situācijas analīze rāda, ka slāpekḷa dioksīda koncentrācijas pārsniedz piel̦aujamo normatīvu cilvēka veselības aizsardzībai vairākās vietās Rīgā. Tomēr īpaša uzmanība pievēršama Rīgas Centra rajonam, kur galvenais piesānnojuma avots ir autotransports. Paaugstināta piesārņojuma līmeņa veidošanos iespējams novērst:

$\checkmark$ samazinot autotransporta radīto ietekmi;

$\checkmark$ ierobežojot siltumapgādes decentralizācijas tendences.

Lai precizētu slāpekḷa dioksīda piesārnojuma izplatîbu Rīgas pilsētā, izstrādātas piesārṇojuma zonējuma kartes. Izveidotas šādas zonas:

$\checkmark$ I zona (slāpekḷa dioksīda gada vidējā koncentrācija ir robežās no 40$\left.60 \mathrm{mkg} / \mathrm{m}^{3}\right)$ - tiek pārsniegti slāpekḷa dioksīdam $\left(\mathrm{NO}_{2}\right)$ noteiktie robežlielumi cilvēka veselības un ekosistēmu aizsardzībai; pašreizējā situācijā stāvoklis ir neapmierinošs, papildus gaisa piesārņotāju izvietojums šajā zonā nebūtu piel̦aujams;

$\checkmark$ II zona (slāpekḷa dioksīda gada vidējā koncentrācija ir robežās no 30$\left.40 \mathrm{mkg} / \mathrm{m}^{3}\right)$ - slāpekḷa dioksīda $\left(\mathrm{NO}_{2}\right)$ koncentrācijas nepārsniedz cilvēka veselības aizsardzībai noteiktos robežlielumus, tomēr tiek pārsniegts ekosistēmu aizsardzībai noteiktais robežlielums; pašreizējā situācijā stāvoklis ir apmierinošs; atsevišķos izņēmuma gadījumos piel̦aujams papildus gaisa piesārņotāju izvietojums, ja tas nepalielina kopējo piesārñojuma līmeni.

$\checkmark$ III zona (slāpekḷa dioksīda gada vidējā koncentrācija ir zemāka par $\left.30 \mathrm{mkg} / \mathrm{m}^{3}\right)$ - slāpekḷa dioksīda $\left(\mathrm{NO}_{2}\right)$ koncentrācija nepārsniedz ne cilvēka, ne ekosistēmu aizsardzībai noteiktos robežlielumus; šajā zonā pię̧aujama papildus gaisa piesārṇotāju izvietošana, ja tā atbilst LR noteiktajai likumdošanai. 


\title{
HUMUSVIELU IZDALĪŠANA NO KŪDRAS, IZMANTOJOT DAŽĀDAS EKSTRAKCIJAS METODES
}

\author{
Jānis ŠīRE \\ LU Ģeogrāfijas un Zemes zinātñu fakultāte, \\ e-pasts: Janis.Sire@lu.Iv
}

Līdz šim Latvijā iegūtā kūdra pārsvarā tikusi izmantota kurināmā ražošanai un neapstrādātā veidā - dārzniecībā. Taču pēdējo gadu laikā pasaulē strauji attīstās jaunas kūdras izmantošanas un pārstrādes metodes, līdz ar to paplašinās tās izmantojuma jomas.

Kūdras sastāvā ietilpst dažādas dabiskas izcelsmes organiskas vielas, no kurām pēc izplatības nozīmīgākās ir humusvielas (HV). Tās veidojas galvenokārt vidē esošo mikroorganismu un fermentu ietekmēe kā arī kondensācijas reakciju rezultātā notiekot HV sintēzei no mazmolekulāriem organiskiem savienojumiem. Humusvielas veido lielāko dạı no augsnes organiskajām vielām, tādēl tām ir nozīmīga ietekme uz vidē noritošajiem procesiem un oglekḷa geoķ̄īmisko apriti. Humusvielu makromolekulu pamatsastāvā ietilpst kondensēti aromātiski gredzeni, lignīnu struktūras elementi, alkilaromātiskas struktūras, fenoli un hinoni, kas savā starpā ir saistīti ar alifātiskām, skābekli, slāpekli vai sēru saturošām ķīmiskajām saitēm.

Pētījumu aktualitāte par HV iegūšanu, izmantošanu ir nozīmīga, jo HV iegūšanas izmaksas ir samērā zemas un izmantojuma jomas ir loti daudzveidīgas. Turklāt humusvielas saturoši produkti ir videi draudzīgi un netoksiski, tādēl to pielietojuma jomu spektrs aizvien papildinās. Šobrīd HV izmanto organiskajā lauksaimniecībā, lopbarības piedevu, pārtikas piedevu, krāsvielu un kosmētikas līdzekḷu ražošanā, kā arī augšņu rekultivācijā. Ir zināms, ka humusvielām piemīt nozīmīgas antivīrusu, pretiekaisuma, hormonālo sistēmu stimulējošas, profibrinolītiskas un smago metālu saistǐšanas spējas.

Humusvielu izdalī̌sanā no kūdras galvenā problēma ir tā, ka tikai neliela humusvielu daļa atrodas brīvā veidā. Lielākā daḷa atrodas dažādās formās saistībā ar augsnes minerāliem, tādēḷ, lai iegūtu HV šķīiduma veidā, nepieciešams šo saistību izjaukt. Visplašāk kūdras HV ekstrahēšanai izmanto nātrija hidroksīda šķīdumus, jo tas salīdzinājumā ar citiem šķīdumiem ļauj izdalīt 30-60\% humusa. Darbā pētītas humusvielu ekstrakcijas iespējas, izmantojot dažādas metodes apstrādājot ar sārmiem, kālija pirofosfātu, izmantojot divas dažādu jaudu ultraskaņas vannas, kavitācijas un elektroizlādes iekārtas.

Visaugstāko HV iznākumu ir iespējams panākt, izmantojot elektroizlādes un kavitācijas metodes un kā ekstraǵentu lietojot NaOH. Rezultātā 30 minūšu laikā var panākt HV koncentrācijas attiecīgi 13 g/l un 10 g/l, savukārt, izmantojot $0,27 \mathrm{~kW}$ spēcīgu ultraskaņu, ļoti straujš HV koncentrācijas pieaugums ir vērojams pirmajās 10 minūtēs, kad humusvielu koncentrācija pieaug no 0 līdz 6 g/l. Apstrādājot kūdras-sārma maisījumu 80 minūtes, humusvielu koncentrāciju 
ir iespējams dubultot, sasniedzot $12 \mathrm{~g} / 1$, taču turpmāka apstrāde HV pieaugumu nedod. Kūdras - sārma maisījumu vārot samērā straujš HV koncentrācijas pieaugums ir vērojams pirmajās 10 minūtēs, tam pieaugot līdz $7 \mathrm{~g} / \mathrm{l}$, turpmāka apstrāde dod zemāku HV pieaugumu - apstrādājot 3 stundas, HV koncentrācija palielinās līdz $10 \mathrm{~g} / \mathrm{l}$, taču tālāka apstrāde ievērojamu HV koncentrācijas pieaugumu nedod.

Tomēr jāṇem vērā arī izdalīšanas ekonomiskais pamatojums, jo tikai vārīšanu var veikt bez īpašām iekārtām, kā tas ir kavitācijas, ultraskaņas vannu un elektroizlādes gadījumā, kur cena var būt samērā augsta. Turklāt ir jāṇem vērā arī izdalīšanas procesā nepieciešamais enerǵijas daudzums, kas var pat būtiski ietekmēt galaprodukta cenu. Tāpat šajos procesos veidojas liels daudzums atkritumproduktu - ekstrakcijas procesā izmantotā kūdra, par kuras izmantošanas iespējām un īpašībām ir jāveic atsevišķi pêtījumi.

\title{
ĶĪMISKO ELEMENTU IENESE AR NOBIRĀM UZ AUGSNES PRIEŽU MEŽU EKOSISTĖMĀS LATVIJĀ
}

\author{
Evija TĒRAUDA, Olggerts NIKODEMUS, Māris LAIVIN̦Š \\ LU Ģeogrāfijas un Zemes zinātņu fakultāte, \\ e-pasts: evija.terauda@lu.Iv \\ Guntis TABORS \\ LU Bioloǵijas fakultāte
}

Meža ekosistēmā piesārṇojošās vielas un barības vielas no nokrišņiem, kā arī sauso daḷiņu izsēšanos vispirms uztver koku vainagi (Staaf and Berg, 1981). Elementus var uzṇemt arī ar augu saknēm no augsnes, kas tālāk transportējas uz lapām un skujām (Gjengedal \& Steinnes, 1990). Elementi, kas nogulsnējas uz lapu virsmas, var tikt uzņemti lapā caur atvārsnītēm. Elementi (lielākoties puteklıs) var arī pielipt uz lapu virsmas, no kurienes tos ar lietus ūdeñiem noskalo un aizvieto ar citu elementu spektru (Reimann et al., 2001). Tādējādi arī nobiras, kas katru mēnesi nonāk uz augsnes, satur ķīmiskas vielas, kas akumulējušās koku skujās un lapās un uz to virsmām.

Integrālā monitoringa programmas ietvaros Taurenes un Rucavas integrālā monitoringa stacijās, kas raksturo divus atšķirīgus dabas reǵionus - Vidzemes augstienes centrālo dạı un Piejūras zemieni - tiek ievāktas meža nobiras un veiktas to ķīmiskās analīzes, nosakot gan biogēno, gan smago metālu saturu tajās.

Piecu gadu (1999.-2003.g.) pētījumu rezultāti rāda, ka nobiru daudzums, kas nonāk uz augsnes, nedaudz lielāks ir Rucavas IM parauglaukumā no 32230$39470 \mathrm{~kg} / \mathrm{ha}^{-1}$ nekā Taurenes IM parauglaukumā, kur vidēji tas ir no 27400$34640 \mathrm{~kg} / \mathrm{ha}^{-1}$. To varētu skaidrot Rucavā ar lielāku vainaga projektīivo segumu. Salīdzinot nobiru daudzumu gada griezumā, novērojamas izmaiñas starp abām IM stacijām. Taurenē pavasarī un vasaras sākumā nobiru daudzums vidēji ir 2852- 
$2910 \mathrm{~g} / \mathrm{ha}^{-1}$ un tas ir nedaudz lielāks nekā Rucavā 726-2748 kg/ha ${ }^{-1}$, savukārt rudens mēnešos novērojama pretēja tendence. Kopumā vislielākais nobiru daudzums, kas nonāk uz augsnes, konstatēts rudenī. Taurenē septembrī vidēji no 4560$11160 \mathrm{~kg} / \mathrm{ha}^{-1}$, bet Rucavā oktobrī no $5770-11930 \mathrm{~kg} / \mathrm{ha}^{-1}$. Atšksirīibas nobiru daudzumā nosaka veǵetācijas perioda izmaiņas, jo Latvijas rietumu dạ̦ā tas sākās ātrāk un beidzās vēlāk nekā valsts austrumu dạ̧ā. Salīdzinoši liels nobiru daudzums Taurenes IM stacijas parauglaukumos novērojams ziemas mēnešos no 5260$11820 \mathrm{~kg} / \mathrm{ha}^{-1}$. Tas saistīts ar nobiru biologisiskā sastāva atšķirīibām, jo Taurenē mežaudzē bez priedēm sastopami arī bērzi un egles. Eglēm raksturīgi, ka tās savas vecās skujas ,met” galvenokārt ziemas mēnešos. Lielāku nobiru daudzumu ziemas mēnešos Taurenē ietekmē arī lielāks sniega daudzums, jo, pēc Latvijas hidrometeorolog̣ijas aǵentūras datiem, vidējais sniega segas biezums Vidzemes augstienē ir no $40-50 \mathrm{~cm}$, bet Piejūras zemienē tikai no $10-20 \mathrm{~cm}$.

Starp abām IM stacijā novērojamas arī nobiru ķīmiskā sastāva atšķirības. Augstāka $\mathrm{Ca}, \mathrm{Mg}$ un $\mathrm{K}$ koncentrācija, iznemot Fe, konstatēta Taurenes IM parauglaukuma nobirās. Tas saistīts ar iepriekš minēto nobiru bioloǵiskā sastāva atšķirību, jo Taurenē mežaudzē ir lielāks bērzu īpatsvars. Noskaidrots, ka lapu koku nobiras ir ar bāzes elementiem bagātākas nekā skuju koku nobiras (Binkley, 1994). Turpretim pētāmo smago metālu ( $\mathrm{Pb}, \mathrm{Cu}, \mathrm{Zn}, \mathrm{Ni}$ un $\mathrm{Mn})$ koncentrācija nobirās augstāka konstatēta Rucavas IM parauglaukumā. Tas ir saistîts ar piesārṇojuma pārrobežu pārnesi, kad atmosfēras gaisa masu pārvietošanās dēl, tiek ienesti smagie metāli no Eiropas lielajiem rūpnieciskajiem rajoniem, kā arī no Lietuvas (Brūmelis un citi, 1997).

Meža nobiru pētījumos Taurenes un Rucavas IM staciju mežaudzēs novērotas ķīmisko elementu koncentrācijas izmaiņas gada gaitā. Barības elementu koncentrāciju sezonālās izmaiņas koku lapotnē saistītas ar barības elementu uzņemšanu un iekšējo pārvietošanos, gatavojoties pārziemošanai un iepriekš rudenī lapu un skuju biršanai (Helmisaari, 1992). Ca koncentrācija nobirās vismazākā ir pavasarī (Taurenē 3372,32 mg/kg, Rucavā 2126,05 mg/kg) un vasarā (Taurenē 2860,41 mg/kg, Rucavā 2438,43 mg/kg), bet visaugstākā rudenī (Taurenē 4309,03 mg/kg, Rucavā 4332,37 mg/kg), kad novērojams vislielākais nobiru daudzums. Ca saistās šūnu struktūrās un ir mazkustīgs augu organismā, tādēḷ, it īpaši vecākās šūnās, tas var uzkrāties lielākos daudzumos (Mauriṇa, 1987). Savukārt Mg un K, mazāk Fe, koncentrācija nobirās augstāka ir pavasara mēnešos, bet savu minimumu tā sasniedz oktobrī un ziemā, kas saistīts ar minēto elementu pārvietošanos augā no vecākām daļām uz jaunākām, kur notiek intensīvāki dzīvības procesi. No smagajiem metāliem $\mathrm{Mn}$ un $\mathrm{Zn}$ visvairāk satur rudens, bet $\mathrm{Pb}, \mathrm{Cu}$ un Ni pavasara nobiras.

Analizējot ķīmisko elementu ienesi ar nobirām uz augsnes virskārtas, konstatēts, ka gan Taurenē, gan Rucavā visaugstākā tā ir laikā, kad novējojams vislielākais nobiru daudzums. Barības elementiem Taurenes IM tas ir septembrī un 
ziemā, bet Rucavas IM oktobrī. Līdz̄ịi arī smagie metāli uz augsnes visvairāk gan Taurenes, gan Rucavas parauglaukumā nonāk ar rudens un ziemas nobirām.

\title{
Literastūra
}

1. Binkley D., 1994. The influence of tree species on forest soils: Processes and Patterns // Mead D. J., Cornforth I. S. (eds.). Proceedings of tree species and soil workshop. Agronomy Society of New Zealand Special Publication \# 10, Lincoln Univ. Press, Canterbury, NZ, 1996: pp. 1 - 33.

2. Brūmelis G., Lapina L., Nikodemus O., Tjarve D., 1997. Estimation of atmospheric heavy metal deposition in Latvia using feather moss. Proc. Latvian Academic Science., Section B, Vol. 51 (1997), No. 3/4 (590/591): 1pp. 159 - 164.

3. Gjengedal E. \& Steinnes E., 1990. Uptake of metal ions in moss from artificial precipitation. Environmental Monitoring and Assessment 14, pp. 77-87.

4. Helmisaari H. - S., 1992. Nutrient retranslocation within the foliage of Pinus sylvestris. Tree Physiology., 10: pp. $45-58$.

5. Mauriņa H., 1987. Augu fiziolog̣ija. Zvaigzne, Rīga. 104-116.lpp.

6. Reimann C., Koller F., Kashulina G., Niskavaara H., Englmaier P., 2001. Influence of extreme pollution on the inorganic chemical composition of some plants. Environmental Pollution 115, pp. 239-252.

7. Staaf H., Berg B., 1981. Accumulation and release of plant nutrients in decomposing Scots pine needle litter. Long - term decomposition in a Scots pine forest II . Canadian Journal of Botanic, vol. 60: pp. $1561-1568$.

\section{NOTURĪGO ORGANISKO PIESĀRN̦OTĀJU PĀRVALDĪBAS PROBLĒMAS UN TO IESPĒJAMIE RISINĀJUMI LATVIJĀ}

\author{
Valters TOROPOVS, Magnuss VIRCAVS, \\ LU Ģeogrāfijas un Zemes zinātņu fakultāte, \\ e-pasts:sg20007@lanet.Iv, Magnuss.Vircavs@lu.Iv
}

Noturīgo organisko piesārņotāju izmetes, noplūdes un pārrobežu pārneses novēršanai ir pieņemti vairāki starptautiskie dokumenti, piemēram, Eiropas Kopienas direktīvas 76/769/EEC un 1999/29/EC. 1998.gadā Dānijas pilsētā Orhūsā tika pieņemts $\mathrm{ANO} / \mathrm{EEK}$ „Konvencijas par robežšḳērsojošo piesārņošanu lielos attālumos protokols „Par noturīgajiem organiskajiem piesārṇotājiem””, kuru parakstīja arī Latvija. Tas ietver 16 īpaši bīstamas vielas - 12 pesticīdus, 2 ḳīmiskos produktus, kurus izmanto rūpniecībā, un 3 termisko procesu blakusproduktus. Protokols (stājās spēkā 2003.g. 23.oktobrī) aizliedz ražot un izmantot vairākus ķīmiskos produktus, kā arī tajā ir iekl̦auti noteikumi darbībām ar šo vielu atkritumiem un noteiktas emisiju robežvērtības sadzìves, bīstamo un slimnīcu atkritumu sadedzināšanai. Tas izvirza prasību Protokolu parakstījušām valstīm samazināt dioksīnu, furānu, poliaromātisko ogḷūdeņražu un heksahlorbenzola izmetes, salīdzinot ar minēto vielu 1990.gada izmešu līmeni (vai cita gada līmenim laika posmā no 1985.g. līdz 1995.g.). Savukārt 2001.gada 22. un 23.maijā Stokholmā tika pieņemta Konvencija par noturīgajiem organiskajiem piesārņotājiem (Stokholmas konvencija). Tā jau ir stājusies spēkā. Tā kā arī Latvija 
ir pievienojusies šai konvencijai, tad Latvijas vides likumdošanas atbilstība tās izvirzịtajām prasībām, iespējamajām problēmām un to risinājumu variantiem ir l̦oti nozīmīgs vides politikas jautājums. Analizējot esošos Latvijas tiesību aktus vides aizsardzības jomā, izriet, pirmkārt, ka tie nesatur jēdziena "noturīgie organiskie piesārņotāji" definīciju Stokholmas konvencijas un Orhūsas protokola izpratnē, lai gan 2004.gada 9.septembrī pieņemts un 29.septembrī stājies spēkā likums "Par Konvencijas par robežšķērsojošo gaisa piesārṇošanu lielos attālumos Protokolu par noturīgajiem organiskajiem piesārṇotājiem”, kas būtībā ir Orhūsas protokola tulkojums. Kā prioritāte Stokholmas konvencijas dalībvalstīm ir tās 3.panta nosacījumi, kas dalībvalstīm izvirza stingras prasības veikt administratīvas vai juridiskas darbības, lai aizliegtu Pielikumā A uzskaitīto ķīmisko vielu ražošanu, izmantošanu, eksportu un importu. Otrkārt, Latvijā pašreiz nav tādu spēkā esošu normatīvo aktu, kas aizliegtu šo ķīmisko vielu ražošanu. Attiecībā uz izmantošanu šobrīd ir aizliegta Pielikumā A uzskaitīto vielu izmantošana augu aizsardzībā, to imports un registrācija par augu aizsardzības līdzekli. Taču, tā kā minētajām vielām ir arī citi izmantošanas veidi, kā arī vides likumdošana neparedz izṇēmumus un piẹ̦aujamos lietošanas veidus, tad izriet, ka minētā Konvencijas prasība nav izpildīta. Treškārt, tas pats attiecas arī uz Pielikumā B iekḷauto vielu DDT. 1.pantā aizliegumi ir spēkā par PHB izmantošanu un tirdzniecību, bet nav aizliegts tos ražot, importēt un eksportēt. Ceturtkārt, MK 2003.gada 15.aprīịa noteikumos Nr.184 "Prasības darbībām ar biocīdiem" ir minēti ierobežojumi bīstamo ķīmisko vielu reǵistrēšanai par biocīdiem, taču, iztrūkstot NOP jēdzienam, noteikumos nav arī īpašu atrunu vai aizliegumu izmantot Stokholmas konvencijā norādītās vielas. Tāpat arī Konvencijā izvirzītie eksporta un importa ierobežojumi Latvijas normatīvajos aktos šobrīd nav iekļauti. Ķīmisko vielu un ķīmisko produktu likums regulē iepriekš norunātas piekrišanas kārtību starptautiskajā tirdzniecībā par dažām bīstamajām vielām (atbilstoši Roterdamas konvencijai), tomēr Stokholmas konvencijas izpratnē eksporta un importa aizliegums kā tāds, kā arī noteiktie ierobežojumi eksportam un importam netiek regulēti.

Lai panāktu Stokholmas konvencijas prasību ievērošanu, nepieciešams:

Pirmkārt, Latvijas vides normatīvajos aktos definēt jēdzienu NOP.

Otrkārt, juridiski apstiprināt NOP sarakstu un kritēriju sarakstu jaunu ķīmisko vielu novērtēšanai atbilstoši NOP pazīmēm un Konvencijā noteiktajiem kritērijiem.

Treškārt, aizliegt ražot, izmantot, importēt un eksportēt minētās vielas atbilstoši Konvencijā noteiktajiem ierobežojumiem.

Ceturtkārt, visiem NOP jānosaka piel̦aujamās koncentrācijas. Pārējās Stokholmas konvencijas prasības varētu tikt izstrādātas pakāpeniski, atbilstoši nacionālajam NOP ieviešanas plānam un inventarizācijas rezultātiem.

Piektkārt, vairākiem NOP gaisa, augsnes un ̄deṇu kvalitāti regulējošajos normatīvajos aktos nav noteiktas pieḷaujamās koncentrācijas. 


\title{
SADZĪVES ATKRITUMU PROBLËMAS TALSU RAJONĀ
}

\author{
Raimonds VAIVODS \\ Ģeogrāfijas un Zemes zinātņu fakultāte, \\ e-pasts: dingo18@one.Iv
}

Katras valsts sociālā un industriālā attīstība ir cieši saistîta ar ekonomikas izaugsmi un nemitīgu atkritumu daudzuma palielināšanos. Straujais atkritumu daudzuma pieaugums pašreiz ir viena no lielākajām vides aizsardzības problēmām ne tikai Latvijāa, bet visā pasaulē. Tāpēc lọti svarīgi atkritumu apsaimniekošanas jautājumus ir analizēt kā valsts, tā arī pašvaldību līmenī.

Referāts veltīts atkritumu apsaimniekošanai un ar to saistītajām problēmām un iespējamiem risinājumiem Talsu rajonā.

Talsu rajonā (55000 iedzīvotāju, no kuriem 12500 dzīvo Talsu pilsētā) gadā vidēji tiek saražots $41439 \mathrm{~m}^{3}$ jeb 8280 t sadzīves atkritumu. Vairāk nekā $61 \%$ no tiem ir mājsaimniecības atkritumi, bet tikai 39\% rūpniecības atkritumi, kas norāda uz relatīvi zemo rūpniecības īpatsvaru rajonā.

Ar sadzīves atkritumu savākšanu un glabāšanu Talsu rajonā nodarbojās 2 atkritumu apsaimniekošanas uzn̄ēmumi - SIA „Kurzemes ainava Talsi”, kurš apsaimnieko 12 no rajona 16 pagastiem un Talsu pilsētu, un SIA „Krauklis AS”, kurš apsaimnieko Roju un Rojas un Valdemārpils pagasta teritorijas. Šo uzñēmumu un pašvaldību aktīvās darbības dēḷ sadzīves atkritumu apsaimniekošanas situācija Talsu rajonā ir krietni uzlabojusies salīdzinājumā ar 1990.gadu sākumu. Galvenie aspekti šajā sakarībā ir atkritumu škirošana gan to rašanās vietās, gan arī pirms to apglabāšanas, lielgabarīta atkritumu savākšanas laukumu izveidošana. Pilnībā ir nomainīta atkritumu transporta tehnika, atkritumu savākšanas konteineri, uzlabota vides inspektoru kontroles kvalitāte.

Saskaņā ar „Stratēgiju sadzīves atkritumu apsaimniekošanā 1998-2010" pēdējo 4 gadu laikā Talsu rajonā ir slēgtas 4 bijušās atkritumu izgāztuves, kurās pašreiz tiek veikta rekultivācija.

Tomēr Talsu rajonā atkritumus saimniecības jomā pastāv vairākas lioti būtiskas problēmas vides politikas kontekstā.

1. Finansiālo līdzekḷu nepietiekamība, kas acīmredzot ir saistīta ar lauku rajonu iedzīvotāju maksātnespēju. Pēdējā izraisa vairākas problēmas - a) vides aizsardzības principa "piesārņotājs maksā" ignorēšana; b) nelegālās izgāztuves mežu un karjeru teritorijās degradē ainavu un mazina meža rekreācijas funkciju, kā arī rada augsnes un gruntsūdeņu piesārņojumu; c) izgāztuvju rekultivācijas zema kvalitāte, kā dēl nav iespējams ievērot nozares labākos tehnologiskos risinājumus, piemēram, modernākas atkritumu apsaimniekošanas tehnikas lietošanu; d) nepilnīga darba apmaksas sistēma.

2. Nepilnīgas Latvijas vides tiesību normu ievērošanas cēlonis izriet no iepriekš minētās finanšu līdzekḷu nepietiekamības un vājas pašvaldību un reǵionālās vides pārvaldes sadarbības. Tai sekas ir atkritumu apsaimniekošanas kā vienas no 
Latvijas vides politikas prioritātēm ignorēšana. Vēl joprojām Talsu rajonā ir vairāk nekā 12 slēgtās izgāztuves, kuru paviršās sakopšanas dēl turpinās vides piesārṇošana. Lauku reǵionos, arī Talsu rajonā, neatrisināta ir atkritumu savākšanas regularitāte (grafiks), kura visbiežāk ir tikai reizi mēnesī.

3. Sadzives atkritumu daudzuma palielināšanās. Šāda tendence ir raksturīga ne tikai Talsu rajonā, bet visā Latvijā un daudzviet Eiropā. Par atkritumu palielināšanās tendenci liecina tas, ka 1998.gadā tika savākts $34533 \mathrm{~m}^{3}$, bet 2002.gadā jau par 20\% vairāk atkritumu. Tiek prognozēts, ka 2010.gadā atkritumu daudzums rajonā varētu sasniegt pat $53871 \mathrm{~m}^{3}$ un vairāk. Kā iespējamais risinājums atkritumu daudzuma samazināšanai būtu to otrreizējā pārstrāde, bet tā savukārt ir cieši saistīta ar pieprasījumu pēc šādām otrreizējām izejvielām un materiāliem.

4. Rojas izgāztuves slēgšanas un rekultivācijas aizkavēšanās rada ievērojamu augsnes un gruntsūdens piesārņojumu. Pie tam teritorijas neregulāra gruntsūdens monitoringa dēl faktiski notiek legāla ūdeņu piesārņošana. To apstiprina arī Ietekmes uz vidi novērtējuma valsts biroja atzinums "Piejūras regiona sadzīves atkritumu poligona ietekmes uz vidi novērtējums", kurā inter alia teikts, ka piesārņojums no izgāztuves nonāk Rojas upē, kas savukārt ieplūst Rīgas jūras līcī, tādējādi izmainot upes un dậ̄ēi Rīgas līča ūdeņu ķīmisko sastāvu. Arī sadzīves atkritumu poligonā „Janvāri” ir konstatēts grunsūdeņu piesārņojums (paaugstinātas slāpekḷa koncentrācijas, augsta elektrovadītspēja). Iespējams, ka tuvākā nākotnē poligona darbība tiks uzlabota ar jaunā reǵionālā poligona „Piejūra” izbūvi. Tā rezultātā tiks mazināta vides piesārṇošana, uzlabota arī teritorijas infrastruktūra, piemēram, autocel̦i, attīstīta Talsu rajona ekonomika un pilnveidota sociālā vide.

5. Strādājošo kvalifikācijas līmenis. Luoti svarīgs atkritumu apsaimniekošanas sistēmas darbības faktors ir darbinieku kvalifikācija, kas patlaban ir zema, jo atkritumu šķirošanu veic bezdarbnieki bez attiecīgās kvalifikācijas šajā jomā. Tas ir pamatā nekvalitatīvai atkritumu šķirošanai, kuru īsteno, nenodrošinot atbilstošus darba apstākḷus. Tas savukārt var radīt atsevišķu ekosistēmu piesārņošanu, kā arī negatîvu ietekmi uz strādājošo veselību. Tā ir svarīga problēma gan konkrēti atkritumu saimniecībā, gan arī dažās tautsaimniecības nozarēs tieši lauku rajonos. Iespējamais risinājumus ir speciālu atkritumu apsaimniekošanas kursu izveidošana, kā arī savstarpējas konkurences veidošana, tādējādi uzlabojot darbinieku kvalifikāciju.

6. Informētība. Jānorāda arī uz relatīvi zemo iedzīvotāju informētības līmeni par sadzīves un bīstamo atkritumu nozīmi, ietekmi, to savākšanas un šķirošanas nepieciešamību un citām svarīgām problēmām šajā jomā. Iedzīvotāju informētību nepieciešams risināt.

7. Zināmie risinājumi. Kā iespējamos risinājumus var minēt: stingrāku dabas resursa nodokḷa iekasēšanu, administratīvo sodu palielināšanu, atsevišķa finansējuma līdzekḷu piesaiste no valsts budžeta, kā arī Eiropas struktūrfondu līdzekḷu lietderīga izmantošana un to kontrole. 


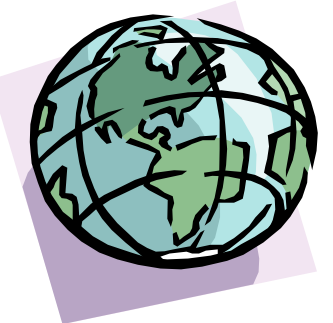

\title{
LATVIJAS ŪDEN̦U VIDES PËTİJUMI UN AIZSARDZİBA
}

\section{KOPEPODA LIMNOCALANUS MACRURUS BAROŠANĀS INTENSITĀTES SAISTIIBA AR VERTIKĀLĀM MIGRĀCIJĀM BOTNIJA LĪCĪ}

\author{
G.AIŠPURE \\ Latvijas Universitātes Hidroekoloǵijas institūts Jūras monitoringa nodaḷa, \\ e-pasts: gunta@monit.lu.Iv
}

Kopepods Limnocalanus macrurus (Sars) ir unikāls Baltijas jūrā dzīvojošs ledus laikmeta relikts. Suga apdzīvo galvenokārt dzilākos ūdens slāṇus zem termoklīna, bet veic vertikālas migrācijas uz virsējiem ūdens slāniem, lai barotos un izvairītos no plēsējiem. Šì darba mērḳis ir noteikt dažādu Limnocalanus macrurus attīstības stadiju barošanās intensitāti diennakts vertikālo migrāciju laikā un noteikt migrāciju paradumus.

Iepriekš veiktie pētījumi pierāda, ka sugas attīstības sekmes lielā mērā nosaka barības apstākḷi, īpaši pavasara fitoplanktona ziedēšanas laikā, kad Limnocalanus macrurus populācijā dominē naupliju stadija. Lai noteiktu Limnocalanus macrurus kopepodītu un pieaugušo stadiju barošanās izmaiņas un sugas diennakts vertikālo migrāciju paradumus, tika ievākti paraugi Botnijas līča stacijā, kuras dziļums - $130 \mathrm{~m}$. Paraugu ievākšanas laiks bija augusts, kad Limnocalanus macrurus populācijā dominē kopepodītu un pieaugušo attīstības stadijas. Ir noskaidrots, ka pēc saulrieta proporcionāli neliela daḷa Limnocalanus macrurus indivīdu migrē virs termoklīna, lai barotos. Nosakot hlorofila $a$ koncentrāciju Limnocalanus macrurus zarnās, visintensīvākā barošanās naktī konstatēta 20 m slānī zem termoklīna. Dienā Limnocalanus macrurus barošanās dziḷākajos ūdens slāņos ir bijusi neaktīva. Šì darba rezultāti rāda, ka dažādu Limnocalanus macrurus attīstību stadiju vertikālās migrācijas un barošanās paradumi atšksiras un tiks diskutēti tālāk. 


\title{
BIOTESTËŠANAS IZMANTOŠANAS IESPËJAS VIDES KVALITĀTES KONTROLĒ
}

\author{
Maija BALODE, Māra PFEIFERE, Solvita STRĀĶE, Ingrīda PURIN̦A, leva BĀRDA, \\ Katrīne POVIDIŠ̉A \\ Latvijas Universitātes Hidroekoloǵijas institūts, \\ e-pasts: maija@hydro.edu.Iv; solvita@hydro.edu.Iv; ingrida@hydro.edu.Iv
}

Pieaugošā piesārṇojuma un to komplicētā ķīmiskā sastāva dēl biotestěšanas metožu izmantošana vides kvalitātes kontrolē mūsdienās gūst aizvien lielāku pielietojumu. Pasaules pieredze liecina, ka biotestēšanu var veiksmīgi izmantot vides kvalitātes kontrolēe kā arī dažāâ sadzīvē un rūpniecībā lietojamu vielu kaitīguma novērtēšanai. Biotestēšanas metodes balstās uz dzīvo organismu atbildes reakcijas noteikšanu un salīdzinājumā ar ķīmiskajām metodēm sniedz virkni priekšrocību, piedāvājot iespēju novērtēt dažādu vielu negatīvo ietekmi uz dzīvo organismu attīstību neatkarīgi no to k̦īmiskā sastāva un izcelsmes veida. Tās ļauj konstatēt nelabvēlīgā faktora ietekmi arī nezināmas izcelsmes - ķ̄imiski grūti nosakāmu vielu -, kā arī kombinētā piesārņojuma gadījumos. Tās ir precīzas un adekvātas vides stāvokḷa novērtēšanas metodes, kas izceḷas ar salīdzinoši lētām izmaksām un augsto jūtības pakāpi. Biotestēšanas iespējas ir l̦oti plašas: tās var izmantot praktiski jebkurai ekosistēmai un pārbaudīt ne tikai mākslīgas izcelsmes, bet arī dabiskos procesos radušās vielas. Ekoloǵiskā riska noteikšanai biotestēšanu plaši izmanto arī pirms jaunas produkcijas laišanas apgrozībā, pirms derīgo izrakteņu ieguves vietas izmantošanas u.c. Biotestus sevišķi plaši izmanto tādās pasaules ienesīgās tautsaimniecības nozarēs kā farmakologija un kosmētikas rūpniecība.

Balstoties uz pasaules pieredzi, darbā tika izvērtēta biotestēšanas loma vides kvalitātes kontrolē un ķīmisko savienojumu toksiskuma pārbaudē; noteiktas šo metožu priekšrocības un trūkumi; to saistība ar ES Ūdens Struktūrdirektīvu izpildi. Darbs sniedz pamatinformāciju par biotestēšanas izmantošanu hidroekosistēmu ekologiskā stāvokḷa analīzē, šo testu pamatprincipiem un norises gaitu, sīkāk iepazīstinot ar metodēm, kurās par testobjektiem tiek izmantoti ūdens organismi. Pētījumos aplūkoti biotestēšanā visplašāk lietotie testi un to standarti, kā arī to lietošana Latvijas vides kvalitātes kontrolē.

LU Hidroekolog̣ijas institūta pētnieku pieredze biotestēšanas jomā saistās ar mājsaimniecībā izmantojamo trauku mazgājamo līdzekḷu biotestēšanu; atsevišksu rūpniecībā izmantojamu vielu - un alğgu toksīnu biotestēšanu. Lai noteiktu minēto komponentu ietekmi uz hidroekosistēmu ekoloǵisko stāvokli, biotestēšanai tika izmantoti gan plašu pielietojumu ieguvuši testi, gan to modifikācijas. Kā testobjekti tika izmantoti ūdens augi un dzīvnieki (mikroskopisko aļğu tīrkultūras; zooplanktona organismi; zivju ikri un to mazulii), kā testkritēriji - alğgu augšanas intensitāte, fotosintētiskā aktivitāte; zooplanktona organismu olu produkcija, šķilšanās spējas, izdzīvotība; novirzes ikru un zivju 
mazul̦u attīstībā, zivju asins sastāva izmainas. No plaši pazīstamiem testiem tika izmantoti Artemia salina tests un Daphnia magna tests.

\title{
SKUĶU (GRĪVAS) EZERA FITOPLANKTONA SEZONĀLĀS IZMAIŅAS
}

\author{
Dāvis GRUBERTS \\ Daugavpils Pedagoǵiskā universitāte, \\ e-pasts: davis@dau.Iv \\ Ivars DRUVIETIS \\ LU Bioloǵijas institūts, e-pasts: ivarsdru@latnet.Iv
}

Pirmie fitoplanktona pētījumi Skuķu (Grīvas) ezerā tika uzsākti 1999.gadā, un laika posmā no 1999. līdz 2000.gadam ezerā tika konstatēti 90 alğgu taksoni no 8 aļgu nodalījumiem [1]. Kopš 2004.gada marta Skuķu ezerā tiek turpināti sezonālie fitoplanktona pētījumi.

Līidz šim ezera hidroloǵisko un hidroķīmisko režīmu pavasara palu laikā noteica Daugavas hidrologiskāa režīma izmaiņas, kā rezultātā ezerā tika konstatētas tikai palienes ezeriem raksturīgās uzpildīšanās, drenāžas un izolācijas fãzes $[2,3]$.

Gan 1999.-2000., gan arī 2004.gadā fitoplanktona attīstības cikls ezerā raksturojams ar kramaļ̧gu dominanci un ļoti zemām biomasām. Būtiska ir Daugavas ūdeņu ietekme, kā rezultātā 1999.gadā uzpildīšanās fāzes laikā Skuķu (Grīvas) ezerā konstatēts Daugavai raksturīgs fitoplanktona sugu sastāvs ar zemām biomasām $(\sim 0,02 \mathrm{mg} / \mathrm{l})$, kurā dominē agram pavasarim raksturīgās planktoniskās kramaḷges. Tai sekojošās drenāžas fāzes laikā pavasara maksimumu veido kramalğges Aulacoseira italica, Asterionella formosa, Cyclotella spp. un zaļaļges. Ciklam beidzoties izolācijas fāzes laikā vasaras fitoplanktona attīstību ierobežo makrofïti, kas akumulē barības vielas un noēno ūdens virsmu. Gan 1999.-2000.g. pêtījumu laikā, gan arī 2004.gada vasaras fitoplanktonā atrastas hlorokokāļu rindas zaļaļges, kā arī planktonā ieskalotās epifìtiskās, perifītiskās un bentiskās kramaļgées. Zilaļğu klātbūtne - minimāla, kas raksturīgi makrofìtu tipa ezeriem. Salīdzinoši ar iepriekš pētīto, 2004.gadā konstatēts ievērojams Cryptophyta īpatsvara pieaugums visās sezonās, kas liecina par eitrofikāciju.

1. Gruberts, D., Druvietis I., 2001. Grīvas ezera fitoplanktona attīstības īpatnības. Latvijas Universitātes 59. konferences tēzes, Zemes un vides zinātņu sekcija. -Rīga, LU izd ., 59.-61. lpp.

2. Gruberts, D., Druvietis I., 2001. Phytoplankton periodicity in floodplain lake Grīvas, Latvia - Baltic State. $9^{\text {th }}$ International Conference on the Conservation and Management of Lakes. Conference Proceedings, Session 4 - BIWAKO, Shiga, Japan, pp. 54-57.

3. Gruberts, D. (2003) Four largest floodplain lakes in Latvia: hydrology, hydro-chemistry and hydrobiology. Ecohydrological Process in Northern Wetlands. Selected papers. Ed. by A. Jarved\&E. Lode. Tallinn-Tartu., Tartu University Press. 


\title{
TEKOŠO SALDŪDEŅU BIOTOPI GAUJAS NACIONĀLAJĀ PARKĀ
}

\author{
Mārtingš KALNIŅŠ \\ Dabas aizsardzības pārvalde, e-pasts: martins.kalnins@dap.gov.Iv
}

Tekošo ūdeņu biotopi Gaujas Nacionālajā parkā ir pētīti relatīvi maz. Nedaudzie pētījumi (Клявиня 1979, Pakalne u.c. 2002) pamatā attiecas uz Gaujā vai atsevišķās upēs apsekotajiem augstākajiem ūdensaugiem. Par salīdzinoši labi izpētītu var tikt uzskatīta 2003. gada vasarā apsekotā (A.Urtāns, nepubl. mat.) no Vaidavas ezera iztekošā Gaujas labā krasta pieteka Strīksupe. Tur veiktie pētījumi dod ieskatu un l̦auj precīzāk izprast arī citu Gaujas pieteku ūdensaugu sugu spektru.

Laika posmā no 1998. līdz 2004.gadam Gaujas NP veikti epizodiski tekošo saldūdeņu biotopu pētījumi. Gaujas NP teritorijā esošās ūdensteces var iedalīt vairākās grupās - lielās (Gauja), vidējās (Brasla, Rauna, Amata), mazās upes un avoti un strauti.

Gauja. Pārstāvēto biotopu ziņā Gauja ir daudzveidīgākā ūdenstece. Gaujas krasti NP teritorijā pārsvarā ir smilšaini, 1 līdz $5 \mathrm{~m}$ augsti, vietām izskaloti. Gaujai nav izteikta upes piekrastes virsūdens augu un saliktā ūdensaugu josla, kas saistāms ar lielajām ūdenslīmeņa svārstībām un īpašo gultnes raksturu - vāji saistīgām un viegli pārvietojamām smiltīm. Līdz ar to vairāk vai mazāk patstāvīgas iegremdēto ūdensaugu asociācijas veidojas tikai atsevišşās atstraumju vietās starp akmeņiem, aiz upē iekritušiem kokiem. To aizņemtās platības ir nelielas. Šīs joslas pamatā veido parastais miežubrālis Typhoides arundinacea, ūdeņu glicērija Glyceria fluitans, mazāk čemurainais puķumeldrs Butomus umbellatus, ķemmveida glīvene Potamogeton pectinatus u.c. Atsevišķās vietās, nelielās platībās sastopamas ūdensmētras Mentha aquatica, parastās niedres Phragmites australis vai ežgalvǐšu Sparganium erectum un Sp.emersum virsūdens audzes upju piekrastē. Peldaugu (lemnītu) augājs veidojas neregulāri, pie upē iekritušiem kokiem vai koku sanesumiem. Biežāk sastopamie biotopi ir parastās mazlēpes Hydrocharis morsus-ranae un ūdensziedu Lemna segas upēs. Gaujas gultne pamatā ir smilšaina vai grantaina, retāk oḷaina. Atsevišķās vietās sastopamas laukakmeņu krāces. Tur veidojas citi biotopu tipi - hildenbrandiju Hildenbrandia rivularis un ūdenssūnu Fontinalis audzes, čemurainā puķumeldra Butomus umbellatus vai ezera meldra Scirpus lacustris zemūdens audzes straujteces posmos upēs.

Vidējās upes. Vidējajās upēs pie izplatītākajiem biotopiem var minēt ūdenssūnu Fontinalis audzes krāčainos posmos un straujteces upju posmos, hildenbrandiju Hildenbrandia rivularis audzes un Alpu glīvenes Potamogeton alpinus peldlapu audzes upēs.

Mazās upes. Gaujas NP mazajās upēs izplatīti ir akmeņaini, oḷaini vai granšaini biotopi. Relatīvi maz ir smilšainu un dūņainu upju. Tomēr pārsvarā mazās upes ir ar retu, mozaīkveida augāju vai vispār bez augāja. Dominējošie 
biotopi ir hildenbrandiju Hildenbrandia rivularis un ūdenssūnu Fontinalis audzes upēs, kā arī ūdensmētras Mentha aquatica virsūdens audzes upju piekrastēs. Atsevišķās upēs bagātīgi pārstāvētas arī Kanādas elodejas Elodea canadensis un ūdensgundegu Batrachium audzes un avota veronikas Veronica beccabunga audzes upēs.

Avoti un strauti. Gaujas NP teritorijā ir liela avotu un avotu strautu daudzveidība. Šeit pārstāvēti gandrīz visi avotu un avotu strautu tipi - kalcifilu avotu strauti, sēravotu strauti, ar dzelzi bagātu avotu strauti, karbonātiski avotu strauti, minerotrofu avotu strauti un temporāli strauti. Strauti pārsvarā ir bez augāja. Atsevišksos strautos ir sastopamas ūdenssūnu Fontinalis vai kladoforu Cladophora audzes.

Pavisam Gaujas NP konstatēti 12 tekošo saldūdeņu biotopu veidi - visi Latvijā izdalītie (Kabucis 2001), kā arī divi jauni - avoti un strauti. Ir izdalīti 82 tekošo saldūdeñu biotopu veidu apakštipi no kuriem Gaujas NP konstatēts 61 biotops. Visplašāk pārstāvēti strauji tekošo ūdeņu biotopu tipi. Konstatēts, ka pēc dominējošajiem biotopu veidiem Gaujas labā krasta pietekas ir atškirīigas no Gaujas kreisā krasta pietekām.

Kā ūdensaugu daudzveidību samazinošs faktors Gaujas pietekām ir jāmin noēnojums no upes krastiem bijušās piekrastes plsavās, kuras, apsīkstot saimnieciskajai darbībai, ir strauji aizaugušas ar alkšņiem. Šādos upju posmos no augstākajiem ūdensaugiem vairāk vai mazāk regulāri ir sastopami tikai vienkāršās ežgalvītes Sparganium emersum un dzeltenās lēpes Nuphar lutea iegremdētās formas.

Gaujas NP teritorijā konstatētie tekošo saldūdeņu biotopi un

konstatēto apakštipu skaits (..) (biotopu klasifikācija pēc Kabucis 2001)

D.1. Krāces upēs (2)

D.2. Straujteces posmi upēs (3)

D.3. Akmeñu sakopojumi upēs (2)

D.4. Ūdenskritumi un kāples upēs (1)

D.5. Smilšu sēres

D.6. Olıu sēres

D.7. Upju piekrastes virsūdens augu josla (9)

D.8. Saliktā ūdensaugu josla upēs (20)

D.9. Peldaugu (lemnītu) augājs upēs (5)

D.10. Upju krasti bez veǵetācijas (5)

D.11. Upju krasti ar amfībisku veǵetācijas (4)

D.12. Avoti* (4)

D.13. Strauti* (5)

* - nav Latvijas biotopu klasifikatorā 


\title{
Literatūra
}

1. Kabucis I. (red.) 2001. Latvijas biotopi. Klasifikators. Rīga: Latvijas Dabas fonds, 1-96.lpp.

2. Pakalne M., Āboliņa A., Čakare I., Opmanis A. un Lācis A. 2002. Eiropas nozīmes un Latvijas aizsargājamie biotopi Gaujas nacionālajā parkā. Projekta atskaite. Rīga.

3. Клявиня Г.Б. 1979. Флора водных (цветковых) растений реки Гауя. В кн. Флора и растений реки Гауя.- В кн.: Флора и растетельность Латвийской ССР: Северо-Видземский геоботанический район. Рига: Зинатне, с. 79-85.

\section{OGLEKĻA UN BIOGËNO VIELU APRITE RĪGAS LĪČA ATKLĀTAJĀ DAĻĀ}

\author{
Bārbele MILLERE-KARULIS, Solvita STRĀĶE \\ Latvijas Universitātes Hidroekoloǵijas Institūts, \\ e-pasts: baerbel@latnet.Iv; solvita@hydro.edu.Iv \\ Didzis USTUPS, Atis MINDE, Georgs KORŅILOVS \\ Latvijas Zivju resursu aǵentūra, \\ e-pasts: didzisu@latfri.Iv; atis@latfri.Iv
}

Oglekḷa un biogēno vielu apriti Rīgas līcī ietekmē gan izmaiņas biogēno vielu slodzēs, kas nosaka jauno fitoplanktona produkciju, gan planktonēdāju, īpaši reņgu, dinamika, kas kopā ar klimatiskajiem faktoriem ietekmē zooplanktona biomasu. Analizējot ilglaicīgās datu rindas, Rīgas līča pelaǵiski trofiskajā sistēmā var izdalīt trīs atšķirīgus periodus. Pirmais ir 1970.gadu periods ar samērā zemu biogēno vielu slodzi, zemu reņgu un zooplanktonu biomasu, kam seko eitrofikācijas kulminācija 1980.gados ar augstām biogēno vielu slodzēm, augstu zooplanktona biomasu, bet vidēju reṇğu krājumu. Savukārt 1990.gadu vidū konstatēta biogēno vielu slodžu samazināšanās, zema zooplanktona biomasa un augsts reņǵu krājums.

Oglekļa un biogēno vielu aprite izdalītajos periodos tiek simulēta ar divu veidu modeḷiem. Pirmais - bioǵeoķīmiskais modelis - raksturo trofiskās sistēmas sākumposmu - biogēnu vielu slodžu transformāciju fitoplanktona un zooplanktona biomasā. Otrais - ECOPATH modelis - simulē mijiedarbību starp fitoplanktonu, zooplanktonu un zivīm.

Model̦a rezultāti parāda Rīgas līča atklātās daļas trofiskās sistēmas struktūru katrā periodā. Modelıi skaidro biogēnās vielas aprites un trofiskās sistēmas kontroles mehānismu - katrā apskatītajā periodā kā biogēno vielu slodžu vai reṇǵu krājumu, kontrolētu „no apakšas” (bottom up control) vai ,no augšas” (top down control). 


\title{
ŪDENS TEMPERATŪRAS DINAMIKA RĪGAS JŪRAS LĪČA PIEKRASTË UN AR TO SAISTITTĀS IHTIOFAUNAS IZMAIN̦AS 2004.GADĀ
}

\author{
Atis MINDE, Viesturs BĒRZIN̦Š \\ Latvijas Zivju resursu aǵentūra, e-pasts: atis@latfri.lv , viesthyd@latfri.Iv
}

Piekrastes zona ir atvērta dinamiska un neviendabīga sistēma, kuras izpētei līdz šim pievērsta nepietiekama uzmanība. Viens no svarīgākajiem faktoriem, kas ietekmē zivju organisma fizioloǵisko procesu aktivitāti un to uzvedību, ir vides temperatūra.

2004.gadā Rīgas jūras līča austrumu piekrastē (pie Salacgrīvas - aprīḷa beigās, jūlija sākumā un augusta vidū) un dienvidu piekrastē (pie Lapmežciema aprịḷa beigās, jūnija vidū un septembra sākumā) veikti ihtiocenozes struktūras pētījumi, kā arī laikā no aprīḷa līdz novembrim - nepārtraukta ūdens temperatūras reg̣istrēšana ( $\sim 5 \mathrm{~m}$ dziḷumā) ar sensoru "HOBO Water Temp Pro".

Konstatēts, ka novērojumu periodā Rīgas jūras līča piekrastē bija vērojamas krasas ūdens temperatūras svārstības - no 1 līdz $22^{\circ} \mathrm{C}$, kuras ir saistītas ar vēja režīma īpatnībām, bieži novērota auksto ūdeņu pacelšanās piekrastes zonas virsējos slāņos - apvelings (skatīit 1.attēlu).

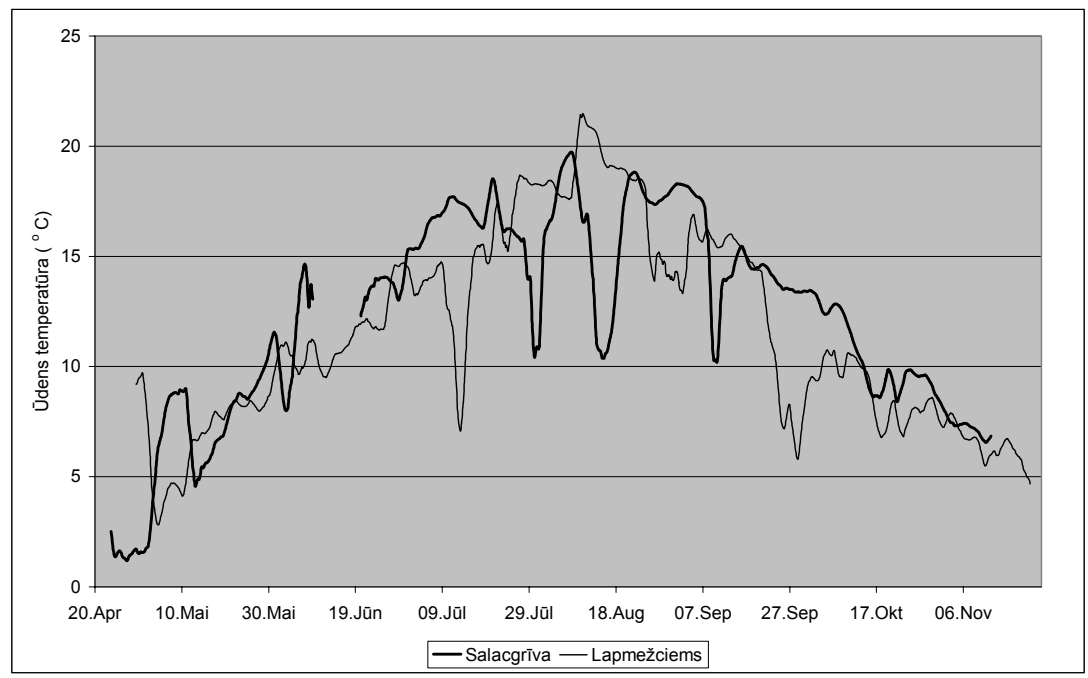

1.attēls. Ũdens temperatūras izmaiṇas Rīgas jūras līča austrumu (Salacgrīva) un dienvidu (Lapmežciems) piekrastē 2004.gadā. 
Salīdzinājumā ar Rīgas jūras līča atklātās daḷas virsējo slāni, kur temperatūra pavasarī un vasarā bija paaugstināta, piekrastē ūdens temperatūra bija ievērojami pazemināta, kas acīmredzot saistīts ar biežo apvelinga atkārtojamību.

Līča austrumos apvelings konstatêts jūlija beigās, augusta vidū un septembra sākumā, kas saistīts ar palielinātu ziemeḷu un ziemeḷietumu vēju atkārtojamību. Līča dienvidos apvelings konstatēts jūlija vidū, augusta beigās un septembra sākumā un beigās, kas saistīts ar palielinātu dienvidu un dienvidrietumu vēju atkārtojamību.

Zemās temperatūras ietekmē piekrastes ihtiocenozes struktūra kā Salacgrīvā, tā arī Lapmežciemā bija izmainījusies - tika novērots zemāks siltummīlošo saldūdens zivju daudzums un periodiski pieauga aukstummīlošo jūras zivju (reṇge, salaka, lucītis, plekste) īpatsvars, kas novērojumu laikā svārstìjās no 3,3 līdz 81,4\%. Saistot aukstummīlošo zivju īpatsvaru ar vidējo ūdens temperatūru 5 dienu laikā pirms ihtiolog̣isko novērojumu veikšanas, konstatēta negatīva korelācija $(\mathrm{r}=-0,85)$ ar augstu ticamību.

\title{
DAUGAVAS PALIENES EZERU HIDROBIOLOĢISKĀ IZPĒTE
}

\author{
Arkādijs POPPELS \\ Latvijas Zivju resursu aǵentūra, \\ e-pasts: apoppels@hotmail.com \\ Dāvis GRUBERTS \\ Daugavpils Universitāte, Dabaszinātṇu un matemātikas fakultāte, \\ e-pasts: davis@dau.Iv \\ Ivars DRUVIETIS \\ LU Bioloǵijas institūts, e-pasts: ivarsdru@latnet.lv
}

Latvijas upju palienēs ir daudz vecupju ezeru, grants karjeru, dīķu, kuru izmēri parasti nepārsniedz dažus hektārus. Š̄im ūdenstilpēm vairumā gadījumu nav ievērojama sateces baseina, un vasaras mazūdens periodā tās bieži vien izžūst pavisam. Izṇēmums ir atsevišķi glaciālas izcelsmes ezeri - Skuķu (Grīvas), Dvietes, L̦ubasta, Koša ezeri, kas atrodas Daugavas palienē un izceḷas ar salīdzinoši lieliem izmēriem un ievērojamu sateces baseinu.

2004.gada jūlijā-augustā tika veikta vecupju, karjerezeru un ezeru apsekošana, lai noskaidrotu Daugavas palienes ezeru hidrogrāfiskos, morfometriskos, un hidrobiologiskos rādītājus un konstatētu šo ūdenstilpju ekologisko stāvokli. Pēc ūdens līmen̦u starpības jāsecina, ka gandrīz visas pētîtās ūdenstilpes ir pakḷautas Daugavas plūdu ietekmei (1.tab.)

Lai gūtu ieskatu par šo ezeru attīstības tendencēm, trofisko stāvokli, bioloǵisko daudzveidību, kā ar̄i zivju barības bāzi, tika veikta fitoplanktona un zoobentosa sugu kompleksu izpēte. Potenciāli toksisko zilaḷgu ziedēšana tika konstatēta tikai Koša ezerā, savukārt uz eitrofikācijas procesiem norādošās 
nodalījuma Cryptophyta aḷges Cryptomonas spp. dominēja Skuķu, Dvietes, L,ubasta ezeru un Pl̦intovkas un Elernes karjerezeru fitoplanktonā (2.tab.).

\section{4.gadā pētīto Daugavas palieņu ūdenstilpju morfometriskie un} hidroloğiskie rādītāji .

\begin{tabular}{|c|c|c|c|c|c|}
\hline Ezers & \begin{tabular}{|c|}
$\begin{array}{c}\text { Maksi- } \\
\text { mālais } \\
\text { dziluums, } \\
\mathrm{m}\end{array}$ \\
\end{tabular} & \begin{tabular}{|c|} 
Vidējais \\
dziḷums, $\mathrm{m}$
\end{tabular} & $\begin{array}{c}\text { Augstums, } \\
\text { m v.j.l. }\end{array}$ & $\begin{array}{l}\text { Palu līmeña } \\
\text { augstums, m }\end{array}$ & $\begin{array}{c}\text { Līmeņu } \\
\text { starpība, m }\end{array}$ \\
\hline Skuķu (Grīvas) ez. & 1,1 & 0,6 & 85,6 & 89,2 & 3,6 \\
\hline Dvietes ez. & 1 & 0,5 & 85,3 & 88,9 & 3,6 \\
\hline Berezovkas vecupe & 0,7 & $0,4 *$ & 84,8 & 90,6 & 5,8 \\
\hline Paukštes (Mundas) ez. & 4,7 & $1,9 *$ & 88,1 & 89,2 & 1,1 \\
\hline Apaḷais (Zaķu) ez. & 0,5 & $0,3 *$ & 91,3 & 91,8 & 0,5 \\
\hline Pḷintovkas karjerez. & 4 & $1,6^{*}$ & 90,9 & 91,9 & 1 \\
\hline Koša ez. & 8 & 3,0 & 88,7 & 89,4 & 1,7 \\
\hline Linmārka karjerez. & 4,8 & $1,9^{*}$ & 88,9 & 91,8 & 2,9 \\
\hline L̨ubasts & 1 & 0,5 & 88,9 & 92,2 & 3,3 \\
\hline dīķis pie DU jaunā korpusa & 2,8 & $1,2 *$ & 90,0 & & 0,3 \\
\hline Gaišais ez. & 6 & $2,3^{*}$ & 93,8 & 93,9 & 0,1 \\
\hline Piskuñicas (Gatenes) ez. & 1,5 & $0,7^{*}$ & 90,1 & 92,5 & 2,4 \\
\hline Pjatačoks & 9 & $3,2 *$ & 93,4 & 93,5 & 0,1 \\
\hline Elernes karjerez. I & 1,5 & $0,7 *$ & 93,5 & 96,6 & 3,1 \\
\hline
\end{tabular}

* - aprēķināts pēc formulas $Z_{\text {vid }}=0,51 * Z_{\max }{ }^{0,84}$, kur $Z_{\text {vid }}-$ vidējais dziļums; $Z_{\max }-$ maksimālais dziḷums

Jūlija - augusta fitoplanktonu un zoobentosu veidojošie sugu kompleksi

\begin{tabular}{|c|c|c|}
\hline Ūdenstilpe & Fitoplanktons & Zoobentoss \\
\hline Skuksu (Grīvas) ez. & $\begin{array}{l}\text { Cryptomonas sp., Cocconeis } \\
\text { placentula, C. pediculus }\end{array}$ & $\begin{array}{l}\text { Caenis robusta }\left(32 \mathrm{~g} / \mathrm{m}^{2}\right), \\
\text { Oligochaeta, Asellus aquaticus, } \\
\text { Chironomidae }\end{array}$ \\
\hline Dvietes ez. & $\begin{array}{l}\text { Cryptomonas sp., Nitzschia } \mathrm{sp} . \\
\text { Aulacoseira } \mathrm{sp} .\end{array}$ & $\begin{array}{l}\text { Glossiphonia } \text { spp., Sphaerium } \\
\text { corneum }\left(64 \mathrm{~g} / \mathrm{m}^{2}\right) ., \text { Anisus } \\
\text { vortex }\end{array}$ \\
\hline Berezovkas vecupe & $\begin{array}{l}\text { Synura uvella, Dinobryon divergens, } \\
\text { Eudorina elegans }\end{array}$ & $\begin{array}{l}\text { Mollusca, Pisidium amnicum, } \\
\text { Sphaerium sp. }\end{array}$ \\
\hline Paukštes (Mundas) ez. & $\begin{array}{l}\text { Dinobryon divergens, Staurastrum } \\
\text { sp., Dictyosphaerium pulchellum, } \\
\text { Botryococcus braunii, Synedra acus }\end{array}$ & $\begin{array}{l}\text { Chaoborus flavicans (līdz 90\% } \\
\text { no biomasas), Oligochaeta }\end{array}$ \\
\hline Apal̦ais (Zak̦u) ez. & Volvox aureus - masveidā & Chironomidae \\
\hline
\end{tabular}




\begin{tabular}{|c|c|c|}
\hline Pl̦intovkas karjerez. & $\begin{array}{l}\text { Cryptomonas sp., Anabaena spp., } \\
\text { Asterionella formosa, Oocystis } \\
\text { lacustris }\end{array}$ & $\begin{array}{l}\text { Chaoborus fluvicans, Bithynia } \\
\text { tentaculata, }\end{array}$ \\
\hline Koša ez. & Oscillatoria sp., Anabaena spiroides & $\begin{array}{l}\text { Chironomidae, Chironomus } \\
\text { plumosus }\left(70,3 \mathrm{~g} / \mathrm{m}^{2}\right)\end{array}$ \\
\hline Linmārka karjerez. & $\begin{array}{l}\text { Anabaena sp., Peridinium cinctum, } \\
\text { Peridinium Willei, Gymnodinium spp., } \\
\text { Oscillatoria spp., }\end{array}$ & Chaoborus sp. - masveidā \\
\hline Lubasts & Cryptomonas sp., Gymnodinium sp., & Chironomidae, Trichoptera \\
\hline $\begin{array}{l}\text { Dīksis pie Daugavpils } \\
\text { Universitātes jaunā korpusa }\end{array}$ & $\begin{array}{l}\text { Ceratium hirudinella, Volvox sp., } \\
\text { Anabaena spp., Scenedesmus } \\
\text { quadricauda. }\end{array}$ & \\
\hline Gaišais ez. & $\begin{array}{l}\text { Botryococcus braunii, Oocystis } \\
\text { lacustris, Cryptomonas sp., } \\
\text { Ankistrodesmus spp., Staurastrum sp. }\end{array}$ & Chironomidae, Culicoides, \\
\hline Piskuṇicas (Gatenes) ez. & $\begin{array}{l}\text { Dinobryon divergens, D. sertularia, } \\
\text { Gymnodinium } \mathrm{sp} ., \text { Phacus } \\
\text { pleuronectes, Ph. longicauda, } \\
\text { Asterionella formosa, Cosmarium sp., } \\
\text { Euglena } \mathrm{sp} .\end{array}$ & $\begin{array}{l}\text { Chironomidae, Oligochaeta, } \\
\text { Bithynia tentaculata }\end{array}$ \\
\hline Pjatačoks & Goniostomum semen - masveidā & \\
\hline Elernes karjerez. & $\begin{array}{l}\text { Cryptomonas sp., Staurastrum sp., } \\
\text { Ankistrodesmus spp. }\end{array}$ & Mollusca, Oligochaeta \\
\hline
\end{tabular}

Īpaši jāuzsver, ka gandrīz visās apsekotajās ūdenstilpēs tika konstatēts smalks detrìts ar l̦oti daudziem zivju asaku fragmentiem, kas liecina ne tikai par palu sanesām, bet arī par to, ka, iespējams, pēc paliem tur ir ievērojams daudzums zivju, kas šajās ūdenstilpēs nespēj izdzīvot un vēlāk aiziet bojā.

\title{
ZIEMEĻU UPESPĒRLENES MARGARITIFERA MARGARITIFERA L. POPULĀCIJU IZDZĪVOTĪBA ATKARĪBĀ NO UPES BASEINA TERITORIJAS APSAIMNIEKOŠANAS VEIDIEM
}

\author{
Mudīte RUDZīTE \\ Latvijas Universitātes Zooloǵijas muzejs, fondu glabātāja, \\ e-pasts: Mudite.Rudzite@lu.Iv
}

Laika periodā no 1999.gada līdz 2003.gadam apsekotas 163 upes, tajās pētīto upju posmu kopējais garums $610 \mathrm{~km}$. Pērlenes konstatētas 8 upēs, to kopējais skaits ap 25000 eksemplāri. 6 upēs konstatētas čaulas un to fragmenti, kas ir pierādījums tam, ka populācijas bijušas un iznīkušas. No visām apsekotajām upēm izvēlētas 19 upes, kuras atbilst vismaz vienai no šādām pazīmēm: upē pašlaik ir pērleņu populācija; upē nav atrastas dzīvas pērlenes, bet atrastas čaulas vai to fragmenti, un ir ziņas no literatūras, ka pērlenes tur bijušas; 
LU ZM R.Kampes kolekcijā ir čaulas, kas ievāktas upē 20.gs. 20.-30.gados, bet pēdējo gadu apsekojumos tomēr nekas nav atrasts; ir pietiekami precīza informācija no literatūras, ka pērlenes bijušas, bet pēdējo gadu apsekojumos tomēr nekas nav atrasts. Upju baseinu teritorijās veikts salīdzinājums teritoriju apsaimniekošanas veidiem un to platībām. Upju baseinu teritoriju analīzē izmantoti LU Ģeodēzijas un ǵeoinformātikas institūta kartogrāfiskie materiāli un digitālie dati. Datu ievadei, apstrādei un zemes lietojuma veidu upju baseinos noteikšanai tika izmantotas Ģeogrāfisko Informācijas Sistēmu programmas ArcInfo 8.0.2. un ArcView 3.1.

Upē, kur saglabājies visvairāk pērleṇu, ir arī vislielākā dabisko biotopu platība: dabiskie biotopi aizṇem $87 \%$ no platības, bet apsaimniekotās teritorijas tikai $13 \%$.

Katrs atsevišķs teritorijas apsaimniekošanas veids vai dabisko biotopu veids būtiski neietekmē pērleņu populāciju izdzīvošanu, taču varam secināt, ka dabisko biotopu saglabāšanās lielākās platībās kopumā ir veicinājusi pērleṇu populāciju izdzīvošanu.

\section{METĀLU UZVEDĪBA DAUGAVAS HIDROFRONTES ŪDENĪ UN SEDIMENTĀ}

\section{Zinta SEISUMA, Irīna KUĻIKOVA}

Latvijas Universitātes Hidroekoloǵijas institūts, Jūras ekoloǵijas projektu grupa, e-pasts:zinta@inbox.lv; irinaluhei@inbox.lv

2001.gada decembrī, 2002.gada jūlijā un 2003.gada aprīlī pirmo reizi veikts vienlaikus metālu pētījumu komplekss, lai noskaidrotu $\mathrm{Cu}, \mathrm{Zn}, \mathrm{Ni}, \mathrm{Mn}$ un Fe koncentrācijas Daugavas, sajaukšanās zonas un Rīgas līča virsējā un $1 \mathrm{~m}$ virs sedimenta ūdens slānī, kā arī nosakot $\mathrm{Hg}, \mathrm{Cd}, \mathrm{Pb}, \mathrm{Cu}, \mathrm{Zn}, \mathrm{Ni}, \mathrm{Mn}$ un $\mathrm{Fe}$ koncentrācijas šo pašu staciju sedimentā.

Salīdzinājumam izmantoti 1999.gada septembra un 2000.gada maija dati, kad metālu koncentrācijas analizēja tikai virsējā ūdens slānī un sedimentā.

Pavasaros ir izteikta Daugavas saldūdeņu ietekme uz Rīgas līča ūdeņiem. 2003.gada pavasarī Daugavas virsējie un $1 \mathrm{~m}$ virs grunts ūdeñi ir piln̄̄gi bez jūras ietekmes, bet 2003.gafā pavasarī Daugavas grīvas $1 \mathrm{~m}$ virs grunts ūden̄̄ konstatējam jūras ūdenu ietekmi.

Abu gadu hidroķīmisko datu atšķirības ietekmē $\mathrm{Cu}, \mathrm{Zn}, \mathrm{Ni}, \mathrm{Mn}$ un $\mathrm{Fe}$ koncentrācijas ūdenī un gruntīs. Tā virsējā ūdens slānī visās zonās $\mathrm{Zn}$ un Fe koncentrācijas augstākas un $\mathrm{Cu}$ - zemākas 2000.gada pavasarī. Savukārt Ni koncentrācijas virsējā slāņa ūdenī abos pavasaros ir tuvas. Mn koncentrācijas ūdens virsējā slān̄ mainās atkarībā no zonas, tā, piemēram, Daugavā ir vienādas, bet sajaukšanās zonā 2000.gadā Mn koncentrācijas ir zemākas nekā 2003.gadā. Salīdzinot 2000.g. un 2003.g. pavasarus, vislielākās metālu koncentrāciju 
atšķirības ir Daugavas gruntīs, tad seko sajaukšanās zona un viszemākās atšķirības Rīgas līča stacijās.

Salīdzinot 2001.g. ziemu un 2002.g. vasaru, $\mathrm{Cu}, \mathrm{Zn}, \mathrm{Ni}, \mathrm{Mn}$ un Fe koncentrācijas Daugavas hidrofrontes ūdens virsējā slānī un $1 \mathrm{~m}$ virs sedimenta ir atšksirīgas, tāpat metālu koncentrācijas atšksiras Daugavā, sajaukšanās zonā un Rīgas līcī. Vairumā gadījumu Zn, Ni un Mn koncentrācijas ir augstākas ūden̄̄ $1 \mathrm{~m}$ virs sedimenta, bet $\mathrm{Cu}$ - virsējā slānī. Ziemā Fe koncentrācijas ir augstākas virsējā slānī, bet vasarā - $1 \mathrm{~m}$ virs sedimenta. Vasarā $\mathrm{Cu}, \mathrm{Zn}$ un Fe koncentrācijas ūden̄̄ ir mazākas nekā ziemā, jo hidrobiontiem (sevišksi fitoplanktonam) šie metāli ir nepieciešami to attīstībai. Ziemā Mn koncentrācija ir augstāka Rīgas līcī, bet vasarā Daugavā. Starp $\mathrm{Cu}, \mathrm{Zn}, \mathrm{Ni}, \mathrm{Mn}$ un Fe koncentrācijām ūdenī nav korelācijas. Ziemā visas hidrofrontes sedimentos ir augstākas $\mathrm{Hg}$ un $\mathrm{Cu}$ koncentrācijas nekā vasarā. Pārējiem metāliem ziemā augstākas koncentrācijas nekā vasarā raksturīgas atsevišksās hidrofrontes zonās. Ziemā ir izteikti augsta korelācija (korel.koef. 0,8-0,96) starp visiem pētītajiem metāliem $(\mathrm{Hg}, \mathrm{Cd}, \mathrm{Cu}$, $\mathrm{Ni}, \mathrm{Pb}, \mathrm{Zn}, \mathrm{Mn}, \mathrm{Fe})$ sedimentā. Arī vasarā ir būtiska korelācija starp pētītajiem metāliem sedimentā, izņemot Hg.

Izmantojot Galvenā komponenta analīzi, ar Varimax rotāciju statistiski analizēta 1999.gada rudens un 2000.gada pavasara $\mathrm{Cu}, \mathrm{Zn}$, Mn un $\mathrm{Fe}$ koncentrācijas Daugavas, sajaukšanās zonas un Rīgas līča ūdenī un gruntīs kopsakarā ar sāļuma, pH, skābekl̦a izmaiṇām ūdenī. Tāpat kā 2001.gada ziemā un 2002.gada vasarā arī 1999.gada ruden̄̄ un 2000.gada pavasarī.

Galvenā komponenta analīze parāda, ka $\mathrm{Cu}, \mathrm{Zn}, \mathrm{Mn}$ un Fe koncentrācijas sedimentā l̦oti labi korelē savā starpā (korel. koef. 0.9-1). Abos gados sāḷums ūdens virsējā slān̄i Daugavā un tās sajaukšanās zonā ar Rīgas līci būtiski atšksiras. Konstatējam vispārīgu tendenci: pieaugot sāļumam ūden̄̄, samazinās metālu koncentrācija ūden̄̄. Abos gados starp dabiskās izcelsmes metāliem Mn un Fe ūden̄̄ ir laba korelācija. Pie intensīvas saldūdens plūsmas no Daugavas sajaukšanās zonā pieaug Mn un Fe koncentrācijas. Paaugstinātās Mn un Fe koncentrācijas Daugavas ūden̄̄, kā redzams, ir saistītas ar to resuspenziju no sedimenta smalkajām frakcijām. Pavasara plūdu straumes erodē krastus un grunts sedimentu.

Dažādos gados un sezonās neatkarīgi no sāļuma un citiem fizikāli ķīmiskiem parametriem metālu koncentrācijas Daugavā, sajaukšanās zonas un Rīgas līča sedimentos, kā arī ūden̄̄, saglabā katrai zonai raksturīgo amplitūdu. 


\title{
MAKSTEN̦U TRICHOPTERA SUGU SABIEDRĪBAS DOMINEEJOŠAJOS LATVIJAS MAZO UPJU MIKROBIOTOPOS
}

\author{
Agnija SKUJA \\ LU Bioloǵijas institūts, e-pasts: agnija@lanet.lv
}

Makstenes aiz divspārņiem ir otrā sugām bagātākā ūdens kukaiṇu kārta. Maksteņu kāpuri ir makrozoobentosa organismi, kas plaši tiek izmantoti ūdens ekologiskās kvalitātes novērtēšanā. Makrozoobentosa organismu sugu sabiedrību telpisko izplatību ietekmē gan abiotiskie, gan biotiskie faktori, tāpēc svarīga ir sugu sabiedrību telpiskās izplatības izpēte.

Latvijā pilnīgi izpētīta ir ezeru un lielo upju fauna, apmierinoši - vidējo upju fauna, bet nepietiekami - mazo upju, strautu un purva maksteñu fauna. Taču ekoloǵiski pētījumi par maksteņu sadalījumu mikrobiotopos Latvijā līdz šim nav veikti.

2003.gada pavasarī, izmantojot Latvijas standartmetodi (LVS 240: 1999), 20 Latvijas mazo upju 100 metrus garos posmos tika ievākti makrozoobentosa paraugi piecos dominējošajos mikrobiotopos, lai raksturotu tajos maksteņu sugu sabiedrības. Materiāls ievākts, LU Biologiijas institūta Hidrobiologijas laboratorijai piedaloties ES 5. Ietvara programmas projektā: "Upju klasifikācijas standartizācija: struktūras metode dažādu bioloǵisko apskatu rezultātu kalibrēšanai atbilstoši ekologiiskās kvalitātes klasifikācijai, izstrādātai Ūdens Struktūrdirektīvas vajadzībām" (STAR).

Pavisam noteiktas 57 taksonomiski atšķirīgas maksteņu kārtas vienības.

Pētīto upju posmos dominējoši ir oḷu, akmeņu, smalkā detrīta, rupjā detrīta un grants mikrobiotopi, bet mazākas platības aizṇem koksnes, makroskopisko aļğu, ūdenssūnu un laukakmeņu mikrobiotopi.

Augstākā sugu daudzveidība konstatēta akmens un rupjā detrīta mikrobiotopos, zemāka - koksnes, smalkā detrīta un akmeņu ar ūdenssūnu mikrobiotopos, bet zema - augu un smilts mikrobiotopos. Sugu daudzveidību upju posmos nosaka mikrobiotopu stabilitāte un telpiskā struktūra. Lielākais īpatņu blīvums konstatēts rupjā detrīta un akmeṇu ar ūdenssūnu mikrobiotopos, vidējs akmeņu un koksnes mikrobiotopos, bet zems - augu un smilts mikrobiotopos. İpatṇu blīvums ir atkarīgs no substrāta stabilitātes un barības vielu pieejamības. Izmantojot Hierarhisko klāsteranalīzi un Detrendēto korespondentanalīzi, pierādīta maksteņu specializācija akmens, akmens ar ūdenssūnu un detrīta mikrobiotopiem, izdalītās speciālās un eiribiontās sugas. 


\title{
VIDES FAKTORU IETEKME UZ UPJU BIOCENOŽU STRUKTŪRU
}

\author{
Gunta SPRIŅĢE ${ }^{1}$, Agrita BRIEDE ${ }^{1}$, Agnija SKUJA ${ }^{2}$ \\ ${ }^{1}$ LU Ģeogrāfijas un Zemes zinātņu fakultāte, \\ e-pasts: gspringe@email.lubi.edu.Iv \\ ${ }^{2}$ LU Bioloǵijas institūts, e-pasts: agnija@lanet.Iv
}

Eiropas Parlamenta un Padomes 2000.gada 23.oktobra direktīva 2000/60/EC, kas nosaka struktūru Eiropas Kopienas rīcībai ūdeņu aizsardzības politikas jomā jeb Ūdens struktūrdirektīva, paredz, ka ūdens ekologisiskās kvalitātes novērtēšanā izmantojamas dažādas organismu grupas -zivis, augstākie augi, fitobentoss un bentiskie bemugurkaulnieki, kas labi reaǵē uz vides izmaiņām dažādos telpiskajos mērogos.

Šajā sakarā, lai novērtētu vides ekoloǵisko kvalitāti, svarīgi ir noteikt, kāda ir biocenožu dabiskā mainība telpā un laikā. LU Bioloğijas institūts, piedaloties 5.satvara programmas projektā "Upju klasifikācijas standartizācija: struktūras metode dažādu bioloǵisko apskatu rezultātu kalibrēšanai atbilstoši ekoloǵiskās kvalitātes klasifikācijai, izstrādātai Ūdens Struktūrdirektīvas vajadzībām” (STAR), ir veicis pētījumus, kuros tika noskaidrota vides faktori ietekme uz augstāko augu, zivju, bentisko bezmugurkaulnieku un fitobentosa biocenozēm neskartos jeb mazskartos upju biotopos, kuri nav pakḷauti antropogēnajai ietekmei. Pētījums tika veikts, analizējot rezultātus upju baseina līmenī.

Izmantojot Principiālo komponentu analīzi (PKA), tika analizēta raksturīgo vides faktoru (hidromorfoloǵisko, fizikāli ķīmisko un morfometrisko) ietekme uz pētītajām biocenozēm, kuras raksturotas, izmantojot dažādus organismu grupas raksturojošus trofiskos un daudzveidības indeksus.

Veikto analīžu rezultāti liecina, ka lielākā ietekme uz augstāko ūdens augu cenožu struktūru ir upju morfometriskajam gradientam, būtiska ir arī baseina geoķīmisko rādītāju loma, ko raksturo ūdens elektrovadītspēja, sārmainība un cietība. Zivju biocenozes visbūtiskāk ietekmē hidroķīmiskais gradients (skābekḷa koncentrācija, sārmainība, pH, elektrovadītspēja). Bentisko bezmugurkaulnieku cenožu struktūra visvairāk ir saistīta ar morfometrisko gradientu. Fitobentosa biocenozēm, kuru raksturojumam izmantoti kramalğgu trofiskie indeksi, konkrēta gradienta ietekme ir visgrūtāk nosakāma. Konstatēts, ka fitobentosa attīstībā salīdzinoši nozīmīgākais ir morformetriskais gradients. 


\title{
INVAZĪVĀS SUGAS CERCOPAGIS PENGOI SADALĪJUMA İPATNĪBAS RĪGAS LĪCĪ
}

\author{
S.STRĀĶE, A.IKAUNIECE, G.AIŠPURE \\ Latvijas Universitātes Hidroekoloǵijas institūts, \\ e-pasts: solvita@hydro.edu.Iv; anda@monit.lu.Iv; gunta@monit.lu.Iv
}

Cilvēka darbības rezultātā arvien straujāk tiek veicināta dažādu sugu izplatîšanās ārpus to dabiskajiem areāliem. Kuğu satiksme un to balasta ūdeni ir viens no galvenajiem jaunu sugu introducēšanas vektoriem Baltijas jūrā. 1991.1992.gadā Rīgas līcī introducētā planktoniskā vēzīša Cercopagis pengoi (Ostroumov, 1891), dabiskais izplatības areāls ir Ponto-Kaspijas regions, kas kḷuvis par donoru vēl vairākām citām Rīgas līcī sastopamajām vēžveidīgo sugām. N̦emot vērā Baltijas un Kaspijas jūru atšķirīgos vides apstākḷus, introducēto sugu, t.s. Cercopagis pengoi, izplatība ārpus dabiskā areāla robežām liecina par ievērojamu sugas plastiskumu.

Cercopagis pengoi biologija pētīta 1992.-2003.gadā, pievēršot īpašu uzmanību gan skaita un biomasas dinamikai, gan vertikālajām un horizontālajām sadalījuma īpatnībām Rīgas līcī. Rezultāti parāda, ka 1992.-1996.gadā Cercopagis pengoi īpatñu skaits svārstās robežās no $0-10 \mathrm{eks} / \mathrm{m}^{3}$, bet kopš 1997.gada to skaits krasi palielinās, dažādos Rīgas līča rajonos mainoties no 50 līdz pat vairākiem simtiem īpatñiem $\mathrm{m}^{3}$.

Cercopagis pengoi populācijas struktūra un īpatņu sadalījums ūdens stabā nav viendabīgs. Rezultāti parāda, ka Cercopagis pengoi galvenokārt uzturas siltajā ūdens slānī virs termoklīna un tikai neliela populācijas daļa ir sastopama zem tā. Interesanti, ka Rīgas līča pētījumu dziḷajā stacijā maksimālā Cercopagis pengoi skaita koncentrācija $-420 \mathrm{eks} / \mathrm{m}^{3}$ ir konstatēta tieši termoklīna slānī un nedaudz virs tā (20-40 m). Savukārt populācijas struktūras analīze parāda, ka jaunākās īpatņu attīstības stadijas koncentrējas virsējā $0-4 \mathrm{~m}$ slānī $(92 \%$ no kopējās populācijas), bet, palielinoties dziļumam, pakāpeniski pieaug arī pieaugušo īpatņu skaits.

Maksimālās skaita un biomasas vērtības Cercopagis pengoi sasniedz augustā, kad ūdens temperatūra pārsniedz $15^{\circ} \mathrm{C}$ temperatūru. Apsekojot dažāda dziļuma stacijas Rīgas līča piekrastē un atklātajā daļā, Cercopagis pengoi novērots $90 \%$ gadījumu, skaitam svārstoties no $12 \mathrm{li} \mathrm{dz} 317 \mathrm{eks} / \mathrm{m}^{3}$. Tomēr atsevišķos gadījumos pie labvēlīgiem vides apstākḷiem Cercopagis pengoi var sasniegt ievērojamas koncentrācijas $\left(5790 \mathrm{eks} / \mathrm{m}^{3}\right)$. Tādējādi pēc izmēriem lielais, salīdzinājumā ar pārējām Rīgas līča zooplanktona sugām invazìvais planktona vēzītis var pat aizsprostot zvejnieku tīklus, radot apgrūtinošus apstākḷus zvejniecībai. 


\title{
NOTEKŪDEN̦U DŪṆU KOMPOSTU MIKROBIOLOĢISKĀ KVALITĀTE VIDES AIZSARDZĪBAS ASPEKTĀ
}

\author{
Astrīda ZANDMANE, Dace KL̨AVIN̦A \\ Latvijas Vides aǵentūra \\ e-pasts: astrida.zandmane@Iva.gov.Iv
}

Notekūdeņu attīrīšana un aktīvo dūņu apsaimniekošana kā tautsaimniecības uzdevumi ir risināmi ciešā saistībā ar vides aizsardzības standartiem. Šajā sakarā 2002.gadā Latvijas Republikas Ministru kabinets apstiprināja likumdošanas dokumentu "Noteikumi par notekūdeņu dūņu un to kompostu izmantošanu, monitoringu un kontroli", kuros stingri noteikti dūņu apsaimniekošanas un ekoloğiskās drošības juridiskie principi.

Latvijā esošajās notekūdeṇu biolog̣iskās attīīšanas iekārtās (BAI) tiek saražots un uzkrāts liels apjoms atūdeņoto dūņu - ap 20 tūkst. tonnu sausnas gadā. Dūņu otrreizēja izmantošana ir ekonomiski izdevīga, jo tās satur augiem nepieciešamās barības vielas, kā arī uzlabo augsnes struktūru un bagātina to ar aktīvu mikrofloru. Tomēr notekūdeņu attīrǐšanas procesā ne vienmēr izdodas pilnīgi atbrīvoties no cilvēku veselībai un videi bīstamajiem mikroorganismiem (Salmonella spp., Clostridium perfringens, helmintu oliņas), kas nereti saglabājas atūdeñoto dūņu masā. Viens no veidiem to iznīcināšanai ir dūņu kompostēšana un higienizēšana (izsaldēšana, karsēšana, kalı̧̧̧šana, pildvielu izmantošana). Parasti dūṇu kompostus gatavo no svaigām atūdeñotām dūņām, kuras 6-9 mēnešus uzglabā un izsaldē ziemas periodā atklātā laukā (glabātuvē). Šis paṇēmiens ir vienkāršākais no ES normatīvos minētajiem piẹ̦aujamajiem dūņu kompostēšanas veidiem, kas visbiežāk tiek praktizēts arī Latvijā.

2002./2003.gada rudens-pavasara periodā tika veikta notekūdeņu dūṇu un to kompostu mikrobiologiiskās un higiēniskās kvalitātes izpēte piecos objektos Aizkraukles, Bauskas, Dobeles, Kuldīgas un Saldus BAI. Šo iekārtu celtniecībā, kā arī tehnologijijā, izmantota Dānijas pieredze. Notekūdeņu bioloǵiskās attīīǐsanas procesā ietverti priekšattīrīšanas, denitrifikācijas, aerācijas, nostādināšanas, aktīvo dūņu atūdeņošanas, dūņu deponēšanas/kompostēšanas darbības bloki.

Šo pētījumu mērḳis - veikt notekūdeņu dūṇu mikrobiologiskās kvalitātes novērtējumu saskaṇā ar standartu prasībām ES un nacionālā līmenī; pamatojoties uz iegūto datu informāciju un metodisko pieredzi, izstrādāt Latvijas nacionālo standartu patogēno baktēriju Salmonella spp. noteikšanai.

Tika noteikti šādi mikrobioloǵiskie un parazitoloǵiskie parametri - kopējās un fekālās koliformas, enterokoki, Clostridia spp., Salmonella spp., heterotrofo mikrobu un saprofìto baktēriju koloniju skaits, helmintu oliņas, kā arī galvenie fizikālie un ķ̄īmiskie rādītāji.

Patogēnie mikroorganismi: Salmonella spp. klātbūtne tika analizēta 15 svaigu un 13 kompostētu dūṇu paraugos; Clostridium spp. skaits testēts 
12 svaigu un 10 kompostētu dūṇu paraugos; helmintu oliṇu daudzums - 12 svaigu un 7 kompostētu dūņu paraugos. Iegūti šādi secinājumi:

$\checkmark$ atūdeņoto dūņu higiēniskā kvalitāte pēc "izsaldēšanas" ievērojami uzlabojas;

$\checkmark \quad 79 \%$ dūṇu un to kompostu paraugu kvalitāte saskaṇā ar Salmonella spp. klātbūtnes testa rezultātiem atbilst Latvijas normatīvajām prasībām;

$\checkmark \quad 82 \%$ dūņu un to kompostu paraugu kvalitāte saskaņā ar Clostridium perfringens skaitu atbilst labākajai A klasei $(<100000 \mathrm{KVV} / \mathrm{g})$, bet pārējie - vidējai B klasei (Lietuvas nacionālo normatīvu prasības);

$\checkmark \quad 86 \%$ dūṇu un kompostu paraugu kvalitāte pēc helmintu oliṇu skaita atbilst vidējai B klasei (1-100 eks./kg), pārējie - C kvalitātes klasei (Lietuvas normatīvās prasības);

$\checkmark$ izmantojot mēslošanai pētīto dūnu kompostus, pastāv neliels risks inficēties ar Salmonella spp. un Cl.perfringens, salīdzinoši lielāks - ar parazītu oliņām.

Sanitāri bakterioloğiskie indikatororganismi: kopējo koliformu skaits noteikts 18 svaigu un 16 kompostētu dūn,u paraugos; fekālo koliformu (varb. E.coli) un enterokoku skaits - 18 svaigu un 15 kompostētu dūṇu paraugos.

Secinājumi:

$\checkmark \quad 33 \%$ dūṇu un galvenokārt tieši kompostu paraugu kvalitāte saskaṇā ar E.coli skaitu atbilst labākajai A kvalitātes klasei $(<100000 \mathrm{KVV} / \mathrm{g})$, pārējie - vidējai B klasei (Lietuvas normatīvās prasības);

$\checkmark$ tikai $6 \%$ paraugu galvenokārt kompostētu dūṇu paraugu kvalitāte saskañā ar fekālo enterokoku skaitu atbilst normatīvajām prasībām;

$\checkmark$ saskaņā ar indikatororganismu datiem kompostēšanas efekts varētu būt labāks;

$\checkmark \quad$ svaigu dūņu paraugi parasti satur l̦oti lielu fekālo enterokoku skaitu, kas kompostēšanas gaitā samazinās maz. Enterokoki ārējā vidē ir izturīgāki par E.coli un precīzāk identificē fekālā piesārņojuma kātbūtni. No šñ viedokḷa enterokoki kā ļoti indikatīvs parametrs vērtē dūṇu komposta higienisko kvalitāti stingrāk.

Sausnas saturs. Analīzes parāda, ka visās dūņās sausnas saturs svaigās un kompostētās dūn̄ās kopumā ir apmierinošs - robežās no 15,5 līdz 35,7\%. No lentpreses atūdeņotajās dūñās sausnas iznākums ir samērā stabils - ap 15\%. Dūñu laukā kompostētajās (pēc izsalšanas) dūn̄ās sausnas saturs sasniedz vidēji 20,0\% (19-35,7\%), kas vērtējams l̦oti pozitīivi. Augstāks sausnas īpatsvars kompostā ir viens no faktoriem, kas atrisina virkni praktisku jautājumu komposta daudzveidīgākai izmantošanai (izmaksas, transports).

Agronomiskā kvalitāte. Mikrobioloğiskie rādītāji nav limitējošie parametri dūņu kompostu agronomiskās kvalitātes novērtēšanai ES vai nacionālo normatīvu prasībās. Kanādā kompostu kvalitātes standartā ir ietverti 6 mikrobioloǵiskie parametri, no kuriem viens - heterotrofās plates skaits jeb 
mikrobu koloniju skaits tika noteikts arī mūsu pētījumos. Šis standarts nosaka, ka sagatavotu dūn,u kompostā mikrobu koloniju skaitam jābūt robežās no 1 x $10^{8}$ $1 \times 10^{10} \mathrm{KVV} / \mathrm{g}$ sausās masas.

Mikrobu (aerobo) koloniju skaits tika noteikts 18 svaigu un 15 kompostētu dūṇu paraugos. Secinājums: kompostēšanas procesā heterotrofo mikroorganismu daudzums dūn̄ās palielinās, tomēr normatīvo prasību robežās iekḷaujas tikai $28 \%$ svaigu un $60 \%$ kompostēto dūņu.

Pētījumu rezultātā tika iegūta līdz šim maz apzināta informācija par notekūdeņu dūņu un to kompostu mikrobioloǵisko, higiēnisko un agroksīmisko kvalitāti. Pamatojoties uz iegūto datu informāciju un metodisko pieredzi, tika izstrādāta oriǵināla stadartmetodika patogēno baktēriju Salmonella spp. klātbūtnes (ir/nav tests) semi-kvalitatīvai noteikšanai notekūdeṇu dūñās un to kompostos (LVS 366:2003), kas ir saskan̄ā ar pašreizējām Eiropas Savienības direktīvu vadlīnijām un EN ISO standartu prasībām. Apliecināta Salmonella spp. un Clostridium perfringens testēšanas kompetence, piedaloties starptautiskajā starplaboratoriju interkalibrācijā (QWAS, Water Analysis Proficiency Testing Scheme; QMS, Quality in Microbiology, London UK).

\section{Literatūra}

1. EC "Disposal and Recycikling Routes for Sewage Sludge", Part 2. Regulatory report, 2001/2002.

2. Inta Gemste, Alberts Vucāns. Notekūdeņu dūṇas un to izmantošana. Jelgava, Latvijas Lauksaimniecības universitāte, 2002, 172 lpp.

3. Inta Gemste, Alberts Vucāns. Notekūden̦u dūṇu un to komposta izmantošanas vides monitoringa Rokasgrāmata. Rīga, 2003, 43 lpp.

4. Noteikumi par notekūden̦u dūṇu un to kompostu izmantošanu, monitoringu un kontroli”, Ministru kabineta noteikumi Nr. 365, 20.08.02., prot. Nr. 35, 2 §, Rīgā, 2002. 
LU Akadēmiskais apgāds

Baznīcas iela 5, Rīga, LU-1010

lespiests SIA „AGRAVE” 